\title{
New actors in the global economy
}

Citation for published version (APA):

Broich, T. (2017). New actors in the global economy: the case of Chinese development finance in Africa. [Doctoral Thesis, Maastricht University]. Boekenplan. https://doi.org/10.26481/dis.20171213tb

Document status and date:

Published: 01/01/2017

DOI:

10.26481/dis.20171213tb

Document Version:

Publisher's PDF, also known as Version of record

\section{Please check the document version of this publication:}

- A submitted manuscript is the version of the article upon submission and before peer-review. There can be important differences between the submitted version and the official published version of record.

People interested in the research are advised to contact the author for the final version of the publication, or visit the DOI to the publisher's website.

- The final author version and the galley proof are versions of the publication after peer review.

- The final published version features the final layout of the paper including the volume, issue and page numbers.

Link to publication

\footnotetext{
General rights rights.

- You may freely distribute the URL identifying the publication in the public portal. please follow below link for the End User Agreement:

www.umlib.nl/taverne-license

Take down policy

If you believe that this document breaches copyright please contact us at:

repository@maastrichtuniversity.nl

providing details and we will investigate your claim.
}

Copyright and moral rights for the publications made accessible in the public portal are retained by the authors and/or other copyright owners and it is a condition of accessing publications that users recognise and abide by the legal requirements associated with these

- Users may download and print one copy of any publication from the public portal for the purpose of private study or research.

- You may not further distribute the material or use it for any profit-making activity or commercial gain

If the publication is distributed under the terms of Article $25 \mathrm{fa}$ of the Dutch Copyright Act, indicated by the "Taverne" license above, 


\section{NEW ACTORS IN THE GLOBAL ECONOMY}

The case of Chinese development finance in Africa

\section{Tobias Broich}

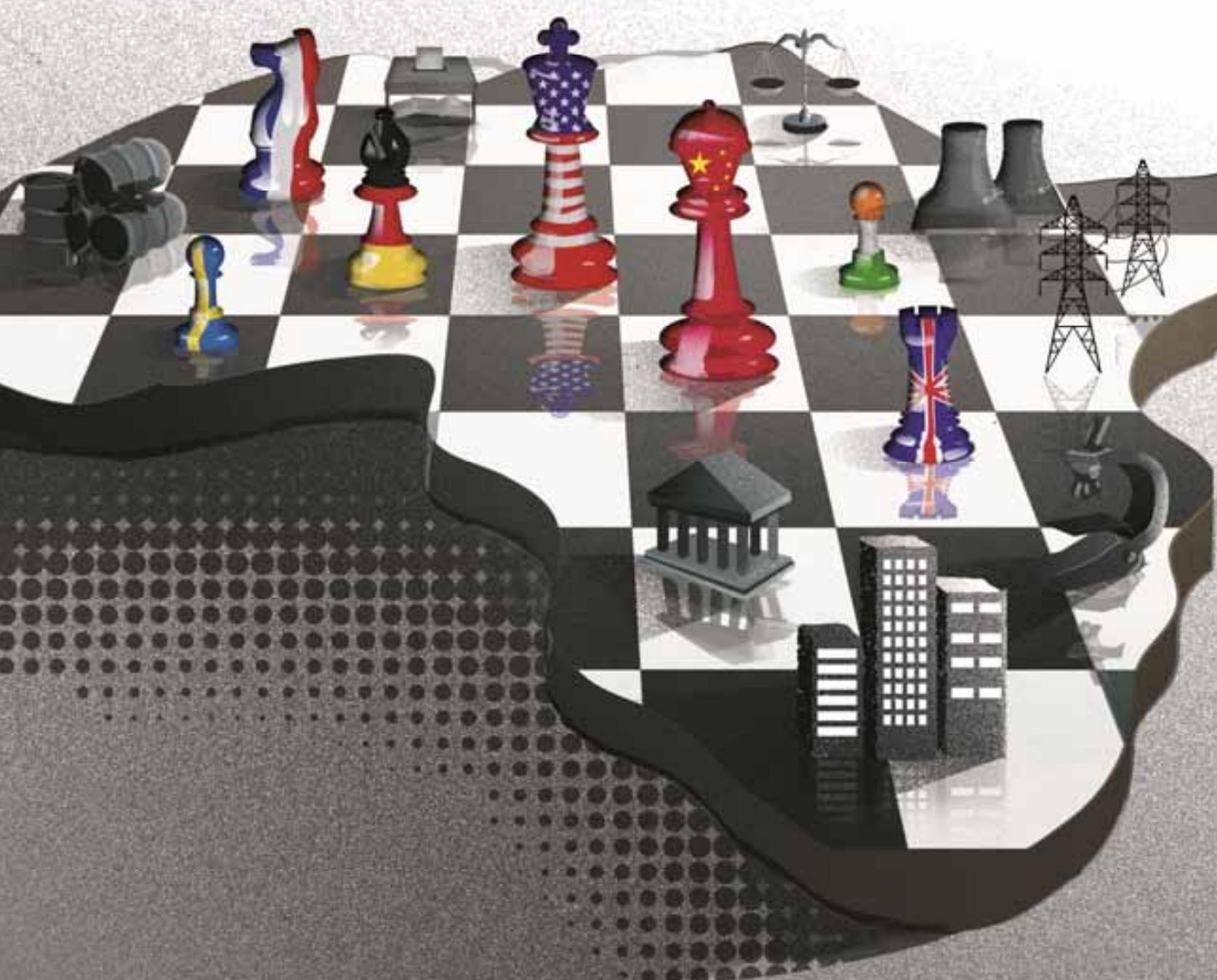





\title{
New Actors in the Global Economy
}

\author{
The Case of Chinese
}

Development Finance in Africa

\section{DISSERTATION}

to obtain the degree of Doctor at Maastricht University, on the authority of the Rector Magnificus, Prof. Dr. Rianne M. Letschert in accordance with the decision of the Board of Deans, to be defended in public on

Wednesday 13 December 2017, at 14:00 hours

$$
\text { by }
$$

Tobias Broich 


\title{
Supervisor:
}

Prof. Dr. Adam Szirmai

\section{Co-Supervisor:}

Dr. Kaj Thomsson

\author{
Assessment Committee: \\ Prof. Dr. Jo Ritzen (chair) \\ Prof. Dr. Ewout Frankema (Wageningen University) \\ Dr. Mulu Gebreeyesus (Ethiopian Development Research Institute) \\ Dr. Maty Konte
}

(C) Tobias Broich, 2017

ISBN: 9789086664382

Published by Boekenplan, Maastricht

www.boekenplan.nl

Illustration cover: Melanie Waidler

All rights reserved. No part of this publication may be reproduced, stored in a retrieval system, or transmitted in any form or by any means, electronic, mechanical, photocopying, recording or otherwise, without the written permission from the author. 
To my parents, Hans Josef and Doris, who taught me the true value of education. 



\section{ACKNOWLEDGEMENTS}

According to Jose Martí, a Cuban revolutionary and poet, every person should do three things in the course of one's life: (i) plant a tree, (ii) have a child, and (iii) write a book, because these all live on after us, insuring a measure of immortality. As a grammar school student I scratched the first item off that list already. I am now about to tick the third item off the list. Like any other projects, my $\mathrm{PhD}$ project and the book resulting out of it would not have been possible without the generous support from my supervisors, colleagues, family, friends and several other people. I would hereby like to thank them for helping me to scratch the third item off that list.

First and foremost, I would like to thank my supervisory team, Eddy Szirmai and Kaj Thomsson, who have accompanied my path since the very beginning. Eddy, you are more than a supervisor. You are a mentor and role model and the institute is lucky to still have you around. Kaj, I already enjoyed having you as my supervisor for my Master Thesis and I was happy that you agreed to be my second supervisor. Thanks to both of you for your guidance over the past years, for providing comments and suggestions when I needed advice, for being patient when I needed more time and for being critical when I needed to sharpen parts of my thesis. Eddy and Kaj, I am truly grateful for all the dedication, time and effort during the past five years we worked together.

My sincere thanks also goes to the members of the assessment committee: Jo Ritzen, Ewout Frankema, Mulu Gebreyesus and Maty Konte. Their insightful comments and constructive feedback improved the quality of the thesis and the final version of the dissertation significantly.

I would also like to thank Bart Verspagen, the director of UNU-MERIT and director-dean of the Maastricht Graduate School of Governance (MGSoG), who always listened thoughtfully and sympathetically to the concerns of us $\mathrm{PhD}$ students. A special thanks goes to the PhD directors of the program, Robin Cowan, Mindel van de Laar and Tatiana Skripka who gave me the opportunity to start and finish a PhD at UNU-MERIT/MGSoG. Mindel, Tatiana and Robin, your guidance throughout this $\mathrm{PhD}$ journey was highly appreciated. 
I would also like to highlight the role of the administrative staff (Wilma, Susan and Marc), administrative support staff (Danny, Sueli, Mieke, Ingeborg, Marlies, Howard, Janneke, Anouk, Liesbeth, Ad, Monique, Diego, Ingrid, Ralph, Mitie and Vivianne) and the technical staff (Eric, Mourik Jan and Herman). You are the backbone of the institute and you make a difference to the institute. You keep things running smoothly. I clearly acknowledge what you have been and will be doing for us PhD students: Dank je wel! I would like to single out Eveline for her relentless emotional support along the way. Eveline, you have been there for us from the very first day and the fact that you are eager to visit every single $\mathrm{PhD}$ defence really shows me that you do care about us.

I have been privileged to present my work across at several occasions in Maastricht and across different continents. I am grateful for critical and challenging feedback, comments and suggestions from internal Maastricht University staff members such as Lutz Krebs, Pierre Mohnen, Eleonora Nillesen, Thomas Ziesemer, Neil Foster-McGregor, Théophile Azomahou and Tom van Veen, but also from the participants of the International UNU-MERIT Conference in Maastricht, the CSAE Conference in Oxford, United Kingdom, the GLOBELICS Conference in Havana, Cuba, the UNU-MERIT/CRES 2nd International Conference on Sustainable Development in Africa, held in Dakar, Senegal, the 6th Euro-African Conference in Finance and Economics in Marseille, France, the WUN Annual General Meeting in Maastricht, the Annual International Conference of the Research Group on Development Economics in Heidelberg, Germany, the 4th African Studies Conference in Pécs, Hungary, the Annual Conference of the Society for Institutional and Organizational Economics in Paris, France, the Annual Conference of the Chinese Economic Association (CEA) at the Institute of East Asian Studies at University DuisburgEssen, Germany, the Dutch Economist Day at the Dutch Central Bank in Amsterdam, Netherlands, and the WINIR Symposium in Johannesburg, South Africa.

I would also like to thank a few people who enormously helped facilitating my fieldwork in Ethiopia. Kaleab Haile was my first contact person after arriving in Addis Ababa and he helped me settling in. Biniam Bedasso, Mulu Gebreyesus and Fikru Debele from the Ethiopian Development Research Institute helped and succeeded in linking me up with some valuable contacts in Ethiopia. I would also like to thank all interviewees who were willing to answer my questions 


\section{ACKNOWLEDGEMENTS}

during my stay in Ethiopia. The answers by the interviewees - working for Ethiopian government ministries, in Western development organizations, nongovernmental organization, international financial institutions, embassies, research institutes and universities - have been an indispensable source of data for my case study on Ethiopia. Even though I have barely scratched the surface of this country during my six weeks, I have quickly realized that Ethiopia is a very special place both culturally and historically. With its diverse mix of ethnic, linguistic and religious backgrounds, Ethiopia is a truly fascinating African country and probably one of the last truly original travel destinations in the world. The warm-hearted hospitality of the Ethiopian people will always stay in my mind.

A lovely and wonderful group of friends made this $\mathrm{PhD}$ experience unforgettable. While the $\mathrm{PhD}$ process involves a lot of blood, sweat and tears (not to be taken literally), the process was also filled with a lot of fun and unforgettable memories thanks to a lot people I got to meet along the way that I am now proud to call my friends. To the 2012 cohort, Ayokunu, Saba, Biljana, Carla, Caro, Eriko, Eva, Gintare, Hasse, Juanca, Martin, Ralf, Raquel, Saba, Sheng, Stefania, Thuy and Tigist, thank you for this wonderful first year, our social gatherings in Ed's Café for "one beer only" and for making this $\mathrm{PhD}$ experience one I will never forget.

Working at UNU-MERIT/MGSoG has always been enjoyable. I am grateful to my former office mates Cheng, Eleni, Güney, Hampdon, Nevena, Yessuf, Maria, Ibrahima, and Wonde for the pleasant working atmosphere. I am glad that I got to know Richard who helped me with econometrics and STATA-related questions, before, during and after the Econometrics course that we taught together. I am grateful to the founders and participants of the Wives Lunch Club and WhatsApp group "WLC around the world": Our group administrators Andrea and Paula, as well as the participants Alison, Beatriz, Charlotte, Danilo, Elisa, Emmanuel, Giacomo, Iulia, Jenny, Mary, Omar, Shivani and Simone. While women dominated this institution at the very beginning, we have slowly but steadily established gender equality. I am proud of having played my part in achieving gender equality, partly due to the fact that my interpretation of an Insalata Caprese has always been well received. Our chats and mostly healthy food at $13.00 \mathrm{hrs}$ and our social gatherings outside the institute have been a welcome change to the sometimes stressful days at work. 


\section{ACKNOWLEDGEMENTS}

I would also like to mention other colleagues from the institute and Maastricht University more general that enormously contributed to the Maastricht experience. In no particular order: Hugo, Mueid, Cho, Beatriz, Danilo, Pablo, Francesca G., Alejandro, Julietta, Agustin, Jennifer, Giorgio, Daniel, Elvis, Mira, Ortrun, Iman, Shuan, Eduardo, Clotilde, Francesca R., Sachin, Luciana, Fernando, Serdar, Nga, Elise, Tamer, Vincenzo, Hassen, Emmanuel, Rose, and Inez. I find it amazing how international our community is. All of you have global minds who share similar interests. You have shown me that the diversity of our world's many cultures, languages, religions and ethnicities is a treasure.

During my time in Maastricht, I was also very lucky to have sympathetic housemates: Matthias, Sven, Michael, Andrea, Patrick, Alex, Monia, Johanna, Jan, Markus, Kathrin, Jannet, Moritz, Lukas, Stefan, Luca, Richard, Lisa, Jonas, Nicholas, Janina, Lara, Marius, Britta, Franzi, Casper, Wolf, Fabian and Sophie! The constant flow of people moving in and out of the house has always reminded me that it became the place in which I nearly spent one-third of my life. A big 'Thank you' to the Bloemenweg-Gang. Out of those, I would like to single out Matthias, who has spent almost five years with me in that house. Our joint gym sessions, our library trips to Randwyck, our obligatory grocery shopping trips to Albert Heijn and LIDL, and the installation of a satellite dish on the roof of our house in early 2012 in the freezing cold at the risk of our lives are invaluable memories. A special 'Thank you' goes to my Maastricht friends Manuel and André for our legendary deep fry parties. Themba, I am happy that my favourite football team has gained a supporter from Zimbabwe!

I would also like to mention my very special friends from high school times in my hometown region. Arne, Christian, Dirk, Daniel, Felix, Marc, Malte, Timo: I am proud to call you my friends. Our endless football debates, political and philosophical discussions, and occasional nights of drinking will always be valuable memories. There are many other friends, spread all over the Europe and the world, that I am in contact with through visits, phone or skype calls, emails, and postcards: Matthias and Julia in Paderborn, Richard and Gerda in Berlin, Sebastian and Ute in Hückelhoven, John and Silvana in Melbourne, Ann, Geoff, Michael and Alicia in Melbourne, the Rowlinson and Radice families in Adelaide, Heike, Joao and Daniel in Pacos de Ferreira and 'Fussballphilosoph' Alexander in Lausanne. I am very happy and proud to call you my friends. 
I would also like to express my gratitude to my current employer ECORYS, and Albert de Groot and Corina Certan in particular, for having offered me a job as consultant in the International Development Unit. A big Thank you to all my colleagues at ECORYS for helping me to settle into my new workplace.

More than anything, I am indebted to my family. First and foremost, I would like to thank my parents for their love and support throughout my life, for encouraging me in all of my pursuits and inspiring me to follow my dreams. Mama und Papa: Euch ist dieses Buch gewidmet! Carsten and Carmen, I am proud to call you my siblings. Carmen, you are such kind-hearted, helpful, unselfish, considerate and reliable sister with a big heart. Carsten, your humorous, clownish, quick-witted and enterprising character is inspiring. Carsten and Xandra: I am impressed by your endless love towards your daughter Leah. You have been amazing parents! Leah, you are a joy to my heart and a precious gift to our entire family.

I would also like to thank "Onkel” Uwe, Tante Birgit, Ruth und Thorsten. You have been nothing but wonderful and loving. Our numerous family events, trips and holidays show me how strong my bond with you is. Thank you for all you have done, do, and will do. I am also grateful to four deceased loved ones: my paternal grandparents and my maternal grandparents. I have been incredibly blessed to have such amazing grandparents.

A special acknowledgement goes to Nicola Carr for proof-reading and editing a preliminary version of my thesis, to Melanie Waidler for creating a unique book cover design and to Liliane and the Boekenplan team for printing this book. Your tremendous help in finalizing my dissertation book is greatly appreciated.

Half way through my $\mathrm{PhD}$, the most wonderful girl entered my life out of nowhere and she now means the world to me. Clare, I am truly blessed to have you in my life. The fact that you are a native-English speaker came in very handy for proofreading my thesis. :) You gave me all the help, strength and determination to complete my thesis. You constantly remind me that happiness is the only thing that doubles when you share it: You are precious in every way, the sunshine in my day, the joy in my soul and the love of my life. 


\section{TABLE OF CONTENTS}

Acknowledgments

$\mathrm{V}$

List of Figures

List of Tables

List of Maps

Abbreviations

xii

xiii

$\mathrm{XV}$

xvi

\section{PART A}

1. Introduction

1.1. Background to the Research

1.2. Purpose of the Research

1.3. The Concept of Global Development Finance

1.4. Structure of the Dissertation

2. China's Economic Embrace of Africa An International Comparative Perspective

3. Do Authoritarian Regimes Receives More Chinese Development Finance than Democratic Ones? Empirical Evidence for Africa

4. Precolonial Centralisation, Foreign Aid and Modern State Capacity in Africa 


\section{PART B}

5. U.S. and Soviet Foreign Aid During the Cold War -
A Historical Case Study of Ethiopia

6. The Entry of China into the Development Finance Game - A Contemporary Case Study of Ethiopia

7. China's Entry into the Foreign Aid Game and Its Implications for the Donor-Recipient Relationship A Game Theoretical Approach

8. Conclusion

8.1. Summary of Findings

8.2. Policy Implications

8.3. Concluding Thoughts and Future Outlook

References

394

Valorization

Short Biography 


\section{LIST OF FIGURES}

Figure 1.1: An Overview of Global Development Finance 18

Figure 2.1: Evolution of China's Foreign Aid to Africa, 1953-2013 32

Figure 3.1: Distribution of Chinese Development Finance by regime type 76

Figure 3.2: Chinese Development Finance and Democracy Level of African Recipient Governments, 2000-2011 (abs.) 77

Figure 3.3: Chinese Development Finance and Democracy Level of African Recipient Governments, 2000-2011 (rel.) 79

Figure 4.1: Relationship between Precolonial Centralisation and State Capacity 125 Figure 4.2: Relationship between Precolonial Centralisation and Aid Dep. 129

Figure 5.1: Western Bilateral Development Assistance to Ethiopia, 1960-1990 212

Figure 6.1: Bilateral and Multilateral Aid to Ethiopia, 1960-2014 255

Figure 6.2: China's Health Aid to Africa in $2012 \quad 270$

Figure 6.3: Ethiopia's Aggregate Infrastructure Spending Needs 278

Figure 6.4: International competitiveness of foreign contractors in Sub-Saharan Africa by country of origin, 2005-06 280

Figure 6.5: Route of the Addis Ababa Light Rail Network 282

Figure 6.6: The Grand Ethiopian Renaissance Dam Project on the Nile River 288

Figure 6.7: Sectoral Distribution of Chinese Investment in Ethiopia, $2012 \quad 290$

Figure 6.8: Chinese Special Economic Zones in Africa, 2015

Figure 6.9: Special Economic Zones in Ethiopia, 2015

Figure 6.10: Average Education of Workers in Chinese Invested Enterprises 302

Figure 6.11: Evolution of Ethiopia’s GDP per capita, 1950-2012 308

Figure 6.12: Poverty Reduction in Ethiopia, 1990-2011 311

Figure 6.13: Poverty Reduction and Economic Growth in Ethiopia, 1990-2011 311

Figure 6.14: Press Freedom in Ethiopia, 1993-2013 317

Figure 6.15: World Governance ratings for Ethiopia, 1996-2012 318

Figure 6.16: Fiscal State Capacity in Ethiopia, 1990-2013 319

Figure 6.17: Bureaucratic State Capacity in Ethiopia, 1990-2012 320

Figure 6.18: The Evolution of Democracy in Ethiopia, 1946-2013 321

Figure 6.19: Africa Democracy Indices, 1900-2012 322

Figure 6.20: Democratic Accountability in Ethiopia, 1990-2013 322

Figure 7.1: Bilateral ODA Disbursements to Africa, 1990-2014 339

Figure 7.2: Ethiopia’s Aid Dependence in Comparative Perspective, 1990-2013 355

Figure 7.3: Bilateral DAC-ODA to Ethiopia, 1990-2013 (absolute\&per capita) 356

Figure 7.4: Democracy Aid Commitments to Ethiopia by DAC donors 362

Figure 7.5: Foreign Aid to the Horn of Africa, 1990-2014, Selected Donors 368 


\section{LIST OF TABLES}

Table 1.1: Chinese Actors in Sino-African Relations 12

Table 2.1: Chinese and Total Western Foreign Aid to Africa, 1960-2013 33

Table 2.2: Chinese and Individual DAC Donors Bilateral Foreign Aid to Africa, 1990 vs. 2013

Table 2.3: FDI Stock in Africa by Major Countries of Origin, 1985-2011 36

Table 2.4: Trade with Africa for Selected Countries, 1990 vs. 201237

Table 2.5: Sectoral Distribution of China's Foreign Aid, 1950-2009 39

Table 2.6: Sectoral Distribution of China's Completed Projects, 1950-2009 40

Table 2.7: Regional Distribution of China's External Flows to Africa 42

Table 2.8: Sectoral Distribution of Total Bilateral Net ODA Disbursements to the World, 1967-2012

Table 2.9: Sectoral Distribution of Total Bilateral Net ODA Disbursements in Africa, 1973-2012

Table 2.10: Sectoral Distrib. of World Bank Lending to Africa, 1946-2011 48

Table 2.11: Sectoral Distriution of China's Outward FDI Stock, 2010

Table 2.12: Investment/Aid Ratio in Africa for Major Home Economies 52

Table 2.13: China's Trade with African Countries by Sector, 2012 (\%) 54

Table 3.1: Recipients of Chinese Development Finance in Africa, 2000-2011 (abs.)

Table 3.2: Recipients of Chinese Development Finance in Africa, 2000-2011 (rel.)

Table 3.3: Correlation between Democracy Indices 74

Table 3.4: Summary Statistics

Table 3.5: Chinese Development Finance and Democracy Level of African Recipient Countries, 2000-2011, OLS (EDI)

Table 3.6: Chinese Development Finance and Democracy Level of African Recipient Countries, 2000-2011, OLS (P4I)

Table 3.7: Chinese Development Finance and Democracy Level of African Recipient Countries, 2000-2011, OLS (FHI)

Table 3.8: Chinese Development Finance and Democracy Level of African Recipient Countries, 2000-2011, OLS (VDI)

Table 3.9: Absolute Chinese Development Finance and Democracy Level of African Recipient Countries, 2000-2011, RE and FE

Table 3.10: Relative Chinese Development Finance and Democracy Level of African Recipient Countries, 2000-2011, RE and FE 
Table 3.11: Absolute Chinese Development Finance and Democracy Level of African Recipient Countries, 2000-2011, 2SLS Estimation

Table 3.12: Relative Chinese Development Finance and Democracy Level of African Recipient Countries, 2000-2011, 2SLS Estimation

Table 4.1: Summary Statistics for the Main Variables

Table 4.2: Precolonial Centralisation and Bureaucratic Quality in 2014, OLS

Table 4.3: Precolonial Centralisation and Bureaucratic Quality in 1986, OLS

Table 4.4: Aid Dependence, Precolonial Centralisation and Change in Bureaucratic Quality, 1984-2014, OLS

Table 4.5: Aid Dependence, Precolonial Centralisation and Change in Bureaucratic Quality, 1984-1995, OLS

Table 4.6: Aid Dependence, Precolonial Centralisation and Change in Bureaucratic Quality, 1996-2014, OLS

Table 4.7: Aid Dependence and Change in Bureaucratic Quality, Controlling for Initial Conditions, 1996-2014, OLS

Table 4.8: Precolonial Centralisation and Bureaucratic Quality in 2014, 2SLS

Table 4.9: Aid Dependence, Precolonial Centralisation and Change in Bureaucratic Quality, 1984-2014, 2SLS

Table 4.10: Aid Dependence, Precolonial Centralisation and Change in Bureaucratic Quality, 2SLS Estimates

Table 5.1: Crop production in 1972 by region, rel. to previous avg. production 190

Table 5.2: Total production of various crops in 1972, relative to previous average production

Table 5.3: Evolution of GDP (per capita) in Ethiopia, 1950-1974

Table 5.4: Sectoral Data on Value Added and Employment, Ethiopia, 1960-75 197

Table 5.5: People affected by Serious Food Shortages by Region, 1984-1986 214

Table 5.6: Evolution of GDP (per capita) in Ethiopia, 1975-1990

Table 5.7: Sectoral Data on Value Added and Employment, Ethiopia, 1975-90 222

Table 6.1: Net ODA Flows to Ethiopia by Major Donors, 1990-2011 238

Table 6.2: Evolution of GDP and GDP per capita in Ethiopia, 1990-2003 242

Table 6.3: Bilateral Aid to Ethiopia, 2000-2008, Selected Donors 250

Table 6.4: Multilateral Aid to Ethiopia, 2000-2008, Selected Donors 250

Table 6.5: Sectoral Distribution of DAC bilateral ODA commitments,Ethiopia 256

Table 6.6: Sectoral Distribution of U.S. bilateral ODA commitments, Ethiopia 257

Table 6.7: China's Aid to Ethiopia in Comparative Perspective, 1959-98, 2012263

Table 6.8: Ethiopia's Major Aid Donors, 1992 and 2012

Table 6.9: China's FDI Flows to Ethiopia in Comp. Perspective, 2003+2013 264

Table 6.10: China's FDI Stock in Ethiopia in Comp. Perspective, 2003+2013 265

Table 6.11: Ethiopia's Major Investors, 1992-2015 265 
Table 6.12: China's Trade with Ethiopia in Comp. Perspective, 1992/2012 266

Table 6.13: Ethiopia's Major Trading Partners, 1995 and 2012

Table 6.14: Infrastructure endowments in the early 2000s, Ethiopia vs. Africa 277

Table 6.15: Ethiopian Industrial operated/owned by the IPDC, Sept. 2016299

Table 6.16: Chinese Shoe Imports and the Ethiopian Shoe Industry 301

Table 6.17: Numbers of Ethiopian Employees in Chinese Invested Enterprises 303

Table 6.18: Economic Growth Rates Under Three Regimes 307

Table 6.19: Sectoral Data on Value Added and Employment in Ethiopia, 1990-2010

Table 6.20: Poverty Headcount Ratio in Ethiopia, 1996-2011 313

Table 6.21: Education and Health Indicators in Ethiopia, 1992-2012 314

Table 6.22: Infrastructure Indicators in Ethiopia, 1992-2012 316

Table 7.1: U.S. and Chinese Foreign Finance to Africa, 1992 and $2012 \quad 340$

Table 7.2: Chinese Official Development Finance to Africa, 2000-2013 341

Table 7.3: Official development assistance and development finance to Ethiopia 361

Table 7.4: ODA disbursements to Ethiopia, 1990-2015, Selected Donors 364

Table 7.5: Official development finance disbursements to Ethiopia, 1990-2015, Selected Donors 366

Table 7.6: Yearly Average Foreign Aid and Democracy Assistance, 2002-2014, Selected Western Donors 370

\section{LIST OF MAPS}

Map 5.1: Ethiopia and the Horn of Africa

Map 5.2: Administrative Regions and Zones in Ethiopia 


\section{ABBREVIATIONS}

2SLS $\quad-$ Two Stage Least Squares

AALRT - Addis Ababa Light Railway Transit

ABED - Arab Bank for Economic Development

AfDB - African Development Bank

AFRODAD - African Forum and Network on Debt and Development

ANDM - Amhara National Democratic Movement

ATDC - Agricultural Technology Demonstration Centres

AU - African Union

BEA - US Bureau of Economic Analysis

BRICS - Brazil, Russia, India, China and South Africa

CCECC - China Civil Engineering Construction Corporation

COMESA - Common Market for Eastern and Southern Africa

CRG - China Railway Group Limited

CSP - Center for Systemic Peace

CUD - Coalition for Unity and Democracy

DAC - Development Assistance Committee

DAG - Development Assistance Group to Ethiopia

DCD - Development Co-operation Directorate

DFID - United Kingdom Department for International Development

DGA - Democracy and Governance Aid

DRC - Democratic Republic of Congo

EAC $\quad-$ East African Community

EC - European Commission

ECOWAS - Economic Community of West African States

EDI - Electoral Democracy Index

EDRI $\quad-$ Ethiopian Development Research Institute

EIA - Energy Information Administration

EIB - European Investment Bank

EIZ - Eastern Industrial Zone

ELF - Eritrean Liberation Front

EOM - Election Observation Mission 
EPDM $\quad-$ Ethiopian People's Democratic Movement

EPLF - Eritrean People's Liberation Front

EPRDF $\quad-$ Ethiopian People's Revolutionary Democratic Front

EPRP $\quad-$ Ethiopian People's Revolutionary Party

ESM $\quad-$ Ethiopian Student Movement

EU - European Union

EUE $\quad-$ Emergencies Unit for Ethiopia

EXIMBANK - Export-Import Bank of China

FAO $\quad-$ Food and Agriculture Organization of the United Nations

FDI $\quad-$ Foreign Direct Investment

FHI - Freedom House Index

FOCAC - Forum on China-Africa Cooperation

GDP $\quad-$ Gross Domestic Product

GGDC - Groningen Growth and Development Centre

GNP $\quad-$ Gross National Product

GTP $\quad-$ Growth and Transformation Plan

HIPC - Heavily Indebted Poor Countries

IBRD - International Bank for Reconstruction and Development

ICBC - Industrial and Commercial Bank of China

ICRG - International Country Risk Guide

IDA - International Development Association

IHA - Imperial Highway Authority

IMF - International Monetary Fund

IPDC - Industrial Parks Development Corporation

ITT - International Telephone and Telegraph

JICA - Japan International Cooperation Agency

KGB - Committee for State Security in the Soviet Union

MAAG - Military Assistance Advisory Group

MGDs - Millennium Development Goals

MoF - Chinese Ministry of Finance

MOFA - Chinese Ministry of Foreign Affairs

MOFCOM - Chinese Ministry of Commerce

MSF - Médecins Sans Frontières (Doctors Without Borders)

NEBE - National Election Board of Ethiopia

NGO - Non-Governmental Organization

OAU - Organization of the African Union 


$\begin{array}{ll}\text { ODA } & \text { - Official Development Assistance } \\ \text { OECD } & \text { - Organisation for Economic Cooperation and Development } \\ \text { OLS } & \text { - Ordinary Least Squares } \\ \text { OOF } & \text { - Other Official Flows } \\ \text { OPDO } & \text { - Oromo Peoples' Democratic Organization } \\ \text { OPEC } & \text { - Organization of the Petroleum Exporting Countries } \\ \text { P4I } & \text { - Polity IV Index } \\ \text { PASDEP } & \text { - Plan for Accelerated, Sustained Development to End Poverty } \\ \text { PPP } & \text { - Purchasing Power Parity } \\ \text { PRC } & \text { - People's Republic of China } \\ \text { PRS } & \text { - Political Risk Services } \\ \text { PRSP } & \text { - Poverty Reduction Strategy Papers } \\ \text { PVO } & \text { - Private Voluntary Organizations } \\ \text { PWT } & \text { - Penn World Tables } \\ \text { RCT } & \text { - Randomized Control Trial } \\ \text { ROC } & \text { - Republic of China (Taiwan) } \\ \text { RRC } & \text { - Relief and Rehabilitation Commission } \\ \text { SADEC } & \text { - Southern African Development Community } \\ \text { SAP } & \text { - Structural Adjustment Programme } \\ \text { SDG } & \text { - Sustainable Development Goal } \\ \text { SDPRP } & \text { - Sustainable Development and Poverty Reduction Programme } \\ \text { SEPDM } & \text { - Southern Ethiopian People's Democratic Movement } \\ \text { SEZ } & \text { - Special Economic Zone } \\ \text { SIDA } & \text { - Swedish International Development Agency } \\ \text { SIRA } & \text { - Ethiopian Security, Immigration and Refugees Affairs Authority } \\ \text { SME } & \text { - Small and Medium-sized Enterprise } \\ \text { SNA } & \text { - Somali National Army } \\ \text { SNNP } & \text { - Southern Nations, Nationalities, and Peoples Region } \\ \text { SOE } & \text { - State-owned Enterprise } \\ \text { SPLA/M } & \text { - Sudan People's Liberation Army/Movement } \\ \text { SSA } & \text { - Sub-Saharan Africa } \\ \text { TAZARA } & \text { - Tanzania-Zambia Railway } \\ \text { TPLF } & \text { - Tigrayan People's Liberation Front } \\ \text { TSI } & \text { - Tsetse Fly Suitability Index } \\ \text { TUFF } & \text { - Tracking Underreported Financial Flows } \\ \text { UEDF } & \text { - United Ethiopian Democratic Forces }\end{array}$


UK - United Kingdom

UN - United Nations

UNCTAD - United Nations Conference on Trade and Development

UNDP - United Nations Development Programme

UNGA - United Nations General Assembly

UNICEF - United Nations Children's Fund

UNITAF - Unified Task Force for Somalia

USA - United States of America

USAID - United States Agency for International Development

USSR - Union of Soviet Socialist Republics

VDI - Vanhanen Democratization Index

WDI - World Development Indicators

WFP - World Food Programme of the United Nations

WGI - World Governance Indicators

WTO - World Trade Organization

WWI - First World War

WWII - Second World War

ZTE - Zhong Xing Telecommunication Equipment Company Limited 



\section{CHAPTER 1}

\section{INTRODUCTION}

\section{"Ex Africa semper aliquid novi." (From Africa always something new) - Gaius Plinius Secundus, better known as Pliny the Elder (AD 23 - AD 79) Roman author, naturalist, and natural philosopher}

"China is a sleeping giant. Let her sleep, for when she wakes she will move the world." - Napoléon Bonaparte (1769-1821) Emperor of France (1804-1814, and 1815) 


\section{CHAPTER 1}

A "silent revolution" 1 has taken place in the developing world: The rules of the game of international development cooperation between donor countries and recipient countries have begun to change as emerging economies like China, India or Brazil have started to significantly increase their foreign finance to the developing world at the beginning of the $21^{\text {st }}$ century (for a clear definition of the term 'foreign finance' or 'development finance', see Section 1.3). It must be emphasized that the change in the rules of international development cooperation is not a phenomenon primarily arising out of Africa. Though African governments have started to actively solicit development finance from non-traditional donors and investors, the changes in the international order have much more to do with the rise of China and other emerging economies. China can be considered at the forefront of this "silent revolution".

Using the case of Chinese development finance in Africa, the main research question throughout the dissertation is how the entry of players from the Global South like China into the foreign aid game (or development finance game more broadly) affects the current framework of international development cooperation between the traditional donors and investors on the one hand and African recipient countries on the other hand. Can the arrival of new actors in the global economy be regarded a significant game changer in the international development architecture, until recently dominated by Western ${ }^{2}$ development ideas, finance and practices? And if so, what are the mechanisms and channels at play through which powerful new actors such as China gain increasing bargaining power in the developing world?

The term 'foreign aid game' is borrowed from Beim (1964). I use the term 'game' to refer to the game theoretical aspect of providing development finance, rather than the idea that people and countries are playing games in the literal sense. During the aid negotiation process both the donor community and recipient governments have specific motivations and goals (i.e. preferences), follow particular negotiating strategies aimed at maximizing the success (i.e. payoff) of their negotiating strategies. Donors pursue specific strategic goals when

\footnotetext{
${ }^{1}$ These words are borrowed from Woods (2008).

${ }^{2}$ Throughout the dissertation, I will define the 'West' as the Development Assistance Committee (DAC) members of the Organisation for Economic Co-operation and Development's (OECD). The DAC was established in 1960 by Belgium, Canada, France, Germany, Italy, Portugal, the United Kingdom, the United States and the Commission of the European Economic Community to coordinate their aid policies (Stokke, 2009).
} 
delivering development finance to recipient countries. As a result, donors often attach political or economic conditions to the delivery of money and try to enforce compliance with those. Recipient countries, of course, want to maximize the amount of foreign finance resources while minimizing the amount of compliances that come with the delivery of aid. The donor-recipient exchanges can therefore be regarded as strategic outcomes of bargaining games (Putnam, 1988), and the only "acceptable outcomes of the bargaining game are aid arrangements within each player's win set, varying according to which side pulls the other closest to its preferred position" (Hopkins, 2000, p. 330).

A second objective of this dissertation is to assess the relationships between both traditional Western and Chinese development finance and Africa's political, economic, social and institutional development (Part A), and in particular at the country level where Ethiopia is used as case study (Part B).

The rest of this introductory part is structured as follows. Section 1.1 provides some background information to the research topic. Section 1.2 highlights the purpose of the research conducted in this dissertation. Section 1.3 aims to familiarize the reader with the concept of global development finance. Eventually, Section 1.4 gives an outline of the thesis.

\subsection{Background to the Research}

\subsubsection{Western Development Assistance and African Development}

Since the wave of struggles for independence in formerly European-ruled African territories spread across the continent in the late 1950s, more than $\$ 1$ trillion of development-related aid has been transferred from 'Western' countries to Africa until the early $21^{\text {st }}$ century (Moyo, 2009). ${ }^{3}$ Despite this gigantic one-way financial transfer, much of the African continent has been haunted by natural and man-made disasters, diseases, dictators and little development, exemplified

\footnotetext{
${ }^{3}$ The overall amount of Western aid to developing regions across the world between the 1950s and mid-2000s is estimated to be $\$ 2.3$ trillion with Africa being the main destination of foreign aid (Easterly, 2006).
} 


\section{CHAPTER 1}

by high poverty levels, economic stagnation, ethnic violence, civil wars as well as poor health and education records (Collier, 2007; Easterly, 2007).4

During the mid-2000s, roughly 50 percent of Africa's population (380 million) lived below the World Bank's international extreme poverty line with a mean consumption of $\$ 0.73$ a day (Chen \& Ravallion, 2010). ${ }^{5}$ Some scholars even argue that much of Africa's 'underdevelopment' has been caused by the systemic aid flows triggering a wide-ranging debate about the effectiveness of aid in reducing poverty and promoting socio-economic development (Banerjee, 2007; Easterly, 2006; Moyo, 2009; Riddell, 2007; Sachs, 2005).

The Western donor community succumbed to donor fatigue throughout much of the 1990s. It seemed like huge foreign aid flows had contributed very little to economic growth and development in poor countries. Witnessing (i) recurring economic slumps, famines, civil wars and coup d'états on the continent, (ii) the emergence of new recipient countries in Eastern Europe, and (iii) growing demands by the Western population for increased social spending at home led both public and private development organizations to increasingly turn their back to the developing world, particularly Africa. C. Payne Lucas, head of the Washington-based aid group "Africare", commented in 1991: "Africa's just off the map. People think Africa is marginalized, that it doesn't have any potential." 6

More generally, the African continent has witnessed "many of the 'negative flows' of globalization such as competitive displacement of manufacturing through trade, massive capital flight and debt" (Carmody \& Owusu, 2007, p.

\footnotetext{
${ }^{4}$ Africa's political trajectory by the end of the Cold War looked bleak: by 1989, thirty-eight out of forty-five Sub-Saharan African countries were being ruled either by (i) an autocrat, (ii) the military or (iii) a single party (Ake, 1996). Before 1990, more than nine out of ten incoming national leaders were appointed to their posts by military or party elites. Bates (2008) remarks that between the early 1970s and 1980s, more than 80 percent of the yearly country observations did either contain no- or one-party systems, while more than 50 percent cent experienced multiparty systems by the mid-1990s. In fact, 41 out of 47 Sub-Saharan African countries implemented significant political reforms in the period 1989-1994 (Bratton \& van de Walle, 1997). For a recent discussion on the state of democracy in Sub-Saharan Africa, see Bates, Fayad and Hoeffler (2012).

${ }^{5}$ Chen and Ravallion (2010) observe that "the mean consumption of Africa's poor is not only lower than for other regions, it has shown very little increase over time (...). The mean consumption of those living under $\$ 1.25$ per day in SSA [Sub-Saharan Africa] was $\$ 0.72$ per person per day in 1981 and was almost unchanged at $\$ 0.73$ in 2005” (p. 1611).

${ }^{6}$ For more information, see http://articles.latimes.com/1991-03-08/news/mn-2351 1 donorfatigue
} 
518) and experienced "very few (...) of the 'positive flows' of FDI [foreign direct investment] in manufacturing or information and communication technology" (Carmody \& Owusu, 2007, p. 518). In the mid-1990s, Manuel Castells (1996) portrayed much of Africa as a "black hole of informational capitalism", remaining at the extreme margin of the world economy due to a systematic exclusion from global capital accumulation and global information flows.

\subsubsection{From the "Hopeless Continent" to the "Hopeful Continent"}

In May 2000, the front page of the Economist magazine depicted Africa as the "hopeless continent" characterized by "brutality, despotism and corruption", inimical for economic development, peace, political stability and good governance. Eleven years later, in December 2011, the front cover of the Economist devoted its cover page once again to the African continent. The message and image of the African continent portrayed by the magazine could not have been more different. Between 2000 and 2011, the Economist made a U-turn on the continent from "Africa: The hopeless continent" to "Africa Rising: The hopeful continent" and "Africa's hopeful economies: the sun shines bright". It argued that "after decades of slow growth, Africa has a real chance to follow in the footsteps of Asia". The Economist was not alone. Since the late2000s, several book publications have highlighted the rise of the African continent with high economic growth, increased educational opportunities, an emerging middle class, abundant business opportunities and political transformations as main drivers. ${ }^{7}$

What has happened on the African continent between 2000 and the early 2010s? During the mid-2000s, one fundamental change that took place in Africa was the rise of the BRICS countries and their strengthening economic and trade

\footnotetext{
7 The list of publications is long and includes, among others, Vijay Mahajan's (2008) "Africa Rising: How 900 Million African Consumers Offer More Than You Think", Steven Radelet's (2010) "Emerging Africa: How 17 Countries Are Leading the Way", Jean-Michel Severino's (2011) “Africa’s Moment”, Robert Rotberg's (2013) “Africa Emerges: Consummate Challenges, Abundant Opportunities", Jonathan Berman's (2013) "Success in Africa: CEO Insights from a Continent on the Rise", Kingsley Chiedu Moghalu's (2014) "Emerging Africa: How the Global Economy's 'Last Frontier' Can Prosper and Matter", "The Emerging Middle Class in Africa” by Mthuli Ncube and Charles Leyeka Lufumpa (2014), Alex Perry's (2015) “The Rift: A New Africa Breaks Free” and "The Rise of Africa's Middle Class" by Henning Melber (2016).
} 


\title{
CHAPTER 1
}

relationships with African countries. While one should be careful in establishing a monocausality between the emergence of the BRICS economies in Africa and Africa's recent impressive economic growth record, the BRICS have certainly contributed to changing perceptions of Africa's economic fortunes among the international donor community. Woods (2008) observes that

\begin{abstract}
"emerging donors are stepping into relations with the 'development partners' of established donors. This is a silent revolution because emerging donors are not overtly attempting to overturn rules or replace them. Rather, by quietly offering alternatives to aid-receiving countries, they are introducing competitive pressures into the existing system." (p. 16-17)
\end{abstract}

The most important emerging player from the BRICS group on African soil is China for three main reasons. First, China provides the largest share of foreign finance for Africa from the Global South. China can therefore be considered the head of the group of emerging donors and investors (Woods, 2008). Second, since China's economy is bigger than that of the rest of the BRICS countries combined (Cooper, 2016; Naudé, Szirmai, \& Haraguchi, 2015), it is Chinese development finance that will most likely have the most profound impact on the international development finance architecture and the negotiation process with African recipient countries. And third, China's economic embrace of Africa increasingly challenges the United States' status as the only superpower in the current world order (Ramo, 2004).

\subsubsection{Historical Sino-African Relations in a Nutshell}

China's socio-economic, cultural, political and military relations with Africa have a long unofficial history dating back as far as 202 BC, when Chinese merchants traded with parts of East Africa (Snow, 1988; Taylor, 2006b). In the mid-14 ${ }^{\text {th }}$ century the Somali scholar and traveller Sa'id of Mogadishu as well as the Moroccan scholar and traveller Ibn Battuta visited Chinese cities such as Beijing, Guangzhou and Hangzhou. Loose Sino-African relationships existed during the Sung dynasty (960-1279), Yuan dynasty (1279-1368) and the Ming dynasty (1368-1644) (Alden \& Alves, 2008). In the early $15^{\text {th }}$ century, the Ming Dynasty 


\section{CHAPTER 1}

admiral Zheng He and his large fleet ${ }^{8}$ arrived in East Africa visiting Mogadishu, Brava and Juba in what is now Somalia, as well as the coastal state of Malindi (which is located in present-day Kenya).

"Unlike the Europeans that arrived 70 years after Zheng He the Chinese were not aggressive and (...) stormed no cities and conquered no land, refraining from plunder.” (Power, Mohan, \& Tan-Mullins, 2012, p. 32)

"Instead they coaxed the coastal rulers into trading by presenting them with gifts of coloured silk. They did not burn (...) with the urge to impose their religious convictions to lay siege to African souls. All they sought from Africans was a gesture of symbolic acquiescence in the Chinese view of the world." (Snow, 1988, p. 29)

Despite the early naval explorations, the Ming Dynasty (1368-1644) adopted an inward-looking strategy prohibiting all trade overseas (Elvin, 1973; Landes, 1998, 2006; Pomeranz, 2000). Consequently, large-scale economic relationships between China and Africa did not occur until the colonial era when European powers used Chinese labour in the 'Scramble for Africa' (Grant, 2005). After the Second World War (WWII), when African countries gradually gained their independence, Sino-African relations entered the modern phase. The AsianAfrican Conference, which took place in April 1955 in Bandung, Indonesia (therefore also known as Bandung Conference), became a historical watershed in Asian-African international relations and can be regarded as an important milestone in the establishment of formal international relationships between the newly independent countries of Africa and Asia (Ampiah, 2007; Kahin, 1956; Mackie, 2005).

Due to China's fear of Soviet dominance and the concomitant doctrinal divergence between the two largest Communist states during the Cold War era, the Beijing administration was eager to promote itself as key development partner for the developing world positioning itself as a buffer between Moscow and Washington. China (i) supported African independence movements, (ii) emphasized the shared colonial experience, (iii) cultivated diplomatic relationships based on the idea of peaceful-coexistence and (iv) provided development finance throughout the 1960s and 1970s even though China itself

\footnotetext{
8 The fleet by Zheng He is considered to be six times larger than Christoph Columbus' small ships used for his voyage across the Atlantic Ocean (Bräutigam, 2009).
} 


\section{CHAPTER 1}

was still a developing country. It was in Africa where the Beijing administration undertook its largest single foreign aid project: Between 1970 and 1975, Chinese authorities constructed the Tanzania-Zambia-Railway (TAZARA) connecting the Tanzanian port of Dar es Salaam with the Copperbelt, the industrial heartland of Zambia (Power et al., 2012).

Counterintuitively, Sino-African relations weakened between the early 1980s and 1990s when China adopted an outward-looking transformation strategy. In December 1978, Deng Xiaoping launched an economic reform package termed "Socialism with Chinese characteristics". Deng Xiaoping's opening up policy was aimed at promoting economic growth, reducing poverty and bolstering the Chinese Communist Party's legitimacy. As a result, the Beijing administration adopted a "Welcoming in" (Yin jinlai) policy that sought to strengthen economic ties with the Western industrialized world primarily through attracting foreign capital in Special Economic Zones (SEZs), domestic capital accumulation, market reform, private sector development, financial sector liberalization, technological advancement and institutional reforms. Generous economic assistance for the developing world, including Africa, was significantly cut back. As a result, Sino-African relations "appeared to be put on the backburner" (Hirono \& Suzuki, 2014, p. 444) until the mid-1990s.

\subsubsection{Re-emergence of China-Africa Relations}

China's "welcoming in" policy has increasingly been complemented by its "going out" policy. Initiated in 1999, Beijing's "Going out" strategy refers to the effort by the Chinese government to encourage domestic firms (i) to expand into foreign markets and consequently (ii) to seek for international and global market opportunities. By integrating into new markets, Chinese firms could acquire Western technology, knowledge, management skills and foreign currency, pursue product diversification and promote brand recognition by improving the level and quality of their goods and services in developed, emerging and underdeveloped markets. China's accession to the World Trade Organization (WTO) in 2001 further accelerated its integration into the world economy. China's expansion in Africa, however, was also driven by strategic and geopolitical issues. Beijing's strengthening ties with the African continent have to be analysed in the context of China's domestic policy and economic trajectory. 


\section{CHAPTER 1}

"China needs to achieve at least 8 percent annual growth to maintain social stability, and therefore a constant supply of raw materials is needed to keep the 'factory of the world' and China's urbanization - two of the country's driving economic forces - from stagnating. For Beijing, there is simply too much at stake to leave such matters in the hands of the market." (Cardenal \& Araújo, 2013, p. 7)

Beijing is determined to become a key development partner for the developing world, including Africa. As this dissertation will show, the arrival of new sources of foreign finance, knowledge, expertise and development ideas from countries like China increasingly challenge the current international development finance architecture as development cooperation between African developing countries and emerging countries from the Global South is quite distinct from traditional development cooperation between African countries and the Western donor community. Very recently, yet another economic paradigm has emerged out of China aimed at expanding its political and economic relationships with the rest of the world. In 2013, the Chinese government launched the 'One Belt, One Road' initiative aimed at connecting China primarily with the rest of Eurasia, but also West Asia, the Middle East, Europe and East Africa through the land-based "Silk Road Economic Belt" and the oceangoing "Maritime Silk Road". The idea of the 'One Belt, One Road' initiative is to move the country's domestic overcapacity and capital towards the establishment of a comprehensive Eurasian infrastructure network which in turn is aimed at promoting intraregional trade relations between China and all regions included in the 'One Belt, One Road' initiative.

China's advancement falls in a time that coincides with the gradual retreat of the West from globalisation, as the rise of populist, anti-globalisation parties in Europe and the recent election of Donald Trump as U.S. president can testify. Trump's decision to end U.S. participation in the Trans-Pacific Partnership trade deal casts significant doubts about the U.S. commitment to global agreements related to free trade, climate change and development cooperation. This, in turn, provides the Chinese government with a unique opportunity to launch its own foreign policy initiatives and to strengthen its global leadership position (Larmer, 2017). 


\section{CHAPTER 1}

Napoleon Bonaparte's observation that China is a sleeping giant and will move the world when she wakes is certainly true in today's world and especially relevant in the African context. Since the beginning of the $21^{\text {st }}$ century, SinoAfrican relationships have strengthened again in the economic, political and diplomatic spheres. When scholars therefore talk about the 'rise' or 'emergence' of China in Africa, they usually refer to strengthening Sino-African ties from the early $21^{\text {st }}$ century onwards. China's economic and political influence is reaching to almost all corners of the globe, including African countries. ${ }^{9}$ Beijing's "GoingOut" strategy coincides with the 'Look East Policy' increasingly adopted by several African governments. The probably most important platform underlining Beijing's "Go Out" Strategy is the Forum on China-Africa Cooperation (FOCAC) with regular meetings held every five years. The FOCAC serves as avenue for dialogue between China and African countries and as a mechanism for expanding development cooperation. While Egypt was the first country to receive development assistance from China in 1956, by 2009, no less than 49 out of then 53 African countries participated in the FOCAC.

Africa's economic development and fate becomes increasingly tied to China's foreign finance and development support. As a result, analysing Africa's economic and political development trajectory cannot be discussed without paying attention to China.

\subsection{Purpose of the Research}

China's rising economic and political influence on the African continent has triggered a vast media response. China's expanding relations with Africa are increasingly regarded as a threat to the current international development finance architecture by the Western world (Carmody \& Owusu, 2007; Tull, 2006).

This dissertation examines China's growing economic and political influence on the African continent and seeks to understand the consequences of China's rise

\footnotetext{
${ }_{9}^{9}$ In a private dinner conversation with Robert Rotberg, Harvard Professor for international relations theory and former member of the U.S. Secretary of State's Advisory Panel on Africa, in Pecs, Hungary, he told me that there are three things that you do not only see in every African city but in every African village as well: Coca-Cola bottles, mobile phones and a Chinese worker. It was a statement with slight exaggeration to convey the true meaning of China's embrace of Africa.
} 


\section{CHAPTER 1}

for the Western donor community, African recipient governments but also Africa's economic, political and institutional development trajectory. The three major research questions that this dissertation aims to address are:

- What is the role of both Western and Chinese foreign aid in explaining current economic, political and institutional developments in Africa?

- To what degree has China's economic embrace of Africa the potential to change the international development finance architecture?

- To what extent has the entry of China into the foreign aid game increased the bargaining power of African recipient governments?

In order to answer these research questions, the Chinese actors need to be defined first. Table 1.1 portrays the different Chinese actors in the Sino-African relations - the Chinese government, Chinese state-owned enterprises, private Chinese firms, Chinese embassies and Chinese migrants - and the Chinese 'instruments' - foreign aid, foreign direct investment (FDI), international trade, other financial flows and migration. The actors and instruments displayed in the darker shaded areas - in particular the Chinese government and Chinese foreign aid, but also Chinese state-owned enterprises and FDI - will lie at the core of the analysis of China's economic embrace of Africa.

Throughout the thesis, "Sino-African relations" will mainly refer to state-to-state (or government-to-government) exchanges subject to particular and deliberate "strategies" as these relationships are by far the most developed and - according to the author - the most interesting ones from a game-theoretical perspective. One should bear in mind, however, that the state-to-state exchanges are only one part of a much larger set of Sino-African relations. The thesis will also, at times, discuss the patterns and motivations of Chinese state-owned enterprises in Africa as their activities are often closely linked to the state-to-state exchanges.

Private Chinese companies but also individual Chinese migrants form yet another (growing) part of Sino-African relations. In particular, Chinese individuals migrate to Africa assemi-permanent or permanent settlers opening up shops, buying land, setting up and running small enterprises and potentially getting married there. Such waves of migration are not new, as they are deeply rooted in centuries of Chinese history, although previous waves of migration focused primarily on South-East Asia and to a lesser extent on North and South 


\section{CHAPTER 1}

America. The recent migration wave to Africa, however, is not part of a deliberate "state-run" program and the motivations by Chinese migrants to come to Africa are often much more complex, ranging from expanding business opportunities to escaping a repressive political climate back home.

Table 1.1: Chinese Actors in Sino-African Relations

\begin{tabular}{ll}
\hline \multicolumn{1}{c}{$\begin{array}{c}\text { Main Chinese actors } \\
\text { in Africa }\end{array}$} & \multicolumn{1}{c}{$\begin{array}{c}\text { Measuring Chinese presence } \\
\text { in Africa }\end{array}$} \\
\hline The Chinese government & $\begin{array}{l}\text { Chinese foreign aid } \\
\text { (grants, soft loans and debt relief) }\end{array}$ \\
\hline State-owned enterprises & Chinese foreign direct investment \\
\hline Private Chinese firms & $\begin{array}{l}\text { Sino-African trade } \\
\text { (Goods and services) }\end{array}$ \\
\hline Chinese embassies & $\begin{array}{l}\text { Other financial flows } \\
\text { (normal loans \& export credit facilities) }\end{array}$ \\
\hline Chinese people & $\begin{array}{l}\text { Migration } \\
\text { (Chinese people living in Africa) }\end{array}$ \\
\hline
\end{tabular}

Source: Based on work by van Dijk (2009)

Even though there is a growing literature on Chinese settlement in Africa which argues that Chinese migrants constitute a non-negligible part of resurgent SinoAfrican ties (French, 2014), these people do not provide foreign aid in a direct sense. Consequenly, while the role of Chinese migrants in China's economic embrace of Africa should not be underestimated, they will not be a major subject throughout this book.

Since the thesis will primarily adopt a state-level perspective when analysing the strengthening Sino-African relationships, the role of non-governmental organizations receives rather limited attention, with the exception of some references in Chapters 5 and 6. The author, however, acknowledges that the role of non-governmental organizations (NGOs) has become extremely important and diversified over the last two or three decades. Similar organizations already existed in the $19^{\text {th }}$ century when large influxes of Christian missionaries, often closely linked to the colonial governments, contributed to the spread of education and health care facilities in some parts of the African continent between 1850 and 1960. So while this thesis primarily views Sino-African relations from a state level perspective, it should be self-evident that there exist 
a variety of "new actors" in the global economy that carry the adjective "Chinese".

The overarching goal of this dissertation is to contribute to a less Eurocentric academic research on the political economy of both traditional and nontraditional development finance in Africa. Despite the rising literature on SinoAfrican relations, several accusations, prejudices and stereotypes about China's increasing presence in Africa have been remarkably durable. One of the most influential global thought leaders, Moisés Naím, distinguished Fellow at the Carnegie Endowment for International Peace, an internationally syndicated columnist, former Minister of Trade and Industry for Venezuela and Executive Director of the World Bank, argued that
"States like China $(. .$.$) are regimes that have the cash and the will to$ reshape the world into a place very different from where the rest of us want to live. (...) If they continue to succeed in pushing their alternative development model, they will succeed in underwriting a world that is more corrupt, chaotic, and authoritarian.” (Naím, 2007)

Former U.S. Secretary of State Hillary Clinton associates China's economic embrace of Africa with a return of colonialism on the continent. During a fiveday Africa tour in June 2011, Clinton exclaimed in a television interview in Lusaka, Zambia:
"We don't want to see a new colonialism in Africa (...) We are beginning to see a lot of problems. (...) There are more lessons to learn from the United States and democracies." 10

During her visit in Dar es Salaam, Tanzania, in the same week, Clinton expressed great concern that "China's foreign assistance and investment practices in Africa have not
always been consistent with generally accepted international norms of
transparency and good governance, and that it has not always utilized the
talents of the African people in pursuing its business interests." (cited in
Power et al., 2012)

\footnotetext{
10 For more information, see http://www.reuters.com/article/us-clinton-africaidUSTRE75A0RI20110611
} 


\section{CHAPTER 1}

In August 2012, during her fourth Africa visit, Clinton warned African governments about the emergence of neo-colonial relations with China arguing that

"[t] he days of having outsiders come and extract the wealth of Africa for themselves, leaving nothing or very little behind, should be over in the 21st century." 11

In a similar vein, then British Prime Minister David Cameron warned African governments over Beijing's 'authoritarian capitalism', during his Africa tour in Lagos, Nigeria, on 20 July 2011:

"I believe the model of authoritarian capitalism [in China] we are seeing will fall short in the long term... When people get economically richer they make legitimate demands for political freedoms to match their economic freedoms. The model is unable to respond." (cited in Power et al., 2012)

Other scholars, like Hirono and Suzuki (2014), argue that more nuanced research on Sino-African relations is needed as it provides an important counterpart

"the dichotomous and myopic debates of the 'China threat' that has impoverished the debate on Sino-African relations (...) [There exist] complacent Western views that Western ideological influences are axiomatically 'universal' and will be welcomed by the peoples throughout the world. (...) We need to overcome the deep sense of Western exceptionalism that has continued to color the lenses by which we view international politics." (Hirono \& Suzuki, 2014, p. 460)

The examples above show that there exists a great amount of anxiety about China's rising activities in Africa. Several scholars associate China's rising exposure to Africa with a 'New Scramble for Africa', a return to colonial trade structures, a return of authoritarian politics and rising political and military conflict (Carmody, 2011; Naím, 2007; Taylor, 2007a; Tull, 2006). One major aim of this dissertation is to empirically investigate two specific major charges against China's development finance in Africa, namely (i) whether China's foreign

11 For more information, see http://www.csmonitor.com/USA/ForeignPolicy/2012/0801/Hillary-Clinton-goes-to-sub-Saharan-Africa-a-counterpoise-to-China-ssway 


\section{CHAPTER 1}

finance is predominantly driven by the need to secure natural resources and (ii) whether Chinese development finance systematically targets more authoritarian recipient countries in Africa, ceteris paribus.

Since the late 1990s, a public debate has emerged between "aid optimists" and "aid pessimists" about the effectiveness of foreign aid. Aid pessimists have argued that large and often unconditional flows of Western development assistance to the developing world, especially Africa, have negative effects on governance and state capacity of recipient governments (Besley \& Persson, 2011; Bräutigam \& Knack, 2004; Deaton, 2013; Djankov, Montalvo, \& Reynal-Querol, 2008; Easterly, 2006; Moyo, 2009; Rajan \& Subramanian, 2007). Aid optimists highlight, both theoretically and empirically, the net positive effects of foreign aid on political institutions, growth and poverty reduction (Altincekic \& Bearce, 2014; Dietrich \& Wright, 2015; Goldsmith, 2001; Jones \& Tarp, 2016; Wright, 2009).

While Part A of this dissertation provides a macro perspective on the continent as a whole, Part B moves to the country level taking both a macro and micro perspective. As this dissertation will show, China's re-emergence on the African continent has profound implications on the international development cooperation architecture. There is overwhelming evidence corroborating the notion that the emergence of countries from the Global South like China on the African continent has altered the international development finance game (Chapter 2, Chapter 6 and Chapter 7). If we want to understand the risks, challenges and opportunities of Africa's political and economic development trajectory, we can no longer discuss it without reference to the BRICS countries.

Even though Africa's traditional donor, investor and trading partners like Europe, the United States, Canada and Japan will remain crucial sources of foreign finance and development ideas, emerging countries from the Global South like China will increasingly shape the international foreign finance agenda and globalization more broadly. As a result, development cooperation with the developing world will no longer be an exclusive domain of Western countries.

At the same time, this dissertation shows how past, present and future African recipient governments can increase their bargaining power in the aid negotiation process with the international donor community (Part B). China's entry into the aid game, its policy of non-intervention in domestic political affairs coupled with 


\section{CHAPTER 1}

rising foreign aid and investment activities are viewed as an attractive alternative to political conditionality-based Western development assistance by all African recipient countries, but in particular by authoritarian regimes such as Ethiopia. Even before Ethiopia's growing ties with China, successive Ethiopian governments already enjoyed a high significant bargaining power for reasons explained in the second half of this dissertation (Part B). China's entry into the aid game, however, has increased the Ethiopian government's bargaining power in the aid negotiation process even further. The Ethiopian government's high bargaining power can therefore be attributed to both its own policy framework and to China's increasing presence in Ethiopia. The fieldwork results presented in Chapter 6 suggest that Ethiopia is regarded as a "unique case" in Africa by Western development organizations and international financial institutions, as the Ethiopian government follows a clear development strategy and presents itself as a very determined and confident negotiating partner. If international development finance seems to threaten the government's development agenda ownership, the authoritarian regime will prefer to reject external help.

This leads to another important topic addressed in this dissertation, namely the critical role of African agency in the international development cooperation architecture, particularly in the aid negotiation process (Brown, 2012, 2013; Carmody \& Kragelund, 2016; Grimm, 2014; Mohan \& Lampert, 2013; Whitfield \& Fraser, 2009). China's economic embrace of Ethiopia and Africa more generally is often presented as a relationship in which the Chinese government sets and dominates the agenda, with African governments and civil society portrayed as bystanders exercising little or no agency (Ramo, 2004). The same is true for the Western international donor community (Ayittey, 2005). Using Ethiopia as a case study, the second part of this dissertation provides a historical perspective (Chapter 5), current perspective (Chapters 6 and 7), and future perspective (Chapters 6 and 7) of how African recipient governments can exert substantial agency in their international relations with traditional Western and emerging donors/investors.

Ethiopia provides a good example of how crucial the role of African agency is in the aid negotiation process if African economies want to benefit from China's increased economic presence on the continent. To what extent foreign finance can serve developmental ends ultimately depends on the policy agenda chosen by African recipient governments. 
While this dissertation appears to be most connected to economics and then to political science, the analysis also draws upon the fields of international relations, history, sociology and anthropology. The largely inter-disciplinary approach to the research topic and the combination of both quantitative and qualitative research methodologies aims (i) to target academic scholars and policymakers from various social science fields and aims (ii) to provide important policy lessons for policymakers, government agencies, international financial institutions, aid agencies, development organizations, research institutes, universities, and other public and private institutions alike.

\subsection{The Concept of Global Development Finance}

This section aims to familiarize the reader with the concept of global development finance to avoid misunderstandings and to facilitate the reading process.

Global development finance, or development finance for short, includes (i) private development finance such as FDI, worker remittances, portfolio equity, debt and grants, and (ii) official development finance. Official development finance can be split up into Official Development Assistance (ODA) such as grants and concessional loans and Other Official Flows (OOF) such as concessional and market-rate export credits as well as military training. Unless specified otherwise, the terms 'development finance' and 'foreign finance' are used interchangeably. The same holds for the terms 'ODA' and 'foreign aid'. Development finance excludes international trade flows. In this dissertation, the term 'external flows' is used to define the sum of both development finance and trade flows. A detailed overview of the term global development finance is given in Figure 1.1.

Throughout this dissertation, a clear distinction is made between "traditional" and "non-traditional" development finance. The members of the OECD-DAC are considered "traditional" donor countries.12 "Traditional" development

\footnotetext{
12 At the time of writing, the DAC consists of 30 members: Australia, Austria, Belgium, Canada, Czech Republic, Denmark, European Union, Finland, France, Germany, Greece, Hungary, Iceland, Ireland, Italy, Japan, Luxembourg, Netherlands, New Zealand, Norway, Poland, Portugal, Slovakia, Slovenia, South Korea, Spain, Sweden, Switzerland, United Kingdom and the
} 
finance institutions include the World Bank and the International Monetary Fund (IMF). The term "non-traditional" development finance refers to finance from non-OECD countries, such as emerging economies from the Global South, including China. ${ }^{13}$

Figure 1.1: An Overview of Global Development Finance

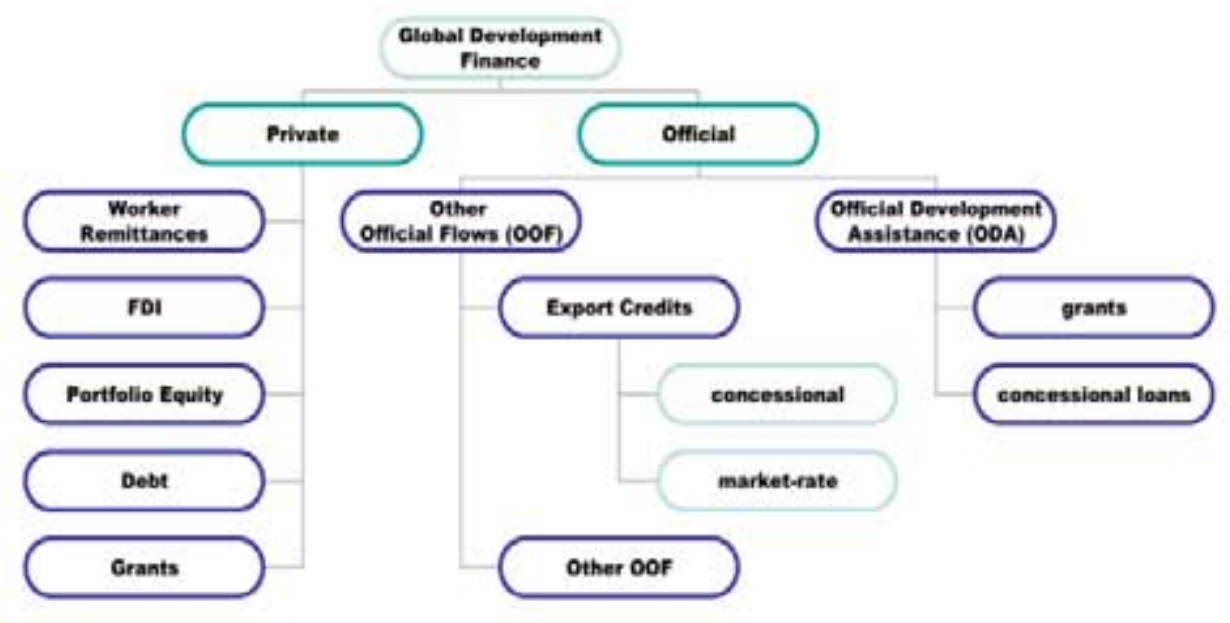

Source: Bräutigam (2011a)

Several non-OECD countries increasingly adhere to OECD standards with regard to their reporting system, but not China (Dreher, Nunnenkamp, \& Thiele, 2011). The lion's share of China's official foreign finance is not ODA as defined by the OECD.

"China does provide finance that meets the definition of ODA, but this is relatively small. Export credits, non-concessional state loans or aid used to foster Chinese investment do not fall into the category of ODA. China's cooperation may be developmental, but it is not primarily based on official development aid. This suggests that the institutions established at the OECD to develop and apply standards for foreign aid (the Development

\footnotetext{
United States (OECD, 2017). For more information, see http://www.oecd.org/dac/dacmembers.htm

13 "Non-traditional" development finance countries include the BRICS countries (Brazil, Russia, India, China and South Africa) as well as OPEC countries such as Saudi-Arabia, Kuwait, the United Arab Emirates and Venezuela.
} 


\section{CHAPTER 1}

Assistance Committee) may not be the right ones to govern these growing ties" (Bräutigam, 2011, p. 752).

"Chinese state-owned enterprises also blur the line between official government finance and private flows; foreign direct investment (FDI) or joint ventures can come from firms that are either private or state-owned" (Strange, Dreher, Fuchs, Parks, \& Tierney, 2017, p. 939).

The Chinese government uses a "package financing" mode that combines aid with investments, and/or concessional and non-concessional financing (Davies, Edinger, Tay, \& Naidu, 2008; Grimm, Rank, McDonald, \& Schickerling, 2011b). Whenever the analysis in the following chapters refers to China's development finance in Ethiopia, it includes both private and official development finance for two mains reasons: First, Chinese private and official development finance are highly interwoven. Second, the share of Chinese private development finance increasingly rivals that of official development finance.

\subsection{Structure of the Dissertation}

The dissertation consists of two main parts, Part A and Part B. Each part contains three chapters: Chapters 2, 3 and 4 belong to Part A while Chapters 5, 6 and 7 belong to Part B. The dissertation makes use of both quantitative and qualitative research methods considering their synergistic complementarity. Social scientists become increasingly aware that a combination of quantitative and qualitative research methods creates considerable leverage, as both methodological approaches have their specific advantages. At the same time, each methodological tradition can offset the limitations of the other (Creswell, 2013; Huber \& Stephens, 2001; Lange, 2009; Rueschemeyer \& Stephens, 1997). As a result, I use statistical and econometric analysis, secondary data on historical developments, interviews based on fieldwork conducted in Ethiopia as well as formal tools of game theory.

Part A takes a broad macro perspective that provides both economic and political insights into the motives, structure and consequences of Western and Chinese foreign finance at the continent level. The research methodology chosen in Part A is predominantly quantitative using both statistical and econometric estimation techniques. While the reader may get the impression that Part A treats 


\section{CHAPTER 1}

Africa as a monolithic entity, the author of this dissertation is well aware that the continent is highly diverse consisting of 54 countries that vary significantly in their history, endowment structure, political systems and economic growth trajectories. As a result, the characteristics and impact of both Western and Chinese foreign finance on the economic growth trajectory, political system and civil society may vary from country to country and from industry to industry.

Since country case studies can provide valuable complementary information on the diverse effects of Western and Chinese presence in Africa, Part B shifts the analysis from the continent to the country level using a case study design. Ethiopia is selected as case study country for reasons explained further below. In contrast to Part A, Part B uses predominantly a qualitative methodological approach. While Chapters 5 and 6 also use secondary quantitative data, both chapters are largely qualitative in nature. In Chapter 6 historical sources as well as qualitative data from open ended interview questions obtained during field research in Ethiopia are used for the analysis. The last chapter of Part B, Chapter 7, presents an analytical narrative of the aid game in Ethiopia combining formal economic theory, namely game theory, descriptive statistics and historical sources. The aim of this last chapter is the formalization of key observations made in the previous chapters and to help to make key predictions about the likely behaviour of all major players involved in the decision-making process of the international aid game.

The chapters in Part B take both macro and micro perspectives of the relationship between Western and Chinese foreign finance and Ethiopia's economic and political trajectory. While all three chapters mainly assess the government-to-government relations in international development cooperation, the economic and political impact of China's rising development finance in Ethiopia on state-civil society relations in Ethiopia will also be discussed, especially in Chapter 5 and Chapter 6.

Despite these differences, Part A and Part B share a major commonality. Both parts focus on the interplay between Western and Chinese foreign finance in Africa discussing how the rise of the latter can acts as significant game changer for the former. The chapters in both Part A and Part B aim to show that the recent patterns of Western development assistance as well as Africa's economic and political fate can no longer be analysed without paying attention to the 


\section{CHAPTER 1}

emerging economic, political and strategic role of China on the continent - be it at the macro or micro level.

Chapter 2 acts as introductory chapter to the topic of traditional and nontraditional finance in Africa. The main goal of the second chapter is to examine the magnitude, sectoral distribution and regional distribution of both Western and Chinese external flows - foreign aid, foreign direct investment and trade to African countries for the period 1950-2013. The chapter therefore provides a macro-level long-run perspective of the evolution of traditional and rising Chinese foreign finance (and external flows more broadly) on the African continent. Chapter 2 discusses the entry of China into the development finance game against the background of changing patterns and trends in foreign aid and foreign direct investment to a lesser extent - originating from Western countries. A similar analysis is also applied to China's FDI and international trade.

Chapter 3 focuses exclusively on China's development finance activities in Africa using quantitative estimation techniques. This chapter empirically investigates whether African authoritarian regimes receive more Chinese development assistance than democratic ones, ceteris paribus. Comprehensive aid statistics from numerous emerging (non-DAC) donors, including China, are still lacking. Therefore, perhaps not surprisingly, the quantitative literature on China's development finance to developing countries is sparse. This chapter exploits an open-source data collection technique - AidData's Tracking Underreported Financial Flows (TUFF) methodology - developed by Strange, Parks, Tierney, Fuchs and Dreher (2013) that aims to provide a more complete picture of nonDAC development finance activities. In order to answer the research question whether African authoritarian regimes receive more Chinese development assistance than democratic ones, the analysis uses four different measures of democracy/autocracy which allows me to check the extent to which my results depend on the specific indicator chosen.

Chapter 4 of this dissertation revisits the aid debate by exploring to what extent present-day state capacity in Africa is shaped by proximate determinants, such as foreign aid, and more ultimate, historic determinants, such as precolonial institutions. The chapter focuses exclusively on Western foreign aid in Africa. While there exists a lot of literature attributing present-day low income levels in 


\section{CHAPTER 1}

Africa to dysfunctional state institutions (Acemoglu, Johnson, \& Robinson, 2001; Acemoglu \& Robinson, 2010, 2012; Bates, 2008; Meredith, 2005), the question which factors can explain differences in state capacity in modern-day Africa is less well explored (Fenske, 2014; Thies, 2009). One novelty of this chapter is the examination to what degree the relationship between bureaucratic state capacity and aid dependence, one of the important proximate determinants of state capacity, is affected when controlling for more ultimate historical variables such as the degree of precolonial centralisation. Chapter 4 therefore connects the aid-governance literature with historical and anthropological work on African state formation.

Chapter 5 provides a historical perspective of Ethiopia's position in the international aid game at the Horn of Africa during the Cold War era. Using Ethiopia as an in-depth case study, the chapter discusses the historical interrelationships between the international donor community, in particular the United States and the Soviet Union, and the two successive Ethiopian recipient governments, the imperial government under Haile Selassie (1941-1974) and the communist government under Mengistu Haile Mariam (1974-1991). While China is largely absent in this historical case study, the value added of this historical case study is the following: first, successive Ethiopian governments during the Cold War era often succeeded to maximize external financial resources while minimizing the amount of loss of sovereignty over the policy agenda. So even before China's entry into the international aid game, the Ethiopian government had already possessed a strong bargaining power vis-àvis the international donor community. Second, the demise of both Ethiopia's imperial government under Selassie and the Marxist government under Mengistu would provide valuable policy lessons for the post-cold War government under Meles Zenawi.

Chapter 6 examines the evolution of international development cooperation in Ethiopia since the end of the Cold War accounting for the entry of China. Using both secondary data and using qualitative interview data obtained from personal fieldwork in Ethiopia, this chapter analyses to what extent China's entry into the aid game and its policy of non-intervention in domestic political affairs has significantly increased the Ethiopian government's bargaining power in the aid negotiation process vis-à-vis the international donor community even further. 
Even though there exists a vast amount of empirical and theoretical research into foreign aid, only little work has formally analysed the foreign aid game in a competitive donor environment. Chapter 7 aims to fill this research gap by developing a game theoretical model that aims to explain the recent entry of China into the foreign aid game in Ethiopia. The chapter first builds a sequential, extensive form game consisting of two competing donors and one recipient government. The testable implications derived from the game theoretical model will then be applied to the country of Ethiopia using both secondary data and qualitative evidence for the post-Cold War era.

Finally, Chapter 8 summarizes the main findings, discusses policy implications and provides some concluding thoughts on the subject matter. 


\section{PART A}

"Aid is a phenomenon whereby poor people in rich countries are taxed to support the lifestyles of rich people in poor countries." - Peter Bauer, 1979

(1915-2002)

British-Hungarian economist

"Foreign aid is the central component of world development." - Hollis B. Chenery, 1981

(1918-1994) American economist

"Aid would be more effective if it were more systematically conditioned on good policy." —Craig Burnside and David Dollar, 2000 Canadian economist and American economist 


\section{CHAPTER 2}

\section{CHINA'S ECONOMIC EMBRACE OF AFRICA - AN INTERNATIONAL COMPARATIVE PERSPECTIVE}

"Good governance is perhaps the single most important factor in eradicating poverty and promoting development." - Kofi Annan, 1998 Seventh Secretary-General of the United Nations (1997-2006)

"To end poverty, first build a road." - Chinese proverb 


\subsection{Introduction}

The African continent remains a prominent battleground for global competition between international players over natural resources, business opportunities, diplomatic relationships and security interests. Over recent years, emerging economies from the Global South have entered the arena and have positioned themselves as alternative sources of foreign finance, most notably China. Consequently, Africa's economic and political fate cannot be analysed without paying attention to the emerging economic, political and strategic role of China on the continent (Ajakaiye \& Kaplinsky, 2009).

This chapter will shed some light on the characteristics of China's rapidly growing economic ties with Africa, particularly in the field of development finance. It will systematically compare the magnitude, the geographic destination and the sectoral distribution of Chinese and Western foreign aid ${ }^{14}$, investment and trade. This study therefore contributes to an emerging literature that analyses China's intensifying economic relationships with Africa (Bräutigam, 2009; Shinn \& Eisenman, 2012; Zafar, 2007).

FDI and trade statistics of emerging economies have become increasingly available and more reliable (MOFCOM, 2009, 2011, UNCTAD, 2006, 2007, 2010). As a result, an increasing body of empirical literature examines the determinants and impacts of Chinese growing outward FDI targeting the African continent (Buckley et al., 2007; Kaplinsky \& Morris, 2009; Sanfilippo, 2010; Shen, 2013). Another strand of literature has contextualized the surge of China's international trade with Africa through either comparative analysis, empirical analysis or both (Broadman, 2007; Giovannetti \& Sanfilippo, 2009; Haugen, 2011; Jacobs, 2011; Shinn \& Eisenman, 2012). Comprehensive aid data from numerous emerging donors is surprisingly sparse. China treats its aid allocations as highly confidential and, until very recently, data on foreign aid have been a state secret (Bräutigam, 2011a; Huse \& Muyakwa, 2008).

In contrast to previous contributions that have focused primarily on the domestic origins of China's rapid embrace of the African continent (Alden, 2005; Lee, 2012; Lin, 2012; Taylor, 2006; Zweig \& Jianhai, 2005), this chapter will discuss Sino-African economic relationships from an international comparative

14 The terms 'development assistance' and 'foreign aid' are used interchangeably. 
perspective. This study will take into account the characteristics of Western ODA on the African continent since the 1960s. More specifically, the entry of China into the development finance game will be discussed against the background of changing patterns and trends in foreign aid and foreign direct investment originating from Western countries. To this end, this chapter presents an analysis of long-run changes in the geographic and sectoral allocation of Western aid both globally and in Africa, along with estimates of the global sectoral allocation of Chinese aid. ${ }^{15}$

This chapter documents rapid growth of Beijing's aid budget though its magnitude is still relatively small compared to development assistance from all traditional OECD-DAC donors combined. The magnitude of China's FDI and international trade with Africa converges to the amount of leading Western donors (United States, United Kingdom, France, Germany). The sectoral distribution of China's development assistance strongly resembles past patterns of Western development assistance in the early 1960s and mid-1970s. Compared to the rather erratic pattern of Western foreign aid with its trends, switches and sudden breaks, however, the pattern and nature of China's development assistance has been relatively stable over time.

Like Western FDI, the bulk of China's FDI takes place in resource extraction but there is also substantial investment in infrastructural projects. Those projects are predominantly carried out by Chinese state-owned enterprises (SOEs). Interestingly, market-seeking FDI from Western countries mainly targets the service sectors of African countries with large market potential, while the evergrowing market-seeking investment of Chinese small and medium-sized entities (SMEs) is heavily concentrated in labour-intensive manufacturing industries.

Sino-African trade patterns reflect Ricardo's law of (static) comparative advantage. Relative factor endowments of labour, capital and natural resources are largely responsible for the nature of Sino-African trade patterns: Similar to the North-South pattern of trade observed between Africa and the European Union or the United States, China largely exports manufactured goods and transport equipment, while it mainly imports energy and mineral resources from Africa.

${ }^{15}$ For China, sectoral aid allocation data are only available at global level, not for Africa. 
The remainder of the chapter is structured as follows. Section 2.2 reviews the causes for China's increasing engagement with Africa. Section 2.3 examines the magnitude and sectoral distribution of China's foreign aid, foreign direct investment and trade in Africa. Section 2.4 highlights trends, switches and breaks of Western development assistance over time. Section 2.5 discusses the similarities and differences of Chinese and Western foreign aid, FDI and international trade. Section 2.6 concludes.

\subsection{Causes for China's increasing engagement with Africa}

One of the major reasons for China's longstanding relationship with many African countries is political: to garner support for the 'One China Policy' (Wenping, 2007). China's struggle to persuade each African country not to recognize Taiwan (in other words to recognize the People's Republic of China (PRC) as the only legitimate government of China) dates back to the 1960s. ${ }^{16}$ Diplomatic ties are cut off and economic aid is suspended if a country establishes diplomatic ties with Taiwan (see also Chapter 3). ${ }^{17}$ The 1960 s were also characterized by Beijing's fear of Soviet dominance and the concomitant ideological divergence between the two largest Communist states at that time. During much of the Cold War era, Beijing was eager to position itself as a buffer between Moscow and Washington.

A second key element in China's increasing engagement with Africa in recent years is strategic, namely the need to secure access to natural resources. During the 1990s and 2000s, China's economy found itself in an energy transition manifested by the shift (i) from low efficiency fuels to oil, gas and electric power,

16 While the terms "One-China policy" and "One-China principle" are often used interchangeably by many authors, they differ strictly speaking. While the "One-China policy" acknowledges the existence of two governments claiming to be the legitimate government of one "China", there is disagreement between mainland China and Taiwan which of the two is legitimate. Mainland China would recognize Taiwan in a state of undeclared independence if Taiwan would tacitly acknowledge the Beijing administration as the true leader of China. In contrast, the "One-China principle" views both mainland China and Taiwan as inalienable parts of a single "China" territory.

${ }^{17}$ As of today, only two African countries have diplomatic ties with Taiwan, namely Burkina Faso and Swaziland. Very recently, in the year 2016, the government of Sao Tomé and Principe has cut diplomatic ties with Taiwan. 


\section{CHAPTER 2}

(ii) from agriculture to urbanization and rapid industrialization and (iii) from low motorization to an increased use of motor vehicles (Adams \& Shachmurove, 2008; Moyo, 2012). While China was the largest oil exporter of East Asia in the mid-1980s, self-sufficiency came to an end in 1993 turning China into a net oil importer (Lee, 2012; Taylor, 2006a; Zweig \& Jianhai, 2005). In 2003, China became the second largest world consumer of oil after the United States and the third largest net oil importer after the United States and Japan (Taylor, 2006a). By 2009, China had become the second largest net oil importer overtaking Japan (Lee, 2012).

An empirical study by Yuan et al. (2010) documents a high correlation between industrialization and total energy consumption in China, as well as a high correlation between economic growth and coal consumption. Furthermore, China's secondary sector accounts for about 50 per cent of total energy consumption in the economy. Obtaining raw materials and energy is therefore crucial for the Communist Party in order to maintain China's impressive growth trajectory. China's soaring demand for oil and other natural resources has significantly contributed to the major upsurge of world commodity prices till 2015.18 As the scramble for natural resources becomes increasingly competitive, Beijing is eager to secure its natural resource supply for the near and distant future (Moyo, 2012).

Over the last couple of years, however, Chinese motivations have also increasingly been driven by market seeking interests - i.e. economic motives - as the African continent serves as a lucrative export market and export platform for the Chinese domestic manufacturing industry (Gu, 2009; Wang, 2007), as well as providing opportunities for off-shoring. The transformation can partly be attributed to the gradual albeit slow appreciation of the renminbi accompanied by its rise as an international currency (Eichengreen, 2013; Lin, 2012) and the rising labour costs in the domestic Chinese manufacturing sector (Bräutigam \& Tang, 2011; Ceglowski \& Golub, 2011). ${ }^{19}$

\footnotetext{
${ }^{18}$ In the same way, the current slowdown of Chinese growth is one of the major causes of the sudden decline in commodity prices since 2015 .

19 As with commodity prices, the appreciation trend has been reversed and the currency has depreciated since 2015 .
} 
The previous literature has mainly focused on domestic drivers of China's increasing engagement with Africa. This chapter will take an international comparative perspective and provide additional external reasons for China's increasing economic activity in Africa in Section 2.4. Before applying an international comparative perspective, however, I will discuss China's foreign aid, investment and trade activities in Africa in the next section.

\subsection{China's Foreign Aid to Africa}

Only a very few studies have tried to quantify the magnitude and investigate the channels of China's development assistance (Bräutigam, 2009). Until very recently, China's foreign aid budget lacked transparency for mainly four reasons. First, China's aid system is multi-layered as it involves a labyrinthine network of ministries. It is believed to be administered through 23 national, local, provincial and regional ministries and commissions (Huang (2007) cited in Strange, Parks, Tierney, Fuchs, \& Dreher, 2013). ${ }^{20}$ Second, foreign aid often comes in the form of tied aid since it is often part of larger investment contracts and trade deals with particular governments (Huse \& Muyakwa, 2008).

A third reason is that Beijing has treated its aid allocations as highly confidential. The government is frightened of emerging criticism at home if the aid figures were officially published (Lancaster, 2007b). Despite its recent success in lifting millions of people out of poverty (Chen \& Ravallion, 2010), many regions in China, predominantly the West and mountain areas, still suffer from (i) high poverty levels (Ravallion \& Chen, 2007) and (ii) large urban-rural income gaps (Wu \& Perloff, 2004). As a result, a substantial part of the Chinese population might have strong objections to Beijing's decision to give aid funding to other developing nations. A fourth possible reason why China's aid figures have been kept a state secret for so long is cultural. In China it may just seem "improper or even immoral" (Bräutigam, 2009, p. 166) to pride oneself on delivering development assistance to other developing countries.

In contrast to most Western donors, Beijing has adopted a relatively broad and often imprecise definition of foreign aid. A vibrant debate has emerged in recent

\footnotetext{
${ }^{20}$ For an excellent discussion of the interaction between China's three central aid institutions, the (i) Ministry of Commerce (MOFCOM), (ii) the Export-Import Bank of China (EXIMBANK) and (iii) the Chinese Ministry of Foreign Affairs (MFA), see Corkin (2011).
} 
years about how much of Chinese foreign aid actually falls under the category of ODA (Bräutigam, 2011a, 2011b; Davies et al., 2008; Woods, 2008). Similar to Western ODA, China's official aid disbursements are broken down into: (i) grants, (ii) interest-free loans and (iii) concessional (fixed-rate, low interest) loans. Among other things, these instruments finance government scholarships for African students, Chinese medical teams, technical assistance in agriculture, government buildings, telecommunication networks, sport venues, youth volunteers, low-cost housing and short-term training programs (Bräutigam, 2011b; Wang, 2007). These three instruments, however, only make up a fraction of China's total official financial assistance to Africa. Other major instruments such as preferential export credits, market-rate export buyers' credits or commercial loans issued by Chinese banks, but also military aid and aid to support joint ventures would all not qualify as ODA, but rather as OOF (Bräutigam, 2011b). In this section I will present Chinese foreign aid data that is comparable to Western ODA.

\subsubsection{The Magnitude of Chinese Foreign Aid Flows to Africa}

Since the early 2000s, a myriad of emerging aid donors has intensified their development assistance on the African continent, of which China can be regarded as one of the most prominent ones. Figure 2.1 provides an overview of the evolution of China's foreign aid to Africa for the time period 1953-2013.

In Figure 2.1, the data for the years 1953-2009 derive from various previous scholars (Bräutigam, 2009; Kobayashi, 2008; Lin, 1996). The data for the years 2010-2013 are my own estimates. The calculation of aid figures for the years 2010-2013 involves the following steps: First, I have calculated the official external assistance expenditure to Africa. Bräutigam (2015) provides data for China's global external assistance expenditures excluding concessional loans for the time period 2010-2013. Africa accounts for approximately 40 per cent of total external expenditures in the years preceding 2009 (Table 2.1). I apply this ratio to the global expenditures from 2010-13 to estimate the volume of aid expenditures to Africa. Second, I calculate the EXIMBANK concessional loans disbursed to Africa for the time period 2010-2013. Concessional loans disbursed to Africa are available for the years 1996-2009 (Bräutigam, 2009). I extrapolate the 2009 figure, using the growth rate of concessional loans disbursed to Africa 
between 1996 and 2009 (approximately 30 per cent). ${ }^{21}$ Finally, I convert the current price series from 1953 onwards, into a constant prices series using the U.S. GDP deflator (base year 2009) from the Bureau of Economic Analysis (BEA, 2015).

Figure 2.1: Evolution of China's Foreign Aid to Africa, 1953-2013 (million 2009 US\$)

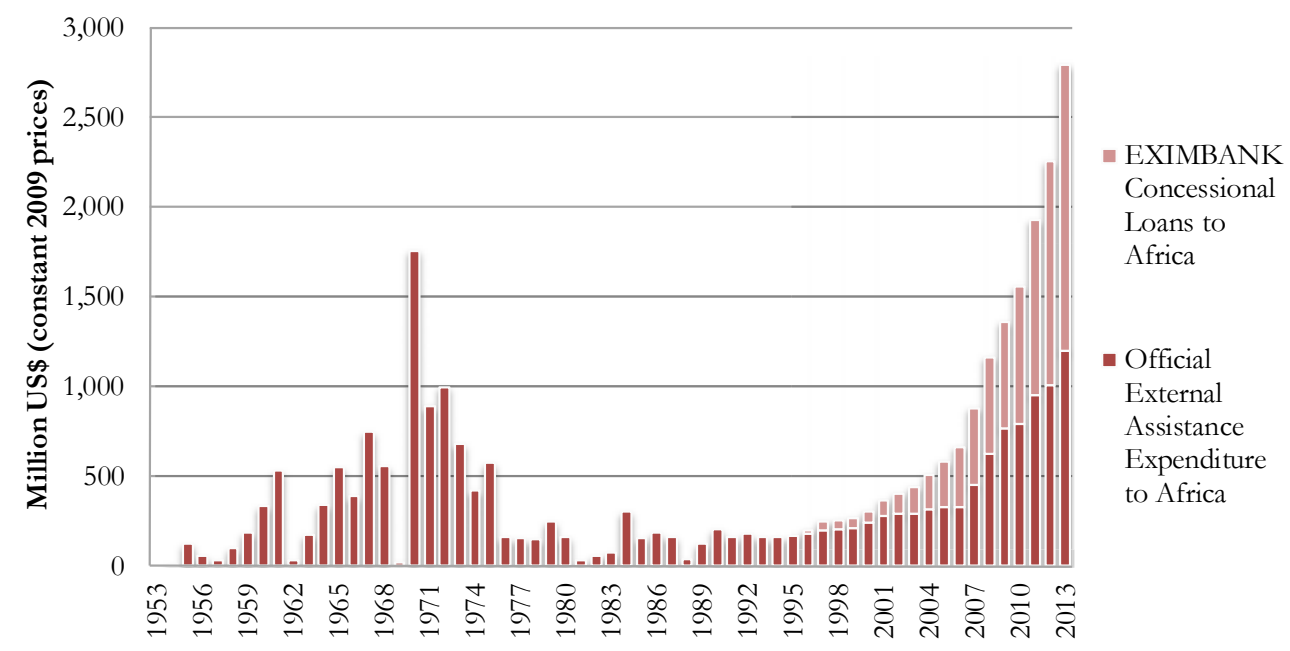

Sources: Lin (1996), Kobayashi (2008) and Bräutigam (2009, 2015), Bureau of Economic Analysis (2015); Authors' own estimations.

China's foreign aid that is comparable to Western ODA consists of (i) external assistance expenditure and (ii) EXIMBANK concessional loans. At their introduction in 1996, concessional loans only represented 5.6 per cent of the entire aid budget. Over time, however, concessional loans have become an integral part of China's aid budget accounting for more than a third of total aid by the year 2009. As concessional loans increasingly gain prominence as a foreign policy instrument tool, it is likely that concessional loans will take on even greater significance in the Chinese aid budget in the near and distant future (Corkin, 2011).22

\footnotetext{
21 The growth rates for the years 1997 (more than 200 percent) and 1998 (minus seven percent) are excluded as the two growth rates must be considered extreme outliers in the series.

${ }^{22}$ For a detailed overview of the magnitude and regional distribution of China's concessional loans, see Hubbard (2007).
} 
Before the 1990s, the volume of China's development assistance was rather small, except during the period 1970-1975. During the Cultural Revolution, especially in the early 1970s, the Beijing administration under Mao Zedong increasingly competed with Washington and Moscow for political support from African leaders. As a consequence, China provided large amounts of foreign aid despite significant domestic economic difficulties. The most famous project during that time was the construction of the TAZARA between 1970 and 1975, a $1,860 \mathrm{~km}$ long project financed in the form of a long-term interest-free loan. Until today, the TAZARA project has been the largest single development assistance project undertaken by China. The railroad linked the port of Dar es Salaam in Tanzania with the town of Kapiri Mposhi in Zambia's Central Province. By the time of completion, TAZARA was the longest railway in SubSaharan Africa. Chinese development assistance declined substantially thereafter.

Table 2.1: Chinese and Total Western Foreign Aid to Africa, 1960-2013

\begin{tabular}{|c|c|c|c|c|}
\hline \multirow[b]{2}{*}{ Year } & \multicolumn{2}{|c|}{$\begin{array}{c}\text { China } \\
\text { (current US\$ Million) }\end{array}$} & \multicolumn{2}{|c|}{$\begin{array}{c}\text { DAC-Donors } \\
\text { (current US\$ Million) }\end{array}$} \\
\hline & Africa & $\begin{array}{c}\text { African share in } \\
\text { total aid }(\%)\end{array}$ & Africa & $\begin{array}{c}\text { African share in } \\
\text { total aid }(\%)\end{array}$ \\
\hline 1960 & 58.0 & 20 & 1286.1 & 31.2 \\
\hline 1970 & 400.0 & 36 & 1186.1 & 23.2 \\
\hline 1980 & 71.0 & 36 & 6344.3 & 42.0 \\
\hline 1990 & 135.0 & 36 & 15818.1 & 47.5 \\
\hline 1996 & 152.0 & 37 & 12858.4 & 38.4 \\
\hline 2000 & 249.0 & 39 & 10401.8 & 37.0 \\
\hline 2005 & 535.0 & 40 & 24661.8 & 34.7 \\
\hline 2009 & 1359.0 & 43 & 28197.6 & 44.9 \\
\hline 2010 & 1576.0 & 44 & 29370.6 & 44.0 \\
\hline 2011 & 1993.0 & 44 & 32754.0 & 47.5 \\
\hline 2012 & 2372.0 & 45 & 30493.7 & 47.7 \\
\hline 2013 & 2985.0 & 45 & 29379.2 & 44.1 \\
\hline
\end{tabular}

Notes: Figures in italics are estimates by the author. Figures are expressed in US\$ Million. The African share in the Chinese aid budget for the years 2010-2013 is an estimation based on extrapolations of China's global and African aid budget. DAC data refer to bilateral aid.

Sources: OECD International direct investment database; Bräutigam (2009); Author's own calculations.

Table 2.1 (i) compares the magnitude of foreign aid between China and the DAC Donors and (ii) documents the African share of the total aid budget from the respective donor group. Since the mid-1990s onwards, Beijing's development 
assistance to Africa has risen exponentially. The Beijing government delivered US\$ 135 million worth of development assistance in 1990. In 2013, foreign aid amounted to almost US $\$ 3.00$ billion, a more than twentyfold increase in real terms since 1990. Note that China's mounting development assistance to Africa has evolved gradually but steadily since the early 1990s. The African share of total Chinese aid has increased over time as well (see Table 2.1 again).

While China's foreign aid was only minimal compared to the total DAC aid in 1990, its magnitude in 2013 was equal to almost 10 per cent of total bilateral Western aid. China has become an important donor over the last two decades overtaking countries like Germany, Japan, Canada, Norway, Sweden and the Netherlands (Table 2.2). The United States is by far the largest Western aid donor in recent years. In 2013, almost one third of total bilateral Western aid to Africa originated from the United States.

Table 2.2: Chinese and Individual DAC Donors Bilateral Foreign Aid to Africa, 1990 vs. 2013

\begin{tabular}{|c|c|c|c|c|c|}
\hline \multicolumn{3}{|c|}{1990} & \multicolumn{3}{|c|}{2013} \\
\hline Donor & $\begin{array}{c}\text { Volume } \\
\text { (US } \\
\text { Billion) }\end{array}$ & $\begin{array}{c}\text { \% of } \\
\text { DAC } \\
\text { Donors }\end{array}$ & Country & $\begin{array}{c}\text { Volume } \\
\text { (US } \\
\text { Billion) }\end{array}$ & $\begin{array}{c}\text { \% of } \\
\text { DAC } \\
\text { Donors }\end{array}$ \\
\hline France & 3.69 & 23.32 & USA & 9.67 & 32.15 \\
\hline USA & 3.53 & 22.31 & UK & 3.92 & 13.05 \\
\hline Germany & 1.82 & 11.53 & France & 3.17 & 10.54 \\
\hline Italy & 1.29 & 8.18 & China & 2.99 & 9.93 \\
\hline Japan & 1.07 & 6.76 & Germany & 2.40 & 7.97 \\
\hline Sweden & 0.71 & 4.47 & Japan & 2.09 & 6.96 \\
\hline Netherlands & 0.71 & 4.46 & Canada & 1.52 & 5.05 \\
\hline $\mathrm{UK}$ & 0.57 & 3.62 & Sweden & 1.17 & 3.88 \\
\hline Canada & 0.50 & 3.15 & Norway & 1.05 & 3.48 \\
\hline Norway & 0.41 & 2.61 & Netherlands & 0.86 & 2.85 \\
\hline China & 0.13 & 0.85 & Belgium & 0.58 & 1.94 \\
\hline $\begin{array}{l}\text { DAC Donors } \\
\text { TOTAL }\end{array}$ & 15.82 & 100.00 & $\begin{array}{l}\text { DAC Donors } \\
\text { TOTAL }\end{array}$ & 30.07 & 100.00 \\
\hline
\end{tabular}

Sources: OECC/DAC database, Author's own calculations.

Comparing the volume of Chinese aid with that of traditional DAC donors, we can draw three conclusions. First, since 1990, China's aid expenditures have increased rapidly and continuously, with Africa receiving a gradually increasing share of total aid since the early 2000s. Second, China's foreign aid budget for the world as a whole and for Africa is still rather small when compared to the 
sum of annual ODA disbursements by traditional DAC donors, though not necessarily compared to individual DAC donors. Third, the African share of the Western and Chinese total aid budget has been remarkably similar from the mid2000s onwards.

\subsubsection{Chinese Trade and FDI}

According to Biggeri and Sanfilippo (2009), China's growing presence in Africa is driven by the strategic interaction between foreign aid, FDI and trade. I will provide further evidence that China's foreign aid is highly interwoven with its foreign direct investment and trade activities on the continent. The steep increase in Beijing's foreign aid over the last two decades is part of a general rise of China's finance activities on the African continent.

The evolution of China's FDI in Africa and that of the major Western economies (namely the United States, France and the United Kingdom) is portrayed for selected years in Table 2.3. Between 1985 and 2011 there was a huge increase in the stock of Western FDI in Africa, as the figures for the United States, United Kingdom and France indicate. But in other parts of the world FDI stocks were growing even more rapidly, so that the share of Africa in global FDI stocks actually declined substantially between 1985 and 2000. After 2000, there was a strong recovery of the African share. In the case of China, the share in global FDI declined between 1990 and 1995, but from that year onwards the share increased steadily reaching 3.8 percent in 2011. While China's outward FDI has traditionally been highly concentrated in Asia, Beijing's going-global strategy has actively encouraged Chinese enterprises to look for expanding international and global market opportunities in other regions of the world, including Africa. While China's FDI stock on the continent was virtually zero in the mid-1980s, it rose to more than US\$21 billion in 2012.

Throughout much of the 1990s, the United States, the United Kingdom, France, Japan, Germany and the Netherlands accounted for the lion's share of total financial inflows to Africa (UNCTAD, 2000, 2013a). The pattern was quite similar with regard to the FDI stock. From the early 2000s onwards, however, emerging Southern economic giants such as the BRIC countries but also Malaysia joined the list of important investors on the African continent. While China has positioned itself as the major emerging donor in Africa, its FDI stock 
of around US\$ 16 billion in 2011 falls short of Malaysia's foreign direct investment worth around US\$ 19 billion in the same year (UNCTAD, 2013b). The figures, however, should be treated with some caution, as they may considerably understate the true amount of China's investment (Shinn, 2013).23 Compared to the FDI volume recorded by the aforementioned emerging countries, the official FDI stock of "traditional" investors such as Germany or Japan is significantly lower (Broich \& Szirmai, 2014). But the United Kingdom, the United States and France are still by far the largest investors.

Table 2.3: FDI Stock in Africa by Major Countries of Origin, 1985-2011

\begin{tabular}{|c|c|c|c|c|c|c|c|c|}
\hline & \multicolumn{2}{|c|}{ China } & \multicolumn{2}{|c|}{ USA } & \multicolumn{2}{|c|}{ France } & \multicolumn{2}{|c|}{ UK } \\
\hline & $\begin{array}{c}\text { Africa } \\
\text { (current } \\
\text { US\$ } \\
\text { billion) }\end{array}$ & $\begin{array}{c}\text { African } \\
\text { share } \\
(\%)\end{array}$ & $\begin{array}{c}\text { Africa } \\
\text { (current } \\
\text { US\$ } \\
\text { billion) }\end{array}$ & $\begin{array}{c}\text { African } \\
\text { share } \\
(\%)\end{array}$ & $\begin{array}{c}\text { Africa } \\
\text { (current } \\
\text { US\$ } \\
\text { billion) }\end{array}$ & $\begin{array}{c}\text { African } \\
\text { share } \\
(\%)\end{array}$ & $\begin{array}{c}\text { Africa } \\
\text { (current } \\
\text { US\$ } \\
\text { billion) }\end{array}$ & $\begin{array}{c}\text { African } \\
\text { share } \\
(\%)\end{array}$ \\
\hline 1985 & & & 5.89 & 2.6 & 1.62 & 3.1 & 6.72 & 7.2 \\
\hline 1990 & 0.05 & 1.1 & 3.65 & 0.8 & 1.58 & 1.4 & 6.83 & 5.7 \\
\hline 1995 & 0.06 & 0.3 & 6.02 & 0.9 & 3.85 & 1.9 & 7.68 & 3.9 \\
\hline 2000 & & & 11.89 & 0.9 & 7.09 & 1.6 & 14.00 & 2.3 \\
\hline 2005 & 1.60 & 1.9 & 22.76 & 1.0 & 21.51 & 2.3 & 35.86 & 5.2 \\
\hline 2011 & 16.24 & 3.8 & 56.63 & 1.4 & 57.82 & 3.6 & 47.19 & 4.5 \\
\hline
\end{tabular}

Sources: OECD International direct investment database, IMF; UNCTAD FDI/TNC Database; UNCTAD (2006, 2013a); MOFCOM (2009, 2011).

China has emerged as the largest individual trading partner for Africa (Table 2.4). In the early 1990s, China's total trade volume with Africa was relatively small compared to that of France and the United States. While the absolute levels of Chinese foreign aid and FDI on the African continent remain modest, China has become Africa's largest trading partner over the last couple of years. China's trade volume has surpassed that of Africa's traditional trading partners such as

\footnotetext{
${ }_{23}$ Numbers and figures provided for China should be regarded as a lower bound for the following reasons: First, official Chinese FDI statistics only contain FDI officially reported to the government. However, there is reason to believe that a certain fraction of private investors does not officially report to Beijing. Second, Chinese foreign direct investment that passes through either Hong Kong or tax havens like the British Virgin Islands or the Cayman Islands is not captured. Third, investment in the financial sector is missing in Beijing's official FDI statistics. And last, China's official FDI statistics do not account for those investments in companies located outside of Africa despite possessing considerable holdings on the continent (see Shinn, 2013).
} 
the United States, and the colonial powers France, United Kingdom and (to a lesser extent) Germany.

Table 2.4: Trade with Africa for Selected Countries, 1990 vs. 2012 (Current US\$ Million)

\begin{tabular}{|c|c|c|c|c|c|c|}
\hline \multirow[b]{2}{*}{ Country } & \multicolumn{3}{|c|}{1990} & \multicolumn{3}{|c|}{2012} \\
\hline & $\begin{array}{c}\text { Total } \\
\text { Trade } \\
\text { Volume } \\
\text { With } \\
\text { Africa } \\
\text { (current } \\
\text { US\$ mill.) }\end{array}$ & $\begin{array}{c}\text { African } \\
\text { Share of } \\
\text { Country's } \\
\text { Trade } \\
\text { Volume } \\
(\%)\end{array}$ & $\begin{array}{c}\text { Country's } \\
\text { Share of } \\
\text { Africa's } \\
\text { Trade } \\
\text { Volume } \\
(\%)\end{array}$ & $\begin{array}{c}\text { Total } \\
\text { Trade } \\
\text { Volume } \\
\text { With } \\
\text { Africa } \\
\text { (current } \\
\text { US\$ mill.) }\end{array}$ & $\begin{array}{l}\text { African } \\
\text { Share of } \\
\text { Country's } \\
\text { Trade } \\
\text { Volume } \\
(\%)\end{array}$ & $\begin{array}{c}\text { Country's } \\
\text { Share of } \\
\text { Africa's } \\
\text { Trade } \\
\text { Volume } \\
(\%)\end{array}$ \\
\hline France & 24,550 & 5.54 & 12.43 & 36,992 & 6.02 & 4.83 \\
\hline Germany & 14,942 & 1.89 & 7.86 & 30,037 & 2.26 & 3.84 \\
\hline UK & 7,364 & 1.79 & 3.73 & 32,433 & 4.33 & 3.33 \\
\hline USA & 21,011 & 2.31 & 10.64 & 68,455 & 2.61 & 6.66 \\
\hline Japan & 5,578 & 1.07 & 1.10 & 21,265 & 2.03 & 2.24 \\
\hline Chinat & 1,696 & 1.02 & 0.73 & 113,244 & 5.13 & 13.04 \\
\hline India & 996 & 2.39 & 0.50 & 43,017 & 9.03 & 4.62 \\
\hline Russia & & & & 2,224 & 1.12 & 0.62 \\
\hline Brazil & 1,397 & 2.59 & 0.71 & 14,266 & 5.68 & 1.74 \\
\hline
\end{tabular}

$\uparrow:$ I obtain only slightly different shares for China if compared to those obtained by Shinn and Eisenman (2012). With regard to the African share of China's trade volume, Shinn and Eisenman obtain values equal to 1.23, 2.10 and 4.25 per cent for the years 1990, 2000 and 2012, respectively. With regard to the Chinese share of Africa's trade volume, Shinn and Eisenman obtain values equal to $0.73,3.48$ and 14.33 per cent for the same years.

Note: The data for Germany and China correspond to the years 1991 and 1992, respectively. Sources: Author's own calculations based on UN COMTRADE Database; Shinn and Eisenman (2012).

I will now turn to the evolution of the relative importance of Africa in the global trade of Western and emerging economies. From the perspective of Western trading partners, the African share of their total trade volumes was very low in 1990 (between 1 and 5.5 per cent). ${ }^{24}$ In the early 2010s, the African share of a country's total trade volume showed a modest increase in all five countries listed in the table. From the African perspective, the European Union is considered to be the most important trading bloc, with almost 50 per cent of Africa's trade flows being connected to the EU (Broich \& Szirmai, 2014). In recent years,

${ }^{24}$ The pattern is very similar with regard to the early 2000s. The data is available upon request. 


\section{CHAPTER 2}

however, the shares of four of the five traditional trading partners listed in the table decreased significantly. In the eyes of particular African countries, other trading partners are becoming more important, namely emerging economies from the Global South (e.g. China, India, Russia and Brazil). As mentioned above, there has been a huge increase in China's trade with Africa. In 2012 it accounted for no less than 13 per cent of Africa's trade volume. China has become a very attractive trading partner for the African continent.

Summarizing, the pace at which China's global external flows to Africa have risen is unprecedented and is likely to remain high in the future. China has already become Africa's largest trading partner. The volume of aid has increased dramatically, though its level still remains modest. China's FDI flows have increased dramatically. While its FDI stock in Africa still falls short of that of the United States and France, it competes with Malaysia as biggest investor from the Global South on the African continent.

\subsubsection{Sectoral Allocation of Chinese Aid}

Table 2.5 provides an overview of the sectoral allocation of China's global foreign aid budget consisting of grants, interest-free loans and concessional loans. According to the figures released by the China State Council, most of China's 2025 completed projects financed through grants and interest-free loans in developing countries from 1950 until 2009 have either targeted the primary sector of the economy (agriculture), the secondary sector of the economy (industry and manufacturing), public utilities or economic infrastructure. Those four sectors together made up more than 94 per cent of all projects completed by Chinese engineers as well as Chinese workers and delivered as finished products to the recipient country. ${ }^{25}$

At the same time, more than 90 per cent of the concessional loans issued from 1996 until 2009 have targeted the development of economic sectors. China's high priority sectors have been economic infrastructure ${ }^{26}$ (61 per cent) and productive

\footnotetext{
25 As the size of the projects can vary considerably, percentage of projects does not immediately translate into percentage of expenditure. Nevertheless, the focus on physical infrastructure and the productive sectors is clear.

${ }^{26}$ The concept "Economic Infrastructure" used by the China State Council is very similar, albeit not entirely identical, to the concept "Physical Infrastructure".
} 
sectors such as industry and agriculture (20 per cent). The share of China's ODA flowing into the political and administrative infrastructure is virtually zero which is consistent with Beijing's principle of non-intervention in internal political affairs. The mutual non-interference in each other's internal affairs is one of the Five Principles of Peaceful Coexistence, announced by the first Premier of the People's Republic of China, Zhou Enlai, in 1954.27

Table 2.5: Sectoral Distribution of China's Global Foreign Aid, 1950-2009

\begin{tabular}{|c|c|c|c|c|}
\hline \multirow[b]{2}{*}{ Sector } & \multicolumn{2}{|c|}{$\begin{array}{c}\text { Grants and } \\
\text { Interest-free } \\
\text { loans, 1950-2009 }\end{array}$} & \multicolumn{2}{|c|}{$\begin{array}{c}\text { Concessional Loans, } \\
1996-2009\end{array}$} \\
\hline & $\begin{array}{c}\text { Number } \\
\text { of } \\
\text { projects }\end{array}$ & $\begin{array}{l}\% \text { of } \\
\text { Total }\end{array}$ & $\begin{array}{c}\text { Value } \\
\text { (RMB¥ million) }\end{array}$ & $\%$ of Total \\
\hline Economic Infrastructure & 390 & 19.3 & 44.87 & 61.0 \\
\hline Energy and resources & & & & \\
\hline $\begin{array}{l}\text { development } \\
\text { Industry }\end{array}$ & - & & $\begin{array}{c}6.55 \\
1184\end{array}$ & $\begin{array}{c}9.0 \\
16.0\end{array}$ \\
\hline $\begin{array}{l}\text { Industry } \\
\text { Agriculture }\end{array}$ & $\begin{array}{l}635 \\
215\end{array}$ & $\begin{array}{l}31.4 \\
10.6\end{array}$ & $\begin{array}{c}11.84 \\
316\end{array}$ & $\begin{array}{c}16.0 \\
4.0\end{array}$ \\
\hline $\begin{array}{l}\text { Agriculture } \\
\text { Public Facilities }\end{array}$ & 670 & $\begin{array}{l}10.6 \\
33.1\end{array}$ & $\begin{array}{l}3.10 \\
2.35\end{array}$ & $\begin{array}{l}4.0 \\
3.0\end{array}$ \\
\hline $\begin{array}{l}\text { Public Facilities } \\
\text { Others }\end{array}$ & 115 & $\begin{array}{c}5.1 \\
5.7\end{array}$ & 4.78 & $\begin{array}{l}7.0 \\
7.0\end{array}$ \\
\hline $\begin{array}{l}\text { TOTALS } \\
\text { TOTAL }\end{array}$ & 2025 & & 73.55 & \\
\hline
\end{tabular}

Note: Completed projects refer to "productive or civil projects constructed in recipient countries with the help of financial resources provided by China as grants or interest-free loans. The Chinese side is responsible for the whole or part of the process, from study, survey, to design and construction, provides all or part of the equipment and building materials, and sends engineers and technical personnel to organize and guide the construction, installation and trial production of these projects. After a project is completed, China hands it over to the recipient country". (China State Council, 2011, p. 6)

Source: China State Council (2011).

Table 2.6 displays a more detailed description of the sectoral distribution of China's grants and interest-free loans at the project level. At the time of this writing, no official information about the sectoral distribution patterns for the African continent has been available for the period under investigation. Since the African continent is China's largest aid recipient, it is safe to assume that the sectoral distribution of China's aid in Africa resembles the global pattern illustrated in Table 2.6.

\footnotetext{
${ }^{27}$ The other four principles of Peaceful Coexistence are (i) mutual respect for sovereignty, (ii) mutual non-aggression, (iii) equality and mutual benefit and (iv) peaceful co-existence.
} 
Table 2.6: Sectoral Distribution of China's Completed Projects, 1950-2009

\begin{tabular}{lcclcc}
\hline \multicolumn{1}{c}{ Sector } & $\begin{array}{c}\text { \# of } \\
\text { projects }\end{array}$ & & Sector (continued) & $\begin{array}{c}\text { \# of } \\
\text { projects }\end{array}$ \\
\cline { 1 - 2 } \cline { 5 - 5 } Agriculture & $\mathbf{2 1 5}$ & & Industry & $\mathbf{6 3 5}$ \\
Farming, animal husbandry, fish & 168 & & Light industry & 320 \\
Water conservancy & 47 & & Textiles & 74 \\
Public Facilities & $\mathbf{6 7 0}$ & & Radio and electronics & 15 \\
Conference buildings & 85 & & Machinery industry & 66 \\
Sports facilities & 85 & & Chemical industry & 48 \\
Theatres \& Cinemas & 12 & & Timber processing & 10 \\
Civil buildings & 143 & & Building materials processing & 42 \\
Municipal facilities & 37 & & Metallurgical industry & 22 \\
Wells and water supply & 72 & & Coal industry & 7 \\
Science, education, health care & 236 & & Oil industry & 19 \\
Economic Infrastructure & $\mathbf{3 9 0}$ & & Geological prospecting & 12 \\
Transport & 201 & & Others & $\mathbf{1 1 5}$ \\
Power Supply & 97 & & TOTAL & $\mathbf{2 0 2 5}$ \\
Broadcasting/telecommunications & 92 & & &
\end{tabular}

Note: Completed projects refer to "productive or civil projects constructed in recipient countries with the help of financial resources provided by China as grants or interest-free loans. The Chinese side is responsible for the whole or part of the process, from study, survey, to design and construction, provides all or part of the equipment and building materials, and sends engineers and technical personnel to organize and guide the construction, installation and trial production of these projects. After the completion of a project, China hands it over to the recipient country." (China State Council, 2011, p. 6)

Source: China State Council (2011)

In fact, the literature provides vast qualitative evidence that the bulk of China's development assistance is aimed at strengthening Africa's infrastructure base (Foster, Butterfield, Chen, \& Pushak, 2009). Africa's low-quality infrastructure is presently considered as one major obstacle holding back commercial activities on the continent. Investment in infrastructure is therefore critical if African countries want to enjoy sustained socio-economic growth and development (Kaberuka, Schwab, \& Zoellick, 2011; Schwab \& Sala-i-Martin, 2011; UNCTAD, 2012). ${ }^{28}$ Regardless of the measure of infrastructure coverage - e.g. paved road density, internet density, electricity coverage, generation capacity, or sanitation - African countries score significantly lower than their equivalents in

\footnotetext{
${ }^{28}$ While over 2.4 million kilometres of roads exist on the African continent, only 22.7 per cent are paved. Despite the existence of a 90,230 kilometres long rail line system, only approximately 7 per cent of the continent is electrified. Even though the four major rivers on the continent total to 18,000 kilometres, only 6000 kilometres are navigable (Dhar, 2011).
} 


\section{CHAPTER 2}

the developing world (Yepes, Pierce, \& Foster, 2009). Besides Beijing's focus on economic infrastructure, empirical evidence by Bräutigam (1998, 2015b) suggests that an increasing part of Chinese foreign aid targets the agricultural sector in rural Africa, encouraging small-scale irrigation techniques of rice growing, and associated activities.

\subsubsection{Geographical Distribution of Chinese Aid}

At the time of writing, no official source providing information on the geographical distribution of China's current foreign aid in Africa is available. I have compiled some first rough estimates for the regional distribution of China's foreign aid in Africa for 2012 (Table 2.7). While Beijing is anxious to treat each country equally by not elevating one nation or group of people over another, the resource-rich endowments of countries like Sudan, Angola, Democratic Republic of Congo and Nigeria make them natural targets for China's rapid economic embrace of the continent. On the grounds of non-interference in political affairs, Beijing enjoys a comparative advantage in dealing with autocratic elites: China's ability to position itself as an alternative partner enables the Beijing government not only to establish political relationships with the Sudanese and Zimbabwean governments but it also allows it to derive direct economic benefits from these relationships (Alden, 2005, 2007; Tull, 2006).

While several resource-rich and authoritarian countries tend to receive a high portion of China's development assistance, this is only half the story: Ghana, a relatively resource-scarce country - compared to other African countries - and an exemplar for a successful democratic transition during the post-Cold War era in Africa, also receives a considerable portion of Beijing's foreign aid (see also Chapter 4). The inclusion of another resource-scarce country such as Ethiopia, as well as countries like Egypt and South Africa in the top ranks of Chinese aid recipients emphasizes the importance of geo-strategic considerations in China's aid policy.

Similar to the geographical distribution patterns of Chinese development aid, more than half China's FDI is concentrated in oil- or mineral-rich countries such as Nigeria, South Africa, Zambia, Angola, Sudan and more recently the Democratic Republic of Congo. The distribution of FDI remains highly skewed, with a few host countries receiving the largest share of investment. Those 
recipient economies are generally characterized by a relatively high abundance of natural resources, sea access and large expanding economic markets. The geographical composition of China's trading volume has become highly skewed in favour of a few major trading partners. Thus, South Africa and Angola accounted for almost fifty per cent of China's total trade volume with Africa in 2012.

Table 2.7: Regional Distribution of China's External Flows to Africa, $2011 / 2012$

\begin{tabular}{lclclc}
\hline \multicolumn{2}{c}{ Foreign Aid 2012 } & \multicolumn{2}{c}{ FDI stock 2011 } & \multicolumn{2}{c}{ Two-way Trade 2012 } \\
\hline Country & $\begin{array}{c}\text { Volume } \\
\text { (current US\$ } \\
\text { million) }\end{array}$ & Country & $\begin{array}{c}\text { Volume } \\
\text { (current US\$ } \\
\text { million) }\end{array}$ & Country & $\begin{array}{c}\text { Volume } \\
\text { (current US\$ } \\
\text { million) }\end{array}$ \\
\hline Sudan & 203 & South Africa & 4,775 & South Africa & 59,977 \\
Ethiopia & 202 & Zambia & 1,998 & Angola & 37,601 \\
Congo, DR & 187 & Nigeria & 1,950 & Nigeria & 10,570 \\
Nigeria & 186 & Algeria & 1,305 & Egypt & 9,545 \\
Angola & 154 & Angola & 1,245 & Libya & 8,760 \\
Ghana & 152 & Sudan & 1,237 & Algeria & 7,729 \\
Zimbabwe & 145 & Congo, DR & 970 & Ghana & 5,434 \\
Equat.Guinea & 143 & Zimbabwe & 875 & Congo, Rep. & 5,076 \\
Cameroon & 111 & Mauritius & 701 & Congo, DR & 4,365 \\
South Africa & 89 & Ethiopia & 607 & Sudan & 3,734 \\
Others & 928 & Others & 6,067 & Others & 45,543 \\
TOTAL & 2497 & TOTAL & 21,730 & TOTAL & 198,333 \\
\hline
\end{tabular}

Source: With regard to foreign aid, the country data for the year 2012 is an estimate calculated by the author based on information provided by Bräutigam (2009, 2013) and Strange et al. (2013). With regard to FDI, data comes from MOFCOM $(2009,2011)$ and UNCTAD $(2014)$. The trade data results are the author's own calculations based on data from UN COMTRADE Database.

\subsection{Changing Sectoral Allocation of Western Aid}

Over the last fifty years, Western ODA was characterized by many switches and fluctuations (Riddell, 2007; Szirmai, 2015, ch. 16). Unfortunately, detailed data at the sectoral level from the OECD/DAC database is only available from 1967 onwards for global bilateral aid and from 1973 onwards for Africa.

My sectoral classification deviates slightly from the sectoral classification by the OECD. I have reallocated "Water Supply \& Sanitation" from social infrastructure to physical infrastructure, but also "Banking \& Financial Services" and "Business \& Other Services" from social infrastructure to the productive 
sector. In Table 2.9, the figures in italics for 2005 and 2012 are estimates and interpolations by the author. For these years, a detailed sectoral breakdown of aid to Africa under the heading social infrastructure is not available (with the exception of data for the education sector). By deducting the share of education, I obtain the shares of total other social infrastructure sectors for those two years. These shares are then divided among the sub sectors of other "Social Infrastructure" by applying the proportions for these sub-categories from Table 2.8 .

Table 2.8: Sectoral Distribution of Total Bilateral Net ODA Disbursements to the World, 1967-2012

\begin{tabular}{|c|c|c|c|c|c|c|c|c|c|c|}
\hline Sector & 1967 & 1970 & 1975 & 1980 & 1985 & 1990 & 1995 & 2000 & 2005 & 2012 \\
\hline Social Infrastructure & 8.3 & 11.5 & 20.6 & 23.2 & 22.8 & 19.3 & 24.9 & 25.5 & 26.1 & 34.6 \\
\hline Education & 0.0 & 0.0 & 11.1 & 13.9 & 11.2 & 9.8 & 11.2 & 7.8 & 5.9 & 8.2 \\
\hline Health & 0.0 & 0.0 & 4.6 & 5.2 & 5.1 & 2.8 & 4.0 & 3.6 & 3.6 & 5.6 \\
\hline $\begin{array}{l}\text { Population and Reproductive } \\
\text { Health }\end{array}$ & 0.0 & 0.0 & 0.0 & 0.0 & 0.3 & 1.0 & 1.6 & 2.4 & 3.3 & 6.5 \\
\hline Government \& Civil Society & 0.0 & 0.0 & 1.4 & 1.1 & 2.2 & 3.0 & 3.3 & 5.0 & 9.6 & 12.2 \\
\hline $\begin{array}{l}\text { Other Social Infrastructure } \\
\& \text { Services }\end{array}$ & 8.3 & 11.5 & 3.5 & 3.1 & 4.1 & 2.8 & 4.8 & 6.7 & 3.7 & 2.1 \\
\hline Physical Infrastructure & 27.8 & 15.3 & 11.8 & 19.3 & 17.9 & 16.6 & 27.6 & 19.3 & 13.7 & 19.8 \\
\hline Transport \& Storage & 11.1 & 6.4 & 2.5 & 9.2 & 5.8 & 6.4 & 10.1 & 8.7 & 5.2 & 7.7 \\
\hline Communications & 3.2 & 2.3 & 1.8 & 1.9 & 2.2 & 2.2 & 1.6 & 0.9 & 0.4 & 0.4 \\
\hline Energy & 13.5 & 6.6 & 5.4 & 6.6 & 7.3 & 4.9 & 10.1 & 3.2 & 3.3 & 5.9 \\
\hline Water Supply \& Sanit & 0.0 & 0.0 & 2.1 & 1.5 & 2.6 & 3.2 & 5.7 & 6.4 & 4.7 & 5.8 \\
\hline Production Sectors & 36.6 & 18.2 & 22.6 & 25.1 & 20.9 & 12.8 & 12.6 & 10.8 & 7.3 & 10.6 \\
\hline Agriculture, Forestry, Fi & 7.0 & 8.0 & 8.6 & 11.5 & 13.0 & 7.5 & 7.4 & 5.1 & 3.4 & 5.5 \\
\hline Industry, Mining, Construction & 29.6 & 10.2 & 6.2 & 5.5 & 5.4 & 3.4 & 1.6 & 1.7 & 1.4 & 1.4 \\
\hline Trade Policies \& Regulations & 0.0 & 0.0 & 0.0 & 0.0 & 0.3 & 0.8 & 0.2 & 0.1 & 0.4 & 0.6 \\
\hline Tourism & 0.0 & 0.0 & 0.0 & 0.0 & 0.5 & 0.0 & 0.1 & 0.0 & 0.1 & 0.1 \\
\hline Banking \& Financial Services & 0.0 & 0.0 & 0.0 & 0.0 & 1.4 & 0.3 & 0.8 & 0.5 & 1.1 & 2.0 \\
\hline Business \& Other Services & 0.0 & 0.0 & 0.7 & 0.3 & 0.4 & 0.7 & 1.2 & 3.3 & 0.8 & 1.0 \\
\hline Non-specified by Sector & 0.0 & 0.0 & 7.2 & 7.8 & 0.0 & 0.1 & 1.4 & 0.1 & 0.0 & 0.0 \\
\hline Multi-Sector / Cross-Cutting & 0.0 & 1.2 & 2.1 & 2.0 & 1.2 & 3.2 & 4.9 & 8.1 & 6.2 & 9.7 \\
\hline $\begin{array}{l}\text { Commodity Aid / } \\
\text { General Prog. Ass. }\end{array}$ & 10.1 & 41.1 & 19.1 & 10.5 & 24.5 & 14.2 & 5.8 & 7.0 & 2.6 & 3.1 \\
\hline Action Relating to Debt & 6.5 & 4.3 & 4.1 & 5.7 & 2.5 & 23.2 & 7.3 & 7.7 & 26.8 & 2.8 \\
\hline Humanitarian Aid & 0.0 & 0.0 & 1.3 & 1.8 & 2.2 & 2.0 & 4.4 & 4.6 & 8.3 & 8.1 \\
\hline Unallocated / Unspecified & 10.8 & 8.4 & 18.4 & 12.4 & 7.9 & 8.5 & 12.7 & 16.9 & 9.2 & 11.2 \\
\hline TOTAL & 100.0 & 100.0 & 100.0 & 100.0 & 100.0 & 100.0 & 100.0 & 100.0 & 100.0 & 100.0 \\
\hline
\end{tabular}

Source: Author's own calculations based on OECD/DAC Statistics.

Table 2.8 presents the changing sector structure of global bilateral ODA; Table 2.9 does the same for Western bilateral ODA disbursements for Africa. The global trends in Table 2.8 and the African trends in Table 2.9 are in many ways 
similar, though the shifts in Table 2.8 are even more marked than those of Table 2.9 focusing on Africa.

Table 2.9: Sectoral Distribution of Total Bilateral Net ODA Disbursements in

\begin{tabular}{|c|c|c|c|c|c|c|c|c|}
\hline \multicolumn{9}{|c|}{ frica, 1973-2012 } \\
\hline Sector & 1973 & 1980 & 1985 & 1990 & 1995 & 2000 & 2005 & 2012 \\
\hline Social Infrastructure & 14.1 & 7.6 & 10.7 & 10.0 & 26.3 & 29.8 & 24.7 & 36.1 \\
\hline Education & 3.9 & 3.0 & 4.3 & 2.5 & 5.1 & 9.1 & 7.3 & 8.3 \\
\hline Health & 2.0 & 1.8 & 2.5 & 2.4 & 4.8 & 5.4 & 3.1 & 5.9 \\
\hline $\begin{array}{l}\text { Population \& Reproductive } \\
\text { Health }\end{array}$ & 0.5 & 0.3 & 1.0 & 1.2 & 2.2 & 5.2 & 2.8 & 6.8 \\
\hline Government \& Civil Society & 6.1 & 0.3 & 2.2 & 2.8 & 9.7 & 6.6 & 8.2 & 12.9 \\
\hline $\begin{array}{l}\text { Other Social Infrastructure } \\
\& \text { Services }\end{array}$ & 1.7 & 2.3 & 0.7 & 1.1 & 4.5 & 3.5 & 3.2 & 2.2 \\
\hline Physical Infrastructure & 30.6 & 29.7 & 22.0 & 23.9 & 21.1 & 10.6 & 8.3 & 18.6 \\
\hline Transport \& Storage & 12.5 & 14.8 & 6.6 & 7.9 & 5.6 & 3.3 & 30 & 72 \\
\hline Communications & 4.5 & 4.4 & 2.2 & 2.4 & 1.4 & 1.3 & J.9 & 1.2 \\
\hline Energy & 8.9 & 6.7 & 5.3 & 6.9 & 6.1 & 1.6 & 2.2 & 5.3 \\
\hline Water Supply \& Sanitation & 4.7 & 3.8 & 7.9 & 6.7 & 8.0 & 4.4 & 2.2 & 6.1 \\
\hline Production Sectors & 12.4 & 17.4 & 20.4 & 18.2 & 12.0 & 15.5 & 5.5 & 10.2 \\
\hline Agriculture, Forestry, Fishing & 6.7 & 11.9 & 12.9 & 12.2 & 8.6 & 7.1 & 2.8 & 6.6 \\
\hline Industry, Mining, Construction & 2.7 & 5.0 & 6.1 & 3.4 & 1.0 & 2.5 & 0.5 & 0.9 \\
\hline Trade Policies \& Regulations & 0.1 & 0.1 & 0.0 & 0.1 & 0.2 & 0.2 & 5 & \\
\hline Tourism & 1.5 & 0.1 & 0.1 & 0.4 & 0.0 & 0.0 & .5 & .3 \\
\hline Banking \& Financial Services & 1.4 & 0.3 & 1.3 & 2.1 & 1.3 & 0.9 & 17 & 23 \\
\hline Business \& Other Services & 0.0 & 0.0 & 0.0 & 0.0 & 0.9 & 4.8 & 1.1 & 2.3 \\
\hline Multi-Sector & 1.0 & 5.1 & 3.1 & 7.2 & 8.1 & 9.2 & 5.2 & 6.3 \\
\hline $\begin{array}{l}\text { Commodity Aid / } \\
\text { General Progr. Assist. }\end{array}$ & 32.4 & 26.7 & 33.8 & 22.5 & 13.0 & 13.5 & 5.3 & 5.9 \\
\hline Debt Relief & 1.0 & 10.7 & 4.9 & 16.5 & 14.1 & 13.2 & 36.9 & 8.2 \\
\hline Humanitarian Aid & 0.7 & 1.1 & 3.8 & 1.1 & 4.6 & 7.1 & 11.9 & 12.4 \\
\hline Unspecified & 7.8 & 1.6 & 1.3 & 0.6 & 0.8 & 1.1 & 2.2 & 2.3 \\
\hline TOTAL & 100.0 & 100.0 & 100.0 & 100.0 & 100.0 & 100.0 & 100.0 & 100.0 \\
\hline
\end{tabular}

Source: Author's own calculations based on OECD/DAC Database and OECD (2003).

Initially, Western development aid was highly focused on infrastructural and industrial development. In the late 1960s almost 30 per cent of global bilateral ODA flowed into physical infrastructure projects (road construction, transport, telecommunications, electricity supply, etc.). In 1973, the share of African ODA disbursements flowing into physical infrastructure projects (road construction, transport, telecommunications, electricity supply, etc.) and the production sector accounted for 30.6 and 12.4 per cent, respectively. By 2005, however, the 


\section{CHAPTER 2}

infrastructure and production sector together only accounted for 13.8 per cent. The share of African bilateral ODA disbursements allocated to the physical infrastructure sector declined even more rapidly than the share of global bilateral ODA disbursements targeting that sector.

Meier (1984) provides qualitative evidence that the emphasis on physical infrastructure development was even more pronounced in the early post-war period. Influential writings in the 1950s and 1960s identified lack of capital and infrastructure as developmental constraints and further examined the role of aid in providing sufficient funds for physical capital accumulation (Chenery \& Strout, 1966; Nurkse, 1953; Rosenstein-Rodan, 1961; Rostow, 1959). With developing countries seen as being caught in a poverty trap, big-push investment programs were advocated to address infrastructural obstacles prominent in most low-income countries.

Influenced by Theodore Schultz' early seminal contributions on agricultural economics (see Schultz, 1956, 1964), increasing attention was paid to investment in the agricultural sector, resulting in major increases in the share of this sector in total aid allocations till 1985 (both globally and in Africa). Rural development programs and agricultural production aimed at enabling self-sufficiency for farmers who could export surpluses to urban regions, where people could then engage in other productive activities apart from subsistence, were put at centre stage of Western development strategies, especially in the context of SubSaharan Africa. After 1985 (globally) and 1990 (Africa), however, the share of aid going to agriculture rapidly declined.

The 1980s were marked by the second oil shock in 1979 and the consequences of the debt crisis of 1982. Consequently, structural adjustment programs were advocated and monitored by the IMF and the World Bank. Economic thought during that period was heavily influenced by earlier work of Bauer $(1972,1975)$ and Friedman (1958). Bauer and Friedman were two of the most ardent critics of foreign aid, seeing development assistance as a powerful force that undermines economic activity in the private sector. Due to aid flows, governments would face less pressure to build a business environment suitable for private (domestic) enterprises, which were considered to be the ultimate engine of growth in a capitalist economy. The "golden era" of development aid in the 1960s and 1970s came to a halt as the focus on development strategy 
shifted towards internal domestic policy failure and the implementation of prudent macroeconomic policies. As a result, the era just before the end of the Cold War was increasingly characterized by structural adjustment lending and debt relief. Meanwhile, development projects aimed at health, education and poverty alleviation were cut back significantly (Riddell, 2007).

In the 1990s, the donor community became increasingly disenchanted with the effectiveness of structural adjustment and conditionality (Meltzer, 2000; Szirmai, 2015 , ch. 16). One response to the disappointment with the outcomes of structural adjustment programmes of the 1980s and early 1990s was an increasing emphasis on poverty reduction. The importance of poverty reduction had already been emphasized since the 1970s (Chenery, Ahluwalia, Duloy, Bell, \& Jolly, 1974; Ghai \& Lee, 1980; The British Ministry of Overseas Development, 1976), but gained increasing force in the wake of structural adjustment. Thus, countries were required to draw up poverty reduction strategy papers (PRSPs) to qualify for debt relief.

A second important response to the perceived failure of structural adjustment was an increased emphasis on far reaching institutional reform and good governance (Burnside \& Dollar, 2000; Rodrik, 2006). During the post-Cold War era and in accordance with the rediscovery of the importance of a sound political institutional structure for delivering long-run growth (North, 1990), 'traditional' foreign aid from rich donor countries to low-income countries became increasingly subject to political conditionality and later aid selectivity. The influential World Bank Report in the late 1990s published by Dollar and Pritchett (1998) summarized major findings of a multi-year research program on aid effectiveness. Political conditionality was regarded as a necessary condition for enhanced aid effectiveness and as useful tool for promoting democratic governance and institutional reform in the least developed countries. ${ }^{29}$ While the share of African ODA flowing into civil society strengthening, as well as local and national government support (what could be called "political infrastructure") amounted to only 0.3 per cent in 1980, 12.9 per cent of total ODA flowed into this sector by 2012 .

\footnotetext{
29 The effectiveness of aid conditionality on promoting democratic governance is still heavily debated (Dreher, 2009; Svensson, 2003). Broad consensus exists that aid selectivity has become a major concern for donor nations (Bourguignon \& Sundberg, 2007; Dollar \& Levin, 2006).
} 
In sum, for a variety of reasons, from the mid-1980s onwards, Western donor countries started to shift the focus away from (i) infrastructure projects and (ii) production sectors. On the other hand, the share of Western ODA flowing into African social infrastructure and capability building has steadily increased over the last three decades. This process reached its apex around 2005. Between 2005 and 2012, the production sector and infrastructure shares have bounced back, possibly in response to the Chinese embrace of the African continent. But the long-run trend remains unmistakable.

Table 2.10 displays the evolution of total World Bank lending to Sub-Saharan Africa by sector over time, including both International Bank for Reconstruction and Development (IBRD) loans and International Development Association (IDA) credits. World Bank lending serves as my proxy for the evolution of Western multilateral development assistance over time. The results are very similar to my findings for Western bilateral development assistance. While approximately 75 per cent of World Bank lending between 1946 and 1960 targeted physical infrastructure development, primarily transport, power generation and telecommunications, the share fell to 36.6 per cent in 1977 and stayed at around that level until 2011. The share of agriculture dropped from a peak of 40 per cent in 1977 to 8.1 per cent in 2003, before rebounding to 11.9 per cent in 2011. It had become a relatively low-priority sector in the mid-2000s, even though around 82 per cent of the rural Sub-Saharan population lives in agriculture-based countries (World Bank, 2007). In a similar vein, World Bank lending into industrial projects has slid from only 5.7 per cent in 1977 to a meagre 1.8 per cent in 1991. While the share increased somewhat since then, the amount of funding channelled into industrial related projects remains negligible.

Another sector which has witnessed a decline in relative terms is the transport sector. These declines contrast with the increasing importance of judicial and public administrative capacity building. While only 0.8 per cent of World Bank lending went into judicial and public administrative capacity building shortly after the fall of the Iron Curtain, the share rose to 26.3 per cent in 2011. Thus, both bilateral and multilateral development assistance have increasingly emphasized judicial and public administrative capacity building at the expense of physical infrastructure development and the fostering of productive sectors. 
The increasing emphasis of Western development assistance on the political and institutional infrastructure in a recipient country, seen as one of the ultimate sources of growth and development, goes hand in hand with a considerable decline in resources made available for specific productive sectors such as (i) Industry and Trade, (ii) Agriculture, Fishing and Forestry or (iii) Transportation, which belong to the more proximate sources of growth (Maddison, 1988; Szirmai, 2012b).

Table 2.10: Sectoral Distribution of World Bank Lending to Sub-Saharan Africa

\begin{tabular}{lcccccccc}
\hline \multicolumn{1}{c}{ Sector } & \multicolumn{2}{c}{$\mathbf{1 9 7 7}$} & $\mathbf{1 9 9 1}$ & $\mathbf{2 0 0 3}$ & $\mathbf{2 0 1 1}$ \\
& Volume & $\mathbf{0}$ & Volume & $\mathbf{0}$ & Volume & $\mathbf{\%}$ & Volume & \% \\
\hline Social Infrastructure & 52.1 & 5.5 & 3876.5 & 10.0 & 1921.2 & 51.4 & 2944.6 & 41.7 \\
Education & 52.1 & 5.5 & 2437.3 & 6.3 & 423.6 & 11.3 & 497.6 & 7.0 \\
Population and Health & - & 0.0 & 1131.5 & 2.9 & 775.9 & 20.8 & 591.4 & 8.4 \\
Government \& Civil Society & - & - & 307.7 & 0.8 & 721.8 & 19.3 & 1855.6 & 26.3 \\
Physical Infrastructure & 345.6 & 36.6 & 15753.7 & 40.8 & 1352.6 & 36.2 & 2732.6 & 38.7 \\
Transport \& Storage & 167.6 & 17.7 & 7081.6 & 18.3 & 690.5 & 18.5 & 937.9 & 13.3 \\
Communications & - & 0.0 & 862.3 & 2.2 & 41.4 & 1.1 & 259.0 & 3.7 \\
Energy & 112.0 & 11.9 & 4272.3 & 11.1 & 324.4 & 8.7 & 890.1 & 12.6 \\
Water supply and sanitation & 22.0 & 2.3 & 1735.3 & 4.5 & 296.3 & 7.9 & 645.7 & 9.1 \\
Urbanization & 44.0 & 4.7 & 1802.2 & 4.7 & - & - & - & - \\
Production Sectors & 489.2 & 51.8 & 13068.7 & 33.8 & 463.3 & 12.4 & 1382.8 & 19.6 \\
Agriculture, Forestry, Fishing & 377.9 & 40.0 & 9347.5 & 24.2 & 303.4 & 8.1 & 843.1 & 11.9 \\
Industry \& Trade & 53.6 & 5.7 & 711.6 & 1.8 & 92.7 & 2.5 & 432.8 & 6.1 \\
Banking \& Financial Services & 57.7 & 6.1 & 2340.2 & 6.1 & 67.2 & 1.8 & 106.8 & 1.5 \\
Business \& Other Services & - & - & 669.4 & 1.7 & - & - & - & - \\
Nonproject & 45.0 & 4.8 & 5071.1 & 13.1 & - & - & - & - \\
Technical assistance & 12.4 & 1.3 & 876.1 & 2.3 & - & - & - & - \\
TOTAL & 944.3 & 100.0 & 38646.1 & 100.0 & 3737.2 & 100.0 & 7060.0 & 100.0 \\
\hline
\end{tabular}

Notes: Volumes are expressed in current US\$ million. My sectoral classification slightly deviates from the sectoral classification by the World Bank. I have reallocated "Water Supply \& Sanitation" from social infrastructure to physical infrastructure, but also "Banking \& Financial Services" and "Business \& Other Services" from social infrastructure to production sectors. Categories have been subject to change due to a new thematic-sectoral coding system installed in the year 2003. Share of Physical Infrastructure for the period 1946-1971 refers to World. Share of "Agriculture, Forestry and Fishing" refers to World and covers the period 1948-1972. Lending includes both IDA and IBRD lending.

Sources: World Bank Annual Reports (various); Krueger, Michalopoulos and Ruttan (1989); Lumsdaine (1993). 


\subsection{Aid, Investment and Trade: Similarities and Differences}

The Chinese aid system drastically differs from the Western system in at least two ways: First, Chinese aid funding is embedded into a wider foreign policy framework characterized by the non-interference in internal affairs and Beijing's upholding of political equality with recipient states (Alden, 2005; Bräutigam, 2009; Huse \& Muyakwa, 2008). While most of the Western development aid in recent years is characterized by political conditionality and aid selectivity, the bulk of Southern development assistance comes with relatively 'few strings attached'. In contrast to most 'traditional' donors, Southern donors impose little or even no macroeconomic or governance conditionality based on the principles of respect for national sovereignty and non-interference in domestic affairs. ${ }^{30}$

In the eyes of African recipient governments, China's aid with almost no strings attached is viewed as welcome alternative to Western aid linked to political conditionality and aid selectivity - despite the fact that much of Beijing's development assistance in Africa is tied to (i) the purchase of Chinese goods and services or (ii) to Chinese access to African natural and energy resources. Primary commodities serve as collateral for the concessional loans in barter agreements. The barter agreement, also known as "Angola model" (Davies et al., 2008) has become China's preferred way of safeguarding its concessional loan packages to the continent. Naidu and Davies (2006) describe this phenomenon as 'coalition investment'.

Second, Chinese and Western development aid flows are based on different core development ideas and ideologies. Among traditional donor countries, aid conditionality and aid selectivity are nowadays viewed as necessary condition for enhanced aid effectiveness and as useful tool for promoting democratic governance and institutional reform in developing countries. Influenced by theoretical underpinnings by authors such as North (1990), Acemoglu, Johnson and Robinson (2001, 2002) or Rodrik, Subramanian and Trebbi (2004) the traditional donors have increasingly stressed the significance of the ultimate sources of growth, namely the (political) intangibles of development, for

\footnotetext{
${ }^{30}$ The notable exception from China's rejection of political demands is Beijing's 'One China Policy'.
} 
example capacity building, democratization, adherence to human rights principles, rule of law and good governance.

The increasing emphasis of Western development assistance on the (political) intangibles of development is in marked contrast to Beijing's emphasis on the (economic) tangibles of development such as productivity gains in agriculture, industrial processing, or the refurbishment of physical infrastructure. The patterns of China's aid remarkably resemble ideas put forward in the big push literature (Hirschman, 1958; Nurkse, 1953; Rosenstein-Rodan, 1943, 1961) or in developmental work by Kuznets (1966).

Beijing's present foreign aid with its focus on infrastructure and the productive sector is highly reminiscent of the approach of Western foreign aid policy in the 1960s. In contrast to traditional development assistance, however, China's sectoral allocation has been relatively stable over time compared to the erratic patterns of Western foreign aid with its trends, switches and sudden breaks. Chinese authorities have spotted the vacuum and actively contribute to filling the gap by aiding a majority of African countries in the productive sectors of the economy.

We observe some similarities between Chinese and Western FDI in Africa, but also some distinct differences. Before China's surge of private investment on the African continent, most of Western FDI has taken place in resource extractive industries, and in recent years increasingly in service sectors. The majority of Western firms has disengaged from African manufacturing. Like Western resource-seeking FDI, a large fraction of investment carried out by Chinese state-owned enterprises predominantly takes place in resource extraction. Beijing becomes increasingly dependent on the extraction of foreign natural resources to fuel its domestic economic growth (Lee, 2012; Moyo, 2012; Wenping, 2007). When comparing China's resource extractive activities as a proportion of both its global and African FDI stock (14.1 per cent versus 29.2 per cent), we see that investment in resource-extractive sectors is twice as important on the African continent (Table 2.11).

However, one of the sectors in several African economies which has also witnessed a major influx of investment flows from China is the manufacturing sector. While Chinese investors have paid relatively little attention to investments in manufacturing industries on a global scale, manufacturing FDI 
from China has played a much more important role on the African continent. Interestingly here, it is not the state-owned companies that play a prominent role, but private-owned Chinese SMEs. The bulk of investment by Chinese SOEs tends to be assigned to big projects related to natural resource-extraction, contracting and service sectors such as telecommunications or the large-scale refurbishment of physical infrastructure. These projects are often linked to concessional loans and economic cooperation projects thereby signifying the strong nexus to aid funding. Manufacturing FDI only plays a negligible role for Chinese SOEs. In contrast, small or medium-sized private companies tend to be concentrated in manufacturing and wholesale trade (Kaplinsky \& Morris, 2009; Shen, 2013; Wang, 2007).

Table 2.11: Sectoral Distribution of China's Outward FDI Stock, 2010

\begin{tabular}{|c|c|c|c|c|}
\hline \multirow[b]{2}{*}{ Sector } & \multicolumn{2}{|c|}{ AFRICA* } & \multicolumn{2}{|c|}{ WORLD } \\
\hline & $\begin{array}{l}\text { Volume } \\
\text { (current } \\
\text { US\$ mill.) }\end{array}$ & $\begin{array}{c}\% \text { of } \\
\text { China's } \\
\text { total } \\
\text { outward } \\
\text { stock in } \\
\text { Africa }\end{array}$ & $\begin{array}{l}\text { Volume } \\
\text { (current } \\
\text { US\$ mill.) }\end{array}$ & $\begin{array}{c}\% \text { of China's } \\
\text { global } \\
\text { outward stock }\end{array}$ \\
\hline Mining/Resource Extraction & $2,724.9$ & 29.2 & $44,660.6$ & 14.1 \\
\hline Manufacturing & $2,053.0$ & 22.0 & $17,801.7$ & 5.6 \\
\hline Construction & $1,474.5$ & 15.8 & $6,173.3$ & 1.9 \\
\hline Finance & $1,297.2$ & 13.9 & $55,253.2$ & 17.4 \\
\hline Transport, Storage and Post & 5030 & 54 & $23,187.8$ & 7.3 \\
\hline Leasing and Business Services & & & $97,246.1$ & 30.7 \\
\hline Wholesale and Retail Trade & 373.3 & 4.0 & $42,006.5$ & 13.2 \\
\hline IT & 298.6 & 3.2 & $8,406.2$ & 2.7 \\
\hline Real Estate & - & - & $7,266.4$ & 2.3 \\
\hline Others & 317.3 & 3.4 & $15,208.8$ & 4.8 \\
\hline Agriculture & 289.3 & 3.1 & & \\
\hline TOTAL & $9,332.0$ & & $317,210.6$ & \\
\hline
\end{tabular}

*: Figures for Africa refer to the year 2009.

$\dagger$ : The volumes with respect to each sector are estimated by multiplying the sectoral share with China's total FDI stock in Africa for the year 2009.

Sources: China State Council (2010); China State Council (2013); MOFCOM (2011).

In Table 2.12, I compare investment to aid ratios for China and the DAC donors to assess the relative importance of investment to aid. I do this by calculating the ratio of investment to aid flows. The table provides the results for the major players on the African continent. For all but one of the DAC donors, aid flows 
have been larger than FDI in 2000. In contrast, Chinese annual investment activities exceeded its annual development assistance on the continent. Compared to China, Western donors such as Germany, Japan and the United States had investment/aid ratios of less than one, indicating a dominance of aid over investment.

Table 2.12: Investment/Aid Ratio in Africa for Major Home Economies, Selected Years

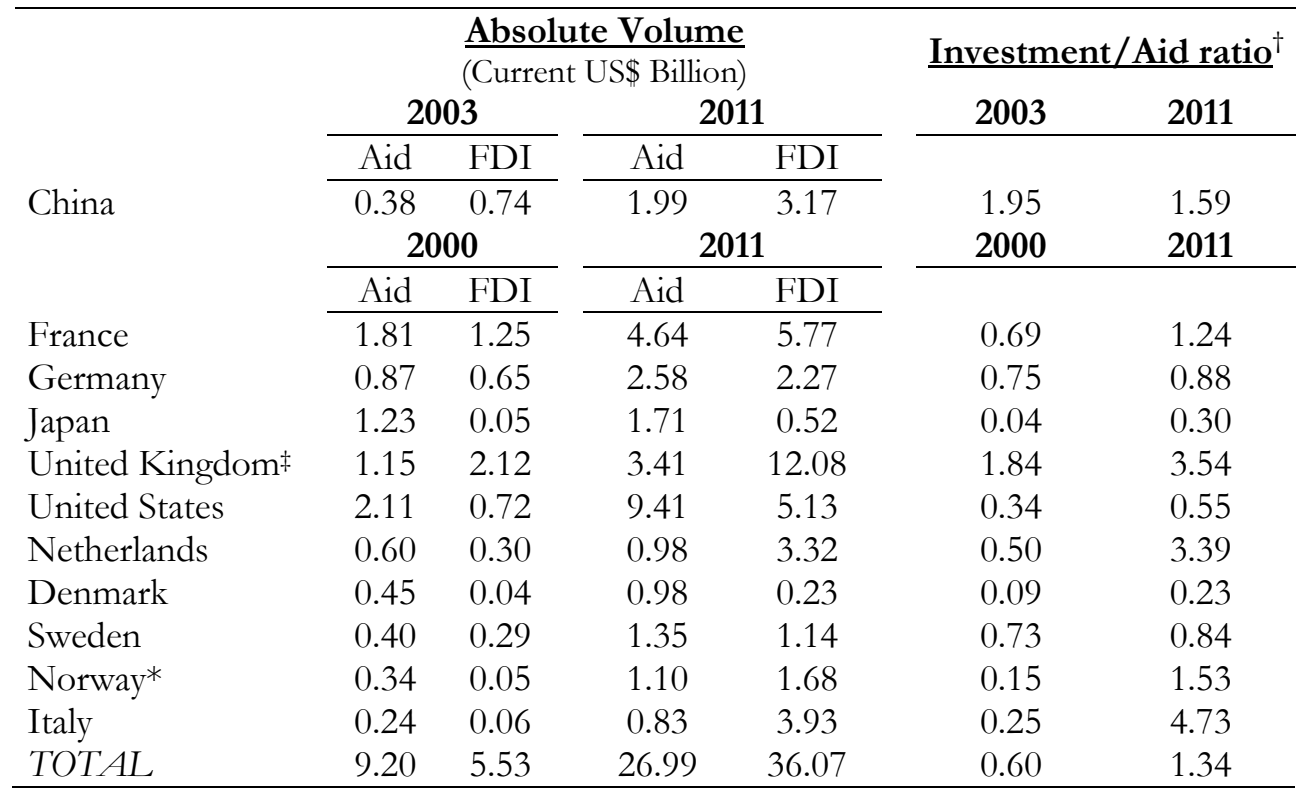

$t:$ The ratio is equal to the country's yearly FDI flows to Africa divided by the yearly aid disbursements to Africa.

¥: Data with regard to the United Kingdom refers to the years 2000 and 2010. FDI inflows in the year 2011 were actually negative (therefore FDI outflows). This observation, however, was a severe outlier in the long-term evolution of British FDI flows to Africa.

*: FDI data with regard to Norway refers to the years 1999 and 2010, respectively.

Sources: FDI-Aid ratio refers to authors' own calculations; Aid data comes from Bräutigam (2009) and OECD/DAC Database. FDI data comes from MOFCOM (2009, 2011) and from UNCTAD FDI/TNC database.

But perhaps in response to Beijing's strong emphasis on direct investment in the game of foreign finance, the relative importance of investment has been increasing in all Western countries, particularly in the Netherlands and Italy. The average investment-aid ratio of 10 major Western players increased from 0.6 in 2003 to 1.34 in 2011. I therefore conclude that China's commercial activities tend to dominate aid, while until recently the opposite has been true for most Western players (such as Germany, Japan, United States, Denmark, Sweden). 
Even in 2011, the investment/aid ratio is substantially higher for China than all but three of the advanced economies.

Summarizing, while the developed countries have accounted for the lion's share of inward FDI stock and of flows to many African countries since the mid1970s, FDI from Southern investors is growing rapidly. Before the emergence of China, the volume of development assistance was larger than the volume of direct investment among many Western players. Beijing's strong emphasis on direct investment in the game of foreign finance, however, led to a paradigm shift of the composition of foreign finance among at least a few traditional players, with FDI inflows to Africa originating from Western players outstripping annual development assistance.

Compared to the remarkable differences in the sectoral allocation of Western and Chinese development assistance, and also to some extent with respect to the allocation of Western and Chinese FDI, trade patterns of the West and China with Africa tend to be remarkably similar. Table 2.13 shows the sectoral distribution of Chinese, European and U.S. trade flows at the country level for the year 2012. European and U.S. imports from several African countries mainly comprise crude materials and mineral fuels. Manufactured goods form the lion's share of exports in many African trading countries. Regarding the selected countries, one can observe that China's imports are even more highly concentrated in the resource sector compared to those of the United States and the European Union.

While the increasing trade relationships between China and Africa are often described as South-South trade, the pattern highly resembles the typical NorthSouth trade patterns predicted by Ricardo (1817). The evolution of Sino-African trade patterns mirrors Ricardo's law of (static) comparative advantage. Relative factor endowments of labour, capital and natural resources are largely responsible for the nature of Sino-African trade patterns: Similar to the NorthSouth pattern observed between the European Union, the United States and Africa, China largely exports manufactured goods and transport equipment, while it mainly imports energy and mineral resources from Africa in return. Similar to the advanced economies from the Global North, China trades with Africa in a North-South fashion exchanging processed goods and services for primary products. 
Table 2.13: China's Trade with Selected African Countries by Sector, 2012 (\%)

\begin{tabular}{|c|c|c|c|c|c|c|c|c|c|}
\hline & \multicolumn{6}{|c|}{$\begin{array}{l}\text { Imports from Africa } \\
\text { (in \% of total imports) }\end{array}$} & \multicolumn{3}{|c|}{$\begin{array}{l}\text { Exports to Africa } \\
\text { (in } \% \text { of total exports) }\end{array}$} \\
\hline & \multicolumn{3}{|c|}{$\begin{array}{l}\text { Extraction of } \\
\text { oil and gas }\end{array}$} & \multicolumn{3}{|c|}{$\begin{array}{l}\text { Mining of coal, } \\
\text { metal ores, } \\
\text { uranium, etc. }\end{array}$} & \multicolumn{3}{|c|}{ Manufacturing } \\
\hline & China & $\mathrm{EU}$ & USA & China & EU & USA & China & EU & USA \\
\hline Algeria & 99.8 & 84.8 & 56.7 & 0 & 0.3 & 0 & 99.4 & 98.7 & 88.6 \\
\hline Angola & 99.4 & 90.4 & 94.3 & 0.4 & 5.8 & 0.8 & 99.7 & 99.4 & 98.3 \\
\hline Cameroon & 56.1 & 52.9 & 15.0 & 0 & 0 & 0 & 98.9 & 99.0 & 96.5 \\
\hline DRC & 20.5 & 0 & 0 & 11.5 & 28.6 & 40.2 & 98.5 & 99.5 & 91.2 \\
\hline Egypt & 66.6 & 44.2 & 45.7 & 18.4 & 1.3 & 0.4 & 98.1 & 97.3 & 74.7 \\
\hline Ethiopia & 0 & 0 & 0 & 3.7 & 0 & 3.6 & 99.9 & 99.5 & 59.5 \\
\hline Ghana & 52.9 & 68.6 & 0 & 28 & 5.5 & 0.7 & 99.9 & 99.6 & 97.0 \\
\hline Kenya & 0 & 0 & 0 & 24.2 & 1.9 & 0 & 99.7 & 99.3 & 87.6 \\
\hline Libya & 100.0 & 95.3 & 90.2 & 0 & 0 & 0 & 98.7 & 97.0 & 97.4 \\
\hline Morocco & 0 & 0 & 0 & 30.1 & 5.1 & 33.9 & 99.3 & 96.3 & 76.0 \\
\hline Mozambique & 0 & 0 & 0 & 35.1 & 9.0 & 46.3 & 99.7 & 99.8 & 91.2 \\
\hline Nigeria & 81.8 & 96.2 & 92.9 & 5.5 & 0 & 0 & 99.9 & 99.6 & 79.9 \\
\hline South Africa & 2.4 & 0 & 0 & 60.3 & 18.0 & 7.2 & 99.3 & 94.8 & 96.9 \\
\hline Sudan & 96.8 & 0 & 0 & 0.3 & 0 & 0 & 99.3 & 98.4 & 33.6 \\
\hline Tanzania & 0 & 0 & 0 & 58.3 & 20.1 & 1.2 & 99.9 & 99.7 & 97.1 \\
\hline Zambia & 0 & 0 & 0 & 1.6 & 8.8 & 2.6 & 100.0 & 99.6 & 99.9 \\
\hline
\end{tabular}

Source: Own calculations based on World Bank WITS database

\subsection{Competition and Complementarity}

Here, I will briefly examine the degree of static complementarity and competition between Chinese and Western economic activities in Africa. Complementarity between Chinese and Western economic activity implies that their activities focus on different sectors at the same point in time. Competition occurs when China and the West are active in the same sectors competing for the same kind of activities and the same resources in the same countries.

Chinese activities in the primary and secondary sector can be seen as a competitive threat for Western firms. The international competitiveness of Chinese firms is visible in the African construction industry. Between 1999 and 2009, Chinese contractors have won up to 20 per cent of African infrastructure contracts awarded by the IDA. In the area of civil works, around 20 per cent of all contracts are won by Chinese construction enterprises. Very often, the second most highly ranked bidder was also a Chinese firm (Foster et al., 2009). Chinese 


\section{CHAPTER 2}

construction enterprises are particularly successful in the field of transport (mainly roads) and water sectors. In terms of the sectoral distribution of civil works contracts won by Chinese firms, 97 percent of their value went to transport and water services between 2005 and 2006.

Another clear case of competition is China's resource-seeking FDI. Most of Western and Chinese investment takes place in the primary sectors of African economies, predominantly in the field of resource extraction. In order to fuel its domestic growth back home, securing access to natural as well as mineral resources has become a priority for the Beijing administration (Moyo, 2012). The resource-backed financing agreements between Chinese SOEs and African governments often lack transparency and accountability (Corkin, 2013; Taylor, 2006a).

China's increasing FDI in the natural resource sector can also be viewed as a response to voluntary withdrawal of Western resource-seeking FDI. When Western governments imposed sanctions against the Sudanese government in 2003 because of human rights violation in Darfur, most Western companies pulled out of resource-rich Sudan (Patey, 2014). Some Western firms were forced to exit because Western civil societies have exerted pressures on their respective governments for the adherence of (civil and political) human rights norms. Some other companies deliberately chose to exit because they were no longer willing to invest in a politically and economically risky environment. Beijing's quiet diplomacy, its frequent insistence on respect for national sovereignty and non-interference in internal affairs has served as comparative advantage in doing business in such autocratic resource-rich regimes.

In the case of market-seeking FDI, Chinese manufacturing FDI acts as a complement to Western market-seeking FDI in the service sector. As previously discussed, an increasing share of Western FDI flows has gone into the tertiary (service) sector of developing economies since the late 1990s. Concomitant with the continent's emerging middle class and its growing purchasing power, Western FDI in services such as banking, retail sales and telecommunications is beginning to rise (Radelet, 2010; UNCTAD, 2013a). Part of the vacuum left by shrinking Western FDI in manufacturing is filled with Chinese investment in labour-intensive industries in Africa. This is an example of substitution rather than competition. With the arrival of capital goods, the transfer of technology, 
and the potential for integration in global value chains (clothing, textile industry), Chinese manufacturing FDI could potentially act as catalyst for industrial development (Bräutigam, 2003). However, even though China's FDI in Africa is on the rise, its African FDI stock is still significantly smaller than that of traditional investors such as France, the United States or the United Kingdom.

Like Chinese manufacturing FDI, Beijing's increasing development assistance in the productive sectors of African recipient economies serves as a complement to the increasing focus on capacity building by the West. Beijing's present development finance with its focus on infrastructure and the productive sector is highly reminiscent of the approach of Western foreign aid policy in the 1960s. Over time, the share of bilateral (and multilateral) Western ODA flowing into some productive sectors of recipient economies such as agriculture, manufacturing and infrastructure has steadily declined. Consequently, China's development activities may serve as a complement to kinds of foreign aid provided by the traditional donor countries, even though Beijing's foreign aid budget is still relatively small compared to that of the combined DAC donors.

\subsection{Concluding Remarks}

The main objective of this chapter was to shed some light on the characteristics of China's rapidly growing economic ties with Africa. I have discussed China's rapid embrace of the African continent from an international comparative perspective. More specifically, I have analysed China's increasing development assistance in Africa against the background of changing patterns and trends in development aid originating from Western countries over the time period from the early 1960s until today. Chinese development assistance directed at the productive and infrastructural sectors of developing economies in Africa and elsewhere fills gaps created by the voluntary withdrawal of Western donors. Beijing's development assistance in the infrastructure and productive sectors of African recipient economies, namely agriculture, manufacturing and infrastructure, acts as a complement to present day Western development assistance.

Second, while resource-seeking FDI is a major motive for both Western and Chinese investors on the African continent, the sectoral destination of marketseeking FDI of the two respective players differs. In the view of the emergence 


\section{CHAPTER 2}

of middle class consumers in many African countries, Western companies have recognized increasing market opportunities in the service sector of those economies. Chinese small or medium-sized private companies, however, are characterized by market-seeking FDI in manufacturing sectors across the African territory. Those Chinese companies have spotted a vacuum that has been left by a majority of Western firms who pulled out of manufacturing activities to a large extent during the late 1990s. With regard to the geographic destination of FDI, I observe more similarities than differences between traditional Western investors and Chinese entrants. The distribution of foreign direct investment remains highly skewed, with a few host countries receiving the largest bulk of investment. Those recipient economies are generally characterized by a relatively high abundance of natural resources, coastal location and large expanding economic markets.

Third, African trade patterns with the West and China are rather similar. Though trade between China and Africa is often labelled as South-South trade, its structure very much resembles North-South trade patterns. Africa's exports to their leading trading partners consist mainly of exports of natural resources. With the increasing thirst for African oil, gas and other mineral resources, the trade deficits of the key international players have widened in recent years, while the African continent as a whole has enjoyed major trade surpluses with its leading trading partners. The trade pattern based on comparative advantage considerations is more pronounced for resource-rich African countries, which underscores that the pattern of trade depends more on the endowment structure of the African partner, than its levels of per capita income. Moreover, compared to Western imports from Africa, Chinese imports are geographically more concentrated. Compared to Western exports to Africa, however, Chinese exports are more diverse in terms of destination countries.

The topic of China's rapidly increasing finance flows to Africa is of considerable interest. Country case studies along the lines of Chau (2014), Corkin (2013), King (2013), van Reybrouck (2010, ch. 15) and Patey (2014) plus more extensive quantitative research on the developmental implications of China's growing economic presence on the African continent are promising avenues for further research. 


\section{CHAPTER 3}

\section{DO AUTHORITARIAN REGIMES RECEIVE MORE CHINESE DEVELOPMENT FINANCE THAN DEMOCRATIC ONES? EMPIRICAL EVIDENCE FOR AFRICA}

"The Chinese government always bases itself on the principle of equality and mutual benefit in providing aid to other countries. It never regards such aid as a kind of unilateral alms but as something mutual. In providing aid to other countries, the Chinese government strictly respects the sovereignty of recipient countries, and never attaches any conditions or asks for any privileges (...) In providing aid to other countries, the purpose of the Chinese government is not to make recipient countries dependent on China but to belp them embark step by step on the road of self-reliance and independent economic development."

- People's Republic of China (PRC), 1964 Excerpt from 'China's Eight Principles for Economic Aid and Technical Assistance to Other Countries'

"States like China (...) are regimes that have the cash and the will to reshape the world into a place very different from where the rest of us want to live. (...) If they continue to succeed in pushing their alternative development model, they will succeed in underwriting a world that is more corrupt, chaotic, and authoritarian." - Moisés Naím Former Venezuelan Minister of Trade and Industry (1989-1990) 


\subsection{Introduction}

Since the beginning of the $21^{\text {st }}$ century the rules of the international development finance game have slowly and quietly begun to change. Emerging economies from the Global South (such as China, United Arab Emirates, India, Brazil, Saudi-Arabia, Venezuela or Kuwait) increasingly strengthen their economic and political relationships with developing countries, including those in Africa. Recent qualitative and quantitative evidence suggests that China must be considered the biggest and most influential actor amongst the emerging donors (Bräutigam, 2009; Dreher \& Fuchs, 2015).

A burgeoning literature has discussed the potential opportunities and challenges of China's economic embrace of Africa (Alden, 2005; Biggeri \& Sanfilippo, 2009; He, 2013; Manning, 2006; Taylor, 2007a; Tull, 2006; Zhao, 2014). One specific strand of that increasing literature is qualitative work which labels Chinese development assistance as rogue aid that is guided merely by selfish motives and not by needs-based considerations (Naím, 2007; Taylor, 2007a, 2007b; Tull, 2006).

Sophisticated econometric work on the subject matter is sparse through a lack of comprehensive aid statistics from numerous emerging (non-DAC) donors. As already mentioned in Chapter 2, the Chinese government treats its aid allocation as a state secret. Very recently, Strange, Parks, Tierney, Fuchs and Dreher (2013) have developed an open-source data collection technique that aims to provide a more complete picture of non-DAC development finance activities, including China. It may therefore not come as a surprise that the quantitative literature on China's development finance to developing countries is sparse (Bader, 2015; Dreher, Fuchs, Parks, Strange, \& Tierney, 2017; Strange et al., 2017; Strüver, 2016).

This study is among the first to shed light on China's development finance activities in Africa using quantitative estimation techniques. My study is based on recent work by Dreher et al. (2017). The authors systematically analyse the determinants of China's official financing in Africa applying pooled Ordinary Least Squares (OLS) estimation methods. In contrast, my study is more specific and seeks to answer the research question: Do African Authoritarian Regimes receive more Chinese Development Assistance than Democratic Ones? In order to answer this 


\section{CHAPTER 3}

question, I first focus on the absolute amount of Chinese official development finance. Then I create a variable which measures the difference between the relative share of Chinese aid and the relative share of traditional DAC aid for each African country.

I use four different proxies for the degree of democracy/autocracy in the recipient country, which allows me to check whether my results depend on the specific indicator chosen. Besides OLS estimation, I use fixed effects and random effects models to account for unobserved heterogeneity. I also perform a Two Stage Least Squares (2SLS) estimation model to account for the possibility of reverse causality. ${ }^{31}$ First, I follow Ansell's (2010) approach and instrument the lagged democracy level of a specific country ( $t-1)$ with the democracy level of the previous year ( $t-2)$. I then instrument the lagged democracy level of a specific country with each country's year of independence drawing on the theory of institutional path dependence in economics (David, 1994; Greif, 1994; North, 1990) and historical institutionalism in political science (Hall \& Taylor, 1996; Pierson \& Skocpol, 2002; Putnam, 1993). The analysis includes 53 countries and covers the time period 2000-2011.32

My results suggest that Chinese official development finance does not systematically flow to more authoritarian countries, controlling for strategic, economic, political, institutional and geographic confounding factors. The major determinants of absolute Chinese development finance that are almost always statistically significant are: (i) whether a country recognises the People's Republic of China (PRC) or Taiwan (Republic of China, ROC) and (ii) whether English is considered one of the three most common languages in the recipient country and (iii) whether a country possesses large oil rents or not. In contrast to previous studies that found voting alignment with China in the United Nations Security Council (UNSC) to be a strong predictor of Chinese development finance, I show that this is not the case for voting alignment with China in the United Nations General Assembly (UNGA).

\footnotetext{
31 A vast amount of qualitative literature discusses to what extent Chinese development finance could deteriorate good governance and the democratization process in respective African recipient countries (Manning, 2006; Naím, 2007; Taylor, 2007a, 2007b; Tull, 2006; Zhao, 2014). 32 The analysis therefore covers all African countries except for South Sudan.
} 


\section{CHAPTER 3}

Furthermore, I do not find a strongly negative and highly statistically significant relationship between the institutional quality of a recipient country and Chinese official finance, both in absolute and relative terms. As a result, my findings suggest that equating Chinese development assistance with "rogue aid" (Naím, 2007) is unfounded.

The chapter is structured as follows. In the next section I briefly provide some background information with regard to the subject. Section 3.3 introduces the data and discusses the methodology. I present my main empirical results using OLS regressions in Section 3.4. Section 3.5 investigates the robustness of my results using FE and RE estimation as well as instrumental variable regression. Section 3.6 concludes.

\subsection{Background Information}

\subsubsection{Rise of Development Finance from non-DAC donors}

While extensive literature exists on the determinants of aid allocation by the traditional Western (DAC) donors (Alesina \& Dollar, 2000; Alesina \& Weder, 2002; Dreher, Sturm, \& Vreeland, 2009; Faye \& Niehaus, 2012; Fleck \& Kilby, 2006, 2010; Kersting \& Kilby, 2016; Kuziemko \& Werker, 2006; Neumayer, 2003a, 2005; Reynaud \& Vauday, 2009), studies that have empirically examined the determinants of aid allocation by emerging donors is surprisingly sparse. With the arrival of foreign aid data for emerging donors, some scholars have recently started to analyse the aid allocation of non-DAC donors using quantitative estimation methods. ${ }^{33}$ Neumayer (2003b, 2004) examines the factors that determine the aid allocation by Arab countries and multilateral agencies to recipient countries worldwide. Fuchs and Vadlamannati (2013) empirically assess India's foreign aid motives for a set of 125 countries over the 2008-2010 period. A study by Dreher, Nunnenkamp and Thiele (2011) compares the allocation of aid between DAC and non-DAC donors. Bermeo (2011) compares differences in preferences between democratic donors and authoritarian donors, including

\footnotetext{
${ }^{33}$ Here, I specifically refer to AidData, a new dataset of foreign assistance. AidData covers more bilateral and multilateral donors and more types of aid than existing datasets while also improving project-level information about the purposes and activities funded by aid (see Tierney et al., 2011).
} 


\section{CHAPTER 3}

donors from Arab countries (such as Kuwait, Saudi-Arabia or the United Arab Emirates).

In this chapter, I focus on Chinese development finance in Africa for three reasons. First, China can be regarded as the largest and possibly most influential emerging donor at the time of writing. Second, the African continent is by far the highest aid-dependent continent in the world. Third, data on Chinese aid has not been publicly available until recently. Strange, Parks, Tierney, Fuchs and Dreher (2013) have developed an open-source data collection technique AidData's Tracking Underreported Financial Flows (TUFF) methodology - that assembles a first-of-its-kind, project-level dataset on China's official financing activities in Africa from 2000 onwards.

Kitano and Harada (2016) estimate China's foreign aid between 2001 and 2013 that is comparable to net ODA figures. Using both OECD data and AidData, Kilama (2016) examines how aid flows of emerging donors, including China, affect the fiscal behavior of African recipient governments. Two very recent studies have analysed the motivations behind China's increasing foreign aid and other forms of state financing (Dreher \& Fuchs, 2015; Dreher et al., 2017). Dreher and Fuchs (2015) discuss the allocation and motivations of China's development aid for the 1956-2006 period. ${ }^{34}$ Moreover, they compare the allocation of China's project aid to that of the OECD-DAC and other emerging donor countries in a cross-section of 132 recipient countries over the 1996-2005 period.

A contribution by Dreher et al. (2017) studied the determinants of Chinese foreign aid and other official forms of state financing in Africa over the time period 2000-2012 using pooled OLS regression estimation techniques. Their results suggest that Beijing's motives for delivering foreign aid and other forms of state finance do not differ much from the motives behind the allocation of Western official finance. Moreover, the authors also test whether Chinese development finance is strongly associated with the level of democracy/autocracy in the respective recipient country. Using the polity2 variable from the Polity IV dataset (Jaggers \& Gurr, 1995; Marshall, 2014), the authors do not find a strong relationship. In contrast to Dreher et al. (2017), I

\footnotetext{
${ }^{34}$ For an extensive overview of China's aid, FDI and trade flows to Africa, see Chapter 2 of this dissertation.
} 


\section{CHAPTER 3}

will use four different proxies for degree of democracy/autocracy in the recipient country which allows me to check the extent to which my results depend on a specific indicator of democratic/authoritarian regime characteristics. I will also go beyond the simple OLS estimation model to account for potential endogeneity issues (which will be discussed more in detail in Section 3.2.2 and Section 3.3).

\subsubsection{Non-DAC Development Finance and Regime Survival}

Traditional research on authoritarianism focuses on domestic roots and characteristics (Bueno de Mesquita, Smith, Siverson, \& Morrow, 2003; Gandhi \& Przeworski, 2007; Geddes \& Zaller, 1989; Svolik, 2012; Tullock, 1987; Wintrobe, 1990). The bulk of research that seeks to understand the external determinants of regime type has been strongly biased toward democracy. Morgenthau (1962) argues that a convergence of donor interests and recipient needs will determine the cross-country allocation of aid. Based on his early theory, several studies have analysed the motivations of democratic donors' aid allocation. Several scholars suggest that democratic donors mainly target 'democracy aid' to countries which will likely care about both transitions to democracy and maintaining or consolidating existing democratic regimes (Bermeo, 2011; Nielsen, 2013). A separate strand of literature empirically examines the effects of democratic aid on the probability of democratic transition yielding ambiguous results (Bueno de Mesquita \& Smith, 2007; Djankov et al., 2008; Dunning, 2004; Goldsmith, 2001; Knack, 2004).

As authoritarian powers such as China, Russia and several Arab countries reemerge as powerful players on the international scene, scholars increasingly debate as to whether the rise of influential autocratic players goes hand in hand with the increasing attractiveness of autocratic government models and a general disenchantment with the Western democracy model on a global scale (Ambrosio, 2009; Bader, Grävingholt, \& Kästner, 2010; Kagan, 2008; Way, 2015). A contribution by Vanderhill (2012), for example, concludes that authoritarian countries like Iran, Russia and Venezuela actively promote autocracy in other states. 


\title{
CHAPTER 3
}

The emergence of new authoritarian powers in the international development finance game somewhat resembles the development finance game between the United States and the Soviet Union during the Cold War (see Chapter 5). During that time, both the United States and the Soviet Union used foreign aid and military assistance to extend their influence as far as possible, in an attempt to prevent the recipient country from switching political ideology (Beim, 1964; Bueno de Mesquita \& Smith, 2016). While the international aid game during the Cold War could largely be modelled along the communism-capitalism dimension, the contemporary aid game may be characterised along the democracy-autocracy dimension. Similar to democratic donors who mainly target their aid flows towards democratic recipient countries, autocratic donors like China have

\begin{abstract}
"good reasons to work against a liberal order that facilitates challenges to authoritarian governments. China opposes both specific instances of liberal intervention and efforts to create international norms that favor intervention in the affairs of authoritarian states. Shielding existing authoritarian states undermines the creation of liberal-interventionist norms." (Bader, 2015, p. 23-24)
\end{abstract}

The successful overthrow of an autocratic regime could lead to a domino effect whereby pro-democracy movements at the grassroots level may increasingly challenge authoritarian regimes elsewhere. As a result, successful democratic transitions in developing countries could undermine the legitimacy of remaining authoritarian regimes (Ambrosio, 2009; Kagan, 2008).

A somewhat related question to the research question addressed in this chapter is why Chinese development finance and foreign policy in general could contribute to the survival of authoritarian regimes irrespective of whether Beijing actively seeks to promote authoritarianism abroad. It is based on a vast strand of theoretical literature that takes a critical stance towards China's increasing political and economic presence in developing countries, most notably in Africa.

While Western aid conditionality has given African political elites less leeway to pursue undemocratic policies, Collier (2007) argues that 


\section{CHAPTER 3}

"[governance] in the bottom billion is already unusually bad, and the Chinese are making it worse, for they are none too sensitive when it comes to matters of governance.” (p. 86)

Bader's (2015) empirical study is among the first to provide quantitative evidence on whether or not Chinese development assistance increases the stability of authoritarian clients. Her study demonstrates that Chinese bilateral interactions have little effect on the longevity of autocratic regimes. My research question turns Bader's research question on its head by asking whether authoritarian regimes receive more Chinese development assistance than democratic ones. In order to account for the possibility of reverse causality I will run a 2SLS estimation model in the robustness section.

\subsubsection{Possible Determinants of China's Development Finance}

One of the major reasons for China's longstanding relationship with many African countries is related to China's foreign policy: to garner support for the 'One China Policy' (Alden, 2005; Bräutigam, 2009, 2011b; Rich, 2009; Taylor, 1998; Wenping, 2007). This policy can be considered the major exception to China's position of not attaching political conditionality to foreign aid. In order to limit Taiwan's efforts to become an influential player in Africa, Beijing's aid negotiation with respective African recipient countries follow diplomatic ties. The absence of diplomatic ties with Taiwan is a precondition for any fruitful diplomatic relations with Beijing (see Chapter 2 again).

In a similar vein, a recipient country's alignment with the People's Republic of China's diplomatic interests can be positively associated with more development assistance coming from China. In fact, voting alignment in the United Nations Security Council (UNSC) or political support in international financial institutions can capture the degree of political alignment between donor and recipient country (Andersen, Hansen, \& Markussen, 2006; Dreher \& Fuchs, 2015; Kilby, 2009, 2011). This hypothesis is based on previous studies that found a strong link between foreign aid received and voting alignment in the UNSC, where 10 out of 15 seats are held by rotating members serving two-year terms (Dreher et al., 2009; Kuziemko \& Werker, 2006; Rai, 1980). China increasingly garners support for its commitment to its foreign policy principle of nonaggression and non-interference in domestic political affairs. Empirical findings 


\section{CHAPTER 3}

by Strüver (2016) suggest that governments receiving foreign aid from China are more likely to demonstrate high levels of voting alignment with China.

As China's economic growth is very resource intense, Beijing's foreign aid and other forms of state financing may increasingly be driven by geostrategic motivations, namely the need to secure access to natural resources. In the mid1980s, China was the largest oil exporter in East Asia. Only a few years later, in 1993, China became a net oil importer and had become the second largest net oil importer in 2009, just behind the United States (Lee, 2012; Taylor, 2006a; Zweig \& Jianhai, 2005). Between 2002 and 2025, China's energy consumption is expected to rise by more than 150 percent (Klare \& Volman, 2006). Obtaining raw materials and energy is crucial for the Beijing administration in order to maintain their impressive economic growth trajectory (Moyo, 2012).

Another major motive for China's growing presence on the African continent is economic. Beijing's development finance has increasingly taken a 'commercial or corporatist orientation’. Econometric results by Biggeri and Sanfilippo (2009) suggest that China's external flows (aid, FDI and trade) are highly interwoven (see also Chapter 2).

A selection of case studies suggests that China uses its foreign aid to promote investment and trade activities in the recipient country. Mohan and Power (2008) observe that

"although China continues to give foreign aid to selected African countries the emphasis today has shifted toward providing official loans with government subsidised interest rates and to developing partnership or joint ventures between companies from China and Africa" (p. 27).

Beijing's official finance (e.g. foreign aid and other official flows) is also aimed at promoting exports to recipient countries. Numerous case studies show that Chinese development assistance is tied to the purchase/procurement of Chinese goods (Berthélemy, 2011; Bräutigam, 2009).

With the fall of the Iron Curtain, foreign aid by Western donors and international organizations became increasingly oriented towards good governance and capacity building. Seminal contributions in the academic literature around that time highlighted that the returns to foreign aid are greatest in recipient countries with a sound institutional environment, regardless of whether 'environment' is 


\section{CHAPTER 3}

defined in terms of prudent macroeconomic policy or a broader set of political and economic institutions (Burnside \& Dollar, 1997, 2000; World Bank, 1998). Among policymakers and international financial organisations it was argued that "aid should function as a lever for institutional (including political) change" (Molenaers, Dellepiane, \& Faust, 2015, p.3).

Alden (2005) argues that "with the imposition of 'conditionalities' by Western donors that are designed to punish those regimes which violate standards and practices of good governance (economic and political), these regimes need to find an alternative source of foreign support" (p. 155). Chinese foreign aid is often viewed as such an alternative. Due to its upholding of non-interference in domestic affairs, China's motivations for allocating aid may not be linked to the quality of political institutions in the recipient countries. In fact, China's historic non-intervention foreign policy strategy may provide Beijing a comparative advantage in dealing with non-democratic governments (Naím, 2007; Taylor, 2007a, 2007b; Tull, 2006).

\subsection{Data and Methodology}

The main objective of this chapter is to investigate whether authoritarian regimes in Africa receive more Chinese development finance than democratic ones, ceteris paribus. My first dependent variable is the (logged) monetary value of total Chinese development finance to a recipient country in a given year (in constant 2009 US\$). 35 Since China does not officially report its foreign aid and other forms of state financing to the OECD-DAC, I need to rely on Aid Data's Chinese Official Finance database (version 1.2) introduced by Strange, Dreher, Fuchs, Parks and Tierney (2017). The authors obtain data on Chinese development finance using AidData's TUFF methodology.36 Their database includes more than 2,000 projects in 50 recipient countries in Africa over the 2000-2011 period.

\footnotetext{
35 In order to be able to take the logarithm of the monetary value of total Chinese development finance for each country and each year, I add 0.01 to each value as some countries do not receive any Chinese development finance in a given year.

36 The methodology for tracking under-reported financial flows is documented and discussed in more detail by Strange, Parks, Perla and Desai (2015).
} 


\section{CHAPTER 3}

China's official development finance includes, among others, "ODA-like” flows which consist of grants, technical assistance and scholarships, loans with large grant elements, debt relief, and military aid under the condition that these projects are provided with development intent. China's official finance also consists of "OOF-like" flows such as loans and export credits that have little or no grant element or that are not primarily intended to improve economic development or welfare in the recipient country, as well as grants that are not intended for development purposes.

It is important to include "OOF-like" flows in the analysis as the bulk of China's official development finance would not fall under the category of ODA (Bräutigam, 2011a). Official development finance, however, excludes private development finance such as worker remittances, FDI or portfolio equity. The data used in the analysis are Chinese official development finance commitments and exclude pledges and suspended projects.

Table 3.1 gives an overview of the major and minor recipients of Chinese official development finance in Africa over the 2000-2011 period. The volume is expressed in constant 2009 US dollars. The data suggest that between 2000 and 2011, Ghana received by far the largest amount of Chinese development finance, namely US\$ 11.6 billion. China's development finance is also highly skewed towards a few countries. The five major aid recipients (Ghana, Congo Republic, Ethiopia, Sudan and Angola) have received almost 50 percent of China's entire budget. At the other end, countries like Burkina Faso, Gambia, Sao Tome and Principe, and Swaziland did not receive any development finance from China. This is not a coincidence: all four countries had strong diplomatic ties with Taiwan throughout the period. ${ }^{37}$

\footnotetext{
${ }^{37}$ In 2013, the Gambian government has cut diplomatic ties with Taiwan. Very recently, in 2016, the government of Sao Tome and Principe re-established diplomatic ties with China, thereby ending diplomatic relations with Taiwan.
} 
Table 3.1: Recipients of Chinese Development Finance in Africa, 2000-2011, absolute

\begin{tabular}{|c|c|c|c|c|c|}
\hline \multicolumn{3}{|c|}{ Major } & \multicolumn{3}{|c|}{ Minor } \\
\hline Country & $\begin{array}{c}\text { Volume } \\
(2009 \\
\text { US\$ } \\
\text { million) }\end{array}$ & $\begin{array}{l}\% \text { of } \\
\mathrm{CDF}\end{array}$ & Country & $\begin{array}{c}\text { Volume } \\
(2009 \\
\text { US\$ } \\
\text { million) } \\
\end{array}$ & $\begin{array}{l}\% \text { of } \\
\mathrm{CDF}\end{array}$ \\
\hline Ghana & 11600.00 & 16.44 & Tunisia & 84.10 & 0.12 \\
\hline Congo & 7810.00 & 11.07 & Guinea-Bissau & 83.90 & 0.12 \\
\hline Ethiopia & 6560.00 & 9.30 & Comoros & 71.90 & 0.10 \\
\hline Sudan & 5330.00 & 7.56 & Benin & 57.20 & 0.08 \\
\hline Angola & 4230.00 & 6.00 & Cape Verde & 32.00 & 0.05 \\
\hline Equatorial Guinea & 3770.00 & 5.34 & Somalia & 28.50 & 0.04 \\
\hline Zimbabwe & 3490.00 & 4.95 & Burkina Faso & 0.00 & 0.00 \\
\hline Nigeria & 3060.00 & 4.34 & Gambia & 0.00 & 0.00 \\
\hline Cameroon & 3000.00 & 4.25 & Sao Tome and Principe & 0.00 & 0.00 \\
\hline South Africa & 2330.00 & 3.30 & Swaziland & 0.00 & 0.00 \\
\hline
\end{tabular}

Note: Chinese Official Finance between 2000 and 2011 amounted to US\$70544.20 million (in constant 2009 dollars).

Source: Author's own calculations based on data from Strange, Dreher et al. (2017).

My second dependent variable is a proxy for the relative importance of Chinese official development finance for an African recipient country. The variable is constructed as follows:

$$
\begin{aligned}
& \text { Relative CODF } \text { share }_{i, t}
\end{aligned}
$$

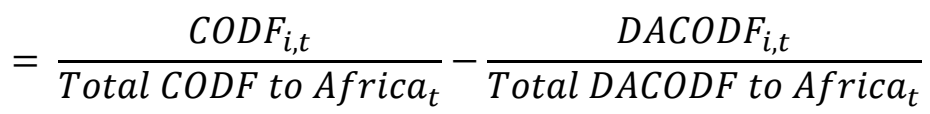

This variable therefore measures the difference between the relative share of Chinese official development finance and the relative share of traditional DAC official development finance ${ }^{38}$ for each African country for all years during the 2000-2011 period. Positive (negative) shares for a specific recipient country correspond to a 'relative donor darling status' in the Chinese (Western) donor community.

Table 3.2 shows the major and minor recipients of Chinese official development finance in relative terms. The major recipients of Chinese official development

${ }^{38} \mathrm{DAC}$ official development finance includes both DAC foreign aid and other official flows. 


\section{CHAPTER 3}

countries are displayed on the left of Table 3.2. Among the usual suspects are the resource-rich and largely authoritarian countries of Angola, Sudan, Equatorial Guinea and Zimbabwe. However, Ghana and Mauritius, two prime examples of consolidated democratic governance in Africa, are among the major recipients of Chinese Development Finance in relative terms. In fact, Ghana is ranked first. While Ghana is often portrayed as a donor darling among the Western donor community (Hughes, 2005; Lawson, 2011), this is even more true for the Chinese donor community when we look at development finance in relative terms. North African countries like Egypt and Morocco, and SubSaharan African countries like Tanzania, Mozambique, Uganda and Senegal receive a lower share of Chinese development finance than they receive from traditional DAC donors.

Table 3.2: Recipients of Chinese Development Finance in Africa, 2000-2011, relative

\begin{tabular}{|c|c|c|c|}
\hline \multicolumn{2}{|c|}{ Major } & \multicolumn{2}{|c|}{ Minor } \\
\hline Country & $\begin{array}{c}\text { Finance Share } \\
\text { Difference } \\
\text { (in percentage } \\
\text { points) }\end{array}$ & Country & $\begin{array}{c}\text { Finance Share } \\
\text { Difference } \\
\text { (in percentage } \\
\text { points) }\end{array}$ \\
\hline Ghana & 7.84 & Egypt & -4.90 \\
\hline Angola & 6.91 & Tanzania & -4.24 \\
\hline Sudan & 5.40 & Mozambique & -3.86 \\
\hline Equatorial Guinea & 4.34 & Uganda & -2.49 \\
\hline Zimbabwe & 3.31 & Morocco & -1.96 \\
\hline Cameroon & 2.06 & Burkina Faso & -1.91 \\
\hline Congo Republic & 1.94 & Senegal & -1.77 \\
\hline Algeria & 1.77 & Mali & -1.62 \\
\hline Nigeria & 1.37 & Malawi & -1.55 \\
\hline Mauritius & 1.34 & Madagascar & -1.40 \\
\hline
\end{tabular}

Source: Author's own calculations based on data from Strange, Dreher et al. (2017).and OECD/DAC Statistics.

My main explanatory variable is a new measure of electoral democracy, the electoral democracy index (EDI) or "polyarchy" index, based on the Varieties of Democracy (V-Dem) data project, which draws on multiple expert perceptions of a large number of disaggregated indicators from a global sample of countries since 1900 (Teorell, Coppedge, Skaaning, \& Lindberg, 2016). ${ }^{39}$ The

\footnotetext{
${ }^{39}$ In order to better conceptualize and measure democracy, the V-Dem project distinguishes between 7 high-level principles of democracy. The electoral democracy index is one of them.
} 


\section{CHAPTER 3}

index is closely anchored to Dahl's (1971) seminal theoretical framework on polyarchy. According to Teorell et al. (2016), polyarchy "provides to most fully fleshed theory of what constitutes an electoral democracy" (p. 6), since

"democracy requires not only free, fair, and competitive elections, but also the freedoms that make them truly meaningful such as freedom of organization and freedom of expression, alternative sources of information, and institutions to ensure that government policies depend on the votes and preferences of citizens" (Diamond, 2002, p. 21).

The electoral principle of democracy developed by V-Dem seeks to

"embody the core value of making rulers responsive to citizens, achieved through electoral competition for the electorate's approval under circumstances when suffrage is extensive; political and civil society organizations can operate freely; elections are clean and not marred by fraud or systematic irregularities; and elections affect the composition of the chief executive of the country. In between elections, there is freedom of expression and an independent media capable of presenting alternative views on matters of political relevance. In the V-Dem conceptual scheme, electoral democracy is understood as an essential element of any other conception of (representative) democracy - liberal, participatory, deliberative, egalitarian, or some other." (Dahlberg, Holmberg, Rothstein, Khomenko, \& Svensson, 2016, p. 117)

The EDI measures the five Dahlian (1988) components of "Elected officials", "Free and fair elections", "Freedom of expression", "Associational autonomy" and "Inclusive citizenship". The aggregate indicator is scaled between 0-1. The more a country approximates polyarchy, the higher its EDI score.

The systematic, historical and disaggregated approach by V-Dem addresses several deficiencies and drawbacks in existing measures of electoral democracy, such as the Polity IV index, the Freedom House index or the Vanhanen democratization index (discussed further below). The new measure of polyarchy by V-Dem is the first measure that meets all the following theoretical and methodological criteria simultaneously: (1) covering all the components of Dahl's theoretical framework of polyarchy; (2) providing disaggregated data to

The other six high-level principles of democracy are (i) liberal, (ii) participatory, (iii) egalitarian, (iv) majoritarian, (v) consensual and (vi) deliberative. 


\title{
CHAPTER 3
}

check dimensionality and allowing users to evaluate what lower-level changes account for the shifts in higher-level indices, or what lower-level components drive aggregate correlations; (3) a global sample of countries and across long periods of time; (4) usage of transparent data generating processes and aggregation rules; and (5) the provision of estimates of measurement uncertainty (for more information, see Teorell et al., 2016).

My second democracy indicator is the executive constraints (decision rule) variable from Polity IV (Jaggers \& Gurr, 1995; Marshall, Jaggers, \& Gurr, 2014), the most widely used dataset in political science according to Plümper and Neumayer (2010). I use the executive constraints variable because executive constraints can be considered the most important component for the combined democracy-autocracy score (Gleditsch \& Ward, 1997). According to Eckstein and Gurr (1975), decision rules are defined in the following manner:

\begin{abstract}
"Superordinate structures in action make decisions concerning the direction of social units. Making such decisions requires that supers and subs be able to recognize when decision-processes have been concluded, especially "properly" concluded. An indispensable ingredient of the processes, therefore, is the existence of Decision Rules that provide basic criteria under which decisions are considered to have been taken" (Eckstein \& Gurr, 1975, p. 121).
\end{abstract}

At the operational level, the polity IV index (P4I) captures the extent of institutionalised constraints on the decision-making powers of chief executives, whether individuals or collectivities. The scale ranges between 0 and 7 , whereby a value of zero corresponds to "unlimited authority" and a value of seven corresponds to "Executive Parity or Subordination" - e.g. accountability groups have effective authority equal to or greater than the executive in most areas of activity. ${ }^{40}$

The third suitable explanatory variable for the purpose of this study is a democracy index from the Freedom House data set. It needs to be emphasised that the authors of both Polity and Freedom House use similar definitions of

\footnotetext{
${ }^{40}$ Examples for executive parity or subordination include, among others: (i) a legislature, ruling party, or council of nobles initiates much or most important legislation; (ii) the executive (president, premier, king, cabinet, council) is chosen by the accountability group and is dependent on its continued support to remain in office (as in most parliamentary systems); (iii) in multi-party democracies, there is chronic "cabinet instability".
} 


\section{CHAPTER 3}

democracy and both indices are based on subjective expert judgments. The Freedom House Index (FHI) provides values for all countries from 1972 onwards. It is "the second most used data set for measuring democracy after Polity" (Plümper \& Neumayer, 2010, p. 215). The FHI is constructed in the following manner: both the civil liberties score ${ }^{41}$ and the political rights score ${ }^{42}$ by Freedom House are transformed into a 0-10 scale. Similarly, the polity 2 index from the PolityIV dataset is transformed into a 0-10 scale. These three variables are then averaged into the FHI. The scale ranges from $0-10$ where 0 is least democratic and 10 most democratic.

My fourth measure of democracy is Vanhanen's democratisation index (VDI) (Vanhanen, 2000). The VDI is based on two dimensions of democracy; public contestation (competition) and the right to participate (participation). The index is measured as the percentage of votes not cast for the largest party (competition) times the percentage of the population who actually voted in the election (participation). This product is divided by 100 to form an index that could theoretically vary from 0 (no democracy) to 100 (full democracy). Both the competition and participation dimension are weighted equally. ${ }^{43}$ The index has been frequently used as an alternative proxy for democracy in the empirical literature (Chowdhury, 2004; Coppedge, Alvarez, \& Maldonado, 2008; Neumayer, 2002). One major strength of the VDI is the large spatiotemporal coverage: it includes all independent contemporary countries of the world and their main predecessors since 1810 , or from the year of independence. ${ }^{44}$

\footnotetext{
41 "Civil liberties allow for the freedoms of expression and belief, associational and organizational rights, rule of law, and personal autonomy without interference from the state" (FreedomHouse, 2016). Countries are graded between 1 (most free) and 7 (least free).

42 "Political rights enable people to participate freely in the political process, including the right to vote freely for distinct alternatives in legitimate elections, compete for public office, join political parties and organizations, and elect representatives who have a decisive impact on public policies and are accountable to the electorate" (FreedomHouse, 2016). Countries are graded between 1 (most free) and 7 (least free).

43 The values of competition and participation can be combined variously, depending on how much weight should be given to both competition and participation. Bollen $(1979,1980)$, for example, excludes the degree of electoral participation from his concept of democracy because he thinks that the percentage of the population voting in an election does not necessarily reflect the degree of political democracy.

44 The VDI does suffer from several drawbacks. First, the index does not disaggregate the concept of democracy. Even though the index avoids problems of conceptual logic, it forgoes the "opportunity to flesh out the concept analytically and to provide a bridge between the abstract concept of democracy and its more concrete attributes" (Munck \& Verkuilen, 2002, p.
} 


\section{CHAPTER 3}

The Democracy-Dictatorship indicator proposed by Przeworski, Alvarez, Cheibub and Limongi (2000) and further developed by Cheibub, Gandhi, and Vreeland (2010) would be a good complement to the existing analysis. Even though the index covers the annual data points of 199 countries, it is only available from 1946 (or date of independence) until 2008, unfortunately. It is for this reason that I have not included the indicator in my analysis.

Table 3.3 shows the correlation between the four democracy variables. Not surprisingly, the correlation between the Polity IV index and the Freedom House index is very high. The Polyarchy index by V-Dem also strongly correlates with the P4I and the FHI, but not with the VDI. Overall, the VDI shows the weakest positive correlation with the other three indicators. All the correlations are statistically significant at the 1 percent significance level.

Table 3.3: Correlation between Democracy Indices

\begin{tabular}{lcccc}
\hline & V-DEM & Polity IV & $\begin{array}{c}\text { Freedom } \\
\text { House }\end{array}$ & Vanhanen \\
\hline V-DEM & 1 & & & \\
Polity IV & $0.802^{* * *}$ & 1 & & \\
$\begin{array}{l}\text { Freedom } \\
\text { House }\end{array}$ & $0.909^{* * *}$ & $0.911^{* * *}$ & 1 & \\
Vanhanen & $0.629^{* * *}$ & $0.632^{* * *}$ & $0.649^{* * *}$ & 1 \\
\hline
\end{tabular}

***denotes significance at the $1 \%$ level, $* *$ at the $5 \%$ level, *at the $10 \%$ level.

For some individual African countries like Botswana, the individual democracy measures strongly disagree. Botswana has earned itself the reputation as one of the oldest and most stable democracies in Africa with very high levels of electoral participation (Acemoglu, Johnson, \& Robinson, 2003; Lekalake, 2016; Ntsabane $\&$ Ntau, 2000). This development is well reflected in Botswana's high Polity IV, Freedom House and V-Dem electoral democracy scores. The Vanhanen index, however, suggests that Botswana's democratic quality is low. What is the reason for the opposing finding? While the competition dimension of the Vanhanen index "effectively distinguishes one party-rule from democratic electoral contestation,

15). Second, Plümper and Neumayer (2010) doubt "whether regime type can be measured solely based on election results data, which not only ignores important institutional features of democracies but also precludes a change in the democracy score between elections" (p. 215). Third, Vanhanen's objective index does not pay much attention to subjective judgments that shape the selection of "objective" indicators (Bollen, 1979, 1980, 1993; Hadenius, 1992; Munck \& Verkuilen, 2002). 


\section{CHAPTER 3}

[...] it also necessarily suffers from the bias that two-party systems tend to get lower scores than multiparty systems" (Lijphart, 2008, p. 90-91).

Botswana's First-Past-The-Post electoral system has encouraged a two-party system with the Botswana Democratic Party dominating the polls. Both the First-Past-The-Post electoral system and the continued Botswana Democratic Party hegemony have contributed to weak and fragmented opposition parties inside the country (De Jager \& Sebudubudu, 2017; Good, 2008). The Vanhanen democracy index therefore strongly punishes democratic countries with twoparty systems and/or weak opposition parties, a frequently observed phenomenon in parts of Africa.

Based on the qualitative, theoretical literature one would expect a strongly negative and highly statistically negative relationship between Chinese development finance and the average democracy level of African recipient governments. The descriptive statistics provided below cast doubt on whether this is true. Figure 3.1 displays the distribution of $\log$ Chinese development finance for both autocracies and democracies over the time period 2000-2011.

Looking at the distribution for the EDI first, the histogram of Chinese Development Finance for democracies shows a spread that is much wider than expected by previous research. In fact, the distribution is much wider than for autocracies. The same is true for the P4I, FHI and VDI. Although perhaps somewhat surprising, the peaks of Chinese development finance are not systematically different for democracies vis-à-vis autocracies. Moreover, there is no strong evidence that mean Chinese development finance is significantly higher for autocracies if compared to democracies.

In Figure 3.2, I plot the average absolute Chinese development finance (in logarithmic form) against the average democracy level of African recipient government over the time period 2000-2011. All four scatterplots show a weak, non-negative the relationship. Figure 3.3 plots the relative share of Chinese development finance against the four democracy indicators. The bivariate relationship is slightly negative when using the EDI, the P4I and the FHI as proxies for democracy. The negative relationship disappears when the VDI is used. Overall, the bivariate correlations presented in Figure 3.2 and Figure 3.3 do not suggest that Chinese development finance is systematically flowing to more authoritarian recipient countries as often suggested by anecdotal evidence. 


\section{CHAPTER 3}

This does not rule out the possibility that the availability of Chinese development finance may contribute to the regime survival in authoritarian countries like Angola, Democratic Republic of Congo, Sudan, or Zimbabwe.

Figure 3.1: Distribution of Chinese Development Finance by regime type, 2000-2011

(a) Electoral Democracy Index (V-DEM)

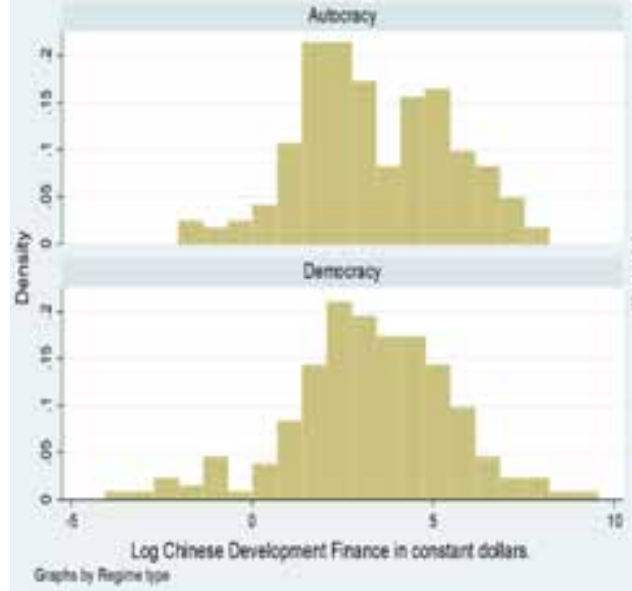

(c) Freedom House Index

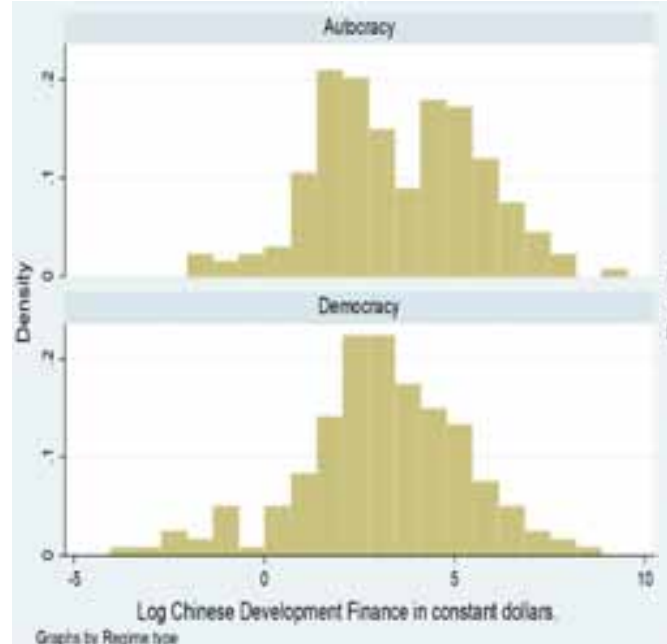

b) Polity IV Index

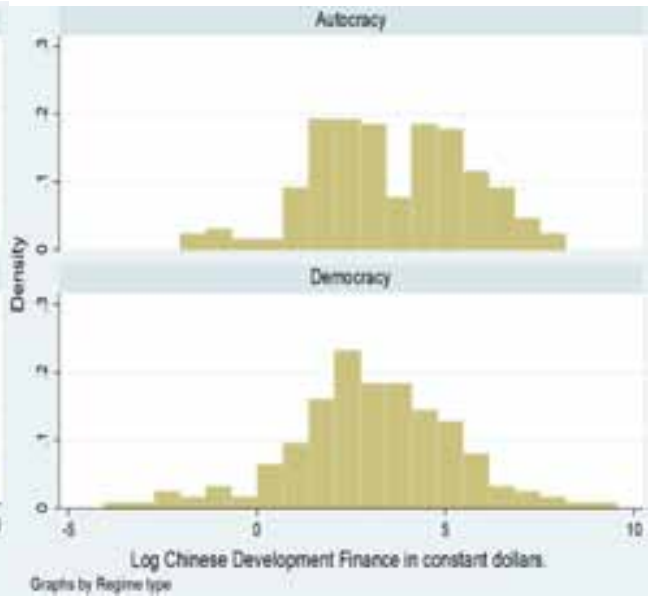

d) Vanhanen Democratisation Index

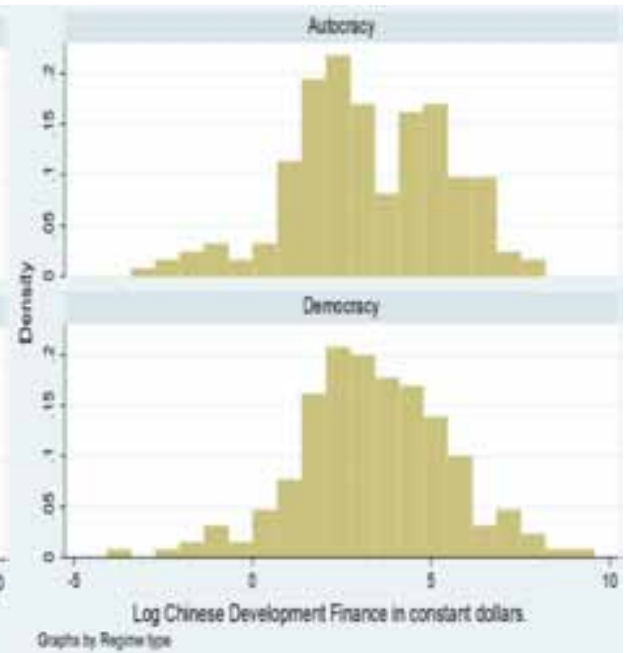

Note: For each democracy indicator (V-Dem, Polity IV, Freedom House and Vanhanen, respectively), I created standardized values after dropping all observations that had a value of zero for Chinese development finance. Only those individual country observations that have a positive value are classified as "democracy", while negative values are classified as "autocracy". Source: Author's own calculations 


\section{CHAPTER 3}

Figure 3.2: Relationship between Chinese Development Finance (in absolute terms) and Democracy Level of African Recipient Governments, 2000-2011
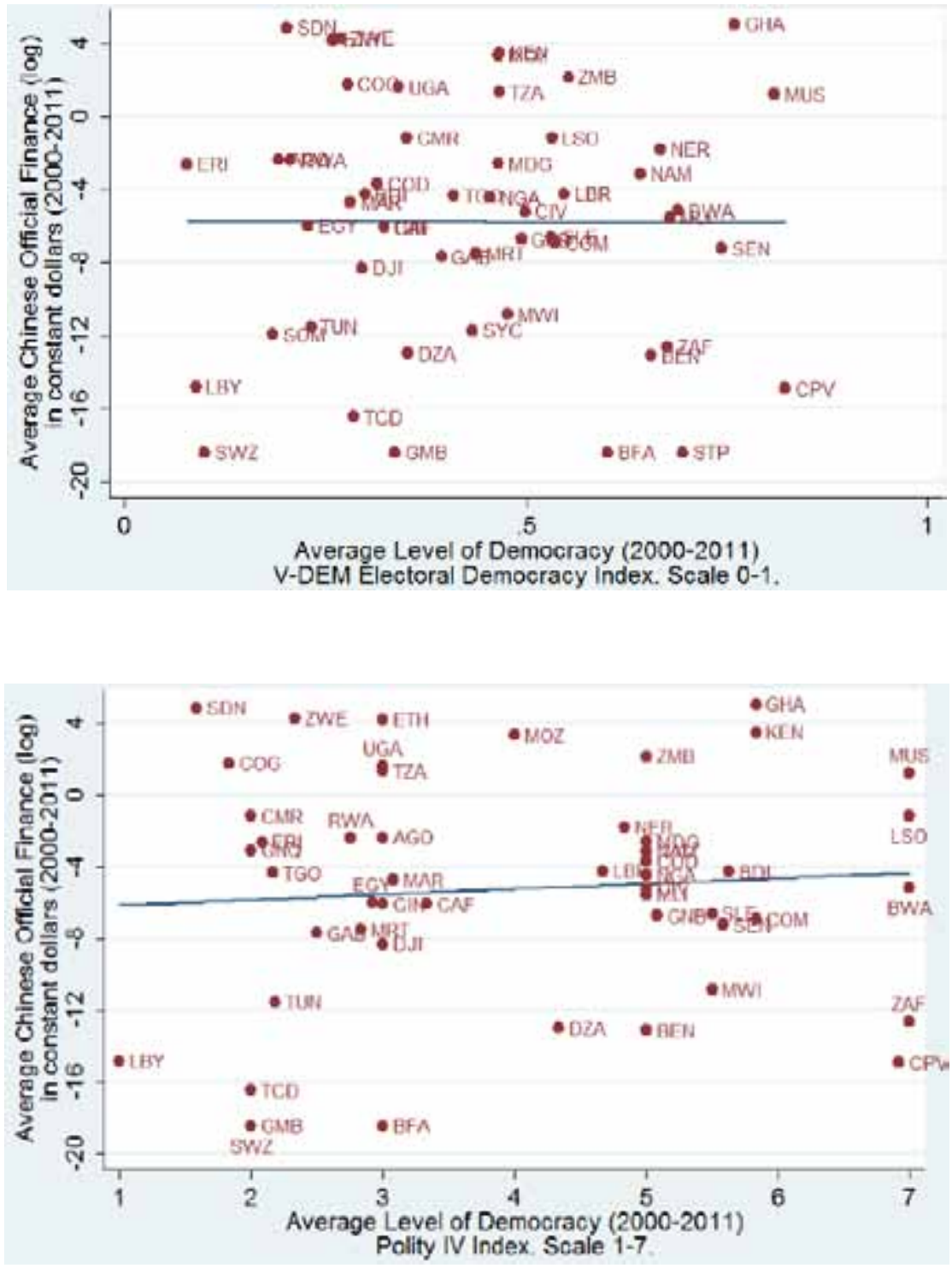

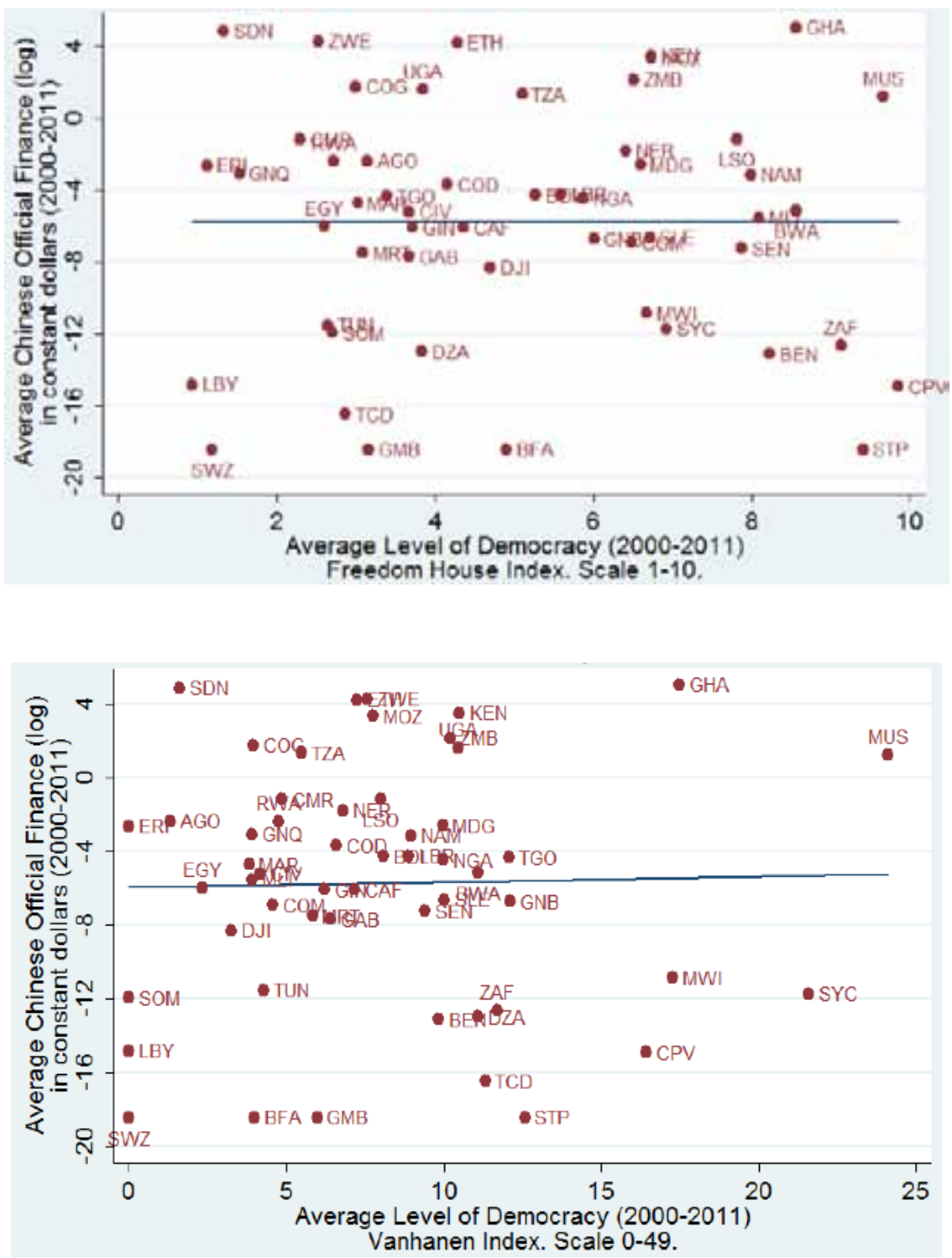
Figure 3.3: Relationship between Relative Chinese Development Finance and Democracy Level of African Recipient Governments, 2000-11
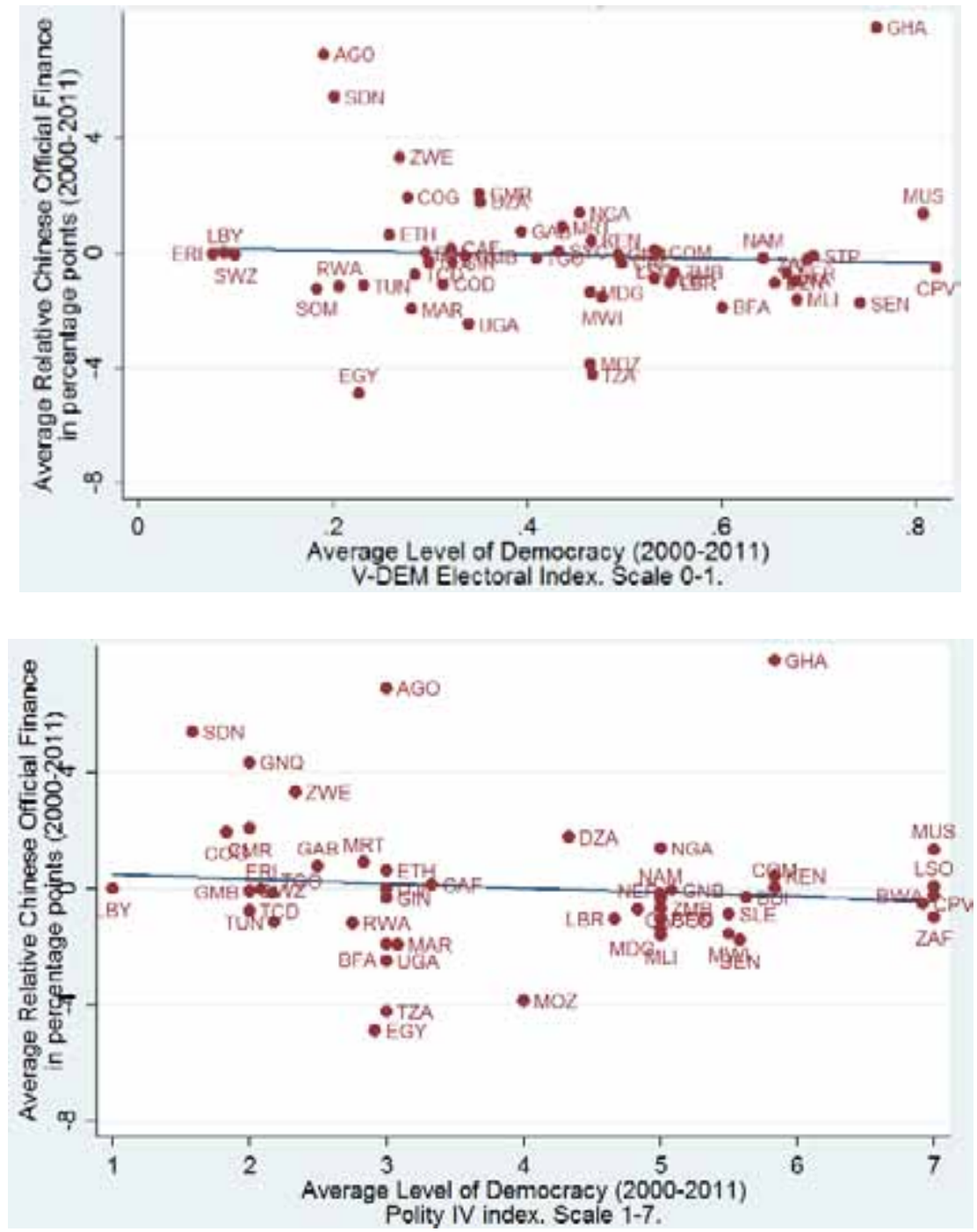


\section{CHAPTER 3}
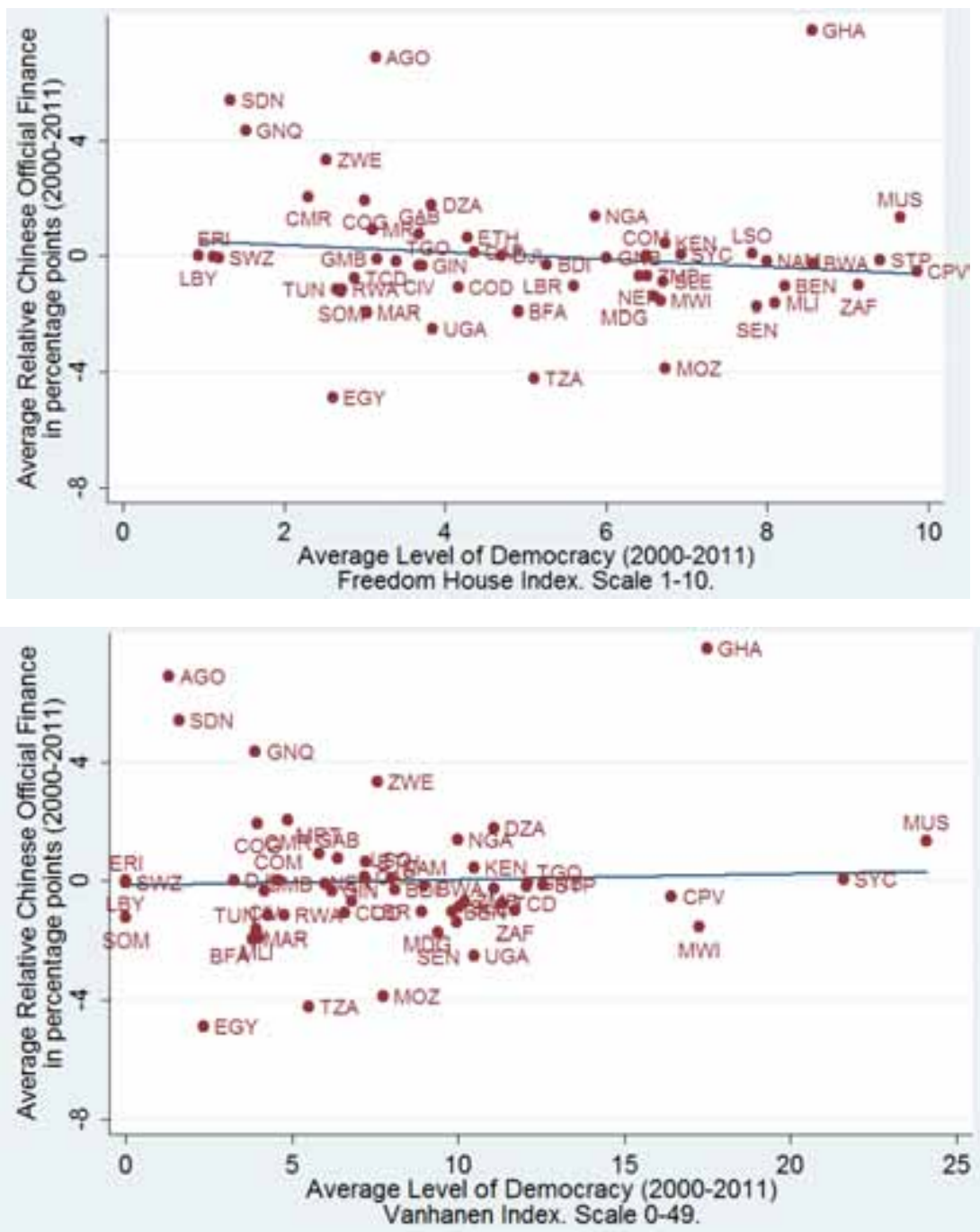

Using OLS regression, I test whether the descriptive statistics confirm my first impressions. In the econometric analysis, I explore to what extent Chinese development finance systematically targets more authoritarian regimes if compared to democratic ones controlling for other potential confounding factors. I use the yearly level of Chinese development finance in logarithmic form as the dependent variable. The main explanatory variable of interest is the democracy/autocracy score for each recipient country $i$ over time $t$. Similar to Dreher et al. (2017), I lag the time-varying explanatory variable by one year to mitigate endogeneity concerns. The regression specification for the analysis is: 


$$
\begin{aligned}
\text { aid }_{i t}=\beta_{0}+ & \beta_{1} \\
& * \text { democracy }_{i t-1}+\beta_{2} * \text { strategic }_{i t-1}+\beta_{3} * \text { economic }_{i t-1} \\
& +\beta_{4} * \text { geographic }_{i t-1}+\beta_{5} * \text { language }_{i}+\beta_{6} \\
& * \text { institutional }_{i t-1}+\beta_{7} * \text { conflict }_{i t-1}+\tau_{t}+\varepsilon_{i t}
\end{aligned}
$$

where aid $_{i t}$ measures China's development finance to country $i$ in year $t$, democracy $_{i t-1}$ is the level of democracy as measured by the respective democracy index explained above. $\beta_{1}$ captures the relationship between Chinese development finance and the level of democracy in the recipient country. I also include vectors of time-varying covariates and one time-invariant covariate of Chinese development finance (English language), in order to control for potential confounding factors. $\tau_{t}$ represents year-fixed effects and $\varepsilon_{i t}$ is a stochastic error term.

strategic $_{i t-1}$ is a vector of foreign policy variables. To test whether Beijing's One-China policy is a significant determinant of Beijing's aid allocation, I use a dummy variable that is equal to one if the respective African recipient government maintained diplomatic relationships with the Taiwanese government in a given year. The data comes from Rich (2009), Bräutigam (2011a) and is updated by the author of this study. I also control for (log) net ODA received from all DAC donors (in constant 2009 US\$) as Chinese development activities could increasingly compete with those of the West. ${ }^{45}$

Furthermore, I investigate whether a country's voting alignment with China in the UNGA is a significant determinant of Chinese development finance. This approach differs from previous studies that looked at the relationship between Chinese (but also Western) development finance and voting alignment in the UNSC (Dreher, Eichenauer, \& Gehring, 2016; Dreher et al., 2009; Kuziemko \& Werker, 2006). For a given year, the index equals one if a state always agrees with China. It is equal to zero if it always votes the other way. If one state votes yes and the other abstains, the vote is coded as 0.5 . Data on voting alignment comes from Bailey, Strezhnev and Voeten (2017).

\footnotetext{
${ }^{45}$ In order to be able to take the logarithm of the monetary value of total net ODA received from all DAC donors, I only take positive ODA flows into account. Negative ODA flows will be recorded as zero ODA flows. I then simply add 0.01 to each value - including both positive and zero values - before taking the logarithm.
} 


\section{CHAPTER 3}

economic $_{\text {it-1 }}$ represents the economic motives of China's development finance. By controlling for population size I try to capture the market-seeking motive of China's development finance to Africa. I use population size as proxy for the market size of the respective recipient country. At the same time, population size could capture the strategic interests of donor countries, as "there is an exogenous small country bias in aid such that smaller countries get higher aid per capita and higher aid as ratio to their income" (Easterly, 2009, p. 388). If the coefficient on population is strongly positive and highly statistically significant, I interpret this as the economic motive "overriding" the strategic motive. The interpretation would be the other way around if the coefficient on population is strongly negative and highly statistically significant.

In order to capture needs-based, altruistic motives of Chinese development assistance, I use GDP per capita data as a proxy for the recipient country's level of development. On the basis of need, it is expected that poorer countries should receive more development finance, ceteris paribus. Both population and GDP per capita data come from the World Bank's World Development Indicators (WDI).

As qualitative evidence suggests that a bulk of China's development assistance is tied to the purchase/procurement of Chinese goods, I will also control for the $\log$ (net) import value of Chinese goods and services (in constant 2009 US $\$$ ) for each African partner country. Data on Chinese exports to African partner countries are obtained from the United Nations Commodity Trade Statistics Database (UN Comtrade). I will take the logarithm of all three variables (population, GDP per capita, imports from China) to facilitate the interpretation of the regression coefficients.

Furthermore, institutional $l_{i t-1}$ captures the overall institutional quality of the recipient country. My composite index for institutional quality is constructed in the following way: I average all six World Bank good governance indicators for each recipient country for each year. The data comes from the World Bank's Good Governance Indicators (Kaufmann, Kraay, \& Zoido-Lobatón, 2000). Since China's development finance is supposedly shaped by the policy of noninterference in domestic political affairs, I do not expect the coefficient to be strongly positive. 


\section{CHAPTER 3}

geographic $_{i t-1}$ denotes the set of two proxies for natural resource wealth. One variable is oil rents as a percentage of GDP. Oil rents are the difference between the value of crude oil production at world prices and total costs of production. The other variable is gas rents as a percentage of GDP. Natural gas rents are the difference between the value of natural gas production at world prices and total costs of production. Given China's increasing demand for natural resources, I expect a strong positive relationship between Chinese development finance and natural resource rents. The data on both gas and oil rents come from the WDIs as well.

I also introduce a conflict variable that controls for the degree of political violence in the recipient country. I expect a positive relationship between Chinese development finance and conflict as more aid - especially humanitarian assistance - should be allocated to more conflict-prone areas. Last but not least, I add a binary indicator that is equal to one if English is considered at least the third-most common language in the recipient country. The reason why I control for English language has to do with the set-up of the AidData's China's Official Finance to Africa Dataset (version 1.2). The dataset
"draws primarily upon Chinese and English-language sources. Therefore, the dataset may underrepresent China's development finance activities in states where other languages are more prominent in media outlets, business relations and politics. In particular, we expect a negative bias against Francophone and Lusophone African states" (Dreher et al., 2017, p. 14).

Data on English language come from Mayer and Zignago (2011). Similar to the main explanatory variable, I will lag the time-varying control variables by one year to mitigate endogeneity concerns. Table 3.4 provides the summary statistics of my main variables for the empirical analysis. A detailed overview of the data and its sources used in the analysis is given in Appendix 3.C. 
CHAPTER 3

Table 3.4: Summary Statistics

\begin{tabular}{lccccc}
\hline Variable Name & Obs & Mean & $\begin{array}{c}\text { Std. } \\
\text { Dev. }\end{array}$ & Min & Max \\
\hline $\begin{array}{l}\text { Dependent Variable } \\
\text { Chinese Development Finance }\end{array}$ & 636 & -5.69 & 10.82 & -18.42 & 8.88 \\
(log) & & & & & \\
Rel. Chinese Development & 636 & 0.00 & 0.06 & -0.34 & 0.62 \\
$\begin{array}{l}\text { Finance } \\
\text { Explanatory Variable }\end{array}$ & & & & & \\
Democracy Index & 623 & 0.43 & 0.20 & 0.07 & 0.84 \\
(V-DEM; Electoral) & & & & & \\
Democracy Index & 572 & 3.93 & 1.80 & 1.00 & 7.00 \\
(Polity IV) & & & & & \\
Democracy Index & 613 & 4.93 & 2.51 & 0.75 & 10.00 \\
(Freedom House) & & & & & \\
Democracy Index & 578 & 7.86 & 6.05 & 0.00 & 29.80 \\
(Vanhanen) & & & & & \\
Control Variables & & & & & \\
Taiwan Recognition & 636 & 0.11 & 0.31 & 0.00 & 1.00 \\
UN Voting with China & 636 & 85.12 & 14.80 & 0.00 & 100.00 \\
Western ODA (log) & 635 & 4.86 & 3.11 & -18.31 & 9.34 \\
Imports from China (log) & 635 & 4.38 & 2.45 & -4.64 & 9.47 \\
Population (log) & 636 & 1.93 & 1.57 & -2.51 & 5.10 \\
GDP per capita (log) & 636 & 6.80 & 1.15 & 4.65 & 10.07 \\
Conflict & 612 & 0.61 & 1.48 & 0.00 & 7.00 \\
Gas Rents (\% of GDP) & 617 & 0.79 & 2.62 & 0.00 & 21.25 \\
Oil Rents (\% of GDP) & 616 & 7.08 & 16.27 & 0.00 & 78.25 \\
English Language & 636 & 0.43 & 0.50 & 0.00 & 1.00 \\
Institutional Quality & 636 & -0.66 & 0.61 & -2.49 & 0.87 \\
\hline
\end{tabular}

\subsection{Empirical Analysis}

Table 3.5 reports the OLS estimates when using the EDI by V-Dem. Columns 1-4 have the absolute amount of Chinese aid as dependent variable, columns 58 take the difference between Chinese and Western relative shares as dependent variable. In the base specifications, column (1) and column (5), I do not find a strong negative and highly statistically significant coefficient on democracy. Therefore, my OLS results suggest that more authoritarian recipient governments do not systematically receive more development finance from 


\section{CHAPTER 3}

China while controlling for all the potential confounding factors discussed above.

In column (1) and column (5), I do not control for year and regional fixed effects. The coefficient for Taiwan recognition is strongly negative and highly statistically significant. This result provides evidence of a strong connection between Beijing's One-China policy and its aid allocation. Countries that maintain diplomatic relationships with Taiwan receive less development finance from China, ceteris paribus, in both absolute and relative terms. The magnitude of the coefficient is large. On average, a country that holds diplomatic relationships with Taiwan receives almost 100 percent less development finance compared to a country that does not have diplomatic ties with Taiwan, holding all other factors constant, which means that Taiwan recognizers do not receive any Chinese aid.

As expected, the coefficient for English language is both positive and statistically significant. As mentioned above, it is more likely that AidData's TUFF methodology picks up Chinese official financing projects in English-speaking countries vis-à-vis non-English-speaking countries. An African recipient country where English can be considered at least the third most common language tends to receive more development finance from China compared to a country where English is not considered to be among the three most important languages.

I do not find empirical evidence that countries which receive more Chinese development finance import on average more goods from China. This result is not straightforward and requires an explanation. It might be the case that the scope for tying aid to purchase goods from China is especially high in those countries that have very weak trade relationships with China to begin with, i.e. smaller African trading countries that import less from China at an absolute scale if compared to other larger African trading countries. The opposite is true for countries that have already established strong trade relationships with other more traditional trading partners. 
Table 3.5: Chinese Development Finance and Democracy Level of African Recipient Countries, 2000-2011, OLS (EDI)

\begin{tabular}{|c|c|c|c|c|c|c|c|c|}
\hline & \multicolumn{4}{|c|}{ Absolute (1)-(4) } & \multicolumn{4}{|c|}{ Relative (5)-(8) } \\
\hline & $\begin{array}{l}\text { OLS } \\
\text { (1) }\end{array}$ & $\begin{array}{l}\text { OLS } \\
(2)\end{array}$ & $\begin{array}{l}\text { OLS } \\
\text { (3) }\end{array}$ & $\begin{array}{c}\text { OLS } \\
(4)\end{array}$ & $\begin{array}{l}\text { OLS } \\
(5)\end{array}$ & $\begin{array}{c}\text { OLS } \\
(6)\end{array}$ & $\begin{array}{c}\text { OLS } \\
(7)\end{array}$ & $\begin{array}{c}\text { OLS } \\
(8)\end{array}$ \\
\hline $\begin{array}{l}\text { Democracy } \\
\text { (EDI) }\end{array}$ & $\begin{array}{l}4.65 \\
(2.94)\end{array}$ & $\begin{array}{c}2.54 \\
(3.04)\end{array}$ & $\begin{array}{l}8.29^{* *} \\
(3.82)\end{array}$ & $\begin{array}{c}6.25 \\
(3.81)\end{array}$ & $\begin{array}{c}2.55 \\
(1.65)\end{array}$ & $\begin{array}{c}2.73 \\
(1.68)\end{array}$ & $\begin{array}{l}-0.45 \\
(1.56)\end{array}$ & $\begin{array}{l}-0.29 \\
(1.57)\end{array}$ \\
\hline Taiwan & $\begin{array}{c}-14.69^{* * *} \\
(1.03)\end{array}$ & $\begin{array}{c}-14.78^{* * *} \\
(1.08)\end{array}$ & $\begin{array}{c}-13.12^{* * *} \\
(1.25)\end{array}$ & $\begin{array}{c}-13.48^{* * *} \\
(1.28)\end{array}$ & $\begin{array}{l}-0.62^{* *} \\
(0.32)\end{array}$ & $\begin{array}{l}-0.62^{*} \\
(0.33)\end{array}$ & $\begin{array}{c}-1.18^{* * *} \\
(0.43)\end{array}$ & $\begin{array}{c}-1.16^{* * *} \\
(0.44)\end{array}$ \\
\hline $\begin{array}{l}\text { UN Voting } \\
\text { with China }\end{array}$ & $\begin{array}{c}0.01 \\
(0.03)\end{array}$ & $\begin{array}{l}-0.01 \\
(0.03)\end{array}$ & $\begin{array}{c}0.00 \\
(0.03)\end{array}$ & $\begin{array}{l}-0.02 \\
(0.03)\end{array}$ & $\begin{array}{c}0.00 \\
(0.01)\end{array}$ & $\begin{array}{c}0.01 \\
(0.01)\end{array}$ & $\begin{array}{c}0.01 \\
(0.01)\end{array}$ & $\begin{array}{c}0.01 \\
(0.01)\end{array}$ \\
\hline $\begin{array}{l}\text { Western } \\
\text { ODA }\end{array}$ & $\begin{array}{l}0.29^{* *} \\
(0.14)\end{array}$ & $\begin{array}{c}0.14 \\
(0.14)\end{array}$ & $\begin{array}{l}0.25^{*} \\
(0.15)\end{array}$ & $\begin{array}{c}0.13 \\
(0.15)\end{array}$ & $\begin{array}{c}0.03 \\
(0.05)\end{array}$ & $\begin{array}{c}0.04 \\
(0.05)\end{array}$ & $\begin{array}{c}0.01 \\
(0.05)\end{array}$ & $\begin{array}{c}0.02 \\
(0.05)\end{array}$ \\
\hline Population & $\begin{array}{l}1.06^{* *} \\
(0.41)\end{array}$ & $\begin{array}{l}1.19^{* * *} \\
(0.41)\end{array}$ & $\begin{array}{l}1.01^{* *} \\
(0.46)\end{array}$ & $\begin{array}{l}1.10^{* *} \\
(0.45)\end{array}$ & $\begin{array}{l}-0.36 \\
(0.24)\end{array}$ & $\begin{array}{l}-0.37 \\
(0.25)\end{array}$ & $\begin{array}{l}-0.21 \\
(0.28)\end{array}$ & $\begin{array}{l}-0.22 \\
(0.29)\end{array}$ \\
\hline Imports & $\begin{array}{c}-0.49^{* *} \\
(0.19)\end{array}$ & $\begin{array}{c}-0.67^{* * *} \\
(0.19)\end{array}$ & $\begin{array}{l}-0.19 \\
(0.22)\end{array}$ & $\begin{array}{l}-0.38^{*} \\
(0.23)\end{array}$ & $\begin{array}{l}-0.03 \\
(0.22)\end{array}$ & $\begin{array}{l}-0.03 \\
(0.23)\end{array}$ & $\begin{array}{l}-0.10 \\
(0.22)\end{array}$ & $\begin{array}{l}-0.09 \\
(0.24)\end{array}$ \\
\hline GDPpc & $\begin{array}{l}-1.23^{* *} \\
(0.63)\end{array}$ & $\begin{array}{c}-1.90^{* * *} \\
(0.66)\end{array}$ & $\begin{array}{l}-1.22^{*} \\
(0.68)\end{array}$ & $\begin{array}{l}-1.87^{* *} \\
(0.75)\end{array}$ & $\begin{array}{c}0.12 \\
(0.41)\end{array}$ & $\begin{array}{c}0.16 \\
(0.39)\end{array}$ & $\begin{array}{c}0.38 \\
(0.46)\end{array}$ & $\begin{array}{c}0.40 \\
(0.43)\end{array}$ \\
\hline $\begin{array}{l}\text { Gas Rents } \\
(\% \text { of GDP) }\end{array}$ & $\begin{array}{l}-0.27 \\
(0.19)\end{array}$ & $\begin{array}{l}-0.24 \\
(0.20)\end{array}$ & $\begin{array}{l}-0.24 \\
(0.22)\end{array}$ & $\begin{array}{l}-0.25 \\
(0.22)\end{array}$ & $\begin{array}{c}0.03 \\
(0.12)\end{array}$ & $\begin{array}{c}0.04 \\
(0.12)\end{array}$ & $\begin{array}{c}0.12 \\
(0.12)\end{array}$ & $\begin{array}{c}0.13 \\
(0.13)\end{array}$ \\
\hline $\begin{array}{l}\text { Oil Rents } \\
(\% \text { of GDP) }\end{array}$ & $\begin{array}{l}0.08^{* *} \\
(0.04)\end{array}$ & $\begin{array}{l}0.09^{* *} \\
(0.04)\end{array}$ & $\begin{array}{l}0.10^{* *} \\
(0.04)\end{array}$ & $\begin{array}{l}0.11^{* *} \\
(0.04)\end{array}$ & $\begin{array}{l}0.06^{* *} \\
(0.03)\end{array}$ & $\begin{array}{l}0.06^{* *} \\
(0.03)\end{array}$ & $\begin{array}{l}0.05 \\
(0.04)\end{array}$ & $\begin{array}{c}0.05 \\
(0.04)\end{array}$ \\
\hline English & $\begin{array}{l}4.51^{* * *} \\
(0.90)\end{array}$ & $\begin{array}{l}4.41^{* * *} \\
(0.90)\end{array}$ & $\begin{array}{l}2.73^{* *} \\
(1.08)\end{array}$ & $\begin{array}{l}2.88^{* * *} \\
(1.10)\end{array}$ & $\begin{array}{l}1.32^{* *} \\
(0.56)\end{array}$ & $\begin{array}{l}1.34^{* *} \\
(0.59)\end{array}$ & $\begin{array}{l}1.47^{* *} \\
(0.75)\end{array}$ & $\begin{array}{l}1.48^{*} \\
(0.78)\end{array}$ \\
\hline Conflict & $\begin{array}{l}-0.31 \\
(0.39)\end{array}$ & $\begin{array}{l}-0.09 \\
(0.40)\end{array}$ & $\begin{array}{l}-0.37 \\
(0.39)\end{array}$ & $\begin{array}{l}-0.14 \\
(0.39)\end{array}$ & $\begin{array}{c}0.40 \\
(0.43)\end{array}$ & $\begin{array}{c}0.38 \\
(0.43)\end{array}$ & $\begin{array}{c}0.37 \\
(0.43)\end{array}$ & $\begin{array}{c}0.34 \\
(0.44)\end{array}$ \\
\hline Institutions & $\begin{array}{l}-0.90 \\
(1.32)\end{array}$ & $\begin{array}{c}0.77 \\
(1.39)\end{array}$ & $\begin{array}{l}-1.97 \\
(1.39)\end{array}$ & $\begin{array}{l}-0.45 \\
(1.43)\end{array}$ & $\begin{array}{l}-0.75 \\
(0.69)\end{array}$ & $\begin{array}{l}-0.86 \\
(0.75)\end{array}$ & $\begin{array}{l}-0.13 \\
(0.75)\end{array}$ & $\begin{array}{l}-0.22 \\
(0.82)\end{array}$ \\
\hline Year FE & No & Yes & No & Yes & $\mathrm{No}$ & Yes & No & Yes \\
\hline Regional FE & No & No & Yes & Yes & No & No & Yes & Yes \\
\hline Observations & 535 & 535 & 535 & 535 & 535 & 535 & 535 & 535 \\
\hline $\mathrm{R}^{2}$ & 0.26 & 0.29 & 0.28 & 0.31 & 0.04 & 0.05 & 0.05 & 0.05 \\
\hline adj. $R^{2}$ & 0.24 & 0.26 & 0.26 & 0.27 & 0.02 & 0.01 & 0.02 & 0.00 \\
\hline
\end{tabular}

Notes: Constant is omitted. Robust standard errors are shown in parentheses. ${ }^{* * *}$ denotes significance at the $1 \%$ level, ${ }^{* *}$ at the $5 \%$ level, *at the $10 \%$ level. The set of regional fixed effects includes Northern Africa, West Africa, Central Africa, East Africa and Southern Africa. 


\section{CHAPTER 3}

The coefficient on Western ODA is highly statistically significant. My results suggest that a one-percent increase in Western ODA is associated with a 37 percent increase in official financing. Third, countries that tend to be poorer receive, on average, more development finance from China in absolute terms. This result suggests that China's aid allocation is at least partly driven by needsbased motives. Fourth, there exists some empirical evidence that oil-rich countries tend to receive, on average, more development finance in both absolute and relative terms, ceteris paribus.

My empirical findings strongly reject the claim that Chinese development finance mainly targets countries with poor institutional quality. Moreover, I do not find empirical evidence that recipient countries who show a strong voting alignment with China in the UNGA receive more development finance from Beijing, ceteris paribus. With regard to population size, my results suggest that more populous countries do benefit from greater Chinese development assistance.

In column (2) and column (6), I include a set of year dummy variables in the regression to account for year fixed effects. In column (3) and column (7), I capture unobserved time-invariant heterogeneity at the regional level using regional fixed effects, without controlling for year fixed effects. The set of regional fixed effects includes Northern Africa, West Africa, Central Africa, East Africa and Southern Africa. The regression specifications in column (4) and column (8) control for both year fixed effects and regional fixed effects. My results do not change in any fundamental way.

I then test the relationship between Chinese development finance and the democracy level of the recipient country using the P4I, FHI and the VDI, respectively (Table 3.6, Table 3.7 and Table 3.8). The main results remain virtually unchanged. In fact, the coefficient on the VDI is often positive and statistically significant. This result would suggest that more democratic countries tend to receive, on average, more development finance from China. Given the potential drawbacks associated with the VDI, I do not want to overemphasize this empirical finding. Rather, this result should be interpreted as additional empirical evidence against the popular claim that Beijing's development finance systematically targets more authoritarian recipient countries. 
Table 3.6: Chinese Development Finance and Democracy Level of African Recipient Countries, 2000-2011, OLS (P4I)

\begin{tabular}{|c|c|c|c|c|c|c|c|c|}
\hline & \multicolumn{4}{|c|}{ Absolute (1)-(4) } & \multicolumn{4}{|c|}{ Relative (5)-(8) } \\
\hline & $\begin{array}{c}\text { OLS } \\
\text { (1) }\end{array}$ & $\begin{array}{l}\text { OLS } \\
\text { (2) }\end{array}$ & $\begin{array}{c}\text { OLS } \\
\text { (3) }\end{array}$ & $\begin{array}{c}\text { OLS } \\
\text { (4) }\end{array}$ & $\begin{array}{c}\text { OLS } \\
(5)\end{array}$ & $\begin{array}{c}\text { OLS } \\
(6)\end{array}$ & $\begin{array}{c}\text { OLS } \\
(7)\end{array}$ & $\begin{array}{c}\text { OLS } \\
(8)\end{array}$ \\
\hline $\begin{array}{l}\text { Democracy } \\
\text { (P4I) }\end{array}$ & $\begin{array}{c}0.11 \\
(0.32)\end{array}$ & $\begin{array}{l}-0.11 \\
(0.33)\end{array}$ & $\begin{array}{l}-0.05 \\
(0.33)\end{array}$ & $\begin{array}{l}-0.22 \\
(0.33)\end{array}$ & $\begin{array}{c}0.07 \\
(0.18)\end{array}$ & $\begin{array}{c}0.10 \\
(0.19)\end{array}$ & $\begin{array}{c}0.00 \\
(0.20)\end{array}$ & $\begin{array}{c}0.03 \\
(0.21)\end{array}$ \\
\hline Taiwan & $\begin{array}{c}-14.90^{* * *} \\
(1.18)\end{array}$ & $\begin{array}{c}-15.11^{* * *} \\
(1.24)\end{array}$ & $\begin{array}{c}-14.01^{\text {*** }} \\
(1.32)\end{array}$ & $\begin{array}{c}-14.36^{* * *} \\
(1.36)\end{array}$ & $\begin{array}{l}-0.73 \\
(0.46)\end{array}$ & $\begin{array}{l}-0.71 \\
(0.48)\end{array}$ & $\begin{array}{l}-1.30^{* *} \\
(0.55)\end{array}$ & $\begin{array}{c}-1.25^{* *} \\
(0.57)\end{array}$ \\
\hline $\begin{array}{l}\text { UN Voting } \\
\text { with China }\end{array}$ & $\begin{array}{c}0.02 \\
(0.03)\end{array}$ & $\begin{array}{l}-0.01 \\
(0.03)\end{array}$ & $\begin{array}{c}0.01 \\
(0.03)\end{array}$ & $\begin{array}{l}-0.01 \\
(0.03)\end{array}$ & $\begin{array}{c}0.00 \\
(0.01)\end{array}$ & $\begin{array}{c}0.01 \\
(0.01)\end{array}$ & $\begin{array}{c}0.01 \\
(0.01)\end{array}$ & $\begin{array}{c}0.02 \\
(0.02)\end{array}$ \\
\hline $\begin{array}{l}\text { Western } \\
\text { ODA }\end{array}$ & $\begin{array}{l}0.32^{* *} \\
(0.15)\end{array}$ & $\begin{array}{c}0.19 \\
(0.15)\end{array}$ & $\begin{array}{l}0.24^{*} \\
(0.14)\end{array}$ & $\begin{array}{c}0.14 \\
(0.14)\end{array}$ & $\begin{array}{c}0.01 \\
(0.04)\end{array}$ & $\begin{array}{c}0.03 \\
(0.05)\end{array}$ & $\begin{array}{l}-0.02 \\
(0.05)\end{array}$ & $\begin{array}{l}-0.00 \\
(0.05)\end{array}$ \\
\hline Population & $\begin{array}{c}0.70 \\
(0.43)\end{array}$ & $\begin{array}{l}0.81^{*} \\
(0.42)\end{array}$ & $\begin{array}{l}0.89^{*} \\
(0.47)\end{array}$ & $\begin{array}{l}0.93^{* *} \\
(0.46)\end{array}$ & $\begin{array}{l}-0.46^{* *} \\
(0.22)\end{array}$ & $\begin{array}{l}-0.48^{* *} \\
(0.23)\end{array}$ & $\begin{array}{l}-0.28 \\
(0.28)\end{array}$ & $\begin{array}{l}-0.28 \\
(0.28)\end{array}$ \\
\hline Imports & $\begin{array}{l}-0.37^{* *} \\
(0.19)\end{array}$ & $\begin{array}{c}-0.55^{* * *} \\
(0.19)\end{array}$ & $\begin{array}{l}-0.09 \\
(0.22)\end{array}$ & $\begin{array}{l}-0.25 \\
(0.23)\end{array}$ & $\begin{array}{c}0.07 \\
(0.21)\end{array}$ & $\begin{array}{c}0.09 \\
(0.22)\end{array}$ & $\begin{array}{l}-0.03 \\
(0.21)\end{array}$ & $\begin{array}{l}-0.01 \\
(0.22)\end{array}$ \\
\hline GDPpc & $\begin{array}{l}-1.51^{* *} \\
(0.63)\end{array}$ & $\begin{array}{c}-2.10^{* * *} \\
(0.68)\end{array}$ & $\begin{array}{l}-1.27^{*} \\
(0.73)\end{array}$ & $\begin{array}{l}-1.89^{* *} \\
(0.82)\end{array}$ & $\begin{array}{l}-0.13 \\
(0.43)\end{array}$ & $\begin{array}{l}-0.05 \\
(0.43)\end{array}$ & $\begin{array}{c}0.11 \\
(0.50)\end{array}$ & $\begin{array}{c}0.24 \\
(0.46)\end{array}$ \\
\hline $\begin{array}{l}\text { Gas Rents } \\
(\% \text { of GDP) }\end{array}$ & $\begin{array}{l}-0.27 \\
(0.19)\end{array}$ & $\begin{array}{l}-0.22 \\
(0.20)\end{array}$ & $\begin{array}{l}-0.10 \\
(0.21)\end{array}$ & $\begin{array}{l}-0.10 \\
(0.21)\end{array}$ & $\begin{array}{l}-0.02 \\
(0.12)\end{array}$ & $\begin{array}{l}-0.02 \\
(0.13)\end{array}$ & $\begin{array}{c}0.08 \\
(0.12)\end{array}$ & $\begin{array}{c}0.09 \\
(0.13)\end{array}$ \\
\hline $\begin{array}{l}\text { Oil Rents } \\
(\% \text { of GDP) }\end{array}$ & $\begin{array}{l}0.08^{* *} \\
(0.04)\end{array}$ & $\begin{array}{l}0.10^{* *} \\
(0.04)\end{array}$ & $\begin{array}{c}0.06 \\
(0.04)\end{array}$ & $\begin{array}{l}0.08^{*} \\
(0.04)\end{array}$ & $\begin{array}{l}0.05^{*} \\
(0.03)\end{array}$ & $\begin{array}{l}0.05^{*} \\
(0.03)\end{array}$ & $\begin{array}{c}0.02 \\
(0.04)\end{array}$ & $\begin{array}{c}0.02 \\
(0.04)\end{array}$ \\
\hline English & $\begin{array}{l}4.33^{* * *} \\
(0.90)\end{array}$ & $\begin{array}{l}4.38^{* * *} \\
(0.91)\end{array}$ & $\begin{array}{l}2.26^{* *} \\
(1.09)\end{array}$ & $\begin{array}{l}2.44^{* *} \\
(1.12)\end{array}$ & $\begin{array}{l}1.09^{* *} \\
(0.53)\end{array}$ & $\begin{array}{l}1.07^{*} \\
(0.55)\end{array}$ & $\begin{array}{l}1.55^{* *} \\
(0.78)\end{array}$ & $\begin{array}{l}1.49^{*} \\
(0.82)\end{array}$ \\
\hline Conflict & $\begin{array}{c}0.30 \\
(0.37)\end{array}$ & $\begin{array}{c}0.46 \\
(0.39)\end{array}$ & $\begin{array}{c}0.24 \\
(0.38)\end{array}$ & $\begin{array}{c}0.43 \\
(0.40)\end{array}$ & $\begin{array}{c}0.86^{*} \\
(0.48)\end{array}$ & $\begin{array}{l}0.83^{*} \\
(0.47)\end{array}$ & $\begin{array}{l}0.79^{*} \\
(0.48)\end{array}$ & $\begin{array}{c}0.76 \\
(0.48)\end{array}$ \\
\hline Institutions & $\begin{array}{l}-0.21 \\
(1.28) \\
\end{array}$ & $\begin{array}{c}1.25 \\
(1.33) \\
\end{array}$ & $\begin{array}{l}-0.08 \\
(1.26) \\
\end{array}$ & $\begin{array}{c}1.16 \\
(1.32)\end{array}$ & $\begin{array}{l}-0.32 \\
(0.79)\end{array}$ & $\begin{array}{l}-0.52 \\
(0.93)\end{array}$ & $\begin{array}{l}-0.26 \\
(0.71)\end{array}$ & $\begin{array}{l}-0.48 \\
(0.85)\end{array}$ \\
\hline Year FE & No & Yes & No & Yes & No & Yes & No & Yes \\
\hline Regional FE & No & No & Yes & Yes & No & No & Yes & Yes \\
\hline Observations & 514 & 514 & 514 & 514 & 514 & 514 & 514 & 514 \\
\hline $\mathrm{R}^{2}$ & 0.27 & 0.30 & 0.29 & 0.31 & 0.06 & 0.06 & 0.07 & 0.08 \\
\hline adj. $R^{2}$ & 0.25 & 0.27 & 0.27 & 0.28 & 0.04 & 0.02 & 0.04 & 0.03 \\
\hline
\end{tabular}

Notes: Constant is omitted. Robust standard errors are shown in parentheses. ${ }^{* * *}$ denotes significance at the $1 \%$ level, ${ }^{* *}$ at the $5 \%$ level, ${ }^{*}$ at the $10 \%$ level. The set of regional fixed effects includes Northern Africa, West Africa, Central Africa, East Africa and Southern Africa. 
Table 3.7: Chinese Development Finance and Democracy Level of African Recipient Countries, 2000-2011, OLS (FHI)

\begin{tabular}{|c|c|c|c|c|c|c|c|c|}
\hline & \multicolumn{4}{|c|}{ Absolute (1)-(4) } & \multicolumn{4}{|c|}{ Relative (5)-(8) } \\
\hline & $\begin{array}{l}\text { OLS } \\
\text { (1) }\end{array}$ & $\begin{array}{l}\text { OLS } \\
\text { (2) }\end{array}$ & $\begin{array}{c}\text { OLS } \\
\text { (3) }\end{array}$ & $\begin{array}{c}\text { OLS } \\
\text { (4) }\end{array}$ & $\begin{array}{c}\text { OLS } \\
(5)\end{array}$ & $\begin{array}{c}\text { OLS } \\
(6)\end{array}$ & $\begin{array}{c}\text { OLS } \\
(7)\end{array}$ & $\begin{array}{c}\text { OLS } \\
(8)\end{array}$ \\
\hline $\begin{array}{l}\text { Democracy } \\
\text { (FHI) }\end{array}$ & $\begin{array}{c}0.22 \\
(0.26)\end{array}$ & $\begin{array}{l}-0.00 \\
(0.27)\end{array}$ & $\begin{array}{c}0.01 \\
(0.30)\end{array}$ & $\begin{array}{l}-0.18 \\
(0.30)\end{array}$ & $\begin{array}{c}0.10 \\
(0.14)\end{array}$ & $\begin{array}{c}0.11 \\
(0.15)\end{array}$ & $\begin{array}{l}-0.05 \\
(0.15)\end{array}$ & $\begin{array}{l}-0.03 \\
(0.16)\end{array}$ \\
\hline Taiwan & $\begin{array}{c}-14.71^{* * *} \\
(1.14)\end{array}$ & $\begin{array}{c}-15.00^{* * *} \\
(1.20)\end{array}$ & $\begin{array}{c}-13.99^{* * *} \\
(1.29)\end{array}$ & $\begin{array}{c}-14.48^{* * *} \\
(1.34)\end{array}$ & $\begin{array}{l}-0.64 \\
(0.41)\end{array}$ & $\begin{array}{l}-0.62 \\
(0.42)\end{array}$ & $\begin{array}{l}-1.23^{* *} \\
(0.48)\end{array}$ & $\begin{array}{l}-1.20^{* *} \\
(0.49)\end{array}$ \\
\hline $\begin{array}{l}\text { UN Voting } \\
\text { with China }\end{array}$ & $\begin{array}{c}0.01 \\
(0.03)\end{array}$ & $\begin{array}{l}-0.02 \\
(0.03)\end{array}$ & $\begin{array}{l}-0.01 \\
(0.03)\end{array}$ & $\begin{array}{l}-0.03 \\
(0.03)\end{array}$ & $\begin{array}{c}0.00 \\
(0.01)\end{array}$ & $\begin{array}{c}0.00 \\
(0.01)\end{array}$ & $\begin{array}{c}0.00 \\
(0.02)\end{array}$ & $\begin{array}{c}0.01 \\
(0.02)\end{array}$ \\
\hline $\begin{array}{l}\text { Western } \\
\text { ODA }\end{array}$ & $\begin{array}{l}0.34^{* *} \\
(0.15)\end{array}$ & $\begin{array}{c}0.19 \\
(0.15)\end{array}$ & $\begin{array}{l}0.27^{*} \\
(0.14)\end{array}$ & $\begin{array}{c}0.14 \\
(0.15)\end{array}$ & $\begin{array}{c}0.03 \\
(0.04)\end{array}$ & $\begin{array}{c}0.04 \\
(0.05)\end{array}$ & $\begin{array}{c}0.01 \\
(0.05)\end{array}$ & $\begin{array}{c}0.02 \\
(0.05)\end{array}$ \\
\hline Population & $\begin{array}{l}0.89^{* *} \\
(0.42)\end{array}$ & $\begin{array}{l}0.98^{* *} \\
(0.41)\end{array}$ & $\begin{array}{l}1.05^{* *} \\
(0.45)\end{array}$ & $\begin{array}{l}1.09^{* *} \\
(0.44)\end{array}$ & $\begin{array}{l}-0.36 \\
(0.23)\end{array}$ & $\begin{array}{l}-0.37 \\
(0.24)\end{array}$ & $\begin{array}{l}-0.20 \\
(0.27)\end{array}$ & $\begin{array}{l}-0.20 \\
(0.28)\end{array}$ \\
\hline Imports & $\begin{array}{c}-0.47^{* *} \\
(0.20)\end{array}$ & $\begin{array}{l}-0.66^{* * *} \\
(0.19)\end{array}$ & $\begin{array}{l}-0.18 \\
(0.23)\end{array}$ & $\begin{array}{l}-0.35 \\
(0.23)\end{array}$ & $\begin{array}{l}-0.02 \\
(0.21)\end{array}$ & $\begin{array}{l}-0.02 \\
(0.23)\end{array}$ & $\begin{array}{l}-0.10 \\
(0.21)\end{array}$ & $\begin{array}{l}-0.09 \\
(0.23)\end{array}$ \\
\hline GDPpc & $\begin{array}{l}-1.17^{*} \\
(0.65)\end{array}$ & $\begin{array}{c}-1.95^{* * *} \\
(0.69)\end{array}$ & $\begin{array}{l}-0.94 \\
(0.70)\end{array}$ & $\begin{array}{l}-1.71^{\text {** }} \\
(0.77)\end{array}$ & $\begin{array}{c}0.06 \\
(0.41)\end{array}$ & $\begin{array}{c}0.09 \\
(0.39)\end{array}$ & $\begin{array}{c}0.30 \\
(0.45)\end{array}$ & $\begin{array}{c}0.33 \\
(0.41)\end{array}$ \\
\hline $\begin{array}{l}\text { Gas Rents } \\
(\% \text { of GDP })\end{array}$ & $\begin{array}{l}-0.23 \\
(0.19)\end{array}$ & $\begin{array}{l}-0.19 \\
(0.20)\end{array}$ & $\begin{array}{l}-0.08 \\
(0.22)\end{array}$ & $\begin{array}{l}-0.08 \\
(0.22)\end{array}$ & $\begin{array}{c}0.02 \\
(0.11)\end{array}$ & $\begin{array}{c}0.02 \\
(0.12)\end{array}$ & $\begin{array}{c}0.10 \\
(0.12)\end{array}$ & $\begin{array}{c}0.10 \\
(0.12)\end{array}$ \\
\hline $\begin{array}{l}\text { Oil Rents } \\
(\% \text { of GDP) }\end{array}$ & $\begin{array}{l}0.09^{* * *} \\
(0.04)\end{array}$ & $\begin{array}{l}0.11^{* * *} \\
(0.04)\end{array}$ & $\begin{array}{l}0.09^{* *} \\
(0.04)\end{array}$ & $\begin{array}{l}0.10^{* *} \\
(0.04)\end{array}$ & $\begin{array}{l}0.06^{* *} \\
(0.03)\end{array}$ & $\begin{array}{l}0.06^{* *} \\
(0.03)\end{array}$ & $\begin{array}{c}0.05 \\
(0.04)\end{array}$ & $\begin{array}{c}0.05 \\
(0.04)\end{array}$ \\
\hline English & $\begin{array}{l}4.48^{* * *} \\
(0.88)\end{array}$ & $\begin{array}{l}4.48^{* * *} \\
(0.88)\end{array}$ & $\begin{array}{l}2.42^{* *} \\
(1.08)\end{array}$ & $\begin{array}{l}2.56^{* *} \\
(1.10)\end{array}$ & $\begin{array}{l}1.22^{* *} \\
(0.52)\end{array}$ & $\begin{array}{l}1.23^{* *} \\
(0.54)\end{array}$ & $\begin{array}{l}1.46^{*} \\
(0.76)\end{array}$ & $\begin{array}{l}1.47^{*} \\
(0.80)\end{array}$ \\
\hline Conflict & $\begin{array}{l}-0.36 \\
(0.39)\end{array}$ & $\begin{array}{l}-0.11 \\
(0.40)\end{array}$ & $\begin{array}{l}-0.38 \\
(0.39)\end{array}$ & $\begin{array}{l}-0.11 \\
(0.40)\end{array}$ & $\begin{array}{c}0.42 \\
(0.43)\end{array}$ & $\begin{array}{c}0.40 \\
(0.43)\end{array}$ & $\begin{array}{c}0.39 \\
(0.43)\end{array}$ & $\begin{array}{c}0.37 \\
(0.43)\end{array}$ \\
\hline Institutions & $\begin{array}{c}-0.74 \\
(1.41)\end{array}$ & $\begin{array}{c}1.20 \\
(1.50)\end{array}$ & $\begin{array}{l}-0.35 \\
(1.44)\end{array}$ & $\begin{array}{c}1.34 \\
(1.51)\end{array}$ & $\begin{array}{l}-0.39 \\
(0.79)\end{array}$ & $\begin{array}{c}-0.49 \\
(0.87)\end{array}$ & $\begin{array}{l}-0.00 \\
(0.77)\end{array}$ & $\begin{array}{l}-0.10 \\
(0.83)\end{array}$ \\
\hline Year FE & No & Yes & No & Yes & No & Yes & No & Yes \\
\hline Regional FE & No & No & Yes & Yes & No & No & Yes & Yes \\
\hline Observations & 540 & 540 & 540 & 540 & 540 & 540 & 540 & 540 \\
\hline$R^{2}$ & 0.25 & 0.29 & 0.27 & 0.30 & 0.04 & 0.05 & 0.05 & 0.05 \\
\hline adj. $R^{2}$ & 0.24 & 0.25 & 0.25 & 0.26 & 0.02 & 0.00 & 0.02 & 0.01 \\
\hline
\end{tabular}

Notes: Constant is omitted. Robust standard errors are shown in parentheses. ${ }^{* * *}$ denotes significance at the $1 \%$ level, ${ }^{* *}$ at the $5 \%$ level, ${ }^{*}$ at the $10 \%$ level. The set of regional fixed effects includes Northern Africa, West Africa, Central Africa, East Africa and Southern Africa. 
Table 3.8: Chinese Development Finance and Democracy Level of African Recipient Countries, 2000-2011, OLS (VDI)

\begin{tabular}{|c|c|c|c|c|c|c|c|c|}
\hline & \multicolumn{4}{|c|}{ Absolute (1)-(4) } & \multicolumn{4}{|c|}{ Relative (5)-(8) } \\
\hline & $\begin{array}{l}\text { OLS } \\
(1)\end{array}$ & $\begin{array}{l}\text { OLS } \\
(2)\end{array}$ & $\begin{array}{l}\text { OLS } \\
\text { (3) }\end{array}$ & $\begin{array}{l}\text { OLS } \\
(4)\end{array}$ & $\begin{array}{l}\text { OLS } \\
(5)\end{array}$ & $\begin{array}{l}\text { OLS } \\
(6)\end{array}$ & $\begin{array}{l}\text { OLS } \\
(7)\end{array}$ & $\begin{array}{c}\text { OLS } \\
(8)\end{array}$ \\
\hline $\begin{array}{l}\text { Democracy } \\
\text { (VDI) }\end{array}$ & $\begin{array}{l}0.15^{*} \\
(0.08)\end{array}$ & $\begin{array}{c}0.08 \\
(0.08)\end{array}$ & $\begin{array}{l}0.14^{*} \\
(0.08)\end{array}$ & $\begin{array}{c}0.09 \\
(0.08)\end{array}$ & $\begin{array}{c}0.09 \\
(0.06)\end{array}$ & $\begin{array}{l}0.09^{*} \\
(0.06)\end{array}$ & $\begin{array}{c}0.06 \\
(0.05)\end{array}$ & $\begin{array}{c}0.07 \\
(0.05)\end{array}$ \\
\hline Taiwan & $\begin{array}{c}-14.79^{* * *} \\
(1.05)\end{array}$ & $\begin{array}{c}-14.85^{* * *} \\
(1.07)\end{array}$ & $\begin{array}{c}-13.77^{* * *} \\
(1.15)\end{array}$ & $\begin{array}{c}-14.00^{* * *} \\
(1.18)\end{array}$ & $\begin{array}{c}-0.67^{* *} \\
(0.33)\end{array}$ & $\begin{array}{l}-0.66^{*} \\
(0.35)\end{array}$ & $\begin{array}{l}-1.04^{* *} \\
(0.41)\end{array}$ & $\begin{array}{c}-1.01^{* *} \\
(0.42)\end{array}$ \\
\hline $\begin{array}{l}\text { UN Voting } \\
\text { with China }\end{array}$ & $\begin{array}{c}0.01 \\
(0.03)\end{array}$ & $\begin{array}{l}-0.02 \\
(0.03)\end{array}$ & $\begin{array}{l}-0.00 \\
(0.03)\end{array}$ & $\begin{array}{l}-0.03 \\
(0.03)\end{array}$ & $\begin{array}{c}0.00 \\
(0.01)\end{array}$ & $\begin{array}{c}0.01 \\
(0.01)\end{array}$ & $\begin{array}{c}0.01 \\
(0.01)\end{array}$ & $\begin{array}{c}0.01 \\
(0.01)\end{array}$ \\
\hline $\begin{array}{l}\text { Western } \\
\text { ODA }\end{array}$ & $\begin{array}{l}0.35^{* *} \\
(0.14)\end{array}$ & $\begin{array}{c}0.19 \\
(0.15)\end{array}$ & $\begin{array}{l}0.28^{*} \\
(0.14)\end{array}$ & $\begin{array}{c}0.16 \\
(0.15)\end{array}$ & $\begin{array}{c}0.03 \\
(0.04)\end{array}$ & $\begin{array}{c}0.05 \\
(0.05)\end{array}$ & $\begin{array}{c}0.01 \\
(0.05)\end{array}$ & $\begin{array}{c}0.03 \\
(0.05)\end{array}$ \\
\hline Population & $\begin{array}{l}0.95^{* *} \\
(0.41)\end{array}$ & $\begin{array}{l}1.07^{* * *} \\
(0.40)\end{array}$ & $\begin{array}{l}1.09^{* *} \\
(0.45)\end{array}$ & $\begin{array}{l}1.13^{* *} \\
(0.44)\end{array}$ & $\begin{array}{l}-0.34 \\
(0.24)\end{array}$ & $\begin{array}{l}-0.35 \\
(0.24)\end{array}$ & $\begin{array}{l}-0.18 \\
(0.28)\end{array}$ & $\begin{array}{l}-0.19 \\
(0.28)\end{array}$ \\
\hline Imports & $\begin{array}{c}-0.51^{* * *} \\
(0.20)\end{array}$ & $\begin{array}{c}-0.67^{* * *} \\
(0.20)\end{array}$ & $\begin{array}{l}-0.24 \\
(0.22)\end{array}$ & $\begin{array}{l}-0.40^{*} \\
(0.23)\end{array}$ & $\begin{array}{l}-0.05 \\
(0.22)\end{array}$ & $\begin{array}{l}-0.03 \\
(0.23)\end{array}$ & $\begin{array}{l}-0.13 \\
(0.22)\end{array}$ & $\begin{array}{l}-0.12 \\
(0.24)\end{array}$ \\
\hline GDPpc & $\begin{array}{l}-1.14^{*} \\
(0.62)\end{array}$ & $\begin{array}{c}-1.76^{* * *} \\
(0.65)\end{array}$ & $\begin{array}{l}-0.90 \\
(0.68)\end{array}$ & $\begin{array}{l}-1.54^{* *} \\
(0.75)\end{array}$ & $\begin{array}{c}0.10 \\
(0.43)\end{array}$ & $\begin{array}{c}0.16 \\
(0.42)\end{array}$ & $\begin{array}{c}0.36 \\
(0.47)\end{array}$ & $\begin{array}{c}0.43 \\
(0.43)\end{array}$ \\
\hline $\begin{array}{l}\text { Gas Rents } \\
(\% \text { of GDP) }\end{array}$ & $\begin{array}{l}-0.25 \\
(0.20)\end{array}$ & $\begin{array}{l}-0.21 \\
(0.20)\end{array}$ & $\begin{array}{l}-0.13 \\
(0.22)\end{array}$ & $\begin{array}{l}-0.14 \\
(0.23)\end{array}$ & $\begin{array}{c}0.00 \\
(0.12)\end{array}$ & $\begin{array}{c}0.00 \\
(0.12)\end{array}$ & $\begin{array}{c}0.08 \\
(0.12)\end{array}$ & $\begin{array}{c}0.08 \\
(0.13)\end{array}$ \\
\hline $\begin{array}{l}\text { Oil Rents } \\
(\% \text { of GDP) }\end{array}$ & $\begin{array}{l}0.09^{* *} \\
(0.04)\end{array}$ & $\begin{array}{c}0.10^{* * *} \\
(0.04)\end{array}$ & $\begin{array}{l}0.09^{* *} \\
(0.04)\end{array}$ & $\begin{array}{l}0.11^{\text {** }} \\
(0.04)\end{array}$ & $\begin{array}{l}0.06^{* *} \\
(0.03)\end{array}$ & $\begin{array}{l}0.06^{* *} \\
(0.03)\end{array}$ & $\begin{array}{c}0.05 \\
(0.04)\end{array}$ & $\begin{array}{c}0.05 \\
(0.04)\end{array}$ \\
\hline English & $\begin{array}{c}4.17^{* * * *} \\
(0.89)\end{array}$ & $\begin{array}{c}4.26^{* * *} \\
(0.89)\end{array}$ & $\begin{array}{l}2.19^{* *} \\
(1.06)\end{array}$ & $\begin{array}{l}2.48^{* *} \\
(1.09)\end{array}$ & $\begin{array}{l}1.09^{* *} \\
(0.51)\end{array}$ & $\begin{array}{l}1.09^{* *} \\
(0.53)\end{array}$ & $\begin{array}{l}1.41^{* *} \\
(0.71)\end{array}$ & $\begin{array}{c}1.39^{*} \\
(0.75)\end{array}$ \\
\hline Conflict & $\begin{array}{l}-0.44 \\
(0.39)\end{array}$ & $\begin{array}{l}-0.21 \\
(0.40)\end{array}$ & $\begin{array}{l}-0.48 \\
(0.39)\end{array}$ & $\begin{array}{l}-0.25 \\
(0.40)\end{array}$ & $\begin{array}{c}0.38 \\
(0.42)\end{array}$ & $\begin{array}{c}0.35 \\
(0.42)\end{array}$ & $\begin{array}{c}0.34 \\
(0.42)\end{array}$ & $\begin{array}{c}0.31 \\
(0.42)\end{array}$ \\
\hline Institutions & $\begin{array}{l}-0.78 \\
(1.12)\end{array}$ & $\begin{array}{c}0.61 \\
(1.14)\end{array}$ & $\begin{array}{l}-1.06 \\
(1.10)\end{array}$ & $\begin{array}{c}0.15 \\
(1.12)\end{array}$ & $\begin{array}{l}-0.48 \\
(0.70)\end{array}$ & $\begin{array}{l}-0.62 \\
(0.77)\end{array}$ & $\begin{array}{l}-0.49 \\
(0.68)\end{array}$ & $\begin{array}{l}-0.62 \\
(0.75)\end{array}$ \\
\hline Year FE & No & Yes & No & Yes & $\mathrm{No}$ & Yes & No & Yes \\
\hline Regional FE & No & No & Yes & Yes & $\mathrm{No}$ & $\mathrm{No}$ & Yes & Yes \\
\hline Observations & 535 & 535 & 535 & 535 & 535 & 535 & 535 & 535 \\
\hline$R^{2}$ & 0.26 & 0.29 & 0.28 & 0.30 & 0.05 & 0.05 & 0.05 & 0.06 \\
\hline adj. $R^{2}$ & 0.24 & 0.26 & 0.25 & 0.27 & 0.03 & 0.01 & 0.02 & 0.01 \\
\hline
\end{tabular}

Notes: Constant is omitted. Robust standard errors are shown in parentheses. ${ }^{* * *}$ denotes significance at the $1 \%$ level, ${ }^{* *}$ at the $5 \%$ level, ${ }^{*}$ at the $10 \%$ level. The set of regional fixed effects includes Northern Africa, West Africa, Central Africa, East Africa and Southern Africa. 


\section{CHAPTER 3}

When controlling for time fixed effects and regional fixed effects, Chinese development finance in absolute terms is positively correlated with oil rents and negatively correlated with GDP per capita. The weak relationship between the autocracy level of the recipient country and Chinese development finance also holds when the sample is reduced to Sub-Saharan Africa only (Appendix 3.B).

The model presented above may suffer from endogeneity problems in the form of omitted variable bias, measurement error or reverse causality. For example, is it the case that Chinese development finance worsens the democratization process of African recipient countries? If reverse causation is a serious concern here, the error term is likely to be correlated with the explanatory variables leading to biased and inconsistent OLS estimates.

The figures in Appendix 3.A show the recent democratic/autocratic trajectory for several African countries between 2000 and 2011. The figures include major recipients of Chinese development assistance (Angola, Ethiopia, Ghana, Sudan and Zimbabwe), minor recipients (Cape Verde, Comoros, Guinea-Bissau, Swaziland), and also countries that rank in the middle (Central African Republic, Kenya and Mauritania). At first sight, I do not find systematic dramatic deteriorations in the democracy level among major recipients of Chinese development finance. In fact, looking at the entire period 2000-2011, the democratic/autocratic trajectory is fairly constant for some major recipients (such as Angola and Zimbabwe), slightly deteriorating for countries like Ethiopia, and even slightly improving in other countries (such as Ghana).

My descriptive statistics and the quantitative evidence by Bader (2015) suggest that the importance of reverse causality should not be overemphasised. But, in order to account for the possibility of reverse causality and other potential endogeneity issues, I use alternative estimation models in the next section.

\subsection{Robustness}

This section presents some additional robustness checks. Section 3.5.1 presents results using fixed effects and random effects estimation techniques to account for unobserved heterogeneity. Section 3.5.2 addresses the possibility for reverse causality using instrumental variable regression estimation. 


\subsubsection{FE and RE estimation}

In order to capture unobservable time-invariant determinants $\left(u_{i}\right)$, I run both random effects estimations and fixed effects estimations for both absolute Chinese official development official finance (Table 3.9) and Chinese official development finance in relative terms (Table 3.10). Both tables report the regression results, the overall $\mathrm{R}^{2}$ and the $\mathrm{p}$-value of the Hausman (1978) specification test to compare the suitability of the RE assumptions versus the FE assumptions.

Table 3.9(a) displays the results for the EDI, and two alternative democracy indices by V-Dem, the liberal democracy index and the participatory democracy index (consult Appendix 3.C for a definition of the two alternative V-Dem indices). Table 3.9(b) does the same for the P4I, FHI and the VDI, respectively. The effects of time-invariant variables such as English language are partialled out in the FE model (columns 1-3). Similar to the OLS results reported above, I do not find any negative statistically significant relationship between the democracy level of the recipient country and Chinese development finance. The only variable that is highly statistically significant in all specifications is the (non)recognition of Taiwan.

Since the RE model assumes that the entity's error term is not correlated with the predictors, it allows for time-invariant variables such as English language to play a role as explanatory variable.

Similar to my OLS results, the English language is a significant determinant of Chinese development finance. Compared to the results presented in the FE model, the coefficient on population has greatly been reduced and is no longer statistically significant. Employing the Hausman test, I have to reject the null hypothesis that both RE and FE are consistent estimators when using the EDI, P4I, FHI or the VDI. Consequently, the FE specification should be preferred in all three cases. 
Table 3.9(a): Absolute Chinese Development Finance and Democracy Level of African Recipient Countries, 2000-2011, RE and FE

\begin{tabular}{|c|c|c|c|c|c|c|}
\hline & $\begin{array}{c}\text { FE } \\
(1) \\
\text { Electoral } \\
\text { V-DEM } \\
\end{array}$ & $\begin{array}{c}\text { FE } \\
(2) \\
\text { Liberal } \\
\text { V-DEM } \\
\end{array}$ & $\begin{array}{c}\text { FE } \\
(3) \\
\text { Participat. } \\
\text { V-DEM }\end{array}$ & $\begin{array}{c}\text { RE } \\
(4) \\
\text { Electoral } \\
\text { V-DEM } \\
\end{array}$ & $\begin{array}{c}\text { RE } \\
(5) \\
\text { Liberal } \\
\text { V-DEM } \\
\end{array}$ & $\begin{array}{c}\text { RE } \\
(6) \\
\text { Participat. } \\
\text { V-DEM }\end{array}$ \\
\hline Democracy & $\begin{array}{l}10.80 \\
(7.81)\end{array}$ & $\begin{array}{c}13.69 \\
(10.86)\end{array}$ & $\begin{array}{c}20.03 \\
(13.81)\end{array}$ & $\begin{array}{l}7.52^{*} \\
(3.90)\end{array}$ & $\begin{array}{c}6.74 \\
(4.83)\end{array}$ & $\begin{array}{l}10.27^{*} \\
(6.03)\end{array}$ \\
\hline Taiwan & $\begin{array}{c}-10.08^{* * *} \\
(3.04)\end{array}$ & $\begin{array}{c}-9.74 * * \\
(3.06)\end{array}$ & $\begin{array}{c}-10.23^{* * *} \\
(3.04)\end{array}$ & $\begin{array}{c}-13.66^{* * *} \\
(1.88)\end{array}$ & $\begin{array}{c}-13.58^{* * *} \\
(1.91)\end{array}$ & $\begin{array}{c}-13.88^{* * *} \\
(1.88)\end{array}$ \\
\hline $\begin{array}{l}\text { UN Voting } \\
\text { with China }\end{array}$ & $\begin{array}{l}-0.00 \\
(0.04)\end{array}$ & $\begin{array}{l}-0.01 \\
(0.04)\end{array}$ & $\begin{array}{l}-0.01 \\
(0.04)\end{array}$ & $\begin{array}{c}0.02 \\
(0.03)\end{array}$ & $\begin{array}{c}0.01 \\
(0.03)\end{array}$ & $\begin{array}{c}0.01 \\
(0.03)\end{array}$ \\
\hline $\begin{array}{l}\text { Western } \\
\text { ODA }\end{array}$ & $\begin{array}{l}-0.01 \\
(0.17)\end{array}$ & $\begin{array}{l}-0.02 \\
(0.18)\end{array}$ & $\begin{array}{l}-0.02 \\
(0.17)\end{array}$ & $\begin{array}{c}0.21 \\
(0.15)\end{array}$ & $\begin{array}{c}0.22 \\
(0.15)\end{array}$ & $\begin{array}{c}0.21 \\
(0.15)\end{array}$ \\
\hline Population & $\begin{array}{c}7.96 \\
(14.37)\end{array}$ & $\begin{array}{c}8.92 \\
(14.31)\end{array}$ & $\begin{array}{c}5.95 \\
(14.62)\end{array}$ & $\begin{array}{c}1.03^{*} \\
(0.60)\end{array}$ & $\begin{array}{c}0.97 \\
(0.60)\end{array}$ & $\begin{array}{c}0.94 \\
(0.60)\end{array}$ \\
\hline Imports & $\begin{array}{l}-1.52^{*} \\
(0.85)\end{array}$ & $\begin{array}{l}-1.48 \\
(0.85)\end{array}$ & $\begin{array}{l}-1.53^{*} \\
(0.85)\end{array}$ & $\begin{array}{l}-0.31 \\
(0.32)\end{array}$ & $\begin{array}{l}-0.26 \\
(0.32)\end{array}$ & $\begin{array}{l}-0.25 \\
(0.31)\end{array}$ \\
\hline GDPpc & $\begin{array}{l}-2.55 \\
(2.33)\end{array}$ & $\begin{array}{l}-2.65 \\
(2.32)\end{array}$ & $\begin{array}{l}-2.25 \\
(2.35)\end{array}$ & $\begin{array}{l}-1.02 \\
(0.84)\end{array}$ & $\begin{array}{l}-1.16 \\
(0.84)\end{array}$ & $\begin{array}{l}-1.16 \\
(0.84)\end{array}$ \\
\hline $\begin{array}{l}\text { Gas Rents } \\
(\% \text { of GDP) }\end{array}$ & $\begin{array}{c}0.11 \\
(0.42)\end{array}$ & $\begin{array}{c}0.11 \\
(0.42)\end{array}$ & $\begin{array}{c}0.14 \\
(0.42)\end{array}$ & $\begin{array}{l}-0.17 \\
(0.23)\end{array}$ & $\begin{array}{l}-0.17 \\
(0.24)\end{array}$ & $\begin{array}{l}-0.17 \\
(0.24)\end{array}$ \\
\hline $\begin{array}{l}\text { Oil Rents } \\
(\% \text { of GDP) }\end{array}$ & $\begin{array}{c}0.15 \\
(0.11)\end{array}$ & $\begin{array}{c}0.14 \\
(0.11)\end{array}$ & $\begin{array}{c}0.14 \\
(0.11)\end{array}$ & $\begin{array}{c}0.08 \\
(0.05)\end{array}$ & $\begin{array}{c}0.08 \\
(0.05)\end{array}$ & $\begin{array}{c}0.08 \\
(0.05)\end{array}$ \\
\hline English & - & - & - & $\begin{array}{l}4.64^{* * *} \\
(1.37)\end{array}$ & $\begin{array}{l}4.32^{* * *} \\
(1.36)\end{array}$ & $\begin{array}{c}4.61^{* * *} \\
(1.37)\end{array}$ \\
\hline Conflict & $\begin{array}{c}0.73 \\
(0.56)\end{array}$ & $\begin{array}{c}0.74 \\
(0.56)\end{array}$ & $\begin{array}{c}0.72 \\
(0.56)\end{array}$ & $\begin{array}{l}-0.12 \\
(0.45)\end{array}$ & $\begin{array}{l}-0.11 \\
(0.45)\end{array}$ & $\begin{array}{l}-0.13 \\
(0.45)\end{array}$ \\
\hline Institutions & $\begin{array}{c}1.52 \\
(3.11)\end{array}$ & $\begin{array}{c}1.67 \\
(3.10)\end{array}$ & $\begin{array}{c}1.03 \\
(3.22)\end{array}$ & $\begin{array}{l}-1.63 \\
(1.70)\end{array}$ & $\begin{array}{l}-1.41 \\
(1.81)\end{array}$ & $\begin{array}{l}-1.48 \\
(1.72)\end{array}$ \\
\hline $\begin{array}{l}\text { Observations } \\
R^{2} \text { (overall) } \\
\text { Hausman p- } \\
\text { value }\end{array}$ & $\begin{array}{c}535 \\
0.126\end{array}$ & $\begin{array}{c}535 \\
0.119\end{array}$ & $\begin{array}{c}535 \\
0.139\end{array}$ & $\begin{array}{c}535 \\
0.257 \\
0.021\end{array}$ & $\begin{array}{c}535 \\
0.255 \\
0.013\end{array}$ & $\begin{array}{c}535 \\
0.254 \\
0.016\end{array}$ \\
\hline
\end{tabular}

Notes: Constant is omitted. Robust standard errors are shown in parentheses. ${ }^{* * *}$ denotes significance at the $1 \%$ level, ** at the $5 \%$ level, *at the $10 \%$ level. The set of regional fixed effects includes Northern Africa, West Africa, Central Africa, East Africa and Southern Africa. 
Table 3.9(b): Absolute Chinese Development Finance and Democracy Level of African Recipient Countries, 2000-2011, RE and FE

\begin{tabular}{|c|c|c|c|c|c|c|}
\hline & $\begin{array}{c}\text { FE } \\
(1) \\
\text { PolityIV }\end{array}$ & $\begin{array}{l}\mathrm{FE} \\
(2) \\
\mathrm{FH}\end{array}$ & $\begin{array}{c}\text { FE } \\
(3) \\
\text { Vanhanen }\end{array}$ & $\begin{array}{c}\text { RE } \\
(4) \\
\text { PolityIV }\end{array}$ & $\begin{array}{l}\mathrm{RE} \\
(5) \\
\mathrm{FH}\end{array}$ & $\begin{array}{c}\text { RE } \\
(6) \\
\text { Vanhanen }\end{array}$ \\
\hline Democracy & $\begin{array}{c}0.02 \\
(0.70)\end{array}$ & $\begin{array}{c}0.53 \\
(0.67)\end{array}$ & $\begin{array}{c}0.21 \\
(0.13)\end{array}$ & $\begin{array}{c}0.27 \\
(0.41)\end{array}$ & $\begin{array}{c}0.47 \\
(0.33)\end{array}$ & $\begin{array}{l}0.21^{* *} \\
(0.10)\end{array}$ \\
\hline Taiwan & $\begin{array}{c}-10.76^{* * *} \\
(3.14)\end{array}$ & $\begin{array}{c}-10.18^{* * *} \\
(3.05)\end{array}$ & $\begin{array}{c}-10.66^{* * *} \\
(3.05)\end{array}$ & $\begin{array}{c}-13.70^{* * *} \\
(1.94)\end{array}$ & $\begin{array}{c}-13.56^{* * *} \\
(1.93)\end{array}$ & $\begin{array}{c}-13.93^{* * *} \\
(1.89)\end{array}$ \\
\hline $\begin{array}{l}\text { UN Voting } \\
\text { with China }\end{array}$ & $\begin{array}{c}0.01 \\
(0.04)\end{array}$ & $\begin{array}{l}-0.01 \\
(0.04)\end{array}$ & $\begin{array}{l}-0.00 \\
(0.04)\end{array}$ & $\begin{array}{c}0.02 \\
(0.03)\end{array}$ & $\begin{array}{c}0.01 \\
(0.03)\end{array}$ & $\begin{array}{c}0.01 \\
(0.03)\end{array}$ \\
\hline $\begin{array}{l}\text { Western } \\
\text { ODA }\end{array}$ & $\begin{array}{l}-0.01 \\
(0.17)\end{array}$ & $\begin{array}{l}-0.03 \\
(0.18)\end{array}$ & $\begin{array}{l}-0.02 \\
(0.18)\end{array}$ & $\begin{array}{c}0.23 \\
(0.15)\end{array}$ & $\begin{array}{c}0.23 \\
(0.15)\end{array}$ & $\begin{array}{c}0.24 \\
(0.15)\end{array}$ \\
\hline Population & $\begin{array}{c}3.96 \\
(14.78)\end{array}$ & $\begin{array}{c}8.76 \\
(14.25)\end{array}$ & $\begin{array}{c}7.48 \\
(14.23)\end{array}$ & $\begin{array}{c}0.73 \\
(0.60)\end{array}$ & $\begin{array}{c}0.85 \\
(0.59)\end{array}$ & $\begin{array}{c}0.87 \\
(0.59)\end{array}$ \\
\hline Imports & $\begin{array}{l}-1.86^{* *} \\
(0.88)\end{array}$ & $\begin{array}{l}-1.58^{*} \\
(0.85)\end{array}$ & $\begin{array}{l}-1.66^{*} \\
(0.85)\end{array}$ & $\begin{array}{l}-0.26 \\
(0.32)\end{array}$ & $\begin{array}{l}-0.29 \\
(0.32)\end{array}$ & $\begin{array}{l}-0.33 \\
(0.32)\end{array}$ \\
\hline GDPpc & $\begin{array}{l}-1.26 \\
(2.46)\end{array}$ & $\begin{array}{l}-2.58 \\
(2.32)\end{array}$ & $\begin{array}{l}-2.55 \\
(2.31)\end{array}$ & $\begin{array}{l}-1.19 \\
(0.86)\end{array}$ & $\begin{array}{l}-0.90 \\
(0.86)\end{array}$ & $\begin{array}{l}-1.01 \\
(0.84)\end{array}$ \\
\hline $\begin{array}{l}\text { Gas Rents } \\
(\% \text { of GDP })\end{array}$ & $\begin{array}{c}0.14 \\
(0.41)\end{array}$ & $\begin{array}{c}0.10 \\
(0.41)\end{array}$ & $\begin{array}{c}0.16 \\
(0.41)\end{array}$ & $\begin{array}{l}-0.16 \\
(0.23)\end{array}$ & $\begin{array}{l}-0.12 \\
(0.23)\end{array}$ & $\begin{array}{l}-0.14 \\
(0.23)\end{array}$ \\
\hline $\begin{array}{l}\text { Oil Rents } \\
(\% \text { of GDP) }\end{array}$ & $\begin{array}{c}0.15 \\
(0.11)\end{array}$ & $\begin{array}{c}0.16 \\
(0.11)\end{array}$ & $\begin{array}{c}0.16 \\
(0.11)\end{array}$ & $\begin{array}{c}0.08 \\
(0.05)\end{array}$ & $\begin{array}{l}0.09^{*} \\
(0.05)\end{array}$ & $\begin{array}{l}0.09^{*} \\
(0.05)\end{array}$ \\
\hline English & - & - & - & $\begin{array}{l}4.31^{* * *} \\
(1.40)\end{array}$ & $\begin{array}{l}4.54^{* * *} \\
(1.37)\end{array}$ & $\begin{array}{l}4.17^{* * *} \\
(1.38)\end{array}$ \\
\hline Conflict & $\begin{array}{c}0.90 \\
(0.59)\end{array}$ & $\begin{array}{c}0.73 \\
(0.56)\end{array}$ & $\begin{array}{c}0.67 \\
(0.56)\end{array}$ & $\begin{array}{c}0.37 \\
(0.48)\end{array}$ & $\begin{array}{l}-0.17 \\
(0.45)\end{array}$ & $\begin{array}{l}-0.19 \\
(0.45)\end{array}$ \\
\hline Institutions & $\begin{array}{r}1.60 \\
(3.26)\end{array}$ & $\begin{array}{r}2.09 \\
(3.18) \\
\end{array}$ & $\begin{array}{r}1.55 \\
(3.07) \\
\end{array}$ & $\begin{array}{l}-0.86 \\
(1.65) \\
\end{array}$ & $\begin{array}{l}-1.59 \\
(1.78) \\
\end{array}$ & $\begin{array}{l}-1.06 \\
(1.51) \\
\end{array}$ \\
\hline $\begin{array}{l}\text { Observations } \\
R^{2} \text { (overall) } \\
\text { Hausman p- } \\
\text { value }\end{array}$ & $\begin{array}{c}514 \\
0.163\end{array}$ & $\begin{array}{c}540 \\
0.110\end{array}$ & $\begin{array}{c}535 \\
0.125\end{array}$ & $\begin{array}{c}514 \\
0.270 \\
0.063\end{array}$ & $\begin{array}{c}540 \\
0.248 \\
0.011\end{array}$ & $\begin{array}{c}535 \\
0.254 \\
0.009\end{array}$ \\
\hline
\end{tabular}

Notes: Constant is omitted. Robust standard errors are shown in parentheses. $* * *$ denotes significance at the $1 \%$ level, ** at the $5 \%$ level, *at the $10 \%$ level. The set of regional fixed effects includes Northern Africa, West Africa, Central Africa, East Africa and Southern Africa. 
Table 3.10(a): Relative Chinese Development Finance and Democracy Level of African Recipient Countries, 2000-2011, RE and FE

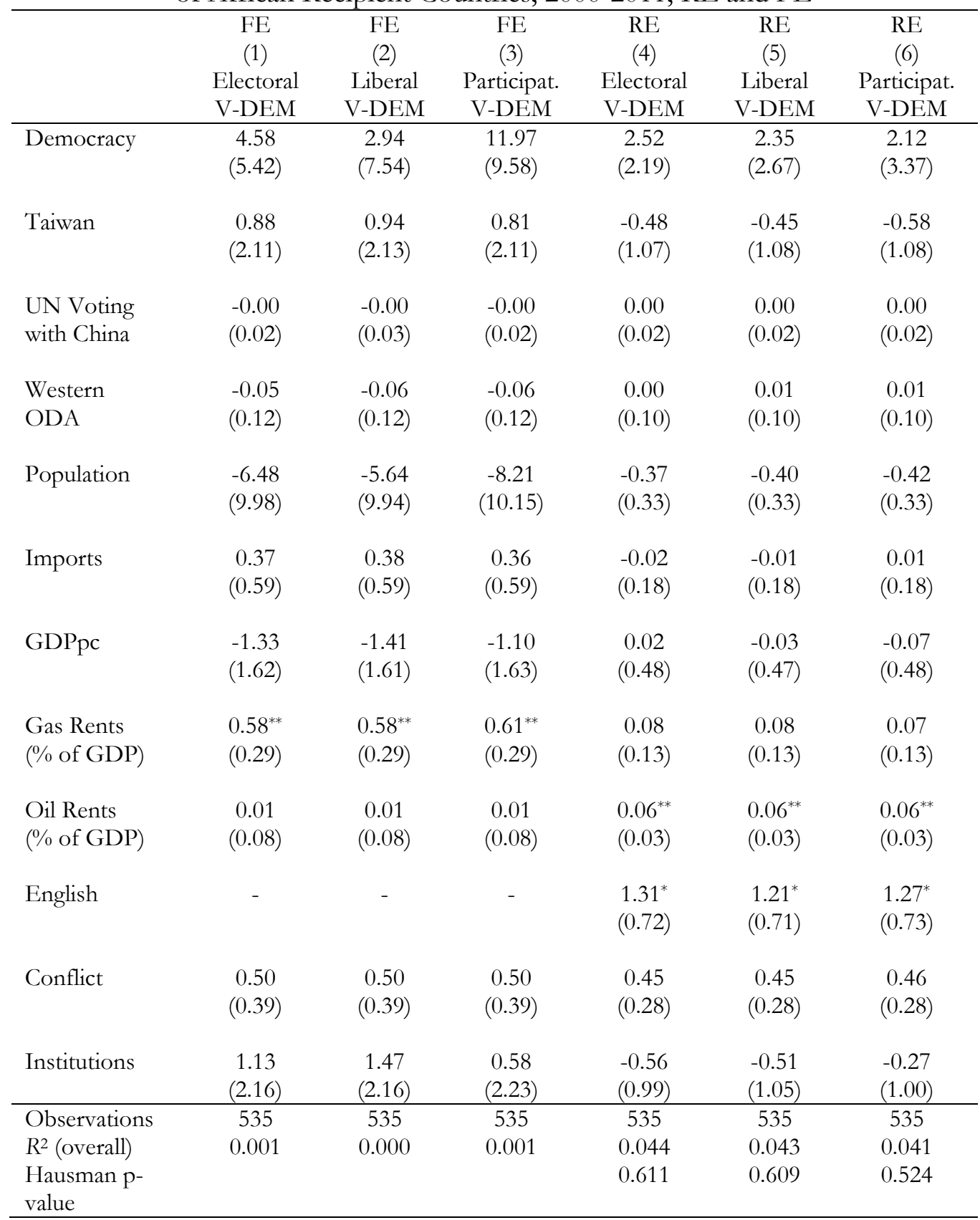

Notes: Constant is omitted. Robust standard errors are shown in parentheses. ${ }^{* * *}$ denotes significance at the $1 \%$ level, ** at the $5 \%$ level, *at the $10 \%$ level. The set of regional fixed effects includes Northern Africa, West Africa, Central Africa, East Africa and Southern Africa. 
Table 3.10(b): Relative Chinese Development Finance and Democracy Level of African Recipient Countries, 2000-2011, RE and FE

\begin{tabular}{|c|c|c|c|c|c|c|}
\hline & $\begin{array}{c}\text { FE } \\
(1) \\
\text { PolityIV }\end{array}$ & $\begin{array}{l}\text { FE } \\
(2) \\
\text { FH } \\
\end{array}$ & $\begin{array}{c}\text { FE } \\
(3) \\
\text { Vanhanen } \\
\end{array}$ & $\begin{array}{c}\text { RE } \\
(4) \\
\text { PolityIV }\end{array}$ & $\begin{array}{l}\mathrm{RE} \\
(5) \\
\mathrm{FH} \\
\end{array}$ & $\begin{array}{c}\text { RE } \\
(6) \\
\text { Vanhanen } \\
\end{array}$ \\
\hline Democracy & $\begin{array}{l}-0.28 \\
(0.48)\end{array}$ & $\begin{array}{c}0.36 \\
(0.46)\end{array}$ & $\begin{array}{c}0.08 \\
(0.09)\end{array}$ & $\begin{array}{c}0.04 \\
(0.22)\end{array}$ & $\begin{array}{c}0.10 \\
(0.19)\end{array}$ & $\begin{array}{c}0.08 \\
(0.06)\end{array}$ \\
\hline Taiwan & $\begin{array}{c}0.29 \\
(2.14)\end{array}$ & $\begin{array}{c}0.89 \\
(2.11)\end{array}$ & $\begin{array}{c}0.70 \\
(2.13)\end{array}$ & $\begin{array}{l}-0.66 \\
(1.06)\end{array}$ & $\begin{array}{l}-0.50 \\
(1.09)\end{array}$ & $\begin{array}{l}-0.57 \\
(1.04)\end{array}$ \\
\hline $\begin{array}{l}\text { UN Voting } \\
\text { with China }\end{array}$ & $\begin{array}{c}0.00 \\
(0.03)\end{array}$ & $\begin{array}{l}-0.00 \\
(0.02)\end{array}$ & $\begin{array}{l}-0.00 \\
(0.03)\end{array}$ & $\begin{array}{c}0.00 \\
(0.02)\end{array}$ & $\begin{array}{c}0.00 \\
(0.02)\end{array}$ & $\begin{array}{c}0.00 \\
(0.02)\end{array}$ \\
\hline $\begin{array}{l}\text { Western } \\
\text { ODA }\end{array}$ & $\begin{array}{l}-0.06 \\
(0.12)\end{array}$ & $\begin{array}{l}-0.06 \\
(0.12)\end{array}$ & $\begin{array}{l}-0.05 \\
(0.12)\end{array}$ & $\begin{array}{l}-0.00 \\
(0.09)\end{array}$ & $\begin{array}{c}0.01 \\
(0.10)\end{array}$ & $\begin{array}{c}0.01 \\
(0.09)\end{array}$ \\
\hline Population & $\begin{array}{c}-8.34 \\
(10.09)\end{array}$ & $\begin{array}{l}-5.24 \\
(9.84)\end{array}$ & $\begin{array}{l}-5.52 \\
(9.92)\end{array}$ & $\begin{array}{l}-0.44 \\
(0.32)\end{array}$ & $\begin{array}{l}-0.37 \\
(0.32)\end{array}$ & $\begin{array}{l}-0.35 \\
(0.31)\end{array}$ \\
\hline Imports & $\begin{array}{c}0.19 \\
(0.60)\end{array}$ & $\begin{array}{c}0.30 \\
(0.59)\end{array}$ & $\begin{array}{c}0.24 \\
(0.59)\end{array}$ & $\begin{array}{c}0.04 \\
(0.17)\end{array}$ & $\begin{array}{l}-0.01 \\
(0.18)\end{array}$ & $\begin{array}{l}-0.04 \\
(0.18)\end{array}$ \\
\hline GDPpc & $\begin{array}{l}-1.17 \\
(1.68)\end{array}$ & $\begin{array}{l}-1.35 \\
(1.60)\end{array}$ & $\begin{array}{l}-1.41 \\
(1.61)\end{array}$ & $\begin{array}{l}-0.23 \\
(0.47)\end{array}$ & $\begin{array}{l}-0.04 \\
(0.49)\end{array}$ & $\begin{array}{l}-0.00 \\
(0.46)\end{array}$ \\
\hline $\begin{array}{l}\text { Gas Rents } \\
(\% \text { of GDP })\end{array}$ & $\begin{array}{l}0.57^{* *} \\
(0.28)\end{array}$ & $\begin{array}{l}0.53^{*} \\
(0.29)\end{array}$ & $\begin{array}{l}0.55^{*} \\
(0.29)\end{array}$ & $\begin{array}{c}0.03 \\
(0.12)\end{array}$ & $\begin{array}{c}0.06 \\
(0.13)\end{array}$ & $\begin{array}{c}0.04 \\
(0.13)\end{array}$ \\
\hline $\begin{array}{l}\text { Oil Rents } \\
(\% \text { of GDP) }\end{array}$ & $\begin{array}{c}0.03 \\
(0.07)\end{array}$ & $\begin{array}{c}0.03 \\
(0.07)\end{array}$ & $\begin{array}{c}0.03 \\
(0.08)\end{array}$ & $\begin{array}{l}0.06^{* *} \\
(0.03)\end{array}$ & $\begin{array}{l}0.06^{* *} \\
(0.03)\end{array}$ & $\begin{array}{l}0.06^{* *} \\
(0.03)\end{array}$ \\
\hline English & - & - & - & $\begin{array}{c}1.10 \\
(0.70)\end{array}$ & $\begin{array}{l}1.21^{*} \\
(0.71)\end{array}$ & $\begin{array}{c}1.10 \\
(0.70)\end{array}$ \\
\hline Conflict & $\begin{array}{c}0.48 \\
(0.40)\end{array}$ & $\begin{array}{c}0.52 \\
(0.39)\end{array}$ & $\begin{array}{c}0.49 \\
(0.39)\end{array}$ & $\begin{array}{c}0.83^{* * *} \\
(0.29)\end{array}$ & $\begin{array}{c}0.46 \\
(0.28)\end{array}$ & $\begin{array}{c}0.42 \\
(0.28)\end{array}$ \\
\hline Institutions & $\begin{array}{c}1.77 \\
(2.23) \\
\end{array}$ & $\begin{array}{c}1.21 \\
(2.20)\end{array}$ & $\begin{array}{c}1.33 \\
(2.14)\end{array}$ & $\begin{array}{l}-0.11 \\
(0.92)\end{array}$ & $\begin{array}{l}-0.23 \\
(1.03)\end{array}$ & $\begin{array}{l}-0.30 \\
(0.84)\end{array}$ \\
\hline $\begin{array}{l}\text { Observations } \\
\mathrm{R}^{2} \text { (overall) } \\
\text { Hausman } \mathrm{p}^{-} \\
\text {value }\end{array}$ & $\begin{array}{c}514 \\
0.001\end{array}$ & $\begin{array}{c}540 \\
0.001\end{array}$ & $\begin{array}{c}535 \\
0.001\end{array}$ & $\begin{array}{c}514 \\
0.060 \\
0.488\end{array}$ & $\begin{array}{c}540 \\
0.043 \\
0.674\end{array}$ & $\begin{array}{c}535 \\
0.046 \\
0.690\end{array}$ \\
\hline
\end{tabular}

Notes: Constant is omitted. Robust standard errors are shown in parentheses. ${ }^{* * *}$ denotes significance at the $1 \%$ level, ** at the $5 \%$ level, *at the $10 \%$ level. The set of regional fixed effects includes Northern Africa, West Africa, Central Africa, East Africa and Southern Africa. 


\section{CHAPTER 3}

Table 3.10 shows the FE and RE results when using relative Chinese official development finance as dependent variable. Similar to the results found in Table 3.9, there is no negative statistical relationship between Chinese official development finance received and a recipient country's level of democracy. Interestingly, the coefficient on Taiwan is no longer statistically significant. The coefficient on English language, however, remains statistically significant. In all cases, the random effects specification should be preferred.

\subsubsection{SLS Estimation}

One possibility to tackle endogeneity issues would be to instrument the lagged democracy level of a specific country ( $\mathrm{t}-1)$ with the democracy level of the previous year ( $\mathrm{t}-2)$. Due to institutional inertia, the democracy variable tends to have a very high correlation with its own lag following Ansell (2010). Using lags as instruments, however, will not remove the bias that is caused by any serial correlation in the error term (Arellano \& Bond, 1991; Arellano \& Bover, 1995; Blundell \& Bond, 1998). Therefore, I will also use the democracy level at each country's year of independence as an instrument for a country's contemporary democratic institutions. The rationale for using the democracy level at a country's year of independence as an instrument for a country's current democracy level goes back to the theory of institutional path dependence in economics (David, 1994; Greif, 1994; North, 1990) and historical institutionalism in political science (Hall \& Taylor, 1996; Pierson \& Skocpol, 2002; Putnam, 1993).

For the EDI, P4I and the VDI I have data available for each African country from its year of independence onwards. Unfortunately, the data on the FHI only exists from 1972 onwards. The FHI is therefore excluded from the 2SLS analysis when using use the democracy level at each country's year of independence as an instrument.

Applying the path dependence theory and historical institutionalism to this case implies that the level of democratic institutional characteristics of a country is bound by its previous institutional history. For the instruments to be valid, I must rule out any direct effect of the instrument on the dependent variable or any effect running through omitted variables (Angrist, Imbens, \& Rubin, 1996). While I believe that the instrumental variables are reasonable in this context, I 


\section{CHAPTER 3}

cannot fully guarantee the validity of my instrument, and I wish to emphasize that I think of the estimates in this section merely as checks on the robustness of the OLS estimates. ${ }^{46}$

Table 3.11 reports the 2SLS estimates for absolute Chinese official development finance. In the odd columns, the democracy level at a country's year of independence is used as instrument. The lagged democracy level is used as instrument in the even columns. The first stage regressions results are excluded due to limited space but are available upon request. In all regression specifications, the coefficient on democracy remains statistically insignificant. The coefficient on democracy is in fact not much larger than the OLS estimate reported in Tables 3.5-3.8, which suggests that the democracy coefficients in the uninstrumented regression did not suffer from attenuation bias (Wooldridge, 2002).

46 I considered novel instruments for democracy, along the lines of Ansell (2010), Aidt and Jensen (2013), Gallego (2010), and Madsen, Raschky and Skali (2015) but I did not find them suitable for the following reasons: Aidt and Jensen (2013) use revolutionary threat by revolutionary events in other countries as instrument in a panel of Western European nations. The instrumented variable, however, is suffrage (the size of the electorate in percentage of all men of voting age), a totally different democracy concept from mine. Gallego (2010) follows Acemoglu, Johnson and Robinson (2002) and uses settler mortality (and population density) in the $16^{\text {th }}$ century as instrument for democratic institutions. Gallego, however, uses cross-sectional data while I use panel data. The aforementioned instruments are better suited for regressions based on cross-section analysis. In their panel data analysis covering the time period 1500-2000, Madsen et al. (2015) use the strength of democracy in linguistically and genetically comparable countries and the natural death of political leaders as external instruments for domestic democracy. Unfortunately, both the linguistic and genetic distance weighted foreign democracy indicators are only available until the year 2000. Moreover, using a political leader's natural death as instrument is much better suited for regressions based on such longer time-spans. Lastly, I tried to follow Ansell's (2010) approach using the level of democracy in neighbouring countries as instrument for a set of 115 countries. The logic behind the instrument is based on the wellknown diffusion effect in democratization (Huntington, 1991). Additionally, the instrument would not suffer from the lag autocorrelation problem. I ran the analysis using the regional level of democracy as instrument for democracy, but the validity of the instrument was weak. For an excellent discussion on viable instruments for democracy, see Acemoglu, Naidu, Restrepo and Robinson (2015). 


\section{CHAPTER 3}

Table 3.11: Absolute Chinese Development Finance and Democracy Level of African Recipient Countries, 2000-2011, 2SLS Estimation

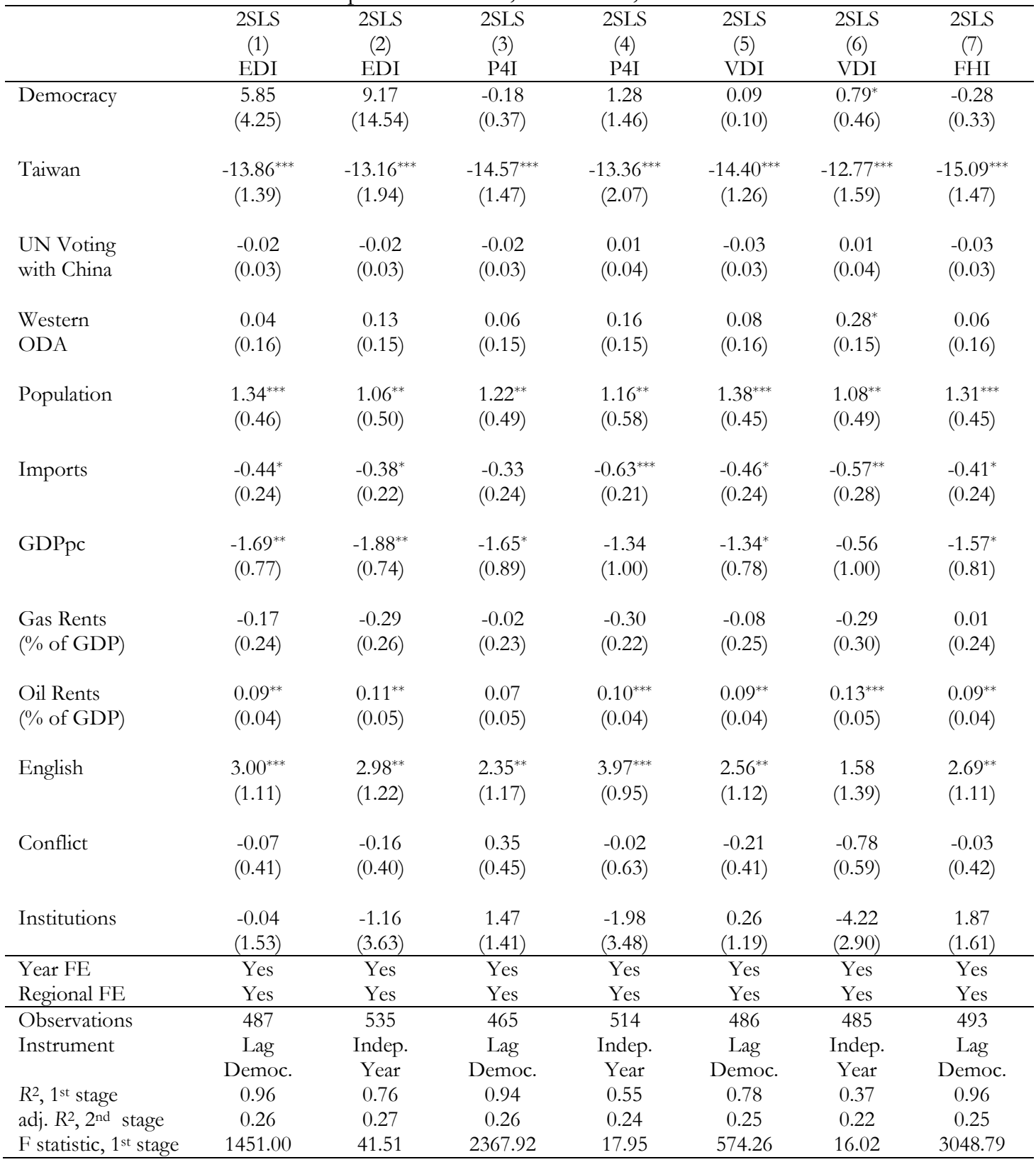

Notes: Constant is omitted. Robust standard errors are shown in parentheses. ${ }^{* * *}$ denotes significance at the $1 \%$ level, ** at the $5 \%$ level, *at the $10 \%$ level. The set of regional fixed effects includes Northern Africa, West Africa, Central Africa, East Africa and Southern Africa. 


\section{CHAPTER 3}

Table 3.12: Relative Chinese Development Finance and Democracy Level of African Recipient Countries, 2000-2011, 2SLS Estimation

\begin{tabular}{|c|c|c|c|c|c|c|c|}
\hline & $\begin{array}{c}2 \text { SLS } \\
(1) \\
\text { EDI }\end{array}$ & $\begin{array}{c}2 \text { SLS } \\
(2) \\
\text { EDI }\end{array}$ & $\begin{array}{c}2 \text { SLS } \\
\text { (3) } \\
\text { P4I }\end{array}$ & $\begin{array}{c}2 \text { SLS } \\
(4) \\
\text { P4I }\end{array}$ & $\begin{array}{l}2 \text { SLS } \\
(5) \\
\text { VDI }\end{array}$ & $\begin{array}{c}\text { 2SLS } \\
(6) \\
\text { VDI }\end{array}$ & $\begin{array}{l}\text { 2SLS } \\
(7) \\
\text { FHI }\end{array}$ \\
\hline Democracy & $\begin{array}{l}-1.68 \\
(1.69)\end{array}$ & $\begin{array}{l}-12.29 \\
(9.14)\end{array}$ & $\begin{array}{l}-0.06 \\
(0.19)\end{array}$ & $\begin{array}{l}-1.34 \\
(2.20)\end{array}$ & $\begin{array}{c}0.04 \\
(0.07)\end{array}$ & $\begin{array}{l}-0.10 \\
(0.30)\end{array}$ & $\begin{array}{l}-0.05 \\
(0.18)\end{array}$ \\
\hline Taiwan & $\begin{array}{l}-1.22^{* *} \\
(0.47)\end{array}$ & $\begin{array}{l}-2.46^{* *} \\
(1.10)\end{array}$ & $\begin{array}{c}-1.38^{* *} \\
(0.58)\end{array}$ & $\begin{array}{l}-3.16 \\
(3.25)\end{array}$ & $\begin{array}{l}-0.99^{* *} \\
(0.42)\end{array}$ & $\begin{array}{l}-1.30^{* *} \\
(0.59)\end{array}$ & $\begin{array}{c}-1.17^{* *} \\
(0.53)\end{array}$ \\
\hline $\begin{array}{l}\text { UN Voting } \\
\text { with China }\end{array}$ & $\begin{array}{c}0.01 \\
(0.02)\end{array}$ & $\begin{array}{l}-0.01 \\
(0.02)\end{array}$ & $\begin{array}{c}0.00 \\
(0.01)\end{array}$ & $\begin{array}{l}-0.01 \\
(0.04)\end{array}$ & $\begin{array}{c}0.01 \\
(0.02)\end{array}$ & $\begin{array}{c}0.00 \\
(0.02)\end{array}$ & $\begin{array}{c}0.01 \\
(0.02)\end{array}$ \\
\hline $\begin{array}{l}\text { Western } \\
\text { ODA }\end{array}$ & $\begin{array}{c}0.01 \\
(0.06)\end{array}$ & $\begin{array}{c}0.01 \\
(0.06)\end{array}$ & $\begin{array}{c}0.01 \\
(0.05)\end{array}$ & $\begin{array}{l}-0.01 \\
(0.06)\end{array}$ & $\begin{array}{c}0.02 \\
(0.06)\end{array}$ & $\begin{array}{c}0.02 \\
(0.07)\end{array}$ & $\begin{array}{c}0.01 \\
(0.05)\end{array}$ \\
\hline Population & $\begin{array}{l}-0.15 \\
(0.29)\end{array}$ & $\begin{array}{l}-0.06 \\
(0.32)\end{array}$ & $\begin{array}{l}-0.18 \\
(0.30)\end{array}$ & $\begin{array}{l}-0.41 \\
(0.31)\end{array}$ & $\begin{array}{l}-0.13 \\
(0.29)\end{array}$ & $\begin{array}{l}-0.31 \\
(0.31)\end{array}$ & $\begin{array}{l}-0.14 \\
(0.29)\end{array}$ \\
\hline Imports & $\begin{array}{l}-0.12 \\
(0.25)\end{array}$ & $\begin{array}{l}-0.10 \\
(0.23)\end{array}$ & $\begin{array}{l}-0.10 \\
(0.22)\end{array}$ & $\begin{array}{c}0.09 \\
(0.27)\end{array}$ & $\begin{array}{l}-0.12 \\
(0.25)\end{array}$ & $\begin{array}{l}-0.14 \\
(0.29)\end{array}$ & $\begin{array}{l}-0.11 \\
(0.24)\end{array}$ \\
\hline GDPpc & $\begin{array}{c}0.56 \\
(0.46)\end{array}$ & $\begin{array}{c}0.46 \\
(0.44)\end{array}$ & $\begin{array}{c}0.51 \\
(0.50)\end{array}$ & $\begin{array}{l}-0.08 \\
(0.76)\end{array}$ & $\begin{array}{c}0.60 \\
(0.47)\end{array}$ & $\begin{array}{c}0.15 \\
(0.69)\end{array}$ & $\begin{array}{c}0.51 \\
(0.43)\end{array}$ \\
\hline $\begin{array}{l}\text { Gas Rents } \\
(\% \text { of GDP) }\end{array}$ & $\begin{array}{c}0.18 \\
(0.13)\end{array}$ & $\begin{array}{c}0.26^{*} \\
(0.16)\end{array}$ & $\begin{array}{c}0.14 \\
(0.12)\end{array}$ & $\begin{array}{c}0.22 \\
(0.26)\end{array}$ & $\begin{array}{c}0.11 \\
(0.13)\end{array}$ & $\begin{array}{c}0.16 \\
(0.16)\end{array}$ & $\begin{array}{c}0.13 \\
(0.12)\end{array}$ \\
\hline $\begin{array}{l}\text { Oil Rents } \\
(\% \text { of GDP) }\end{array}$ & $\begin{array}{c}0.03 \\
(0.04)\end{array}$ & $\begin{array}{c}0.03 \\
(0.03)\end{array}$ & $\begin{array}{c}0.03 \\
(0.03)\end{array}$ & $\begin{array}{c}0.01 \\
(0.04)\end{array}$ & $\begin{array}{c}0.04 \\
(0.04)\end{array}$ & $\begin{array}{c}0.06 \\
(0.04)\end{array}$ & $\begin{array}{c}0.04 \\
(0.04)\end{array}$ \\
\hline English & $\begin{array}{l}1.36 \\
(0.83)\end{array}$ & $\begin{array}{c}1.06 \\
(0.78)\end{array}$ & $\begin{array}{l}1.53^{*} \\
(0.88)\end{array}$ & $\begin{array}{l}1.31^{*} \\
(0.72)\end{array}$ & $\begin{array}{l}1.38^{*} \\
(0.76)\end{array}$ & $\begin{array}{l}1.82^{* *} \\
(0.93)\end{array}$ & $\begin{array}{l}1.42^{*} \\
(0.85)\end{array}$ \\
\hline Conflict & $\begin{array}{c}0.36 \\
(0.48)\end{array}$ & $\begin{array}{c}0.46 \\
(0.42)\end{array}$ & $\begin{array}{c}0.42 \\
(0.47)\end{array}$ & $\begin{array}{c}1.16 \\
(0.80)\end{array}$ & $\begin{array}{c}0.30 \\
(0.50)\end{array}$ & $\begin{array}{c}0.51 \\
(0.51)\end{array}$ & $\begin{array}{c}0.35 \\
(0.48)\end{array}$ \\
\hline Institutions & $\begin{array}{c}0.18 \\
(0.88) \\
\end{array}$ & $\begin{array}{c}2.67 \\
(2.44) \\
\end{array}$ & $\begin{array}{l}-0.42 \\
(0.85) \\
\end{array}$ & $\begin{array}{c}2.19 \\
(4.82) \\
\end{array}$ & $\begin{array}{l}-0.59 \\
(0.80) \\
\end{array}$ & $\begin{array}{c}0.58 \\
(2.17) \\
\end{array}$ & $\begin{array}{l}-0.20 \\
(0.90) \\
\end{array}$ \\
\hline Year FE & Yes & Yes & Yes & Yes & Yes & Yes & Yes \\
\hline Regional FE & Yes & Yes & Yes & Yes & Yes & Yes & Yes \\
\hline Observations & 487 & 535 & 465 & 514 & 486 & 485 & 493 \\
\hline Instrument & $\begin{array}{c}\text { Lag } \\
\text { Democ. }\end{array}$ & $\begin{array}{l}\text { Indep. } \\
\text { Year }\end{array}$ & $\begin{array}{c}\text { Lag } \\
\text { Democ. }\end{array}$ & $\begin{array}{l}\text { Indep. } \\
\text { Year }\end{array}$ & $\begin{array}{c}\text { Lag } \\
\text { Democ. }\end{array}$ & $\begin{array}{l}\text { Indep. } \\
\text { Year }\end{array}$ & $\begin{array}{c}\text { Lag } \\
\text { Democ. }\end{array}$ \\
\hline $\begin{array}{l}R^{2}, 1^{\text {st }} \text { stage } \\
\text { adj. } R^{2}, 2^{\text {nd }} \text { stage }\end{array}$ & $\begin{array}{l}0.96 \\
0.05\end{array}$ & $\begin{array}{l}0.76 \\
0.01\end{array}$ & $\begin{array}{l}0.94 \\
0.01\end{array}$ & $\begin{array}{r}0.55 \\
-0.05\end{array}$ & $\begin{array}{c}0.78 \\
0.00\end{array}$ & $\begin{array}{l}0.37 \\
0.00\end{array}$ & $\begin{array}{l}0.96 \\
0.00\end{array}$ \\
\hline F statistic, $1^{\text {st }}$ stage & 1451.00 & 41.51 & 2367.92 & 9.86 & 574.26 & 16.02 & 3048.79 \\
\hline
\end{tabular}




\section{CHAPTER 3}

Similar to my previous results, there exists a strong and highly statistically significant inverted relationship between the recognition of Taiwan and Chinese development finance. The coefficient on English language is also strongly positive and highly statistically significant in most cases. Like in the FE results presented above, there is a highly significant negative relationship between trade imports from China and Chinese official financing. Interestingly, the coefficients on population and oil rents are strongly positive and highly statistically significant in most cases. In 5 out of 7 cases, the coefficient on GDP per capita is negative and statistically significant.

The 2SLS results suggest that population size, oil rents as a percentage of GDP, and the level of economic development are major determinants of Chinese official finance. In contrast to oil rents, gas rents cannot be considered a major determinant for Chinese development finance. The coefficient on institutional quality is not statistically significant. The claim that Chinese development assistance systematically targets countries with weaker institutions can therefore be refuted.

The relatively high $\mathrm{R}^{2}$ from fitting the first-stage regression indicates the high relevance of my instrument. Since my instruments are strongly correlated with the endogenous democracy variable, my instrumental-variables estimators exhibit less bias when compared to the OLS estimators reported in Tables 3.53.8. In all cases, the instrument is strong, since my first-stage F-statistics exceed the rule-of-thumb threshold of 10 (Staiger \& Stock, 1997; Stock \& Watson, 2012; Stock, Wright, \& Yogo, 2002). ${ }^{47}$

The 2SLS results for relative Chinese official development finance are reported in Table 3.12. While the coefficient on democracy often has a negative sign, the bivariate relationship of democracy and relative Chinese official development finance is still not statistically significant. Overall, my empirical results do not provide empirical evidence that Chinese development finance systematically flows to more authoritarian countries, holding all other factors constant.

\footnotetext{
${ }^{47}$ Stock, Wright and Yogo (2002) suggest that the F statistic must be above 10 for inference based on the 2SLS estimator to be reliable when there is one endogenous regressor.
} 


\subsection{Concluding Remarks}

Until very recently the growing literature on China's economic embrace of Africa has mainly been driven by qualitative studies and anecdotal evidence. A bulk of theoretical literature suggests that development finance from non-traditional, non-democratic donors, such as China, to developing countries could actively promote autocracy in recipient states and offset the efforts of traditional democratic DAC donors to deliver development assistance to democratic recipient countries.

This chapter set out to examine whether Chinese development finance systematically flows to more authoritarian countries in Africa, ceteris paribus. I have used both absolute Chinese official development finance and a proxy for relative Chinese official development finance to answer the research question.

Using various econometric estimation techniques, I did not find a strong negative and highly statistically significant relationship between the democracy level of a recipient country and Chinese development finance. Or put differently, Chinese development finance does not systematically target more authoritarian countries, controlling for political, economic, institutional, strategic and geographic factors. This finding remains unchanged if I reduce the sample to Sub-Saharan Africa only. The finding also survives several robustness checks including FE, RE and instrumental variable estimation.

My empirical results are only partly in line with the theoretical expectations. The only major determinants of Chinese development finance in absolute terms that remain highly statistically significant irrespective of the econometric estimation model chosen are the absence of political ties with Taiwan, English as one of the three most common languages in the recipient country and the existence of oil rents in the recipient country. Furthermore, I do not find a strongly negative and highly statistically significant relationship between the good governance record of a recipient country and Chinese official finance. The accusation that Beijing's official finance to developing countries must be considered 'rogue aid' seems unjustified.

While DAC members are required to officially report their data on official development assistance to the OECD, non-DAC donors' reporting takes place on a voluntary basis. As long as non-DAC donors like China refuse to make 
their development finance activities publicly available, researchers and policymakers alike have to rely on databases such as the TUFF for the time being. The disclosure of development finance data by governments outside the DAC would have the potential of "enriching the aid effectiveness agenda with the practices and experiences of South-South cooperation" (DCD-DAC, 2010, p. 10). 


\section{Appendix 3.A: List of Figures}

Figure 3.A1: Evolution of Democracy for Selected African Countries, 20002011 (Electoral Democracy Index)

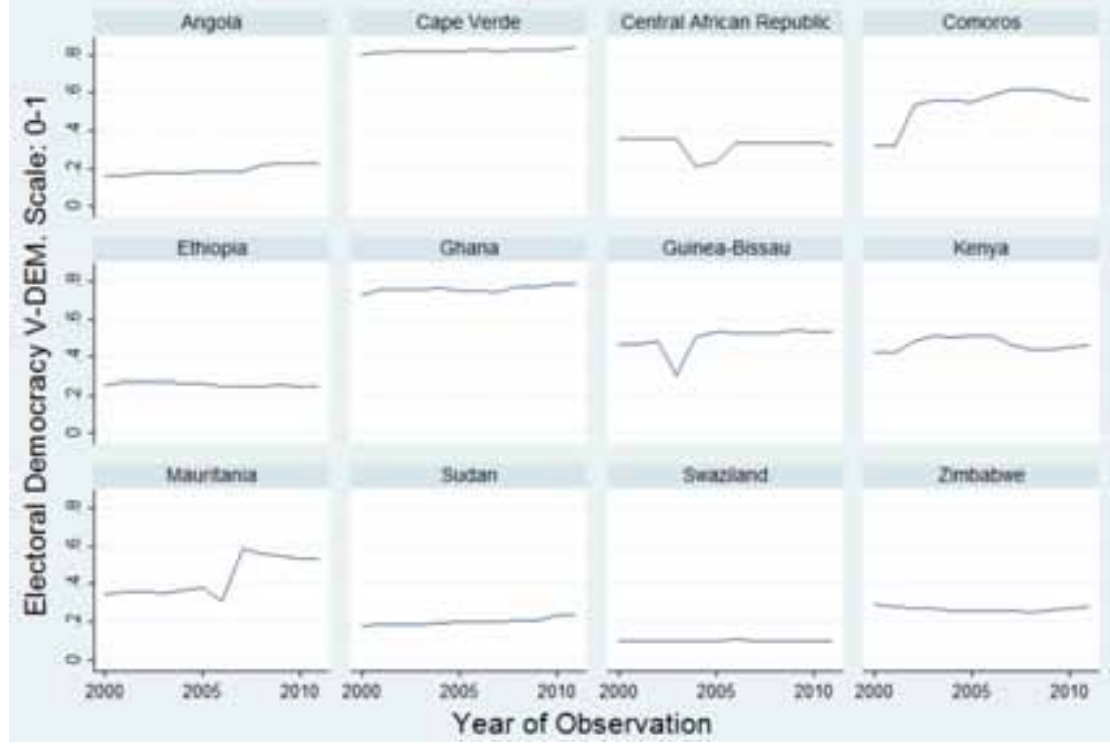

Figure 3.A2: Evolution of Democracy for Selected African Countries, 20002011 (Polity IV Index)

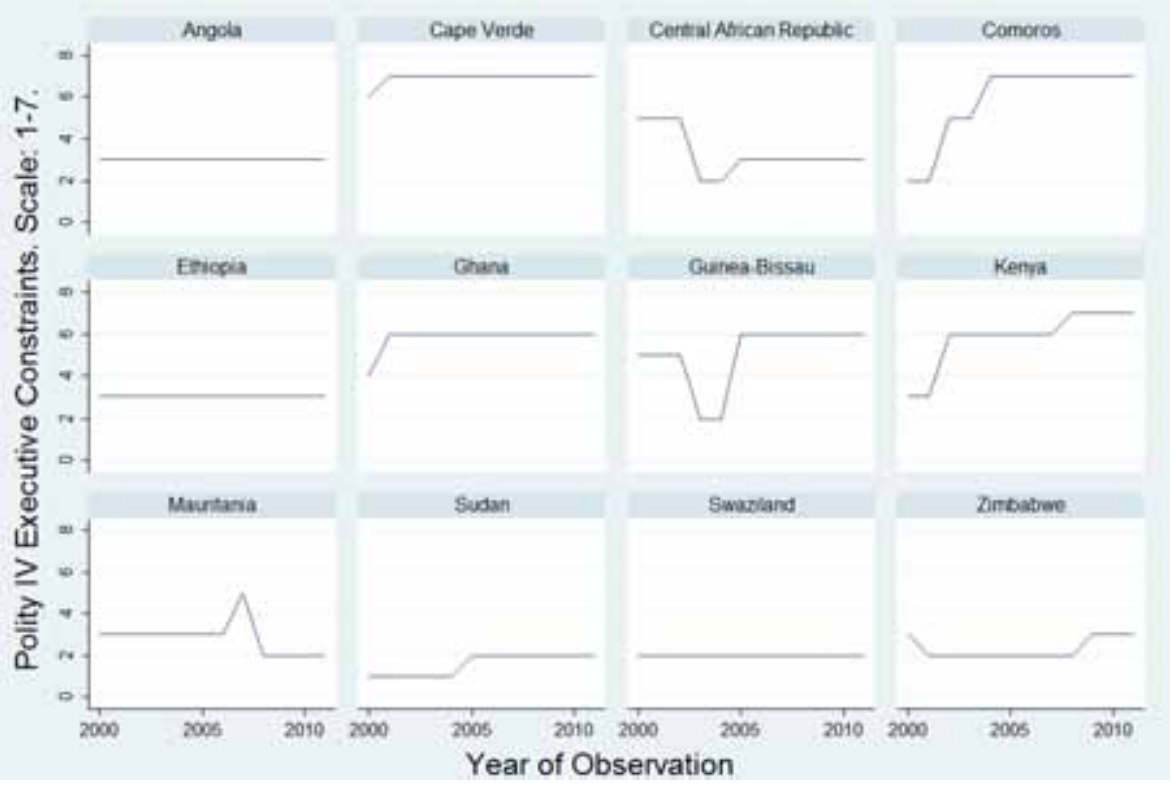


Figure 3.A3: Evolution of Democracy for Selected African Countries, 20002011 (Freedom House Index)

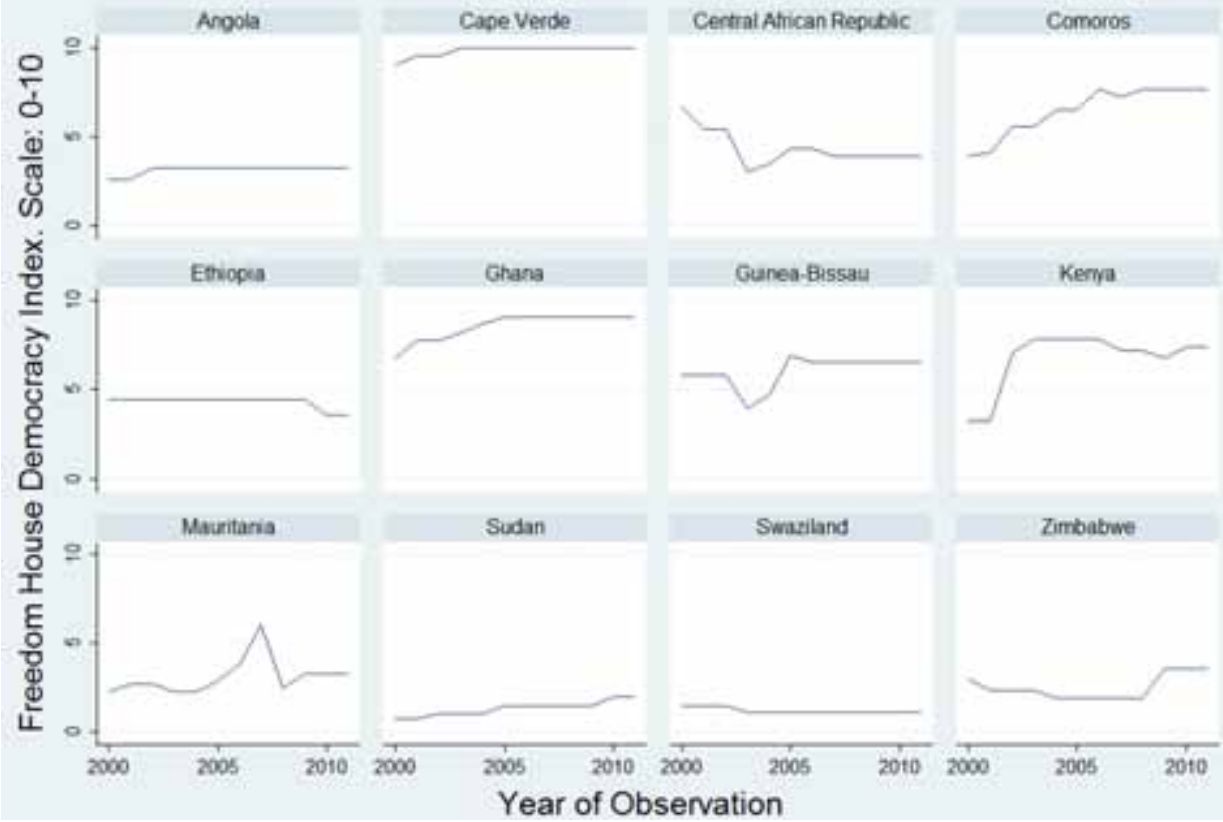

Figure 3.A4: Evolution of Democracy for Selected African Countries, 20002011 (Vanhanen Democratization Index)

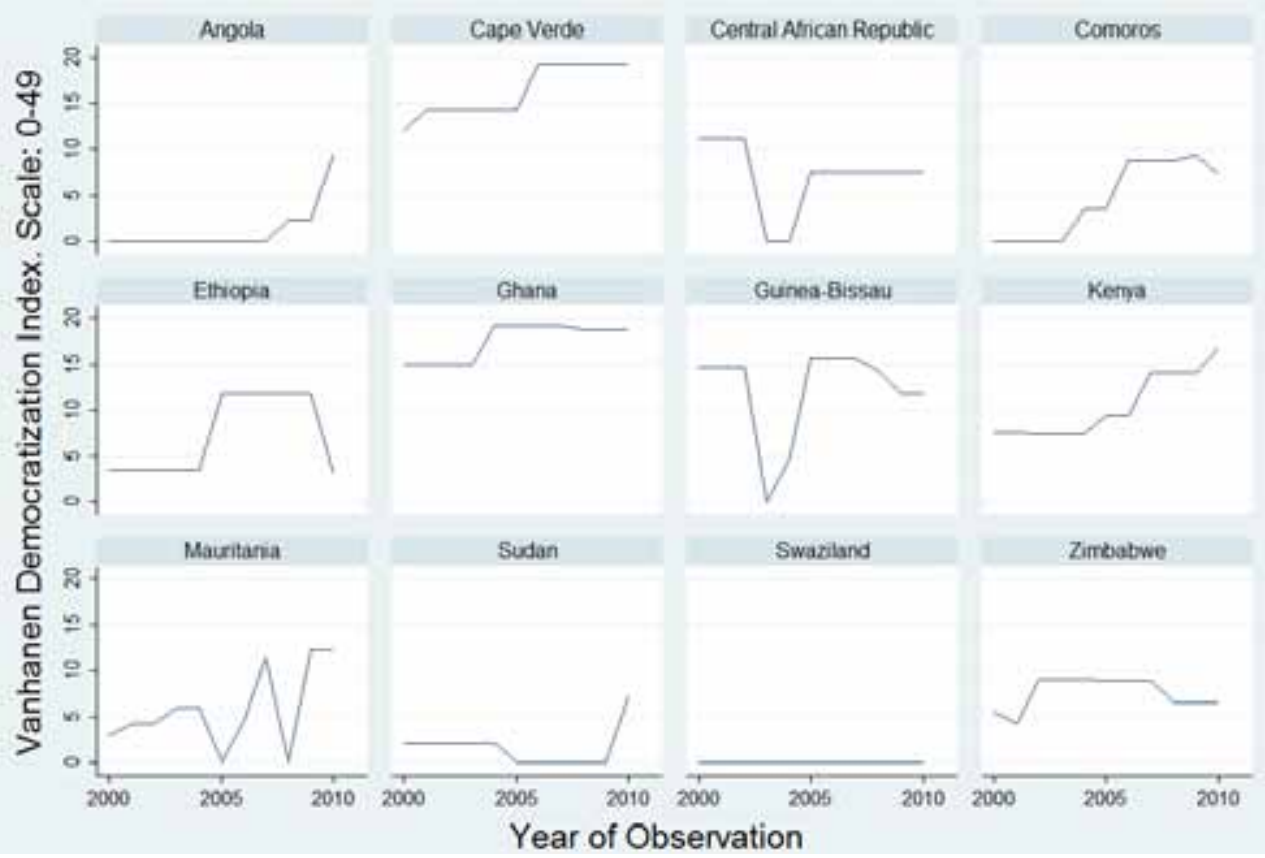




\section{Appendix 3.B: List of Tables}

Table 3.B1: Absolute Chinese Development Finance and

Democracy Level of Sub-Saharan African Recipient Countries, 2000-2011

\begin{tabular}{|c|c|c|c|c|c|c|}
\hline & $\begin{array}{c}\text { OLS } \\
(1) \\
\text { V-DEM } \\
\text { (Electoral) }\end{array}$ & $\begin{array}{c}\text { OLS } \\
(2) \\
\text { V-DEM } \\
\text { (Electoral) }\end{array}$ & $\begin{array}{c}\text { OLS } \\
(3) \\
\text { V-DEM } \\
\text { (Liberal) }\end{array}$ & $\begin{array}{c}\text { OLS } \\
(4) \\
\text { V-DEM } \\
\text { (Liberal) }\end{array}$ & $\begin{array}{c}\text { OLS } \\
(5) \\
\text { V-DEM } \\
\text { (Particip.) }\end{array}$ & $\begin{array}{c}\text { OLS } \\
(6) \\
\text { V-DEM } \\
\text { (Particip.) }\end{array}$ \\
\hline Democracy & $\begin{array}{c}3.74 \\
(3.43)\end{array}$ & $\begin{array}{l}8.19^{* *} \\
(3.95)\end{array}$ & $\begin{array}{c}2.53 \\
(3.78)\end{array}$ & $\begin{array}{l}7.11^{*} \\
(4.23)\end{array}$ & $\begin{array}{c}1.64 \\
(5.41)\end{array}$ & $\begin{array}{c}5.27 \\
(5.90)\end{array}$ \\
\hline Taiwan & $\begin{array}{l}-14.78^{* * *} \\
(1.04)\end{array}$ & $\begin{array}{c}-13.31^{* * *} \\
(1.33)\end{array}$ & $\begin{array}{c}-14.80^{* * *} \\
(1.09)\end{array}$ & $\begin{array}{c}-13.33^{* * *} \\
(1.39)\end{array}$ & $\begin{array}{c}-14.97^{* * *} \\
(1.01)\end{array}$ & $\begin{array}{c}-13.99^{* * *} \\
(1.23)\end{array}$ \\
\hline $\begin{array}{l}\text { UN Voting } \\
\text { with China }\end{array}$ & $\begin{array}{c}0.01 \\
(0.03)\end{array}$ & $\begin{array}{l}-0.03 \\
(0.03)\end{array}$ & $\begin{array}{c}0.01 \\
(0.03)\end{array}$ & $\begin{array}{l}-0.03 \\
(0.03)\end{array}$ & $\begin{array}{c}0.01 \\
(0.03)\end{array}$ & $\begin{array}{l}-0.03 \\
(0.03)\end{array}$ \\
\hline $\begin{array}{l}\text { Western } \\
\text { ODA }\end{array}$ & $\begin{array}{c}0.05 \\
(0.21)\end{array}$ & $\begin{array}{l}-0.17 \\
(0.21)\end{array}$ & $\begin{array}{c}0.06 \\
(0.21)\end{array}$ & $\begin{array}{l}-0.17 \\
(0.21)\end{array}$ & $\begin{array}{c}0.06 \\
(0.21)\end{array}$ & $\begin{array}{l}-0.16 \\
(0.21)\end{array}$ \\
\hline Population & $\begin{array}{l}1.18^{* *} \\
(0.47)\end{array}$ & $\begin{array}{l}1.10^{* *} \\
(0.47)\end{array}$ & $\begin{array}{l}1.19^{* *} \\
(0.47)\end{array}$ & $\begin{array}{l}1.14^{* *} \\
(0.47)\end{array}$ & $\begin{array}{l}1.18^{* *} \\
(0.47)\end{array}$ & $\begin{array}{l}1.12^{* *} \\
(0.48)\end{array}$ \\
\hline Imports & $\begin{array}{l}-0.54^{* * *} \\
(0.21)\end{array}$ & $\begin{array}{l}-0.45^{*} \\
(0.23)\end{array}$ & $\begin{array}{l}-0.51^{* *} \\
(0.20)\end{array}$ & $\begin{array}{l}-0.43^{*} \\
(0.23)\end{array}$ & $\begin{array}{l}-0.49^{* *} \\
(0.20)\end{array}$ & $\begin{array}{l}-0.42^{*} \\
(0.23)\end{array}$ \\
\hline GDPpc & $\begin{array}{l}-0.92 \\
(0.68)\end{array}$ & $\begin{array}{l}-1.88^{* *} \\
(0.75)\end{array}$ & $\begin{array}{l}-0.92 \\
(0.68)\end{array}$ & $\begin{array}{l}-1.89^{* *} \\
(0.75)\end{array}$ & $\begin{array}{l}-0.95 \\
(0.68)\end{array}$ & $\begin{array}{l}-1.96^{* *} \\
(0.76)\end{array}$ \\
\hline $\begin{array}{l}\text { Gas Rents } \\
\text { ( } \% \text { of GDP) }\end{array}$ & $\begin{array}{c}0.59 \\
(0.37)\end{array}$ & $\begin{array}{c}0.38 \\
(0.35)\end{array}$ & $\begin{array}{c}0.60 \\
(0.36)\end{array}$ & $\begin{array}{c}0.40 \\
(0.36)\end{array}$ & $\begin{array}{c}0.58 \\
(0.35)\end{array}$ & $\begin{array}{c}0.32 \\
(0.35)\end{array}$ \\
\hline $\begin{array}{l}\text { Oil Rents } \\
\text { ( } \% \text { of GDP) }\end{array}$ & $\begin{array}{l}0.08^{* *} \\
(0.04)\end{array}$ & $\begin{array}{l}0.14^{* * *} \\
(0.04)\end{array}$ & $\begin{array}{l}0.08^{*} \\
(0.04)\end{array}$ & $\begin{array}{l}0.14^{* * *} \\
(0.05)\end{array}$ & $\begin{array}{l}0.08^{*} \\
(0.04)\end{array}$ & $\begin{array}{l}0.14^{* * *} \\
(0.05)\end{array}$ \\
\hline English & $\begin{array}{l}4.43^{* * *} \\
(1.05)\end{array}$ & $\begin{array}{l}3.26^{* * *} \\
(1.15)\end{array}$ & $\begin{array}{l}4.15^{* * *} \\
(0.97)\end{array}$ & $\begin{array}{l}2.89^{* *} \\
(1.13)\end{array}$ & $\begin{array}{l}4.16^{* * *} \\
(1.07)\end{array}$ & $\begin{array}{l}3.10^{* * *} \\
(1.17)\end{array}$ \\
\hline Conflict & $\begin{array}{l}-0.46 \\
(0.40)\end{array}$ & $\begin{array}{l}-0.23 \\
(0.40)\end{array}$ & $\begin{array}{l}-0.46 \\
(0.41)\end{array}$ & $\begin{array}{l}-0.26 \\
(0.40)\end{array}$ & $\begin{array}{l}-0.44 \\
(0.41)\end{array}$ & $\begin{array}{c}-0.20 \\
(0.40)\end{array}$ \\
\hline Institutions & $\begin{array}{l}-1.11 \\
(1.38) \\
\end{array}$ & $\begin{array}{l}-1.26 \\
(1.47) \\
\end{array}$ & $\begin{array}{r}-0.82 \\
(1.41) \\
\end{array}$ & $\begin{array}{r}-0.99 \\
(1.47) \\
\end{array}$ & $\begin{array}{r}-0.45 \\
(1.38) \\
\end{array}$ & $\begin{array}{r}-0.07 \\
(1.44) \\
\end{array}$ \\
\hline Observations & 480 & 480 & 480 & 480 & $\frac{1 N 0}{480}$ & 480 \\
\hline$R^{2}$ & 0.27 & 0.33 & 0.27 & 0.33 & 0.27 & 0.32 \\
\hline $\operatorname{adj} . R^{2}$ & 0.25 & 0.29 & 0.25 & 0.29 & 0.25 & 0.29 \\
\hline
\end{tabular}

Notes: Constant is omitted. Robust standard errors are shown in parentheses. ${ }^{* * *}$ denotes significance at the $1 \%$ level, ** at the $5 \%$ level, *at the $10 \%$ level. The set of regional fixed effects includes Northern Africa, West Africa, Central Africa, East Africa and Southern Africa 
Table 3.B2: Absolute Chinese Development Finance and Democracy Level of Sub-Saharan African Recipient Countries, 2000-2011

\begin{tabular}{|c|c|c|c|c|c|c|}
\hline & $\begin{array}{c}\text { OLS } \\
(1) \\
\text { P4I }\end{array}$ & $\begin{array}{l}\text { OLS } \\
(2) \\
\text { P4I }\end{array}$ & $\begin{array}{c}\text { OLS } \\
\text { (3) } \\
\text { FHI }\end{array}$ & $\begin{array}{c}\text { OLS } \\
(4) \\
\text { FHI }\end{array}$ & $\begin{array}{c}\text { OLS } \\
(5) \\
\text { VDI }\end{array}$ & $\begin{array}{c}\text { OLS } \\
(6) \\
\text { VDI }\end{array}$ \\
\hline Democracy & $\begin{array}{c}0.07 \\
(0.34)\end{array}$ & $\begin{array}{l}-0.09 \\
(0.35)\end{array}$ & $\begin{array}{c}0.11 \\
(0.30)\end{array}$ & $\begin{array}{l}-0.00 \\
(0.30)\end{array}$ & $\begin{array}{l}0.15^{*} \\
(0.08)\end{array}$ & $\begin{array}{c}0.10 \\
(0.08)\end{array}$ \\
\hline Taiwan & $\begin{array}{c}-14.89^{* * *} \\
(1.19)\end{array}$ & $\begin{array}{c}-14.25^{* * *} \\
(1.42)\end{array}$ & $\begin{array}{c}-14.86^{* * *} \\
(1.16)\end{array}$ & $\begin{array}{c}-14.24^{* * *} \\
(1.39)\end{array}$ & $\begin{array}{c}-14.79^{* * *} \\
(1.06)\end{array}$ & $\begin{array}{c}-14.05^{* * *} \\
(1.23)\end{array}$ \\
\hline $\begin{array}{l}\text { UN Voting } \\
\text { with China }\end{array}$ & $\begin{array}{c}0.02 \\
(0.03)\end{array}$ & $\begin{array}{l}-0.02 \\
(0.03)\end{array}$ & $\begin{array}{c}0.01 \\
(0.03)\end{array}$ & $\begin{array}{l}-0.04 \\
(0.03)\end{array}$ & $\begin{array}{c}0.01 \\
(0.03)\end{array}$ & $\begin{array}{l}-0.03 \\
(0.03)\end{array}$ \\
\hline $\begin{array}{l}\text { Western } \\
\text { ODA }\end{array}$ & $\begin{array}{c}0.04 \\
(0.21)\end{array}$ & $\begin{array}{l}-0.14 \\
(0.22)\end{array}$ & $\begin{array}{c}0.06 \\
(0.21)\end{array}$ & $\begin{array}{l}-0.15 \\
(0.21)\end{array}$ & $\begin{array}{c}0.07 \\
(0.21)\end{array}$ & $\begin{array}{l}-0.14 \\
(0.21)\end{array}$ \\
\hline Population & $\begin{array}{l}1.07^{* *} \\
(0.49)\end{array}$ & $\begin{array}{l}1.01^{* *} \\
(0.49)\end{array}$ & $\begin{array}{l}1.21^{* *} \\
(0.47)\end{array}$ & $\begin{array}{l}1.18^{* *} \\
(0.47)\end{array}$ & $\begin{array}{l}1.24^{* * *} \\
(0.46)\end{array}$ & $\begin{array}{l}1.20^{* *} \\
(0.47)\end{array}$ \\
\hline Imports & $\begin{array}{l}-0.42^{* *} \\
(0.19)\end{array}$ & $\begin{array}{l}-0.34 \\
(0.23)\end{array}$ & $\begin{array}{l}-0.52^{* *} \\
(0.21)\end{array}$ & $\begin{array}{l}-0.46^{*} \\
(0.24)\end{array}$ & $\begin{array}{c}-0.58^{* * *} \\
(0.20)\end{array}$ & $\begin{array}{l}-0.49^{* *} \\
(0.23)\end{array}$ \\
\hline GDPpc & $\begin{array}{l}-1.02 \\
(0.72)\end{array}$ & $\begin{array}{l}-1.96^{* *} \\
(0.82)\end{array}$ & $\begin{array}{l}-0.85 \\
(0.69)\end{array}$ & $\begin{array}{l}-1.78^{* *} \\
(0.77)\end{array}$ & $\begin{array}{l}-0.83 \\
(0.67)\end{array}$ & $\begin{array}{l}-1.69^{* *} \\
(0.75)\end{array}$ \\
\hline $\begin{array}{l}\text { Gas Rents } \\
(\% \text { of GDP) }\end{array}$ & $\begin{array}{l}0.58^{*} \\
(0.33)\end{array}$ & $\begin{array}{c}0.49 \\
(0.34)\end{array}$ & $\begin{array}{l}0.62^{*} \\
(0.32)\end{array}$ & $\begin{array}{c}0.48 \\
(0.33)\end{array}$ & $\begin{array}{l}0.66^{* *} \\
(0.33)\end{array}$ & $\begin{array}{c}0.49 \\
(0.33)\end{array}$ \\
\hline $\begin{array}{l}\text { Oil Rents } \\
\text { (\% of GDP) }\end{array}$ & $\begin{array}{c}0.06 \\
(0.04)\end{array}$ & $\begin{array}{l}0.10^{* *} \\
(0.05)\end{array}$ & $\begin{array}{l}0.08^{* *} \\
(0.04)\end{array}$ & $\begin{array}{l}0.13^{* * *} \\
(0.04)\end{array}$ & $\begin{array}{l}0.08^{* *} \\
(0.04)\end{array}$ & $\begin{array}{l}0.13^{* * *} \\
(0.04)\end{array}$ \\
\hline English & $\begin{array}{l}3.92^{* * *} \\
(0.97)\end{array}$ & $\begin{array}{l}2.76^{* *} \\
(1.16)\end{array}$ & $\begin{array}{l}4.16^{* * *} \\
(0.98)\end{array}$ & $\begin{array}{l}2.98^{* * *} \\
(1.14)\end{array}$ & $\begin{array}{l}4.00^{* * *} \\
(0.94)\end{array}$ & $\begin{array}{l}2.81^{* *} \\
(1.13)\end{array}$ \\
\hline Conflict & $\begin{array}{c}0.17 \\
(0.37)\end{array}$ & $\begin{array}{c}0.37 \\
(0.40)\end{array}$ & $\begin{array}{l}-0.49 \\
(0.41)\end{array}$ & $\begin{array}{l}-0.20 \\
(0.41)\end{array}$ & $\begin{array}{l}-0.56 \\
(0.40)\end{array}$ & $\begin{array}{l}-0.28 \\
(0.40)\end{array}$ \\
\hline Institutions & $\begin{array}{l}-0.55 \\
(1.29)\end{array}$ & $\begin{array}{c}0.82 \\
(1.35)\end{array}$ & $\begin{array}{l}-0.66 \\
(1.47)\end{array}$ & $\begin{array}{c}0.62 \\
(1.51)\end{array}$ & $\begin{array}{l}-1.02 \\
(1.11)\end{array}$ & $\begin{array}{l}-0.05 \\
(1.12)\end{array}$ \\
\hline Year FE & No & Yes & No & Yes & No & Yes \\
\hline Regional FE & No & Yes & No & Yes & No & Yes \\
\hline Observations & 459 & 459 & 485 & 485 & 484 & 484 \\
\hline$R^{2}$ & 0.29 & 0.34 & 0.27 & 0.32 & 0.27 & 0.32 \\
\hline adj. $R^{2}$ & 0.27 & 0.30 & 0.25 & 0.28 & 0.26 & 0.29 \\
\hline
\end{tabular}

Notes: Constant is omitted. Robust standard errors are shown in parentheses. ${ }^{* * *}$ denotes significance at the $1 \%$ level, ${ }^{* *}$ at the $5 \%$ level, ${ }^{*}$ at the $10 \%$ level. The set of regional fixed effects includes Northern Africa, West Africa, Central Africa, East Africa and Southern Africa 


\section{CHAPTER 3}

Table 3.B3: Relative Chinese Development Finance and Democracy Level of Sub-Saharan African Recipient Countries, 2000-2011

\begin{tabular}{|c|c|c|c|c|c|c|}
\hline & $\begin{array}{c}\text { OLS } \\
(1) \\
\text { V-DEM } \\
\text { (Electoral) }\end{array}$ & $\begin{array}{c}\text { OLS } \\
(2) \\
\text { V-DEM } \\
\text { (Electoral) }\end{array}$ & $\begin{array}{c}\text { OLS } \\
(3) \\
\text { V-DEM } \\
\text { (Liberal) } \\
\end{array}$ & $\begin{array}{c}\text { OLS } \\
(4) \\
\text { V-DEM } \\
\text { (Liberal) }\end{array}$ & $\begin{array}{c}\text { OLS } \\
(5) \\
\text { V-DEM } \\
\text { (Particip.) } \\
\end{array}$ & $\begin{array}{c}\text { OLS } \\
(6) \\
\text { V-DEM } \\
\text { (Particip.) } \\
\end{array}$ \\
\hline Democracy & $\begin{array}{c}1.74 \\
(2.15)\end{array}$ & $\begin{array}{l}-0.20 \\
(1.79)\end{array}$ & $\begin{array}{c}1.98 \\
(2.59)\end{array}$ & $\begin{array}{l}-0.20 \\
(2.30)\end{array}$ & $\begin{array}{l}-0.22 \\
(2.94)\end{array}$ & $\begin{array}{l}-3.70 \\
(3.37)\end{array}$ \\
\hline Taiwan & $\begin{array}{l}-0.65^{*} \\
(0.33)\end{array}$ & $\begin{array}{l}-1.18^{* *} \\
(0.46)\end{array}$ & $\begin{array}{l}-0.59 \\
(0.37)\end{array}$ & $\begin{array}{c}-1.18^{* *} \\
(0.48)\end{array}$ & $\begin{array}{l}-0.75^{* *} \\
(0.33)\end{array}$ & $\begin{array}{c}-1.32^{\text {*** }} \\
(0.49)\end{array}$ \\
\hline $\begin{array}{l}\text { UN Voting } \\
\text { with China }\end{array}$ & $\begin{array}{c}0.00 \\
(0.01)\end{array}$ & $\begin{array}{c}0.01 \\
(0.02)\end{array}$ & $\begin{array}{c}0.00 \\
(0.01)\end{array}$ & $\begin{array}{c}0.01 \\
(0.02)\end{array}$ & $\begin{array}{c}0.00 \\
(0.01)\end{array}$ & $\begin{array}{c}0.01 \\
(0.02)\end{array}$ \\
\hline $\begin{array}{l}\text { Western } \\
\text { ODA }\end{array}$ & $\begin{array}{l}-0.01 \\
(0.08)\end{array}$ & $\begin{array}{c}0.01 \\
(0.08)\end{array}$ & $\begin{array}{l}-0.01 \\
(0.08)\end{array}$ & $\begin{array}{c}0.01 \\
(0.08)\end{array}$ & $\begin{array}{l}-0.00 \\
(0.08)\end{array}$ & $\begin{array}{c}0.01 \\
(0.08)\end{array}$ \\
\hline Population & $\begin{array}{l}-0.21 \\
(0.26)\end{array}$ & $\begin{array}{l}-0.14 \\
(0.30)\end{array}$ & $\begin{array}{l}-0.21 \\
(0.26)\end{array}$ & $\begin{array}{l}-0.14 \\
(0.30)\end{array}$ & $\begin{array}{l}-0.20 \\
(0.27)\end{array}$ & $\begin{array}{l}-0.08 \\
(0.32)\end{array}$ \\
\hline Imports & $\begin{array}{l}-0.00 \\
(0.22)\end{array}$ & $\begin{array}{l}-0.06 \\
(0.24)\end{array}$ & $\begin{array}{c}0.01 \\
(0.22)\end{array}$ & $\begin{array}{l}-0.06 \\
(0.24)\end{array}$ & $\begin{array}{c}0.03 \\
(0.22)\end{array}$ & $\begin{array}{l}-0.08 \\
(0.24)\end{array}$ \\
\hline GDPpc & $\begin{array}{c}0.25 \\
(0.46)\end{array}$ & $\begin{array}{c}0.42 \\
(0.44)\end{array}$ & $\begin{array}{c}0.25 \\
(0.46)\end{array}$ & $\begin{array}{c}0.42 \\
(0.44)\end{array}$ & $\begin{array}{c}0.25 \\
(0.48)\end{array}$ & $\begin{array}{c}0.49 \\
(0.46)\end{array}$ \\
\hline $\begin{array}{l}\text { Gas Rents } \\
(\% \text { of GDP) }\end{array}$ & $\begin{array}{l}-0.20 \\
(0.36)\end{array}$ & $\begin{array}{l}-0.21 \\
(0.34)\end{array}$ & $\begin{array}{l}-0.20 \\
(0.37)\end{array}$ & $\begin{array}{l}-0.21 \\
(0.35)\end{array}$ & $\begin{array}{l}-0.20 \\
(0.35)\end{array}$ & $\begin{array}{l}-0.20 \\
(0.34)\end{array}$ \\
\hline $\begin{array}{l}\text { Oil Rents } \\
(\% \text { of GDP) }\end{array}$ & $\begin{array}{l}0.06^{* *} \\
(0.03)\end{array}$ & $\begin{array}{c}0.06 \\
(0.04)\end{array}$ & $\begin{array}{l}0.06^{* *} \\
(0.03)\end{array}$ & $\begin{array}{c}0.06 \\
(0.04)\end{array}$ & $\begin{array}{l}0.06^{*} \\
(0.03)\end{array}$ & $\begin{array}{c}0.06 \\
(0.04)\end{array}$ \\
\hline English & $\begin{array}{c}1.09 \\
(0.70)\end{array}$ & $\begin{array}{c}1.36 \\
(0.85)\end{array}$ & $\begin{array}{l}1.00^{*} \\
(0.60)\end{array}$ & $\begin{array}{c}1.37^{*} \\
(0.81)\end{array}$ & $\begin{array}{c}0.90 \\
(0.67)\end{array}$ & $\begin{array}{c}1.24 \\
(0.82)\end{array}$ \\
\hline Conflict & $\begin{array}{c}0.35 \\
(0.48)\end{array}$ & $\begin{array}{c}0.34 \\
(0.47)\end{array}$ & $\begin{array}{c}0.34 \\
(0.48)\end{array}$ & $\begin{array}{c}0.34 \\
(0.47)\end{array}$ & $\begin{array}{c}0.37 \\
(0.47)\end{array}$ & $\begin{array}{c}0.37 \\
(0.47)\end{array}$ \\
\hline Institutions & $\begin{array}{l}-0.70 \\
(0.70)\end{array}$ & $\begin{array}{l}-0.40 \\
(0.86)\end{array}$ & $\begin{array}{l}-0.77 \\
(0.75)\end{array}$ & $\begin{array}{l}-0.40 \\
(0.84)\end{array}$ & $\begin{array}{l}-0.24 \\
(0.77)\end{array}$ & $\begin{array}{c}0.15 \\
(1.06) \\
\end{array}$ \\
\hline $\begin{array}{l}\text { Year FE } \\
\text { Regional FE }\end{array}$ & $\begin{array}{l}\text { No } \\
\text { No }\end{array}$ & $\begin{array}{l}\text { Yes } \\
\text { Yes }\end{array}$ & $\begin{array}{l}\mathrm{No} \\
\mathrm{No}\end{array}$ & $\begin{array}{l}\text { Yes } \\
\text { Yes }\end{array}$ & $\begin{array}{l}\text { No } \\
\text { No }\end{array}$ & $\begin{array}{l}\text { Yes } \\
\text { Yes }\end{array}$ \\
\hline $\begin{array}{l}\text { Observations } \\
R^{2} \\
\text { adj. } R^{2}\end{array}$ & $\begin{array}{l}480 \\
0.04 \\
0.01\end{array}$ & $\begin{array}{c}480 \\
0.05 \\
-0.00\end{array}$ & $\begin{array}{l}480 \\
0.04 \\
0.01\end{array}$ & $\begin{array}{c}480 \\
0.05 \\
-0.00\end{array}$ & $\begin{array}{l}480 \\
0.04 \\
0.01\end{array}$ & $\begin{array}{c}480 \\
0.05 \\
-0.00\end{array}$ \\
\hline
\end{tabular}

Notes: Constant is omitted. Robust standard errors are shown in parentheses. ${ }^{* * *}$ denotes significance at the $1 \%$ level, ** at the $5 \%$ level, *at the $10 \%$ level. The set of regional fixed effects includes Northern Africa, West Africa, Central Africa, East Africa and Southern Africa. 
Table 3.B4: Relative Chinese Development Finance and Democracy Level of Sub-Saharan African Recipient Countries, 2000-2011

\begin{tabular}{|c|c|c|c|c|c|c|}
\hline & $\begin{array}{l}\text { OLS } \\
(1) \\
\text { P4I } \\
\end{array}$ & $\begin{array}{l}\text { OLS } \\
(2) \\
\text { P4I } \\
\end{array}$ & $\begin{array}{c}\text { OLS } \\
(3) \\
\text { FHI } \\
\end{array}$ & $\begin{array}{l}\text { OLS } \\
(4) \\
\text { FHI }\end{array}$ & $\begin{array}{c}\text { OLS } \\
(5) \\
\text { VDI } \\
\end{array}$ & $\begin{array}{c}\text { OLS } \\
(6) \\
\text { VDI } \\
\end{array}$ \\
\hline Democracy & $\begin{array}{l}-0.01 \\
(0.20)\end{array}$ & $\begin{array}{c}0.02 \\
(0.23)\end{array}$ & $\begin{array}{l}-0.01 \\
(0.16)\end{array}$ & $\begin{array}{l}-0.04 \\
(0.17)\end{array}$ & $\begin{array}{c}0.07 \\
(0.06)\end{array}$ & $\begin{array}{c}0.07 \\
(0.06)\end{array}$ \\
\hline Taiwan & $\begin{array}{l}-0.77 \\
(0.49)\end{array}$ & $\begin{array}{c}-1.27^{* *} \\
(0.60)\end{array}$ & $\begin{array}{l}-0.77^{*} \\
(0.44)\end{array}$ & $\begin{array}{c}-1.24^{* *} \\
(0.51)\end{array}$ & $\begin{array}{l}-0.66^{*} \\
(0.34)\end{array}$ & $\begin{array}{c}-1.02^{* *} \\
(0.42)\end{array}$ \\
\hline $\begin{array}{l}\text { UN Voting } \\
\text { with China }\end{array}$ & $\begin{array}{c}0.00 \\
(0.01)\end{array}$ & $\begin{array}{c}0.02 \\
(0.02)\end{array}$ & $\begin{array}{c}0.00 \\
(0.01)\end{array}$ & $\begin{array}{c}0.01 \\
(0.02)\end{array}$ & $\begin{array}{c}0.00 \\
(0.01)\end{array}$ & $\begin{array}{c}0.01 \\
(0.02)\end{array}$ \\
\hline $\begin{array}{l}\text { Western } \\
\text { ODA }\end{array}$ & $\begin{array}{l}-0.03 \\
(0.08)\end{array}$ & $\begin{array}{c}0.01 \\
(0.08)\end{array}$ & $\begin{array}{l}-0.00 \\
(0.08)\end{array}$ & $\begin{array}{c}0.01 \\
(0.08)\end{array}$ & $\begin{array}{c}0.00 \\
(0.08)\end{array}$ & $\begin{array}{c}0.02 \\
(0.08)\end{array}$ \\
\hline Population & $\begin{array}{l}-0.30 \\
(0.25)\end{array}$ & $\begin{array}{l}-0.26 \\
(0.28)\end{array}$ & $\begin{array}{l}-0.20 \\
(0.25)\end{array}$ & $\begin{array}{l}-0.15 \\
(0.28)\end{array}$ & $\begin{array}{l}-0.19 \\
(0.25)\end{array}$ & $\begin{array}{l}-0.15 \\
(0.28)\end{array}$ \\
\hline Imports & $\begin{array}{c}0.10 \\
(0.21)\end{array}$ & $\begin{array}{c}0.04 \\
(0.22)\end{array}$ & $\begin{array}{c}0.02 \\
(0.21)\end{array}$ & $\begin{array}{l}-0.06 \\
(0.22)\end{array}$ & $\begin{array}{l}-0.01 \\
(0.22)\end{array}$ & $\begin{array}{l}-0.08 \\
(0.24)\end{array}$ \\
\hline GDPpc & $\begin{array}{c}0.10 \\
(0.53)\end{array}$ & $\begin{array}{c}0.29 \\
(0.48)\end{array}$ & $\begin{array}{c}0.24 \\
(0.47)\end{array}$ & $\begin{array}{c}0.39 \\
(0.43)\end{array}$ & $\begin{array}{c}0.29 \\
(0.48)\end{array}$ & $\begin{array}{c}0.49 \\
(0.44)\end{array}$ \\
\hline $\begin{array}{l}\text { Gas Rents } \\
(\% \text { of GDP) }\end{array}$ & $\begin{array}{l}-0.23 \\
(0.25)\end{array}$ & $\begin{array}{l}-0.17 \\
(0.24)\end{array}$ & $\begin{array}{l}-0.21 \\
(0.25)\end{array}$ & $\begin{array}{l}-0.22 \\
(0.23)\end{array}$ & $\begin{array}{l}-0.19 \\
(0.25)\end{array}$ & $\begin{array}{l}-0.20 \\
(0.24)\end{array}$ \\
\hline $\begin{array}{l}\text { Oil Rents } \\
(\% \text { of GDP) }\end{array}$ & $\begin{array}{c}0.05 \\
(0.03)\end{array}$ & $\begin{array}{c}0.02 \\
(0.04)\end{array}$ & $\begin{array}{l}0.06^{* *} \\
(0.03)\end{array}$ & $\begin{array}{c}0.06 \\
(0.04)\end{array}$ & $\begin{array}{l}0.06^{* *} \\
(0.03)\end{array}$ & $\begin{array}{c}0.06 \\
(0.04)\end{array}$ \\
\hline English & $\begin{array}{c}0.81 \\
(0.55)\end{array}$ & $\begin{array}{c}1.38 \\
(0.85)\end{array}$ & $\begin{array}{c}0.91 \\
(0.57)\end{array}$ & $\begin{array}{c}1.34 \\
(0.84)\end{array}$ & $\begin{array}{c}0.90^{*} \\
(0.52)\end{array}$ & $\begin{array}{c}1.27 \\
(0.77)\end{array}$ \\
\hline Conflict & $\begin{array}{c}0.83 \\
(0.55)\end{array}$ & $\begin{array}{c}0.80 \\
(0.54)\end{array}$ & $\begin{array}{c}0.36 \\
(0.47)\end{array}$ & $\begin{array}{c}0.35 \\
(0.47)\end{array}$ & $\begin{array}{c}0.32 \\
(0.47)\end{array}$ & $\begin{array}{c}0.29 \\
(0.46)\end{array}$ \\
\hline Institutions & $\begin{array}{l}-0.37 \\
(0.83)\end{array}$ & $\begin{array}{l}-0.62 \\
(0.88)\end{array}$ & $\begin{array}{l}-0.23 \\
(0.83)\end{array}$ & $\begin{array}{l}-0.29 \\
(0.84)\end{array}$ & $\begin{array}{l}-0.59 \\
(0.72)\end{array}$ & $\begin{array}{l}-0.85 \\
(0.74)\end{array}$ \\
\hline $\begin{array}{l}\text { Year FE } \\
\text { Regional FE }\end{array}$ & $\begin{array}{l}\text { No } \\
\text { No }\end{array}$ & $\begin{array}{l}\text { Yes } \\
\text { Yes }\end{array}$ & $\begin{array}{l}\text { No } \\
\text { No }\end{array}$ & $\begin{array}{l}\text { Yes } \\
\text { Yes }\end{array}$ & $\begin{array}{l}\mathrm{No} \\
\mathrm{No}\end{array}$ & $\begin{array}{l}\text { Yes } \\
\text { Yes }\end{array}$ \\
\hline $\begin{array}{l}\text { Observations } \\
R^{2} \\
\text { adj. } R^{2}\end{array}$ & $\begin{array}{l}459 \\
0.06 \\
0.03\end{array}$ & $\begin{array}{l}459 \\
0.07 \\
0.02\end{array}$ & $\begin{array}{l}485 \\
0.04 \\
0.02\end{array}$ & $\begin{array}{l}485 \\
0.05 \\
0.00\end{array}$ & $\begin{array}{l}484 \\
0.04 \\
0.02\end{array}$ & $\begin{array}{l}484 \\
0.05 \\
0.00\end{array}$ \\
\hline
\end{tabular}

Notes: Constant is omitted. Robust standard errors are shown in parentheses. ${ }^{* * *}$ denotes significance at the $1 \%$ level, ** at the $5 \%$ level, * at the $10 \%$ level. The set of regional fixed effects includes Northern Africa, West Africa, Central Africa, East Africa and Southern Africa 


\section{Appendix 3.C: Data and Sources}

\begin{tabular}{|c|c|}
\hline Variable Name & Definition \\
\hline \multicolumn{2}{|l|}{ Dependent Variable } \\
\hline $\begin{array}{l}\text { Chinese Development } \\
\text { Finance (absolute) }\end{array}$ & $\begin{array}{l}\text { (Log) Official Finance (ODA+OOF) } \\
\text { amount in constant } 2009 \text { US\$. }\end{array}$ \\
\hline $\begin{array}{l}\text { Chinese Development } \\
\text { Finance (relative) }\end{array}$ & $\begin{array}{l}\text { Difference between the relative share of } \\
\text { Chinese official development finance and } \\
\text { the relative share of traditional DAC } \\
\text { official development finance (in \%). }\end{array}$ \\
\hline \multicolumn{2}{|l|}{ Explanatory Variables } \\
\hline $\begin{array}{l}\text { Electoral Democracy } \\
\text { Index (V-DEM) }\end{array}$ & $\begin{array}{l}\text { Electoral principle of democracy seeks to } \\
\text { embody the core value of making rulers } \\
\text { responsive to citizens, achieved through } \\
\text { electoral competition for the electorate's } \\
\text { approval under circumstances when } \\
\text { suffrage is extensive; political and civil } \\
\text { society organizations can operate freely; } \\
\text { elections are clean and not marred by } \\
\text { fraud or systematic irregularities; and } \\
\text { elections affect the composition of the } \\
\text { chief executive of the country. In } \\
\text { between elections, there is freedom of } \\
\text { expression and an independent media } \\
\text { capable of presenting alternative views on } \\
\text { matters of political relevance. }\end{array}$ \\
\hline
\end{tabular}

Liberal Democracy Index (V-DEM)
The liberal principle of democracy emphasizes the importance of protecting individual and minority rights against the tyranny of the state and the tyranny of the majority. The liberal model takes a "negative" view of political power insofar as it judges the quality of democracy by the limits placed on government. This is achieved by constitutionally protected civil liberties, strong rule of law, an independent judiciary, and effective checks and balances that, together, limit the exercise of executive power.
Source

Aid Data

(Strange et al., 2017)

Own calculations based on Strange et al. (2017) and OECD/DAC database

\section{$\mathrm{V}-\mathrm{DEM}$}

(Coppedge, Lindberg, Skaaning, \& Teorell, 2016; Teorell et al., 2016)

\section{V-DEM}

(Coppedge et al., 2016;

Teorell et al., 2016) 


\section{CHAPTER 3}

Participatory Democracy Index (V-DEM)

Democracy Index (Polity IV)

Democracy Index (Freedom House)

Democracy Index (Vanhanen)

\section{Control Variables}

Taiwan Recognition

UN Voting with China

Western ODA

Imports from China

Population

GDP per capita
The participatory principle of democracy emphasizes active participation by citizens in all political processes, electoral and non-electoral. It is motivated by uneasiness about a bedrock practice of electoral democracy: delegating authority to representatives. Thus, direct rule by citizens is preferred, wherever practicable. This model of democracy thus takes suffrage for granted, emphasizing engagement in civil society organizations, direct democracy, and subnational elected bodies.

Executive constraints (decision rule) variable. Scale ranges between 0 ("unlimited authority") and 7 ("Executive Parity or Subordination"), lag

Freedom House polity2 variable. Scale ranges from 0 (least democratic) and 10 (most democratic); lag

Percentage of votes not cast for the largest party (competition) times the percentage of the population who actually voted in the election (participation), divided by 100 . Index could vary from 0 (no democracy) to 100 (full democracy); lag

$=1$ if country has diplomatic relations with Taiwan, 0 otherwise; lag

Voting alignment with China in the UN General Assembly on all votes; lag

(Log) Western (DAC donors) total net bilateral official development assistance flows; lag

(Log) net import value of Chinese goods and services (in constant 2009 US\$) for each African partner country; lag

(Log) Total population size; lag

(Log) GDP per capita (2009 US\$); lag
V-DEM

(Coppedge et al., 2016;

Teorell et al., 2016)
Polity IV Dataset

(Marshall et al., 2014)

Freedom House

(2016)

Vanhanen

(2000, 2016)

Bräutigam (2011a), Rich (2009), own update

Bailey, Strezhnev and Voeten (2017)

OECD/DAC Database

WITS/UN Comtrade,

WDI, World Bank

WDI; World Bank 
Conflict

Gas Rents (\% of

GDP)

Oil Rents (\% of GDP)

English Language

Institutional Quality
Total summed magnitudes of all societal intrastate major episodes of political violence (civil violence, civil war, ethnic violence ethnic war). Scale: 0 (lowest) to 10 (highest); lag

Gas rents as percent of GDP. Natural gas rents are the difference between the value of natural gas production at world prices and total costs of production; lag

Oil rents as percent of GDP. Natural gas rents are the difference between the value of natural gas production at world prices and total costs of production; lag

$=1$ if English is at least the third mostcommon language, 0 otherwise
Center for Systemic

Peace

(Marshall, 2014)

WDI; World Bank

WDI; World Bank

CEPII

(Mayer and Zignago, 2011)

WGI, World Bank 


\section{CHAPTER 4}

\section{PRECOLONIAL CENTRALISATION, FOREIGN AID AND MODERN STATE CAPACITY IN AFRICA}

"The longer you can look back, the farther you can look forward" - Winston Churchill, 1944 (1874-1965)

Prime Minister of the United Kingdom (1940-1945 and 1951-1955)

"In much of the current policy work on the development of state capacity in Third World Countries... there is a strong voluntarist or architectonic streak. that argues that state capacity can be 'built' as part of a policy imperative. The historical record belies this assumption." - Thomas Callaghy, 1989 Emeritus Professor, Department of Political Science, University of Pennsylvania 


\subsection{Introduction}

The functioning of the state is one of the core issues in economic development. A major strand of literature in political science and economics highlights the importance of state institutional capacity for collecting taxes, protecting property rights, and ultimately for economic growth and development (Acemoglu et al., 2001, 2002; Aoki, 2007; Besley \& Persson, 2010, 2011; Chang, 2010; Dincecco \& Prado, 2012; Engerman \& Sokoloff, 1997; North, 1990; North \& Weingast, 1989; Rodrik et al., 2004; Weingast, 1995). Findings from this literature help us understand why some regions are more prosperous than others. In particular, many authors argue that present-day low income levels in Africa can partly be attributed to dysfunctional state institutions (e.g. Acemoglu \& Robinson, 2010; Bates, 2008; Meredith, 2005). The question which factors explain differences in state capacity in modern-day Africa is less well explored (Fenske, 2014; Thies, 2009).

In this chapter, I empirically explore the determinants of contemporary bureaucratic capacity - generally considered a key component of state capacity - in modern Africa. The term bureaucratic capacity refers to a state with an effective public administration (Evans \& Rauch, 1999; Rauch \& Evans, 2000). My point of departure is a "Weberian bureaucracy which is structured along impersonal, technocratic, hierarchical lines. Its written records provide a strong institutional memory, and its personnel has formal salaries, relies on standard operating procedures and knowledge-based rules, and answers to superiors who (ideally) take decisions according to impersonal, technocratic criteria" (Bräutigam, 2008, p. 15).

I first examine the historical determinants of the level of bureaucratic quality in 2014. I find a strong and statistically significant positive relationship between the degree of precolonial political centralisation and present bureaucratic quality. The estimated impact of this variable trumps all other variables in my level regressions. Furthermore, I find a clear difference before and after the late1990s, with a stronger estimated impact of precolonial centralisation in the latter period.

I then examine the correlates of changes in bureaucratic quality over time. Foreign aid is found to be a major correlate of deteriorations in bureaucratic quality over 


\section{CHAPTER 4}

time, which is consistent with the views and findings of aid pessimists (Ayittey, 2005; Bauer, 1975; Easterly, 2006; Friedman, 1958; Moyo, 2009). Here, the contribution of this study is that I subsequently examine to what extent the relationship between bureaucratic state capacity and aid dependence, one of the important proximate determinants of state capacity, is affected when I control for more ultimate historical variables such as the degree of precolonial centralisation. When precolonial centralisation is included in the regressions, the results with respect to aid dependence change dramatically. The aid dependence variable loses most of its explanatory power, while I find a positive and highly statistically significant relationship between precolonial centralisation and improvements in bureaucratic quality. Countries with a more centralised political history tend to improve their bureaucratic capacity over time. My findings suggest that the previous empirical literature on the aid-governance link failed to account for more ultimate causes of bureaucratic development. Foreign aid simply appears less important than deeper historical experiences in explaining the recent evolution of bureaucratic quality in Africa.

To my knowledge, no previous work has examined the relationship between precolonial centralisation and bureaucratic capacity. However, the role of precolonial centralisation in shaping the related concept of good governance has been studied by Gennaioli and Rainer (2006); they find a positive impact of precolonial centralisation on two proxies of good governance, rule of law and control of corruption, during the period 1996-2004. My contribution differs from their approach in a number of important ways. First, I focus on state capacity, a more limited and more precisely defined concept than good governance. Next, my data on bureaucratic quality cover a much longer time period (1984-2014) than the dataset of Gennaioli and Rainer. This is crucial as my findings suggest that the relationship between ancient political centralisation and contemporary state capacity becomes less strong and less statistically significant the further back I go in time. The findings of Gennaioli and Rainer (2006) suggest that the link between precolonial centralisation and institutional quality has been persistent since independence; I show that this is not the case. Finally, a core, and novel, contribution of this study is the inclusion of precolonial centralisation in studies evaluating the impact of foreign aid on state capacity and the finding that such centralisation fundamentally alters the estimated impact of aid. 


\section{CHAPTER 4}

My results in the level analysis are robust to controlling for a variety of political, economic, demographic and geographic variables. The regression specification in the changes analysis mitigates problems related to omitted variables since I control for the initial level of bureaucratic quality. Accounting for the initial level of bureaucratic quality helps to control for a variety of historical slow moving factors that can explain different levels of bureaucratic quality in contemporary Africa. Furthermore, the results remain intact when I use an alternative estimation strategy based on instrumental variables. In sum, my empirical findings imply that precolonial experiences have become more important over recent decades, suggesting a re-emergence of deeper historical roots in Africa as the colonial experience is fading.

The chapter is structured as follows. In the next section I briefly review the relevant literature. Section 4.3 discusses data and methodology. In Section 4.4 I present my main empirical results using OLS regressions. Section 4.5 investigates the robustness of my results using instrumental variable regression. Section 4.6 concludes.

\subsection{Background and Literature Review}

\subsubsection{Measurement of State Capacity}

The concept of state capacity is often combined with more general good governance indicators such as the rule of law, control of corruption or protection of property rights. However, I argue that state capacity is an important and separate (although related) concept. Most scholars using the term 'good governance' refer to the normative aspect of governance, in particular decisionmaking practices which are considered ethically and socially desirable (Kaufmann, Kraay, \& Zoido-Lobatón, 1999). The concept of 'state capacity' avoids normative conceptions about what the state ought to do or how it ought to do it. It can refer to different dimensions of state power, such as coercive/military capacity, fiscal, administrative, legal or political capacity or relational/territorial coverage, but all dimensions have a clear, positive basis rather than a normative interpretation.

Hendrix (2010) concludes that (1) survey measures of bureaucratic quality and (2) indicators of taxation capacity are the most theoretically and empirically 


\section{CHAPTER 4}

grounded indicators of state capacity. The fiscal dimension of state capacity emphasises the ability of the state to collect taxes from its citizenry (Levi, 1988; Tilly, 1975). Commonly used proxies for fiscal capacity in both the theoretical and empirical political economy literature are (i) the share of direct taxes in total tax revenues or (ii) tax revenue as a percentage of GDP (Besley \& Persson, 2008; Dincecco \& Prado, 2012; Tammen \& Kugler, 2012). Those indicators, however, suffer from a number of shortcomings: First, those measures do not only measure the capacity to tax, but also the willingness to tax and be taxed. Normative preferences of the population about the optimal level of taxation may vary quite significantly. Second, governments in countries with rich natural resources find it fairly easy to collect tax revenues provided they have enough coercive capacity to protect the resources.

With this in mind, I choose to focus on the administrative (or bureaucratic) component of state capacity. Bureaucratic capacity can be regarded as a precondition for taxation capacity, and survey-based measures of bureaucratic capacity are available over a long period of time for a substantial number of countries. Furthermore, in contrast to the fiscal dimension of state capacity, bureaucratic quality is a conceptually clearer measure of state capacity. It is also, due to the powerful theoretical legacy of Max Weber (1922), probably the most widely studied component of state capacity. ${ }^{48} \mathrm{~A}$ key reason behind its suggested importance is that a professional bureaucracy outlives rulers and is crucial for the impersonal implementation of politics (North, Wallis, \& Weingast, 2009). Moreover, countries with high bureaucratic quality possess bureaucracies that tend to be somewhat autonomous from political and economic pressures and tend to have developed extensive mechanisms for recruitment and training (Evans, 1995; Rauch \& Evans, 2000).

\subsubsection{Foreign Aid and Contemporary African Development}

A large literature attributes a part of the weakening of central administrations and the decline in state capacity in several African countries to the negative influences of foreign aid (e.g. Ayittey, 2005; Bauer, 1975; Easterly, 2006; Moyo,

\footnotetext{
48 The theoretical and empirical associations between bureaucratic autonomy and the various measures of state capacity that scholars have presented are discussed by Cingolani, Thomsson and De Crombrugghe (2015).
} 


\section{CHAPTER 4}

2009). According to aid pessimists, state institutions in recipient countries have lost a significant amount of decision-making power through large aid dependence, as a result of which policy making was partly or entirely externalized. The nature of the African state made it perfectly possible that a neo-patrimonial regime could coexist with a Weberian rational bureaucracy (van de Walle, 2001). Van de Walle (2001) is convinced that the "institutionalization of crisis management over a twenty-year period has disempowered central administrations for the benefit of donor experts and ad hoc domestic decisionmaking structures. The decline of state capacity has invigorated patrimonial tendencies throughout the region" (p. 275).

Numerous studies have examined the effect of foreign aid on economic growth yielding ambiguous results (Arndt, Jones, \& Tarp, 2010; Burnside \& Dollar, 2000; Clemens, Radelet, Bhavnani, \& Bazzi, 2011; Doucouliagos \& Paldam, 2008; Easterly, Levine, \& Roodman, 2004; Lensink \& White, 2001; Mekasha \& Tarp, 2013; Rajan \& Subramanian, 2008). Another strand of the aid literature has aimed at quantifying the effects of development assistance on good governance and democratization (Bermeo, 2011; Bueno de Mesquita \& Smith, 2010; Djankov, Montalvo, \& Reynal-Querol, 2008; Dunning, 2004; Goldsmith, 2001; Kalyvitis \& Vlachaki, 2012; Knack, 2004; Rajan \& Subramanian, 2007). However, the literature that empirically explores the causal link between aid dependence and state capacity remains surprisingly sparse. Knack (2001) finds a robust statistical relationship between high aid levels in Africa and deteriorations in bureaucratic quality. Similarly, Bräutigam and Knack (2004) find robust statistical evidence that higher aid levels correspond with larger declines in tax revenues as a share of GDP in Sub-Saharan Africa. Knack and Rahman (2007) explore how competitive donor practices can erode administrative capacity in recipient countries. Empirical results by Selaya and Thiele (2012) suggest that the functioning of the bureaucracy is adversely affected by grants, but not by loans.

A more nuanced view is taken by another group of scholars who are less pessimistic about the consequences of foreign aid. I will call them conditional optimists. Their work shows that large quantities of development assistance do not systematically affect the quality of policies or institutional capacity (Alesina \& Dollar, 2000; Rodrik, 1996). Those scholars argue that the economic returns to aid are highest in sound institutional environments and lowest in poor institutional environments (Burnside \& Dollar, 1997, 2000; World Bank, 1998). 
While Collier and Dollar (2002) admit that aid could become detrimental beyond a certain threshold level even in a 'good' policy environment, "the point at which aid starts to have negative effects is well above the range pertinent for most of Africa" (Collier, 1999, p. 531). ${ }^{49}$ My results challenge many of the findings of both pessimists and conditional optimists by showing that the inclusion of precolonial centralisation alters previously estimated links between aid and bureaucratic capacity.

\subsubsection{Historical Roots of Contemporary African State Structures}

An interesting strand of literature emphasizes the role of deep historical roots of contemporary state characteristics. It addresses the question why both state formation and institutional development evolved differently in Europe and Africa. The applicability of the Eurasian model to explain differential political institutional development between Europe and Africa plays a major role in the work of Diamond (1997), Herbst (2000) and Bates (2001).

One of the central paradoxes in European state formation is the fact that "the pursuit of war and military capacity, after having created national states as a sort of by-product, led to a civilianization of government and domestic politics" (Tilly, 1990, p. 206). A large number of African states, however, gained independence without the need to combat former colonial rulers or regional neighbours (important exceptions being Algeria, Angola, Kenya and Mozambique). Most of the conflicts in post-colonial Africa were intrastate conflicts. Since African states have seldom fought wars of conquest, e.g. interstate wars, their governments faced few significant external threats. As a result, the pressure to build an effective central administration that levies taxes and protects private property was significantly lower compared to the European experience (Bates, 2001; Herbst, 1990).

Another major factor which is positively associated with state formation in Europe is increasing population density. According to Bairoch (1988), increased urbanization and better transportation networks during the Industrial

\footnotetext{
${ }^{49}$ See chapter 14 of Szirmai (2015) for a recent survey on the theoretical and empirical literature on foreign aid.
} 


\section{CHAPTER 4}

Revolution in Europe significantly promoted state formation and modern state capacity. The increasing population density in Europe made land relatively scarce and therefore very attractive to control (Tilly, 1990). In contrast, low population density and land abundance formed obstacles to political centralisation in large parts of Africa as many African governments found it difficult to penetrate and control major parts of their hinterlands (Mamdani, 1996). As low population densities make territorial conflicts less likely, governments have fewer incentives and less means to extend their rule beyond the capital cities and a few other population centres (Bates, 2001; Herbst, 2000). Diamond (1997), in turn, argues that differences in prehistoric biogeographical conditions have influenced the timing of the transition from hunter-gatherer societies to subsistence farming. Compared to other continents, Eurasia benefited from an advantageous geographical location that gave the latter a head start in the Neolithic Revolution. Thanks to its location in the Mediterranean zone and its West-East orientation of the continent's major axis, (Western) Eurasia was prehistorically better endowed with valuable wild plant and animal species suited for domestication than other continents such as Africa. With Eurasia being the earliest centre of domestication, settled agriculture and subsistence farming developed earlier and faster leading to a more rapid population density and ultimately state formation.

Other scholars argue that political institutional development in Africa took a different path historically creating qualitatively very different state structures. In many developing countries, the legitimacy of modern state institutions remains weak as the internal pacification of the territory has not yet been completed, partly because the impetus for modern state formation and institutional capacity development in developing countries was colonial penetration (Szirmai, 2015; Young, 1994). In fact, one of the most salient features of Africa's contemporary state bureaucracy is its inherited colonial legacy. An important strand of quantitative and qualitative literature has stressed the long-term effects of colonial intrusion on contemporary development, public goods provision and state capacity in developing regions, including Africa (Acemoglu et al., 2001, 2002; Banerjee \& Iyer, 2005; Engerman \& Sokoloff, 1997; Frankema, 2011; Frankema \& van Waijenburg, 2014; Huillery, 2009, 2010, Lange, 2004, 2009; Sokoloff \& Engerman, 2000; Young, 1994). One of the negative consequences of colonization is the arbitrary nature of post-colonial boundaries in the process of colonial state formation (Alesina, Easterly, \& Matuszeski, 2011; Englebert, 2000). Yet another strand of literature goes further back in time, emphasizing 


\section{CHAPTER 4}

the importance of the slave trade in explaining the weakness of contemporary African states and the lack of economic development (Manning, 1990; Nunn, 2008; Nunn \& Wantchekon, 2011).

The historical, political science literature and the anthropological literature on African state formation emphasize the continuity of precolonial institutions in African history (Boone, 2003; Fortes \& Evans-Pritchard, 1940; Mamdani, 1996). Their line of reasoning is supported by a growing body of empirical research that studies the importance of precolonial ethnic institutions for contemporary public goods provision and economic development in Africa. On average, better provision of basic public goods (education, health, and infrastructure) is found in African regions with more centralised precolonial institutions (Gennaioli \& Rainer, 2007; Osafo-Kwaako \& Robinson, 2013). Michalopoulos and Papaioannou $(2013,2014,2015)$ attribute a higher regional economic development in the historical homelands of ethnicities to centralised, hierarchical, precolonial political institutions. Precolonial centralisation is a robust correlate of regional development outside Africa as well: Studying the historical formation of Native American reservations, Dippel (2014) uncovers a negative link between forced integration of autonomous polities into a system of shared governance and longrun economic development.

The relationship between precolonial centralisation and political or administrative development is less well explored. Hariri (2012) studies the impact of precolonial state development on current levels of democracy for a large sample of nonEuropean countries. In the study most closely related to mine, Gennaioli and Rainer (2006) suggest that African countries with higher precolonial centralisation show lower levels of corruption and a stronger rule of law today. As outlined in the introduction, I focus on a different outcome variable and use a longer time-series than Gennaioli and Rainer. Most importantly, I also connect the historical, political and anthropological literature on African state formation reviewed in this sub-section with the aid-governance literature of the previous sub-section. In doing so, my work simultaneously explores both the proximate and more ultimate determinants of modern state capacity in Africa. 


\subsection{Data and Methodology}

I pursue two lines of analysis, one focusing on levels of bureaucratic capacity, the other on changes in bureaucratic capacity. In the level analysis, my dependent variable is the level of bureaucratic quality in 2014. In the change analysis, the dependent variable is the degree of change in bureaucratic quality over time. The bureaucratic quality index used in this analysis comes from the Political Risk Services (PRS) Group's International Country Risk Guide (ICRG). It measures bureaucratic capabilities and the extent to which the bureaucracy succeeds in minimizing policy shifts when governments change. The index is an expert survey measure and must therefore be regarded as a subjective indicator. It reflects perceptions of changes in bureaucratic quality, not actual changes. According to Hendrix (2010), this index "most closely captures the important components of the theoretical construct of bureaucratic/administrative capacity: professionalism, insulation from political pressure, and efficacy in delivering government services" (p. 278). The index ranges from zero to four and covers 37 African countries for the period 1984-2014. ${ }^{50}$

As a check for the robustness of my findings, I also use the Government Effectiveness Index - one of the six Worldwide Governance Indicators of the World Bank. I emphasize that the ICRG measure of bureaucratic quality is closer to what I aim to study in this chapter. Hence, the World Bank Government Effectiveness Index should be thought of only as a proxy - for administrative state capacity - that allows us to check the extent to which the results depend on a specific indicator of state capacity. Besides suffering from the drawbacks of good governance indicators discussed above, the Government Effectiveness Index covers a much shorter time span (1996-2014) than the Bureaucratic Quality Index. On the positive side, data are available for almost all 54 African countries - except South Sudan. This allows me to increase the sample size. ${ }^{51}$ I

\footnotetext{
50 The first observation for the countries of Botswana, Burkina Faso, Congo Republic, Ethiopia, Madagascar, Mozambique, Niger, Sierra Leone and Somalia is 1985. The coverage for Gambia and Guinea-Bissau starts in 1986. For those countries, I will assume that the starting value in 1984 equals the value in 1985 or 1986, respectively. Data for Namibia is available from 1990 onwards.

51 A list of countries for which the Bureaucratic Quality Index and the Government Effectiveness Index is available can be found in Appendix 4.A (Table 4.A1).
} 


\section{CHAPTER 4}

shall see that the proxy indicator gives results very similar to those found using my preferred indicator.

My main explanatory variables are (i) foreign aid dependence and (ii) precolonial centralisation. My measure for aid dependence is constructed in the following way: I take annual total DAC-ODA disbursements in current dollars from the OECD/DAC database and divide them by the GDP (in current dollars) of the respective recipient country. GDP data come from the World Development Indicators published by the World Bank. Several previous studies within the foreign aid literature have used the same or similar variables (Bräutigam \& Knack, 2004; Djankov et al., 2008).

My proxy for the degree of precolonial centralisation comes from Gennaioli and Rainer (2007). The authors developed a centralisation index at the national level for 48 countries in Africa. ${ }^{52}$ The index aims to capture the degree of political complexity on the continent in precolonial times. ${ }^{53}$ Their original data come from Murdock (1967) and from the Atlas Narodov Mira, a Soviet ethnographic source (Bruk \& Apenchenko, 1964). Gennaioli and Rainer (2006, 2007) measure precolonial political institutions using Murdock's “Jurisdictional Hierarchy Beyond the Local Community Level” index. The index is an ordered variable, ranging from 0 to 4 . It describes the number of political jurisdictions above the local level for each ethnicity. ${ }^{54} \mathrm{~A}$ zero score indicates stateless societies "lacking any form of centralized political organization.” A score of 1 designates petty

\footnotetext{
52 In their study, Gennaioli and Rainer (2007) focus on Sub-Saharan Africa excluding South Africa which reduces their sample to 42 countries.

${ }^{53}$ Gennaioli and Rainer distinguish between centralised and fragmented ethnic groups as follows: "In areas inhabited by centralized ethnic groups, the existence of precolonial chiefly hierarchy made local chiefs accountable to higher-level traditional authority. By bargaining with senior traditional leaders, colonial and postcolonial governments could foster policy coordination and implementation in those areas, leading to faster adoption of European policies and technologies (...) By contrast, in areas inhabited by politically fragmented groups the presence of too many traditional power holders rendered such bargaining very costly or infeasible. As a result, in those areas unrestrained local chiefs were often allowed to follow parochial and personalistic policies, leading to tyranny, disorder and ultimately halting modernization.” (Gennaioli \& Rainer, 2007, p. 186).

54 The local level usually refers to the village level.
} 


\section{CHAPTER 4}

chiefdoms; a score of 2 is associated with paramount chiefdoms; and a score of 3 or 4 refers to ethnic groups that were part of large states..$^{55}$

An ethnic group is defined as "centralised" if it has 2, 3, or 4 jurisdictional levels above the local community. An ethnic group is defined as "fragmented" if it has "only" 0 or 1 jurisdictional levels above the local community. While highly centralised ethnic groups "have developed a form of government with large, territorially integrated political entities, (...) fragmented ethnic groups have been traditionally organized in a multitude of small and fragmented, political entities, often lacking any political integration above the local village" (Gennaioli \& Rainer, 2007, p. 188). Prime examples of highly centralised groups are the Kaffa (Ethiopia), the Luba (Democratic Republic of Congo) or the Yoruba (Nigeria). ${ }^{56}$ For each country, Gennaioli and Rainer construct an index at the national level measuring the share of the non-European population that belongs to indigenously "centralised" ethnic groups. The scale ranges between 0 and 1, whereby a higher value corresponds to a more "centralised" precolonial national state. ${ }^{57}$

\section{Level analysis}

A first exploration of the relationship between precolonial centralisation and bureaucratic quality is provided in the bivariate plots of Figure 4.1. The upper graph plots the level of bureaucratic quality in 1986 against the degree of precolonial centralisation. The lower graph does the same for 2014. ${ }^{58}$ While the relationship between precolonial centralisation and bureaucratic quality is

\footnotetext{
55 The classification resembles that of Diamond (1997), who distinguished between four different social structures: bands, tribes, chiefdoms, and centralised states.

56 The ancient kingdom of Kaffa (c.1390-1897) was an early modern state located in what is now Ethiopia. The Luba Empire (c. 1585-1885) was once an influential Central African state in what is now the Katanga Province of the Democratic Republic of the Congo. The Oyo Empire (c. 1400-1895) was a Yoruba empire of what is today western and northern Nigeria. It became one of the largest West African states in precolonial times.

${ }^{57}$ Detailed descriptive statistics on bureaucratic quality, foreign aid dependence and precolonial centralisation can be found in Appendix 4.A.

${ }^{58} \mathrm{I}$ use the year 1986 as data on bureaucratic quality in 1984 and 1985 is missing for several countries (Botswana, Burkina Faso, Congo Republic, Ethiopia, Gambia, Guinea-Bissau, Madagascar, Mozambique, Namibia, Niger, Sierra Leone and Somalia). To make a meaningful comparison between different years, I prefer to compare the same sample of countries for both the starting and end year of the period.
} 
strongly positive in 2014, there is hardly any relationship to be discerned in 1986. Thus the relationship weakens as one goes back in time. ${ }^{59} 60$

Figure 4.1: Relationship Precolonial Centralisation and State Capacity

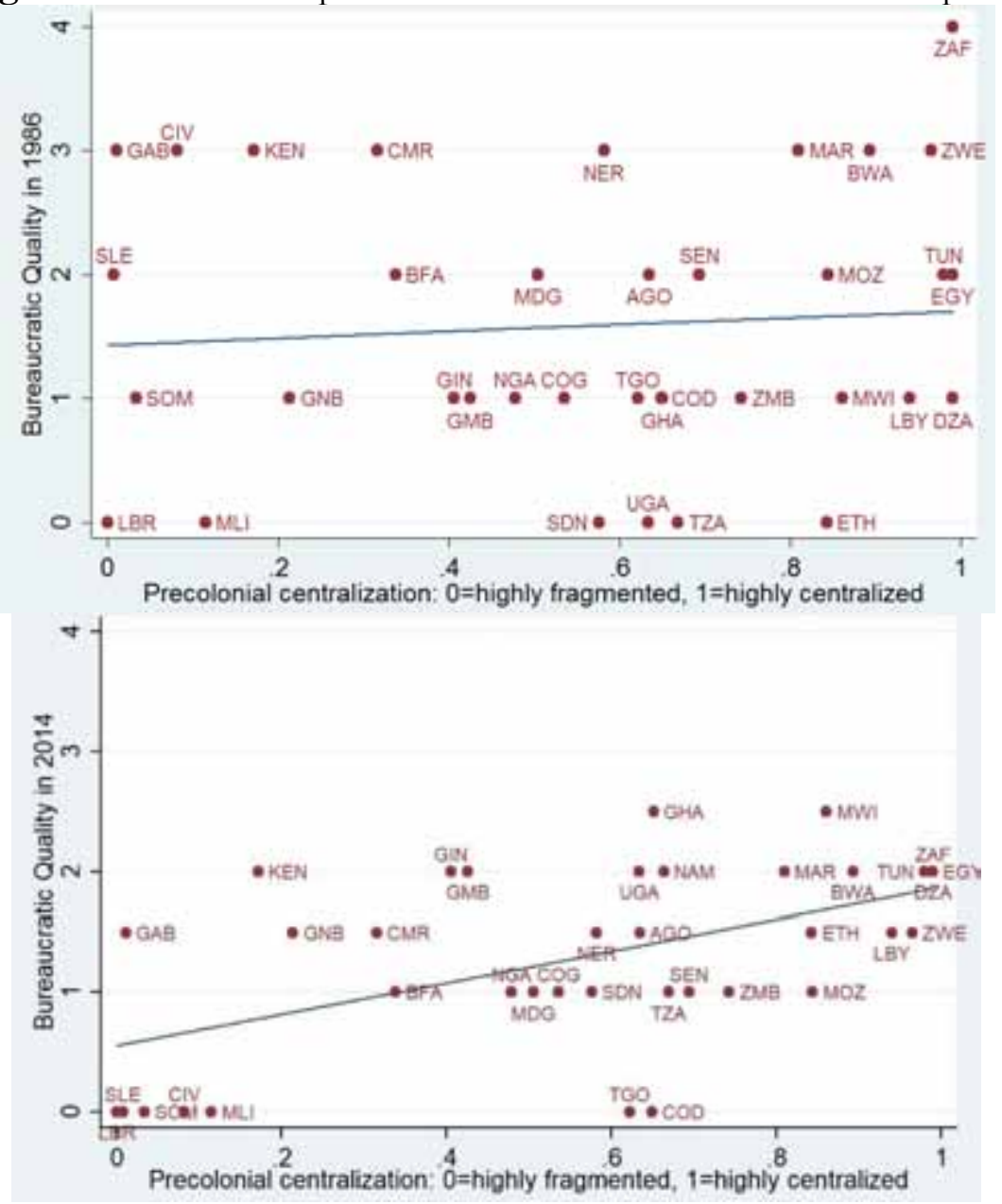

Subsequently using OLS regression, I will test whether the empirical results confirm these first impressions. In the level analysis, I will explore to what extent contemporary African bureaucratic capacity can be explained by long-run historical factors. I use the level of bureaucratic quality in 2014 as my dependent

${ }^{59}$ This is clear if one compares the plots for 1984, 1990, 1995, 2000, 2005, 2010 and 2014 (see Figure 4.B1 in Appendix 4.B).

${ }^{60}$ Scatterplots describing the relationship between the level of bureaucratic quality and precolonial centralisation for other intermediate years are available upon request. 
variable. My main explanatory variable of interest is the country-level measure of precolonial centralisation. The regression specification for the level analysis is:

$$
B Q_{i}=\beta_{0}+\beta_{1} * \text { precolonial centralisation }{ }_{i}+\beta_{2}^{\prime} * X_{i}+\varepsilon_{i}
$$

The parameter $\beta_{1}$ captures the relationship between precolonial centralisation and the level of bureaucratic quality in 2014. I include a vector of covariates of bureaucratic quality, in order to control for potential confounding factors. My main control variables for the analysis are colonial legacy ${ }^{61}$, legal origin ${ }^{62}$, population density in 140063 , artificial state borders ${ }^{64}$, geographic factors ${ }^{65}$, aid dependence ${ }^{66}$, domestic and external violence ${ }^{67}$, natural resource wealth ${ }^{68}$ and level of economic development measured by GDP per capita ${ }^{69}$.

There are, of course, several other potential confounding factors mentioned in the literature. These include, among others, slave exports, the length of experience with state institutions, communist legacy, constraints on the

\footnotetext{
${ }^{61}$ The only two non-colonized African countries are Ethiopia and Liberia.

${ }^{62}$ Legal systems in Africa either belong to the English common law or the French civil law family (La Porta, Lopez-de-Silanes, Shleifer \& Vishny, 1999).

${ }_{63}$ Based on previous work by Boserup (1981), Reynolds (1986), Acemoglu et al. (2002), as well as Ashraf and Galor (2011, 2013), I believe that it makes sense to use population density as an indicator of technological performance and therefore as rough proxy for comparative economic development during the Middle Ages.

${ }^{64}$ I use the partitioned measure from Alesina et al. (2011) as proxy for artificial state characteristics.

${ }^{65}$ Geography controls include (i) latitude, (ii) percent of cultivated land in Köppen-Geiger climate zone A (humid climate with no winter), (iii) percent of cultivated land in Köppen-Geiger climate zone B (dry climate with no winter), (iv) mean distance (in kilometers) to nearest coastline or sea-navigable river and (v) the extent of mountainous terrain. Data with regard to the first four variables come from Gallup et al. (1999), data on mountainous terrain is obtained from Fearon and Laitin (2003).

${ }^{66}$ The average aid dependence is taken for each country between 1961 and 2013 for those African countries that became independent in 1960 or before. For those countries that became independent after 1960, I take the average value of aid dependence between the year after the country's year of independence and 2013.

${ }^{67}$ I use data from the Major Episodes of Political Violence (1946-2013) dataset produced by the Center for Systemic Peace (Marshall, 2014).

${ }^{68}$ I construct an oil production dummy. The variable measures the proportion of years, for each country, in which oil has been produced. Oil-rich countries like Angola and Sudan that have produced oil every single year since independence are coded as one. Non-oil countries such as Botswana or Ethiopia are coded as zero.

${ }^{69}$ The variables domestic and external violence as well as GDP per capita are constructed in the same way as the aid dependence variable (see Footnote 66).
} 


\section{CHAPTER 4}

executive, ethnolinguistic fractionalization and polarization, cultural heritage proxied by differences in religion, gross public revenue per capita extracted from the citizenry during the colonial period, or the intensity of European settlement during colonial and modern times.

Due to space limitations these variables are not further discussed in this chapter. I have performed additional regression estimations controlling for these variables, but the main results are not affected in any crucial ways. The additional regression estimations can be found in the online appendix. A detailed description of all variables used in the analysis is given in Appendix 4.D.

\section{Change analysis}

In this subsection, I empirically investigate the changes of bureaucratic capacity in Africa over time. My changes analysis covers the years 1984-2014. The regression specification for the change analysis is:

$$
\begin{gathered}
\Delta B Q_{i, 84-14}=\beta_{0}+\beta_{1} * B Q_{i, 84}+\beta_{2} * \overline{\text { Ald Dependence }}_{i, 84-13}+ \\
\beta_{3}^{\prime}{ }_{3} * X_{i, 84-13}+\varepsilon_{i}(2)
\end{gathered}
$$

where $\Delta B Q_{i, 84-14}$ is the change in bureaucratic quality in country $i$ over the time period 1984-2014, $B Q_{i, 84}$ is the level of initial bureaucratic quality in country $i$ in 1984, $\overline{\text { Ald Dependence }}_{i, 84-13}$ is the average level of DAC-ODA aid as a percentage of GDP over the time period 1984-2013. Parameter $\beta_{2}$ captures the relationship between aid dependence and the change in bureaucratic quality. I also include a vector of time-varying covariates of bureaucratic quality, $X_{i, 84-13}$, in order to control for potential confounding factors. ${ }^{70}$

This specification limits the extent of problems related to omitted variable bias. By regressing the change of bureaucratic quality over time on its initial level, I account for the correlation between the initial level of bureaucratic quality and changes of bureaucratic quality. I therefore capture regression-to-the-mean effects and control for the possibility of initially high- and low-performing countries to decrease and increase their scores, respectively. Accounting for the initial level of bureaucratic quality also helps to control for the impact of

\footnotetext{
${ }^{70}$ Due to the limited degrees of freedom, the control variables are not all entered simultaneously.
} 


\section{CHAPTER 4}

historically slow-moving factors and the fact that differences in the evolution of bureaucratic quality across countries might depend on idiosyncratic initial conditions.

I also control for domestic and external political violence in the host country. Domestic (and external) violence usually attracts a significant amount of development assistance - particularly humanitarian and post-conflict assistance. Failing to account for political violence can therefore produce a spurious correlation between aid levels and weakened state capacity. ${ }^{71} \mathrm{I}$ also control for ethnic tensions..$^{72} 73$ Since the ICRG ratings on bureaucratic quality are subjective indicators, economic performance may influence the ratings even in the absence of a causal relation. If recipient countries witness economic growth concomitant with improving state capacity and declining levels of development aid, or vice versa, controlling for changes in the development level is crucial to avoid a spurious correlation between aid dependence and bureaucratic quality. I also control once again for natural resource wealth.

The main difference with the existing literature on the relationship between foreign aid and various political or institutional features (including the small literature on aid and state capacity) is that I will control for precolonial centralisation. Controlling for precolonial centralisation may be counterintuitive at first, since I already control for the initial level of bureaucratic quality. By controlling for the initial level of bureaucratic quality, previous studies aimed at fully accounting for idiosyncratic time-invariant initial conditions such as geography, cultural heritage or precolonial political institutions. However, I have found that the positive relationship between precolonial centralisation and bureaucratic quality has become more pronounced over time. As a result, the

\footnotetext{
${ }^{71}$ Data on both domestic and external political violence come from the Center for Systemic Peace (Marshall, 2014) and from the International Country Risk Guide (ICRG) by the PRS Group. Data on political violence from the PRS Group's International Country Risk Guide (ICRG) is only available from 1984, however, and thus only used for robustness checks.

72 The data comes from the PRS Group's International Country Risk Guide (ICRG) as well. The index of ethnic tensions is time-variant and assesses the degree of tensions within a country attributable to racial, nationality or language divisions. Seminal contributions on ethnic, linguistic, and religious fractionalization using time-invariant indices include Alesina, Devleeschauwer, Easterly, and Kurlat (2003), Desmet, Ortuño-Ortín and Wacziarg (2012), Easterly and Levine (1997) as well as Montalvo and Reynal-Querol (2005).

${ }^{73}$ In the empirical analysis, I am using the average values of the domestic violence, external violence and ethnic tension indices for each country over the time period 1984-2013.
} 


\section{CHAPTER 4}

initial level of bureaucratic quality would fail to control for the increasing impact of precolonial political institutions in Africa from the late-1990s onwards. It is for this reason that I control for precolonial centralisation in the regression specification.

Figure 4.2 provides a first indication of the relationship between precolonial centralisation and aid dependence. It shows a negative relationship. ${ }^{74}$ Consequently, the sparse literature studying the relationship between foreign aid and state capacity likely suffered from omitted variable bias by failing to control for precolonial centralisation, and this may be true also for the larger body of literature evaluating the impact of aid on various institutional features. Table 4.1 provides the summary statistics of the main variables for the level and changes analysis.

Figure 4.2: Relationship between Precolonial Centralisation and Aid Dependence

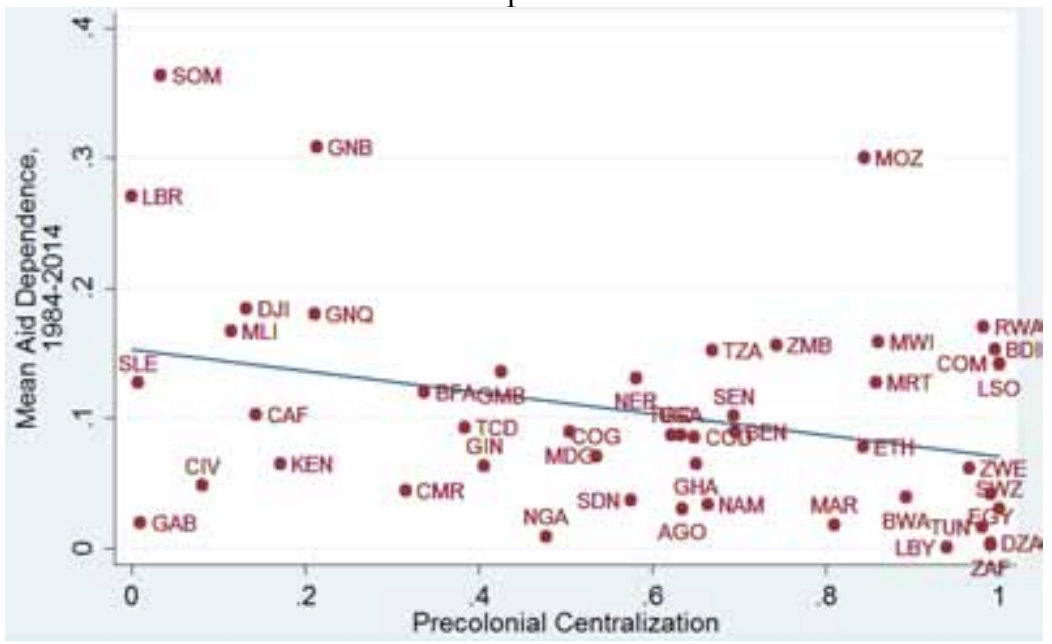

As a test of the robustness of the findings, the 30 -year period is subdivided into two sub-periods, 1984-1995 and 1996-2014. I split the sample in this way because during the 1990s, foreign aid to Africa was threatened by a complex crisis of legitimacy. In particular, foreign aid was "facing its most severe crisis

\footnotetext{
74 The negative relationship between precolonial centralisation and aid dependence also holds for different sub-periods (see Appendix 4.B).
} 


\section{CHAPTER 4}

and the pressures for changes were greater than ever before. Aid agencies were beginning to experiment with new approaches" (van de Walle, 1999, p. 233).

Table 4.1: Summary Statistics for the Main Variables

\begin{tabular}{lccccc}
\hline Variable & Obs. & Mean & Std. Dev. & Min & Max \\
\cline { 1 - 3 } & Level Analysis & & & & \\
Dependent Variables & & & & & \\
Bureaucratic Quality in 2014 & 37 & 1.30 & 0.77 & 0 & 2.50 \\
Bureaucratic Quality in 1984 & 25 & 1.14 & 1.15 & 0 & 4 \\
Government Effectiveness in 2014 & 53 & -0.80 & 0.66 & -2.48 & 1.13 \\
Government Effectiveness in 1996 & 52 & -0.70 & 0.69 & -2.10 & 0.88 \\
Main Explanatory Variable & & & & & \\
Precolonial Political Centralisation & 48 & 0.59 & 0.33 & 0 & 1 \\
Main Controls & & & & & \\
Aid as \% of GDP, 1961-2013 & 53 & 14.45 & 9.73 & 0.12 & 41.46 \\
Log GDP per capita, 1961-2013 & 53 & 6.60 & 1.01 & 5.06 & 9.14 \\
External Violence, 1961-2013 & 51 & 0.05 & 0.13 & 0 & 0.75 \\
Domestic Violence, 1961-2013 & 51 & 0.70 & 1.15 & 0 & 5.05 \\
Oil Production Dummy, 1961-2013 & 53 & 0.26 & 0.39 & 0 & 1 \\
British Colonial Legacy & 53 & 0.42 & 0.50 & 0 & 1 \\
French Colonial Legacy & 53 & 0.38 & 0.49 & 0 & 1 \\
Belgian Colonial Legacy & 53 & 0.06 & 0.23 & 0 & 1 \\
British Legal Origin & 53 & 0.34 & 0.48 & 0 & 1 \\
French Legal Origin & 53 & 0.66 & 0.48 & 0 & 1 \\
Log Population Density, 1400 & 52 & 0.11 & 1.33 & -2.30 & 3.04 \\
Artificial State Borders & 41 & 0.48 & 0.31 & 0 & 1 \\
& & & & &
\end{tabular}

Changes Analysis

Dependent Variable

$\Delta$ Bureaucratic Quality, 1984-2014

36

0.03

1.29

$-3$

2.50

Main Explanatory Variables

Precolonial Centralisation

Aid as \% of GDP, 1984-2013

47

0.59

0.33

$\begin{array}{ll}0 & 1\end{array}$

51

7.18

5.83

0

24.02

Main Controls

Initial Bureaucratic Quality, 1984

36

1.29

1.10

$\begin{array}{ll}0 & 4\end{array}$

$\Delta$ Relative GDP per capita, 1984-2013

51

1.04

3.81

$-0.52$

27.05

Ethnic Tension, 1984-2013

$36 \quad 2.80$

0.98

1.00

5.18

Domestic Violence, 1984-2013

49

0.81

1.31

5.73

External Violence, 1984-2013

49

0.11

0.58

$0 \quad 4.03$

Oil Production Dummy, 1984-2013

51

0.32

0.44

0

1

The end of the Cold War heralded the emergence of a new development paradigm among policymakers and international donor communities, and from 
the mid-1990s onwards foreign aid by Western donors and international organizations became increasingly oriented towards good governance and institutional reform (see also Chapter 2). A radical shift away from emphasizing physical infrastructure and the economic sectors towards the social sectors and capacity building took place (Broich \& Szirmai, 2014; Burnside \& Dollar, 2000; World Bank, 1997, 1998). With this in mind, it is sensible to split my sample before and after the mid-1990s and investigate whether the paradigm shift in development altered the relationships I estimate in this chapter.

\subsection{Empirical Results}

\subsubsection{Precolonial Centralisation and State Capacity Levels}

In Table 4.2 I report my OLS estimates for the determinants of contemporary state capacity in Africa. In my basic specification, column (1), precolonial centralisation has a significant positive impact on bureaucratic quality in 2014 . The estimated coefficient on precolonial centralisation implies that a one standard deviation increase (s.d. $=0.77)$ in precolonial centralisation translates, on average, into an expected change in bureaucratic quality by 1.01 points.

In the remaining columns, I control for other potential confounding factors. In column (3), I add the colonizer identity to the regressions. The non-colonized countries Ethiopia and Liberia serve as the baseline group. The dummy for being a Belgian colony, which captures the Democratic Republic of Congo, is highly statistically significant and negative. With King Leopold II creating the Congo Free State in 1885 and colonizing the area as his private holding, the Democratic Republic of Congo serves as primary example of the extractive state (Hochschild, 1998; van Reybrouck, 2010). British colonial legacy is associated with better bureaucratic capacity; the coefficient is statistically significant whether or not geographic variables are controlled for. Only when controlling for geographical variables is the same true for French colonial legacy.

In column (5) several proximate sources of bureaucratic capacity are added such as foreign aid dependence. Even though all control variables have their expected sign, the coefficients are not statistically significant. In column (7), I control for British legal origin where French legal origin serves as the baseline category. I do not find empirical evidence that countries with a civil law system have lower 


\section{CHAPTER 4}

state capacity than countries with a common law system, in contrast to what one might expect based on the findings of La Porta, Lopez-de-Silanes, Shleifer and Vishny (1997, 1998, 1999). In column (9) and column (11), I control for initial population density in 1400 and artificial state characteristics proxied by my partitioned measure, respectively. Both coefficients are not statistically significant at any conventional significance level. More importantly, the addition of those control variables does not drastically change the estimated effect of precolonial centralisation.

The even-numbered columns include a set of five geographic characteristics latitude, mountainous terrain, percent of cultivated land in Köppen-Geiger climate zones A and B (dry climate with no winter) and mean distance to nearest coastline or sea-navigable river - as controls. The results change little after controlling for geographic factors. I conduct an F-test on all geographic controls to see if the coefficients on my geographic factors are jointly significant. In all regression estimations, the F-statistic is very low. I therefore fail to reject the null hypothesis of no significant effect of my geographic variables. Overall, the results presented in Table 4.2 show a large and statistically significant effect of precolonial centralisation on contemporary bureaucratic quality in Africa.

I subsequently examine the relationship for an earlier period. When I regress the level of bureaucratic quality in 1986 (the first year I have data for all variables) against precolonial centralisation, the coefficient on precolonial centralisation is no longer statistically significant (Table 4.3). ${ }^{75}$ Previous results by Gennaioli and Rainer (2006) seemed to suggest that the link between precolonial centralisation and institutional quality has been persistent throughout the entire independence era. In contrast, the results do not support the notion of historical continuity in the effects of precolonial institutions. Interestingly, all the coefficients of the colonial dummies are statistically significant in 1986, suggesting a strong colonial legacy up until the mid-1980s. Thus the relationship between precolonial centralisation and bureaucratic quality only surfaces in the more recent period.

\footnotetext{
75 Even though the Bureaucratic Quality index published by the PRS Group covers the time period 1984-2014, the index is only available from 1986 onwards for several African countries. As a consequence thereof, I use bureaucratic quality in 1986 as the dependent variable to cover more African countries. The results are similar, however, when I include the year 1984. The results can be found in the online appendix.
} 


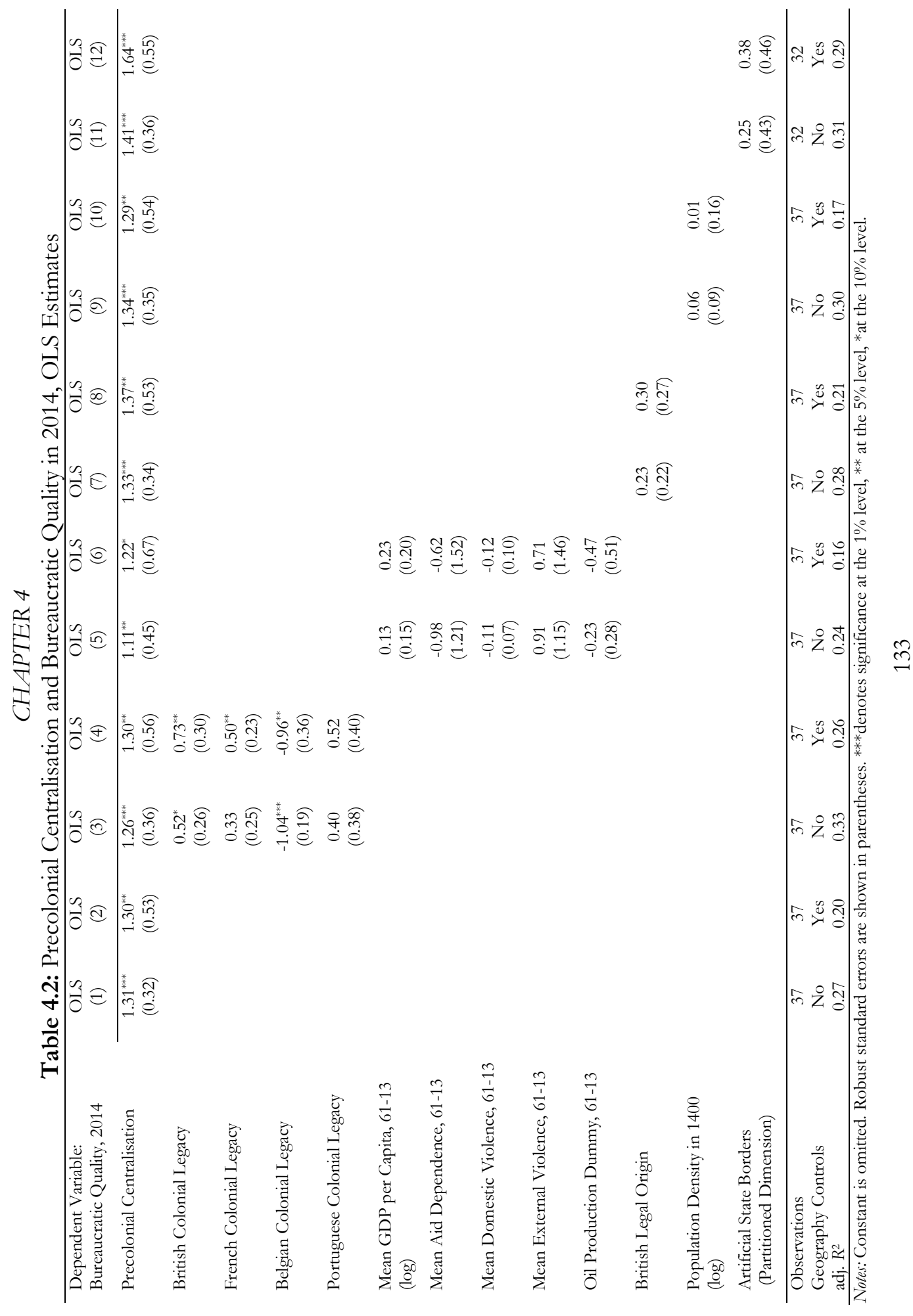




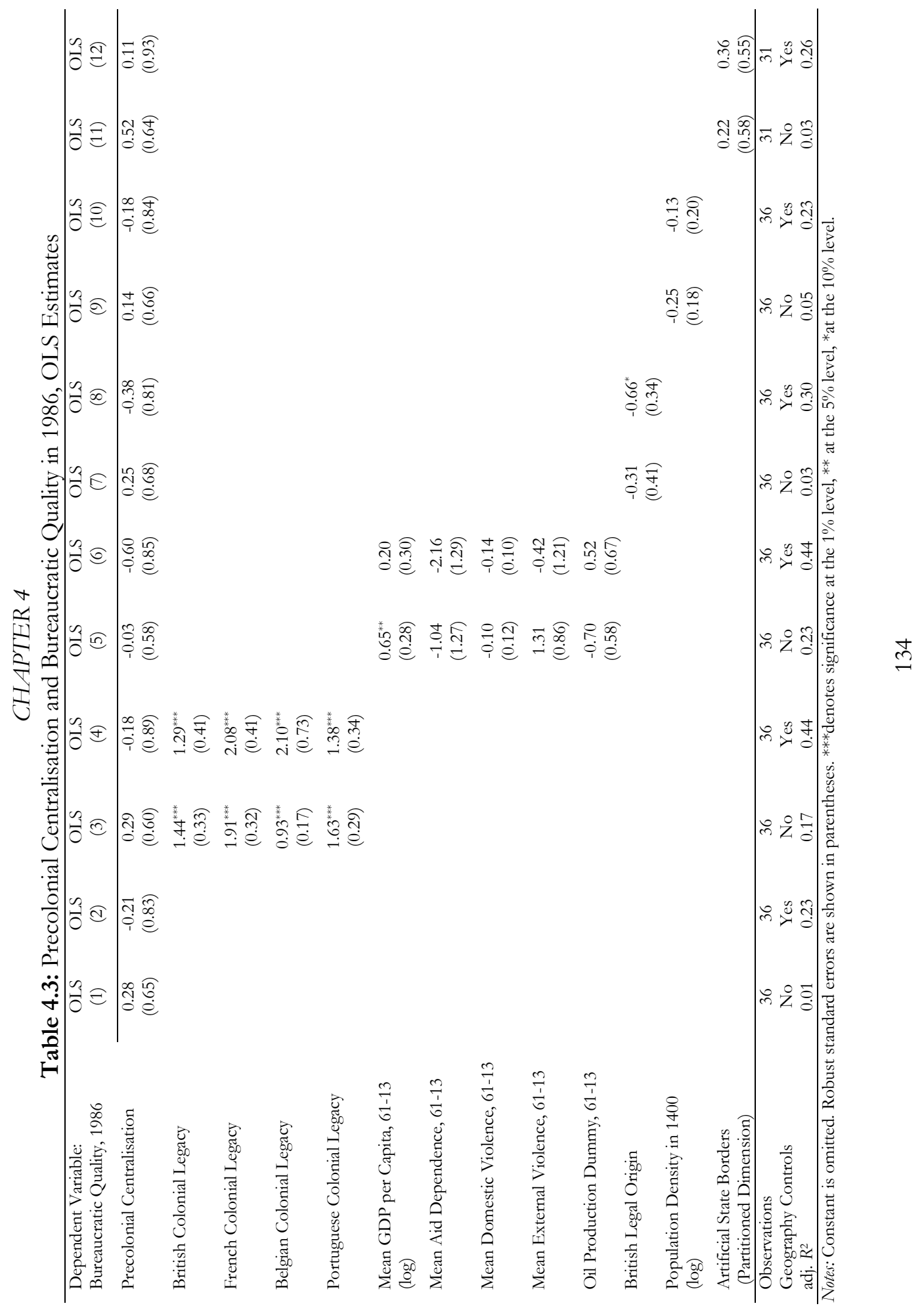




\section{CHAPTER 4}

My interpretation of the difference between the findings for 1986 and 2014 is that the influence of precolonial political institutions on modern state capacity is reasserting itself only recently as the effects of the colonial interlude are fading. I performed additional regression estimations using the level of bureaucratic quality for intermediate years. Over time, the coefficient on precolonial centralisation becomes larger and more statistically significant (see Table 4.A5 in Appendix 4.A). This phenomenon will be further examined in section 4.4.2 where I focus on changes in bureaucratic quality.

\subsubsection{Aid, Precolonial Centralisation, Changes in State Capacity}

In Table 4.4 I report my results for the full time period. In columns (1)-(5), I report the effect of foreign aid on bureaucratic quality without controlling for precolonial centralisation. Columns (6)-(10) do control for precolonial centralisation. The results are intriguing. First, the negative relationship between foreign aid dependence and bureaucratic quality becomes weaker once I control for precolonial centralisation. The magnitude of the coefficient declines and the level of significance is lower. Second, the precolonial centralisation variable enters positively and statistically significant in all my regression estimations. The effect remains robust after controlling for relative changes in GDP per capita, average levels of ethnic tensions, average levels of political violence and a dummy for oil production. Overall, when controlling for precolonial centralisation, the regression estimations explain between 77 percent and 80 percent of the variation in changes of bureaucratic quality over time.

The next step in the analysis splits the period into two sub-periods - 1984-1995 and 1995-2014 - in order to see whether the relationships differ between the sub-periods. Table 4.5 repeats the analysis of Table 4.4 for the period 1984-1995. When controlling for precolonial centralisation, the coefficient on foreign aid dependence remains stable and statistically significant. However, the coefficient on precolonial centralisation is no longer statistically significant. 


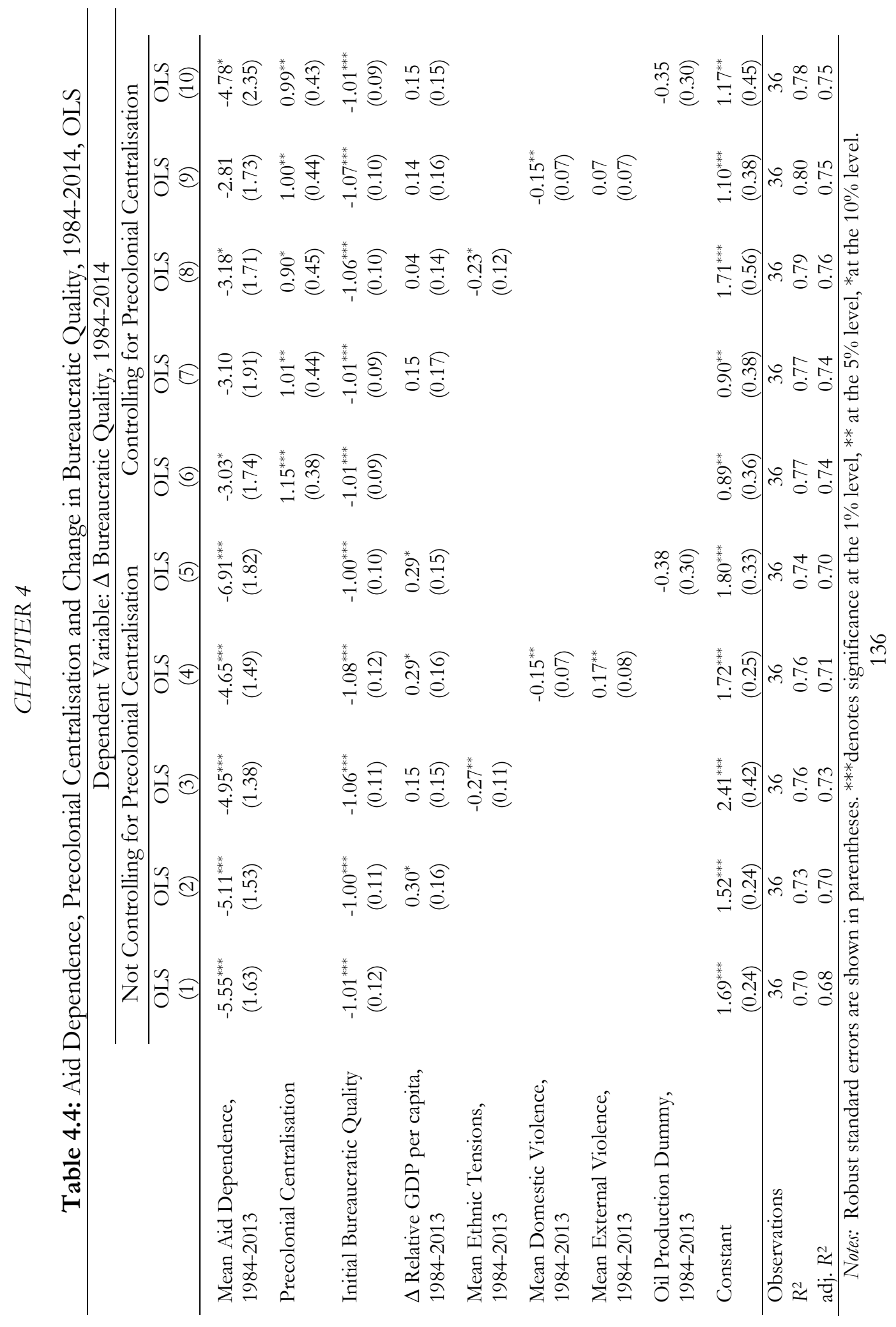




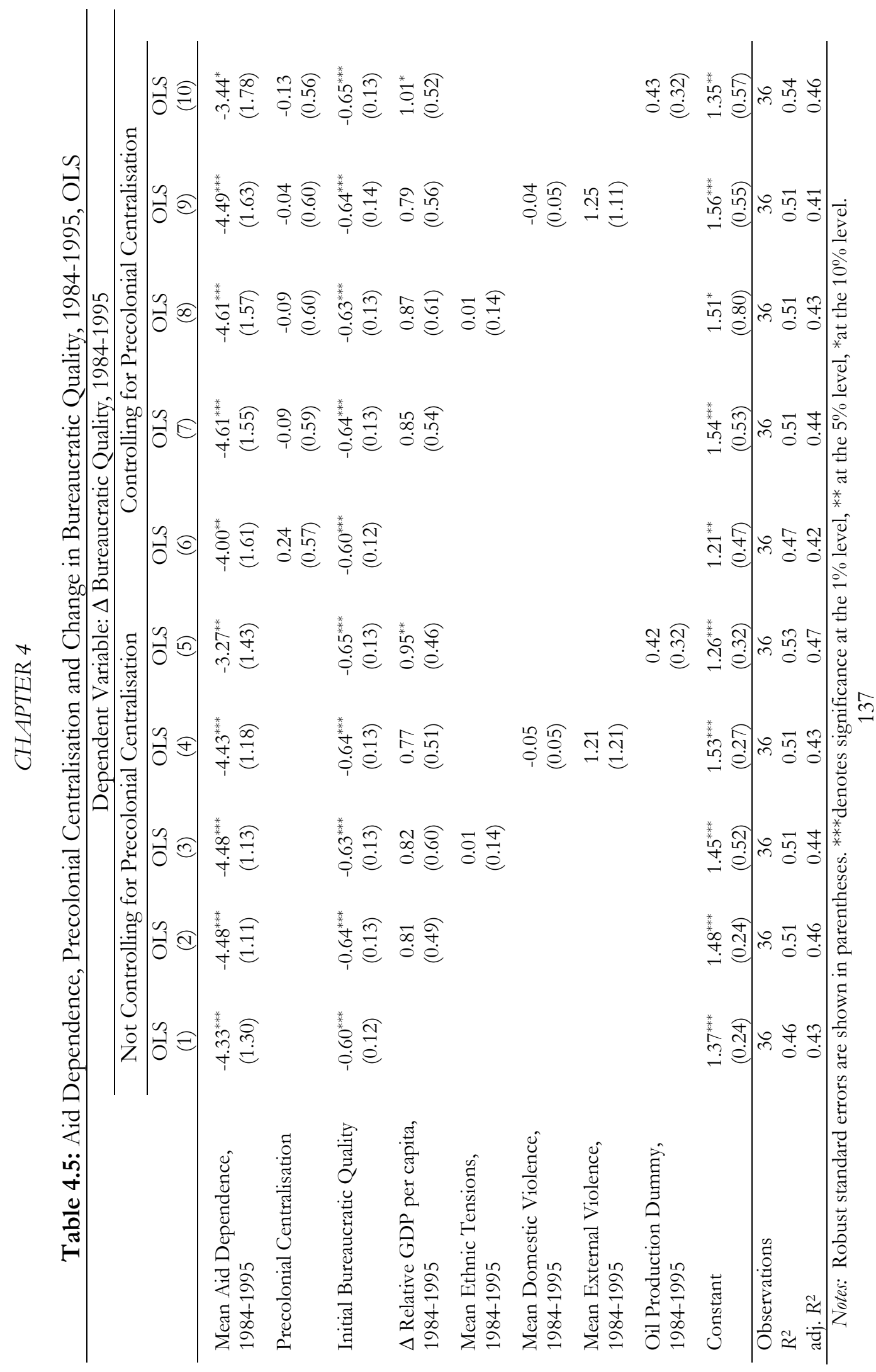




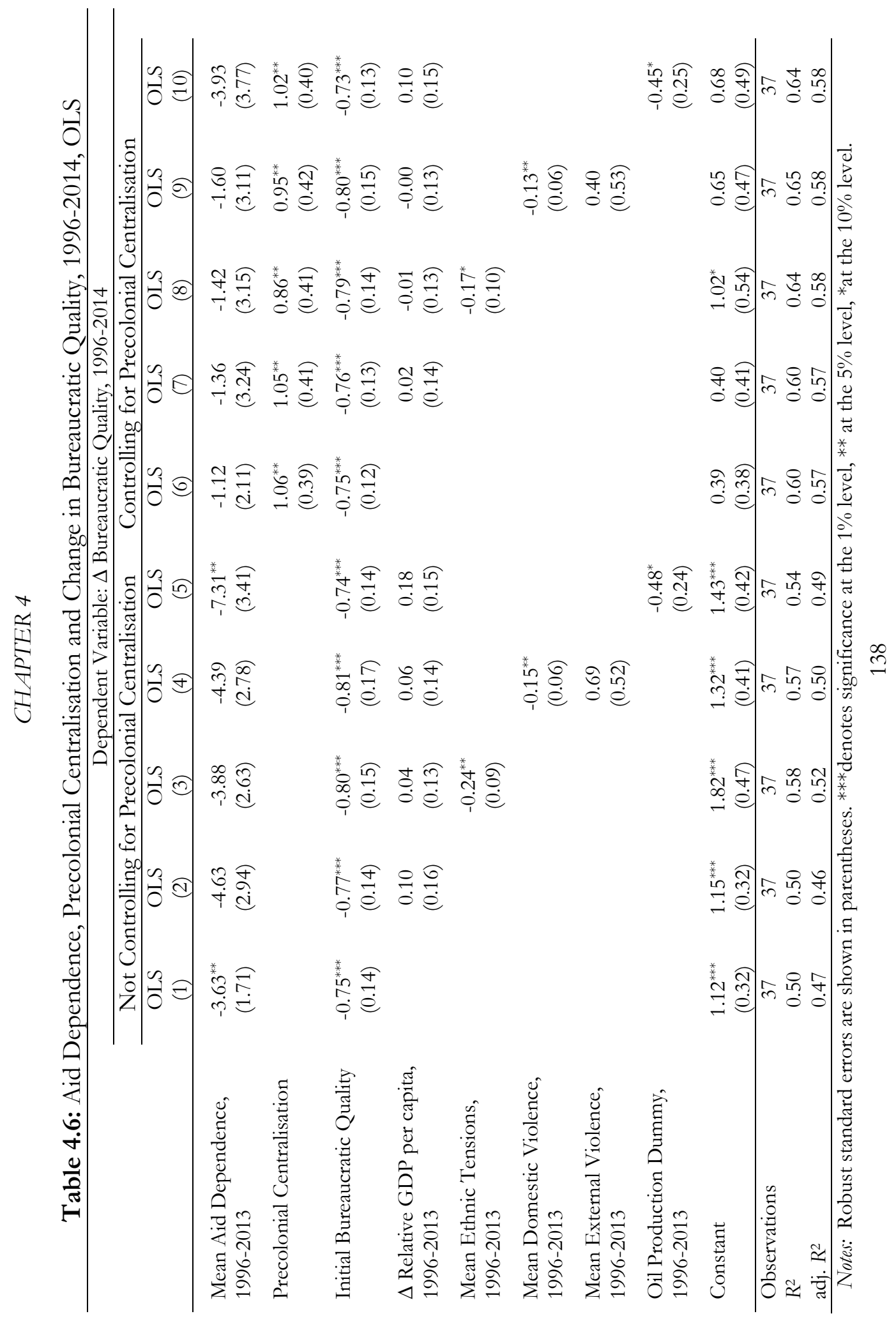




\section{CHAPTER 4}

Next, I look at the relationship between aid dependence and bureaucratic quality for the second sub-period (Table 4.6). When controlling for precolonial centralisation, the negative relationship between foreign aid dependence and bureaucratic quality weakens considerably and is no longer statistically significant in any of the five specifications. In contrast to the earlier sub-period, I document a positive and statistically significant relationship between precolonial centralisation and changes in bureaucratic quality. This implies that, on average, countries with highly centralised precolonial institutions improved their bureaucratic quality between 1996 and 2014 more than countries that had highly decentralised precolonial political systems. Additionally, relative to historical influences, aid dependence appears to be less important than both aid pessimists and conditional optimists would argue, at least in terms of its effect on state capacity.

The strongly positive relationship between precolonial centralisation and improvements in bureaucratic quality over the full time period is mainly driven by the positive relationship between precolonial centralisation and improvements in bureaucratic quality in the later period. The negative relationship between foreign aid dependence and deteriorations in bureaucratic quality over the full time period is mainly driven by the negative relationship between foreign aid dependence and deteriorations in bureaucratic quality in the earlier period.

Burnside and Dollar (2000) have argued for a policy-conditional effect of aid on growth, meaning that the returns to aid are bigger in recipient countries with better institutions. The positive effects of the Marshall aid program after the Second World War, for example, are partly attributed to the well-functioning institutions in the Western European recipient countries (Behrman, 2007). I propose a modified version of the Burnside-Dollar hypothesis, applying it to bureaucratic capacity rather than to economic growth. In my modified BurnsideDollar hypothesis, I test the hypothesis that foreign aid will improve bureaucratic capacity in a recipient country if the initial level of bureaucratic quality is higher. I interact mean aid dependence with the initial level of bureaucratic quality in 1996. A significant positive coefficient of the interaction term is interpreted as supporting the hypothesis. Due to limitations of space, I only focus on the second sub-period 1996-2014, the period in which Western donors have 
increasingly emphasized the crucial importance of institutional quality and good governance.

I find some evidence for the modified Burnside-Dollar hypothesis when not controlling for precolonial centralisation (Table 4.7). However, when controlling for precolonial centralisation I no longer find any empirical support for the modified Burnside-Dollar hypothesis in this period. Once again, I do find a strong positive relationship between precolonial centralisation and improvements in bureaucratic quality. ${ }^{76} \mathrm{My}$ results indicate that precolonial centralisation trumps foreign aid dependence when trying to explain changes in bureaucratic quality on the African continent for the period 1996-2014.

In this section I have documented a strong link between precolonial centralisation and bureaucratic quality. For both the entire period 1984-2014 and the sub-period 1996-2014, the aid dependence variable loses most of its explanatory power when controlling for precolonial centralisation. The positive relationship between precolonial centralisation and changes in bureaucratic quality survives additional controls for the periods 1984-2014 and 1996-2014. For the early period, however, the strong and positive link between the two variables is not visible. When controls are added, there is no significant relationship between precolonial centralisation and changes in bureaucratic quality for the time period 1984-1995 either.

In sum, the empirical findings lend support for the historical persistence of the effects of indigenous political institutions in Africa. My interpretation of the findings presented above is that with the arrival of colonialism on the African continent, new colonial institutions were superimposed on pre-existing precolonial institutions. In the early years of independence, the colonial institutions had a strong influence on bureaucratic institutions and capabilities. While a majority of African countries officially gained independence in the 1960s, most of them were still profoundly vulnerable to external political and economic pressures during the entire postcolonial era (Meredith, 2005).

\footnotetext{
${ }^{76}$ The results for the full period and early period are presented in the online appendix.
} 


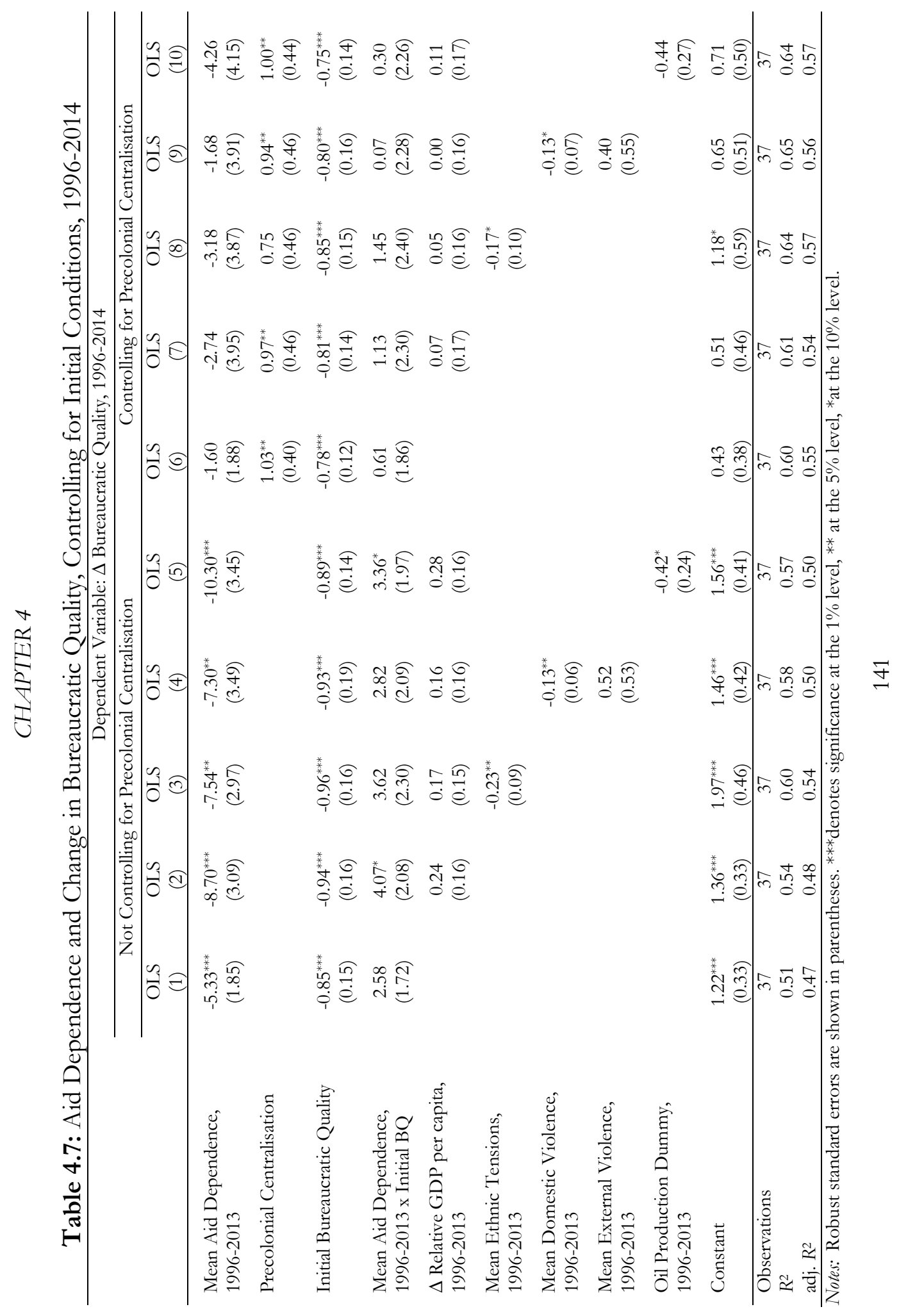




\section{CHAPTER 4}

In fact, a bulk of African countries found themselves struggling for true independence until the early 1990s. Worsening economic conditions, political crises, macroeconomic instability and the emerging debt crisis engulfed the majority of African countries in the 1980s.

When the wave of democratisation swept across Africa in the 1990s as a result of the fall of communist regimes and the cessation of the Cold War, a majority of African countries slowly witnessed more varieties of freedom - press freedom, freedom of speech, freedom of movement and freedom of organization. As years passed, the temporary colonial influences faded and precolonial institutions reasserted their importance and increasingly came to shape bureaucratic quality. On average, countries with high precolonial political centralisation witnessed an improvement in bureaucratic quality, while countries with highly fragmented precolonial political systems suffered from a decline in administrative capacity. Overall, the results highlight the historical legacy of the precolonial bureaucratic state in Africa.

\subsection{Robustness}

This section presents some additional robustness checks. Section 4.5.1 presents results for the level analysis when using an alternative indicator as rough proxy for administrative state capacity. Section 4.5.2 addresses potential endogeneity problems with regard to the level analysis. Section 4.5.3 tackles endogeneity concerns with regard to the analysis of changes in bureaucratic quality.

\subsubsection{Government Effectiveness as Dependent Variable}

In this section, I check whether the results depend on the specific measure of state capacity that I have selected. I do this with additional regressions using the World Bank measure of Government Effectiveness from the World Governance indicators as my dependent variable in the level analysis. This indicator is available for almost all 54 African countries (except for South Sudan), but for a shorter period (1996-2014). Similar to the bureaucratic quality measure, I use the starting value and the end value of the government effectiveness indicator as my dependent variable. Both for the years 1996 and 2014, I find that the results with the alternative measure are perfectly consistent with my previous findings. The 
relationship between precolonial centralisation and government effectiveness is strongly positive (Tables 4.C1 and 4.C2 in Appendix 4.C), which suggests that my results hold for a broader range of measures of administrative effectiveness.

\subsubsection{SLS Estimates for Level Analysis}

The previous OLS estimates may suffer from endogeneity bias. First, the positive relationship between precolonial centralisation and bureaucratic quality might be driven by omitted variable bias. Time-variant non-observable factors may have driven both precolonial state formation and contemporary state capacity, potentially producing misleading cross-country estimates. Second, Murdock's (1967) classification of precolonial centralisation as proxy for the level of ancient statehood is subject to the critique that it may contain sizeable measurement error (Michalopoulos \& Papaioannou, 2015). In order to tackle the endogeneity problems, I instrument precolonial centralisation with the Tsetse fly suitability index (TSI) developed by Alsan (2015). She argues that ethnic groups inhabiting Tsetse suitable areas were less likely to be politically centralised at the regional level. In her empirical study, Alsan constructs the TSI at the regional level. In contrast to Alsan, I construct a TSI at the national level. The construction of the national TSI indicator as well as the TSI values for the sample countries are documented in Appendix 4.A (Table 4.A6).

Table 4.8 reports the 2SLS estimates. The first stage regressions results are excluded due to limited space but are available upon request. The precolonial centralisation coefficient in column (2) remains highly statistically significant and is in fact larger than the OLS estimate reported in Table 4.2. This may suggest that the coefficient of precolonial centralisation in the uninstrumented regression suffered from attenuation bias (Wooldridge, 2002). The attenuation bias resulting from measurement error in the precolonial centralisation variable would therefore be more important than omitted variable bias. ${ }^{77}$ The positive link between precolonial statehood and contemporary state capacity remains intact after adding several other control variables. ${ }^{78}$

\footnotetext{
${ }^{77}$ Endogeneity problems due to simultaneity bias/reverse causality are obviously of little concern here.

${ }^{78}$ Additional 2SLS results using alternative control variables can be found in the online appendix.
} 
Table 4.8: Precolonial Centralisation and Bureaucratic Quality in 2014,

2SLS Estimates

\begin{tabular}{lcc}
\hline $\begin{array}{l}\text { Dependent Variable: } \\
\text { Bureaucratic Quality, 2014 }\end{array}$ & $\begin{array}{c}\text { 2SLS } \\
(1)\end{array}$ & $\begin{array}{c}\text { 2SLS } \\
(2)\end{array}$ \\
\hline Precolonial Centralisation & $1.74^{* * *}$ & $1.45^{* * *}$ \\
& $(0.62)$ & $(0.56)$ \\
British Colonial Legacy & & $0.43^{*}$ \\
& & $(0.22)$ \\
French Colonial Legacy & 0.33 \\
& & $(0.23)$ \\
Belgian Colonial Legacy & $-1.08^{* * *}$ \\
& & $(0.16)$ \\
Portuguese Colonial Legacy & & 0.38 \\
& & $(0.36)$
\end{tabular}

Mean GDP per Capita,

1961-2013

0.10

(0.14)

Mean Aid Dependence,

1961-2013

Mean Domestic Violence,

1961-2013

Mean External Violence,

1961-2013

Oil Production Dummy,

1961-2013

$(0.26)$

British Legal Origin

0.18

$(0.22)$

Population Density in 1400

0.04

$(0.10)$

Artificial State Borders

0.21

(Partitioned Dimension)

(0.00)

\begin{tabular}{lcccccc} 
Constant & 0.30 & 0.14 & 0.03 & 0.25 & 0.27 & 0.41 \\
& $(0.42)$ & $(0.26)$ & $(0.95)$ & $(0.45)$ & $(0.44)$ & $(0.46)$ \\
\hline Observations & 35 & 35 & 35 & 35 & 35 & 31 \\
F-statistic, first stage & 14.30 & 12.06 & 7.28 & 13.68 & 11.88 & 13.74 \\
Wooldridge's & .435 & .071 & .258 & .368 & .435 & .015 \\
heteroscedasticity-robust & $(0.510)$ & $(0.790)$ & $(0.611)$ & $(0.544)$ & $(0.510)$ & $(0.903)$
\end{tabular}

score test

(p-value in brackets)

Notes: The variables GDP per capita and Population Density are log transformed. Robust standard errors are shown in parentheses. ${ }^{* * *}$ denotes significance at the $1 \%$ level, ** at the $5 \%$ level, *at the $10 \%$ level. The instrument for precolonial centralisation is the "national" TSI which is constructed by the authors. 


\section{CHAPTER 4}

In all but one case, the instruments used are strong, since the first-stage Fstatistics exceed the rule-of-thumb threshold of 10 (Staiger \& Stock, 1997; Stock \& Watson, 2012). I cannot answer the question whether my instrument meets the exogeneity condition. As the regression coefficients are exactly identified, I cannot deploy a test of overidentifying restrictions. I can, however, test whether or not precolonial centralisation or one of the other explanatory variables are highly endogenous. ${ }^{79}$ In all six cases, Wooldridge's score test fails to reject the null hypothesis that the variable precolonial centralisation is exogenous at all conventional significance levels. ${ }^{80}$ If the endogenous regressor is in fact exogenous, then the OLS estimator is more efficient. The econometric analysis shows that concerns with regard to endogeneity are to a large extent unwarranted. Based on this analysis, precolonial centralisation will be treated as exogenous for the rest of the analysis.

\subsubsection{SLS Estimates for Changes Analysis}

In this section I address the endogeneity problem between foreign aid dependence and changes in bureaucratic quality. On the one hand, more aid could flow to countries with conditions impeding institutional change, as there is no evidence that less corrupt governments or less authoritarian regimes receive more aid (Alesina \& Dollar, 2000; Alesina \& Weder, 2002). On the other hand, foreign aid may predominantly flow to countries whose bureaucratic capacity is improving as the return of aid is biggest in a sound institutional environment (Burnside \& Dollar, 1997, 2000). In order to correct for potential reverse causality, I need to instrument for foreign aid dependence.

One of my instruments is population size. Population size captures the strategic interests of donor countries, as "there is an exogenous small country bias in aid such that smaller countries get higher aid per capita and higher aid as ratio to their income" (Easterly, 2009, p. 388). Knack and Rahman (2007) show that the relationship between population size and bureaucratic quality is both

\footnotetext{
${ }^{79}$ The most commonly used test is the Hausman test (Hausman, 1978). Since the Hausman test assumes homoscedasticity of the residuals, I used Wooldridge's (1995) heteroscedasticity-robust score test instead. The test score and the associated p-value are reported in Table 4.8 as well. ${ }^{80}$ Assuming homoscedasticity, I deploy the Durbin and Wu-Hausman tests as well for all six regression specifications. Both tests arrive at the same conclusion that precolonial centralisation can be treated as exogenous. The results are available upon request.
} 


\section{CHAPTER 4}

theoretically and empirically weak. This suggests that the first instrument may satisfy the relevance and exogeneity condition.

My second instrument is the initial development level, proxied by GDP per capita (log transformed). This instrument captures needs-based preferences and altruistic motives of aid. Generally, more development assistance goes to poor countries (Riddell, 2007). ${ }^{81}$ Since the two variables are uncorrelated among themselves, any linear combination is valid as well. ${ }^{82}$ Using a linear combination of the two also allows me to deploy the test of overidentifying restrictions, which tests whether my instruments are purely exogenous. As mentioned before, I will not instrument for precolonial centralisation, as I think this variable can be considered exogenous. ${ }^{83}$

Table 4.9 presents the 2SLS estimates for the changes analysis covering the full period. In the base specification (column 1), the coefficient on aid dependence is negative but not statistically significant. In contrast, however, and similar to

\footnotetext{
${ }^{81}$ Both the population data and the GDP per capita data come from Maddison (2010) and from the World Development Indicators. Ideally, I would like to use the initial population size and the initial development level for the period under consideration as instruments. I find, however, that population size at the beginning of the decade of the period under consideration is a much stronger instrument for aid dependence than initial population size. This result is perhaps surprising and I do not have an intuitive explanation for it. I therefore use the initial development level and population size at the beginning of the decade of the period under consideration as instruments for aid dependence.

82 The correlation between log GDP per capita in 1984 and population in 1980 is -0.072 and is not statistically significant at all conventional significance levels. In a similar way, the correlation between log GDP per capita in 1996 and population in 1990 is -0.098 and not statistically significant at all conventional significance levels.

${ }^{83}$ While I believe that these instrumental variables are reasonable in the context of regressions where bureaucratic capacity is the outcome variable, I cannot fully guarantee the validity of my instruments, and I wish to emphasize that I think of the estimates in this section merely as checks on the robustness of the OLS estimates. I considered novel instruments for foreign aid, along the lines of Dreher, Eichenauer and Gehring (2016), Galiani, Knack, Xu and Zou (2017) as well as Nunn and Qian (2014), but I did not find them suitable for the following reasons: First, the aforementioned authors instrument for foreign aid over time intervals of shorter lengths than used here, and their instrumental variables are better suited for regressions based on such (shorter) time-spans. More specifically, their studies use panel data with time periods between one and four years, while I work with significantly longer time-spans. Second, the contributions by Dreher et al. (2016) and Galiani et al. (2017) in particular investigate the effect of foreign aid on economic growth, while the study by Nunn and Qian (2014) examines the relationship between food aid from the United States exclusively and conflict in the recipient country. My study, however, discusses the impact of foreign aid on bureaucratic capacity, a fundamentally different concept.
} 
my OLS estimates, the coefficient on precolonial centralisation is positive and statistically significant. The empirical results remain intact after including the usual control variables. In four out of five cases, the instruments used appear to be valid. The first stage F-statistics are always above the critical rule-of-thumb threshold of 10, except in column (5).

Table 4.9: Aid Dependence, Precolonial Centralisation and Change in Bureaucratic Quality, 1984-2014, 2SLS Estimates

\begin{tabular}{|c|c|c|c|c|c|}
\hline $\begin{array}{l}\text { Dependent Variable: } \\
\Delta \text { Bureaucratic Quality, } \\
1984-2014\end{array}$ & $\begin{array}{l}2 \mathrm{SLS} \\
(1)\end{array}$ & $\begin{array}{c}\text { 2SLS } \\
(2)\end{array}$ & $\begin{array}{c}2 \mathrm{SLS} \\
(3)\end{array}$ & $\begin{array}{c}2 \text { SLS } \\
(4)\end{array}$ & $\begin{array}{c}2 \text { SLS } \\
(5)\end{array}$ \\
\hline $\begin{array}{l}\text { Mean Aid Dependence, } \\
\text { 1984-2013 }\end{array}$ & $\begin{array}{l}-1.29 \\
(2.92)\end{array}$ & $\begin{array}{l}-2.08 \\
(3.03)\end{array}$ & $\begin{array}{l}-1.36 \\
(2.49)\end{array}$ & $\begin{array}{l}-1.87 \\
(2.33)\end{array}$ & $\begin{array}{l}-5.43 \\
(5.50)\end{array}$ \\
\hline Precolonial Centralisation & $\begin{array}{l}1.28^{* * *} \\
(0.44)\end{array}$ & $\begin{array}{l}1.09^{* *} \\
(0.48)\end{array}$ & $\begin{array}{l}1.07^{* *} \\
(0.43)\end{array}$ & $\begin{array}{l}1.19^{* * *} \\
(0.38)\end{array}$ & $\begin{array}{l}1.08^{* *} \\
(0.51)\end{array}$ \\
\hline Initial Bureaucratic Quality & $\begin{array}{l}-1.00^{* * *} \\
(0.09)\end{array}$ & $\begin{array}{l}-1.00^{* * *} \\
(0.08)\end{array}$ & $\begin{array}{l}-1.04^{* * *} \\
(0.08)\end{array}$ & $\begin{array}{l}-1.06^{* * *} \\
(0.09)\end{array}$ & $\begin{array}{c}-1.02^{* * *} \\
(0.08)\end{array}$ \\
\hline $\begin{array}{l}\Delta \text { Relative GDP per capita, } \\
1984-2013\end{array}$ & & $\begin{array}{c}0.15 \\
(0.16)\end{array}$ & & & \\
\hline $\begin{array}{l}\text { Mean Ethnic Tensions, } \\
\text { 1984-2013 }\end{array}$ & & & $\begin{array}{l}-0.23^{* *} \\
(0.11)\end{array}$ & & \\
\hline $\begin{array}{l}\text { Mean Domestic Violence, } \\
1984-2013\end{array}$ & & & & $\begin{array}{l}-0.15^{* *} \\
(0.07)\end{array}$ & \\
\hline $\begin{array}{l}\text { Mean External Violence, } \\
\text { 1984-2013 }\end{array}$ & & & & $\begin{array}{c}0.05 \\
(0.06)\end{array}$ & \\
\hline $\begin{array}{l}\text { Oil Production Dummy, } \\
\text { 1984-2013 }\end{array}$ & & & & & $\begin{array}{l}-0.40 \\
(0.44)\end{array}$ \\
\hline Constant & $\begin{array}{c}0.68 \\
(0.45)\end{array}$ & $\begin{array}{l}0.78^{*} \\
(0.45)\end{array}$ & $\begin{array}{l}1.52^{* * *} \\
(0.56)\end{array}$ & $\begin{array}{l}0.99^{* * *} \\
(0.36)\end{array}$ & $\begin{array}{c}1.26 \\
(0.79)\end{array}$ \\
\hline Observations & 36 & 36 & 36 & 36 & 36 \\
\hline$F$ statistic, first stage & 14.57 & 19.79 & 11.69 & 11.45 & 3.28 \\
\hline $\begin{array}{l}\text { Overidentifying restrictions, } \\
J \text {-test and } p \text {-value }\end{array}$ & $\begin{array}{c}1.271 \\
(0.259)\end{array}$ & $\begin{array}{c}1.760 \\
(0.185) \\
\end{array}$ & $\begin{array}{c}0.122 \\
(0.727)\end{array}$ & $\begin{array}{c}0.504 \\
(0.478) \\
\end{array}$ & $\begin{array}{r}2.010 \\
(0.156)\end{array}$ \\
\hline
\end{tabular}

Notes: Robust standard errors in parentheses. ${ }^{* * *}$ denotes significance at the $1 \%$ level, ${ }^{* *}$ at the 5\% level, *at the 10\% level. Instruments in 2SLS for the period 1984-2014 and 1984-1995 include population in 1980 and initial log GDP per capita. Instruments in 2SLS for the period 1996-2014 include population in 1990 and initial log GDP per capita. 


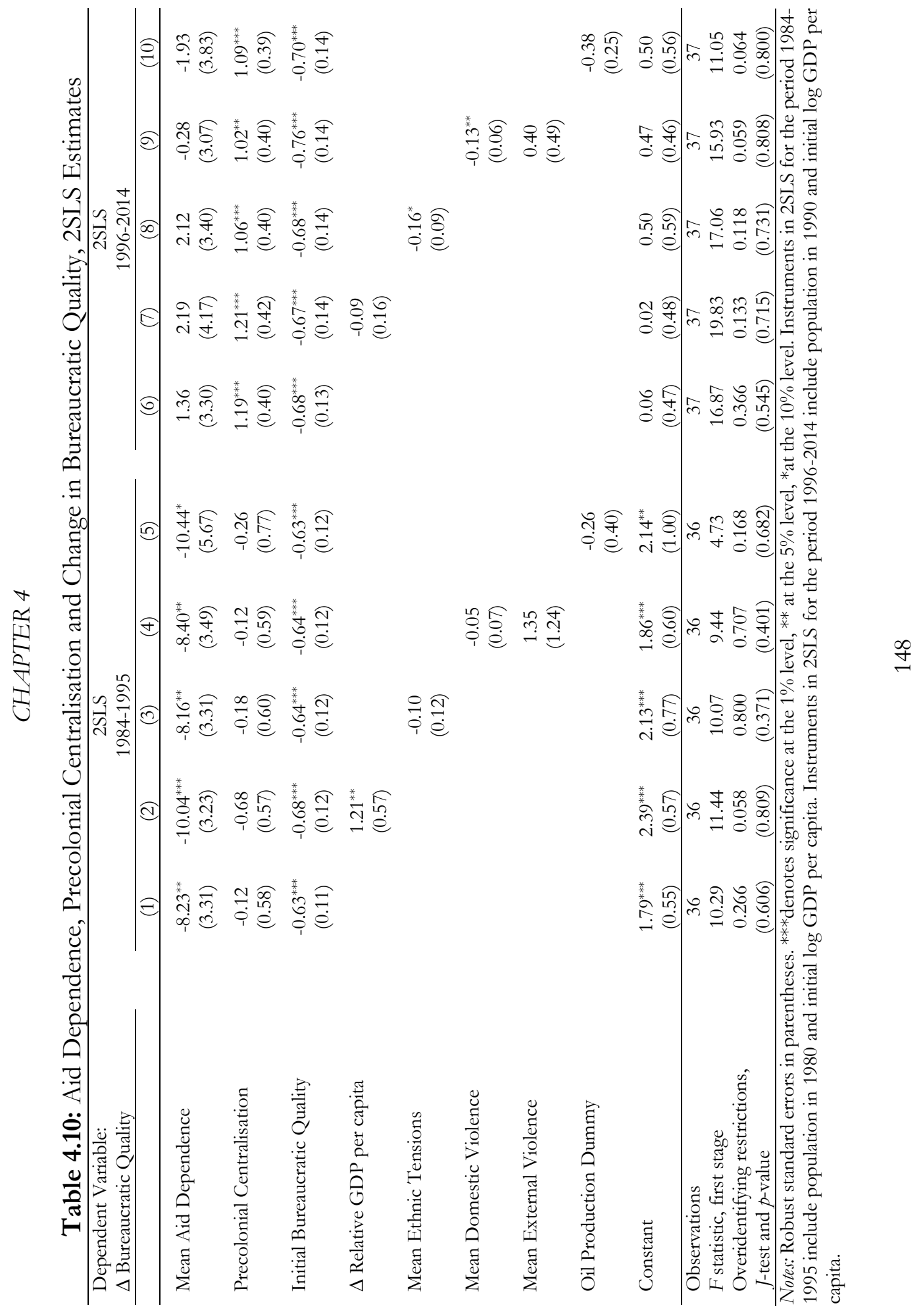




\section{CHAPTER 4}

Moreover, the instruments appear to satisfy the exogeneity assumption as can be interpreted from the high $\mathrm{p}$ values for the Hansen's J-test of overidentification. In all cases, I fail to reject the null hypothesis that my two instruments are exogenous.

I now interpret the results for the two sub-periods (Table 4.10). While the aid coefficient is strongly negative and highly statistically significant in the early period, the effect of foreign aid on bureaucratic capacity remains ambiguous for the later period. Moreover, the negative effect of foreign aid on bureaucratic quality for the period 1984-1995 is now a lot stronger when compared to my OLS estimates in Table 4.5. The relationship between precolonial centralisation and the change in state capacity for the two-sub periods is similar to the OLS estimates in Table 4.5 and Table 4.6. The main findings change very little after including other control variables. The first stage F-statistics are more often than not above the critical rule-of-thumb threshold of 10 . In all cases, I once again fail to reject the null hypothesis that my two instruments are exogenous.

\subsection{Concluding Remarks}

In this chapter I have empirically examined the ultimate and proximate determinants of contemporary state capacity in Africa. This chapter provides two key contributions. First, I have found that precolonial institutions strongly predict the level of bureaucratic capacity of current-day states. The positive relationship between precolonial statehood and contemporary state capacity, however, becomes less strong and less statistically significant the further I go back in time (and the closer I get to the colonial period). Second, when assessing changes in bureaucratic quality over time, the inclusion of precolonial centralisation in the econometric analysis nullifies the estimated negative impact of foreign aid in recent years. Aid dependence no longer has a significant influence on changes in bureaucratic quality. Hence, my results suggest that previous studies examining the link between aid and institutional quality in Africa suffer from omitted variables bias by not including measures of precolonial experience.

My work is closely related to a set of studies that find historical continuity of indigenous political institutions in Africa (Gennaioli \& Rainer, 2006). However, in contrast to earlier studies, I find that the strong link between precolonial 


\section{CHAPTER 4}

centralisation and modern institutional and political capabilities in Africa has only emerged from the late-1990s onwards. In many African countries, colonial institutions were superimposed upon deeper institutional foundations. The postcolonial institutions resulting from colonial state legacies were often incongruent with precolonial systems. As the colonial period is slowly fading, the influence of precolonial political institutions on modern state capacity is reasserting itself. The empirical findings presented in this chapter highlight the historical legacy of the precolonial bureaucratic state in Africa and provide further evidence for the importance of precolonial centralisation in our understanding of present day economic and political developments on the continent

This quantitative empirical work calls for further research, both theoretical and empirical. While it appears clear from my findings that contemporary institutional development on the African continent has deep historical roots, the channels through which these roots shape modern states are less clear. A rich understanding of these channels is going to require a combination of quantitative and qualitative analysis, ideally accompanied by theory-development. In particular, I believe that future fieldwork and case studies will paint a more complete picture of the trajectory of institutional development and state capacity in Africa from precolonial times until today. 


\section{Appendix 4.A: Descriptive Statistics}

Table 4.A1: Bureaucratic Quality and Government Effectiveness Index Country Sample

\begin{tabular}{|c|c|c|c|c|c|}
\hline Country & $\begin{array}{c}\text { BQ } \\
\text { index }\end{array}$ & $\begin{array}{c}\text { GE } \\
\text { index }\end{array}$ & Country & $\begin{array}{c}\text { BQ } \\
\text { index }\end{array}$ & $\begin{array}{c}\text { GE } \\
\text { index }\end{array}$ \\
\hline Algeria & $\mathrm{x}$ & $\mathrm{x}$ & Libya & $\mathrm{x}$ & $\mathrm{x}$ \\
\hline Angola & $\mathrm{x}$ & $\mathrm{x}$ & Madagascar & $\mathrm{x}$ & $\mathrm{x}$ \\
\hline Benin & & $\mathrm{x}$ & Malawi & $\mathrm{x}$ & $\mathrm{x}$ \\
\hline Botswana & $\mathrm{x}$ & $\mathrm{x}$ & Mali & $\mathrm{x}$ & $\mathrm{x}$ \\
\hline Burkina Faso & $\mathrm{x}$ & $\mathrm{x}$ & Mauritania & & $\mathrm{x}$ \\
\hline Burundi & & $\mathrm{x}$ & Mauritius & & $\mathrm{x}$ \\
\hline Cameroon & $\mathrm{x}$ & $\mathrm{x}$ & Morocco & $\mathrm{x}$ & $\mathrm{x}$ \\
\hline Cape Verde & & $\mathrm{x}$ & Mozambique & $\mathrm{x}$ & $\mathrm{x}$ \\
\hline $\begin{array}{l}\text { Central African } \\
\text { Republic }\end{array}$ & & $\mathrm{x}$ & Namibia & $\mathrm{x}$ & $\mathrm{x}$ \\
\hline Chad & & $\mathrm{x}$ & Niger & $\mathrm{x}$ & $\mathrm{x}$ \\
\hline Comoros & & $\mathrm{x}$ & Nigeria & $\mathrm{x}$ & $\mathrm{x}$ \\
\hline Congo Republic & $\mathrm{x}$ & $\mathrm{x}$ & Rwanda & & $\mathrm{x}$ \\
\hline Cote d'Ivoire & $\mathrm{x}$ & $\mathrm{x}$ & Sao Tome Principe & & $\mathrm{x}$ \\
\hline Dem. Rep. Congo & $\mathrm{x}$ & $\mathrm{x}$ & Senegal & $\mathrm{x}$ & $\mathrm{x}$ \\
\hline Djibouti & & $\mathrm{x}$ & Seychelles & & $\mathrm{x}$ \\
\hline Egypt & $\mathrm{x}$ & $\mathrm{x}$ & Sierra Leone & $\mathrm{x}$ & $\mathrm{x}$ \\
\hline Equatorial Guinea & & $\mathrm{x}$ & Somalia & $\mathrm{x}$ & $\mathrm{x}$ \\
\hline Eritrea & & $\mathrm{x}$ & South Africa & $\mathrm{x}$ & $\mathrm{x}$ \\
\hline Ethiopia & $\mathrm{x}$ & $\mathrm{x}$ & South Sudan & & \\
\hline Gabon & $\mathrm{x}$ & $\mathrm{x}$ & Sudan & $\mathrm{x}$ & $\mathrm{x}$ \\
\hline Gambia & $\mathrm{x}$ & $\mathrm{x}$ & Swaziland & & $\mathrm{x}$ \\
\hline Ghana & $\mathrm{x}$ & $\mathrm{x}$ & Tanzania & $\mathrm{x}$ & $\mathrm{x}$ \\
\hline Guinea & $\mathrm{x}$ & $\mathrm{x}$ & Togo & $\mathrm{x}$ & $\mathrm{x}$ \\
\hline Guinea-Bissau & $\mathrm{x}$ & $\mathrm{x}$ & Tunisia & $\mathrm{x}$ & $\mathrm{x}$ \\
\hline Kenya & $\mathrm{x}$ & $\mathrm{x}$ & Uganda & $\mathrm{x}$ & $\mathrm{x}$ \\
\hline Lesotho & & $\mathrm{x}$ & Zambia & $\mathrm{x}$ & $\mathrm{x}$ \\
\hline Liberia & $\mathrm{x}$ & $\mathrm{x}$ & Zimbabwe & $\mathrm{x}$ & $\mathrm{x}$ \\
\hline
\end{tabular}

Note: " $\mathrm{x}$ " indicates that the index is available for the respective country. The bureaucratic quality index is available for 37 African countries. The government effectiveness index is available for all African countries, except for South Sudan. 
Table 4.A2: Bureaucratic Quality in Africa Across Countries and Over Time

\begin{tabular}{|c|c|c|c|}
\hline Country & $\begin{array}{c}\text { Average } \\
\text { Bureaucratic } \\
\text { Quality, } \\
1984-2014\end{array}$ & Country & $\begin{array}{c}\text { Change in } \\
\text { Bureaucratic } \\
\text { Quality, } \\
\text { 1984-2014 }\end{array}$ \\
\hline
\end{tabular}

\section{High performing countries}

\begin{tabular}{|c|c|c|c|}
\hline South Africa & 2.83 & Ghana & 2.50 \\
\hline Kenya & 2.39 & Botswana ${ }^{\dagger}$ & 2.00 \\
\hline Namibia* & 2.36 & Gambia & 2.00 \\
\hline Botswanat & 2.24 & Guinea & 2.00 \\
\hline Ghana & 2.18 & Namibia* & 2.00 \\
\hline Zimbabwe & 2.14 & Uganda & 2.00 \\
\hline Gabon & 2.13 & Ethiopiat & 1.50 \\
\hline Morocco & 2.09 & Guinea-Bissau $¥$ & 1.50 \\
\hline Tunisia & 2.00 & Malawi & 1.50 \\
\hline Egypt & 1.97 & Niger ${ }^{\dagger}$ & 1.50 \\
\hline \multicolumn{4}{|c|}{$\underline{\text { Low performing countries }}$} \\
\hline Zambia & 0.98 & & \\
\hline Ethiopia† & 0.78 & Gabon & -0.17 \\
\hline Tanzania & 0.75 & Morocco & -0.42 \\
\hline Sudan & 0.74 & Angola & -0.50 \\
\hline Sierra Leonet & 0.48 & Zimbabwe & -0.83 \\
\hline Togo & 0.44 & Cameroon & -0.92 \\
\hline $\begin{array}{l}\text { Dem. Rep. } \\
\text { Congo }\end{array}$ & 0.38 & Senegal & -1.00 \\
\hline Somaliat & 0.16 & Togo & -1.00 \\
\hline Liberia & 0.00 & South Africa & -2.00 \\
\hline Mali & 0.00 & Cote d'Ivoire & -3.00 \\
\hline
\end{tabular}


Table 4.A3: Ranking of the Largest and Smallest Aid Recipients in Africa, 1984-2014

\begin{tabular}{lclc}
\hline \multicolumn{1}{c}{ Country } & $\begin{array}{c}\text { Average } \\
\text { ODA/GDP }(\%)\end{array}$ & Country & $\begin{array}{c}\text { Average } \\
\text { ODA/GDP (\%) }\end{array}$ \\
\hline Somalia & 24.02 & Libya & 0.07 \\
Liberia & 21.70 & Tunisia & 0.10 \\
Mozambique & 19.44 & South Africa & 0.17 \\
Sao Tomé and Principe & 19.40 & Algeria & 0.25 \\
Guinea-Bissau & 18.69 & Nigeria & 0.73 \\
Cape Verde & 16.76 & Mauritius & 0.94 \\
\hline
\end{tabular}

Source: Own calculations based on OECD DAC Statistics and World Development Indicators.

Table 4.A4: Precolonial Political Centralisation in Africa

\begin{tabular}{|c|c|c|c|}
\hline Country & Centralisation & Country & Centralisation \\
\hline Comoros & 1 & Angola & 0.635 \\
\hline Lesotho & 1 & Uganda & 0.634 \\
\hline Swaziland & 1 & Togo & 0.622 \\
\hline Burundi & 0.995 & Niger & 0.582 \\
\hline Algeria & 0.990 & Sudan & 0.576 \\
\hline Egypt & 0.990 & Congo Republic & 0.536 \\
\hline South Africa & 0.990 & Madagascar & 0.505 \\
\hline Rwanda & 0.982 & Nigeria & 0.478 \\
\hline Tunisia & 0.980 & Gambia & 0.426 \\
\hline Zimbabwe & 0.965 & Guinea & 0.406 \\
\hline Libya & 0.940 & Chad & 0.384 \\
\hline Botswana & 0.893 & Burkina Faso & 0.338 \\
\hline Malawi & 0.861 & Cameroon & 0.316 \\
\hline Mauritania & 0.858 & Guinea-Bissau & 0.214 \\
\hline Mozambique & 0.844 & Equatorial Guinea & 0.211 \\
\hline Ethiopia & 0.843 & Kenya & 0.172 \\
\hline Morocco & 0.810 & Central African Republic & 0.144 \\
\hline Zambia & 0.743 & Djibouti & 0.133 \\
\hline Benin & 0.695 & Mali & 0.115 \\
\hline Senegal & 0.694 & Cote d'Ivoire & 0.082 \\
\hline Tanzania & 0.669 & Somalia & 0.034 \\
\hline Namibia & 0.664 & Gabon & 0.011 \\
\hline Ghana & 0.651 & Sierra Leone & 0.008 \\
\hline \multirow[t]{2}{*}{ Dem. Rep. Congo } & 0.649 & Liberia & 0 \\
\hline & & $\begin{array}{l}\text { AVERAGE } \\
\text { (non-weighted) }\end{array}$ & 0.587 \\
\hline
\end{tabular}

Note: The precolonial political centralisation index measures the share of the Non-European population that had centralised political institutions before colonisation. Data is missing for Cape Verde, Eritrea, Mauritius, Sao Tome and Principe, Seychelles and South Sudan.

Source: Gennaioli and Rainer (2007). 
Table 4.A5: Bivariate Correlation between Precolonial Centralisation and Bureaucratic Quality, 1984-2014

\begin{tabular}{lcccccccc}
\hline Year & $\begin{array}{c}\text { Precolonial } \\
\text { Centralisation } \\
\text { Coefficient }\end{array}$ & $\begin{array}{c}\text { Sample } \\
\text { Size }\end{array}$ & Year & $\begin{array}{c}\text { Precolonial } \\
\text { Centralisation } \\
\text { Coefficient }\end{array}$ & $\begin{array}{c}\text { Sample } \\
\text { Size }\end{array}$ & $\begin{array}{c}\text { Year } \\
\text { Centralisation } \\
\text { Coefficient }\end{array}$ & $\begin{array}{c}\text { Sample } \\
\text { Size }\end{array}$ \\
\hline $\mathbf{1 9 8 4}$ & 0.532 & 25 & $\mathbf{1 9 9 4}$ & 0.815 & 37 & $\mathbf{2 0 0 4}$ & $1.321^{* * *}$ & 37 \\
$\mathbf{1 9 8 5}$ & 0.252 & 34 & $\mathbf{1 9 9 5}$ & 0.795 & 37 & $\mathbf{2 0 0 5}$ & $1.322^{* * *}$ & 37 \\
$\mathbf{1 9 8 6}$ & 0.278 & 36 & $\mathbf{1 9 9 6}$ & 0.737 & 37 & $\mathbf{2 0 0 6}$ & $1.281^{* * *}$ & 37 \\
$\mathbf{1 9 8 7}$ & 0.226 & 36 & $\mathbf{1 9 9 7}$ & 0.811 & 37 & $\mathbf{2 0 0 7}$ & $1.301^{* * *}$ & 37 \\
$\mathbf{1 9 8 8}$ & 0.252 & 36 & $\mathbf{1 9 9 8}$ & $0.948^{* *}$ & 37 & $\mathbf{2 0 0 8}$ & $1.319^{* * *}$ & 37 \\
$\mathbf{1 9 8 9}$ & 0.361 & 36 & $\mathbf{1 9 9 9}$ & $0.889^{* *}$ & 37 & $\mathbf{2 0 0 9}$ & $1.332^{* * *}$ & 37 \\
$\mathbf{1 9 9 0}$ & 0.532 & 36 & $\mathbf{2 0 0 0}$ & $1.121^{* * *}$ & 37 & $\mathbf{2 0 1 0}$ & $1.262^{* * *}$ & 37 \\
$\mathbf{1 9 9 1}$ & 0.730 & 37 & $\mathbf{2 0 0 1}$ & $1.142^{* * *}$ & 37 & $\mathbf{2 0 1 1}$ & $1.262^{* * *}$ & 37 \\
$\mathbf{1 9 9 2}$ & 0.817 & 37 & $\mathbf{2 0 0 2}$ & $1.194^{* * *}$ & 37 & $\mathbf{2 0 1 2}$ & $1.262^{* * *}$ & 37 \\
$\mathbf{1 9 9 3}$ & 0.815 & 37 & $\mathbf{2 0 0 3}$ & $1.220^{* * *}$ & 37 & $\mathbf{2 0 1 3}$ & $1.275^{* * *}$ & 37 \\
& & & & & & $\mathbf{2 0 1 4}$ & $1.314^{* * *}$ & 37 \\
\hline
\end{tabular}

Note: $* * *$ denotes significance at the $1 \%$ level, ${ }^{* *}$ at the $5 \%$ level, $*$ at the $10 \%$ level. The coefficient on precolonial centralisation is identical for the years 2010, 2011 and 2012 because bureaucratic quality levels remained the same for all countries in the sample during those years. 
Table 4.A6: Tsetse Suitability Index in Africa at the National Level

\begin{tabular}{llll}
\hline Country & TSI & Country & TSI \\
\hline Equatorial Guinea & 1.475 & Namibia & -0.329 \\
Gabon & 1.403 & Algeria & -0.345 \\
Liberia & 1.123 & Sudan & -0.352 \\
Congo Republic & 1.015 & Guinea-Bissau & -0.378 \\
Cameroon & 0.986 & Burkina Faso & -0.390 \\
Cote d'Ivoire & 0.978 & Malawi & -0.420 \\
Sierra Leone & 0.850 & Kenya & -0.430 \\
Central African Republic & 0.815 & Zambia & -0.434 \\
Mozambique & 0.807 & Eritrea & -0.482 \\
Benin & 0.754 & Tanzania & -0.530 \\
Dem. Rep. Congo & 0.725 & Niger & -0.692 \\
Togo & 0.601 & Burundi & -0.729 \\
Ghana & 0.541 & Mauritania & -0.822 \\
Guinea & 0.526 & Rwanda & -0.875 \\
Somalia & 0.489 & Zimbabwe & -0.956 \\
Botswana & 0.369 & Mali & -0.963 \\
Libya & 0.329 & Senegal & -0.994 \\
Nigeria & 0.285 & Ethiopia & -1.021 \\
Uganda & 0.283 & Swaziland & -1.131 \\
Angola & 0.278 & Morocco & -1.205 \\
Egypt & 0.050 & Tunisia & -1.265 \\
Chad & -0.244 & South Africa & -2.708 \\
\hline Nots:The Tre
\end{tabular}

Notes: The Tsetse Suitability Index has originally been constructed at the regional level for 522 mainland-associated African ethnic groups (Alsan, 2015). African ethnic groups from Cape Verde, Comoros, Djibouti, Gambia, Lesotho, Madagascar, Mauritius, Sao Tomé and Principe and Seychelles were not included in the analysis. In order to construct a TSI index at the national level, I use land area of ethnic groups as weight. Data on land area at the sub-regional level comes from Fenske (2014). I therefore join Alsan's ethnic groups with Fenske's land area data. Unfortunately, land area is not available for each mainland-associated ethnic group. This leaves me with 467 ethnic groups for which I have data on both the TSI and land area. I then sort the 467 mainland-associated ethnic groups according to country. The data shows huge variations in terms of ethnic groups per country. While I have 60 observations for Nigeria (Igbo, Yoruba, Woodabe, Kanuri, among others), I have only two observations for Somalia (Somali, Bajun), and only one observation for Swaziland (Swazi). I then calculate the national TSI for each country. 


\section{Appendix 4.B: List of Figures}

Figure 4.B1: Relationship between Precolonial Centralisation and State Capacity (Other Years)

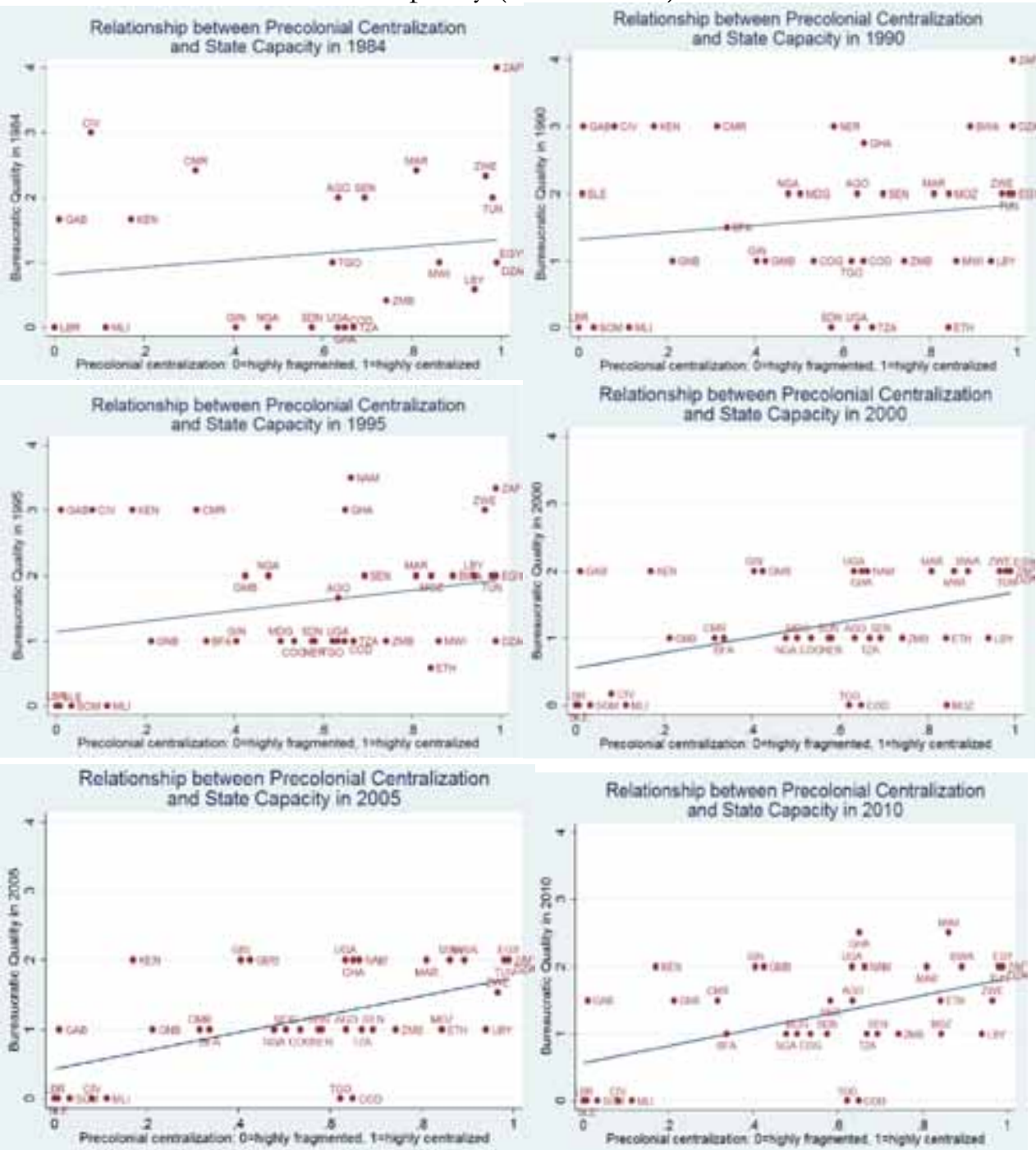




\section{CHAPTER 4}

Figure 4.B2: Relationship between Precolonial Centralisation and Foreign Aid (Other Periods)

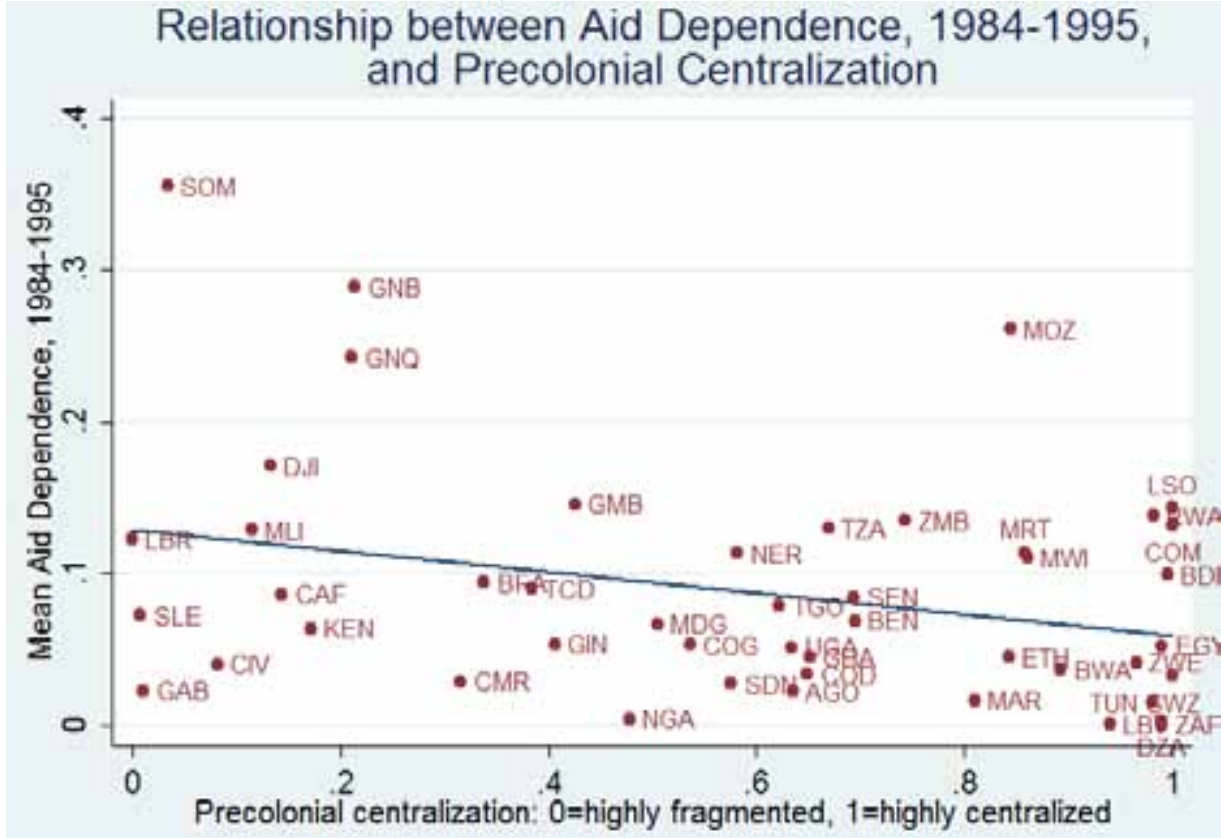

Relationship between Aid Dependence, 1996-2014, and Precolonial Centralization

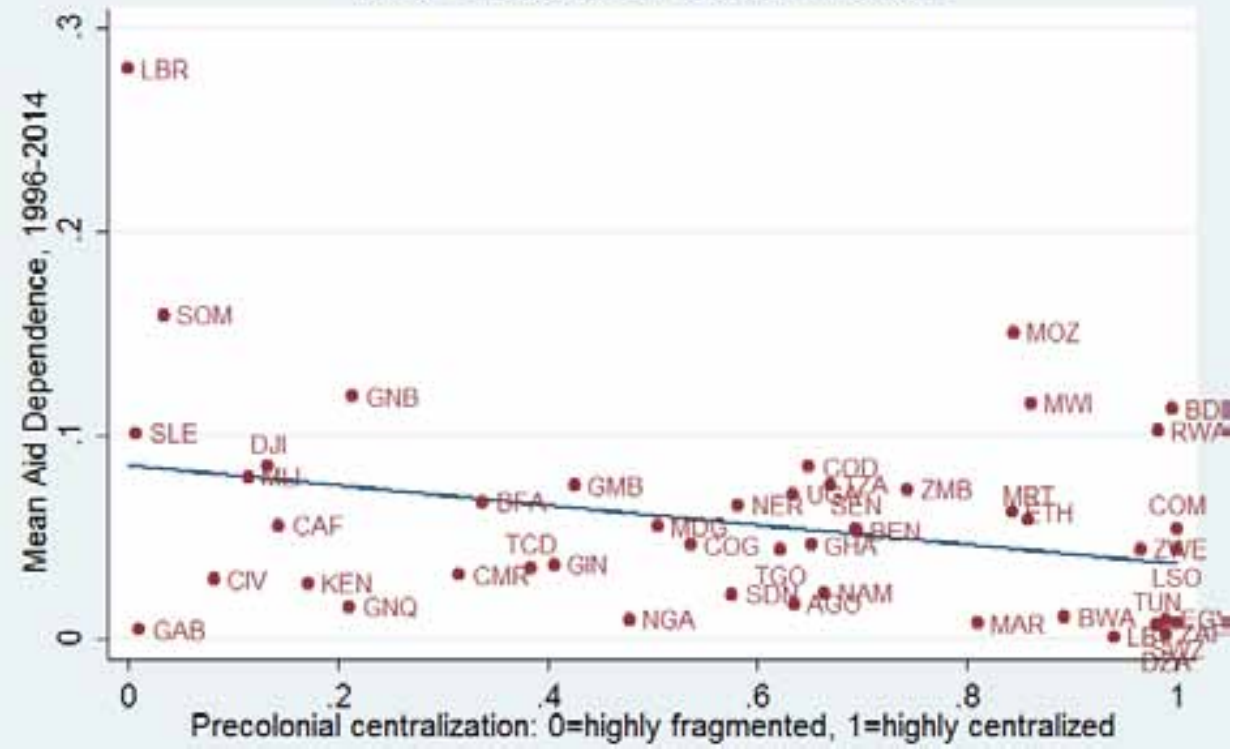

Appendix 4.C: List of Tables 


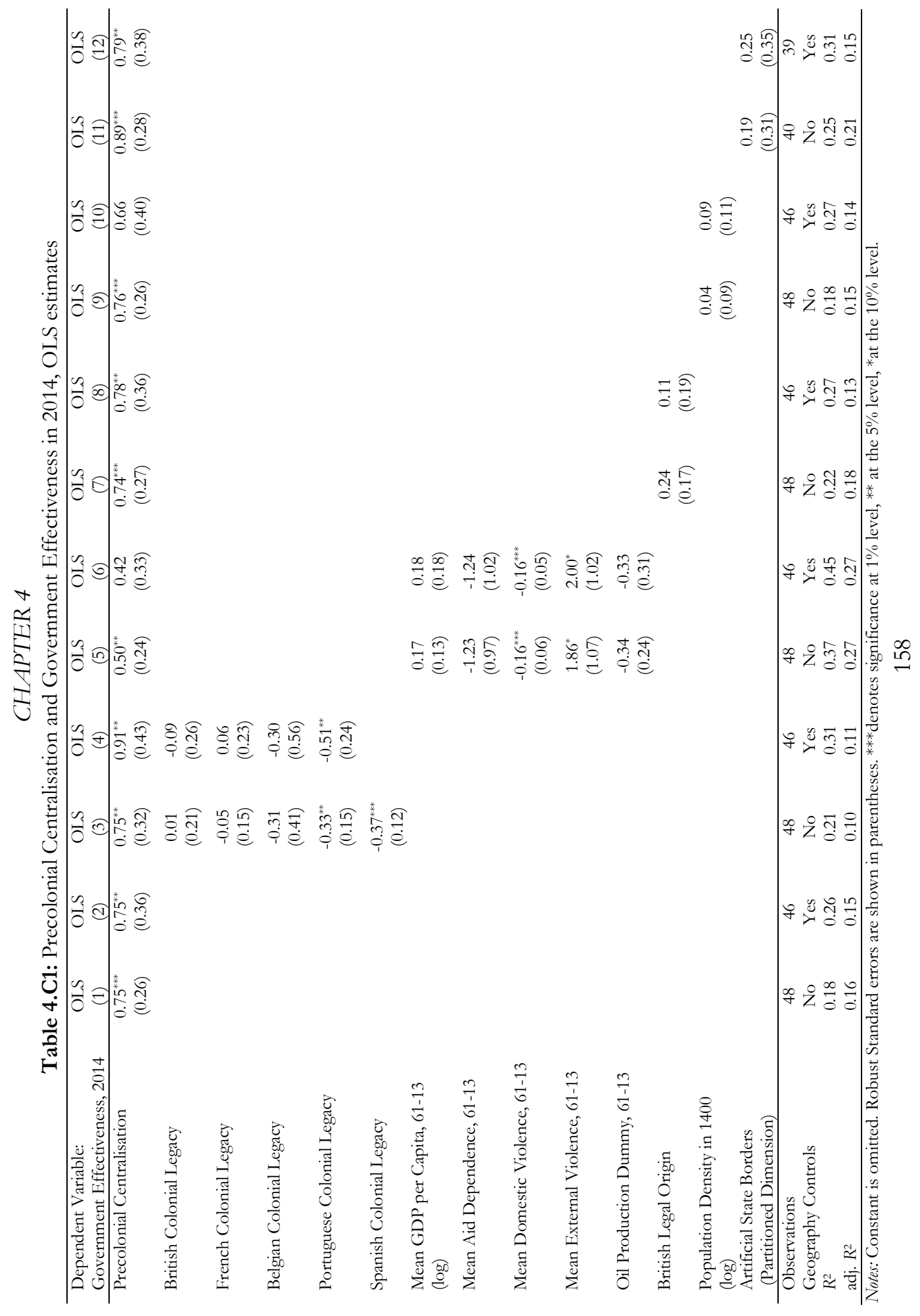




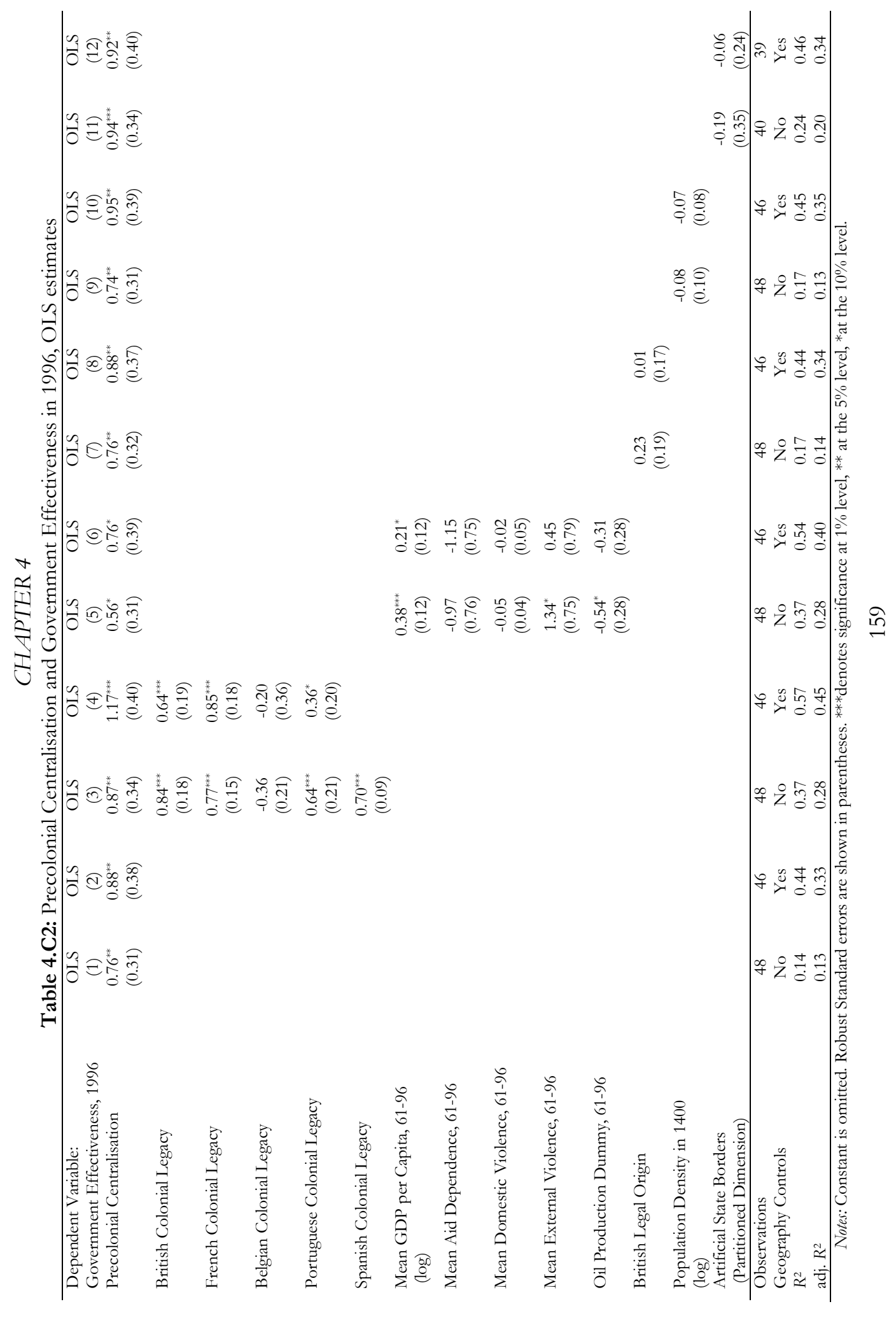




\section{Appendix 4.D: Data and Sources}

\section{Dependent Variables}

Bureaucratic The quality of the bureaucracy is a proxy for institutional strength. Quality Bureaucratic Quality tends to minimise revisions of policy when governments change. Therefore, high points are given to countries where the bureaucracy has the strength and expertise to govern without drastic changes in policy or interruptions in government services. In these low-risk countries, the bureaucracy tends to be somewhat autonomous from political pressure and tends to have an established mechanism for recruitment and training. Countries that lack the cushioning effect of a strong bureaucracy receive low points because a change in government tends to be traumatic in terms of policy formulation and day-to-day administrative functions. Scale is $0-4$.

Source: ICRG Index from PRS Group.

Government Captures perceptions of the quality of public services, the quality of civil Effectiveness service and the degree of its independence from political pressure, the quality of policy formulation and implementation, and the credibility of the government's commitment to such policies. Scale: The composite measure is measured in units of standard normal distribution, with mean zero, standard deviation of one, and running from approximately -2.5 to 2.5 , with higher values corresponding to better government effectiveness.

Source: The Worldwide Governance Indicators (WGI) published by the World Bank.

\section{Explanatory Variables}

Aid Annual total DAC-ODA Net Disbursements in current dollars. Dependence Western aid flows include net disbursements from DAC donors only. GDP is expressed in current dollars.

Source: OECD/DAC database (2014) for Western aid flows in current dollars. World Development Indicators from World Bank (2014) for GDP data in current dollars.

Precolonial For each country, the index measures the share of the non-European Centralisation population that belongs to indigenously "centralised" ethnic groups. Scale is $0-1$. An ethnic group is defined as "centralised" if it has 2,3 , or 4 jurisdictional levels above the local community according to Murdock's Jurisdictional Hierarchy variable. It is defined as "fragmented" if it has 0 or 1 jurisdictional levels above the local community.

Source: Constructed by Gennaioli and Rainer (2007) using Murdock (1967) and Atlas Narodov Mira (Bruk \& Apenchenko, 1964).

\section{Control Variables}

\section{Historical determinants}

Colonial Ethiopia and Liberia are the only two countries I classify as independent. Legacy I follow the approach taken by Bertocchi and Canova (2002). The former German colonies - Burundi, Cameroon, Rwanda, Tanzania and Togo - were taken over by new colonial rulers after the First World War (WWI). Consequently, I will divide them among the countries that took them over after 1918. Morocco is considered a former French colony, 


\section{CHAPTER 4}

even though it was a joint protectorate of France and Spain. Moreover, I have classified Somalia as a British colony, even if there were also (bigger) Italian and (smaller) French portions. Burundi and Rwanda became Belgian colonies, while Tanzania was under British rule after WWI. Cameroon and Togo were subject to a joint French and British mandate. I list Togo under French rule, because the country consists of the French portion only while the British part has been annexed to Ghana. I place Cameroon under France since it is currently a member of the CFA-franc zone.

Slave Exports

Years of Independence

State Antiquity Index
Source: Bertocchi and Canova (2002).

a) Number of slave exports normalised by size, measured by land area in square kilometres.

b) Number of slave exports normalised by size, measured by average population between 1400 and 1900 .

No slave exports are recorded for Botswana, Cape Verde, Comoros, Lesotho, Mauritius, Morocco, Rwanda, Sao Tomé and Principe, Swaziland, Seychelles and Tunisia. Because the natural logarithm of zero is undefined, the natural logarithm of 0.1 is taken for zero-export countries.

Source: Nunn (2008)

http://scholar.harvard.edu/nunn/pages/data-0

Years of a country's independence from colonial rule. The only two African countries that were not colonised are Liberia and Ethiopia. Liberia proclaimed independence in 1847. I use the year 1855 as independence year for Ethiopia. In 1855 Ethiopia was reunified by the Emperor Tewodros II. Many historians view the coronation of Emperor Tewodros II as the beginning of Ethiopia's modern history.

Measures the depth of experience with state-level institutions. The authors began dividing the period 1 to 1950 C.E. into 39 half centuries. Years before 1 C.E. were ignored on the grounds that the experience of more than 2000 years ago would be unlikely to have much effect today, and in order to avoid low-return research effort using low quality information. For each period of fifty years, they asked three questions (and allocated points) as follows:

1.) Is there a government above the tribal level? ( 1 point if yes, 0 points if no); 2.) Is this government foreign or locally based? (1 point if locally, 0.5 points if foreign [i.e., the country is a colony], 0.75 if in between [a local government with substantial foreign oversight]); 3.) How much of the territory of the modern country was ruled by the government? ( 1 point if over $50 \%, 0.75$ points if between $25 \%$ and $50 \%, 0.5$ points if between $10 \%$ and $25 \%, 0.3$ points if less than $10 \%$ ).

Answers were extracted from the historical accounts on each of the countries in the Encyclopaedia Britannica. For a given fifty-year period, what is today a country has a score of 50 if it is an autonomous nation, 0 if it had no government above the tribal level, 25 if the entire territory was ruled by another country, and so on. To combine the data of the 39 periods, the authors tried alternative rates for discounting the influence of the past, ranging from 0 to a discount of $50 \%$ for each half century. In their analysis, the authors mainly focus on the variable statehist 05 , which has a discount rate of $5 \%$. For that reason, I am using the same 


\section{CHAPTER 4}

variable. Scale is $0-1$. Higher values are associated with more depth of experience with state-level institutions.

Source: Bockstette, Chanda and Putterman (2002).

http://www.econ.brown.edu/fac/louis putterman/antiquity $\% 2$

0index.htm

Ancient state Logarithm of Discounted Sum of Years of Ancient Statehood, 1 AD to history 1950 AD.

\section{Political determinants}

Source: Putterman (2007).

Vertical

Legitimacy

Artificial State

Borders

Communist

Legacy

Executive

Constraints
Dummy variable that takes on the value of 1 if the post-colonial state is embedded into precolonial relations of authority. Dummy $=1$ for Botswana, Burundi, Cape Verde, Ethiopia, Lesotho, Mauritius, Rwanda, Sao Tome and Principe, Seychelles, Swaziland.

Source: Englebert (2000).

Measures the degree to which country borders are natural or artificial. Partitioned dimension: Defined as "the percentage of a country's population that belongs to a partitioned group. The latter is a group that is present in two bordering countries." Fractal dimension: Captures the straightness or squiggliness of country borders. The fractal dimension variable is $\log$ transformed. The rationale behind the construction of the fractal measure is based on the assumption that borders drawn with straight lines increase the chances that those borders were drawn artificially, while squiggly lines are less likely to be artificial. Since the partitioned dimension turns out to be considerably more robust in the analysis by Alesina, Easterly and Matuszeski (2011), I will use the partitioned measure as my proxy for the level of artificial state characteristics in the main analysis.

Source: Alesina, Easterly and Matuszeski (2011).

Dummy variable that takes on the value of 1 if a country has been under communist rule. The following countries were under communist rule. Angola: 1975-1992; Benin 1975-1990; Congo Republic 1970-1992; Eritrea 1993-today; Ethiopia 1974-1991; Mozambique 1975-1990; Somalia 1976-1991.

Source: Constructed by the author.

This variable refers to the extent of institutionalised constraints on the decision-making powers of chief executives, whether individuals or collectivities. Such limitations may be imposed by any "accountability groups." In Western democracies, these are usually legislatures. Other kinds of accountability groups are the ruling party in a one-party state, councils of nobles or powerful advisors in monarchies, the military in coup-prone polities, and in many states a strong independent judiciary. The concern is therefore with the checks and balances between the various parts of the decision-making process. Scale is 1-7. A high value equates to high constraints on the executive concomitant with effective checks and balances systems. I am using three different variables: i) Constraints on the executive in the first year of independence (i.e. the first year a country enters the data set); ii) Mean constraints on the executive between first year of independence and 2013; iii) Mean constraints on the executive between 1961 and 2013. 


\section{CHAPTER 4}

Source: Jaggers and Gurr (1995); Marshall, Jaggers and Gurr (2014). Center for Systemic Peace. Polity IV Project, Political Regime Characteristics and Transitions, 1800-2013.

Internal This is an assessment of political violence in the country and its actual Conflict

External or potential impact on governance. To avoid awkwardness in interpreting the coefficients, I recoded the measure so that a high number reflects a higher degree of internal conflict. The lowest rating is given to those countries where there is no armed or civil opposition to the government and the government does not indulge in arbitrary violence, direct or opposition to the government and the government does not indulge in arbitrary violence, direct or indirect, against its own people. The highest rating is given to a country embroiled in an on-going civil war. Scale is $0-12$.

Source: ICRG Index from PRS Group.

Conflict

The external conflict measure is an assessment both of the risk to the incumbent government from foreign action, ranging from non-violent external pressure (diplomatic pressures, withholding of aid, trade restrictions, territorial disputes, sanctions, etc.) to violent external pressure (cross-border conflicts to all-out war). To avoid awkwardness in interpreting the coefficients, I recoded the measure so that a high number reflects a higher degree of external conflict. A low score equates to a very low risk and a high score equates to a very high risk. Scale is 0 12.

Source: ICRG Index from PRS Group.

Domestic Total summed magnitudes of all societal major episodes of political Violence violence (civil/ethnic violence and civil/ethnic war). Scale is $0-10$. Source: Marshall (2014). Centre for Systemic Peace. Major Episodes of Political Violence, 1946-2013 (War List).

External Total summed magnitudes of all interstate major episodes of political Violence violence (interstate violence and war). Scale is $0-10$.

Source: Marshall (2014). Centre for Systemic Peace. Major Episodes of Political Violence, 1946-2013 (War List).

\section{Economic determinants}

GDP per GDP per capita in current and constant (2005) dollars.

capita Sources: Maddison (2010). Statistics on World Population, GDP and Per Capita GDP, 1-2008 AD. Groningen Growth and Development Center (GGDC), University of Groningen, The Netherlands: http://www.ggdc.net/maddison/oriindex.htm; World Development Indicators, World Bank.

Gross Public Gross public revenue per capita in 1925 and 1929. Measured in 1911 Revenue per British pounds.

capita Source: Frankema and van Waijenburg (2014).

\section{Legal determinants}

Legal Origin Identifies the legal origin of the company law or commercial code of each country. There are originally five possible origins: (1) English Common Law, (2) French Commercial Code, (3) Socialist/Communist Laws, (4) German Commercial Code and (5) Scandinavian Commercial Code. Legal systems in Africa either belong to the English common law or the French civil law family. Dummy variable that takes on the value 


\section{CHAPTER 4}

of 1 for countries with English legal origin, 0 for countries with French legal origin.

Cultural determinants

Source: La Porta et al. (1999).

Ethnolinguistic Measures the probability that two randomly selected people from a Fractionali-

sation given country will not belong to the same ethnolinguistic group. Scale is $0-1$. A higher index is associated with a higher probability and therefore corresponds to higher ethnolinguistic fractionalisation.

Source: Easterly and Levine (1997).

Polarisation Measures the degree to which several ethnic groups are dominant in a Index country. Levels of ethnic polarisation vary with the size of rival ethnic groups. A higher index is associated with a higher polarisation (e.g. two rivalling ethnic groups have more or less the same size). A lower index is associated with a lower polarisation (e.g. the disparity in size between the majority and minority ethnic group is large).

Source: Montalvo and Reynal-Querol (2005).

Ethnic This component is an assessment of the degree of tension within a Tensions country attributable to racial, nationality, or language divisions. To avoid awkwardness in interpreting the coefficients, I recoded the measure so that a high number reflects a higher degree of ethnic tensions. Higher ratings are given to countries where racial and nationality tensions are high because opposing groups are intolerant or unwilling to compromise. Lower ratings are given to countries where tensions are minimal. Scale is $0-6$.

Source: ICRG Index from PRS Group.

Religion Identifies the percentage of the population of each country that belonged to the three most widely spread religions in the world in 1980. The numbers are in $\%$ (scale from 0 to 100). The three religions identified are Roman Catholic, Protestant, and Muslim. The residual is called "other religions".

Source: La Porta et al. (1999).

\section{Geographical determinants}

Oil Production Indicator ranges between 0 and 1. Equal to 1 if country was oil producer Dummy in each year in the period studied. Equal to 0 if country has never been an oil producer in each year in the period studied. Intermediate value (between 0 and 1) otherwise.

Source: Own calculations based on U.S. Energy Information Administration (EIA) Agency and Ross (2013-02), "Oil and Gas Data, 1932-2011".

Oil production Average annual oil production per thousand inhabitants from 1970 to 2000. Crude petroleum is measured in thousands of carats.

Source: Nunn (2008) using British Geological Survey's World Mineral Statistics and World Mineral Production http://scholar.harvard.edu/nunn/pages/data-0

Gold Average annual gold production per thousand inhabitants from 1970 to production 2000. Mined gold is measured in kilograms.

Source: Nunn (2008) using British Geological Survey's World Mineral Statistics and World Mineral Production http://scholar.harvard.edu/nunn/pages/data-0 


\section{CHAPTER 4}

Diamond

production

Tsetse

Suitability

Index (TSI)

Latitude

Climate zone

$\mathrm{A}$ and zone $\mathrm{B}$

Distance

Mountainous

Terrain

\section{Demographic determinants} boundary.

Average annual diamond production per thousand inhabitants from 1970 to 2000. Diamonds include both gemstones and industrial diamonds and are measured in thousands of carats.

Source: Nunn (2008) using British Geological Survey's World Mineral Statistics and World Mineral Production http://scholar.harvard.edu/nunn/pages/data-0

The Tsetse suitability index (TSI) is a measure for the potential prevalence of the Tsetse fly in a region. Using the potential rather than the observed prevalence as index purges the estimates of bias arising from states with stronger institutions being better able to control the fly. A high index corresponds to a highly Tsetse suitable area. A low index corresponds to a less Tsetse suitable area within Africa. The index is created using insect physiology and demographic modelling.

Source: Alsan (2015).

Latitude of country centroid. In those countries where the country centroid fell in the ocean, it was moved to within the nearest land

Source: Gallup, Sachs and Mellinger (1999).

Population

Total population is based on the de facto definition of population which counts all residents regardless of legal status or citizenship. Refugees not permanently settled in the country of asylum are generally considered to be part of the population of their country of origin.

Source: Maddison (2010), Bolt and van Zanden (2014). Statistics on World Population, GDP and Per Capita GDP, 1-2008 AD. Groningen Growth and Development Centre (GGDC), University of Groningen, The Netherlands. http://www.ggdc.net/maddison/oriindex.htm; World Development Indicators, World Bank.

Population Total population in 1400 divided by land area in square kilometres. Total Density population is based on the de facto definition of population which counts all residents regardless of legal status or citizenship. Refugees not permanently settled in the country of asylum are generally considered to be part of the population of their country of origin. Land area is a country's total area, excluding area under inland water bodies. The definition of inland water bodies includes major rivers and lakes.

Source: McEvedy and Jones (1975).

$\%$ of

European Measure of European settlements. \% of population that was European descent or of European descent in 1900. Scale is 0-100.

Sources: McEvedy and Jones (1975) and Curtin, Feierman, Thompson and Vansina (1995). 


\section{PART B}

"Ethiopia has always held a special place in my own imagination and the prospect of visiting Ethiopia attracted me more strongly than a trip to France, England, and America combined. I felt I would be visiting my own genesis, unearthing the roots of what made me an African. Meeting the Emperor himself would be like shaking hands with history."

- Nelson Mandela, 1995

(1918-2013)

President of South Africa, 1994-1999

Citation is quoted from Mandela's Autobiography Long Walk, to Freedom 


\section{CHAPTER 5}

\section{U.S. AND SOVIET FOREIGN AID \\ DURING THE COLD WAR: \\ A HISTORICAL CASE STUDY OF \\ ETHIOPIA}

"History, in general, only informs us what bad government is." - Thomas Jefferson, 1807

(1743-1826)

$3^{\text {rd }}$ President of the United States

"History repeats itself, first as tragedy, then as farce." - Karl Marx, 1852 (1818-1883)

German philosopher, social scientist, historian and revolutionary

"Ethiopia is our closest friend in Africa."

- Henry Kissinger, 1969

United States National Security Advisor (1969-1975) $56^{\text {th }}$ United States Secretary of State (1973-1977) 


\subsection{Introduction}

This chapter provides a historical perspective of Ethiopia's position in the international aid game during the Cold War era. Using Ethiopia as an in-depth case study of the 'aid game', I will discuss the historical interrelationships between the international donor community and the two successive Ethiopian recipient governments led by Haile Selassie (1941-1974) and Mengistu Haile Mariam (1974-1991).

The country of Ethiopia is used as a case study since a rigorous analysis of the evolution of the development finance game can probably nowhere be better applied than in Ethiopia. Foreign aid has played a major role in Ethiopia's development efforts since the end of the Second World War (WWII) (McVety, 2012; Metaferia, 2009; Zewde, 1991). With regard to its foreign policy, both the Imperial Government of Ethiopia under Haile Selassie and the Marxist government under Mengistu Haile Mariam have been considered classic examples of Metternichean realpolitik, "resolutely identifying their state interests and pursuing them” (De Waal, 2004, p. 182). In historical terms, Ethiopia's foreign policy was primarily rooted in "Westphalian principles with its emphasis on the security, territorial integrity and sovereignty of the Ethiopian state" (Tadesse, 2015, p. 334) which has often been exemplified in the Ethiopian government's aid negotiation process with the international donor community.

Ethiopia was ranked as one of the most aid dependent countries during the Cold War period and is still one of the poorest nations in the world. As this case study will show, the Ethiopian government under Haile Selassie became completely dependent on the goodwill of the United States, while the Marxist government under Mengistu Haile Mariam became completely dependent on the fortunes of the Soviet Union. Between 1954 and 1974, the United States became Ethiopia's most important source of foreign finance, and Ethiopia, in turn, was considered the major strategic partner for the United States in the Horn of Africa (McVety, 2012). In the mid-1970s, the Soviet Union joined the foreign aid game in a global contest for power and influence in the Horn of Africa (Lefebvre, 1991; Patman, 1990). Somalia became the first Sub-Saharan African country to sign a friendship and cooperation treaty with the Soviet Union. In 1978, the two superpowers suddenly switched sides. After the overthrow of the imperial government under Selassie, the Derg regime under Mengistu Haile Mariam was to rule the country 


\section{CHAPTER 5}

until 1991. Ethiopia, a traditional American ally, turned Marxist and the Soviet Union became Ethiopia's main source of foreign finance. Ethiopia's neighbouring country, Somalia, a traditional Soviet ally, turned to the United States and U.S.-Somali relationships strengthened during the 1980s (Lefebvre, 1991; Patman, 1990; Westad, 2005; Yordanov, 2016).

There are three major conclusions that we can draw from this historical case study of Ethiopia in the Cold War era. First, the fact that the two superpowers switched sides at the apex of the Cold War in the Horn of Africa clearly demonstrates how the countries of Ethiopia and Somalia became classic examples of pawns in Cold War politics. The Horn of Africa has been considered one of the most strategic locations for the international donor community. Foreign aid did not primarily serve humanitarian and developmental ends, but to a very large extent strategic ends.

Second, this case study demonstrates how recipient governments can use international development assistance as a tool to implement as much of their policy agenda as possible. The notion that governments receiving foreign aid are passive subjects is flawed. In fact, both successive Ethiopian regimes have been just as active as players in the aid game as the donor countries during the Cold War. Both the imperial and the Marxist government aimed at maximizing external financial resources while minimizing the amount of loss of sovereignty over their policy agenda.

Third, the 1984-86 famine of unprecedented proportions in the Horn of Africa, one of the most food-insecure regions in the world, convincingly highlights the moral dilemma that the international donor community faced when assisting non-democratic recipient states. Attributing the 1984-86 famine mainly to the long drought between July and September 1983, crop failure and the slow response by the international donor community omits the crucial social and political context in which the famine took place (De Waal, 1991; Gill, 1986; Kaplan, 2003; Kissi, 2000, 2005). The massive mobilization of humanitarian intervention and relief assistance during and in the immediate aftermath of the 1984-86 famine also contributed, though unintentionally, to the prolonged life of the communist government under Mengistu. 


\section{CHAPTER 5}

Ethiopia's history provided valuable lessons for the transitional government of Ethiopia that assumed office in 1991.84 The lack of economic development as well as widespread death caused by famine had contributed to the demise of the two previous Ethiopian governments during the Cold War era. Additionally, the large financial and military dependence of both the imperial government and the Marxist government on one major ally (United States and Soviet Union, respectively) also played an important role in the overthrow of both Haile Selassie and Mengistu Haile Mariam. In both periods, the demise of the Ethiopian government can partly be attributed to the instability of aid flows and aid fatigue. As a result, economic growth and poverty reduction would have to become major pillars of the transitional government's domestic policy agenda. Securing multiple sources of foreign finance through taking a much more pragmatic stance towards the international donor and investor community would have to become major pillars of the transitional government's foreign policy agenda (see Chapter 6).

The rest of this chapter proceeds as follows. Section 5.2 briefly provides background information on Ethiopia. Section 5.3 examines the evolution of the aid game under Selassie's imperial government and Mengistu's Marxist government. Section 5.4 provides a discussion on the findings. Section 5.5 concludes.

\subsection{Country Background}

Ethiopia is a landlocked country located in the Horn of Africa, one of the most food-insecure and conflict-ridden regions in the world. The country is bordered by Eritrea to the north, Djibouti and Somalia to the east, Sudan and South Sudan to the west, and Kenya to the south (see Map 5.1). Home to a population of more than 100 million, Ethiopia is not only the second-most populous nation in Africa after Nigeria, but also the most populous landlocked country in the world.

\footnotetext{
84 After the overthrow of the Mengistu regime in 1991, a transitional government ruled the country until 1995. Meles Zenawi was the president of the transitional government and Tamrat Layne acted as the prime minister. Between May and June 1995, Ethiopia held a general election and a new constitution became effective on 21 August 1995, thereby ending the transition period (see Chapter 6 for more information).
} 


\section{CHAPTER 5}

The Ethiopian territory covers a total area of 1,100,000 square kilometres (420,000 square miles). Its capital and largest city is Addis Ababa.

Today, Ethiopia is divided into nine administrative regions called kililoch (singular - kilil) and two special city administrations. The two city administrations are Addis Ababa and Dire Dawa. The division of the nine administrative regions is ethnicity based. The nine administrative regional states are (i) Afar, (ii) Amhara, (iii) Benishangul-Gumuz, (iv) Gambela, (v) Harari, (vi) Oromia, (vii) Somali, (viii) Southern Nations, Nationalities, and Peoples Region (SNNP) and (ix) Tigray (see Map 5.2). The kililoch are subdivided in 68 zones. The zones, considered the second-level administrative division of Ethiopia, are subdivided in more than 600 woredas, the third-level administrative division. The woredas, in turn, are composed of a number of kebele, the fourth-level administrative division and smallest unit of local government. A kebele is a neighbourhood or a localized and delimited group of people. The Ethiopian third level districts are governed by a woreda council.

Originally called Abyssinia, Ethiopia is Africa's oldest independent country and one of the most ancient states in the world (together with Egypt, Persia and China). The country is often considered as one of the cradles of mankind and civilization (Marcus, 2002; Milkias, 2011). Ethiopia has a long history of centralised rule and can therefore be considered a prime example of high political centralisation in precolonial times (see Chapter 4). ${ }^{85}$ Located in the Tigray region in northern Ethiopia, the Kingdom of Axum (or Aksum) became the first Ethiopian empire. Under King Ezana, around the $4^{\text {th }}$ century, Axum became the first state in Africa to adopt (Orthodox) Christianity as its official faith. The Semitic language Geez (Ge'ez) - or Ethiopic - served as first official language in the kingdom of Axum. ${ }^{86}$ The kingdom of Axum thrived from approximately AD 100-940. During that time, Axum was regarded as one of the most powerful civilizations in the world, comparable to the Persian and Roman Empires (Munro-Hay, 1991).

\footnotetext{
85 The importance of precolonial centralisation for contemporary bureaucratic quality and economic development has been empirically documented by several scholars (Gennaioli \& Rainer, 2007; Michalopoulos \& Papaioannou, 2013, 2014, 2015; Osafo-Kwaako \& Robinson, 2013).

${ }^{86}$ The contemporary literature and liturgy of the Ethiopian Orthodox Church are still written in Geez.
} 
Map 5.1: Ethiopia and the Horn of Africa

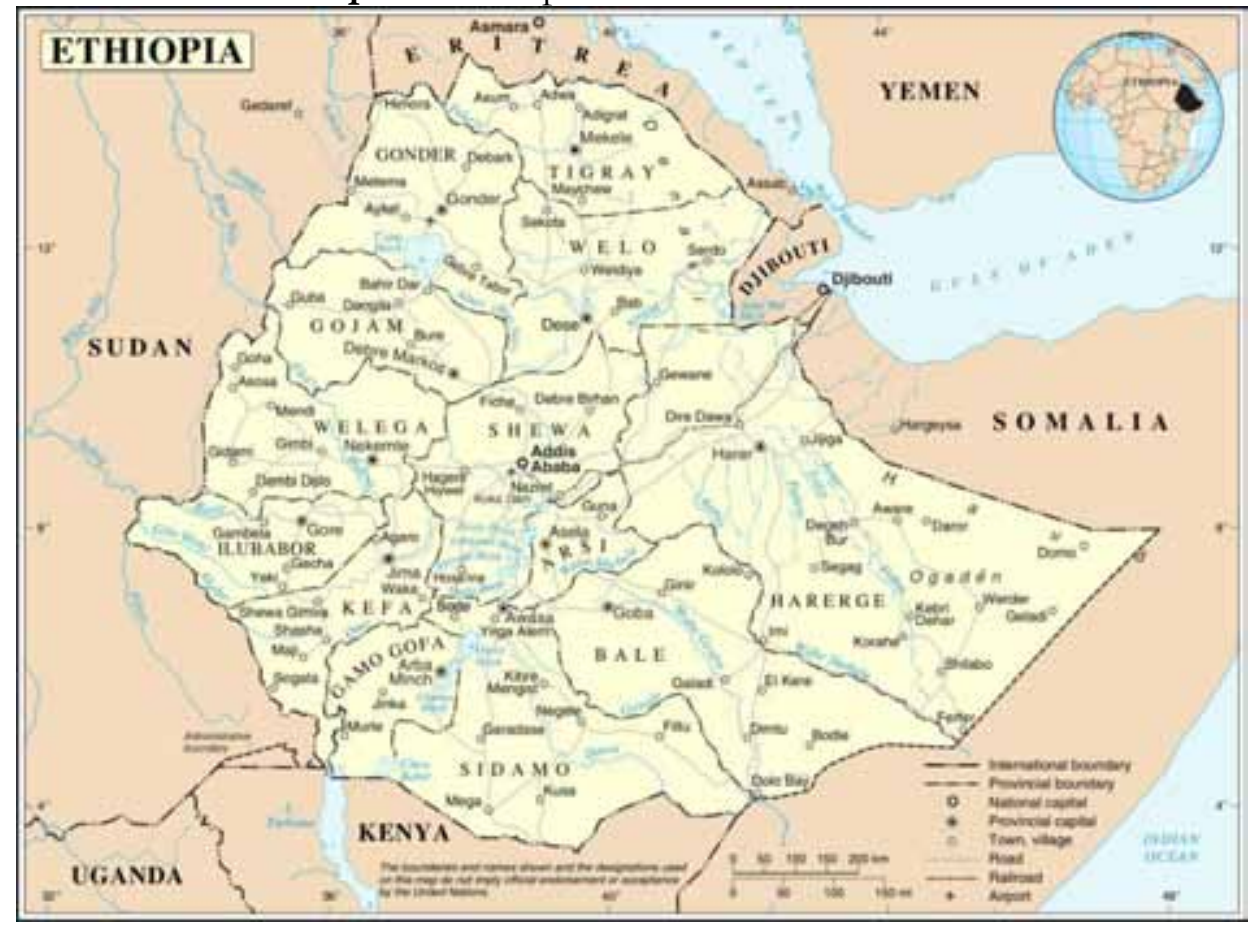

Map 5.2: Administrative Regions and Zones in Ethiopia

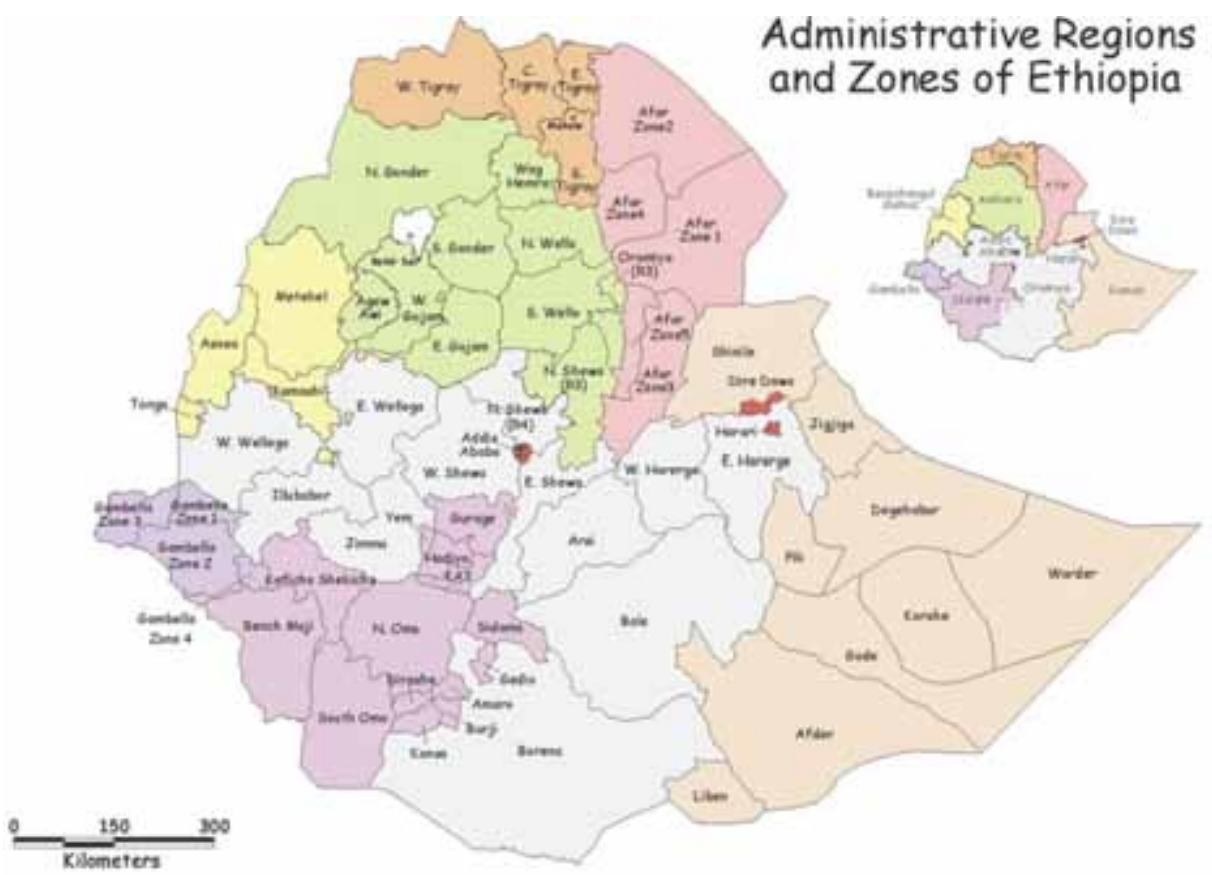


In the 7th century, the first Muslims arrived in Ethiopia as immigrants from Mecca. The more rapid spreading of Islam in the eastern part of the Horn of Africa, particularly among the Somali and Harari, can be attributed to the strong anti-Muslim sentiments of the northern, mostly Christian, people of Abyssinia, including Amhara, Tigray and north western Oromia (Braukämper, 2003). Just before the collapse of the Axumite Empire, Muslim Ethiopian and Arab merchants monopolised trade in the Horn of Africa region, with trade activities spanning from Suez and Cairo in Egypt to Aden and Jeddah on the Arabian Peninsula and from Damascus in Syria to Iraq and even Persia (Abir, 1980).

With the decline of Axum, the country witnessed a large population migration. The part of the population that stayed in the North developed Tigre and Tigrigna (or Tigrinya) languages from Geez. ${ }^{87}$ Those who moved to the south developed Amharic and Guragigna languages from Geez. The Aksumite imperial tradition of conquest, however, remained and Christian expansion continued under the Zagwe dynasty (1137-1268). The most well-known ruler of the Zagwe dynasty was King Gebre Meskel Lalibela who ruled the country from the early 1180s onwards and was declared a saint by the Ethiopian Orthodox Church after his death. ${ }^{88}$ Between 750 and 1270, the Axumite Empire gradually transformed into Abyssinia, a Christian empire covering most of the Ethiopian highlands.

Yekumlo Amlak, a descendant of the Axum rulers, put an end to the Zagwe dynasty and reigned between 1270 and 1285. Yekumlo Amlak restored the Solomonic dynasty by declaring to be a lineal descent of Menelik I. who was the first Solomonic Emperor of Ethiopia ruling around 950 BC. Menelik I. was credited with being the child of King Solomon of ancient Israel and the Queen of Sheba. Ecclesiastical writings and religious practices flourished - especially under the Abyssinian King Zara Yaqob (1434-68) - and the Ethiopian Orthodox Church gained more wealth and political power (Milkias, 2011).

\footnotetext{
${ }^{87}$ The language of Tigre should not be confused with the Ethiopian province of Tigre (Tigray), where Tigrinya is spoken. Ethiopia's neighbouring country Eritrea, in turn, is home to Tigrinyaspeaking, predominantly Christian (Coptic Orthodox) highlanders and Tigre-speaking, predominantly Muslim, lowlanders.

${ }^{88}$ During his reign, Lalibela ruled from the town of Roha (now known as Lalibela in his honour). Lalibela is located in the Wollo (Welo) region of northern Ethiopia. It was King Lalibela who is credited with the excavation of the eleven medieval rock-hewn churches, a high place of Ethiopian Christianity and a place of pilgrimage and devotion until the present day.
} 


\section{CHAPTER 5}

In the late $15^{\text {th }}$ century, the Portuguese gained a strong economic and military foothold in the Red Sea and the Indian Ocean. The Portuguese, led by Afonso de Paiva and Pedro da Covilhão, had arrived in the mainly Christian country of Ethiopia during the 1480s. Around the same time, the Ethiopian empire was threatened by two outside parties. The first major threat were the Ottoman Turks which competed with the Portuguese empire for control of the Red Sea (Shinn \& Ofcansky, 2013; Taddesse, 1972).

The second group that threatened the existence of the Ethiopian empire was the Muslim sultanate of Adal to the east of Ethiopia. The Adal Sultanate was ruled by Imam Ahmad ibn Ibrahim al-Ghazi (also known as Ahmad Grāñ) since 1527. In 1529, Gran's 'Conquest of Ethiopia' (Futuh al-Habasha) heralded the start of the Abyssinian-Adal war (Abir, 1980). Together with the help of the Ottoman troops, the Somali and Afari armies led by Ahmad Grāñ invaded Ethiopia. Then Ethiopian ruler Dawit II (baptised as Lebna Dengel) turned to the Portuguese Empire to ask for military support. A small expeditionary force led by the son of Vasco da Gama, Cristóvão da Gama, came to help the Ethiopian emperor. Dawit II was killed in a battle near Debre Damo in 1540 and Galawdewos (throne name Asnaf Sagad I) became Dawit II's successor.

After Dawit II's death, most of the Ottoman military forces were withdrawn by Ahmad Grāñ. Meanwhile, the Portuguese forces rearmed themselves and rallied a significant amount of Ethiopian troops. Two years later, the Portuguese and Ethiopian troops defeated the remaining Ottoman troops. Ahmad Grāñ was killed in the battle of Wayne Data near Lake Tana in 1543 (Abir, 1980). After the death of Ahmad Grāñ, the Ottoman army fled from the Ethiopian highlands and north-central Ethiopia therefore remained Christian. ${ }^{89}$ The Portuguese Jesuit missionaries aimed at establishing a local Catholic culture in Ethiopia and continued their involvement until the early 1630s (Shinn \& Ofcansky, 2013; Taddesse, 1972).

The war resulted in the weakening of the Abyssinian and Adalite regions and the Oromo emerged as the main beneficiaries of the war. Their original territory in the Rift Valley expanded to land areas laid waste by the war. Islam grew during

\footnotetext{
89 Several historians and political scientists attribute the origins of hostility between contemporary Ethiopia and Somalia to the Abyssinian-Adal war (see, among others, Laitin \& Samatar, 1987).
} 


\section{CHAPTER 5}

the north-eastern expansion of the Oromo people (Hassen, 1990). During the large Oromo migrations in the $16^{\text {th }}$ and $17^{\text {th }}$ century, several Oromo communities underwent political centralisation and adopted Islam as their main religion (Braukämper, 2003). After the reigns of Menas (or Admas Sagad I, 1559-1563), Sarsa Dengel (or Malak Sagad I, 1563-1597), Yaqob I (or Malak Sagad II, 1597 1606), and Susenyos I (or Malak Sagad III, 1606-1632), Susenyos' son Fasilides (or Alam Sagad) came to rule the empire. His reign heralded the start of the Gondarine period (1635-1855).

Fasilides restored the union of the Ethiopian Orthodox Church and founded the city of Gondar, north of Lake Tana, in an attempt to reunite the Church and state. In 1634, all Jesuits priests and Europeans were expelled from Ethiopia by Fasilides (Zwartjes, 2011). After Axum and Lalibela, Gondar became the third permanent capital of Ethiopia in 1636 and remained so until 1855. By 1855, Ethiopia's state regressed into feudal, regional compartments. Between the late $18^{\text {th }}$ century and 1855 , political power became largely decentralised and Ethiopia was de facto no longer a unified state (Keller, 1995).

The foundations of the modern Ethiopian state can be traced back to the Emperors Tewodros II (1855-1868), Yohannes IV (1872-1889), Menelik II (1889-1913) and Haile Selassie (1941-1974). Until the mid-19 ${ }^{\text {th }}$ century, the main inhabitants of the Abyssinian heartland were Orthodox Christians who would speak either Amharic or Tigrinya languages (Milkias, 2011). Fearing that the territorial expansion of Islam could undermine Christian control of Ethiopia, Tewodros took a strong anti-Islam stance. By emphasizing Christian identity and suppressing regional autonomy, Tewodros set out to restore and to reunify the Ethiopian kingdom but he was frequently undermined by disloyal leaders. The capital was moved from Gondar to Debre Tabor, and later to Magdala under his rule.

Tewodros' successors Yohannes of Tigray and Menelik of Shewa continued Tewodros' reunification policy. Yohannes was mostly engaged during his rule in military struggles in northern Ethiopia against Ottoman Egypt and Sudan. Menelik expanded the Abyssinian heartland at the end of the $19^{\text {th }}$ century, by conquering western, southern and eastern provinces of contemporary Ethiopia. Those areas were inhabited mainly by the Oromo, Sidama, Gurage and Wolayta (Marcus, 1975). At the same time, the empire absorbed Muslim minorities in 


\section{CHAPTER 5}

Arsi, Bale, Eritrea, Harar and Sidamo under his rule. Menelik, himself Amharic, promoted the Amharic language and idealized Ethiopian Orthodox Christianity while other languages, cultures and religions were suppressed. Founded in 1887 at the site of a hot springs, the town of Addis Ababa became Ethiopia's capital under Menelik's rule in 1889.

Besides Liberia, Ethiopia was the only African country to resist colonization. Italy's first attempt to colonize Ethiopia happened in 1896 but the Italians were defeated by Menelik and his 100,000-man army at the Battle of Adwa in northern Ethiopia on 1 March, 1896. Thanks to Menelik's strategic skills on the battlefield, an African army had defeated a European army and it became "the founding event in the history of modern Ethiopia" (Jonas, 2011, p. 1). Menelik II died in 1913.

Since Menelik had no surviving sons, Menelik's grand-son Lil Iyasu became the designated Emperor of Ethiopia. Lil Iyasu's father was Ras Mikael who was the Governor of Wollo at that time and a close friend and advisor of Menelik. Ras Mikael was a Muslim and was forced to convert to Christianity in 1875 under Yohannes IV (Marcus, 1975; Metaferia, 2009). Since the Council of State and the Ethiopian Orthodox Church were suspicious of Lil Iyasu's alleged Muslim sympathies, Lil Iyasu was never crowned Emperor of Ethiopia. The Ethiopian Orthodox Church deposed Iyasu and made Menelik's oldest daughter Zewditu (baptised as Askala Maryam) the head of state in 1916. Empress Zewditu became the first female head of state of a modern African country and the last monarch directly descended in the line of Solomonic dynasty.

After Zewditu's death in 1930, Haile Selassie became Emperor of Ethiopia on 2 November 1930. Born in 1892 and a member of the Amhara ethnic group, Ras Tafari - as he was known before his coronation as Emperor - was crowned Negusa Nagast, literally King of Kings. Upon his accession, he took as his regnal name Haile Selassie I (Asserate, 2014, 2015; Murrell, Spencer, \& McFarlane, 1998; Zewde, 1991).90 Seven years earlier, the regent Ras Tafari had already signed up Ethiopia to be the first African country to join the League of Nations,

${ }_{90}$ Haile means "Power of" in Ge'ez and Selassie means "trinity". Therefore, Haile Selassie roughly translates to "Power of the Trinity". Haile Selassie's full title in office was "By the Conquering Lion of the Tribe of Judah, His Imperial Majesty Haile Selassie I, King of Kings of Ethiopia, Elect of God". Selassie claimed to be the 225th direct line descendant of Menelik I. For more information see Murrell, Spencer \& McFarlane (1998) and Asserate (2014, 2015). 


\section{CHAPTER 5}

the forefather of the United Nations, promoting and defending African interest in the global political arena.

Under Haile Selassie's rule Ethiopia, for a second time, resisted Italian colonization when most of Africa was conquered by European powers. During the Second Italo-Ethiopian War in October 1935, the Italian army under Mussolini invaded the northern part of Ethiopia and, by early 1936, had overrun large areas of Ethiopia (Mockler, 2003; Pearce, 2014). Italian forces captured Addis Ababa on 5 May 1936. Despite Selassie's appeal to the League of Nations in June 1936 to stop Italy's aggression, the Ethiopian government had little support from Western democracies, especially Great Britain and France, in its fight against the Italian occupation until the outbreak of WWII (Mockler, 2003; Pearce, 2014). Together with the royal family, Selassie went into exile to Fairfield House in Newbridge, Bath, Great Britain between 1936 and 1941. Meanwhile, the Italian King Victor Emmanuel III was declared Emperor of Ethiopia. When Mussolini entered WWII by joining Adolf Hitler as his Axis ally on 10 June 1940, Haile Selassie eventually secured British support.

In January 1941, the Patriots Movement, an indigenous resistance movement, coupled with British military assistance defeated Mussolini's army and eventually liberated Ethiopia (Berhe, 2003; Zewde, 1991). On 5 May 1941, Haile Selassie, alongside an army of Ethiopian Free Forces, returned to Addis Ababa, exactly five years to the day when the Italian occupation started. In January 1942, the British government officially reinstated Haile Selassie as Emperor of Ethiopia. ${ }^{91}$ Ethiopia's resistance to European colonization has become a symbol of African independence throughout the colonial period.

The end of the Italian occupation in 1941 heralded the start of a British decade in Ethiopia:

"The tripartite competition among Britain, France and Italy for control of Ethiopia in the pre-1935 period was replaced by unilateral British domination. (...) The British came to assume extensive control over

\footnotetext{
91 Anthony Mockler's (2003) book "Haile Selassie's War" describes in compelling detail the Second Italo-Ethiopian War between October 1935 and May 1936. In his meticulously researched work "Prevail: The Inspiring Story of Ethiopia's Victory over Mussolini's Invasion, 1935-1941”, Jeff Pearce (2014) shows how Ethiopia successfully resisted Italy's invasion between 1935-1941, eventually prevailing against Mussolini’s forces against all odds.
} 


\section{CHAPTER 5}

Ethiopia's finance, administration and territorial integrity (...). [The British Military Mission to Ethiopia (BMME) was] entrusted with the task of assisting the Ethiopian government in the 'organization, training and administration of the Ethiopian army.” (Zewde, 1991, p. 179-180)

In the early period of his reign, Haile Selassie launched a first wave of modernization efforts, such as the abolition of slavery, the launch of the printing press, the establishment of modern hospitals, electrical grids and foreign language schools in major cities, the initiation of the National Bank of Ethiopia, the provision of telephone and wireless services throughout the country, the introduction of cars, motorcycles, trucks, bicycles and airplanes, the creation of a sophisticated road network linking major Ethiopian cities, the introduction of Ethiopian embassies and consulates abroad, the formation of cabinet ministries based on the European example and the inauguration of Ethiopia's first modern Constitution (Zewde, 1991).

The fact that contemporary Ethiopian society can be considered one of the most ethnically, linguistically and religiously diverse African societies is a direct result of the territorial expansion under Emperor Menelik II (Milkias, 2011). According to the Ethiopian national 2007 census, the country contains over 80 different ethnic groups. The Oromo are the largest ethnic group in Ethiopia representing 34.4 percent of the total population, followed by the Amhara (Amara) with 27 percent, the Somali (Somalie) with 6.2 percent and the Tigray (Tigrinya) with 6.1 percent. Approximately 90 languages are spoken in Ethiopia. The majority speaks Afro-asiatic languages of the Cushitic or Semitic branches. Both the Oromo language and the Somali language can be grouped into the Cushitic branch. The Amharic and Tigrinya languages can be classified as Semitic languages. Those four languages are spoken by almost three quarters of Ethiopia's population.

Religion plays an important role in Ethiopian society. Christianity and Islam are the most widely practiced religions in Ethiopia. According to the 2007 national census, Ethiopia is home to over 60 million Christian adherents (around 60 percent) and 25 million Muslim adherents (around 34 percent). According to estimates by the U.S. Department of State, however, Ethiopian Orthodox Christians and Muslims are thought to make up 40-45 percent and 45 percent of the Ethiopian population, respectively (US-DOS, 2009). 


\section{CHAPTER 5}

"Ethiopia is located on a religious fault line. This diversity can be a source of stability or instability. Over the past 100 years Ethiopia's complex mélange of religious communities has generally lived side by side in harmony. (...) No one knows with certainty the percentage of Christians and Muslims living in Ethiopia. It is likely, however, that they are nearing parity. This result has important implications for political power and stability. Ethiopia (tied with Morocco) now has the eleventh-highest number of Muslims in the world; it has more Muslims than Saudi-Arabia, the Sudan, Iraq, or Afghanistan. Ethiopia is no longer a 'Christian nation' (..) Although the leadership continues to be largely Christian, Ethiopia now officially recognizes both Christian and Muslim holy days.” (Shinn, 2005, p. 96-97)

Ethiopia consistently ranks among the poorest countries on the planet. The country's history is filled with terrible famines, most notably the ones in 197374 and 1984-86. Many scholars consistently refer to Ethiopia as one of the most aid dependent nations not only in Africa but in the world. Visiting Mekelle in northern Ethiopia in the year 2006, Australian journalist Peter Greste noted that "like a patient addicted to pain killers, Ethiopia seems hooked on aid. For most of the past three decades, it has survived on millions of tons of donated food and millions of dollars in cash. It has received more emergency support than any other African nation in that time." 92

\subsection{Foreign Aid Game in Ethiopia During the Cold War}

After the end of WWII, the United States became increasingly aware of the strategic importance of the Middle East in geopolitics (McVety, 2012). With the increasingly hostile rivalry between the United States and the Soviet Union during the Cold War period, the two superpowers considered foreign aid and military assistance as valuable tools to prevent recipient countries from switching political allegiance.

${ }_{92}$ The entire news article can be found at http://news.bbc.co.uk/2/hi/africa/4671690.stm 


\subsubsection{Foreign Aid under Haile Selassie}

During the post-WWII era, some of the ways in which Haile Selassie sought to promote the modernization of his country was through the opening of Ethiopia's first university; a new Ethiopian Constitution that extended the power of the parliament; increased public goods provision such as new hospitals and physical infrastructure expansion and strengthened diplomatic ties with the rest of the world, particularly with the United States (Asserate, 2014, 2015; Clapham, 1969; Metaferia, 2009).

The British influence in Ethiopia significantly declined during the immediate aftermath of WWII and gave rise to Ethiopia's close partnership with the United States. Concomitant with the increasing U.S. predominance in global politics during the post-WWII period, U.S. political, economic, military and humanitarian involvement in Africa steadily increased from the early 1950s onwards. Three major factors led to America's increasing strategic interests in Ethiopia: (i) the withdrawal of the British Military Mission to Ethiopia in the late 1950s forced the Ethiopian government to look for a new partner in terms of military assistance; (ii) the Egyptian revolution in 1952 forced the U.S. to establish new political relationships in the Middle East and the Red Sea; (iii) the start of the Cold War era forced the United States to search for allies against the spread of communism. According to Connell (2005), "Ethiopia provided an entry point for influence over emergent African states and a base for pursuing strategic interests in the region. It was the first African state to which the United States turned" (p. 66). Consequently, the British decade of the 1940s was replaced by the American era of the 1950s and 1960s.

The U.S.-Ethiopian diplomatic relationships intensified under the Eisenhower administration (1953-1961). Haile Selassie made his first royal state visit to the United States on 26 May 1954 (Metaferia, 2009). ${ }^{93}$ Zewde (1991) notes that "the initiative for closer contacts came from the Ethiopian side, (...) the emperor sought the Americans as counterweight [against the British]" (p. 184). U.S. political and economic involvement in Africa by that time was almost nonexistent:

\footnotetext{
93 The last visit of an African head of state to the United States dated back to 1944 when Theodore Roosevelt welcomed then Liberian President Edwin Barclay (Asserate, 2014, 2015).
} 


\section{CHAPTER 5}

"In 1954, most Americans knew little about the dark continent. (...) The dominant colors of maps of Africa were the colonial-designating pinks for Great Britain and blues for France. Even the U.S. State Department deferred responsibility and blame for events in Africa, and especially in sub-Saharan Africa, to the colonial empires that had scrambled to claim lands there in the late $19^{\text {th }}$ and early $20^{\text {th }}$ centuries and still tenaciously held on to their possessions in the face of increasingly strengthening independence movements." (Vestal, 2011, p. 6)

Following the onset of the Cold War, Haile Selassie became a key ally in the U.S. fight against communism, as exemplified by (i) Ethiopian voting alignment with the United States in the United Nations General Assembly (UNGA) against Eastern bloc policy interests and (ii) the provision of thousands of troops known as Kagnew ${ }^{94}$ Battalions - as part of the American-led United Nations force in the Korean War between June 1951 and April 1954 (Vestal, 2011). Fearing that Ethiopia could become a major target for Soviet influence, the United States started to provide foreign aid to Ethiopia from the early 1950 s onwards.

"As early as 1955, American officials perceived famine in Ethiopia as providing the seedbed for a communist revolution and a compelling reason for Ethiopia to take peasant agriculture seriously. For its part, the United States promoted agricultural development rather than military security as the dominant goal of its relations with Ethiopia." (Kissi, 2000, p. 114)

On 15 May 1952, Ethiopia signed a Point IV Technical aid agreement, becoming one of the first developing nations to receive foreign aid from Washington (McVety, 2012; Metaferia, 2009). ${ }^{95}$ The cooperative aid program mainly consisted of agricultural and public health education, scholarships, public administration and locust control. The Point IV program became

"One of the most conspicuous manifestations of the American presence in Ethiopia in the 1950s and 1960s (...) [F]or the Ethiopian government,

\footnotetext{
${ }^{94}$ The name "Kagnew" derives from the name of the warhorse of Ras Makonnen, Menelik II's General and the father of Haile Selassie, at the Battle of Adwa in 1896 during the First ItaloEthiopian War.

95 The Point IV Program became the first official U.S. plan for international economic development.
} 


\section{CHAPTER 5}

[however,] the value of the United States was not so much in such issues of development as in the diplomatic leverage that the USA could exercise on the British, and in the military assistance likely to be offered." (Zewde, 1991, p. 184)

The late 1950s marked both the end of the colonial period in Africa and the rise of national independence movements. In 1957, nationalist (and African Socialist) Kwame Nkrumah became Ghana's first prime minister and president. One year later, on its independence, the outspoken Marxist Sekou Touré became Guinea's first president. Both the Soviet Union and China started to offer foreign aid, technical aid in particular, to several African countries such as Ghana and Guinea (Erlich \& Sonne, 1963). Haile Selassie recognized that he could increase his bargaining power by playing off the United States against the Soviet Union. In 1959 , Selassie visited the Eastern bloc coming back with $\$ 100$ million in credits. The emperor made clear that he would not use the credits if Western aid would increase. In 1960, with Somalia's independence approaching - a country that would be a prime target for Communist infiltration - the U.S. government responded immediately by providing more development assistance to Ethiopia (Marcus, 2002).

The creation of the United States Agency for International Development (USAID) under the Kennedy administration in November 1961 heralded the start of the "decade of development". USAID brought together several existing foreign assistance organizations and programs. While the African continent received
"the highest per capita assistance of any region - around $\$ 6$ per person throughout the 1960s - USAID funding for the continent amounted to less than 10 percent of total grants and loans of the global aid budget. Loans were limited to those nations who showed the most promise for development, with the exception of Ethiopia and Liberia, which were in a ‘special relationship’ category” (McVety, 2012, p. 182-183).

The USAID programme carried out in Ethiopia during the 1950s and 1960s had its largest impact in three particular spheres: (i) connection and communication, (ii) education, and (iii) military assistance. The USAID programme promoted, among others, Ethio-American connection and communication. One major 


\section{CHAPTER 5}

program was the restoration of the road network. ${ }^{96}$ In January 1951, the U.S. government founded the Imperial Highway Authority (IHA). The Americandominated IBRD provided the loans and oversaw the activities of the IHA. The U.S. government also launched a contractual agreement between the Ethiopian government and the U.S. multinational International Telephone and Telegraph (ITT) organization to repair telephone lines destroyed during the Ethiopian liberation movement against Italy. In 1952, the Imperial Board of Telecommunications was established under the recommendation of the ITT and IBRD. The board was run by Swedish authorities until the first Ethiopian general manager was appointed in 1966 (Zewde, 1991).

The establishment of an educational system along American lines ${ }^{97}$ and the provision of U.S. scholarships for Ethiopian students by U.S. agencies such as USAID, Point IV, the African-American Institute and the African Graduate Fellowship Program were a second pillar of U.S. development assistance to the Ethiopian government (Asserate, 2014, 2015; Metaferia, 2009; Vestal, 2011; Zewde, 1991)..$^{98}$ The United States became a major destination for Ethiopian students striving for higher education. While 71 Ethiopian students were recorded at U.S. universities in 1950, the number rose to more than 10,000 by 1973 (Zewde, 1991).

USAID assistance for Ethiopia during the 1960s was not only driven by economic development concerns but also increasingly by military concerns, partly due to Haile Selassie's frequent neglect of food shortages in his country and his focus on military and security issues in U.S.-Ethiopian relations.
"U.S.-Ethiopian relations in the area of famine relief from 1950 to early 1970 resembled the epic drama of two nations debating the basis of a relationship and focusing on two alternative issues: agricultural development to produce food for the Ethiopian people and weapons to

\footnotetext{
96 The formerly sophisticated road network built by the Italians was severely damaged - almost completely destroyed - during the Ethiopian liberation struggle against Italy.

${ }^{97}$ The exception were the few elite schools that still resembled the British and French educational environment (see Zewde, 1991).

${ }_{98}$ Ethiopian schools and universities like the Business School and Law School at Haile Selassie I University [now Addis Ababa University], Alemaya Agricultural College in Harar, College of Public Health in Gondar, as well as Jimma and Ambo agricultural high schools hired American professors, and were equipped with textbook and other school material that was used at U.S. universities and colleges (see Metaferia, 2009).
} 


\section{CHAPTER 5}

provide military security for the Ethiopian government. American policymakers saw agricultural development to prevent famine in a peasant society as providing the only legitimate outcome of this debate." (Kissi, 2000, p. 131)

The 1958 famine in Tigray that left more than 100,000 people dead and the 1966 famine in the Amhara region forced the U.S. administration to strengthen its pressure on the Selassie regime for agrarian reform. ${ }^{99}$ Haile Selassie, however, frequently denied the existence of extreme food shortages and strongly resisted U.S. relief aid. Due to Haile Selassie's skilful manoeuvring in diplomatic talks with the U.S. administration where he frequently highlighted military assistance as a main priority for Ethiopian state security, military assistance became the third major sector of U.S. foreign finance to Ethiopia.

Already in 1953, Addis Ababa and Washington signed two important military agreements: (i) the Mutual Defense Assistance Agreement under which the U.S. administration promised to provide military equipment and training for the Selassie regime, and (ii) an agreement that formally granted the U.S. administration the exclusive right to the Kagnew Communication station near Asmara in Eritrea (Lefebvre, 1991; Metaferia, 2009). Eritrea was an Italian colony between 1889 and 1941. Kagnew Station originally served as an Italian naval radio station, Radio Marina, during WWII. In 1942, the United States took over the radio station. After the Italian defeat in Eritrea in 1941 by the British army, Eritrea was under British administration until 1950. Between the WWII period and 1950, there was little agreement amongst the Western powers whether Eritrea should become independent or become part of Ethiopia (Welde Giorgis, 2014; Wrong, 2005). ${ }^{100}$ The U.S. government showed little interest for Eritrea's quest to become independent. Then U.S. Secretary of State, John Foster Dulles, argued in a Security Council debate:

\footnotetext{
${ }^{99}$ For more information on the 1958 and 1966 famines in Ethiopia, see Zewde (1991) and Kissi (2000).

100 Michaela Wrong's (2005) book "I Didn't Do It for You: How the World Betrayed a Small African Nation" and Andebrhan Welde Giorgis" (2014) publication "Eritrea at a Crossroads: A Narrative of Triumph, Betrayal and Hope" are convincing accounts on how the fate of the Eritrean people has frequently been determined by external players, such as the Ethiopian governments under Selassie and Mengistu, Western powers (in particular Italy, Great Britain and the United States) as well as the United Nations.
} 


\section{CHAPTER 5}

"From the point of view of justice, the opinions of the Eritrean people must receive consideration. Nevertheless, the strategic interests of the United States in the Red Sea basin and considerations of security and world peace make it necessary that the country has to be linked with our ally, Ethiopia." (cited in Kaplan, 2003, p. 56)

Based on the UN General Assembly Resolution 390 A(V) in 1950, the United Nations chose the golden rule: it federated Eritrea with Ethiopia as "an autonomous unit (...) under the sovereignty of the Ethiopian Crown" from September 1951 onwards. Haile Selassie, however, never respected the UN autonomy agreement as he viewed Eritrea as an integral part of Ethiopian territory. Selassie's stance towards Eritrea triggered the start of a thirty-year long war between the Eritrean Liberation Front (ELF) and the Ethiopian government from 1961 onwards. In 1962, Eritrea was forcibly annexed by the Ethiopian government, becoming the fourteenth province of Ethiopia (Welde Giorgis, 2014; Wrong, 2005; Zewde, 1991). ${ }^{101}$

During the 1950s, the U.S. government developed the radio station in Asmara into a crucial military communication and intelligence-gathering complex ${ }^{102}$ through a deal with Haile Selassie that was viewed as mutually beneficial:

"In return for continued use of the communications base in Asmara, (...) the United States undertook to launch a military aid programme. A unit called the Military Assistance Advisory Group (MAAG) was set up to train three divisions, each of 60,000 men, at a cost of 5 million US dollars." (Zewde, 1991, p. 185-186)

"Between 1953 and 1960, U.S. military advisors built black Africa's first modern army, with three divisions of 6,000 men each, equipped largely with surplus weapons and equipment from World War II and the Korean War." (Connell, 2005, p. 67)

\footnotetext{
101 Ethiopia's annexation and the imposition of direct rule over Eritrea took place with the acquiescence of the international community and the United Nations, thereby abrogating the 1950 United Nations Resolution 390 that granted Eritrea a semi-autonomous status.

102 The U.S. base was named "Kagnew" station in 1953 to pay tribute to the first Ethiopian Kagnew Battalion that aided the United States in the Korean War. Kagnew Station was primarily supplied by ships from the Eritrean port of Massawa at the Red Sea and by planes from the U.S. Airbase in Dhahran, Saudi Arabia (Connell, 2005; Kaplan, 2003; Welde Giorgis, 2014; Wrong, 2005; Zewde, 1991).
} 


\section{CHAPTER 5}

Meanwhile, in 1960, Ethiopia's neighbouring country Somalia became independent. Somalia's national flag posed a challenge to the Ethiopian national state. One of the five pointed stars on the Somali flag represented the Somaliinhabited Ogaden region in Ethiopia. All efforts by the Ethiopian government to calm down Somali nationalism in the Ogaden region were unsuccessful. As the Cold War heated up, the Soviet Union joined the United States in the struggle for power and influence in the Horn of Africa. In late 1963, the Soviet Union signed a military assistance pact with Somalia and delivered weapons and other technical equipment worth $\$ 30$ million to the Somali army (Lefebvre, 1991; Marcus, 2002). ${ }^{103}$ The United States offered $\$ 18$ million worth of aid plus a letter indicating that Somalia would benefit from being loyal to the West. The Somali government under President Aden Abdullah Osman Daar ${ }^{104}$, however, declined the offer.

In early 1964, the First Ogaden War between Ethiopia and Somalia broke out. The Ethiopian government was backed by the United States and the Somalis were defeated very quickly with Mogadishu negotiating a cease-fire effective on 6 March 1964 (Lefebvre, 1998). By 1970, almost two-thirds of U.S. total military aid to Africa was allocated to the Selassie regime. Between 1946 and 1972, Washington's military assistance to Ethiopia amounted to more than $\$ 180$ million. More than 2,500 Ethiopians received different forms of military training in the United States between 1953 and 1968 (Connell, 2005; Zewde, 1991).

Under Selassie, formal economic and political diplomatic relationships between Ethiopia and China were not established until 24 November 1970. Haile Selassie made his first visit to China in October 1971 after China's Prime Minister Zhou Enlai had visited Ethiopia seven years earlier. Despite the fact that the two countries signed two economic and trade cooperation agreements in the early 1970s (Sino-Ethiopian Agreement for Economic and Technological Cooperation in 1971 and Sino-Ethiopian Trade Agreement in 1973), SinoEthiopian relations were still in a dormant state around that time (Adem, 2012; AFRODAD, 2011).

\footnotetext{
103 The two major aims of the Soviet Union were the expansion of the Somali Army from 4,000 to 200,00 soldiers and the development of a Somali air force (Lefebvre, 1991).

104 Aden Abdullah Osman Daar became the first President of independent Somalia in 1960. After he was defeated in the presidential election in 1967, he became the first head of state in post-colonial Africa to step down through peaceful means.
} 


\section{CHAPTER 5}

While Ethiopia's interest in Asia beyond the Middle East strengthened from the 1920s onwards, it was not China but Japan that captured Selassie's attention during his imperial rule. The reasons were historical and economic. First, similar to Ethiopia in 1896, Japan was victorious against a major European power in the Russo-Japanese War (1904-1905). Like Ethiopia, Japan had a long-reigning dynastic monarchy and was considered the oldest imperial dynasty in the world. Second, Selassie viewed Japan as an example for Ethiopia's economic modernization. By the end of the $19^{\text {th }}$ century, Japan's economy was rapidly transformed from a feudal society into a global industrial powerhouse. In 1956, Emperor Selassie became the first African head of state to visit post-war Japan (Adem, 2013).

Between 1950 and 1958, Selassie supported Taiwan in the United Nations, partly because of historical reasons. During the Italian fascist occupation (1936-1941), Selassie's regime received public support from Taiwan. Even though Ethiopia supported China in the United Nations from 1960 onwards, Beijing struggled to overcome Ethiopia's close ties with Taiwan and the United States as well as Selassie's strong anti-communist stance (Shinn \& Eisenman, 2012). SinoEthiopian relationships only improved from the early 1970s onwards, when U.S.-Chinese relations entered an era of rapprochement. ${ }^{105}$

The American era in the 1950s and 1960s goes hand in hand with Haile Selassie's consolidation of absolutism:

"The power of the state reached a limit unprecedented in Ethiopian history. This was clearly manifested in such spheres as provincial administration, military organization and fiscal control. A ruling class based on landed property, but with interests in industry and trade as well, exercised this power. The architect and physical embodiment of the absolutist order was the Emperor (...) As years progressed, the emperor tended to detach himself from domestic issues altogether, and to devote his attention to foreign affairs. He was possibly the most widely travelled head of state in the world. His globe-trotting knew no ideological or geographical boundaries (...) As he pursued international fame and

\footnotetext{
105 The era of rapprochement (1970-1979) between the U.S. government and the Chinese government was initiated by then U.S. Secretary of State Henry Kissinger's visit to China in mid1971, followed by U.S. President Nixon's visit to China in February 1972.
} 


\section{CHAPTER 5}

prestige, the emperor became oblivious to the signs of trouble at home." (Zewde, 1991, p. 201-203)

Despite an accelerated reform process in the 1960s, the privileges of landlords largely remained and public dissent grew as exemplified by the tax rebellions in Bale in 1964 and in Gojjam in 1968 (Brietzke, 1976; Chege, 1979; Mengisteab, 1990). 106

Several factors initiated the decline of Haile Selassie's regime. One major factor was the rise of a political opposition due to Ethiopia's economic backwardness, in which the agrarian question played a fundamental role (Chege, 1979; Gilkes, 1975). Despite Selassie's modernization attempts, the country remained one of the poorest countries in the world. Development failures such as the inability to provide more schools, classrooms and teachers but also to improve education opportunities in the countryside and in non-Amhara regions demoralized both the urban elites and peasants in rural areas (Levine, 1961; Marcus, 2002). The increasing opposition against the Emperor, however, mainly stemmed from urban movements as the rural population was largely disengaged from the political process (Chege, 1979; Clapham, 1988).

The coup d'état staged on 13 December 1960 by the Neway brothers seriously jeopardized Selassie's power (Clapham, 1969).107 The coup was crushed, however, and the Selassie's government regained control of the capital four days later. At the same time, the Ethiopian Student Movement (ESM) that emerged primarily from the urban areas, particularly in Addis Ababa, drove the revolution forward. Ethiopian students demanded a free press, labour unions, a land reform

\footnotetext{
106 The accelerated reform process under the Selassie regime included fiscal and administrative reforms such as the Tax Proclamation of 1961, the establishment of the Confederation of Ethiopian Labor Unions in 1962, the establishment of the Investment Decree in 1963, the Investment Proclamation in 1966, as well as the Agricultural Income Tax Proclamation of 1967 (Mascagni, 2016a; Zewde, 1991, 1994).

107 During the coup, Selassie was on a state visit to Brazil but immediately returned to Ethiopia after he heard the news of the staged coup. The two main conspirators in this coup were two brothers, Mangestu and Germane Neway. Mangestu Neway was a member of the patriotic Black Lion Organization while his brother Germane was an intellectual who received both his Bachelor of Arts (BA) and Master of Arts (MA) degree at U.S. universities (Wisconsin University and Columbia University, respectively). The conspirators launched the coup mainly due to their frustration over Ethiopia's economic backwardness while many newly independent African states witnessed rapid economic growth (Clapham, 1969; Zewde, 1991).
} 


\section{CHAPTER 5}

and, later, a socialist societal change along Marxist-Leninist principles. Western principles and influence became increasingly associated with "imperialism" and "neo-colonization" (Asserate, 2014, 2015).

"The preponderance of Americans in almost all aspects of Ethiopian life bred resentment, especially among the students, who viewed the whole situation as being within the global framework of American imperialism. Anti-Americanism grew particularly strong in the late 1960s and early 1970s." (Zewde, 1991, p. 189)

Ironically, many of the members of the ESM enjoyed their education through U.S. teachers in Ethiopia, Peace Corps Volunteers in Ethiopia or U.S. universities. One part of the ESM was even organized by Ethiopian student activity abroad through the Ethiopian Students Union in North America, the successor of the Ethiopian Students Association in North America, and the Ethiopian Students Union in Europe. Their distance from the Imperial Government of Ethiopia and better access to uncensored revolutionary literature gave them a comparative advantage vis-à-vis local Ethiopian students in their efforts to overthrow the government (Asserate, 2014, 2015; Zewde, 1991). Peasant rebellions were also part of a nationwide resentment against Haile Selassie's rule but the rural protest took place at a lower scale and received less attention compared to the urban protest movement.

Meanwhile, Ethiopia's economy seriously deteriorated. One major feature of Haile Selassie's misguided economic policies was the rapid privatization of land ownership without instituting a meaningful land reform. Land privatization mainly benefitted political supporters at the expense of the general farming population. Selassie's land policy created a feudal landholding regime that (i) put a heavy fiscal burden on the rural population, (ii) sharply divided rural society into landlords and tenants and (iii) ultimately hindered agricultural development (Gilkes, 1975; Keller, 1989).

By the early 1970s, between 50 and 60 percent of all private rural holdings fell under the category of land tenancy. Out of 5 million hectares of land allocated after 1941, landless and unemployed people only received a few thousand (Zewde, 1991). The strong political support from the landlord class for Haile Selassie's imperial government successfully thwarted a land reform that would 
relieve pressure on the peasants. The negative consequences of Selassie's land privatization combined with natural disasters such as droughts made the rural population vulnerable to famine.

A related factor that led to the demise of Haile Selassie's rule was the deterioration of Ethiopia's economy concomitant with the Ethiopian Famine of 1973-74. With the sudden and unexpected closure of the Suez Canal at the beginning of the Six Day War in 1967 prices of both imported goods from abroad and Ethiopian exports rose. Government revenues from tariffs and import duties shrank. The economy managed to rebound in 1972 thanks to high international commodity prices and a successful harvest (Marcus, 2002). Ethiopian government statistics demonstrate that Ethiopia's food production in 1972 was about normal (Table 5.1 and 5.2). The Wollo region in the north was the only exception.

Table 5.1: Crop production in 1972 by region, relative to previous average production

\begin{tabular}{|c|c|c|c|c|}
\hline \multirow[b]{2}{*}{ Province } & \multicolumn{4}{|c|}{ Provincial sub-districts (\%) reporting production } \\
\hline & $\begin{array}{c}\text { Above } \\
\text { average }\end{array}$ & Average & $\begin{array}{c}\text { Below } \\
\text { average }\end{array}$ & Poor \\
\hline Arsi & 5 & 70 & 15 & 10 \\
\hline Bale & 82 & 9 & 9 & 0 \\
\hline Begemder/Gonder & 6 & 84 & 2 & 8 \\
\hline Eritrea & 4 & 78 & 9 & 9 \\
\hline Gamo Gofa & 6 & 82 & 12 & 0 \\
\hline Gojam & 14 & 82 & 4 & 0 \\
\hline Hararghe & 22 & 39 & 30 & 9 \\
\hline Ilubador & 22 & 64 & 14 & 0 \\
\hline Kaffa & 33 & 45 & 22 & 0 \\
\hline Shoa & 17 & 54 & 21 & 8 \\
\hline Sidamo & 22 & 78 & 0 & 0 \\
\hline Tigray & 6 & 84 & 2 & 8 \\
\hline Welega & 0 & 86 & 14 & 0 \\
\hline Wollo & 0 & 10 & 38 & 52 \\
\hline All provinces & 14 & 65 & 14 & 7 \\
\hline
\end{tabular}


Table 5.2: Total production of various crops in 1972, relative to previous average production

\begin{tabular}{|c|c|c|c|}
\hline \multirow[b]{2}{*}{ Crop } & \multicolumn{3}{|c|}{ Provincial sub-districts (\%) reporting production } \\
\hline & Above average & Average & Below average \\
\hline Sorghum & 16 & 51 & 33 \\
\hline Teff & 18 & 57 & 25 \\
\hline Barley & 21 & 64 & 15 \\
\hline Wheat & 18 & 60 & 22 \\
\hline Maize & 17 & 55 & 28 \\
\hline All crops & 14 & 65 & 21 \\
\hline
\end{tabular}

Source: Ethiopian Ministry of Agriculture (1973).

The oil crisis in 1973, spurred by the Yom Kippur War, once again put serious strains on the Ethiopian economy. The oil crisis pushed food prices to unaffordable levels for many people. Estimates by Gilkes (1975) suggest that prices increased by 20 percent in 1973, and during the first quarter of 1974 alone, the price rise was equivalent to an annual rate of 80 percent. Rising food prices and a severe drought in 1973-74 in the overpopulated and overfarmed northern regions of Shewa, Wollo and Tigray led to the death of more than 200,000 Ethiopians by 1974 . At the same time, around 2.5 million people, 8 percent of Ethiopia's population, experienced starvation (Gebre-Medhin \& Vahlquist, 1976; Koehn, 1979; Shepherd, 1975). The two northern provinces most seriously afflicted by the famine, Tigray and Wollo, had supplied almost 40 percent of Ethiopia's total food crops before the drought (Holt \& Seaman, 1976; Shepherd, 1975).

While the traditional analysis of famines concentrates on food supply, some scholars believe that supply-side factors such as long-term climatic changes or unusual failure of rains were not the main causes for the 1973-74 famine (Kaplan, 2003; Miller \& Holt, 1974; Sen, 1981). Sen (1981) argues that the famine did not occur primarily due to a lack of food, but due to inequalities built into mechanisms for distributing food, namely the inability of peasants in rural areas to financially cushion the worst effects of natural disasters. ${ }^{108}$ In the same vein,

\footnotetext{
108 Amartya Sen is famous for his assertion that famines do not appear in modern democracies. According to his 'Democracy prevents famine' hypothesis, political processes and institutions play a substantial role in the prevention of famine (Sen, 1999). Sen argues that 'no famine has ever taken place in the history of the world in a functioning democracy'. Since political leaders
} 


\section{CHAPTER 5}

Miller and Holt (1974) argue that "people died in Ethiopia not because of an extreme shortage of food, i.e. famine, but because of an extreme shortage of money, i.e. poverty" (p. 170). These scholars suggest that the 1973 famine must therefore be considered a political and social rather than a natural phenomenon.

As mentioned earlier, the 1973-74 famine mainly took place in the north, namely in the Tigray and Wollo regions. ${ }^{109}$ According to Kaplan, Northern Ethiopia was a region that

"the Amhara emperor had a strategic interest in keeping underdeveloped, on account of Amhara historical conflicts with the Eritreans and Tigreans. A feudal landowning system, an absence of investment, crippling taxation, and drought were the causes of the famine." (Kaplan, 2003, p. 20)

During 1972 and 1973, between 40,000 and 80,000 Ethiopians died in the Wollo region alone (Seaman \& Holt, 1975). Meanwhile, at the height of the famine in 1973, the Ethiopian government exported more than 200,000 tons of grain - the highest export surplus since 1967. Until mid-1973, Haile Selassie denied the existence of a famine in his country.

"Evidence indicates that the Government was aware of the severity of the drought by mid-1973; yet, it would only accept outside assistance that was discreetly provided. Prospective donors such as the World Food Programme, the United Nations Children's Fund (Unicef), and the United States Agency for International Development (U.S.A.I.D.) were approached privately and successfully convinced to begin shipping limited food aid quietly without publicly commenting about the seriousness of the problem.” (Keller, 1992, p. 611)

in democracies feel accountable to their citizenry, they cannot ignore the plight of their population.

109 The Tigray province was also affected by the drought but the famine was less severe there compared to the Wollo province largely due to different modes of land tenure: While most farmers were tenants in the Wollo region, most farmers in the Tigray province were owners of their land (Lundström, 1976). In the middle-altitude areas of northern and central Wollo, "the enforcement of crippling tenancy contracts in time of shortage had the effect of taking food from the hungry. Thus, during 1973, the famine area exported grain to the provincial capital, Dessie, and to Addis Ababa" (De Waal, 1991, p. 60). 


\section{CHAPTER 5}

In November 1973, Haile Selassie visited the Tigray and Wollo regions but "his attitude was that peasants always starve and nothing can be done, and that in any case it was not the Shewan Amhara who were dying" (De Waal, 1991, p. 61).

The 1973-74 famine was one of the first famines that attracted significant media attention throughout the world despite numerous attempts by the Ethiopian government to suppress the news of a famine (Koehn, 1979). ${ }^{110}$ The media reports and pictures from the famine-stricken northern regions triggered a huge international relief operation. By late 1974, more than 40 Ethiopian and foreign aid agencies were operating in Ethiopia to give food and shelter to the Wollo and Tigray rural population (Gebre-Medhin \& Vahlquist, 1976). Much of the overseas aid, however, was not effective in saving people's life as it arrived too late. 20 percent of the human population and 90 percent of the animal population in the Wollo province died as a result of the 1973-74 famine, while 80 percent of the crop was lost (Keller, 1989). The famine and the inappropriate government response to it were the precipitating factors in the deposition of Haile Selassie and the termination of monarchical rule (Kapuściński, 1978; Koehn, 1979).

Another reason for the demise of the imperial government was the declining support from Washington. Under President Richard Nixon (1969-1974), the United States followed a policy of disengagement from Ethiopia for three main reasons. First, following Egyptian President Anwar al-Sadat's pro-Western shift in Egyptian foreign policy, the U.S. government increasingly viewed Ethiopia as a less strategically valuable partner - vis-à-vis Egypt - in the Middle East (Zewde, 1991). Second, advances in technology and satellite communication made the Kagnew Station obsolete. U.S. operations at the Kagnew Station were significantly reduced in August 1973 and the Kagnew Station was eventually closed down by April 1977. Third, the U.S. government became increasingly aware of Haile Selassie's misguided economic and social policies and, as a result, it started to question the sustainability of the generous U.S. welfare program for the Ethiopian government.

\footnotetext{
110 On 18 October 1973, a presentation on British TV by Jonathan Dimbleby called "The Unknown Famine" documented the local circumstances surrounding the famine, exposing to the world the seriousness of the famine.
} 


\section{CHAPTER 5}

"Between 1950 and 1970, the United States used its famine aid as a lever to induce social and economic reforms it believed were desirable for political stability in Ethiopia. The IEG [Imperial Ethiopian Government] viewed those reforms as inimical to its political survival. Instead it placed the demands of state security above those of peasant survival." (Kissi, 2000, p. 131)

By the early 1970s, U.S.-Ethiopian relationships deteriorated gradually and Haile Selassie's regime began to lose its most important ally: "the emperor no longer held the trump card, and a new era of U.S.-Ethiopian relations would begin" (Vestal, 2011, p. 183).

Members of the Crown Council of Ethiopia - the constitutional body which advised the reigning Emperor of Ethiopia - were well aware that Selassie plunged the country into political and economic chaos. However, most of the members of the Crown Council of Ethiopia, as well as the Ethiopian Prime Minister Tsehafi Taezaz Aklilu Habte-Wold and army commander Leul Ras Aserate Kassa, were unwilling to challenge Haile Selassie. The fact that their solidarity with the emperor stood above everything else must be considered a true testimony to unwavering loyalty.

On 12 September 1974, a Marxist group known as the Derg'111, led by Major Mengistu Haile Mariam, staged a coup d'état against Emperor Haile Selassie. Haile Selassie was taken away in a baby blue Volkswagen beetle from the Jubilee Palace and imprisoned, together with the rest of the imperial family. ${ }^{112}$ On 23 December 1974, what came to be known as "Bloody Saturday", Mengistu orchestrated the massacre of 60 former high officials of the imperial government without trial. Haile Selassie spent the last few months of his life imprisoned in the Grand Palace. It is believed that the 82-year-old Emperor was suffocated with an ether-doused pillow and was buried under a bathroom floor in one of

\footnotetext{
111 The word "Derg" means 'committee' in Amharic.

112 Sudanese President Gaffar al-Nimeiry offered asylum to Haile Selassie since he considered the Ethiopian Emperor not only as the legitimate Ethiopian leader but also the leader of the whole of Africa (Metaferia, 2009). Anecdotal evidence suggests that al-Nimeiry had Ethiopian friends and that his mother was originally from northwestern Ethiopia (Wagaw, 1993).
} 
his palaces (Asserate, 2014, 2015).113 The military-led regime under Mengistu was to rule the country from 1974 onwards putting an end to the Solomonic dynasty.

While the period under Haile Selassie's rule can be regarded as a period of peace and national unity, the inherent flaws of Selassie's project of centralised imperial state formation became increasingly obvious in the 1960s.

"There is no doubt that Haile Selassie wants to go down in history as the builder of modern Ethiopia. Indeed, some of the most radical Ethiopians assert that he does not lack good intentions. The tragedy is that he has been kept from realizing his progressive ideals by characteristics traditionally connected with the Ethiopian monarchy. Consistent with the traditional attitude that delegation of authority deprives the ruler of some measure of dignity, he has insisted on retaining the powers of an absolute despot." (Levine, 1961, p. 11)

"His appeal to divine right with an intense personal grasp of power, in much the same way as symbols and controls are combined in the emperorship itself. Highly personalised control is the essence of his style. He stands at the head of a hierarchically ordered government, with comparatively weak horizontal communications, and acts so as to hold its diverse threads as closely as possible in his own hands." (Clapham, 1969, p. 115)

Almost fifty years later, Haile Selassie's rule can be described as a period of "repressive feudalism, built on injustice and inequality, when government was dedicated to the service of a single man, and opportunities to secure peaceful reform were spurned. [Selassie's] project of imperial centralization destroyed any mechanisms through which political power could be linked to changing social forces in a highly diverse country" (Clapham, 2015, p. 206).

\footnotetext{
113 For a detailed account of Haile Selassie's life, consult Asfa-Wossen Asserate's (2014, 2015) "King of Kings: The Triumph and Tragedy of Emperor Haile Selassie I of Ethiopia". Asserate, a German-Ethiopian historian and great nephew of Haile Selassie, provides a fair-minded, insightful, and nuanced portrayal of Haile Selassie using his own experiences and arduous research in family and public archives. His account is a riposte to Ryszard Kapuściński's (1978) "The Emperor: Downfall of an Autocrat", a grotesque and schizophrenic portrayal of Haile Selassie.
} 
In terms of economic development, Selassie's economic results were mixed at best. In his attempt to modernize his country, Selassie heavily emphasized the development of the industrial sector and commercialized agriculture mostly for purposes of import substitution. While Selassie was eager to attract foreign capital for the promotion of Ethiopia's manufacturing industry, manufacturing only accounted for a meagre 5 percent of GDP in 1975 (Keller, 1989). Table 5.3 shows the evolution of economic development in Ethiopia from 1950 until the end of the Selassie regime, using data from the Penn World Tables version 8.1 (PWT8.1) and the Maddison Historical Statistics from the Groningen Growth and Development Centre (GGDC).

Even though the PWT8.1 and GGDC data on Ethiopia's economic growth deviate substantially, a few major patterns emerge. Between 1950 and the late 1960s, real GDP and real GDP per capita grew fast. But the figures also show a deterioration of the Ethiopian economy in the early 1970s. Real GDP per capita in 1974 was almost identical to real GDP per capita in 1970. Economic growth came to a halt in 1974, the last year of Haile Selassie's reign.

Table 5.3: Evolution of GDP (per capita) in Ethiopia, 1950-1974

\begin{tabular}{lcccc}
\hline PWT8.1 & $\mathbf{1 9 5 0}$ & $\mathbf{1 9 6 0}$ & $\mathbf{1 9 7 0}$ & $\mathbf{1 9 7 4}$ \\
\cline { 2 - 5 } $\begin{array}{l}\text { Real GDP (in mil. 2005 US\$) } \\
\text { Real GDP per capita (in mil. 2005 US\$) }\end{array}$ & 419.5 & 589.0 & 698.2 & 698.5 \\
\hline & $\mathbf{1 9 5 0 s}$ & $\mathbf{1 9 6 0 s}$ & Early 1970s & $\mathbf{1 9 7 4}$ \\
\cline { 2 - 5 } & & & & \\
PWT8.1 & 4.9 & 5.0 & 1.8 & 0.0 \\
GDP Growth Rate & 3.0 & 3.0 & -0.3 & -2.4 \\
GDP per capita Growth Rate & & & & \\
GGDC & 3.0 & 5.2 & 3.5 & 1.2 \\
GDP Growth Rate & 1.2 & 3.1 & 1.2 & -1.1 \\
GDP per capita Growth Rate & &
\end{tabular}

Note: The average GDP (per capita) growth rate is shown for the 1950s, 1960s and early 1970s (1970-1974).

Source: Penn World Tables (PWT) version 8.1 (Feenstra, Inklaar, \& Timmer, 2015); Maddison Historical Statistics from the Groningen Growth and Development Centre (GGDC) (Bolt \& van Zanden, 2014).

Table 5.4 provides the main stylised facts and trends in output and employment at the sectoral level for the both the Ethiopian economy and Sub-Saharan Africa (SSA) between 1960 and 1975. The manufacturing sector in Ethiopia expanded during that period, albeit less than manufacturing in Sub-Saharan African as a 


\section{CHAPTER 5}

whole. The share of manufacturing in GDP rose from 2 per cent in 1960 to 4 per cent in 1975. The manufacturing employment share only slightly increased from 1.3 per cent to 1.7 per cent. At the same time, the agriculture value added share in the Ethiopian economy dropped from 81.1 percent in 1960 to 69.5 percent in 1975. The relative employment share in the Ethiopian agricultural sector was reduced by 5.3 percentage points within the same period.

Table 5.4: Sectoral Data on Value Added and Employment in Ethiopia, 1960-1975

\begin{tabular}{|c|c|c|c|c|c|c|c|c|}
\hline \multirow{2}{*}{ ETHIOPIA } & \multicolumn{4}{|c|}{$\begin{array}{l}\text { Value added } \\
(\% \text { of GDP) }\end{array}$} & \multicolumn{4}{|c|}{$\begin{array}{c}\text { Employment } \\
\text { (\% of population) }\end{array}$} \\
\hline & 1961 & 1965 & 1970 & 1975 & 1961 & 1965 & 1970 & 1975 \\
\hline Agriculture & 81.1 & 78.6 & 76.1 & 69.5 & 96.2 & 94.8 & 92.5 & 90.9 \\
\hline Industry & 7.9 & 8.1 & 8.6 & 10.2 & 1.5 & 1.8 & 2.2 & 2.1 \\
\hline Manufacturing & 2.0 & 2.3 & 3.0 & 4.0 & 1.3 & 1.6 & 1.9 & 1.7 \\
\hline Services & 11.1 & 13.2 & 15.3 & 20.3 & 2.3 & 3.4 & 5.3 & 7.1 \\
\hline Total economy & 100.0 & 100.0 & 100.0 & 100.0 & 100.0 & 100.0 & 100.0 & 100.0 \\
\hline \multicolumn{9}{|l|}{ SSA } \\
\hline & 1960 & 1965 & 1970 & 1975 & 1960 & 1965 & 1970 & 1975 \\
\hline Agriculture & 37.6 & 34.0 & 31.7 & 29.2 & 72.7 & 71.2 & 69.3 & 66.0 \\
\hline Industry & 24.3 & 25.1 & 28.3 & 30.0 & 14.3 & 9.8 & 10.3 & 13.1 \\
\hline Manufacturing & 9.2 & 10.9 & 12.6 & 14.7 & 4.7 & 5.2 & 5.8 & 8.9 \\
\hline Services & 38.1 & 40.8 & 39.9 & 40.7 & 18.0 & 19.0 & 20.4 & 40.7 \\
\hline Total economy & 100.0 & 100.0 & 100.0 & 100.0 & 100.0 & 100.0 & 100.0 & 100.0 \\
\hline
\end{tabular}

Note: For some countries time series do not start in the 1960s. For these countries the share is taken from the most nearby year (Botswana: 1964; Ethiopia: 1961; Kenya: 1969; Malawi: 1966; Mauritius: 1970; Senegal: 1970; Tanzania: 1961; Zambia: 1965). Figures are unweighted averages across 11 African countries. Numbers may not sum due to rounding.

Source: Author's own calculations using the Africa Sector Database (De Vries, Timmer, \& De Vries, 2015).

Despite Washington's provision of economic assistance to Ethiopia worth over $\$ 350$ million between 1946 and 1975, the "backwardness and underdevelopment were the hallmarks of the socio-economic order" (Zewde, 1991, p. 200). The modest expansion of the industrial sector can mainly be attributed to Ethiopia's infant stage of industrialization. Moreover, industrialization was (i) confined to the cities of Addis Ababa, Asmara and Dire Dawa and (ii) mainly dominated by foreign capital. 


\title{
CHAPTER 5
}

Even though there exists some weak evidence for a mild structural transformation under the Selassie regime, economic policies did

\begin{abstract}
"little to reform peasant agriculture or to integrate small farmers more fully into the market economy (...) Capitalist classes emerged side-by-side with feudal classes and in some cases overlapped. Inequalities abounded. Traditional relationships were fractured and Ethiopian society became increasingly exploitative and insecure for the impoverished majority." (Keller, 1989, p. 127-128)
\end{abstract}

The Ethiopian government became totally dependent on the goodwill of Washington, both in economic and political spheres (Metaferia, 2009). The United States was Ethiopia's main trading partner. 40 percent of Ethiopia's exports went to the United States (predominantly coffee). Between 1966 and 1969 , the indebtedness of the Ethiopian government rose from $\$$ Eth. 30,310,000 to $\$$ Eth. $445,189,000$ as expenditures diverged considerably from revenues. The Selassie regime had to take on loans from international creditors. According to estimations by Zewde (1991), "some 75 percent of this loan directly or indirectly originated from the USA and underlined Ethiopia's dependence on that country, a dependence duplicated in military and educational spheres" (p. 201).

Haile Selassie's rule can be credited with some historical successes. His government resisted Italian fascism, and contributed to the unity and independence of the Ethiopian state. Selassie was a well-respected politician in the international political arena and an important figure in Africa's decolonization process. However, Haile Selassie was not capable of responding to the economic and technological challenges that arose in the second half of the $20^{\text {th }}$ century. According to Zewde (1994), Haile Selassie's "greatest crime was to rule far too long” (p. 43) and thus losing touch with Ethiopian society (see also Kapuściński, 1978). Mockler's (2003) conclusion is very similar:

"Haile Selassie ruled too long. In his old age he was challenged, discredited, deposed, calumniated, scorned and - probably - smothered to death. For years it looked as if his reputation had died with him. But thankfully this has proved not to be the case. His reputation now stands higher among Ethiopians than it ever did before.” (p. xi) 


\section{CHAPTER 5}

The reason why Haile Selassie's reputation nowadays stands very high among the Ethiopian population is mainly due to the reign that was going to follow from 1974 until 1991.

\subsubsection{Foreign Aid under Mengistu Haile Mariam}

Mengistu Haile Mariam's rule heralded the start of Ethiopia's socialist era. Mengistu was the most prominent officer of the Derg which was undergoing an intra-party struggle whilst also competing with the communist Ethiopian People's Revolutionary Party (EPRP) for full control. Mengistu's control was thereby limited until he gained full control on 3 February 1977.

The Amhara-dominated Derg regime proclaimed "Yaleminim Dem Ityopia Tikdem" ("Without shedding blood, Ethiopia First)" as revolutionary slogan emphasizing the move away from an ethnic hegemony of the Shawan Amhara towards a nationalist approach (Chege, 1979; Clapham, 1988). At the regional level, however, the revolutionary slogan never bore fruit due to the lack of a national identity among the rural population (Clapham, 1988; Keller, 1981).

Mengistu's government vision was a self-reliant future based on transforming the country into a Marxist-Leninist state (Pankhurst, 1992). The fact that the Selassie regime could not avoid the 1973-74 famine with foreign aid, particularly Western foreign aid, was unacceptable in the eyes of the new regime. The Derg believed that the country should not be dependent on aid from foreign countries, particularly capitalist ones. To examine the causes of the 1973-74 famine and to prevent the occurrence of future famines, the government set up the Relief and Rehabilitation Commission (RRC).

"Before the RRC was established, there was no effective mechanism for bringing assistance to bear at times of famine, let alone for raising international alarms. The establishment of the RRC was intended to change this. The centrepiece of its operation would be an early-warning system so that fears about future famines could be given concrete and scientific shape. This would enable donors to respond in time to future emergencies. In the early years of the revolutionary government, the United States and Britain joined UNICEF, the United Nations Children's Fund, in financing the new system." (Gill, 1986, p. 35) 


\section{CHAPTER 5}

Mengistu established an agrarian socialist regime nationalizing most of the country's industry and agriculture between 1974 and 1975 (Brietzke, 1976; Marcus, 2002; Prunier, 2015; Wolde Giorgis, 1989). The Land Reform Proclamation of March 1975 gave all agricultural land to the Ethiopian people, redistributing it to the peasants and prohibiting the sale of land plots (Mengisteab, 1990; Ottaway, 1977).

One of the Derg's major policies was a resettlement program: the enforced population transfer from the more densely populated and exhausted lands of the northern regions to the lowlands of the south and west. ${ }^{114}$ Another main trait of Ethiopian socialism was the villagization of at least seven million people, where the collectivization of farming under the Ujamaa policy in Tanzania served as role model. ${ }^{115}$ In July 1975, the Derg regime established kebeles in Addis Ababa and several other urban centres. Each kebele included, on average, 500 families or between 3500 and 4000 people. While the main purpose of the kebeles was the provision of basic health, education and other social services in their neighbourhoods, the Derg also used the kebele (together with peasant associations) to control the urban regions and to implement land reform (Ottaway, 1977; Shinn \& Ofcansky, 2013; Vaughan, 2015; Wolde Giorgis, 1989). The restructuring of the regional and local government structures was aimed at dismantling feudal privileges enjoyed under Haile Selassie.

Mengistu believed that the "USSR's [Union of Soviet Socialist Republics] revolutionary history of national reconstruction was more in keeping with Ethiopia's political goals than were the traditions of American capitalism and bourgeois liberalism" (Marcus, 2002, p. 196). While Mengistu's commitment to scientific socialism alienated the U.S. government, the latter still provided

114 The solution was not feasible for several reasons. First, the transporting of people was implemented in a brutal way killing more than 50,000 settlers. Second, northern peasants moved from a malaria-free ecosystem in the north to the malaria-prone lowlands killing them in large numbers. Third, the local people in the lowlands were not willing to accommodate the peasants from the North. Fourth, the amount of money budgeted by the government for the transportation of people was insufficient (Prunier, 2015a)

115 Similarly to the Ujamaa village policy in Tanzania (see Ergas, 1980), villagization in Ethiopia failed. Those villages were often considered a dead end for peasants who had been forced to live in them: "they were too far from the outer ring of fields, some markets had become too distant; crop theft became frequent; too many small livestock around the villages themselves led to overgrazing on too small an area, leading in turn to massive killing of animals and later to a dearth of animal production, both milk and meat" (Prunier, 2015a, p. 225). 


\section{CHAPTER 5}

economic development aid and military assistance to prevent Mengistu from switching sides and moving towards the Soviet Union.

The outgoing secretary of state during Gerald Ford's presidency (1974-1977), Henry Kissinger,

"tried to keep an iron in the fire by continuing military assistance to Ethiopia, even after the overthrow of Haile Selassie. [...] Kissinger, [...], seemed to realize that if the United States completely forfeited its presence in Ethiopia, rather than hold its nose for the time being at the awful violations of human rights, the eventual result would be not only a strategic gain for the Soviets, but a more drawn out suffering for the people of the region." (Kaplan, 2003, p. 166)

In the early 1970s, the Soviet Union gained an even stronger foothold in the Horn of Africa by strengthening further its diplomatic relationships with the Somali government under Siad Barre wo ruled the country since 1969 after a successful coup d'état. In July 1974, Somalia became the first Sub-Saharan African country to sign a friendship and cooperation treaty with the Soviet Union.

"The Soviet Union was also Somalia's main source of military assistance, including highly sophisticated weapons, tanks, fighter planes, and bombers. Between 1971 and 1974, the value of Soviet military aid increased tenfold and the number of Soviet military advisors reached 1,400. (...) Over the following three years, Moscow supplied Mogadishu with weapons and military equipment valued at some $\$ 300$ million. By 1976, Somalia boasted a 22,000-man army and was the fourth most heavily armed nation in sub-Saharan Africa, surpassed only by Nigeria, Zaire, and Ethiopia. While Cuban technicians trained Somali troops in the use of Soviet armaments, the Soviet Union and East Germany helped bolster Somalia's National Security Service, which was notorious for arresting and torturing opponents of the Siad Barre regime." (Schmidt, 2013, p. 149)

With the election of Jimmy Carter as U.S. president in November 1976, Washington became increasingly disenchanted with the Derg regime. On 24 February 1977, the Carter administration upset the Mengsitu government by withholding military-aid grants worth $\$ 6$ million due to the Derg's poor human 


\section{CHAPTER 5}

rights record. Carter's human rights agenda provided the Soviet Union with an entry point (Patman, 1990; Westad, 2005; Yordanov, 2016). In contrast to inherently weak Somalia, Ethiopia was the most powerful state in the region and "probably the most valuable piece of real estate in Africa" (Maren, 1997, p. 35). While Moscow continued to provide military assistance to the Somali government, it also promised Mengistu military assistance based on the condition that he would sever Ethiopia's ties with the United States (Marcus, 2002). In December 1976, Mengistu signed a military agreement with the Soviet administration in Moscow.

"The real turning point in Moscow's approach to the region was Mengistu's coup on 3 February 1977, during which he assassinated most of his remaining rivals within the Derg. Although not informed in advance, the Soviets viewed the coup as a giant step forward in its relations with Ethiopia." (Westad, 2005, p. 271)

Forthcoming Soviet military assistance also further pushed the Derg to embrace fully a Marxist-Leninist political philosophy (Chege, 1979; Clapham, 1988; Keller, 1981; Markakis \& Ayele, 1977). The Kremlin supported Mengistu's Red Terror of 1977-78, a violent political campaign that targeted political opponents such as the Derg faction that allied against him and anyone suspected of being an EPRP member. It is estimated that up to 500,000 people were killed during Mengistu's "Red Terror" purge including many innocent civilians and children (Andrew \& Mitrokhin, 2005; De Waal, 1991).

In April 1977, the military relationship between the United States and Ethiopia came to an end under the era of U.S. President Jimmy Carter. On 30 April 1977, Mengistu abrogated the 1953 Mutual Defense Assistance Agreement with the U.S. administration (Yordanov, 2016). Consequently, Washington also stopped providing economic development assistance to Ethiopia. The Carter administration was no longer willing to continue supporting a repressive government perpetrating serious human right abuses with U.S. arms. Similarly, the British Overseas Development Administration stopped its development programs in Ethiopia by 1979. Consequently, the RRC lost two major providers of funding, even though the "early-warning system has continued to function with considerable efficiency with the assistance of UNICEF” (Gill, 1986, p. 35). 


\title{
CHAPTER 5
}

In early May 1977, Mengistu arrived in Moscow for a nine-day official visit where he held talks with Leonid Brezhnev, then General Secretary of the Central Committee of the Communist Party of the Soviet Union.

\begin{abstract}
"The main result from the visit, (...) was the signing of a joint political document, showing each side's commitment to developing bilateral relations. Both parties also concluded economic, cultural and scientific, and consular agreements, which set the stage for an eventual SovietEthiopian friendship treaty. It appears, the Soviet military had also played a key part in the negotiations, as, reportedly, Mengistu managed to sign a US\$ 504 million arms agreement that was the largest Soviet accord with an African country at that time. This increased the total amount of military aid pledged over the course of six months by the Soviet Union to Ethiopia to US\$ 640 million, more than double the military aid provided to Mogadishu over the past decade.” (Yordanov, 2016, p. 168-169)
\end{abstract}

The Somali Ethiopia Ogaden War (or Second Ogaden War) between July 1977 and March 1978 forced the Soviet Union to choose sides between Ethiopia and Somalia. The war started with a Somali military offensive over the disputed Ogaden region in Ethiopia. Moscow condemned the invasion and broke off ties with Somalia and its President Siad Barre (Schmidt, 2013). As a result of the Soviet build-up in Ethiopia, the Ethiopian army grew from 65,000 to nearly 300,000 troops by the late 1970s therefore becoming the largest army in SubSaharan Africa. The Mengistu government, formerly equipped with 62 tanks and 27 jet fighters, received an additional 350 tanks and 70 jet fighters from Moscow (Kaplan, 2003). At the same time, the USSR ceased its support to the Somali government:

"Fuel shipments were cut off; and arms deliveries were squeezed another notch. By mid-September 1977, Mogadishu was only receiving spare parts and some light arms. Delivery of heavy weapons ceased altogether. Nevertheless, Mengistu remained uneasy about what remained of the Soviet-Somali connection. At a press conference on 18 September, the Ethiopian leader floated the idea of fresh American arms supplies and warned Moscow that if socialist countries are still supplying arms to Somalia, then this is not only violating one's principles, but also tantamount to complicity with the reactionary Mogadishu regime'. This public rebuke had the desired effect. On 18 October 1977, Anatoly Ratanov, the Soviet Ambassador to Ethiopia, announced that the USSR 


\section{CHAPTER 5}

had completely stopped supplying arms to Somalia and was now providing Ethiopia with 'defensive weapons to protect her revolution'." (Patman, 1990, p. 219)

In November 1977, Moscow provided 18,000 Cuban troops and \$2 billion worth of arms to the Ethiopian government which was eight times the total value of all U.S. arms delivered to the country between 1953 and the start of the Second Ogaden War in 1977 (Maren, 1997). ${ }^{116}$

As a result, Somalia broke diplomatic relations with the Soviet Union. Siad Barre turned to the U.S. administration after the United States ceased its support to Ethiopia. U.S. Secretary of State Cyrus Vance indicated in July 1977 that Washington considered delivering military assistance to Somalia (Lefebvre, 1991). The U.S. government, however, reversed itself refusing to provide military and economic assistance for Somalia. The U.S. reversal was partly due to President Carter's human rights agenda and his critical stance towards Somalia's violation of Ethiopia's territorial integrity. But two years after the Somali National Army (SNA) evacuated the Ogaden region in 1978 and after President Siad Biarre promised to respect the boundaries of Somalia's neighbouring state Ethiopia, the United States started to provide military assistance to the Somali government in 1980 (Lefebvre, 1991; Westad, 2005).117 Despite Carter's human rights agenda, the U.S. government "ultimately allowed Cold War concerns to govern its policy in Somalia” (Schmidt, 2013, p. 155).

The Soviet support for the Mengistu government during the Second Ogaden War contributed to the "consolidation of Mengistu's power and that of the Kremlin's in Ethiopia - an incredible display of Soviet military strength and determination in support of an ally" (Kaplan, 2003, p. 172).

\footnotetext{
116 Both Kaplan (2003) and Hanhimäki (2012) estimate the monetary value of Soviet arms delivered to the Ethiopian government to be around $\$ 1$ billion 'only'. Even this lower benchmark estimate is still four times larger than the value of all U.S. arms delivered to Ethiopia between 1953 and the beginning of the Second Ogaden War in 1977.

117 The strategy of both recipient countries to gain significant bargaining power by convincing both the United States and Soviet Union that they could swing either way has been identified as 'negotiated extraversion' (Thomson, 2000). The term 'negotiated extraversion' is derived from the concept of 'state extraversion' (Bayart, 2000; Clapham, 1996). It describes the tendency of Third World governments to constantly address an external audience rather than mobilizing support of domestic constituencies for their political agendas.
} 


\section{CHAPTER 5}

"By 1979, Ethiopia was firmly in the Soviet camp - and the beneficiary of the largest Soviet foreign assistance program since Moscow's massive transfer of aid, technology, and know-how to China in the 1950s. More than 7,000 technicians and other personnel arrived from Cuba, the Soviet Union, and Eastern Bloc countries to help Ethiopia build a revolutionary socialist society." (Schmidt, 2013, p. 153-154)

During these years, China remained politically neutral due to its principal of noninterference in domestic political affairs. Since the Derg regime was a strong ally of the Soviet Union between 1977 and its overthrow in 1991, China's popularity gradually increased among leftist movements in Ethiopia (Adem, 2012). While China was willing to strengthen its diplomatic relationship with the Mengistu regime, it was not prepared to compete with the Soviet Union in providing military assistance for Ethiopia's fight against Somalia. Beijing was officially accused by the Derg regime of cooperating with the West and the Somalian government. After this unfounded accusation, Sino-Ethiopian relations deteriorated (Shinn \& Eisenman, 2012). Beijing's foreign aid to Ethiopia during the 1970s and 1980s was minimal and came mainly in the form of emergency relief (food aid). The bulk of China's aid was channelled through multilateral donor organizations such as UN agencies (AFRODAD, 2011).

Besides the external war that the Derg regime fought against Somalia, it also faced several domestic challenges such as the fight against Eritrea's independence movement, and other ethnic minorities that became increasingly hostile towards the increasingly Amhara-dominated Derg regime (Chege, 1979; Clapham, 1988; Keller, 1981; Tareke, 2009). In 1977, former groups of the Eritrean Liberation Front (ELF) joined forces and established the Eritrean People's Liberation Front (EPLF). The EPLF became the dominant opposition group for the Derg regime. The Secretary-General of the EPLF was Ramadan Mohammed Nour, Isaias Afewerki was the Assistant Secretary-General. Two years before the establishment of the EPLF, another opposition party emerged. On 18 February 1975, the Tigrayan People's Liberation Front (TPLF) was established. By 1980, the TPLF claimed to control 80 percent of the Tigray region (De Waal, 1997). The TPLF was largely provided with arms and other supplies by the EPLF. The TPLF and EPLF fought side by side against the Derg regime throughout the Ethiopian Civil War. The Mengistu government 


\title{
CHAPTER 5
}

attempted to crush the guerrilla movement in the north of the country between 1978 and 1986 but had little success.

\begin{abstract}
“The EPLF and TPLF were highly motivated and ruthlessly committed organizations. In contrast to the army, with its debilitating factionalism and rigidity, the fronts were remarkably cohesive and adaptable. Masterful at using the terrain to their advantage, they fought with will, purpose, patience, stealth, and speed, skilfully exploiting the army's weaknesses and mistakes while nullifying its strengths.” (Tareke, 2009, p. 316-317)
\end{abstract}

When Ronald Reagan assumed office in Washington in January 1981, Ethiopia was "well on its way to becoming Moscow's first African satellite" (Kaplan, 2003 , p. 175). In order to counterbalance Soviet military assistance to Ethiopia and to seek replacements for lost strategic facilities in Ethiopia, the Reagan administration obtained Siad Barre's permission to use naval, port and air facilities in Mogadishu and Berbera. The Somali government, in turn, received "\$500 million worth of military and economic assistance between 1981 and 1986, making Mogadishu one of the largest recipients of U.S. military aid in subSaharan Africa” (Schmidt, 2013, p. 155).

In its attempt to institutionalize a communist regime, the Mengistu government made errors similar to those committed by the Soviet Union in the 1930s, especially with regard to agricultural policy and collectivization in particular. Collective farms made up only 5 percent of cultivated land during 1980 and 1985. But collective farms received 43 percent of the investment in the agricultural sector and their returns were lower than what had been invested in their development (Chole, 2004). This policy inhibited the investment in fertilization, high-yield seeds, labour, technical expertise and tractors to raise the production among the peasants. The net effect was lower incentives by peasants to produce food, a higher government dependence on relatively high cost grain from state farms and little food surplus as a cushion against an emergency crisis. In May 1981, the RRC of Ethiopia held a presentation to the United Nations on Least Developed Countries documenting deteriorating weather conditions in Ethiopia (Kumar, 1990). The call by the RRC was largely ignored by the international community and only little food aid was given by donor organizations. 


\section{CHAPTER 5}

The harvest in 1982 was the largest ever recorded in Ethiopian history and the harvest in the subsequent year was the third largest, even though production remained far below the country's potential (McVety, 2012). A long drought between July and September 1983 was a warning sign for a famine in 1984. In the mid-1980s, the four northern Ethiopian provinces - Gojam, Eritrea, Tigray and Wollo - and the eastern Ethiopian province Hararghe witnessed low rainfalls. According to RRC estimates, the number of people "at risk" of famine rose to 3.9 million in 1983 from 2.8 million in 1982, which was less than the 1981 estimate of 4.5 million (De Waal, 1997, p. 112).

On 30 March 1984, the RRC calculated that it needed another 900,000 tons of grain for the remaining months in 1984. The RRC, however, thought that it did not possess the capacity to distribute 900,000 tons. As a result, the RRC only appealed for half of the initial figure, 450,000 tons (Gill, 1986).

"It was, according to some, a fateful error, and started that process by which big donors could wriggle from whatever sense of obligation they may have felt. Tony Vaux [Oxfam relief manager in Ethiopia] described the process: 'It appears that the constant repetition of appeals had produced a sense of scepticism which was not based on any past failure of the RRC's predictions but more a feeling that they were constantly asking for more. Agencies were tired of helping a government that seemed to do so little to help itself."' (Gill, 1986, p. 31)

In its aim to launch its own appeal, the Food and Agriculture Organization of the United Nations (FAO) and its partner agency, the World Food Programme (WFP), sent a mission to Ethiopia in February 1984 to work closely together with the RRC for a month. The FAO mission reduced the latest RRC appeal of 450,000 tons by almost three-quarters to 125,000 tons as it believed that Ethiopia's distribution capacity was even more limited than previously estimated by the RRC. The UN-backed appeal is considered "one of the more fateful conclusions made by any set of experts in the build-up to the Ethiopian famine" (Gill, 1986, p. 44).

"In the field, the voluntary agencies had tended to rely upon their big brothers in the UN system for judgements and expertise in such technical areas as crop assessment. (...) The UN mission's key error - more abundantly plain in retrospect than it may have been at that time - was to 


\section{CHAPTER 5}

underestimate the capacity of the creaky Ethiopian port and distribution system to get food moving in a crisis." (Gill, 1986, p. 47)

The long draught, crop failure and the initially slow response by the international donor community were, however, not the only major determinants for the 198486 famine. As the next few paragraphs will show, Mengistu's initial denial of the famine, his war against secessionist movements in Eritrea and Tigray and the deliberate withholding of food aid by the Derg regime to guerrilla-controlled regions significantly contributed to the vast scale of the famine in (northern) Ethiopia. ${ }^{118}$

Similar to the Selassie government during the 1973-74 famine, the Mengistu government did not fully acknowledge the seriousness of the situation, even after the absence of short rains in early 1984 (Clay \& Holcomb, 1986; De Waal, 1991; Kaplan, 2003). Around one-sixth of Ethiopia's population was directly threatened with starvation and death at the peak of the crisis (Marcus, 2002). By March 1984,
"it was apparent to Ethiopian relief officials that a major famine, with its accompanying death, distress and dislocation, could only be averted through massive Government and international intervention (...) In the middle months of 1984, official attention was simply directed away from the likelihood of severe famine to the political priority in hand, the establishment of the new party [Workers' Party of Ethiopia] ${ }^{119}$ and the [Derg's tenth] anniversary celebrations." (Gill, 1986, p. 9)

In late 1984, hundreds of thousands of people in the northern provinces began to die. More than 300,000 people died in the year 1984, more than twice the number during the 1973-74 famine (Keller, 1992).

\footnotetext{
118 Peter Gill's (1986) "A Year in the Death of Africa: Politics, Bureaucracy and the Famine", Alex De Waal's (1997) "Famine Crimes: Politics \& the Disaster Relief Industry in Africa" and Robert D. Kaplan's (2003) "Surrender or Starve. Travels in Ethiopia, Sudan, Somalia, and Eritrea" are very insightful accounts on the role of domestic political factors and external agents (such as the disaster relief industry) behind the famine that ravaged Ethiopia and the Horn of Africa region more generally.

119 The Workers' Party of Ethiopia was established in 1984, with Mengistu appointing himself as chief of the party. The party was modeled on the Communist Party of the Soviet Union and became the only legal political party in Ethiopia.
} 


\section{CHAPTER 5}

"While Eritreans, Tigreans, and others in the northern provinces died by the hundreds of thousands, the markets of the Amhara fortress of Addis Ababa were brimming with grain.” (Kaplan, 2003, p. 38)

At the height of the famine, the Derg regime announced that it would allocate 46 percent of Ethiopia's gross national product (GNP) to military spending in its war against the Tigrayan and Eritrean rebels in northern Ethiopia. Mengistu created a 3-million-man standing army, the largest and most sophisticated one in Sub-Saharan Africa (Gill, 1986; McVety, 2012; Webb \& Von Braun, 1994). Mengistu fed his army and Ethiopia's main cities by forcing the peasants' association to deliver grain at prices below the average market price alienating the peasantry and stifling their productivity (Tareke, 2009). The Derg's repeated military offensives (including bombings) and discriminatory food policies against the guerrilla-controlled territories in Tigray and Eritrea, mass displacement, and disruption of agricultural production and trade in the guerrilla-controlled areas played an important role in creating the breeding ground for a famine in northern Ethiopia (Davey, 2015; De Waal, 1997; Marcus, 2002; Tareke, 2009; Wolde Giorgis, 1989).

The RRC undertook several efforts to get the Derg regime to respond to the famine but all its attempts failed. The Derg regime faced a dilemma: its main ally, the Soviet Union, was facing food shortages at home and the other Warsaw Pact countries had little financial resources to assist the Ethiopian government. At the same time, both the United States and the European Economic Community held grain surpluses (Marcus, 2002). Throughout the early 1980s, however, Mengistu was largely reluctant to receive humanitarian assistance - including food aid - from the Western donor community thereby prolonging the famine.

At the same time, RRC commissioner, Dawit Wolde Girogis, questioned the morality of rich Western governments and the small scale of their humanitarian assistance for the poor in his country: "It was a formula that seemed at times to exclude his own government from further obligation" (Gill, 1986, p. 33). In the early 1980s, the Reagan administration used food aid as an instrument of foreign policy against the Ethiopian government. Despite several appeals to USAID by international humanitarian agencies working in the Wollo and Tigray regions, the U.S. response was slow. 


\section{CHAPTER 5}

After the U.S. humanitarian agency Catholic Relief Services made an appeal for 16,000 metric tons of grain on 13 October 1983, for example, only 8,000 tons of food aid were promised by USAID in May 1984 (Gill, 1986). The other 8,000 tons were only approved and delivered ten months after the initial request. Between 1982 and 1984, the Reagan administration cut food aid from 8,172 metric tons in 1982 to zero in 1984 (Keller, 1992; Shepherd, 1985).

"The reluctance of the rich countries to respond to the appeals of Ethiopia's Relief Commission is the less easy to understand because the Commission enjoys a remarkably high reputation among the aid agencies. The United States Government, for instance, has gone out of its way to publicize its criticisms of the Ethiopian regime for failing to give a high enough priority to the famine, but the RRC won a grudging commendation. Through clenched teeth, the State Department acknowledged that aid donors considered the RRC to be a 'relatively wellorganized and well-run organization.” (Gill, 1986, p. 37)

The Reagan administration was initially very reluctant to supply food aid to Ethiopia for two reasons. First, the U.S. government viewed food aid as one sector ripe for budget cuts. Second, it was not willing to support an oppressive communist government, "subsidizing a regime that was burning crops and dropping cluster bombs in the drought zone with one hand and using its relief agency to beg with the other" (Kaplan, 2003, p. 29).120 Meanwhile, the Derg was largely preoccupied with its war against separatist forces and the upcoming tenth anniversary celebration of Derg rule. On 10 September 1984, the Mengistu government spent around $\$ 200$ million celebrating the tenth anniversary of the rule of the Derg (Clay \& Holcomb, 1986; Griffin, 1987).

"Ten years before, an imperial regime had been toppled for its failure to cope with drought and attendant famine. As that event [Tenth anniversary of the Derg regime] was commemorated in the middle of a far worse famine, the heavens had spoken. Addis Ababa that day betrayed nothing of the tragedy that was building up in the countryside. Roads had been

\footnotetext{
120 British government officials expressed similar concerns towards the Ethiopian Marxist government. As a result, the British government under Margaret Thatcher initially refused to deliver development assistance to Ethiopia. In November 1984, Rev. Charles Elliott, former director of Christian Aid in Great Britain, accused the U.S. and British governments to deliberately withhold development assistance "in the hope that famine would bring down the communist regime" (Clay \& Holcomb, 1986, p. 216).
} 


\section{CHAPTER 5}

freshly asphalted. Every department of state, including the Government's own Relief and Rehabilitation Commission, had been instructed to devote part of its budget to sprucing up its office buildings. It was even said that beggars had been rounded up and carted out of town for the duration, so as not to offend the Revolution's visiting friends." (Gill, 1986, p. 7)

A few weeks after the tenth anniversary celebrations, on 3 October 1984, Mengistu and his regime belatedly acknowledged the famine in the north and granted international media access to the famine-stricken areas. ${ }^{121}$ The media coverage had an unprecedented impact. Even though Western bilateral and multilateral donors largely condemned Mengistu's socialist experiment and Stalinist policies, a large international relief effort took off and made available vast amounts of surplus grain. The famine set a new wave of aid enthusiasm in motion. Between 1982 and 1985, Western bilateral development assistance to Ethiopia rose by a factor of more than five, while foreign aid to Africa as a whole followed its normal general trend (Figure 5.1). In 1984, less than 20 nongovernmental development organizations were based in Ethiopia, while there were 60 in 1986 (McVety, 2012). Kaplan (2003) reports that in late 1984 "the Hilton Hotel [in Addis Ababa], whose occupancy rate normally hovered around 50 percent, was filled to capacity for the next nine months" (p. 32).

Due to increasing publicity of the famine and increasing pressure from congressmen returning from famine- and poverty-stricken camps, the Reagan administration provided emergency food aid at an unprecedented scale from early October 1984 onwards. By late October 1984, the United States delivered approximately 500,000 metric tons of food and other assistance worth around one billion dollars to Ethiopia (Kissi, 2005). The United States became the major provider of food aid from late 1984 onwards. U.S. food aid represented almost a third of total food aid delivered to Ethiopia by the international donor community (Gill, 1986): the U.S. food aid program to Ethiopia between October

\footnotetext{
121 The probably best known media footage of the 1984-86 famine was the broadcast of a "biblical famine" by BBC journalist Michael Buerk filmed in the Korem refugee camp, a remote part of northern Ethiopia. The first of Buerk's reports was shown on BBC Six O'Clock News on 23 October 1984. According to the BBC, the footage was "subsequently shown by 425 of the world's broadcasting organizations with a potential audience of 470 million people" (Gill, 1986, p. 91).
} 
1984 and late 1985 became the largest one ever recorded in history (Shepherd, 1985).

Figure 5.1: Western Bilateral Development Assistance to Ethiopia, 1960-1990

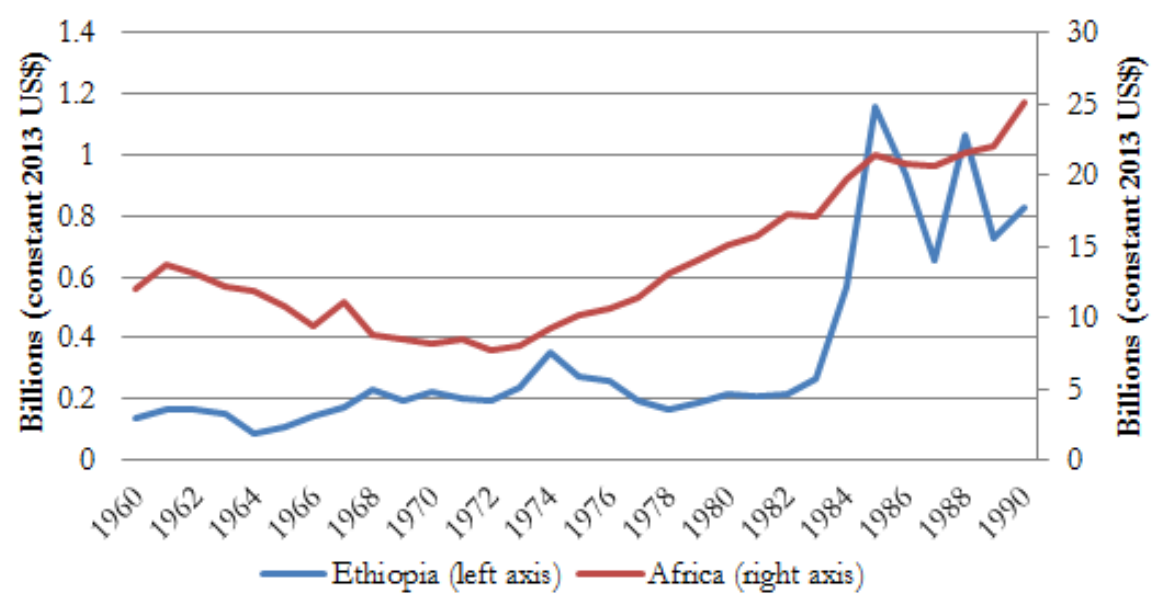

Source: Author's own calculations based on OECD/DAC statistics.

Domestic political factors, however, prevented the international donor community from addressing the famine in northern Ethiopia effectively and efficiently. One major problem in the efficient and effective distribution of food aid to those in need was that the access to the poverty-stricken areas in the north was restricted (Clay \& Holcomb, 1986). The Derg regime denied U.S. officials the right to monitor grain deliveries in rebel-controlled territories like Eritrea and Tigray culminating into the systematic purloining of grain by Derg officials. Moreover, millions of dollars of Western aid money were siphoned off by both the Derg regime and opposition groups such as rebel leaders to buy weapons and military equipment. It is estimated that

"some $\$ 100 \mathrm{~m}$ went through the hands of the TPLF and affiliated groups.

Some $95 \%$ of it was allocated to buying weapons and building up a hardline Marxist political party within the rebel movement." (Plaut, 2010)

The famine became a lucrative business for the Derg regime as well. Import fees for international food aid became Ethiopia's biggest hard currency earner replacing coffee (Kaplan, 2003). 


\section{CHAPTER 5}

"The Derg felt the need to levy changes on all the food and other relief supplies being brought into the country, mainly in order to help finance its war machine. As much as $\$ 30$ million was raised in 1985 by imposing an import fee that was initially set as high as $\$ 50.50$ per metric ton for all donors (except the United Nations, which had to pay $\$ 49)$. However, this levy was reduced to $\$ 20$ following an outcry from all the affected agencies. To make matters worse, some truck-loads of food intended for civilian centres were diverted by military officials in order to meet the needs of their own soldiers and armed supporters." (Keller, 1992, p. 621)

The Derg regime had an interest to keep the guerrilla-controlled regions malnourished. The government used the international food aid as a weapon against its enemies by (i) feeding the army and (ii) denying relief supplies to enter non-government controlled regions (McVety, 2012; Wolde Giorgis, 1989). Out of 1.25 million tons of food relief that Ethiopia received in 1984, only 90,000 tons were distributed in the rebel-held territories of Tigray and Eritrea (Marcus, 2002). Similarly, in the first half of 1985, Ethiopia received more or less the 75,000 tons that it required for that period through foreign assistance, but the RRC was very selective in its distribution: the Wollo region, for example, only received a quarter of the grain allocated to that area. The empirical evidence suggests that most victims came from the Northern provinces (Eritrea, Tigray and Wollo) where the majority of the population resisted the Derg's brutal regime (Table 5.5). By mid-1985, almost 50 to 60 percent of the areas affected by the famine were guerrilla-controlled territories (Kaplan, 2003).

"At the center of the famine - Tigray and north Wollo - the counterinsurgency strategy of the Ethiopian army was the single most important reason why the drought of 1983-4 became not a 'normal' period of hardship but a famine of a severity and extent unparalleled for a century." (De Waal, 1991, p. 133) 
Table 5.5: People affected by Serious Food Shortages by Region, 1984-1986

\begin{tabular}{|c|c|c|c|c|c|c|}
\hline & 1984 & 1985 & 1986 & \multicolumn{3}{|c|}{1985} \\
\hline & \multicolumn{3}{|c|}{ (in thousands) } & $\begin{array}{c}\text { \% of } \\
\text { Total } \\
\text { Affected }\end{array}$ & $\begin{array}{c}\% \% \text { of } \\
\text { Population } \\
\text { (Region) }\end{array}$ & $\begin{array}{c}\% \% \text { of } \\
\text { Population } \\
\text { (Total) }\end{array}$ \\
\hline Arsi & 21 & 82 & 20 & 1.00 & 4.9 & 0.19 \\
\hline Bale & 53 & 193 & 99 & 2.40 & 19.2 & 0.46 \\
\hline Begemder/Gonder & 325 & 363 & 341 & 4.50 & 12.5 & 0.86 \\
\hline Eritrea & 877 & 827 & 650 & 10.30 & 30.6 & 1.97 \\
\hline Gamo Gofa & 80 & 106 & 152 & 1.30 & 8.5 & 0.25 \\
\hline Gojam & 35 & 76 & 0 & 1.00 & 2.3 & 0.18 \\
\hline Hararghe & 279 & 875 & 1520 & 11.00 & 21.1 & 2.08 \\
\hline Ilubabor & - & 20 & 102 & 0.30 & 2.1 & 0.05 \\
\hline Kaffa & - & 58 & 90 & 0.70 & 2.4 & 0.14 \\
\hline Shoa & 204 & 852 & 709 & 11.00 & 8.9 & 2.03 \\
\hline Sidamo & 355 & 533 & 442 & 6.70 & 14.1 & 1.27 \\
\hline Tigray & 1300 & 1400 & 1000 & 17.50 & 58.1 & 3.33 \\
\hline Welega & - & 23 & 116 & 0.30 & 1.0 & 0.05 \\
\hline Wollo & 1821 & 2587 & 1547 & 32.40 & 71.7 & 6.16 \\
\hline TOTAL & 5350 & 7995 & 6788 & - & - & 19.03 \\
\hline
\end{tabular}

Source: Varnis (1990) based on data from USAID Ethiopia and the Relief and Rehabilitation Commission (RRC).

The RRC commissioner Dawit Wolde Giorgis was no longer willing to support the withholding of food aid by the Derg regime and defected to the United States in late 1985. In a New York Times interview in 1988, he argued that the vast amount of international humanitarian assistance contributed to Mengistu's continued hold on power (Wolde Giorgis, 1989). It was only in late 1985 that Eritrea and Tigray started to receive large-scale humanitarian assistance. Relief food aid to Eritrea and Tigray mainly came through Sudan which was also severely affected by the famine (De Waal, 1991; Kaplan, 2003; Varnis, 1990).122

\footnotetext{
122 Sudanese politics played an important role in the significant delay of humanitarian assistance to the northern provinces of Ethiopia. First, the logistical problems at the Sudanese border were severe: "Tens of thousands of tons of wheat and dried milk powder were piling up in Port Sudan warehouses in the early weeks of spring 1985, because there were insufficient trucks to bring the food over the border" (Kaplan, 2003, p. 76). A second major reason was of political nature. Sudanese President Gafaar Al-Nimeiry was afraid that his approval for allowing Western humanitarian assistance for the famine-stricken areas in northern Ethiopia to enter over the Sudanese border could upset Mengistu. Mengistu was reducing his military support for the Sudan People's Liberation Army/Movement (SPLA/M) led by John Garang, an African Christian rebel group in southern Sudan that was fighting a secessionist war against the Muslim government in Khartoum. Mengistu initially supported the SPLA/M because the Muslim government in 


\section{CHAPTER 5}

"By the end of 1985, relief efforts had become considerably stabilized. Food aid continued to be required in order to forestall famine conditions, but famine deaths had slowed significantly as the capacity for distributing aid had become firmly established. PVO [private voluntary organizations] operations continued to support the RRC system for distributing food; tertiary and secondary distribution mechanisms were coordinated with the assistance of UN organizations." (Varnis, 1990, p. 139)

Due to lack of reliable data, estimates of the death toll of the 1984-86 famine in Ethiopia vary between 200,000 and 1 million people (De Waal, 1991; Shepherd, 1985; Varnis, 1990). Apart from the international aid effort for the famine, the international donor community was also implicated in the disastrous consequences of the resettlement programme (De Waal, 1991; Pankhurst, 1992; Woldemeskel, 1989). Only a few weeks after the international media became widely informed of the famine, the Derg regime implemented a resettlement program that had been a major pillar of Mengistu's collectivization program.

"The plan was to move a large section of the population from the north to the south. The target was 1.5 million people. In fact, about 600,000 people were moved in three phases: November 1984-May 1985, October 1985-January 1986, and November 1987-March 1988. The justification presented to the west and to the people of Ethiopia was that it was a famine relief measure - the north of the country was stricken by drought and environmental collapse, and the only alternative was to move most of the people elsewhere." (De Waal, 1991)

During the resettlement campaign, hundreds of thousands of people were "hastily, forcibly, and pitilessly uprooted from the cool, dry highlands of Shewa, Tigray, and Wello to the hot, wet lowlands of Gojjam, Illubabor, Kafa and

\footnotetext{
Khartoum supported Eritrea's separatist movement (Holt \& Daly, 2011; Kaplan, 2003). Third, there was a growing anti U.S.-sentiment among the Sudanese Arabs in the capital of Khartoum when the rescuing of 8,000 black Ethiopian Jews, known as Falasha/Bete Israel, to Israel via Sudan through the U.S. Central Intelligence Agency (CIA) and the Israeli intelligence agency 'Mossad' became public. The rescue became known as Operation Moses. It is believed that alNimeiry was bribed by the United States and Israeli officials to allow the airlifting of the 8,000 Jews (De Waal, 1991; Metaferia, 2009). Al-Nimeiry had to resign in 1985 and the Transitional Military Council took over. The Transitional Military Council eventually gave its approval for the humanitarian assistance project aimed at helping the peasants in northern Ethiopia "provided that publicity about it be kept to an absolute minimum and that the U.S. role in the actual transport of the grain over the border be as indirect as possible" (Kaplan, 2003, p. 76).
} 


\section{CHAPTER 5}

Wellega" (Tareke, 2009, p. 149). The Derg regime often chose the resettlement camps randomly without the consultation of agronomists, anthropologists, ecologists or economists.

The effects of the resettlement campaign proved to be disastrous for the local often indigenous - population and the environment (Pankhurst, 1992; Woldemeskel, 1989). The Derg regime paid little attention to the concerns of the local people. Indigenous people were forcibly driven off their land often causing separations of families. The humanitarian and medical conditions in resettlement centres were inadequate leading to the death of thousands due to tropical diseases like malaria and sleeping sickness (Pankhurst, 1992; Tareke, 2009).

The net effect of the resettlement policies was that the Derg could control areas of civil unrest and advance its socialist policies (Keller, 1992). Dawit Wolde Giorgis compared the resettlement program with concentration camps:

"From the very beginning, resettlement for Mengistu was not a development program but a solution to his social and national security problems. Any dissidents, anyone who created problems or was seen as a security risk, was packed off to a resettlement site. Resettlement programs became our Siberia. As a result, in the minds of the people they were equated with concentration camps." (Wolde Giorgis, 1989, p. 285)

The resettlement program was supported by a large part of the Western donor community. The international organizations and humanitarian agencies that supported the resettlement program believed that it was an effective famine relief measure. The disastrous effects of Mengistu's resettlement policies, however, became obvious over time and there is evidence that the international donor community was not totally unaware of it (Gill, 1986). USAID, for example, was cautious not to channel U.S. aid to relief operations that were connected with the resettlement program. Then U.S. Secretary of State George Shultz wanted to launch a UN resolution condemning the resettlement policies by the Derg regime but backed down as he received no support from Western allies. 


\section{CHAPTER 5}

Great Britain, West Germany, Italy, Sweden and Finland did not support the program either, while Australia, Norway and Canada did (Gill, 1986). Besides several Western governments, the WFP of the United Nations, UNICEF and many private Western donor organizations supported the programme as those groups did not want their projects in Addis Ababa, as well as other urban centres and rural areas, questioned (Davey, 2015; Kaplan, 2003).

"The resettlement programme was heavily reliant on equipment and logistics provided by Western donors; military raids upon aid distribution centres were used to gather people for transfer to the south; and local officials were coerced into participation in the programme by threats of a withdrawal of aid from their region." (Davey, 2015, p. 227)

In mid-1985, the U.S. non-profit group Cultural Survival ${ }^{123}$ published the first independent and statistically highly representative investigation into the conditions of resettlement (Clay \& Holcomb, 1986). The report was based on 277 interviews by the authors and was conducted at six sites in eastern Sudan with Ethiopian refugees from Tigray and other famine-stricken regions.

"The death rates reported by the refugees ranged from 33 deaths per 10,000 people per day to 270 deaths per 10,000. These rates are extremely high given that the camp populations were comprised almost entirely of adults. Such figures were consistently reported from a number of different refugees from different areas. Furthermore, they were relayed by people who did not know each other. Some of the resettled people were undoubtedly malnourished as a result of declining agricultural production in their homelands, but many had not experienced famine until they were captured for resettlement. (...) These figures raise, among other issues, the question of how many of the 400,000 people who were resettled by June of 1985 are still alive. If even the most conservative estimates of the death rate (33 per 10,000 per day) are halved and then halved again (i.e., reduced by 75 percent), then 50,000 to 100,000 of those resettled in this massive program may already have been dead by July 1985." (Clay \& Holcomb, 1986, p. 102)

In December 1985, a few months after the Cultural Survival's report, the French medical agency and non-governmental organisation (NGO) Médecins Sans

\footnotetext{
123 Cultural Survival was founded in 1972 in Cambridge, Massachusetts. The aim of the organization is to defend human rights and cultural heritage of indigenous people and oppressed ethnic minorities.
} 


\section{CHAPTER 5}

Frontières (MSF) denounced the disastrous consequences of Mengistu's resettlement policy through a study that triggered a flood of international media reactions (Pankhurst, 1992). The study estimated that around 300,000 people were most likely to die in the process of resettling 1,500,000 famine victims. The report described the resettlement programme as "one of the most massive violations of human rights we have seen (...) carried out with the equipment and funds supplied by international aid” (Médecins Sans Frontières, 1985, p. 4).

"Humanitarian organizations and the western governments must know that they are in the process of supporting, through weakness, an operation that will be described with hindsight in a few years' time as one of the great slaughters in the history of the twentieth century." (Médecins Sans Frontières, 1985, p. 65)

The claims brought forward by MSF were rejected by, among others, Michael Priestly, United Nations Aid Co-Coordinator for Ethiopia, and Canadian diplomat Maurice Strong, executive coordinator of the United Nations Office for Emergency Operations in Africa. At the same time, MSF was expelled from Ethiopia by the Mengistu government (Pankhurst, 1992). It was only in mid1986 that the Derg regime stopped the resettlement program in order to appease the rising criticism put forward by the international community.

The resettlement program became the most controversial part of Mengistu's famine policy and was responsible for at least as many deaths as the famine itself (Davey, 2015; De Waal, 1991). The largest component of Mengistu's collectivization policy was the forceful uprooting of almost five million people through villagization between 1984 and 1986. In contrast to the resettlement program, however, villagization was to a very large extent not supported by the Western donor community (De Waal, 1991; Kaplan, 2003; Tareke, 2009).

The U.S. administration used international human right principles as a lever for the pursuit of a foreign policy aimed at relieving famine in Ethiopia's faminestricken regions.

"The famine emergency gave the United States what it thought was an opportunity to weaken Moscow's hold over Ethiopia using peaceful means. While the Soviet Union provided less than 1 percent (10,000 tons 
out of 12.5 million) of the emergency food aid, the noncommunist world provided 99 percent" (Kaplan, 2003, p. 175)..$^{124}$

The large-scale humanitarian assistance and food aid delivery brought little political change in Ethiopia. American policymakers overestimated the impact of their large-scale humanitarian assistance and food aid to bring political change in Ethiopia (Kissi, 2005). While the large - albeit late - wave of international development assistance reduced the suffering and mitigated the disastrous effects of the famine (Gill, 2010), it also prolonged the lifespan of the Derg regime and the Ethiopian Civil War (Wolde Giorgis, 1989). The unprecedented relief aid to the politically powerless rural sector in Ethiopia could not compete with the Soviet military assistance to the political elite. Throughout the 1980s, U.S. influence in Ethiopia gradually decreased while Soviet influence in Ethiopia gradually strengthened.

In early 1989, the TPLF and the Ethiopian People's Democratic Movement (EPDM) formed the Ethiopian People's Revolutionary Democratic Front (EPRDF) aimed at ousting Mengistu from power (Tareke, 2009). By the late 1980s, the survival of the Derg regime was increasingly tied to the fortunes and policies of the Soviet Union. Ethiopia's diplomatic relationship with the Soviet Union, however, gradually deteriorated, partly due to the appointment of Mikhail Gorbachev as General Secretary of the Communist Party of the Soviet Union in 1985 (Yordanov, 2016). Gorbachev's policies of glasnost ("openness"), perestroika ("restructuring"), demokratizatsiya ("democratization"), and uskoreniye ("acceleration" of economic development) contributed to the end of the Cold War and the demise of the Soviet Union.

When the guerrilla movement in northern Ethiopia started to launch a major offensive in April 1988 against the Derg regime, Mengistu visited Moscow asking for increased military assistance (Tareke, 2009; Westad, 2005). Gorbachev, however, was only ready to deliver military aid and economic support conditional upon a change in Ethiopia's agricultural policies and a liberalization of the political system. Since Mengistu largely refused any type of Ethiopianstyle glasnost and perestroika policies, the Soviet government only provided a

\footnotetext{
${ }^{124}$ It is believed that the Soviet Union donated food aid to Ethiopia 1984 and 1985 due to the large international pressure. The exact amount delivered by the Soviet Union, however, remains unclear (Uvin, 1985).
} 
tiny fraction of the aid requested by Mengistu. Moscow's declining military assistance to the Derg regime can mainly be attributed to two factors: (i) the Soviet Union was mainly preoccupied with its military involvement in the Afghanistan War (1979-1989); (ii) Gorbachev held a "personal distaste for Mengistu, having been briefed by the KGB [Soviet security agency] on the human rights record of his regime" (Westad, 2005, p. 383). In 1990, with the fall of the Iron Curtain, the Soviet-Ethiopian alliance came to an end.

With the loss of the Soviet Union as Ethiopia's major ally, China became a serious alternative as a development partner. Strong Sino-Ethiopian relationships, however, did not materialize since a revolution led by the TPLFEPRDF alliance under Meles Zenawi and the EPLF under Isaias Afewerki overthrew the Derg regime in May 1991.

"They [TPLF-EPRDF] won not only because enough people supported
them but also because they were willing to make extraordinary sacrifices
and would not consider anything less than total victory. (...) In the end,
the fronts beat a quantitatively and technically superior foe because,
despite divergent goals, they supported each other tactically at critical
moments. They wore down the army through guerrilla tactics and then
annihilated it in conventional wars that were efficiently coordinated."
(Tareke, 2009, p. 317)

The interplay between the Mengistu's internal war against the rebel groups, the Derg government's disastrous agricultural collectivization programme, the famine and the demise of the Soviet Union brought the Ethiopian economy to the brink of collapse and ultimately contributed to the fall of the Derg regime in 1991. Mengistu was forced to go into exile in Zimbabwe (Marcus, 2002; Prunier, 2015). In 1991, Meles Zenawi became the president of the transitional government of Ethiopia and was to become Ethiopia's Prime Minister between 1995 and 2011. The Eritrean War for Independence that lasted for 30 years ended on 29 May 1991. Similar to Meles Zenawi in Ethiopia, EPLF leader Isaias Afewerki became the head of the Provisional Government of Eritrea. Between 23 and 25 April 1993, the overwhelming majority of Eritreans (99.83 percent) voted for Eritrea's independence in a UN-monitored referendum (Wrong, 
2005). Two days later, Eritrea was declared independent by Eritrean authorities and Isaias Afewerki became the president of Eritrea. ${ }^{125}$

Mengistu's legacy was an Ethiopian economy in a poor state of affairs. Table 5.6 shows the evolution of Ethiopia's economic development under the Derg regime. Looking at real GDP first, we observe a positive trend over the time period 1975-1990. During the 1980s, the economy witnessed positive economic growth. If we turn to GDP per capita, however, the picture looks less promising. Between 1975 and 1990, real GDP per capita declined significantly. While real GDP per capita stood at $\$ 652.3$ in 1975 , it dropped to $\$ 578.5$ in 1990 . In a similar vein, the average growth rate of GDP per capita was predominantly negative or close to zero through 1975-1990. These figures demonstrate that Ethiopia's economic growth under the Derg regime has been more than offset by an exploding population. Or put differently, economic growth has been eaten up entirely by rapid population growth. In 1990, Mengistu's last year in power, GDP growth and GDP per capita growth contracted significantly. Compared to 1975, Ethiopian society was a lot poorer in 1990.

Table 5.6: Evolution of GDP (per capita) in Ethiopia, 1975-1990

\begin{tabular}{lcccc}
\hline PWT8.1 & $\mathbf{1 9 7 5}$ & $\mathbf{1 9 8 0}$ & $\mathbf{1 9 8 5}$ & $\mathbf{1 9 9 0}$ \\
\cline { 2 - 5 } Real GDP (in mil. 2005US\$) & 21498.1 & 23220.4 & 24825.5 & 27961.5 \\
Real GDP per capita (in mil. 2005US\$) & 652.3 & 655.5 & 604.4 & 578.5 \\
\hline & $\mathbf{L a t e}$ & $\mathbf{E a r l y}$ & $\mathbf{L a t e}$ & $\mathbf{1 9 9 0}$ \\
\cline { 2 - 5 } & $\mathbf{1 9 7 0 \mathbf { s }}$ & $\mathbf{1 9 8 0 \mathbf { s }}$ & $\mathbf{1 9 8 0 s}$ & \\
PWT8.1 & -0.2 & 2.6 & 2.6 & 0.3 \\
GDP Growth Rate & -1.7 & -0.1 & -0.6 & -3.0 \\
GDP per capita Growth Rate & & & & \\
GGDC & 1.1 & 1.6 & 2.4 & -1.6 \\
GDP Growth Rate & 0.1 & -1.5 & 0.0 & -4.3 \\
GDP per capita Growth Rate & &
\end{tabular}

Note: The table shows the average GDP (per capita) growth rate for the late 1970s (1975-1979), early 1980s (1980-1984) and late 1980s (1985-1989), and the GDP (per capita) growth rate for 1990.

Source: Penn World Tables (PWT) version 8.1 (Feenstra et al., 2015); Maddison Historical Statistics from the Groningen Growth and Development Centre (GGDC) (Bolt \& van Zanden, 2014).

125 Meles Zenawi accepted Eritrea's independence. Article 39 in Ethiopia's 1994 constitution gave Eritrea and other Ethiopian regions the right to secede as part of the Ethiopian government's commitment to self-determination. 
Table 5.7 shows the trends in output and employment at the sectoral level for both the Ethiopian economy and Sub-Saharan Africa between 1975 and 1990. For both Ethiopia and Sub-Saharan Africa as a whole, the industry value added share rose between 1975 and 1980, while the agriculture value added share declined within the same period. Between 1980 and 1990, Ethiopia's agriculture value added increased from 59.7 percent to 64.1 percent. Ethiopia's industry value added, however, dropped from 11.5 percent to 10.8 percent. Between 1980 and 1990, Ethiopia witnessed a phase of deindustrialization since very few workers were moving out of subsistence agriculture and were being absorbed in modern manufacturing. Industry value added also declined for Africa as a whole but it was not compensated by a rise in agriculture value added but service value added.

Table 5.7: Sectoral Data on Value Added and Employment in Ethiopia, 1975-1990

\begin{tabular}{|c|c|c|c|c|c|c|c|c|}
\hline \multirow{2}{*}{ ETHIOPIA } & \multicolumn{4}{|c|}{$\begin{array}{l}\text { Value added } \\
(\% \text { of GDP) }\end{array}$} & \multicolumn{4}{|c|}{$\begin{array}{l}\text { Employment } \\
\text { (\% of population) }\end{array}$} \\
\hline & 1975 & 1980 & 1985 & 1990 & 1975 & 1980 & 1985 & 1990 \\
\hline Agriculture & 69.5 & 59.7 & 65.7 & 64.1 & 90.9 & 89.3 & 88.9 & 89.4 \\
\hline Industry & 10.2 & 11.5 & 10.4 & 10.8 & 2.1 & 2.0 & 2.0 & 2.2 \\
\hline Manufacturing & 4.0 & 1.5 & 4.2 & 4.3 & 1.7 & 1.7 & 1.6 & 1.8 \\
\hline Services & 20.3 & 28.8 & 23.9 & 25.1 & 7.1 & 8.7 & 9.0 & 8.3 \\
\hline Total economy & 100.0 & 100.0 & 100.0 & 100.0 & 100.0 & 100.0 & 100.0 & 100.0 \\
\hline \multicolumn{9}{|l|}{ SSA } \\
\hline & 1975 & 1980 & 1985 & 1990 & 1975 & 1980 & 1985 & 1990 \\
\hline Agricultur & 29.2 & 25.5 & 26.4 & 24.9 & 66.0 & 63.1 & 62.3 & 61.6 \\
\hline Industry & 30.0 & 33.2 & 32.8 & 27.8 & 13.1 & 12.7 & 12.8 & 14.3 \\
\hline Manufacturing & 14.7 & 13.6 & 14.8 & 10.1 & 7.8 & 7.2 & 7.8 & 8.9 \\
\hline Services & 40.7 & 41.3 & 40.8 & 49.8 & 20.9 & 24.2 & 24.9 & 24.1 \\
\hline Total economy & 100.0 & 100.0 & 100.0 & 100.0 & 100.0 & 100.0 & 100.0 & 100.0 \\
\hline
\end{tabular}

Note: Figures are unweighted averages across 11 African countries. Numbers may not sum due to rounding. Relative productivity level is the ratio of the sector and total economy levels. Source: Authors' own calculations using the Africa Sector Database (De Vries et al., 2015).

Since the beginning of the revolution by the Derg regime, agricultural production declined at an average annual rate of 0.4 percent while population grew at approximately 3 percent every year. Trade and industry stagnated from 1974. In 1988, the government spent $\$ 1.5$ billion on armament alone, 54 percent 


\section{CHAPTER 5}

of government revenue in that year. Between 1974 and 1988, Ethiopia's international debt rose from a modest $\$ 51.4$ million to $\$ 530$ million (Marcus, 2002, pp. 212-213). The country stood on the edge of bankruptcy. According to Mockler (2003), Haile Selassie's reign, "compared to the bloodthirsty tyranny that the Revolution of 1974 ushered in, appears almost as a golden age" (p. xi).

\subsection{Discussion}

\subsubsection{The Ethiopian Famine and the Foreign Aid Dilemma(s)}

While international development co-operation surged in the 1960s in the midst of post-war optimism and euphoria, a period of donor fatigue set in with the end of the Cold War during the 1990s. While a bulk of foreign aid provided by donors, non-governmental organizations, private voluntary organizations and international financial institutions alike was aimed at helping the poor and contribute to economic development, foreign aid such as humanitarian assistance often became, unintentionally, an instrument of conflict and for political survival of authoritarian elites as well.

As this historical case study has shown, unconditional foreign aid flows to the Ethiopian government contributed to prolonged military efforts through the purchase of weapons and to human rights abuses (in the resettlement programs, for example) and to the prolonged life of the Derg regime. Ethiopia's catastrophic 1984-86 famine, one of the worst humanitarian crises in the $20^{\text {th }}$ century, but also the 1973-74 famine to a lesser extent, vividly portray three major problems that the international donor community faced vis-à-vis the Ethiopian government and often still faces vis-à-vis recipient countries more generally.

In the context at hand, the first problem of foreign aid is that the prospects for aid effectiveness are often the lowest in those countries that need financial, technical and administrative help the most. The most commonly cited objective of foreign aid is the reduction and eventual elimination of poverty. How to allocate foreign aid efficiently to maximize the number of people lifted out of poverty, however, remains a significant challenge. Collier and Dollar (2002) developed an optimal allocation rule: 


\section{CHAPTER 5}

"To maximize the reduction in poverty, aid should be allocated to countries that have large amounts of poverty and good policy. The presence of large-scale poverty is obviously necessary if aid is to have a large effect on poverty reduction. The good policy ensures that aid has a positive impact." (Collier \& Dollar, 2002, p. 1482)

According to Riddell (2007), however,

"[t]he overarching dilemma of aid is that it is needed most in those countries in which the prospects for its being most effective are the poorest." (Riddell, 2007, p. 377)

This dilemma was certainly visible in the context of Ethiopia's repeated famines. Both the policy environment under Haile Selassie and under Mengistu Haile Mariam made it very difficult for development assistance to be effective for the following reasons: (i) both regimes were not fully committed to solve the humanitarian crisis manifested by both Mengistu's and Selassie's late acknowledgement of the famine and lack of adequate policy responses; (ii) both regimes had not developed a coherent policy framework geared towards poverty reduction, citizen participation and inclusive governance as illustrated by the authoritarian style of government with an emphasis on building military defence capabilities rather than promoting substantial agricultural and industrial reform; (iii) both regimes lacked accountable and transparent institutions for the efficient and effective distribution of foreign aid: ${ }^{126}$ the ill-favoured and unequal delivery of foreign aid among the Ethiopian population was not allocated on needs-based considerations but primarily on political favouritism and nepotism.

A second problem of foreign aid during the Ethiopian famine was the importance of ideological considerations among the international donor community, especially among bilateral donors. Ideology heavily shaped foreign

\footnotetext{
${ }^{126}$ One could argue that the RRC can be regarded as prominent exception even though it was a "paradoxical institution: On the one hand, for the decade after its creation in 1974 it enjoyed considerable institutional strength and legitimacy, and a high degree of autonomy from other government departments. The RRC was relatively efficient at collecting, analyzing and disseminating information, and in coordinating relief programs. It compared well to similar institutions in neighboring countries. (...) However, the RRC fulfilled (...) vital functions which fitted extremely well with the twin government aims of suppressing insurgencies and maintaining food supply sufficient to ensure its independence from the demands of the ordinary rural people" (De Waal, 1991, p. 168-169).
} 
aid policies by the United States and the Soviet Union. Not only the United States, but also other major Western donor countries like Great Britain, cut off systematic development assistance to the communist Derg regime and were even initially reluctant to provide humanitarian aid during the Ethiopian food crisis. This example once again highlights that foreign aid delivery during the Cold War was not exclusively motivated by considerations of poverty reduction, economic development, or humanitarian relief, but also by geostrategic motives. During the Cold War, both the United States and the Soviet Union, and also the majority of other bilateral donors divided the world into enemies and friends. Ken Hackey, regional director for Sub-Saharan Africa for the U.S. based humanitarian aid organization "Catholic Relief Services" during the 1980s, argued:

"To isolate countries because a specific Government espouses an ideal that clashes with our own is short-sighted. Punishing the starving because an oligarchy, under the pseudonym of 'People's Democratic Republic' or whatever, in no way serves our long-term interests...We are closing ourselves out of many of the political processes of Africa because we are delineating friends and foes." (Cited in Gill, 1986, p. 178)

With the end of the Cold War and the collapse of communism in the Soviet Union, the international donor community lost strategic interest in Africa. That did not mean, however, that this problem no longer existed in the post-Cold War era. Some scholars argue that the allocation of donor aid money during the post-Cold War era has still been influenced by an explicit distinction between autocratic and democratic regime types, alongside needs-based considerations (Bader et al., 2010; Bermeo, 2011). However, democratic donor countries that use foreign aid as a tool to promote democracy in recipient countries, for example, face the risk of becoming detached from several of the economic and political processes in the developing world.

A third major problem exemplified by the Ethiopian 1984-86 famine, but also by the 1973-74 famine, is the presence of political and economic vested interests on both the donor and recipient side in the international aid arena. The Ethiopian case is not an exception as entrenched interests existed both on the donor and recipient side. On the recipient side, both Selassie and Mengistu were largely dependent on foreign aid for their political survival as it provided them with a stable source of income. The systematic and mostly unconditional aid 


\title{
CHAPTER 5
}

flows, however, were often used for unproductive rent-seeking activities, or sectors with very little developmental prospects, such as the military sector. On the donor side, workers in the aid industry depended for their livelihood on the ongoing aid flows. During Mengistu's resettlement programme, for example, several international organizations did not question the resettlement policies as they had an interest to stay in the country and support the programme to keep their aid projects going.

In the immediate aftermath of the Ethiopian Famine 1984-86, scholars, policymakers and international organizations began to seriously question the effectiveness of aid. The mismanagement of a significant part of international development assistance by the Ethiopian government, the RRC and rebel groups during the famine led to the erosion in the noble objectives of foreign aid. It also ultimately changed the way in which governments, international financial institutions, private voluntary organisations and NGOs were to deliver development assistance in general and how to respond to international emergencies in the developing world.

\begin{abstract}
"What was urgently needed was a fresh examination of the entire 'aid' relationship, leading perhaps to its termination. Over a period, Africa without aid could scarcely be in a worse state than Africa with aid. A cessation of aid might even embolden those who had never benefited to start imposing their wishes on those who ruled them.” (Gill, 1986, p. 179)
\end{abstract}

\subsubsection{A New Aid Agenda}

One major objective for delivering aid to the developing world vanished with the fall of the Iron Curtain: strategic advantage. As the geostrategic considerations for delivering foreign aid dwindled, a period of donor fatigue set in during the 1990s (Moyo, 2009; Riddell, 2007). Since "a vacuum in Western strategic interest in Africa emerged" (De Waal, 1997, p. 133), numerous interest groups within the international donor community used the end of the Cold War as a golden opportunity to reform the international aid architecture (Lancaster, 2007a; Riddell, 2007). In fact, the end of the Cold War heralded the emergence of a new development paradigm among policymakers and international donor communities. In 1996, the OECD-DAC developed a strategy aimed at reversing the trend of declining aid flows to the developing world by 


\section{CHAPTER 5}

“justifying the aid its members donated in terms of its impact on (an expanded notion of development, 'human development'. The DAC proposed recasting the aid relationship as a partnership between donors and recipient governments. Donors would provide more resources, improve the coordination of assistance in support of domestically owned development strategies, and achieve coherence between their aid policies and other policies which affect developing countries (trade, debt, arms sales, etc.). In return, recipient governments were expected to commit to poverty reduction objectives and accountable governance." (Fraser \& Whitfield, 2009, p. 77)

The emergence of the good governance agenda, in particular, became "the latest philosopher's stone of official aid agencies" (Riddell, 2007) after the end of the Cold War. At the macro level, the increasing use of political conditionality and aid selectivity attached to foreign aid was regarded as a necessary condition for enhanced aid effectiveness and as a useful tool for promoting democratic governance in the least developed countries (Burnside \& Dollar, 1997; World Bank, 1998). The greater part of foreign aid offered by Western aid agencies and international organizations shifted away from unconditional aid flows towards conditionality-based foreign aid. The donor agencies' belief that democratization and constitutional change is a sine qua non condition for enhanced aid effectiveness was especially relevant for aid-dependent Sub-Saharan African countries like Ethiopia.

"[While the new Western approach] involved moral condemnation of the past behaviour of African states, the moral rehabilitation of the Western aid industry also required a contrast with old donor behaviours. Rejecting the self-interested motives inherent in the commercial tying of aid and the strategic focus of Cold War era aid helped ward off scepticism of new, purer motives: the promotion of human rights, democracy, and an end to world poverty. A key aspect of the new discourse was the idea that aid would now be increasingly, or exclusively, 'poverty-focused'.' (Fraser \& Whitfield, 2009, p. 77-78)

At the micro level, numerous contributions gave policy recommendations (i) how to design more efficient impact evaluations to improve development outcomes; (ii) how to improve on-the-ground-experience and expertise of staff and personnel from aid agencies and (iii) how to strengthen the ownership of 


\section{CHAPTER 5}

the recipient countries and their local stakeholders in the design, resource mobilization, learning, and evaluation processes of development assistance programs (see, among others, Gibson, Andersson, Ostrom, \& Shivakumar, 2005). Another strand of microeconomic literature has highlighted the importance of randomised control trials (RCTs) and an experimental approach to development economics in ehnacing the effectiveness of developmental interventions (Banerjee \& Duflo, 2009; Duflo, Glennerster, \& Kremer, 2007). These scholars have argued that policymakers should no longer debate whether or not aid is effective but should analyse how aid effectiveness can be enhanced using scientific research tools (Banerjee, 2007; Banerjee \& Duflo, 2011).

\subsubsection{Policy Lessons for the Ethiopian Government}

After the TPLF-led EPRDF seized Addis Ababa on 28 May 1991, it set up a conference to develop a plan for the country's future. Since the EPRDF had strong ideological foundations, it was "suspicious and careful not to admit those organizations it considered detrimental to the creation of an ethno-regionally structured state" (Tadesse, 2015b, p. 273). The transitional government of Ethiopia was installed after the end of the conference and TPLF Chairman Meles Zenawi became the president of the transitional government.

"The complete victory of the TPLF over all its opponents over the preceding years and the Derg in 1991, the Front's administrative competence, a measure of pragmatism, the invaluable experience of developing a close understanding of the country's peasants, and a belated appreciation of the changed international context had produced (...) a generally smooth transition. Outright military victory also meant that the TPLF could gain the approval of its constitution and predetermined political processes and pursue largely unhindered its programme of political and economic reform.” (Tadesse, 2015b, p. 274)

While the simultaneous implementation of political and economic reforms in developing countries was both desired by the international donor community and the transitional government, Meles Zenawi soon gave a preferential treatment to economics over politics. In July 1992, the Ethiopian transitional government launched an extensive economic reform programme that included macroeconomic stabilization and initial structural reform measures. This reform 


\section{CHAPTER 5}

program aimed at (i) addressing the internal and external structural imbalances within the Ethiopian economy, (ii) developing a strategy of enhanced resource mobilization and allocation as well as (iii) promoting private sector development. As this historical case study has shown, economic backwardness and widespread death caused by famine and starvation led to the eventual demise of both the imperial government and the Derg regime. This historical repetition provided a major domestic policy lesson for the Ethiopia's transitional government, namely that poverty reduction is fundamental not only for economic development but also for political stability.

"From the outset, what needed to be done was to conquer poverty. From his early days in the field through to his last years as an international statesman, Meles was absolutely consistent in this aim. Ethiopia's overriding national challenge was to end poverty." (De Waal, 2012, p. 150)

Ethiopia's transitional government was also fully aware of the changing international context. With the end of the Cold War, the Soviet Union was no longer a source of foreign finance. Moreover, the Western donor community entered a period of aid fatigue and aid flows to Africa were significantly reduced and became increasingly conditionality based. While the new Ethiopian regime was determined to refuse "to bow to the whims and wishes of the donors" (Borchgrevink, 2008, p. 200), Zenawi was still determined to adopt a skilful manoeuvring of the diplomatic field from the early 1990s onwards. Zenawi's political tactics stemmed from a second major policy lesson for the transitional government: both Haile Selassie and Mengistu Haile Mariam were increasingly reliant on the goodwill of Washington and Moscow, respectively, which significantly contributed to the overthrow of both regimes. Consequently, securing multiple sources of foreign finance through taking a much more pragmatic stance towards the international donor and investor community had to become a crucial objective in Ethiopia's foreign policy.

\subsection{Concluding Remarks}

This chapter has examined the evolution of the international foreign aid relations during the Cold War era using Ethiopia as an in-depth case study. The chapter discussed the historical interrelationships between the international donor community and the two successive Ethiopian recipient governments, the 


\section{CHAPTER 5}

imperial government under Haile Selassie and the Derg regime under Mengistu Haile Mariam, between the end of WWII and the fall of the Iron Curtain.

We can draw three major conclusions from the historical case study of Ethiopia. First, Ethiopia and Somalia can be considered classic examples of pawns in Cold War politics. At the height of the Cold War, both the United States and the Soviet Union switched sides supporting countries which they had been furnishing assistance previously. In a global contest for power and influence in the Horn of Africa, both superpowers used foreign aid not only for humanitarian and developmental ends, but also for strategic ends.

Second, the recipient governments have not been passive players in the international aid game. Both the Selassie and the Mengistu regime tried to maximize external financial resources while minimizing the amount of loss of sovereignty over the policy agenda. Both recipient governments used international foreign aid (including military assistance) to pursue their own political objectives.

Third, the unprecedented 1984-86 famine in the Horn of Africa region has clearly demonstrated the moral dilemma that the international community faces when it wants to provide humanitarian/relief assistance in a non-democratic state. By trying to save lives and mitigate the disastrous consequences of the famine one the one hand, development assistance also contributed to a prolonged life of the Mengistu government. The Ethiopian famine therefore provided valuable lessons for the international donor community. For development assistance to be effective, the international donors had to pay attention increasingly to the complex interaction of political, economic, social, historical and environmental factors that shape government policies.

The transitional government had to acknowledge two major lessons in Ethiopia's Cold War history: (i) economic backwardness and widespread death caused by famine and starvation contributed to the eventual demise of both the imperial government under Selassie and the Derg regime under Mengistu. As a result, the EPRDF-led government had to build its domestic legitimacy on developing strategies and programs for economic growth and poverty reduction; (ii) both Haile Selassie and Mengistu Haile Mariam became increasingly dependent on the fortunes of the United States and the Soviet Union, 
CHAPTER 5

respectively, which ultimately led to the overthrow of both governments. Therefore, securing multiple sources of foreign finance through taking a much more pragmatic stance towards the international donor and investor community had to become a major pillar of the transitional government's foreign policy agenda. 


\section{CHAPTER 6}

\section{THE ENTRY OF CHINA INTO THE DEVELOPMENT FINANCE GAME: A CONTEMPORARY CASE STUDY OF ETHIOPIA}

"Ethiopia is a priority partner for China." - Li Keqiang, 2015 Premier of the State Council of the People's Republic of China (2013-today)

"China has taken the initiative in laying the foundation for our cooperation. (...) We continue to view China as a successful economic model and reliable ally in the fight against poverty and in the quest for prosperity."

- Hailemariam Desalegn, 2017 Prime Minister of Ethiopia (2012-today) 


\subsection{Introduction}

The emergence of donors and investors from the Global South on the African continent has triggered a new debate about the aid negotiation process and the most appropriate modalities ${ }^{127}$ for development cooperation (Zimmermann \& Smith, 2011). In particular, China's entry into the development finance game and its increasing economic influence on the African continent changes some of the prevailing practices and parameters in development assistance. China's distinct approach to development assistance and economic policy more general has been termed the "Beijing Consensus" which often serves as an alternative to Western economic and political ideas formulated in the Washington Consensus (Ramo, 2004).

This chapter examines Ethiopia's position in the development finance game since the end of the Cold War until today accounting for the entry of China. This chapter is closely linked to the lessons and conclusions derived in Chapter 5. This study (i) discusses the contemporary interrelationships between the international donor/investor community and the Ethiopian government and (ii) evaluates to what extent China's growing presence in Ethiopia affects the behaviour of both the recipient government and that of traditional donors/investors.

The United States are Ethiopia's main bilateral donor and the World Bank, based in Washington, D.C, headed by an American, and primarily financed by the United States, is Ethiopia's main multilateral donor: "The U.S. government has given foreign aid to many countries. But Ethiopia was on the list in the beginning, and it is on the list today" (McVety, 2012, p. 3). Ethiopia is also one of the most strategically and economically important countries in Africa for both Chinese and European cooperation. However, China's and European foreign finance to Africa are quite distinct: "Differences in Chinese and European approaches to engaging with African states are particularly evident in Ethiopia" (Hackenesch, 2013, p. 9).

\footnotetext{
${ }^{127}$ Aid modalities include, among others, aid-financed debt relief, general budget support, sector budget support, project aid, and balance of payments support.
} 


\section{CHAPTER 6}

A large body of theoretical and empirical literature attributes China's rising contemporary engagement with Africa mainly to Beijing's need to access and secure natural resources (see Chapter 2 again). While this argument is not completely unfounded, "the biggest charge against the Chinese in Africa - that they are interested in the continent exclusively for its vast natural resources cannot be sustained in Ethiopia" (Gill, 2010, p. 246), as Ethiopia is a relatively resource-scarce country. As this chapter will show, China's motives are much more diverse and complex than commonly assumed. The lessons of this study are threefold.

First, this case study demonstrates how recipient governments can use international development assistance as a tool to push through their own policy agenda. The two recent Ethiopian governments under Meles Zenawi and Hailemariam Desalegn provide a good example for a type of recipient government that has a clear 'ownership' of its development strategy which is, as the study will show, particularly visible when engaging with the international community.

Second, with regard to the evolution of Western aid policy, geostrategic and political concerns, besides developmental motives, have started to play an increasing role again. Despite democratic reversals, human rights abuses and less press freedom, Ethiopia remains one of the major aid recipients by the Western donor community. The example of Ethiopia clearly demonstrates that the Western threat to reduce or withhold aid is not credible if the recipient country is economically and strategically valuable for the Western donor community.

Third, China's entry into the development finance game and its policy of nonintervention in domestic political affairs has significantly increased Ethiopia's bargaining power compared to the early years of the Zenawi regime when the government had to adopt political conditionalities. The Ethiopian government welcomes China's increasing foreign aid and investment activities as an alternative to finance from Western counterparts. Ethiopia's partnership with China also demonstrates how crucial the role of African agency is, if African economies are to benefit from China's increased presence on the continent.

Given the process-based and exploratory nature, the complexity, and the contemporary focus of the research, the study will predominantly rely on a 


\section{CHAPTER 6}

qualitative research design. This chapter is based on a two month field visit to Addis Ababa, Ethiopia. The fieldwork was conducted between July and August 2016. The advantage of using primary data is that information for the specific purposes of the study can be collected first hand. The main aims of the fieldwork were (i) to understand how different stakeholders view China's increasing economic role in the Ethiopian economy and (ii) to gain a better understanding of the challenges and risks of China's growing influence in Ethiopia. During the fieldwork, the author undertook 45-60 minutes long semi-structured interviews with 14 key informants from Ethiopian government ministries, Ethiopian research institutes, international financial institutions, and Western aid agencies.

The semi-structured interviews were conducted with a fairly open framework which allowed for a focused, conversational, two-way communication. All research activities were undertaken by the author. The respondents were not offered a financial remuneration or compensation for participating in the study. Participation in this study was strictly voluntary. The analysis in sections 6.3 and 6.4 is largely based on the interviews. The analysis is complemented by other primary sources like historical documents and newspaper articles as well as secondary data like statistical databases.

In this chapter, I argue that it is the coherent policy framework of the Ethiopian government that is primarily responsible for the recent economic growth and poverty reduction in the country, rather than development finance per se. But given the coherent policy framework, the provision of development finance by both the West and China certainly helped and contributed positively to Ethiopia's recent economic development. Throughout this study, both topdown (national level) and bottom-up (local level) perspectives are presented to provide a holistic picture on the subject matter.

The rest of this chapter proceeds as follows. Section 6.2 focuses on the aid negotiation process since the end of the Cold War until today between the West and successive Ethiopian governments under Prime Minister Meles Zenawi and Prime Minister Hailemariam Desalegn. Section 6.3 discusses the entry of China into the development finance game. The theoretical impact of China's economic embrace of Ethiopia is discussed in Section 6.4. In Section 6.5 the recent economic and political development in Ethiopia is analysed using quantitative 
data. Meles Zenawi's legacy and the role of African agency in the aid negotiation process are reviewed in Section 6.6. Finally, Section 6.7 concludes.

\subsection{Western Foreign Aid Under Meles Zenawi}

The fall of the Iron Curtain was associated with the demise of the Soviet Union as a superpower and major economic partner in developing regions. At the apex of Cold War tensions, both Washington and Moscow used foreign aid as a geostrategic tool to increase their sphere of influence in the developing world (see Chapter 5). The end of the Cold War heralded a new development era as foreign policy priorities changed significantly. Western donors increasingly put emphasis on reforming developing countries' political structures. Western donor countries increasingly attached political conditions (and later selectivity) to the provision of foreign aid (Riddell, 2007). The disappearance of the Soviet Union as a main competing development partner in the developing world led to a Western quasi-monopoly over sources of development finance. Western donors were now unconstrained by the need to appease recipients for fear of losing their loyalty in their expansion of political conditionality.

In the early 1990s, the Western donor community increasingly shifted from a project-based approach to a programme-based approach (budget support). Project aid was a major aid modality between the 1950s and 1990 when donorfinanced specific projects often involved direct participation in their design and implementation. Budget support became a major principle in the new aid system delivery, where donors provided financial support for the recipient government's budget while imposing some degree of conditionality on how to use the available resources (Cordella \& Dell'Ariccia, 2007).

Besides the United Nations agencies, five development partners have had strong relationships with the Ethiopian government since 1990 until today: the African Development Bank (AfDB), the European Commission (EC), the International Development Association (IDA) of the World Bank Group, the United Kingdom Department for International Development (DFID) and the United States Agency for International Development (USAID). Those five donor partners provided almost two-thirds of ODA to Ethiopia between 1990 and 2011 (Table 6.1). 


\section{CHAPTER 6}

While all bilateral donors contributed just over half of total ODA during that period (57 percent), the two main bilateral donors, the United States and the United Kingdom, accounted for almost half of that bilateral ODA (26.1 percent).

\section{Transitional Government (1991-1995)}

The Tigray-led EPRDF under Meles Zenawi headed the transitional government and it was fully aware of the changing global aid landscape. Given Ethiopia's strong autocratic legacy and long history of totalitarian rule, Zenawi understood that a move towards liberalizing the political system would be an unprecedented step. At the same time, Ethiopia's economy was strangled by poverty and underdevelopment. Moreover, the start of the Somali Civil War and the fall of the Siad Barre regime in Somalia challenged the peace and political stability in the Horn of Africa.

One year after Zenawi resumed office in 1991, regional elections were held. The transitional government granted ethnic groups the right to appoint political leaders from their own background (Abbink, 2011). Elected officials then had to undergo training in special EPRDF schools where they became familiar with the political programme of the EPRDF. Upon completion of the training, the elected officials were sent back to the home regions where they run their respective regions (Markakis, 2011).

In the early 1990s, the Ethiopian economy was in a bad state. Realizing that a coherent economic policy framework had to become a cornerstone of the government's policy agenda, Zenawi started a Master's degree in Business Administration by correspondence through the Open University of the United Kingdom which he completed in 1995. 


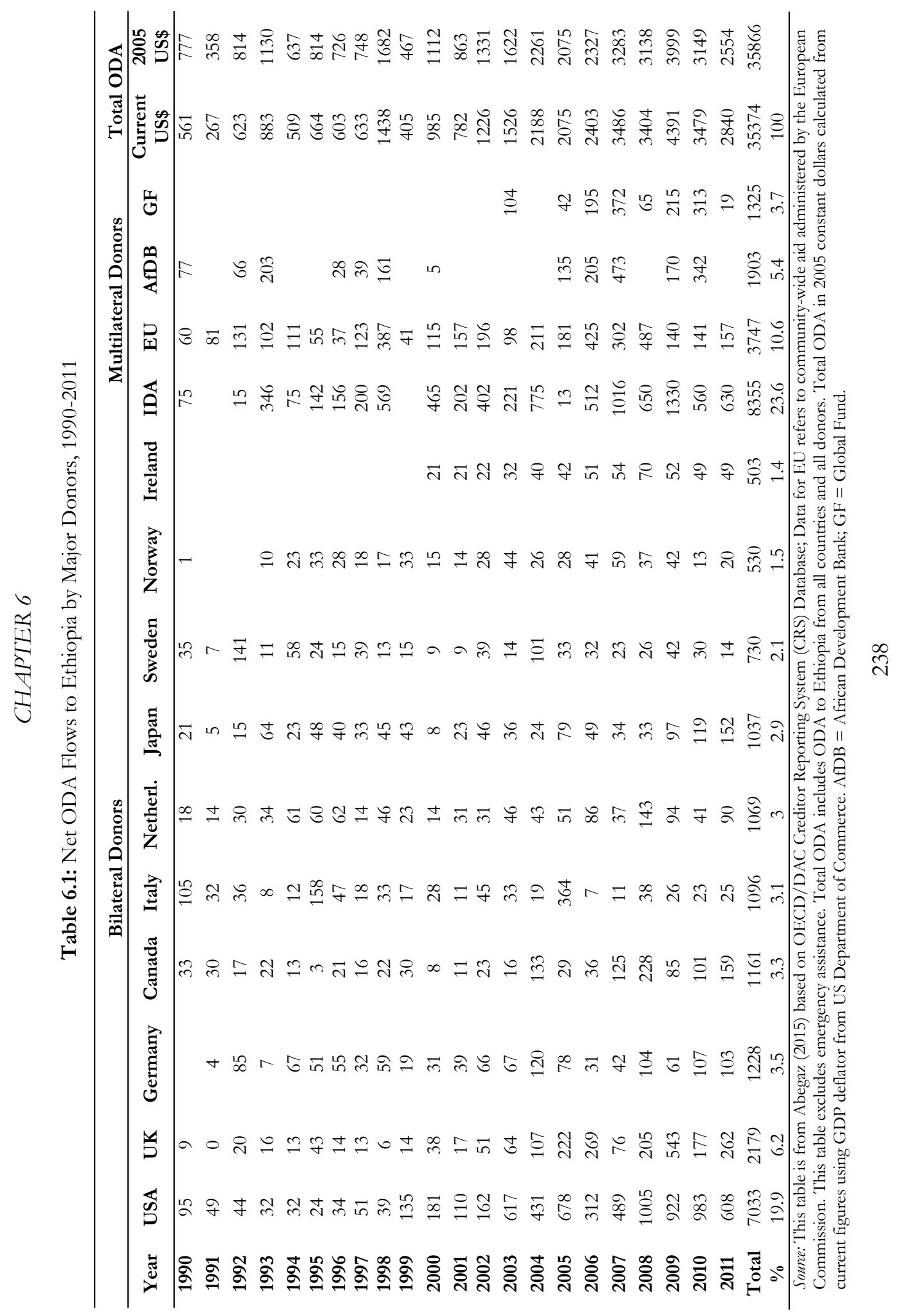




\section{CHAPTER 6}

The concept of 'revolutionary democracy' (abyotawi democracy in Amharic) became the EPRDF's core doctrine in the early 1990s and replaced MarxismLeninism as official ideology (Abbink, 2011) and can be regarded as a hybrid approach to development: it allows for privatization, liberalization of markets while maintaining a strong state control over the economy and civil society (Bach, 2011). ${ }^{128}$ Economic reforms in the early 1990s included a stronger engagement of the Ethiopian private sector in both banking and insurance, as well as the reintroduction of hired wage labour and the permission to sell and purchase unrestricted amounts of agricultural land. Markakis (2011) claims that, in practice, privatization policies often resulted in a direct transfer of ownership from the state to the EPRDF and affiliated party members.

Between 1991 and 1995, the Zenawi regime aimed at restructuring the Ethiopian state and the economy while searching for Western economic support. Without Western aid, particularly American aid, the government would have faced difficulties in feeding its own people. Since development assistance became increasingly conditionality based, the transitional government had to adopt a liberal rhetoric to satisfy Western donors. The liberal rhetoric included the decentralisation of the state, the introduction of ethnic federalism and a multiparty electoral system as well as economic liberalization. Overall, Ethiopia's development strategy in the early 1990s was therefore largely dictated by the international donor community (Feyissa, 2011). Nevertheless, the EPRDF pointed out from the very beginning vis-à-vis the international donor community what it was willing to accept and what would go against the government's vision.

Even though the West remained sceptical about the extent to which the transitional government was committed to a free-market economy and democratization, Ethiopia's foreign policy succeeded in establishing positive relations with the West in the immediate aftermath of 1991. Among the Western donor community, Zenawi was perceived as belonging to a new breed of African leaders: "genuinely pro-poor and committed to modernizing and bringing

\footnotetext{
128 The ideology of revolutionary democracy consists of three main pillars: "the unquestioned monopoly of state power by a vanguard party with an idea of 'national mission' that no one can change; top down leadership and national policies with internal Leninist-like party control and self-evaluation of civil servants and party officials; and the co-opting of all political and state public sectors under its ideology" (Abbink, 2011, p. 221).
} 
development to his country" (Borchgrevink, 2008, p. 200). The transitional government, in turn, regarded the United States as the "ultimate guarantor of donor money" (Tadesse, 2015, p. 349).

\section{First Federal Government (1995-2000)}

In August 1995, the first Ethiopian multi-party elections took place. The transitional government allowed international observers from several countries to monitor the election. The election process was reported to be "peaceful with a high turnout in most polling stations throughout the country" (UNDP-EUE, 1995). Meles Zenawi was elected as prime minister. In the early and mid-1990s, several economic and social achievements were realised under his rule. The Ethiopian government
"managed to maintain a strong local currency and to limit inflation to about 10 percent. It tightly controlled the budget deficit, money supply, and government borrowing (...) In the towns, but also in very remote rural areas, necessary consumer goods were available, and prices were lower than during the previous regime" (Marcus, 2002, p. 244-245).

The economic and social achievements were also acknowledged by the World Bank (World Bank, 2000). The "Stabilize, privatize, and liberalize" agenda codified in John Williamson's (1990) Washington Consensus triggered a wave of structural reforms in Ethiopia. After a structural adjustment programme phased out in 1996, the World Bank wanted to continue its support with regard to the promotion of private sector development and with regard to the privatization and liberalization of the financial sector (Borchgrevink, 2008). Similarly, the IMF required substantial economic reforms. The IMF stopped lending to Ethiopia, however, in the mid-1990s as the Zenawi regime increasingly resisted the conditions attached to foreign aid. The Ethiopian government considered the reforms demanded by the international financial institutions to go against its own development agenda (Stiglitz, 2002).

Economic and social progress under Zenawi was to be interrupted by the advent of the Ethiopian-Eritrean War (1998-2000). The Western donor community faced a dilemma: providing foreign aid to Ethiopia could be interpreted as supporting the regime in its fight against the Eritrean government under Isaias Afewerki; aid cuts would mainly hurt the intended beneficiaries. Since Western 


\section{CHAPTER 6}

donor countries had different viewpoints on the issue, donor coordination failed. The two major donors pursued almost exactly opposing strategies. The European Community reduced foreign aid during the war while the U.S. government significantly increased foreign aid (Borchgrevink, 2008). Zenawi believed that his government was unfairly penalized by parts of the Western donor community during the Ethiopian-Eritrean War. Donor-government relations were damaged and Zenawi developed a sceptical attitude towards Western donors as he considered several donors as unreliable partners who had turned their back on Ethiopia in a time of need (Furtado \& Smith, 2009).

The Ethiopian-Eritrean War officially ended in June 2000 mainly due to the mediation efforts by the Organisation of the African Union (OAU) and the United Nations. Diplomatic relationships between Ethiopia and Eritrea were suspended and tensions between the two nations have remained high until the present day.

\section{Second Federal Government (2000-2005)}

In contrast to the 1995 parliamentary elections, the Ethiopian government refused to allow international observers to monitor the 2000 parliamentary election. Zenawi remained in office but the international community started to raise concerns over the democratic character of the regime. A few key studies document "shattered promises and hopes" and declared "democracy unfulfilled" (Pausewang \& Tronvoll, 2000). The EPRDF was hit by an internal party struggle since the Ethiopian-Eritrean War and two major party factions emerged. The faction led by Meles Zenawi advocated a conciliatory approach towards the conflict to prevent the relationship with the international donor community from getting worse. The other faction, however, argued for a military strategy of full-scale confrontation against Eritrea (Tadesse \& Young, 2003).

Meanwhile, several party officials became increasingly worried that (i) the EPRDF had become unresponsive to the desires, requests and concerns brought forward by its constituency and (ii) that foreign powers had an influential say about Ethiopia's policy agenda. Meles Zenawi, however, emerged as undisputed leader from the internal power struggle. The political crisis of the EPRDF became a critical juncture in Ethiopia's recent political and economic trajectory. 


\section{CHAPTER 6}

"The crisis marked a turning point in the history of the EPRDF for at least three reasons. First, the emergence of a strong single leader implied a shift away from collective leadership and towards centralism. Second, it underlined the need for the EPRDF to improve national legitimacy, thus softening the ethnic discourse. The focus switched from ethnicity to poverty and economic development. This entailed a massive increase in resources for development and service delivery at the woreda [county] level starting in 2001. Notably, devolution of powers to the woreda level had no ethnic salience, as it was a purely administrative process. Third, the attention moved from political to economic issues, in a partial ideological shift. The government was now willing to be integrated in the world economy and to be open to capitalism, which had not been indicated so clearly before.” (Mascagni, 2016, p. 25)

Meanwhile, the Ethiopian economy suffered a major setback caused by harsh climatic conditions and the aftermath of the Ethiopian-Eritrean War. Economic activity, especially agricultural production, contracted between 2000 and 2003 (Table 6.2). In 2003, real GDP per capita was lower than in 1990, the year before Meles Zenawi assumed office.

Table 6.2: Evolution of GDP and GDP per capita in Ethiopia, 1990-2003

\begin{tabular}{lcccc}
\hline PWT8.1 & $\mathbf{1 9 9 0}$ & $\mathbf{1 9 9 5}$ & $\mathbf{2 0 0 0}$ & $\mathbf{2 0 0 3}$ \\
\hline $\begin{array}{l}\text { Real GDP } \text { (in mil. 2005US\$) } \\
\text { Real GDP per capita } \\
\text { (in mil. 2005US\$) }\end{array}$ & 27961.5 & 29421.5 & 36897.6 & 39689.3 \\
\hline
\end{tabular}

PWT8.1

$\begin{array}{lcccc}\text { GDP growth rate } & 0.3 & 0.2 & 4.8 & 3.4 \\ \text { GDP per capita growth rate } & -3.0 & -3.1 & 1.8 & 0.8 \\ \text { GDCC } & & & & \\ \text { GDP growth rate } & -1.6 & -1.1 & 3.5 & 2.8 \\ \text { GDP per capita growth rate } & -4.3 & -4.2 & 1.5 & 0.8\end{array}$

Note: I took the average GDP (per capita) growth rate for the early 1990s (1990-1994), late 1990s (1995-1999) and early 2000s (2000-2003).

Source: Penn World Tables version 8.1 (Feenstra, Inklaar, \& Timmer, 2015); Maddison Historical Statistics from Groningen Growth and Development Centre (GGDC) (Bolt \& van Zanden, 2014).

In the New Millennium, the international community critically examined the shortcomings of development policies under the Washington Consensus (Rodrik, 2006). The policies recommended by the Washington Consensus stood 


\section{CHAPTER 6}

in stark contrast to successful developmental strategies undertaken in a majority of East Asian countries, where the state played an active developmental role. Meles Zenawi, himself critical of the non-interventionist night-watchman state, became a firm supporter of the developmental state concept in the early 2000 s. After the main political challenges within his party were overcome in the early 2000s, Zenawi increasingly focused on economic issues rather than political issues. His East Asian developmental state vision, modelled on countries like Japan and South Korea, put tight state control, with the encouragement of investment, at centre stage (Anonymous 14, 2016; Mkandawire, 2001).

In 2004, Zenawi completed a MSc degree in Economics at the Erasmus University in Rotterdam which he started well before the war with Eritrea. This was a programme for the Ethiopian cabinet funded by the Dutch Minister of Development Cooperation Jan Pronk and executed by visiting professors in Ethiopia. Zenawi was eager to develop more expertise in economics in order to become more confident in aid negotiations with the international donor community. In 2006, Zenawi expressed great concerns about the Western notion that liberalism could easily be applied to a developing country like Ethiopia in his incomplete and unpublished master's thesis, titled 'African development: dead ends and new beginnings'. This, in turn, caused growing tensions between the Ethiopian government and the international donor community (Feyissa, 2011). Initially, Zenawi wanted both economic development and democratization at the same time (Anonymous 11, 2016; Prunier, 2015). Over time, however, he identified poverty - concomitant with lack of economic development - as the number one national security threat, as the fall of the two previous governments had been precipitated by famine, starvation and widespread death (see Chapter 5 again).

During the 1990s, international donor fatigue set in. While international development co-operation surged in the 1960s in the midst of post-war optimism and euphoria, the catastrophic Ethiopian famine of 1984-86 vividly portrays the moral dilemma that the international donor community faced. While foreign aid provided by donors, NGOs, private voluntary organizations and international financial institutions alike was aimed at helping the poor, their humanitarian assistance became, unintentionally, an instrument of conflict as well (see Chapter 5 again). Enhanced aid effectiveness and sustainability through improving aid delivery was especially relevant in highly aid dependent countries 
such as Ethiopia. In 2001, the Development Assistance Group (DAG) was established. It consists of 30 bilateral and multilateral development partners. The DAG and the Ethiopian government established an aid coordination architecture that aims
"to foster and catalyse policy dialogue and to coordinate and harmonize development partners' support in the Government of Ethiopia's preparation, implementation and monitoring and evaluation of the national development plan and the MDGs." (DAG, 2016, p. n/d)

The dialogue structure between the Ethiopian government and the international donor community consists of three major institutions: (i) the High Level Forum, (ii) the Development Effectiveness Task Force and (iii) the Sector Working Group.

During the early 2000s, donor countries and international financial institutions had an ambivalent viewpoint towards the Ethiopian regime. The European Union, for example, used a strategy of criticism ${ }^{129}$ in response to the government's use of low-intensity coercion. Criticizing the human rights situation in several statements, the EU sought to use democracy aid and political dialogue to launch an active cooperation with the Zenawi regime on political reforms (Hackenesch, 2015a). Despite doubts over Zenawi's sincerity in promoting democratic reform and private sector development, both bilateral and multilateral donors increased foreign aid substantially between 2002 and 2005 for the following reasons.

First, Ethiopia's geo-strategic position in the politically unstable Horn of Africa gave the Zenawi government significant bargaining power. Ethiopia has been considered the beacon of political stability at the Horn of Africa after the end of the Eritrean-Ethiopian War (Plaut, 2013; Whitfield \& Fraser, 2009).

Second, Ethiopia has become an important ally against the global war on terror after 9/11, even though Ethiopia has not been at the centre of international terrorism (De Waal, 2004; De Waal \& Abdel Salam, 2004; Fisher \& Anderson, 2015; Shinn, 2005). Terrorist groups from outside the Horn of Africa "have only been minimally active in Ethiopia" (Shinn, 2005, p.109). Even before 9/11,

${ }^{129}$ This term is borrowed from Hackenesch (2015). 


\section{CHAPTER 6}

Ethiopia's national security policy has been characterized by forming diplomatic relationships that "prevent an alliance of the states in the Horn from emerging to challenge its subregional hegemony” (De Waal, 2004, p. 203).

"Although it may not be in the highest threat category in Africa, Ethiopia has too many inherent weaknesses to be considered a bulwark against terrorism. It shares a boundary with five countries: Djibouti, Eritrea, Kenya, Somalia/Somaliland, and the Sudan. (...) Ethiopia's land borders are unusually porous, even by African standards. The Horn of Africa serves as the back door to the troubled Persian Gulf, the source of much of today's international terrorism." (Shinn, 2005, p. 93-94)

Third, in its attempt to achieve the Millennium Development Goals (MDGs), the regime developed Poverty Reduction Strategy Papers (PRSPs) undertaking a serious effort to reduce poverty. The first out of three PRSPs launched between 2001 and 2010 was the Sustainable Development and Poverty Reduction Programme (SDPRP). The pillars of the SDPRP program (2001-2004) were propoor growth (rural and urban), human development (primarily social services) and household resilience. Ethiopia's first and its two future PRSPs were collaboratively developed with the DAG (Abegaz, 2015). Between 2000 and 2005, the World Bank and the United States accounted for the bulk of the increase in foreign aid (Borchgrevink, 2008; Furtado \& Smith, 2009).

\section{Third Federal Government (2005-2010)}

In the run-up to the general national election held on 15 May 2005, both transition theorists and the international donor community expressed great optimism about Ethiopia's move towards democracy. In contrast to the previous elections in 1995 and 2000, opposition parties did not boycott the event. For the first time, all contending parties, including opposition parties such as the Coalition for Unity and Democracy (CUD) - in Amharic Qinijit - and the United Ethiopian Democratic Forces (UEDF) - in Amharic Hibrät - were able to run official campaigns in public and to disseminate their programmes through government owned national media. During the last weekend prior to the elections, the two major competing parties, the EPRDF and the CUD, launched mass rallies in Addis Ababa (Aalen \& Tronvoll, 2009; Abbink, 2006; Gilkes, 2015). In this "atmosphere of hope and dynamism" (Abbink, 2006, p. 176), the run-up to the election showed an 


\section{CHAPTER 6}

"unprecedented level of openness and had a big impact on people's consciousness about the elections. It showed voters that it was possible to talk against the ruling party without being imprisoned, and that the EPRDF leaders were not invincible in discussions with their counterparts." (Aalen \& Tronvoll, 2009, p. 195)

Voter registration was very high and voter turnout was reported to be 90 percent of all registered voters throughout the country. Moreover, the election was very peaceful with no major incidents of violence. The final election results, announced by the National Election Board of Ethiopia (NEBE) on 5 September, provided a considerable surprise to both the ruling party and the opposition parties. While the EPRDF officially won 'only' 327 seats of the 547seat House of Representatives, or 60 percent of the vote, the opposition captured 174 seats. The CUD won 109 seats and the UEDF 52. In the 2000 national general election, the EPRDF had captured 481 seats and the opposition parties only 12 seats. In 2005, the CUD and the UEDF won the majority of seats in virtually all towns and urban areas (Gilkes, 2015). ${ }^{130}$ The opposition, however, was greatly dissatisfied with the official results due to the "highly dubious reelections and re-count process in disputed constituencies" (Aalen \& Tronvoll, 2009, p. 196). Opposition parties accused the NEBE of being biased towards the ruling party. On 25 August, the EU Election Observation Mission (EUEOM) already expressed its concerns about the counting process:

"The EU EOM regrets that the $15^{\text {th }}$ of May post-polling day irregularities, delays and opacity of the counting and aggregation of data, plus the subsequent flawed handling of complaints and re-runs of elections in some constituencies, and the poorly organized electoral process conducted in Somali Region, did not live up to international standards and to the aspirations of Ethiopians for democracy" (EU-EOM, 2005, p. 910).

During the immediate post-election period, the political space for both the opposition parties and civil society was drastically reduced. One day after the

130 The CUD won all seats in Addis Ababa and captured the majority of votes in the Amhara region (East Gojam and North Wollo) and in parts of of Southern region (the Gurage areas). The UEDF won a large majority of votes in Hadiya (Southern region) and in West Shoa, East Wollega, and Arsi (Oromia region). For more information about the 2005 election, see Abbink (2006), Lefort (2007), Aalen and Tronvoll (2009) and Gilkes (2015). 


\section{CHAPTER 6}

election, a ban on public demonstrations was declared for a month. State media campaign accused the opposition of disloyalty; journalists and perceived opposition opponents were arrested (Aalen \& Tronvoll, 2009; Abbink, 2006). The political backlash culminated in police massacres between June and November 2005 killing 193 protesters and injuring more than 700, mostly in the capital Addis Ababa. While opposition members were prosecuted in court cases throughout 2006, the political situation calmed down and the opposition eventually took up their seats in the House of Representatives. Freedom of expression and public debate were significantly curtailed by the Ethiopian government after the elections:

"The government stepped up repressive measures against independent journalists and began implementing one of the most pervasive systems for filtering online political content in sub-Saharan Africa." (Gagliardone, 2014, p. 279-280)

What are the explanations of the EPRDF's victory in the 2005 national elections despite the large-scale voter mobilization campaigns by the opposition parties? Even though the control of vote counts and the violent aftermath contributed to the EPRDF's consolidation of power, the main reason can be found elsewhere, namely in the kebele and sub-kebele system. The EPRDF used the kebele system as a tool to consolidate power. Through the local administrative structures, the incumbent regime set up a tight network of control that intimidated and pressured many rural voters to vote for the EPRDF. Rural voters make up 85 percent of Ethiopia's total population (Aalen \& Tronvoll, 2009). Besides the kebele-system, the EPRDF had introduced sub-kebele structures throughout the country since the 2000 elections, in order to increase the presence of administrative officials, mainly ruling party cadres, at the local level. Anticipating that voting for the opposition is a significant risk and can endanger access to basic resources (land, basic commodities, food aid, state support, etc.), the rural population would generally cast their vote for the ruling party (Lefort, 2007).

During the 2005 elections, the liberal narrative disappeared. In contrast to the widespread optimism that the elections could enhance the democratic transition, some scholars suggest that the EPRDF used the elections as a tool for consolidating power (Aalen \& Tronvoll, 2009; Abbink, 2006). Zenawi was no 


\section{CHAPTER 6}

longer afraid to admit that "democracy was a rich man's toy and that the true problem of Ethiopia was economic" (Prunier, 2015b, p. 431). ${ }^{131}$

Three years later, the 2008 Ethiopian local elections for the woredas and kebeles were interpreted as a signal of the return of electoral authoritarianism in Ethiopia (Aalen \& Tronvoll, 2008). The elections took place essentially without opposition parties. Candidates from the EPRDF did not face significant competition in the majority of constituencies since the opposition parties either boycotted the elections, were intimidated and pressured to withdraw their candidates, were prevented from registering, or were absorbed into the ruling party. Since May 2005, the EPRDF has fully adopted the "developmental state" model as national strategy for poverty reduction and economic transformation. The technocratic state-led development approach
"entailed a full emphasis on nation-wide economic development, whereby 'political' considerations would be secondary and legitimacy would be sought in the economic growth achievements (infrastructure, road building, hydropower mega-projects, 'double digit' GDP growth, foreign investments, etc.). The powers of the central/federal government were hereby reinforced, via new laws and executive organs" (Abbink, 2012, p. 598).

Similar to the successful cases in South-East Asia, Zenawi was convinced that "Ethiopia's overriding national challenge was to end poverty and this needed a comprehensive, theoretically rigorous practice of development" (De Waal, 2012, p. 152). Between 2005 and 2010, Zenawi's state-led development model became increasingly accompanied by neo-patrimonial tendencies - the combination of semi-bureaucratic state and patrimonial tendencies in a highly informal, personalized political system (Abbink, 2006).

The political development surrounding the 2005 national election and its aftermath led to a great disillusionment of the Western donor community. While there was no evidence that the regime had become less concerned with poverty alleviation, concerns over the institutional development, human rights and the

\footnotetext{
131 Zenawi's shift in perspective is rather astonishing as one might argue that it is autocracy which threatens the long run survival of the regime, as evidenced by the recent conflicts in Ethiopia and other parts of the world. In fact, the Ethiopian regime seemed to combine democratization with effective developmental efforts successfully up until 2005.
} 


\section{CHAPTER 6}

curtailing of press freedom rose considerably. By November 2005 it looked as if donors had coordinated their actions in the form of political conditionality. On 11 November 2005, the World Bank and other major donor partners in the DAG, suspended direct budgetary support worth about $\$ 375$ million. The international donor community was committing itself to:

“(i) Move away from direct budget support in favor of alternative instruments that would provide greater oversight over poverty reducing expenditures and promote increased accountability; (ii) reduce aid over time if governance does not improve; and (iii) focus on new governance programs." (World Bank, 2006, p. i) ${ }^{132}$

Moreover, the DAG critically reviewed development cooperation modalities for Ethiopia (Borchgrevink, 2008; Furtado \& Smith, 2009). The EU and other donors used a strategy of confrontation ${ }^{133}$ by conditioning budget support and a $€ 155$ million aid agreement for transport infrastructure on reconciliation between the Ethiopian government and opposition as well as the release of political prisoners.

The level of trust between the donor community and the Zenawi regime worsened rapidly as the Ethiopian government did not show great willingness to compromise on the political issues that had led to the crisis in the aftermath of the 2005 elections. Engaging with the Western international donor community on political reforms was perceived by the Ethiopian government as a direct threat to its political survival (Hackenesch, 2015a). The Western donor community partly gave in: the development funds were not withheld but reallocated to programmes characterized by stricter earmarking and monitoring procedures such as the joint donor-government Protection of Basic Services programme (Borchgrevink, 2008). The Protection of Basic Services programme served as a platform to promote less compartmentalized discussions and a less fragmented policy dialogue between the Ethiopian government and the international donor community (Furtado \& Smith, 2009).

132 The IDA, a member of the World Bank, issued an interim country assistance strategy for Ethiopia in May 2006. The full document can be found under the following link: http://documents.worldbank.org/curated/en/699211468251707216/text/35142.txt

133 This term is once again borrowed from Hackenesch (2015a). 
Table 6.3 and 6.4 show the amount of bilateral and multilateral aid allocated to Ethiopia between 2000 and 2008, respectively. Total bilateral aid by DAC donors declined in the year 2006 but rose again thereafter. The same is true when looking at the two main individual bilateral donors, the United States and the United Kingdom (Table 6.3).

Table 6.3: Bilateral Aid to Ethiopia, 2000-2008, Selected Donors

\begin{tabular}{|c|c|c|c|c|c|c|}
\hline & 2000 & 2004 & 2005 & 2006 & 2007 & 2008 \\
\hline \multicolumn{7}{|l|}{ Total DAC countries } \\
\hline $\begin{array}{l}\text { Absolute Amount } \\
\text { (constant } 2013 \text { US\$) }\end{array}$ & 603.1 & 1262.0 & 1413.3 & 1171.8 & 1296.9 & 1907.2 \\
\hline $\begin{array}{l}\text { Relative share } \\
\text { (as } \% \text { of bilateral aid to Africa) }\end{array}$ & 3.7 & 5.3 & 4.8 & 3.2 & 4.9 & 6.8 \\
\hline \multicolumn{7}{|l|}{ United States } \\
\hline $\begin{array}{l}\text { Absolute Amount } \\
\text { (constant } 2013 \text { US\$) }\end{array}$ & 169.1 & 481.8 & 705.9 & 355.4 & 407.6 & 872.7 \\
\hline $\begin{array}{l}\text { Relative share } \\
\text { (as \% of bilateral aid to Africa) }\end{array}$ & 6.2 & 9.6 & 13.7 & 5.4 & 7.4 & 11.3 \\
\hline \multicolumn{7}{|l|}{ United Kingdom } \\
\hline $\begin{array}{l}\text { Absolute Amount } \\
\text { (constant } 2013 \text { US\$) }\end{array}$ & 15.9 & 155.8 & 78.4 & 164.5 & 260.1 & 243.5 \\
\hline $\begin{array}{l}\text { Relative share } \\
\text { (as \% of bilateral aid to Africa) }\end{array}$ & 1.0 & 6.0 & 2.0 & 3.0 & 11.8 & 9.8 \\
\hline
\end{tabular}

Source: Author's own calculations based on OECD/DAC statistics.

Table 6.4: Multilateral Aid to Ethiopia, 2000-2008, Selected Donors

\begin{tabular}{|c|c|c|c|c|c|c|}
\hline & 2000 & 2004 & 2005 & 2006 & 2007 & 2008 \\
\hline \multicolumn{7}{|l|}{ Total Multilateral } \\
\hline $\begin{array}{l}\text { Absolute Amount } \\
\text { (constant } 2013 \text { US\$) }\end{array}$ & 456.6 & 934.4 & 847.1 & 1139.3 & 1367.3 & 1463.3 \\
\hline $\begin{array}{l}\text { Relative share } \\
\text { (as \% of bilateral aid to Africa) } \\
\text { World Bank (IDA) }\end{array}$ & 6.1 & 7.4 & 6.6 & 7.9 & 9.0 & 8.8 \\
\hline $\begin{array}{l}\text { Absolute Amount } \\
\text { (constant } 2013 \text { US\$) }\end{array}$ & 172.7 & 580.6 & 292.4 & 409.4 & 348.4 & 558.5 \\
\hline $\begin{array}{l}\text { Relative share } \\
\text { (as \% of bilateral aid to Africa) } \\
\text { EU Institutions }\end{array}$ & 6.5 & 12.3 & 6.8 & 10.0 & 7.8 & 13.5 \\
\hline $\begin{array}{l}\text { Absolute Amount } \\
\text { (constant } 2013 \text { US\$) }\end{array}$ & 124.2 & 137.4 & 195.8 & 226.3 & 380.5 & 434.5 \\
\hline $\begin{array}{l}\text { Relative share } \\
\text { (as \% of bilateral aid to Africa) }\end{array}$ & 4.8 & 3.1 & 4.2 & 4.7 & 7.0 & 7.8 \\
\hline
\end{tabular}

Source: Author's own calculations based on OECD/DAC statistics. 


\section{CHAPTER 6}

In relative terms, total bilateral aid allocated to Ethiopia as a percent of total bilateral aid allocated to Africa decreased immediately after the 2005 elections for the DAC donors as a whole and the United States, while it increased for the United Kingdom. With the fading of the 2005 general elections, however, Ethiopia's relative importance as a recipient country on the African continent increased again among all major donors, namely by a factor of 1.5 for the entire DAC donor community, by a factor of two for the United States and by a factor of almost 10 for the United Kingdom. The same trends can be observed for multilateral aid (Table 6.4).

Meanwhile, the government launched its second PRSP, the Plan for Accelerated and Sustained Development to End Poverty (PASDEP). PASDEP (2005-2010) included the strategic directions of the SDPRP but also served as a tool to scale up the efforts to achieve the MDGs. PASDEP focused on rural development, employment opportunities, infrastructure development and improving tax collection and the public finance system in general (Abegaz, 2015). In 2006, the UN Development Assistance Framework announced its intent to implement development projects worth $\$ 1$ billion in Ethiopia by the year 2010. Similarly, the World Bank provided $\$ 1.3$ billion in debt relief under the Heavily Indebted Poor Countries (HIPC) programme accompanied by a debt cancellation worth $\$ 2.3$ billion under the Multilateral Debt Relief Initiative (Borchgrevink, 2008). Shifting from the blunt conditionality of withholding aid towards engagement policy, Western countries maintained or even increased international assistance to the needy sectors of the Ethiopian economy.

The Western donor community implemented a two-track policy. First, it supported the regime in achieving the MDGs of alleviating poverty. Second, it used a strategy of criticism pressuring the Ethiopian government to reduce measures of low-intensity coercion. Even though Ethiopia met all other eligibility criteria, the EU, for example, argued that budget support could only be continued after significant political improvements in Ethiopia were visible (Hackenesch, 2015a). Some evidence, however, suggests that this strategy - especially with regard to the second part of the two-track policy - was carried out only half-heartedly (Abbink, 2011). During the 2006-2010 period, the Ethiopian government remained reluctant to embark on political reforms as the government's primary aim was the strengthening of its legitimacy (Hackenesch, 2015a). Budget support for the Ethiopian government remained forthcoming during much of the 2000s 


\section{CHAPTER 6}

as Western donors, particularly the British government and the World Bank believed in the strength and integrity of the Ethiopian system of public financial management (Fisher \& Anderson, 2015).

The Ethiopian government once again successfully retained a large degree of control and ownership over its policy agenda without making significant policy concessions. Among the Western donor community, the despised Derg dictatorship, the mayhem in neighbouring Somalia, and Eritrea's status as one of the world's poorest and most autocratic countries served as points of comparison in the critical analysis of the Zenawi regime.

\section{Fourth Federal Government (2010-2015)}

On 23 May 2010, Ethiopia conducted its fourth national elections. In the runup to the election, 63 parties registered (at federal and regional levels). The main opposition bloc was the Medrek coalition. Medrek, officially the "Forum for Democratic Dialogue in Ethiopia", was formed in 2008 by four parties: (i) the UEDF, (ii) the Oromo Federalist Democratic Movement, (iii) the Somali Democratic Alliance Forces, and the (iv) Union of Tigrians for Democracy and Sovereignty (also known as Arena party). In the run-up to the elections, a number of opposition candidates were arrested or detained without charge. Some isolated incidents of violence were witnessed as well (Tronvoll, 2010). The EU observer mission "considers that insufficient measures were taken to protect the right to campaign in an environment free from threats and intimidation throughout the country" (EU-EOM, 2010, p. 16).

At Election Day, voter turnout was very high (93.4 percent), considering the tense political climate at that time. The final election results were released by the NEBE in June: the EPRDF secured 99.6 percent of seats in parliament - all but two, one going to the opposition and one to an EPRDF-friendly independent candidate (Tronvoll, 2010). The opposition strongly contested the official results and filed appeals with the election board and the Ethiopian Supreme Court, but both appeals were rejected. The election was criticized by the international donor community as falling short of international standards. According to the EU Election Observation Mission, the electoral process 


\section{CHAPTER 6}

"fell short of international commitments for elections, notably regarding the transparency of the process and the lack of a level playing field for all contesting parties. Insufficient efforts were taken to ensure a more equitable and representative electoral process" (EU-EOM, 2010, p. 1).

The legacy of the 2010 national elections was the emergence of a one-party state and a final confirmation of the return to autocratic rule (Abbink, 2011). In 2010, Zenawi unveiled the third PRSP, the Growth and Transformation Plan (GTP). The GTP (2010-2015) focused on productivity-driven growth (especially in commercial agriculture, infrastructure investments and industrial development), improving the quality of public services and building a capable developmental state (Abegaz, 2015). One of the major goals of the GTP was to achieve a projected GDP growth between 11 and 15 percent per year from 2010 to 2015.

On 20 August 2012, Meles Zenawi died while undergoing treatment for an undisclosed illness in Brussels, Belgium. Following the death of Meles Zenawi, the Deputy Prime Minister of Ethiopia, Hailemariam Desalegn, became the new prime minister of the fourth federal government. Hailemariam Desalegn is a member of the Wolayta ethnic group, one of Ethiopia's smallest ethnic groups located in southern Ethiopia.

The EPRDF-led government under Hailemariam Desalegn has officially continued to promote a policy of ethnic federalism that aims to respect ethnic autonomy while preserving the unity of the state. The recent government appointments made by Hailemariam's government reflect the government's acknowledgement of ethnic federalism and ethnic power distribution. The positions in Hailemariam's cabinet were allocated in proportion to the demographic weight of the respective constituent parties. The Oromo Peoples' Democratic Organization (OPDO) received 8 positions (31 percent), the Amhara National Democratic Movement (ANDM) and Southern Ethiopian People's Democratic Movement (SEPDM) each 7 (27 percent), the TPLF 2 (8 percent) and affiliated parties from Ethiopia's peripheral regions (Afar, Benishangul Gumuz, Gambela, and Somali) also 2 (8 percent).

The fifth general national elections were held in 2015. The EPRDF captured 500 out of the 547 seats. The remaining seats were claimed by allies of the EPRDF. 
The 2015 elections therefore highlight the continued existence of a one-party state in Ethiopia.

Despite the return to an increasingly authoritarian mode of governance, Western bilateral and multilateral aid to Ethiopia gradually rose since the early 2000s onwards (Figure 6.1). What can explain the rise in both bilateral and multilateral aid to Ethiopia since the early 2000s?

One major explanation lies in the re-emergence of the Horn of Africa to heightened geostrategic significance in the eyes of the Western donor community. Geostrategic factors like political security have started to play a major role again in the aid delivery to Ethiopia among most Western development organizations, especially after the terrorist attacks on 11 September 2001 (Anonymous 13, 2016; Anonymous 6, 2016). Since the Ethiopian government takes a strong stance against Islamic terrorism and political Islamism in the Horn of Africa, Ethiopia is being regarded as a strategic partner as the country acts as "stabilizing force in the region" (Anonymous 13, 2016). The Ethiopian government is "primarily supported because of strategic factors" (Anonymous 11, 2016) by some development organizations because "political stability is priority number one in the Horn of Africa" (Anonymous 12, 2016). It is believed that the allocation of foreign aid by countries like Germany and Sweden is largely based on developmental considerations, while strong security considerations drive the development assistance agenda of the United States and, to a lesser extent, the United Kingdom in Ethiopia (Anonymous 11, 2016; Anonymous 6, 2016). The EPRDF regime has deliberately used its important geopolitical position to attract large amounts of foreign finance through positioning itself as a bulwark against terrorism (to be discussed further in Chapter 7).

The Western donor community was largely ignorant of the fact that even before 9/11, the Ethiopian government had already played a largely successful and proactive role in the fight against terrorism: "Ethiopia had its own $9 / 11 \mathrm{~s}$ in the 1990s" (Anonymous 8, 2016) and the fight against terrorism was always on the government's agenda. ${ }^{134}$ The Ethiopian government had put a strategy in place

\footnotetext{
${ }_{134}$ During the 1990s, the Ethiopian government witnessed several terrorist attacks by Ethiopian terrorist organizations or terrorist organizations from neighbouring countries. Those terrorist acts were mostly bombings of hotels, restaurants, government offices and public transportation
} 


\section{CHAPTER 6}

even before it became a platform for the Western governments and the international donor community. Consequently, the "Ethiopian government exploited the topic skilfully by attracting financial resources from the international donor community after 9/11" (Anonymous 8, 2016).

Figure 6.1: Bilateral and Multilateral Aid to Ethiopia, 1960-2014

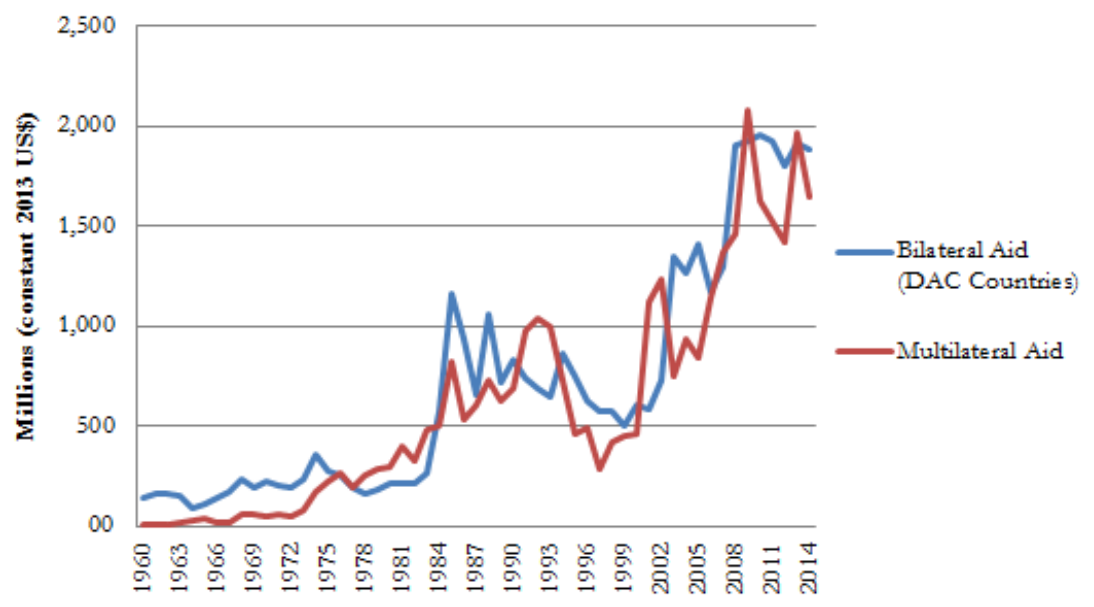

Source: Author's own calculations based on OECD/DAC database.

The Ethiopian regime started a backlash against the Western good governance agenda (Anonymous 6, 2016), even though prior to 2005, the Ethiopian government was able to combine effective economic policies with a reasonable degree of democratic procedures. While compromising on the good governance agenda and the decreasing relative importance of DGA, the U.S. government and the U.K. government to a lesser extent - is able to extend its regional security agenda at the Horn of Africa (Anonymous 11, 2016; Anonymous 12, 2016;

as well as assassination attempts. According to Shinn (2005), the "most embarrassing incident occurred in 1995, when Egyptian terrorists associated with al-Gamaa al-Islamiyya (Islamic Group) attacked President Hosni Mubarak while he was en route from the Addis Ababa airport to a summit meeting of the Organization of African Unity. A former Al Qaeda member testified that the Qatar Charitable Society bankrolled the plot with $\$ 20,000$. With the notable exception of the unsuccessful attempt on the life of Mubarak, terrorist groups from outside the Horn of Africa seem to have been minimally active" (Shinn, 2005, p. 109). As a result of the terrorist attacks in the 1990s, the Ethiopian government has developed a "tough, effective security apparatus that dates from the TPLF's long conflict with the Derg regime. Many personnel in the Ethiopian Security, Immigration and Refugees Affairs Authority (SIRA) are veterans of the military campaign. Their tactics are firm, some would say harsh, and they have developed an impressive intelligence capacity. Corruption appears to be minimal in SIRA" (Shinn, 2005, p. 110). 
Anonymous 3, 2016). This pattern highlights the re-emergence of the primacy of geopolitical considerations in the conduct of American and Western foreign policy in the Horn of Africa.

While the Western donor community maintained a critical position towards elements of Zenawi's policy agenda, especially in terms of democratization, civil society strengthening and press freedom, donors were still willing to provide aid in other specific sectors, especially social infrastructure (such as education, health, reproductive health and population services) and increasingly again the production sectors. Table 6.5 shows the sectoral distribution of DAC bilateral ODA commitments to Ethiopia between 2005 and 2014. Table 6.6 does the same for Ethiopia's main bilateral donor only, the United States.

The figures suggest that, between 2005 and 2014, the Western donor community, and U.S. bilateral development assistance in particular, increasingly shifted its aid allocations towards the Ethiopian social infrastructure. The social infrastructure share of total bilateral DAC aid commitments more than doubled between the early 2005s and 2014, and almost tripled for U.S. bilateral aid commitments. In 2014, almost half of the total bilateral DAC and U.S. aid budget flowed into the social sectors of the Ethiopian economy.

Table 6.5: Sectoral Distribution of DAC bilateral ODA commitments to

\begin{tabular}{|c|c|c|c|c|c|c|}
\hline \multicolumn{7}{|c|}{ Ethiopia $(\%)$} \\
\hline & 2005 & 2008 & 2010 & 2012 & 2013 & 2014 \\
\hline Social Infrastructure $\&$ Services & 19.1 & 40.3 & 35.3 & 49.4 & 34.5 & 47.4 \\
\hline Economic Infrastructure \& Services & 23.9 & 1.5 & 3.0 & 3.0 & 14.8 & 1.4 \\
\hline Production Sectors & 4.4 & 3.9 & 10.0 & 12.7 & 16.8 & 15.6 \\
\hline Agriculture & 2.8 & 2.1 & 9.5 & 11.9 & 15.9 & 14.9 \\
\hline Industry, mining and construction & 1.6 & 1.8 & 0.4 & 0.6 & 0.6 & 0.7 \\
\hline Multisector & 1.7 & 2.9 & 6.6 & 6.3 & 6.1 & 5.1 \\
\hline Programme Assistance & 6.9 & 14.2 & 16.3 & 8.2 & 9.8 & 8.4 \\
\hline Food aid & 6.6 & 14.2 & 15.9 & 8.2 & 9.8 & 8.0 \\
\hline Action relating to Debt & 8.7 & 0.0 & 0.0 & 0.0 & 0.0 & 0.0 \\
\hline Humanitarian Aid & 34.3 & 36.5 & 27.8 & 19.6 & 16.9 & 21.2 \\
\hline Unallocated/Unspecified & 1.0 & 0.6 & 1.1 & 0.8 & 1.1 & 0.9 \\
\hline
\end{tabular}

Source: OECD-DAC Database, http://stats.oecd.org 
Table 6.6: Sectoral Distribution of U.S. bilateral ODA commitments to Ethiopia (\%)

\begin{tabular}{lcccccc}
\hline & $\mathbf{2 0 0 5}$ & $\mathbf{2 0 0 8}$ & $\mathbf{2 0 1 0}$ & $\mathbf{2 0 1 2}$ & $\mathbf{2 0 1 3}$ & $\mathbf{2 0 1 4}$ \\
\cline { 2 - 7 } Social Infrastructure \& Services & 14.6 & 36.2 & 38.1 & 49.4 & 44.5 & 45.8 \\
Economic Infrastructure \& Services & 6.0 & 0.9 & 1.6 & 1.1 & 0.5 & 0.4 \\
Production Sectors & 0.0 & 0.9 & 1.2 & 4.8 & 8.6 & 8.2 \\
Agriculture & 0.0 & 0.8 & 1.0 & 3.9 & 8.3 & 8.2 \\
Industry, mining and construction & 0.0 & 0.0 & 0.0 & 0.7 & 0.3 & 0.0 \\
Multisector & 0.8 & 0.3 & 0.9 & 1.2 & 1.3 & 1.9 \\
Programme Assistance & 2.4 & 3.6 & 7.7 & 10.7 & 8.6 & 11.8 \\
Food aid & 2.4 & 3.6 & 7.7 & 10.7 & 8.6 & 11.8 \\
Action relating to Debt & 0.1 & 0.0 & 0.0 & 0.0 & 0.0 & 0.0 \\
Humanitarian Aid & 76.1 & 58.2 & 50.5 & 32.7 & 36.4 & 31.9 \\
Unallocated/Unspecified & 0.0 & 0.0 & 0.0 & 0.0 & 0.0 & 0.0 \\
\hline S
\end{tabular}

Source: OECD-DAC Database, http://stats.oecd.org

The pattern of an increasing social infrastructure share can also be found for the African continent in general (see Chapter 2 again). The production sector share was at its lowest point in the early 2000s. From the mid-2000s onwards, the share of bilateral DAC aid allocated to Ethiopia's production sectors rose from 4.4 percent in 2005 to 15.6 percent in 2014. The pattern is very similar for the United States: Less than 0.1 percent of total bilateral U.S. aid commitments were allocated to the production sectors. The share rose to 8.2 percent in 2014 .

This trend has mainly been driven by an increasing amount of total aid being allocated to Ethiopia's agricultural sector. In 2005, the U.S. administration allocated less than 0.1 percent of its total bilateral ODA to Ethiopia's agricultural sector which accounts for around 80 percent of employment nationally and 96 percent of employment in rural areas during the 2000s

Compared to agricultural aid, food aid was significantly more popular, both for the United States throughout the entire period and for the entire DAC donor community until 2010. In the year 2003 alone, "the United States spent more on food aid to one country, Ethiopia, than it spent on all foreign aid to agricultural development across the world" (Bräutigam, 2015, p. 29). Unless food aid takes the form of money to buy goods that are produced domestically, food aid can have large negative effects on domestic agriculture as it disincentives domestic farmers to undergo agricultural intensification (Boserup, 1983). 


\section{CHAPTER 6}

The low agricultural sector share of Western development assistance is a result of a long-term trend that started in the late 1970s. Total Western bilateral and multilateral aid funding for African agriculture dropped significantly between the late 1970s and 2000s in relative terms. The reduction, however, was a lot more pronounced for the United States. 135 Over the last few years, the relative importance of U.S. aid - but also DAC aid - for Ethiopia's agricultural sector has risen again (see Table 6.5 and Table 6.6 again). The same pattern can be observed for both Western bilateral and multilateral aid to Africa in general (see Chapter 2).

The rise of the relative importance of Ethiopia's social infrastructure sector and its production sector went hand in hand with a relative decrease in humanitarian aid (both for the DAC community and the U.S. administration in particular) and a declining share of aid allocated to Ethiopia's infrastructure sector. In 2005, the DAC community committed almost one quarter to Ethiopia's infrastructure sector. In 2014, the share dropped to 1.4 percent. The pattern is very similar for the United States, where the relative share of total aid commitments allocated to that sector has been even smaller.

The major sources of finance for Ethiopian infrastructure projects are, as previously mentioned, multilateral donors such as the World Bank and the European Commission but also the AfDB, the OPEC Fund and the Arab Bank for Economic Development (ABED). The figures in Table 6.5 and Table 6.6 provide country-level evidence that the physical infrastructure has received little or almost no attention by Western bilateral donors in recent years. From the early 1960s onwards Western bilateral donors - and Western multilateral donors to a lesser extent - increasingly turned away from building roads, bridges, irrigation, power and the like in both Ethiopia and Africa as a whole (Broich \& Szirmai, 2014; Foster \& Briceño-Garmendia, 2010; Riddell, 2007). As discussed in Chapter 2 already, emerging donors and investors, most notably China, steadily increased their development finance to Africa to fill the vacuum in the physical

\footnotetext{
135 Official development assistance from OECD countries targeting African agriculture declined from 12 percent in mid-1970s to 2.8 percent in 2005. World Bank funding for agriculture dropped from 40 percent of all loans to Sub-Saharan Africa to 8.1 percent between the late 1977 and 2003 (Broich \& Szirmai, 2014). U.S. bilateral development assistance allocated to the agricultural sector dwindled from 25 percent in the 1980s to 1 percent in 2008 (Bräutigam, 2015b).
} 
infrastructure sector - and to a lesser extent in the production sectors - left by the Western donor community. The observations made at the continent level in Chapter 2 also hold at the country level, in particular for Ethiopia, as the next section will demonstrate.

\subsection{The Entry of China into the Development Finance Game}

\subsubsection{China's Foreign Finance to Ethiopia in Historical Perspective}

Even though Sino-Ethiopian relations date back to the early 1970s, qualitative evidence suggests that China's foreign finance to Ethiopia was minimal and mainly limited to emergency relief during much of the 1970s and 1980s (see Chapter 5). A few very recent studies, however, document that Ethiopia has become one of the main recipients of Chinese aid from the early 1990s onwards (see Chapter 2).

Meles Zenawi's tenure in power heralded the return of cordial Sino-Ethiopian relations (Adem, 2012; Shinn \& Eisenman, 2012; Thakur, 2009). After Zenawi was elected as prime minister in 1995, he visited China in the same year followed immediately by Jiang Zemin's - China's president from 1989 to 2003 - visit to Ethiopia the year after. In order to resist the increasing political conditionality and good governance reforms imposed by the Western donor community, the Ethiopian government sought to "counterbalance this pressure by approaching countries whose rhetoric and policies were not always in lockstep with the preferences of leading Western powers" (Adem, 2012, p. 145).

The Ethiopian government increasingly adopted a 'Look East' policy and China was singled out as a reliable ally for the Ethiopian government. Meles Zenawi was impressed by China's rapid growth and its developmental state model. While the Ethiopian government has been eager to maintain good diplomatic relationships throughout the world, "China has become a priority partner for Ethiopia" (Anonymous 10, 2016). In contrast to the political conditionality attached to Western aid, China's long-standing diplomatic principle of non- 


\section{CHAPTER 6}

intervention in the internal affairs of other states and lack of lending conditions on governance became a valuable alternative.

Zenawi became increasingly sympathetic of the Chinese model. Some of China's domestic development reform experience is highly relevant in the Ethiopian context, as well as in the African context more generally (Ravallion, 2009). Like China, Ethiopia is heir to centuries-old cultural traits. Both countries are very aware of their ancient civilizations and their long histories. Since parts of the Chinese and Ethiopian economies could be described as peasant economies, their respective governments needed to find ways to feed their large peasant population. Similar to China's economy during the Mao era, Ethiopia is highly underdeveloped partly due to the lack of high quality infrastructure. Like China, Ethiopia was concerned that a quick political liberalization of its one-party state could be associated with political instability and economic stagnation.

China's development assistance and economic cooperation at the turn of the century started to become heavily shaped by Beijing's "Go Out" Policy. ${ }^{136}$ This policy refers to the effort of the Chinese government to actively support Chinese firms to explore international and global market opportunities. As the next subsection will show, there are several reasons why China's development finance has become increasingly attractive for the Ethiopian government.

First, China's development finance does not come with political strings attached while traditional Western development finance with its political conditionality is viewed as paternalistic by the Ethiopian government (Anonymous 5, 2016; Anonymous 6, 2016; Eggen \& Roland, 2013). While the traditional paternalistic Western aid model might still work in some African countries, it certainly does not work in Ethiopia because the Ethiopian government has a clear strategy and full ownership of its development agenda (Anonymous 11, 2016; Anonymous 5, 2016).

Second, the Ethiopian government and the Chinese government share a strong sense of ideological affinity as Sino-Ethiopian relations are "fundamentally based on economic development aspects" (Anonymous 14, 2016). Similar to the

\footnotetext{
136 Initiated in 1999, the “Go Out Policy” (Chinese: 走出去战略; pinyin: Zǒuchūqū Zhànlüè) is also known as "Going Global Strategy".
} 


\section{CHAPTER 6}

Chinese government, the Ethiopian government has adopted a philosophy that views economic growth as fundamental for political transformation. Beijing does not impose major aid allocation criteria during the aid and investment negotiation process. China's foreign finance is not driven by development priorities but it is driven by demands from the Ethiopian government (Anonymous 11, 2016; Anonymous 12, 2016; Anonymous 3, 2016). Beijing's approach is considered more flexible and adaptable to the development agenda by the Ethiopian government if compared to the Western approach (Anonymous 10, 2016).

Third, China's aid and investment disbursement is regarded as less bureaucratic and less complicated; the provision of turn-key solutions is realized at a faster speed as the negotiation process between the Ethiopian and Chinese government is less complex and less bureaucratic if compared to the SinoWestern negotiation process (Anonymous 3, 2016; Anonymous 5, 2016; Anonymous 6, 2016).

Fourth, Chinese development finance to Ethiopia targets sectors that have been increasingly neglected by the Western donor community (see Chapter 2). Almost 96 percent of China's current foreign finance to Ethiopia targets three specific sectors, namely energy generation and supply (52 percent), transport and storage (30 percent) and industry (12 percent) (Jalata, 2014).

Fifth, in contrast to Western public and private stakeholders, Chinese stakeholders operate on longer time horizons as they strive for long-term partnerships. Beijing thinks about investment and partnerships not in terms of years, but in terms of decades and centuries (Anonymous 7, 2016). Compared to the Western switches and changing patterns of Western development assistance, China's investment pattern in Ethiopia has not changed over last 25 years as Beijing's investment in Ethiopia's infrastructure has always been the main priority (Anonymous 10, 2016). China's approach is increasingly viewed as both a complementary and competing source of foreign finance vis-à-vis the traditional approach of Western development finance (Anonymous 10, 2016).

Ethiopia, in turn, has become an attractive destination for Chinese development finance for four main reasons. First, Ethiopia's political stability and religious peace in the politically unstable Horn of Africa provides a predictable political 


\section{CHAPTER 6}

environment that is conducive to foreign investment (Anonymous 10, 2016; Anonymous 14, 2016). Second, Ethiopia's workforce is said to be cheap, highlyskilled and highly-motivated (Anonymous 10, 2016). Ethiopia has no minimum wage and some workers earn around $\$ 20$ a month which is less than two-thirds of Chinese wages. Trade unions do not exist which enables both domestic and international firms to keep labour costs at a minimum level (Anonymous 10, 2016). Third, Chinese investors consider Ethiopia a large economic market thereby recognizing ample investment opportunities which are facilitated by the Ethiopian government's competitive investment incentive packages (Anonymous 10, 2016; Anonymous 5, 2016). Fourth, relative to other African countries, Ethiopia's government provides a reliable institutional framework with comparatively little corruption, transparent laws and streamlined procedures (Anonymous 14, 2016)..$^{137}$

\subsubsection{China's Aid, Investment and Trade in Comparative Perspective}

It is often difficult to disentangle Chinese development assistance from Chinese foreign direct investment and trade policies in Ethiopia. As previously mentioned, the classifications for Chinese aid, investment and trade often overlap (Biggeri \& Sanfilippo, 2009; Zafar, 2007). Compared to its earlier emergency or humanitarian facet, Beijing's development assistance has increasingly taken a 'commercial or corporatist orientation' (AFRODAD, 2011).

Over time, Ethiopia has become one of the most important recipient countries of Chinese development assistance. Between 1959 and 1998, Ethiopia received 'only' \$155 million worth of aid. In the year 2012 alone, estimates suggest that Ethiopia received around $\$ 200$ million worth of development assistance from China. That makes Ethiopia the largest recipient of Chinese aid, together with Sudan (Table 6.7). Compared to Ethiopia's development assistance received from the DAC donor community, Beijing's foreign aid delivered to Ethiopia still remains modest, though its importance is rapidly increasing. Between 1959 and 1998, China's foreign aid to Ethiopia was minimal compared to the total DAC

\footnotetext{
137 This is confirmed by a recent World Bank study which argues that "in Ethiopia, corruption in the delivery of basic services (primary health, basic education, rural water supply, and justice) is comparatively limited and potentially much lower than in other low-income countries" (Plummer, 2012, p. 12).
} 
aid. By 2012, the DAC donors provided almost $\$ 1.8$ billion worth of aid (Table 6.8), with Chinese aid amounting to a little bit more than $\$ 200$ million.

Table 6.7: China's Aid to Ethiopia in Comparative Perspective

\begin{tabular}{|c|c|c|c|c|}
\hline \multicolumn{2}{|c|}{ 1959-1998 } & \multicolumn{3}{|c|}{2012} \\
\hline Country & $\begin{array}{c}\text { Volume } \\
\text { (current US\$ } \\
\text { million) }\end{array}$ & Country & $\begin{array}{l}\text { Volume } \\
\text { (current US\$ } \\
\text { million) }\end{array}$ & $\begin{array}{c}\% \text { of } \\
\text { TOTAL }\end{array}$ \\
\hline Tanzania & 534.00 & Sudan & 201.76 & 8.08 \\
\hline Zambia & 372.00 & Ethiopia & 201.51 & 8.07 \\
\hline Congo, DR & 303.00 & Congo, DR & 186.78 & 7.48 \\
\hline Mauritania & 239.00 & Nigeria & 185.53 & 7.43 \\
\hline Sudan & 230.00 & Angola & 154.31 & 6.18 \\
\hline Somalia & 220.00 & Ghana & 152.07 & 6.09 \\
\hline Congo Republic & 205.00 & Zimbabwe & 144.58 & 5.79 \\
\hline Egypt & 193.00 & Equat. Guinea & 142.58 & 5.71 \\
\hline Guinea & 161.00 & Cameroon & 111.12 & 4.45 \\
\hline Ethiopia & 155.00 & South Africa & 88.89 & 3.56 \\
\hline Mali & 148.00 & Others & 927.89 & 37.16 \\
\hline AFRICA, TOTAL & - & AFRICA, TOTAL & 2497 & 100.00 \\
\hline
\end{tabular}

Sources: Data for the period 1958-1998 is from Bräutigam (1998) and published in Chaponnière (2009). Country data for the year 2012 is an estimate based on information provided by Bräutigam (2009) and Strange, Parks, Tierney, Fuchs and Dreher (2013).

Table 6.8: Ethiopia's Major Aid Donors, 1992 and 2012

\begin{tabular}{lcclccc}
\hline \multicolumn{1}{c}{ Country } & $\begin{array}{c}\text { Volume } \\
\text { (current } \\
\text { US\$ } \$ \\
\text { million) }\end{array}$ & $\begin{array}{c}\text { \% of } \\
\text { DAC } \\
\text { Donors }\end{array}$ & Country & $\begin{array}{c}\text { Volume } \\
\text { (current } \\
\text { US\$ } \\
\text { million) }\end{array}$ & $\begin{array}{c}\text { \% of } \\
\text { DAC } \\
\text { Donors }\end{array}$ \\
\hline Germany & 135.75 & 29.67 & USA & 693.40 & 38.55 \\
USA & 65.00 & 14.21 & UK & 421.05 & 23.41 \\
Sweden & 45.45 & 9.94 & China & 201.51 & 11.20 \\
Italy & 42.67 & 9.33 & Canada & 123.37 & 6.86 \\
UK & 33.83 & 7.40 & Germany & 116.84 & 6.50 \\
Netherlands & 28.48 & 6.23 & Japan & 108.67 & 6.04 \\
Norway & 26.90 & 5.88 & Netherlands & 79.34 & 4.41 \\
Canada & 21.09 & 4.61 & Norway & 39.15 & 2.18 \\
France & 10.85 & 2.37 & Sweden & 27.23 & 1.51 \\
Japan & 7.29 & 1.59 & France & 20.68 & 1.15 \\
China & - & & Italy & -3.02 & \\
DAC Donors Total & 457.47 & 100.00 & DAC Donors Total & 1798.49 & 100.00 \\
\hline Note: The D C & & & & & &
\end{tabular}

Note: The DAC total of 1.8 billion excludes China.

Source: OECD/DAC database; Author's own calculations. 
While Ethiopia is one of the main recipients of Chinese aid, it trails several African countries in terms of FDI inflows and FDI stocks (Table 6.9 and Table 6.10). Beijing's FDI flows (stock) to (in) Ethiopia rose significantly between 2003 and 2013 and Ethiopia's shares of Chinese FDI flows and stock on the African continent have increased steadily (from 1.31 percent to 3.04 percent). However, African countries like Zimbabwe, Zambia, Kenya or Angola experienced much sharper increases in Chinese investment activities.

When we compare China's FDI in Ethiopia with that of other countries, we can see that between 1992 and 2015, China has been the major investor in Ethiopia, both in terms of FDI volume and number of projects (Table 6.11). Other major investors in Ethiopia were Turkey, India, Saudi-Arabia, United States, Nigeria and Sudan. What may be surprising is that only two Western countries (the United States and the Netherlands) are among the top ten investors in Ethiopia. Even though the Ethiopian share of Chinese investment in Africa is very modest, China must still be considered one of the largest investors in Ethiopia, which highlights the limited investment opportunities in the country.

Table 6.9: China's FDI Flows to Ethiopia in Comparative Perspective, 2003 and 2013

\begin{tabular}{|c|c|c|c|c|c|}
\hline \multicolumn{3}{|c|}{2003} & \multicolumn{3}{|c|}{2013} \\
\hline Country & $\begin{array}{l}\text { Volume } \\
\text { (current } \\
\text { US\$ } \\
\text { million) }\end{array}$ & $\begin{array}{c}\text { \% of } \\
\text { China's } \\
\text { total } \\
\text { flows to } \\
\text { Africa }\end{array}$ & Country & $\begin{array}{c}\text { Volume } \\
\text { (current } \\
\text { US\$ } \\
\text { million) }\end{array}$ & $\begin{array}{c}\text { \% of } \\
\text { China's } \\
\text { total } \\
\text { flows to } \\
\text { Africa }\end{array}$ \\
\hline Nigeria & 24.40 & 32.62 & Zimbabwe & 517.53 & 15.35 \\
\hline Mauritius & 10.27 & 13.73 & Zambia & 292.86 & 8.69 \\
\hline South Africa & 8.86 & 11.84 & Kenya & 230.54 & 6.84 \\
\hline Zambia & 5.53 & 7.39 & Angola & 224.05 & 6.65 \\
\hline Mali & 5.41 & 7.23 & Nigeria & 209.13 & 6.20 \\
\hline Ghana & 2.89 & 3.86 & Algeria & 191.30 & 5.68 \\
\hline Algeria & 2.47 & 3.30 & Tanzania & 150.64 & 4.47 \\
\hline Egypt & 2.10 & 2.81 & Sudan & 140.91 & 4.18 \\
\hline Benin & 2.09 & 2.79 & Mozambique & 131.89 & 3.91 \\
\hline Mauritania & 1.70 & 2.27 & Ghana & 122.51 & 3.63 \\
\hline Ethiopia & 0.98 & 1.31 & Ethiopia & 102.46 & 3.04 \\
\hline Others & 8.11 & 10.84 & Others & $1,056.82$ & 31.35 \\
\hline AFRICA, Total & 74.81 & 100.00 & AFRICA, Total & $3,370.64$ & 100.00 \\
\hline
\end{tabular}


Table 6.10: China's FDI Stock in Ethiopia in Comparative Perspective, 2003 and 2013

\begin{tabular}{|c|c|c|c|c|c|}
\hline \multicolumn{3}{|c|}{2003} & \multicolumn{3}{|c|}{2013} \\
\hline Country & $\begin{array}{c}\text { Volume } \\
\text { (current } \\
\text { US\$ } \\
\text { million) }\end{array}$ & $\begin{array}{c}\% \text { of } \\
\text { China's } \\
\text { total } \\
\text { stock in } \\
\text { Africa }\end{array}$ & Country & $\begin{array}{l}\text { Volume } \\
\text { (current } \\
\text { US\$ } \\
\text { million) }\end{array}$ & $\begin{array}{c}\text { \% of } \\
\text { China's } \\
\text { total } \\
\text { stock } \\
\text { in } \\
\text { Africa }\end{array}$ \\
\hline Zambia & 143.70 & 29.25 & South Africa & $4,400.40$ & 16.80 \\
\hline South Africa & 44.77 & 9.11 & Zambia & $2,164.32$ & 8.27 \\
\hline Zimbabwe & 36.74 & 7.48 & Nigeria & $2,146.07$ & 8.20 \\
\hline Nigeria & 31.98 & 6.51 & Angola & $1,634.74$ & 6.24 \\
\hline Madagascar & 28.13 & 5.73 & Zimbabwe & $1,520.83$ & 5.81 \\
\hline Kenya & 25.53 & 5.20 & Sudan & $1,507.04$ & 5.76 \\
\hline Gabon & 24.05 & 4.90 & Algeria & $1,497.21$ & 5.72 \\
\hline Guinea & 14.34 & 2.92 & Congo DR & $1,091.76$ & 4.17 \\
\hline Egypt & 14.29 & 2.91 & Mauritius & 849.59 & 3.24 \\
\hline Mauritius & 12.59 & 2.56 & Ghana & 834.84 & 3.19 \\
\hline Ethiopia & 4.78 & 0.97 & Ethiopia & 771.84 & 2.95 \\
\hline Others & 115.11 & 23.43 & Others & $8,538.97$ & 32.61 \\
\hline AFRICA, Total & 491.23 & 100.00 & AFRICA, Total & $26,185.77$ & 100.00 \\
\hline
\end{tabular}

Table 6.11: Ethiopia's Major Investors, 1992-2015

\begin{tabular}{|c|c|c|c|}
\hline $\begin{array}{c}\text { Country of } \\
\text { Origin }\end{array}$ & $\begin{array}{c}\text { Capital in } \\
\text { Million USD }\end{array}$ & $\begin{array}{c}\text { Country of } \\
\text { Origin }\end{array}$ & $\begin{array}{c}\text { Number of } \\
\text { Projects }\end{array}$ \\
\hline China & 2,447 & China & 891 \\
\hline Turkey & 2,089 & Sudan & 374 \\
\hline India & 2,066 & India & 339 \\
\hline Saudi-Arabia & 1,210 & USA & 240 \\
\hline USA & 881 & Turkey & 162 \\
\hline Nigeria & 547 & Saudi-Arabia & 124 \\
\hline Sudan & 395 & Netherlands & 85 \\
\hline Pakistan & 339 & Yemen & 63 \\
\hline Netherlands & 259 & Pakistan & 55 \\
\hline Yemen & 219 & Nigeria & 10 \\
\hline
\end{tabular}

Source: Addis Ababa Chamber of Commerce \& Sectoral Associations.

After analysing the magnitude of China's aid and investment in Ethiopia, I will briefly look at the magnitude of China's trade with Ethiopia. Similar to FDI, China's trade volume with Ethiopia is still relatively small if compared to China's trade with other African countries. While Ethiopia's trade volume with China 


\section{CHAPTER 6}

increased almost nine fold between 1992 and 2012, Ethiopia's relative share of China's total trade with Africa stagnated at around 1 percent (Table 6.12).

Nevertheless, just as with regard to investment, China has become the most important trading partner for Ethiopia (since 2006). Between 1995 and 2012, Ethiopia's trade volume with China rose from $\$ 31.8$ million to almost $\$ 2$ billion surpassing Ethiopia's traditional trading partners such as the USA, Germany, France, the UK and Japan (Table 6.13). ${ }^{138}$ If we take the European Union as a single entity, however, the EU-27 still positions itself as the largest trading partner of Ethiopia. Since the figures are expressed in current dollars, I am slighty overestimating the rate of increase.

Table 6.12: China's Trade with Ethiopia in Comparative Perspective, 1992 and 2012

\begin{tabular}{|c|c|c|c|c|c|}
\hline \multicolumn{3}{|c|}{1992} & \multicolumn{3}{|c|}{2012} \\
\hline Country & $\begin{array}{c}\text { Trade } \\
\text { Volume } \\
\text { (current } \\
\text { Million } \\
\text { US\$) }\end{array}$ & $\begin{array}{c}\% \text { of } \\
\text { TOTAL }\end{array}$ & Country & $\begin{array}{c}\text { Trade } \\
\text { Volume } \\
\text { (current } \\
\text { Million } \\
\text { US\$) }\end{array}$ & $\begin{array}{c}\% \text { of } \\
\text { TOTAL }\end{array}$ \\
\hline Libya & 176.4 & 10.40 & South Africa & $59,977.0$ & 30.24 \\
\hline Egypt & 175.6 & 10.36 & Angola & $37,601.1$ & 18.96 \\
\hline Morocco & 144.6 & 8.53 & Nigeria & $10,570.1$ & 5.33 \\
\hline Zimbabwe & 125.3 & 7.39 & Egypt & $9,544.7$ & 4.81 \\
\hline Liberia & 115.7 & 6.82 & Libya & $8,760.1$ & 4.42 \\
\hline Tanzania & 108.7 & 6.41 & Algeria & $7,728.6$ & 3.90 \\
\hline Nigeria & 97.0 & 5.72 & Ghana & $5,434.3$ & 2.74 \\
\hline Togo & 77.0 & 4.54 & Congo, Rep. & $5,076.4$ & 2.56 \\
\hline Mozambique & 59.1 & 3.49 & Congo, Dem. Rep. & $4,364.6$ & 2.20 \\
\hline Gambia & 52.0 & 3.07 & Sudan & 3,732.9 & 1.88 \\
\hline Ethiopiat & 22.2 & 1.31 & Ethiopia & $1,839.2$ & 0.93 \\
\hline Others & 564.5 & 32.96 & Others & $43,704.0$ & 22.04 \\
\hline AFRICA, Total & $1,696.0$ & 100.00 & AFRICA, Total & $198,332.9$ & 100.00 \\
\hline
\end{tabular}

138 Total two-way trade volume data for the Ethiopian economy retrieved from the UN Comtrade database was only available from 1995 onwards. 
CHAPTER 6

Table 6.13: Ethiopia's Major Trading Partners, 1995 and 2012

\begin{tabular}{|c|c|c|c|c|c|}
\hline \multicolumn{3}{|c|}{1995} & \multicolumn{3}{|c|}{2012} \\
\hline Country & $\begin{array}{c}\text { Trade } \\
\text { Volume } \\
\text { (current } \\
\text { Million US\$) }\end{array}$ & $\begin{array}{c}\% \text { of } \\
\text { TOTAL }\end{array}$ & Country & $\begin{array}{c}\text { Trade } \\
\text { Volume } \\
\text { (current } \\
\text { Million } \\
\text { US\$) }\end{array}$ & $\begin{array}{c}\% \text { of } \\
\text { TOTAL }\end{array}$ \\
\hline Germany & 280.7 & 17.96 & EU-27 & $2,301.1$ & 15.54 \\
\hline United States & 182.3 & 11.67 & China & $1,839.2$ & 12.42 \\
\hline Japan & 149.7 & 9.58 & United States & $1,476.9$ & 9.98 \\
\hline United Kingdom & 106.5 & 6.81 & India & 674.0 & 4.55 \\
\hline France & 81.9 & 5.24 & Germany & 480.3 & 3.24 \\
\hline India & 34.5 & 2.21 & Japan & 192.6 & 1.30 \\
\hline China & 31.9 & 2.04 & France & 171.1 & 1.16 \\
\hline & & & United Kingdom & 70.0 & 0.47 \\
\hline Others & 695.5 & 44.50 & Others & $9,900.3$ & 66.87 \\
\hline Ethiopia TOTAL & $1,562.9$ & 100.00 & Ethiopia TOTAL & $14,804.3$ & 100.00 \\
\hline
\end{tabular}

Source: Author's own calculations based on data from UN COMTRADE Database.

Summarizing, in absolute terms, China's aid to Ethiopia is significantly smaller than China's FDI to and trade with Ethiopia. But in African comparative perspective, Ethiopia, with Sudan, is the main recipient of Chinese aid while it still lags far behind other African countries in terms of FDI and two-way trade volume. In the Ethiopian context, however, China has become the biggest investor and trading partner in recent years (a big fish in a small pool).

The rest of this section will mainly deal with China's foreign aid and FDI to Ethiopia as the link between those two types of external flows is particularly strong in the Sino-African context (Sanfilippo, 2010; Wang, 2007).

\subsubsection{Types of China's Aid and Investment}

Broadly speaking, Chinese bilateral aid to Ethiopia consists of grants, aid in kind, interest-free loans, concessional loans, commercial loans, technical cooperation and debt relief. Debt cancellation, however, is not reported in China's official aid figures (Woods, 2008). The main official institutions that govern overseas Chinese development assistance programs are the Chinese State Council, the Ministry of Finance (MoF), the Ministry of Commerce (MOFCOM), the Ministry of Foreign Affairs (MOFA), the Export-Import Bank of China (EXIMBANK) and the China Development Bank. 


\section{CHAPTER 6}

Beijing's economic influence reaches almost every sector of Ethiopia's economy. Chinese official financial assistance to Ethiopia, and Africa more generally, differentiates between social service and business development projects. Grants (including aid in kind) and quasi-grants (interest-free or low-interest-rate loans, with a willingness to reschedule) are mainly used for projects that are meant to provide public goods or social services such as hospitals, schools, public buildings or facilities, and technical assistance. Business development projects that are expected to generate revenue or export earnings are mainly financed by state financial institutions through commercial loans and trade credit (Wang, 2007). One part of Chinese government funding that is directly comparable to Western OECD/DAC aid is concentrated in social sectors such as agriculture, technical assistance and educational training in China (Bräutigam, 2011a; Zhang, 2011).

\section{Education}

As of 2007, Beijing funded a technical and vocational education training program throughout Ethiopia worth $\$ 12$ million. This program was jointly operated by the two countries and opened in early 2009. Two hundred Chinese teachers are assigned to the school that enrols up to 3000 students. The courses are taught by Chinese and Ethiopian teachers and range from construction skills, architecture, engineering, electronics, electrical engineering, computers, textiles, and apparel - all areas of interest to the several hundred Chinese companies now operating in Ethiopia (Bräutigam, 2009; Shinn \& Eisenman, 2012).

Ethiopia was the first African country to receive a contingent of young Chinese volunteers, a program similar to the U.S. Peace Corps or the British Voluntary Service Overseas (Gill, 2010). While China sent 'only' twelve volunteers to Ethiopia in 2005, fifty volunteers (such as doctors, teachers and IT specialists) arrived in the following year, the largest group ever sent to a foreign country. After the 2006 Beijing summit, China's government scholarship programme was expanded. In September 2008, 46 Ethiopian students went to China which drove the total number of Ethiopians studying in China under its scholarship programme to 118 (Thakur, 2009).

China invested around $\$ 30$ million to establish the first and largest agricultural technical and vocational education training college in Ethiopia, the Ethio-China Polytechnic College located at Addis Ababa University (Thakur, 2009). 


\section{CHAPTER 6}

Ethiopia's first Confucius Institute was inaugurated on 23 February 2010 in Addis Ababa. The Addis Ababa Confucius Institute is located in the compound of the Ethio-China Polytechnic College. It provides formal Chinese-Language teaching to 250 full-time students in cooperation with Tianjin University of Technology and Education. The Institute also provides Chinese language training for Ethiopian diplomats in the Ministry of Foreign Affairs. In 2011, the Addis Ababa Confucius Institute signed agreements with Addis Ababa, Hawassa, and Mekelle universities to establish Chinese language learning centres (Shinn \& Eisenman, 2012).

The Ethiopian government provides Chinese scholarships for Ethiopian students. The selection of students eligible for the scholarship program is "primarily based on merit, although not 100 percent on merit" (Anonymous 14, 2016) which suggests that a certain number of scholarships is reserved for Ethiopian students from the government elite. One major advantage of the scholarship program with China vis-à-vis scholarship programs with Western countries is the limited possibility of a brain drain. The majority of highly skilled Ethiopian students studying in China have problems in adapting to the Chinese culture and would like to return to Ethiopia on completion of their studies (Anonymous 14, 2016). In contrast to the Chinese scholarship program, the government fears that scholarship programs with Western countries might contribute to a brain drain, as a majority of Ethiopian students would want to stay in Europe or North America (Anonymous 14, 2016).

\section{$\underline{\text { Health }}$}

China's medical cooperation program in Ethiopia started in 1974. In 1979, Chinese medical cooperation with Ethiopia was discontinued owing to the breach in diplomatic links. Medical cooperation between the two countries resumed in 1984 (Li, 2011; Liu et al., 2014).139 China's medical teams in Ethiopia provided free facilities and medical services. The government of China has a 40 percent share of an Ethiopian company that produces anti-retroviral drugs free of charge for HIV patients. Chinese medical teams in Ethiopia and in Africa

\footnotetext{
139 The beginning of China's provision of medical aid to African countries can be traced back to the early 1960s. In January 1963, shortly after the victory of the liberation movement and the withdrawal of French medical staff, Algeria became the first African country to receive medical assistance from China (Li, 2011; Liu et al., 2014).
} 
more generally often serve in rural areas, something that many African doctors do with great reluctance (Shinn, 2006). ${ }^{140}$ Figure 6.2 shows the geographical destination of Chinese health aid to Africa with countries shaded according to density of medical team coverage.

Figure 6.2: China's Health Aid to Africa: Medical Teams, Facilities, Malaria Control, in 2012

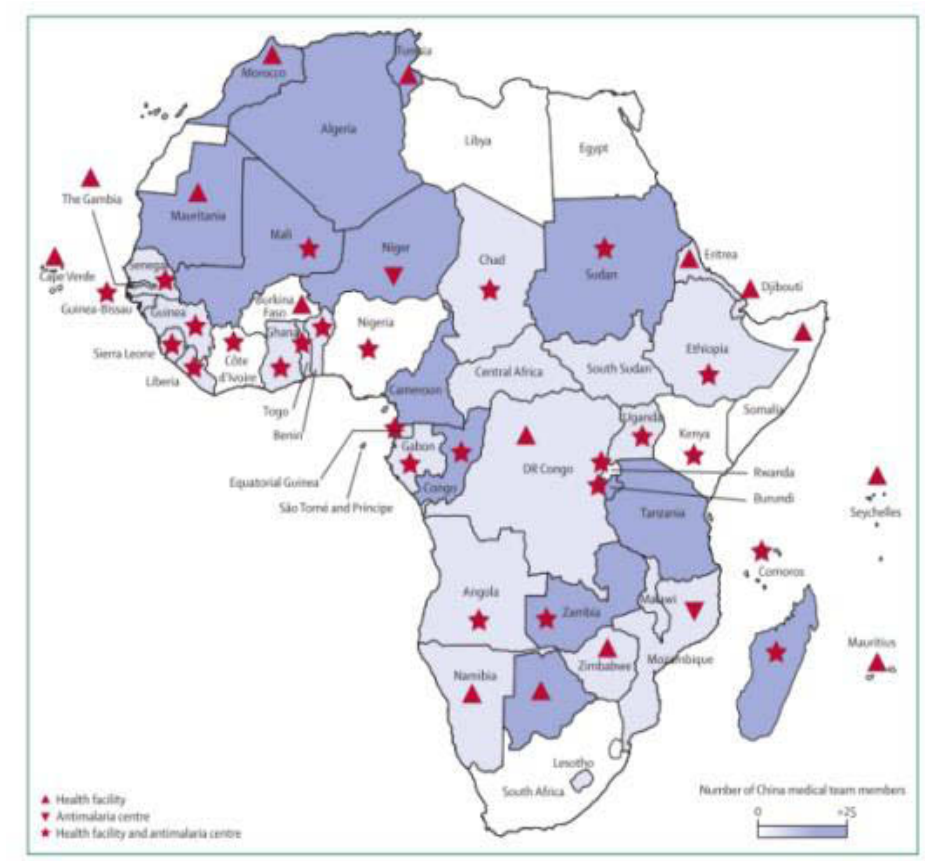

Source: Liu et al. (2014).

As part of its medical cooperation program China sent sixteen medical teams comprising 255 personnel to Ethiopia between 1974 and 2012. In 2012, China opened the $\$ 13$ million Tirunesh-Beijing Hospital, also known as Ethio-China Friendship Hospital, located in Akaki, about 25 kilometres south of Addis Ababa (Shinn, 2014). Chinese development assistance also contributes to malaria prevention. China's first anti-malaria centre in Ethiopia was established in 2008. China funded the construction and completion of an anti-malaria centre in Nazrēt (Adama), Oromia region, including furniture and other necessary

140 Ethiopian doctors working in rural areas cite underdeveloped health facilities as major grievance. Even though the government provides financial incentives such as a wage premium to doctors working in rural areas, the distribution of physicians between urban and rural regions remains highly uneven (Anonymous 4, 2016). 
equipment (AidData, 2016; Li, 2011). While the coverage of China's health aid is rather broad, the distribution shows a higher density of medical teams in western and eastern Africa regions. Economically more advanced countries such as South Africa, Nigeria, Egypt and Kenya do not have Chinese medical teams (see Figure 6.2 again).

\section{$\underline{\text { Agriculture }}$}

Similar to Ethiopia's health sector, China's foreign aid in Ethiopia's agricultural sector is modest albeit growing since the early 2000s (Bräutigam \& Tang, 2012). Besides the commonly known fact that energy has become a national security issue for the Chinese government (Moyo, 2012; Naidu \& Davies, 2006; Zweig \& Jianhai, 2005), resource-scarce Ethiopia provides a strong case for China's second national security issue, namely food security. During the mid-2000s, Beijing set the target for its own food security at 120 million hectares. This red line is just enough to ensure 95 percent self-sufficiency in grain. While China feeds 20 percent of the world's population, it only possesses 8 percent of the world's arable land. Being the second largest food consumer in the world, the Chinese government faces increasing pressure to meet domestic demand from its diminishing local resources in arable land and irrigable water (Bräutigam, 2009, 2015).

At the same time, the African continent has been a net food importer since 1973 (Rakotoarisoa, Iafrate, \& Paschali, 2011). Plagued by low agricultural productivity and policies discriminating against agriculture since the early 1970 s (Bates, 1981, Szirmai 2015, chapter 10), parts of rural Africa experience chronic food insecurity. There is untapped potential for irrigation as irrigation systems are still not very well developed. Agricultural growth is viewed as a critical instrument for sustained poverty reduction. Nowhere is this truer than in Ethiopia with its large peasant economy. Ethiopia has one of the lowest rates of irrigation on cultivated land in Africa, namely 3 percent (Bräutigam, 2009). ${ }^{141} \mathrm{~A}$ large majority of Ethiopia's agriculture is still rain-fed agriculture and its irrigation system remains largely underdeveloped (Anonymous 4, 2016). Even though Ethiopia has 73 million hectares of arable land, only 18 hectares are

\footnotetext{
${ }^{141}$ Madagascar has the highest irrigation rate among African countries (31 percent), followed by Sudan (11 percent). With 0.1 percent, the Democratic Republic of Congo has the lowest irrigation rate (Bräutigam, 2009).
} 


\section{CHAPTER 6}

currently used for cultivation (Anonymous 7, 2016). In the year 2000, Meles Zenawi partly attributed Ethiopia's economic stagnation to the agricultural sector: "The agricultural sector remains our Achilles heel and source of vulnerability. Nonetheless, we remain convinced that agricultural based development remains the only source of hope for Ethiopia" (Quoted in Devereux, Teshome and Sabates-Wheeler, 2005).

Since the start of Sino-Ethiopian diplomatic relationships in 1970, China has taken an active role in Ethiopia's agricultural and rural development. As the majority of China's traditional agricultural aid projects during the 1970s and 1980s often did not economically materialize, the Chinese government shifted from agricultural aid to agribusiness from the mid-1990s onwards. This shift was rooted in the government's belief "that productive aid projects had their best chance of sustainability if Chinese partners with a profit motive were firmly involved as owners or leaseholders, not simply offering long-term technical assistance or serving as managers” (Bräutigam \& Tang, 2009, p. 693).

In 1996, China joined the "South-South Cooperation Program" initiated by the FAO. Ethiopia became one of the earliest participants in the program. In 1998, China sent technicians to work in the area of small-scale irrigation in the Tigray and Amhara regions. The program was interrupted during the EthiopianEritrean War (1998-2000) and continued thereafter until 2006 (Bräutigam \& Tang, 2012). During the 2006 Beijing Summit of the FOCAC both China and African governments pledged to prioritize agriculture and food security in SinoAfrican cooperation (Taylor, 2011). By the year 2008, more than one hundred Chinese agricultural experts have been sent to Ethiopia training more than 50,000 Ethiopians in agricultural techniques (Shinn \& Eisenman, 2012).

A study by Arezki, Denininger, and Selod (2013) suggests that a country's attractiveness to foreign investors is directly correlated the amount of uncultivated land in the economy. Since Ethiopia has large amounts of uncultivated land, China has been widely accused of buying and taking control of vast tracts of African agricultural land, commonly known as "land grabbing". Contrary to the widely held belief, there is no evidence, however, that China engages in buying up vast amount of land in Ethiopia. First, the term land grabbing is misleading since agriculture investment contracts are negotiated and agreed upon between the Ethiopian (African) recipient government and the 


\section{CHAPTER 6}

respective investor country (Anonymous 7), even though many landgrabbing schemes are supported by corrupt elites and governments. Second, it is India rather than China that is considered to be the major investor in agriculture in Ethiopia. Since early 2008, the Ethiopian government has leased more than 600,000 hectares of farmland to Indian companies, primarily in the Gambella region, arguing that these investments will bring foreign currency, technology transfer, improved food supply and poverty reduction. The Indian farm conglomerate Karuturi Global has leased 350,000 hectares in the Gambella province alone to grow palm oil, cereals maize and biofuel crops. India's involvement is seen as mainly negative (Anonymous 3, 2016; Anonymous 7, 2016; Anonymous 8, 2016). The investment had primarily negative consequences for the rural society in Gambella, including forced eviction of farmers, reduced land for farming and hunting, reduction of ecological diversity, loss of local species, little job creation, environmental contamination due to the widespread use of pesticides and herbicides, as well as cattle dying due to ingesting pesticides.

A central feature of China's new model of official agricultural technology aid was the establishment of 23 Agricultural Technology Demonstration Centres (ATDCs) across Africa since 2006 (Xu, Li, Qi, Tang, \& Mukwereza, 2016). ATDCs were aimed at pursuing sustainability of Chinese foreign aid to African countries. ATDCs have a two-fold purpose: (i) on the one hand, ATDCs serve as aid modality to transfer China's agricultural technology to Africa; (ii) on the other hand, the Chinese government considers ATDCs as platform to promote agribusiness as part of China's wider "going out" strategy. ${ }^{142}$ Chinese leaders see Ethiopia and Africa in general as a huge potential market for hybrid seed and other Chinese biotechnology.

One of the 23 ATDCs is located in Ethiopia. The aim of the ATDC was to transfer agricultural technology from China to Ethiopia via the demonstration of Chinese farming approaches to local Ethiopians. The "Ethiopia-China Agricultural Technology Demonstration Centre" was established at Ginchi, Oromia region, in 2011. It was built by Guangxi International Construction

\footnotetext{
142 Based on case studies in Tanzania, Ethiopia, Zimbabwe, and Mozambique the study by Xu et al. (2016) gives an insightful look of how ATDCs can or cannot contribute to knowledge construction at the macro level and to knowledge encounters at the micro level.
} 


\section{CHAPTER 6}

Engineering Company, with subcontracts to several other Chinese companies. Guangxi employed 32 Chinese engineers and technicians and more than 200 Ethiopians; their road subcontractor, who has been working in Ethiopia for many years, has a team of four Chinese, seven or eight skilled permanent Ethiopian staff, and 80-90 temporary workers (Bräutigam \& Tang, 2012). After its completion, the ATDC was handed over to Guangxi Bagui Agricultural Science and Technology Company which managed it for three years financed by the Chinese government. It is believed, however, that the ATDCs are too small to have significant developmental impacts on Ethiopia's agriculture (Anonymous 8, 2016).

ATDCs serve as a good example of how the Chinese government combines aidfunded projects with business operations to ensure financial sustainability after the three-year technical cooperation period. After completing the job of demonstration, the Ethiopian local government and technological partners were supposed to take over the agricultural extension services. From the Chinese point of view, the job of demonstration included on-station comparison studies and pilot research presenting how Chinese technology works in the Ethiopian (and African) context.

There is some anecdotal evidence, however, that the knowledge transfer derived from the ATDC could be significantly improved. Several African farmers do not feel integrated in the demonstration process as technologies are rarely used outside the actual demonstration centre. Additionally, while the ATDC use bigscale farming machines, these are often not available to local small-scale farmers. Chinese experts, in turn, working in the Ethiopian ATDC complain about the low efficiency and under-performance of the extension department in mobilizing resources to promote the technologies introduced by the ATDC (Xu et al., 2016). Chinese agricultural development assistance and investment, however, remains limited in Ethiopia. The largest agricultural investors in Ethiopia to date are companies from India, Germany, Israel, Saudi Arabia and the Netherlands (Gebreeyesus \& Iizuka, 2012; Lavers, 2012).

Besides the importance of knowledge transfer, public investments are necessary to stimulate agricultural growth. Improved physical infrastructure such as better roads, lowers transaction costs with agricultural activities, reduces costs of acquiring inputs, increases output prices, reduces the impact of shocks and 


\section{CHAPTER 6}

permits entry into new, more profitable activities. Dercon, Gilligan, Hoddinott and Woldehanna (2009) observe that African governments are frequently "involved in other dimensions of agricultural activities [even though] there is an a priori strong case for governments undertaking these [infrastructure] investments given the public goods nature of roads and technology transfer" (p. 1007).

\section{$\underline{\text { Physical Infrastructure and Construction }}$}

This brings us to the sector to which most of China's economic assistance is allocated, both in the Ethiopian and the African context. The bulk of China's foreign finance in Ethiopia comes in the form of construction work, infrastructure development and manufacturing activities (Anonymous 10, 2016; Bräutigam, 2009; Davies et al., 2008; Shinn \& Eisenman, 2012). China's development assistance serves as an aid to market penetration for its investment and trade activities. That is, foreign aid allocated to the infrastructure, construction and manufacturing sectors aims at advancing the market seeking and efficiency seeking nature of China's investment (Anonymous 10, 2016; Anonymous 3, 2016).

Market seeking FDI is mostly concentrated in manufacturing, construction and transport sectors while efficiency seeking FDI can be found in agriculture or sectors that produce inputs more efficiently for use by producers based in China. In the Ethiopian context, resource seeking FDI (i.e. investments in major extractive industry sectors) is much less pronounced compared to investment in other mineral rich countries such as Angola, the Democratic Republic of Congo, Nigeria or Sudan.

Regardless of which measure of infrastructure coverage is taken, African countries score significantly lower than their equivalents in the developing world (Yepes et al., 2009). Africa's low-quality infrastructure is presently considered as one major obstacle holding back commercial activities on the continent. For several African countries such as Ethiopia, the negative effect of deficient infrastructure is at least as large as that of crime, red tape, corruption and lack of financing (Foster \& Briceño-Garmendia, 2010). Results by Andersen and Dalgaard (2013) suggest that 


\section{CHAPTER 6}

"if all African countries had experienced South Africa's power quality [over the time period 1995-2007], the continent's average annual rate of real GDP per capita growth would have been increased by 2 percentage points and, measured by the coefficient of variation, the cross-country variation in growth rates would have been reduced by around 20\%." (p. 22)

The lack of infrastructural development - be it transportation, electricity, or IT - is considered one major obstacle for conducting business in Ethiopia (Anonymous 5, 2016; Anonymous 14, 2016). According to estimations by Escribano, Gulasch and Pena (2008), lack of infrastructure in African countries like Ethiopia depresses firm productivity by about 40 percent. Foster and Morella (2010) estimate that infrastructure constraints account for approximately 50 percent of the productivity handicap that Ethiopian companies face. Energy is considered the largest infrastructure constraint followed by the limited availability of telecommunications and internet services. Until the late 2000s, Ethiopia struggled to become the "regional hub" for the private sector for the following reason:

"Ethiopia's infrastructure networks are largely isolated from those of neighboring countries. Ethiopia's infrastructure networks provide no meaningful connectivity with neighboring Kenya, Uganda, Sudan, and Eritrea.” (Foster \& Morella, 2010, p. 6)

In the early 2000s, Ethiopia's infrastructure significantly lagged behind that of several other African countries (Table 6.14). In terms of density of paved roads, coverage of mobile and fixed-line telephones as well as internet, capacity to generate power, access to electricity, or water and sanitation facilities, Ethiopia scored significantly lower than the Sub-Saharan African average. Calculations by Foster and Briceño-Garmendia (2010) suggest that Africa's estimated aggregate infrastructure spending needs between 2006 and 2015 were almost $\$ 93$ billion a year which constitutes 15 percent of African GDP.

At the individual country level, Ethiopia's overall cost per year for the same period amounts to almost 50 percent of its GDP (Figure 6.3). The Democratic Republic of Congo is the only African country that faces higher aggregate infrastructure spending needs (above 60 percent). According to World Bank estimates, the rehabilitation of Ethiopia's poor infrastructure would require an 
average of $\$ 5.1$ billion per year for an entire decade in order to overcome existing constraints to development (Deloitte, 2014).

Table 6.14: Infrastructure endowments in the early 2000s, Ethiopia vs. Sub-Saharan Africa

\begin{tabular}{|c|c|c|}
\hline Sector and measure & Ethiopia & SSA \\
\hline Transport & & \\
\hline $\begin{array}{l}\text { Density of paved road network } \\
\left(\mathrm{km} / 1,000 \mathrm{~km}^{2}, 2001\right)\end{array}$ & 4 & 49 \\
\hline $\begin{array}{l}\text { Density of paved road network } \\
\left(\mathrm{km} / 1,000 \text { arable } \mathrm{km}^{2}, 2001\right)\end{array}$ & 33 & 1,087 \\
\hline $\begin{array}{l}\text { Density of total road network } \\
\left(\mathrm{km} / 1,000 \mathrm{~km}^{2}, 2001\right)\end{array}$ & 29 & 152 \\
\hline $\begin{array}{l}\text { Density of total road network } \\
\left(\mathrm{km} / 1,000 \text { arable } \mathrm{km}^{2}, 2001\right) \\
\text { Information and communication technology }\end{array}$ & 268 & 2,558 \\
\hline $\begin{array}{l}\text { Density of fixed-line telephones } \\
\text { (subscribers per } 1,000 \text { people, 2004) }\end{array}$ & - & 33 \\
\hline $\begin{array}{l}\text { Density of mobile telephones } \\
\text { (subscribers per 1,000 people, 2004) }\end{array}$ & 3 & 101 \\
\hline $\begin{array}{l}\text { Density of Internet connections } \\
\text { (subscribers per 1,000 people, 2004) } \\
\text { Energy }\end{array}$ & 0.2 & 3 \\
\hline $\begin{array}{l}\text { Electrical generating capacity } \\
\text { (MW per } 1 \text { million people, 2003) }\end{array}$ & 10 & 70 \\
\hline $\begin{array}{l}\text { Access to electricity } \\
(\% \text { of households with access, 2002) } \\
\text { Water and sanitation }\end{array}$ & 13 & 18 \\
\hline $\begin{array}{l}\text { Improved water source, total } \\
(\% \text { households with access, } 2002)\end{array}$ & 22 & 63 \\
\hline $\begin{array}{l}\text { Sanitation } \\
\text { (\% of households with access, } 2002)\end{array}$ & 6 & 35 \\
\hline
\end{tabular}
Source: Yepes, Pierce and Foster (2009).

Since the fostering of physical infrastructure development was a main pillar in Meles Zenawi's developmental state vision, it is hardly surprising that China plays an important role in financing Ethiopia's rapid rate of infrastructure construction. The Ethiopian government views infrastructure as a main priority as economic development without infrastructural development is largely impossible (Anonymous 10, 2016; Anonymous 14, 2016; Anonymous 8, 2016). 


\section{CHAPTER 6}

Figure 6.3: Ethiopia's Aggregate Infrastructure Spending Needs in Comparative Perspective

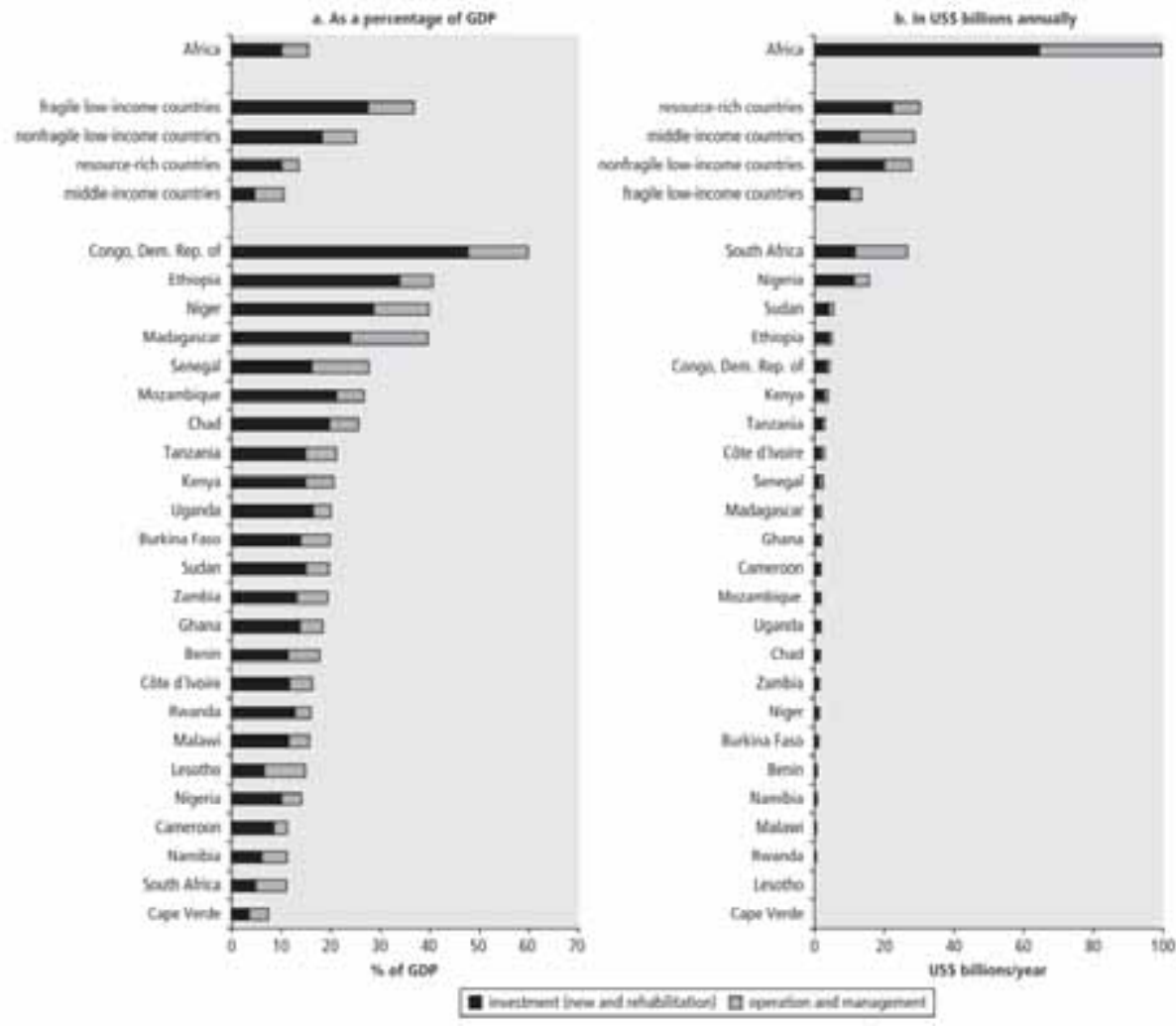

Source: Foster and Briceño-Garmendia (2010).

In fact, the bulk of China's economic assistance is allocated to general, multisector infrastructure projects through broad bilateral co-operation agreements "that allow resources to be allocated in accordance with government priorities" (Thakur, 2009, p. 9). The funding mainly comes in the form of infrastructure loans for road, flyover and bridge construction, as well as machinery acquisition. On the condition that the infrastructure projects are carried out by Chinese companies and a minimum amount of Chinese workers, both the Chinese government and EXIMBANK issue soft loans for infrastructural development in Ethiopia. In line with the "go out" strategy, Beijing is eager to promote the internationalization of Chinese companies on the African continent (Corkin, Burke, \& Davies, 2008). Confirmed Chinese infrastructure finance commitments in Sub-Saharan Africa are highly concentrated in a few African countries. Ethiopia, Nigeria, Angola and Sudan accounted for about 70 percent 


\section{CHAPTER 6}

of Chinese financing commitments during the early and mid-2000s (Foster et al., 2009).

Beijing views Ethiopia's infrastructure deficit as a lucrative business opportunity (Anonymous 14, 2016; Anonymous 5, 2016). The largest infrastructural sectors in Ethiopia to benefit from China's funding are the transportation sector (mainly road construction), the power sector (mainly hydroelectric power) and the telecommunication sector (Anonymous 10, 2016; Anonymous 5, 2016). While Chinese investments make up about a quarter of total FDI in the country, it is estimated that between 60 and 70 percent of the roads in Ethiopia are built by Chinese companies (Geda \& Meskel, 2010; Shinn \& Eisenman, 2012). SOEs dominate China's construction and infrastructure deals in Ethiopia although the size and capacity of private companies is growing (Anonymous 10, 2016; Wang, 2007). China's infrastructural investments in Ethiopia's economy are generally welcomed both by the Ethiopian government and by Ethiopia's civil society as those projects are clearly tangible and visible for the population (Anonymous 10, 2016; Anonymous 7, 2016). This is in line with the more general finding that China enjoys a mostly positive image in Africa (BBC, 2014; PewResearchCenter, 2013). ${ }^{143}$

China's dominating presence in Ethiopia's economy can mainly be attributed to three factors. First, over time, the share of Western ODA disbursements to Ethiopia and Africa in general flowing into the infrastructural projects (road construction, transport, telecommunications, electricity supply, etc.) gradually declined (see Chapter 2 again). Second, investing in infrastructure in poor countries is often perceived as a risky business by the private Western firms (Corkin et al., 2008; Wang, 2007). The third reason is that Chinese contractors have a strong competitive advantage over other (Western) market players (Corkin et al., 2008; Foster et al., 2009; Kurlantzick, 2006; Wang, 2007).

\footnotetext{
143 According to the 2013 Pew Global Attitudes Survey (PewResearchCenter, 2013), "the world's two leading powers, the U.S. and China, enjoy mostly positive images in Africa. Both nations receive higher favorability ratings in Africa than in the other regions" (p. 8). However, "both globally and in Africa, the U.S. has a much stronger reputation than China on human rights issues." (p. 8). Although the country coverage is patchy, the BBC World Public Opinion poll (PIPA) from 2014 concludes that "the most favourable views of China are found in Africa where no surveyed country has less than 65 per cent of positive views" (BBC, 2014, p. 37).
} 
Chinese enterprises active in Ethiopia's infrastructure market have better access to capital, their technology is less capital-intensive and their labour, material and supply-chain costs are significantly lower than those of other international firms. Moreover, labour productivity is higher among Chinese workers. Bids won by Chinese enterprises can also be attributed to lower labour costs, lower profit margins and quicker turnaround. Western companies find it increasingly difficult to win infrastructure contracts as they are often undercut by Chinese companies (Anonymous 10, 2016; Anonymous 11, 2016; Anonymous 13, 2016).

Figure 6.4 illustrates the international competitiveness of China's companies in the area of civil works. Chinese companies win a significant share of African infrastructure contracts awarded by the AfDB and the World Bank. In the field of civil works, the share of contracts going to the Chinese amounted to a little bit more than 30 percent of total contract value between 2005 and 2006.

In Ethiopia, some Chinese firms make unprofitable bids just to get access to the Ethiopian market. Lower salaries and profit margins are often the result of intense competition among China's SOEs. Chinese contractors building Ethiopia's roads seek on average a 3 per cent profit while Western businesses aim for 15 percent or more (Sautman \& Hairong, 2007). All the aforementioned factors give Chinese construction companies a competitive edge in risk taking and pricing.

Figure 6.4: International competitiveness of foreign contractors in Sub-Saharan Africa by country of origin, 2005-06

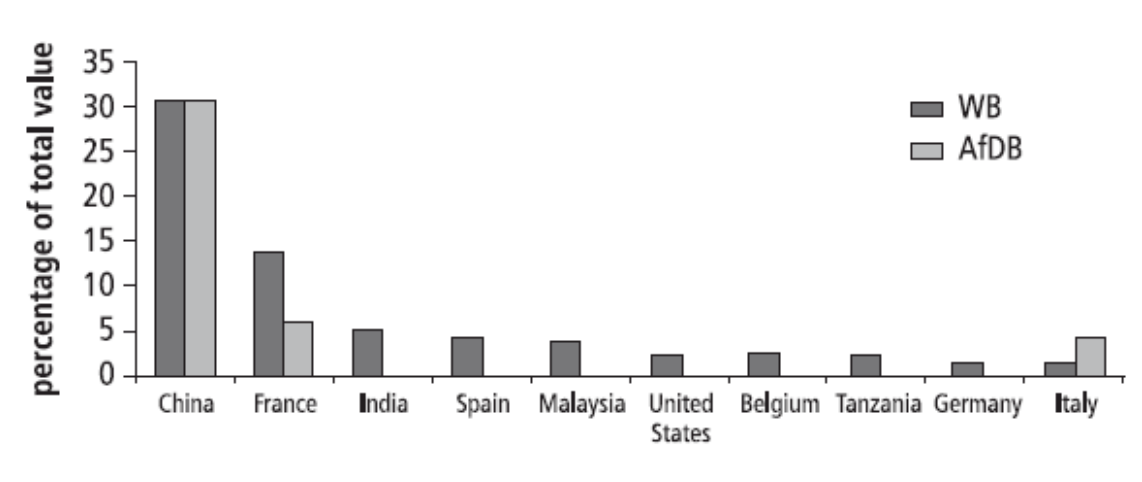

Source: Foster et al. (2009) based on African Development Bank and World Bank procurement data (2005-06). 
One of China's major infrastructure projects in Ethiopia was the Addis Ababa Ring Road constructed by the China Road \& Bridge Corporation between 1998 and 2003. The project was financed partly through an interest-free $\$ 12$ million loan from the Chinese government. The total cost of the Addis Ababa Ring Road project amounted to $\$ 76$ million and contributed to the improvement of Addis Ababa's urban infrastructure and to the reduction in congestion and pollution (Anonymous 1, 2016; Anonymous 10, 2016). Additionally, previously isolated neighbourhoods were now connected to market places, schools and other key services (Davies et al., 2008; Gadzala, 2015). Addis Ababa is also home to the new African Union Headquarters. Construction began in January 2009 and the inauguration took place three years later. The entire $\$ 200$ million project involved 1,200 Chinese and Ethiopian workers and was funded by the Chinese government as a gift to the African Union (BBC, 2012).

To address the weak state of public transportation in the fast growing capital, China launched a $\$ 475$ million metro rail project in the city, commonly known as Addis Ababa Light Railway Transit (AALRT). EXIMBANK covered 85 percent of the costs of the project through the issuance of loans while the Ethiopian government covered the remainder. Contracted by the China Railway Group Limited (CRG), the Ethiopian Railways Construction began the construction of the double track electrified Addis Ababa Light Rail in December 2011 and the metro rail opened in September 2015. The light rail transportation system has two lines: the $17 \mathrm{~km}$ long north-south line connects the city centre with the industrial areas in the south, while the $14.5 \mathrm{~km}$ long west-east line links the western outskirts with the eastern outskirts. CRG supplies the training of around 50 Ethiopian drivers and maintenance staff. It is estimated that the light rail can offer capacity for approximately 15,000 passengers per hour in one direction (Anonymous 1). The metro is very popular among Ethiopian people for three main reasons: (i) workers find it easier to reach their workplace in time; (ii) it is a more environmentally-friendly mode of transportation and (iii) the tickets, thanks to government subsidies, are highly affordable (Anonymous 1, Anonymous 2). The fares vary between 2 and 8 birrs (between $\$ 0.09$ and $\$ 0.37$ ).

The ultimate objective of the AALRT project is to shift transportation from road to rail, based on principles of environmental, social and economic sustainability. To realize environmental sustainability, the trains are running on 100 percent renewable hydroelectric power. To ensure social sustainability, the Ethiopian 


\section{CHAPTER 6}

government pays attention to the country's need for skill transfer. Both the Chinese and Ethiopian government agreed to the following plan: Intially, one Chinese and one Ethiopian driver operate a train together. The Chinese driver is supposed to drive during the first month, while the Ethiopian driver is supposed to drive under Chinese supervision during the second and third month. Afterwards, the Ethiopian driver is supposed to drive by himself (Anonymous 8, 2016). There are plans to extend the light railway in all four directions. One major aim of the Ethiopian government is to increase the role of Ethiopian engineers and workers in future construction plans (Anonymous 10, 2016).

Figure 6.5: Route of the Addis Ababa Light Rail Network

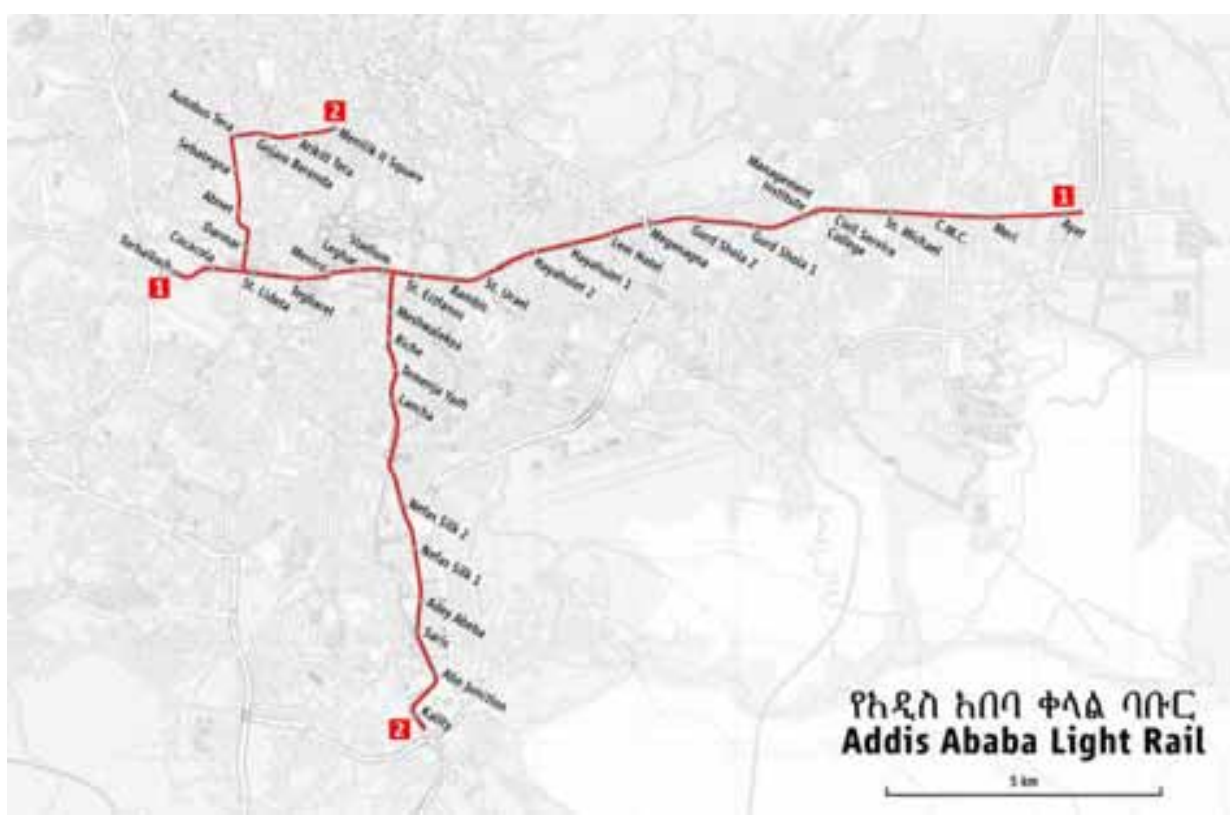

The AALRT project is one perfect example of a carefully designed project that acknowledges the need for local employment opportunities, knowledge creation and skill transfer (Anonymous 1, 2016; Anonymous 8, 2016). Meeting economic sustainability remains the largest challenge. In order to repay the loans, the Ethiopian government has to increase its revenue from the project. At the current stage, the system is not economically sustainable as the government has kept ticket prices very low through large-scale subsidization. The Ethiopian 


\section{CHAPTER 6}

government, however, is not (yet) willing to raise the prices as the light rail is meant to benefit the people from lower income classes (Anonymous 2, 2016).

Chinese companies have also implemented several infrastructural investments outside Addis Ababa, such as the construction of the 83 kilometres long ShireAdi Abune road in northern Ethiopia. Almost $\$ 50$ million, 70 percent of the project costs, were obtained on loan from the World Bank. The Ethiopian government covered the remaining 30 percent (Davies et al., 2008). China also built Ethiopia's first expressway that links Adama (or Narret in Amharic) in central Ethiopia with five major economic centres - Addis Ababa, Arsi, Bale, Harar, Shashemene - and with the port of Djibouti City, the capital of Djibouti. The expressway was built by the China Communications Construction Company between 2010 and 2014. While 25 percent of the costs were covered by the government of Ethiopia, EXIMBANK provided the remaining $\$ 350$ million as a loan to be paid back in 20 years.

Some of the prestigious projects along Ethiopia's expressways, however, are built by other foreign investors, such as Japan, which enjoys a better reputation for providing high quality infrastructure among the Ethiopian government (Anonymous 1, 2016). The most prestigious Japanese project along the Addis Ababa-Djibouti highway is the $145 \mathrm{~m}$ long and $40 \mathrm{~m}$ high two-way bridge that crosses the Awash River, some 350 kilometres away from Addis Ababa. ${ }^{144}$ The project was carried out by the oldest Japanese turnkey contractor, Sato Kogyo, and the Japanese consulting firm Central Consultant Inc. under the implementing agency, Japan International Cooperation Agency (JICA), the aid arm of the Japanese government. Construction began in 2012 and the bridge opened to traffic in December 2014.

Another prestigious Chinese infrastructure project is the Addis Ababa-Djibouti line that links Ethiopia's capital with the port of Djibouti City. ${ }^{145}$ The project is carried out by the CRG and the China Civil Engineering Construction

\footnotetext{
144 The new bridge replaced a 45 years old bridge that was limited to serving trucks only. It only allowed one truck to pass at a time. Vehicles that wanted to cross the bridge therefore were required to wait several minutes for their turn.

145 The Ethiopian government is well aware that the Axumite Empire of Ethiopia largely drew its strength from its control of Red Sea trade (see Chapter 5). Gaining sea access and building new connections to global markets is seen as vital for economic growth and restoring historic prosperity (Assefa, Bienen, \& Ciuriak, 2013).
} 
Corporation (CCECC). EXIMBANK, the China Development Bank and the Industrial and Commercial Bank of China provided the financing. Western development organizations acknowledge that the Addis Ababa-Djibouti railway line is inherently pro-poor as it enables the delivery of food aid to droughtstricken regions (Anonymous 6, 2016). Furthermore, the Addis Ababa-Djibouti railway line gives landlocked Ethiopia a direct corridor to the sea. Currently, Djibouti serves as the main, in fact the only, import-export corridor. All the goods that Ethiopia imports and exports via the sea pass through the Djibouti port. Trial services began in October 2016 when relief food aid was transported from Djibouti to Ethiopia's rural areas in need. Regular services between Djibouti and Ethiopia started in early May 2017.

Since the Ethiopian government has so far been completely reliant on the Djibouti government, it is currently in talks with the Somali, Kenyan and Sudanese authorities to discuss infrastructure developments that could directly help Ethiopia to diversify its import-export corridors (Anonymous 14, 2016; Anonymous 5, 2016). Eritrea, however, would provide the cheapest option for a second import-export corridor, but lasting peace would have to be established first. The massive extension of Ethiopia's rail network is part of Zenawi's Growth and Transformation Plan (GTP), which aims to increase the connectivity both within national and across borders.

China invests large amounts of money in Ethiopia's information and telecommunication infrastructure (Bräutigam, 2009; Foster et al., 2009; Gadzala, 2015). Telecommunications in Ethiopia is among the least developed in the world. The telecommunications sector is state-owned and therefore remains largely closed for foreign investors. By far the largest project of China's involvement in the African ICT sector took place in Ethiopia ( $\$ 1.5$ billion). The project supports the national communication backbone infrastructure as well as the rollout of mobile coverage in rural areas. The four-year project was agreed upon in 2006 and construction started in 2007. It was undertaken by the Chinese global telecom corporation Zhong Xing Telecommunication Equipment Company Limited (ZTE), the Chinese telecom solution provider Huawei and China International Telecommunication Construction Corporation (CITCC). According to Foster et al. (2009), the project will "more than double the country's optical fibre deployment, more than triple mobile network expansion capacity, double rural telecom coverage, and quadruple the length of the fixed 
telephone network" (p. 24). By 2013, ZTE had built more than "two thousand mobile transmission lines and had laid five thousand miles of fibre optic; an estimated twelve million mobile subscribers had been registered, up from one million in 2005” (Gadzala, 2015, p. 94).

Another sector that benefits massively from Chinese investment is the energy sector (Geda \& Meskel, 2010). Due to its high hydropower potential, Ethiopia considers itself the powerhouse of Africa. Hydro-infrastructure construction became a main pillar of Zenawi's nation building project as it would improve the connection of landlocked Ethiopia with its neighbours through energy flows. According to Zenawi, "hydropower will have to be at the centre of Africa's energy future. (...) It will help to electrify villages, increase irrigation and earn money from electricity exports" (Hackley \& van der Westhuizen, 2011).

One major hydroelectric power project was the construction of the Tekezé dam in the northern Tigray region of Ethiopia situated on the Tekezé River. The Ethiopian government initially asked for loans from the World Bank to finance the project. But with the World Bank being reluctant to finance the project, the hydropower dam was consequently built by a joint venture between two Chinese contractors and one Ethiopian contractor: (i) China National Water Resources and Hydropower Engineering Corporation (CWHEC) (now Sinohydro), (ii) China Gezhouba Group Company and (iii) Sur Construction, a construction company with ties to Ethiopia's ruling party. ${ }^{146}$ Construction began in 1999 and the hydroelectric project was completed in February 2009. Its final cost was $\$ 360$ million, which was $\$ 136$ million over budget. The powerhouse contains four 75MW (101,000 hp) turbines, generating 300MW (400,000 hp) of electricity. The dam contributed to the reduction in power shortages. At the time of its completion, the 188 metres (617 ft) Tekezé Dam was Africa's largest arch dam.

The same Chinese-Ethiopian joint venture also undertakes a twin dam project (Geba I and Geba II) on the Geba River across the Jimma and Ilu Aba Bora zones in Oromia, western Ethiopia. Construction began in September 2014. 80

146 When the Ethiopian government approached the World Bank for funding, the World Bank
officials were very reluctant issuing a loan for the Ethiopian government arguing that $300 \mathrm{MW}$
hydropower was too much for a country like Ethiopia that is characterized by underdeveloped
infrastructure and a nascent manufacturing sector. Senior officials from the World Bank argued
that investing millions into the Tekeze Dam would be a "waste of money" (Anonymous 8, 2016). 
percent of the US $\$ 583$ million cost comes from EXIMBANK China in a preferential credit modality. The Ethiopian government covers the remaining 20 percent. Under the Geba agreement, Sur Construction is expected to carry out 25 percent of the construction, with the remaining 75 percent are divided among Sinohydro and China Gezhouba Group Company. The three companies, however, signed a deal that allows the Sur Construction company to increase its share to 40 percent depending on its performance (Tadesse, 2014).

The 1870MW Gilgel Gibe III hydropower dam on the Omo River is currently Ethiopia's biggest hydropower dam and the third largest hydroelectric plant in Africa. The final costs of the project amounted to $\$ 1.8$ billion. Construction started in 2008 and the hydropower dam began to generate electricity in October 2015. Given Ethiopia's total installed capacity of 814 MW in 2007, Gibe III has more than doubled the country's power generation capacity (Hackley \& van der Westhuizen, 2011). While the Italian firm Salini Costruttori S.p.A handled the project construction, the Chinese Dongfang Electric Corporation was one of the largest suppliers of generating equipment (Shinn \& Eisenman, 2012). 85 percent of the $\$ 495$ million cost for electro-mechanical and hydraulic steel structure is covered by a loan from the Industrial and Commercial Bank of China (ICBC). The Industrial and Commercial Bank of China became crucial in providing loans after the World Bank, AfDB and European Investment Bank (EIB) withdrew from the project due to ecological and social concerns (Anonymous 8, 2016; Verhoeven, 2013).

The 6,000MW Grand Ethiopian Renaissance Dam in the Benishangul-Gumuz Region of Ethiopia, about 15 kilometres east of the border with Sudan, is currently under construction. The project is owned by the Ethiopian Electric Power Corporation, and construction started in April 2011. Similar to the Gibe III project, the main contractor is the Italian company Salini Costruttori S.p.A. The dam will be $1,800 \mathrm{~m}$ long, $175 \mathrm{~m}$ high with a total volume of 10 million cubic meters (Salini Impreglio, 2016). The $\$ 4.8$ billion project will become the largest hydropower plant in Africa and the 11th largest worldwide upon completion by 2018 .

Salini Costruttori was awarded the contract without competitive bidding. Foreign finance for the project was blocked by the Egyptian government as it opposed the construction of the dam. With the Grand Ethiopian Renaissance 


\section{CHAPTER 6}

Dam being able to hold 74 billion cubic meters of water, the Egyptian and Sudanese governments fear losing control of the Nile waters, which served as their major water supplier (Moszynski, 2011). The Nile waters originate in Lake Tana, the largest natural lake in Ethiopia (Figure 6.6). Egypt receives 86 percent of its water supplies from the Ethiopian highlands (Swain, 2011). The Egyptian government fears that the Grand Ethiopian Renaissance Dam could not only disrupt the flow of water into Egypt but also cause a severe water shortage crisis in Egypt during the filling of the reservoir that is twice as large as Lake Tana and whose capacity is 1.5 times greater than the Blue Nile's annual flow. As the Ethiopian government received little financial support from the international community, the government decided to fund the entire cost of the dam by itself (Anonymous 8, 2016). As the project started, Beijing showed its willingness to support the Ethiopian government financially. It is estimated that Chinese banks provided $\$ 1.8$ billion in loans for the construction of turbines (Matthews, Nicol, \& Seide, 2012).

China's massive involvement in the improvement of Ethiopia's hydroelectric infrastructure has created a lot of discontent at the local level and outside the country. Local and international environmental groups point out the adverse social and environmental consequences of the projects. The Gibe III dam threatens to ruin the livelihoods of tens of thousands of local communities and deprive animals of vital habitat (Shinn \& Eisenman, 2012). Local communities have to make way for capital-intensive sugar production, facilitated by irrigation waters released by the new hydro-infrastructure (Verhoeven, 2013). The dam would reduce the flow of water into Lake Turkana in northern Kenya, on which some 300,000 people depend. Despite the mounting national and international criticism, Meles Zenawi vowed in August 2010 to complete the dam "at any cost", saying

"They don't want to see developed Africa; they want us to remain undeveloped and backward to serve their tourists as a museum ... These people talk about the hazard of building dams after they have already completed building dams in their country" (Quoted in Moszynski, 2011). 
Figure 6.6: The Grand Ethiopian Renaissance Dam Project on the Nile River

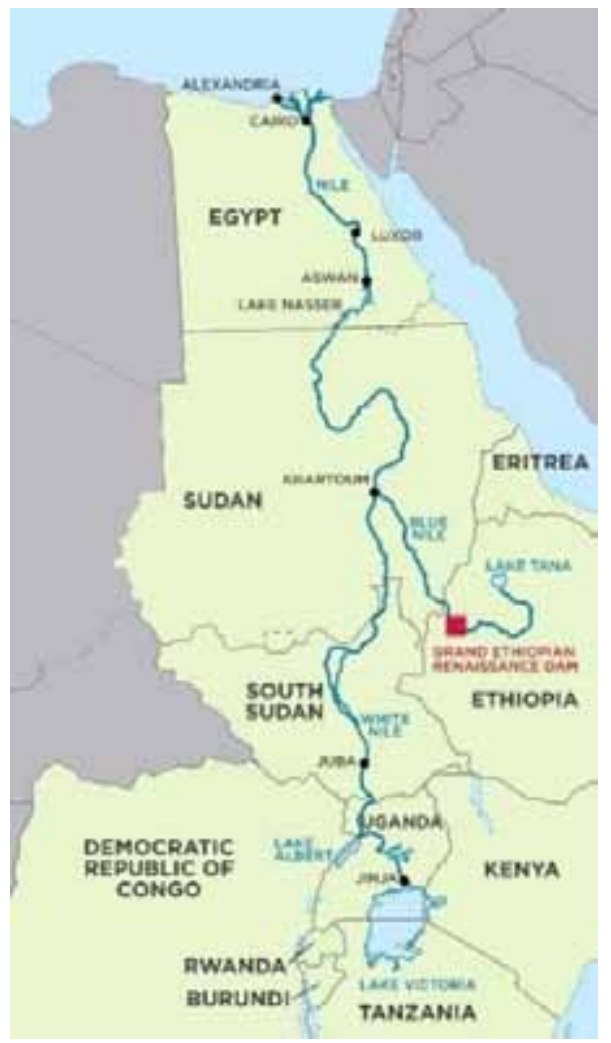

There is a general complaint by several development organizations and parts of Ethiopian civil society that some of the Chinese-built infrastructure is perceived to be of low quality (Anonymous 6, 2016; Anonymous 9, 2016; Anonymous 11, 2016). But, as the numerous examples within the Chinese economy show, Chinese construction companies are capable of building high quality physical infrastructure. First, China is regarded as "one of the most-far sighted nations in the world" (Anonymous 7, 2016) and the Beijing government is very anxious about its long-term reputation. The widely held perception that the quality of China's infrastructural projects is consistently inferior to that of Western counterparts would put China's reputation at risk (Anonymous 7, 2016). In fact, some Chinese construction firms place the responsibility on the government as the quality of roads, bridges and buildings is based on the demands by the Ethiopian recipient government which often prefers quantity over quality due to cost-efficiency considerations (Anonymous 6, 2016; Anonymous 7, 2016). 


\section{CHAPTER 6}

In recent years, Western development assistance has once again undergone a shift. In relative terms, several development organizations have gradually increased the amount of foreign aid targeting the economic sector, particularly infrastructure (Anonymous 13, 2016). The increasing Western involvement in Ethiopia's and Africa's infrastructure and electricity sector was well exemplified in the US Initiative "Power for Africa" launched by the Obama administration (2008-2016) in June 2013 (USAID, 2016).

The interviewed respondents from Western development organizations strongly reject a a causal relationship between China's large scale infrastructure investment in Ethiopia (and in Africa more generally) and a renewed Western focus on infrastructural development (Anonymous 11, 2016; Anonymous 6, 2016). Nevertheless, the recent patterns and trends in Western development assistance suggest that both Western donor organizations and international financial institutions "slowly acknowledge that infrastructure can indirectly help humanitarian ends" (Anonymous 8, 2016) and realize that "infrastructure is an important factor for job creation, industrialization and economic development" (Anonymous 6, 2016).

\section{Manufacturing}

While large Chinese SOEs play an important role in the infrastructural sector, the private sector consisting of small and medium-sized enterprises "has indisputably led the way by contributing to the non-traditional manufacturing sector in many parts of Africa" (Shen, 2013, p. 42). The expansion of SinoAfrican investment ties in the field of manufacturing reflects the structural transformation underway in both China and Africa (Lin, 2012; Monga, 2011; World Bank, 2012). In Ethiopia, Chinese owned firms make up more than 50 percent of foreign owned enterprises in the manufacturing sector (AFRODAD, 2011); around two-thirds of Chinese enterprises present in Ethiopia are active in the manufacturing sector (Geda \& Meskel, 2010). Those results are confirmed by a World Bank survey in 2012 (World Bank, 2012) and displayed in Figure 6.7.

First, Western FDI targeting the Ethiopian manufacturing sector has been very modest. While the Ethiopian economy is one of the few African countries where the secondary sector has been the predominant target for FDI inflows, the most important source of FDI flows to Ethiopia was the developing world in the early 
1990s, primarily the Arab World (Broich \& Szirmai, 2014; UNCTAD, 2008). The same region still accounted for almost 85 per cent of total FDI flows to Ethiopia in 2000, with the remaining 15 per cent coming from Europe and North America.

Figure 6.7: Sectoral Distribution of Chinese Investment in Ethiopia, 2012
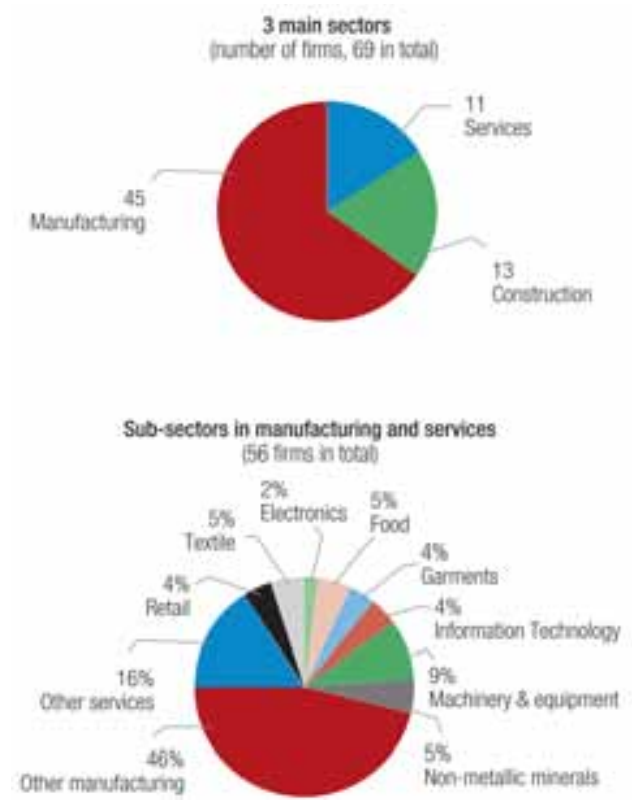

Source: World Bank Survey, Chinese FDI in Ethiopia (May 2012), World Bank (2012).

Second, while the explosive growth in the industrial sector was the main driver of economic development in China until recently (Bosworth \& Collins, 2008; Szirmai \& Ren, 2000), China's comparative advantage in manufacturing slightly eroding. As a result, the Chinese economy is shifting towards service-led growth trajectory. The transformation can partly be attributed to the gradual, albeit slow, appreciation of the renminbi (Yang, Zhang, \& Tokgoz, 2013) and the rising labour costs across all segments of the labour market, including the low- skill, labour intensive manufacturing sector (Bräutigam \& Tang, 2011; Ceglowski \& Golub, 2011; Li, Li, Wu, \& Xiong, 2012). Related push factors include, among others, intense competition in domestic markets, entry into new foreign markets via exports and preferential African regional or international trade agreements (Gu, 2009). According to estimates by Lin (2012), Chinese gradual transformation from a manufacturing-led towards a service-led economy will 


\section{CHAPTER 6}

free up to 100 million labour-intensive manufacturing jobs in the coming years, more than double the number of manufacturing employment in low-income countries. Part of the Chinese manufacturing employment is shifted in "flying geese" style to Africa. ${ }^{147}$

Third, most African countries, including Ethiopia, have not been successful in structural transformation from an agrarian or resource-based economy towards an industry- or services-based economy (Monga, 2011). Only in a very few cases have countries managed to attain a high-income status without sustained structural transformation. With Ethiopia's high quality endowments in agricultural, forestry and animal production, the Zenawi regime succeeded in attracting foreign firms from other emerging countries like China to invest in industries like the textile, clothing, leather and footwear sector as well as in wood processing (Kaplinsky \& Morris, 2009; Shen, 2013). Ethiopia is now home to one of six Chinese Special Economic Zones (SEZs) in Africa (Figure 6.8). ${ }^{148}$

The Ethiopian government has launched a preferential policy for both developers and manufacturers working in SEZs. Manufacturers enjoy (i) income tax holidays for 2-10 years, (ii) a 100 percent exemption from payment of import custom duties and other taxes levied on imports such as plant and machinery, vehicles, spare parts, construction and raw materials, (iii) an exemption of export tax payment and other taxes for products and services destined for exports, (iv) exemption from payment of taxes on remittance of capital earnings, (v) the

\footnotetext{
147 The phase "flying geese pattern of development" was originally coined by Kaname Akamatsu (1962). The industrialization in successful catching up countries often evolves in a leader, follower flying geese pattern, where developing countries can tap into the potential of advantages of backwardness in industrial upgrading (Lin, 2012).

148 Besides the Eastern Industrial Zone (EIZ) in Ethiopia, five other Chinese SEZs have been established in Africa: (i) The Zambia-China Cooperation Zone was the first Chinese economic and trade co-operation zone to be established in Africa. It is located in landlocked Zambia's capital, Lusaka. The Multi-Facility Economic Zone is located in Chambishi, Zambia. Chambishi is a mining area 420 kilometres north of Lusaka, home to a major copper mine complex operated by China Nonferrous Mining Co. Group since 1998; (ii) JinFei Economic and Trade Cooperation Zone is located in Mauritius, three kilometres northwest of Port Louis, (iii) Lekki Free Trade Zone is located 60 kilometres east of Lagos on the Lekki peninsula, (iv) OgunGuangdong Free Trade Zone is located in the Igbessa Region of Ogun State, 30 kilometres from the international airport serving Nigeria's commercial centre, Lagos and (iv) the Suez Economic and Trade Cooperation Zone is located just outside Egypt's new deep water Sokhna Port, just below the southern entrance of the Suez Canal, 120 kilometres from Cairo (Bräutigam \& Tang, 2014).
} 


\section{CHAPTER 6}

availability of one-stop-shops for government services and (vi) long-term land leasing (60-80 years) at zero charge for factories and residential quarters. Similarly, developers enjoy (i) income tax exemption up to fifteen years outside Addis Ababa, (ii) the provision of key infrastructure such a transportation, electricity and telecommunications and (iii) long-term land leasing (60-80 years) at zero charge with sub-lease rights.

Figure 6.8: Chinese Special Economic Zones in Africa, 2015

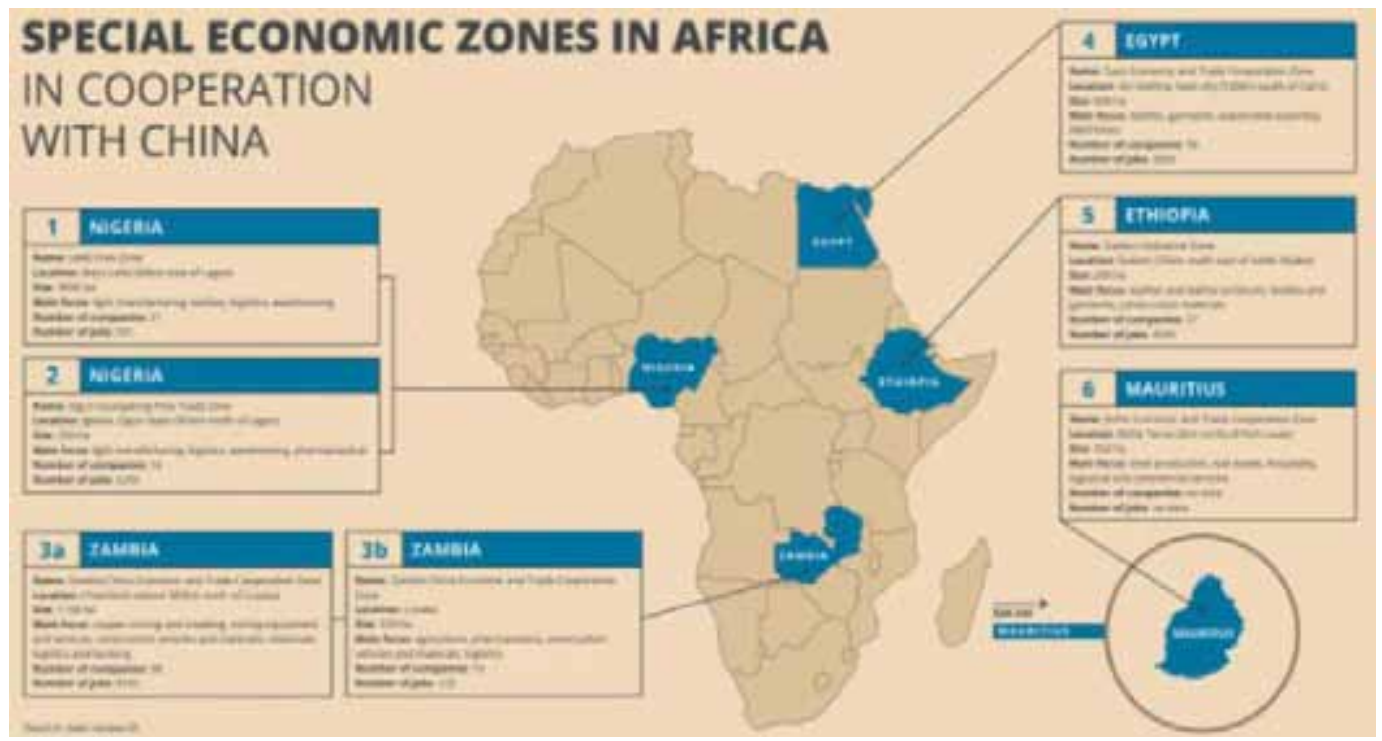

Source: UNDP (2015).

China itself has had successful experiences with its domestic SEZs. ${ }^{149}$ According to Lin and Pradhan (2010),

"the numerous special economic zones (SEZs) and industrial clusters that emerged after the country's reforms are without doubt two important engines of China's remarkable development. (...) Together with the numerous industrial clusters, the SEZs have contributed significantly to national GDP, employment, exports, and attraction of foreign investment. The SEZs have also played important roles in bringing new technologies

${ }^{149}$ SEZs often have different objectives, target different markets and employ different activities. Broadly speaking, SEZs can be categorized into (i) free trade zones, (ii) export processing zones and (iii) multi-purpose zones (UNDP, 2015). 


\section{CHAPTER 6}

to China and in adopting modern management practices" (Lin \& Pradhan, 2010, p. xiii).

Ethiopia's first Chinese SEZ, the Eastern Industrial Zone (EIZ), is located 32 kilometres away from Addis Ababa, near the town of Dukem, on the main road linking Addis Ababa to the port of Djibouti. The main investor in the industrial zone is Qiyuan Group, which was originally a private pipe-making company based in the Zhangjiagang Trade Zone of Jiangsu Province, near Shanghai. In 2006, Lu Qiyuan, the chair of Qiyuan Group, came to Ethiopia and "he was attracted by what appeared to be multiple manufacturing opportunities, and appreciated the political stability, security, comfortable climate, and 'the strong desire of the Ethiopian government 'to get out of poverty"' (Bräutigam \& Tang, 2014, p. 83). Together with three other private companies, Zhangjiagang Qiyuan Group won MOFCOM's 2007 tender and construction of the EIZ began in 2009. Meles Zenawi viewed the development of special economic zones like the EIZ as an integral part of the SDPRP program (2001-2004) and the GTP (20102015). The EIZ was regarded as a means for industrialization and included provisions for the following medium and large scale manufacturing industries: textile and garment, leather and leather products, sugar, cement, metal and engineering, chemicals, pharmaceutics and agro-processing products (UNDP, 2015). The EIZ is 100 percent Chinese-owned. While the EIZ was open to both Ethiopian and international non-Chinese investors, only Chinese enterprises have invested in the zone so far (Anonymous 14, 2016).

One of Meles Zenawi's major goals was to transform Ethiopia's leather sector into the most competitive leather industry in Africa. By the late 2000s, the Ethiopian government promoted the construction of sixteen new footwear and leather goods factories (Bräutigam, 2009). Lin (2015) provides anecdotal evidence that, in August 2011, Meles Zenawi flew to China visiting Chinese shoe manufacturers in Shenzhen and inviting them to invest in Ethiopia. Two months later, a Chinese designer shoe manufacturer called Dong Guan Huajian International visited Addis Ababa. In January 2012, Huajian set up a shoe factory with 550 workers in the Eastern Industrial Park. The workforce grew to 1,750 workers by June 2013 and to 3,500 workers by December 2013. The workers employed by Huajian were mainly Ethiopian (Bräutigam \& Tang, 2014). According to Huajian's projections, it would hire up to 30,000 workers by 2020 . Huajian has expanded its operations in Ethiopia through the establishment of 


\section{CHAPTER 6}

the Dong Guan Huajian International Light Industrial Zone in 2016, the country's latest SEZ. The experience of the Huajian Group in Ethiopia can be regarded as one of the most prominent Chinese success stories in Africa:

"It required the commitment of the country's top leadership to help reduce transaction costs for investors, the development of an industrial park, and a vision that combined Ethiopia's comparative advantageshigh-quality leather and low-cost labor-with China's financial investment and knowledge transfer" (Pigato \& Tang, 2015, p. 21).

However, the EIZ and the Dong Guan Huajian International Light Industrial Zone are the result of a wider government effort to establish industrial parks in the country. In 2014, the Ethiopian government established the Industrial Parks Development Corporation (IPDC), a key agent in Ethiopia's industrialization transformation aimed at attracting both domestic and foreign investors, providing one-stop-shop service for investors and nurturing manufacturing industries. According to the Ethiopian Industrial Parks Law of Commerce, the special economic zones are open for private developers, for public commercial park developers, and for public-private partnerships (Anonymous 14, 2016). At the time of writing, seven other special economic zones or industrial parks have already been developed or are being considered for establishment (Figure 6.9).

One of the most recent industrial zones is the Hawassa Industrial Park, the flagship project of the IPDC. On 1 July 2015, the IDPC signed an almost $\$ 250$ million deal with the CCECC for the construction of the park. Hawassa Industrial Park was built within only one year and the park was inaugurated in July 2016. The main reason why the park was built within such a short time period was Beijing's state sponsoring and the very efficient and non-bureaucratic negotiation process between the IPDC and the CCECC (Anonymous 10, 2016; Anonymous 14, 2016). Hawassa Industrial Park is located (and fully integrated) in the city of Hawassa, 275 kilometres south of Addis Ababa, and close to the newly built Hawassa University. The park is expected to create more than 80,000 jobs in two shifts and to create revenue of around one billion dollars a year (Anonymous 14, 2016). Hawassa University views the park as a key partner for technology transfer and for employment opportunities for university graduates. 
Figure 6.9: Special Economic Zones in Ethiopia, 2015

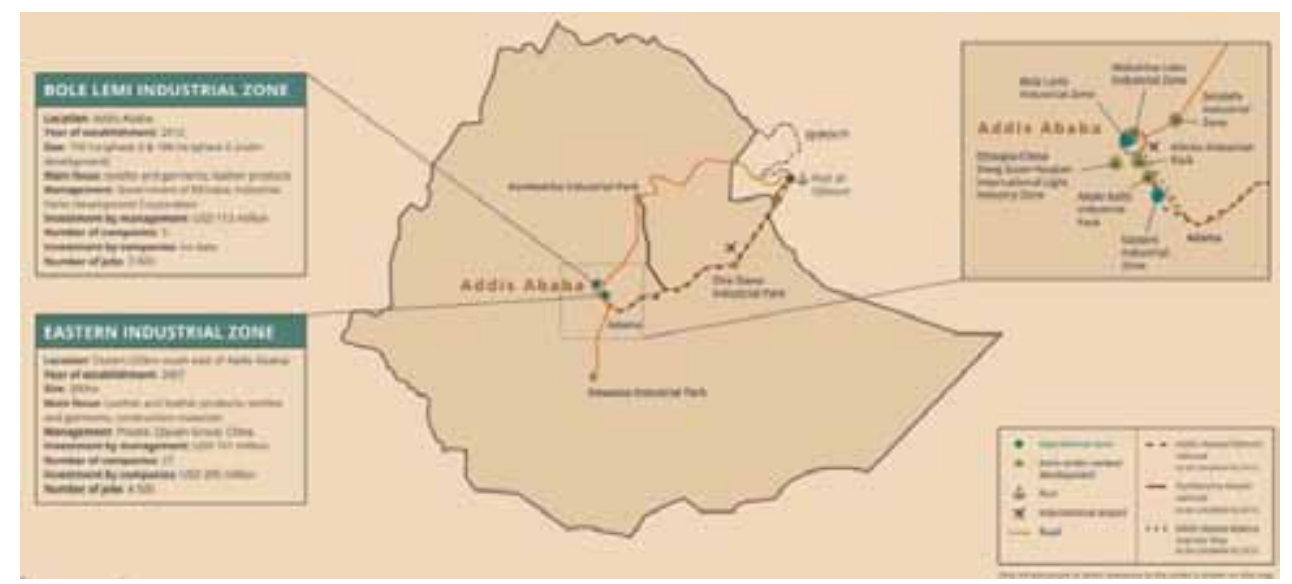

Source: UNDP (2015).

The industrial park largely focuses on textile and garment products. Fifteen international companies from China, the United States, India, Indonesia, Hong Kong and Sri Lanka have entered the park. The two global apparel companies Phillips-Van Heusen (PVH) Corporation, an American clothing company, and Hennes \& Mauritz (H\&M), a Swedish multinational retail-clothing company, but also China's Wuxi Jinmao Foreign Trade Company are among the fifteen firms operating in the park. There are also six local manufacturers working inside the park as the IPDC follows a strategy that guarantees domestic investors 25-30 percent of the factories sheds and space in the park (Anonymous 14, 2016). Those local firms have also started to enter the global value chain of both the garment and textile industry.

Hawassa Industrial Park is primarily powered by renewable electricity sources, namely hydroelectricity, making it Ethiopia's first major eco-friendly industrial park (Anonymous 5, 2016). IPDC officials have made numerous visits to East Asian countries like China, Japan, Singapore, Malaysia, and South Korea learning from the experiences of those countries. The entire resource deployment (roads, power, and telecommunication) in the park is managed by the IPDC (Anonymous 14, 2016).

Another major industrial park in Ethiopia is Bole Lemi-I Industrial Zone, located just south of Addis Ababa. Bole Lemi-I became Ethiopia's first government-owned operational industrial zone. The zone was developed by the 


\section{CHAPTER 6}

IPDC. Bole Lemi Industrial Zone started operating in 2014 and is mainly used as an export processing zone. It focuses on textiles, garments and leather products. All pre-erected factories were rented-out immediately to international companies such as Korean garment-maker Myungsung Textile Company and Taiwan's George Shoe Corporation. Shortly after the construction of Bole LemiI, the Ethiopian government wanted to expand the Bole Lemi industrial park in collaboration with the World Bank Group. While talks started about the design selection of Bole Lemi II in early 2014, the Bole Lemi Phase II is still being developed and will not be finished before mid-2017 (Anonymous 10, 2016; Anonymous 14, 2016).

Ethiopian government officials mainly attribute the long construction phase to the bureaucratic, complex and time-consuming negotiations between the Ethiopian government officials and the World Bank Group and other major Western donor organizations, such as the Swedish International Development Agency (SIDA). Different Western development organizations want to manage different sectors in the Industrial Park which complicate resource deployment and increases administrative costs according to Ethiopian government officials (Anonymous 14, 2016; Anonymous 5, 2016). Both the World Bank Group and Western development organizations require a comprehensive social and environmental impact assessment and management framework prior to the establishment of the zone (MOI, 2014a, 2014b). The fast and flexible negotiation process with officials from the Chinese administration, in contrast, allows for a much shorter construction of SEZs and a faster and more streamlined investment process.

At the same time, however, the Ethiopian government has introduced a comprehensive national legal framework that oversees the management of SEZs:

"Recognizing the need for a more comprehensive and effective legal, regulatory, and operational framework for SEZs, the government developed the Proclamation on Industrial Parks contained in Proclamation No. 886/2015, which came into effect on 9 April 2015. The Proclamation includes a number of provisions to ensure linkages between SEZs and the local economy, provisions on how to foster job creation and skills development and how to ensure environmental protection. The zone 


\section{CHAPTER 6}

developer is also obliged to link local manufacturing companies with industrial park companies to develop local technological capacity and access to international markets. Both developers and companies are required to replace expatriate personnel with Ethiopian workers by transferring required knowledge and skills. The Ministry of Environment and Forest shall establish an office within each industrial park to safeguard the enforcement of environmental regulations. Ethiopia continues to expand its SEZ policy framework and is currently developing a national SEZ strategy." (UNDP, 2015, p. 17)

Industries and SEZs have mainly been concentrated in and around Addis Ababa until very recently (Chole, 2004; Fenta, 2014). It is estimated that in the early 2010s, more than 60 percent of Ethiopia's large and medium-scale manufacturing industries were concentrated in the country's two metropolitan cities, Addis Ababa and Dire Dawa (Wodajo \& Senbet, 2013).

"The industrial policy menu of the country seems to give little attention to the uneven distribution of manufacturing industries in the country notwithstanding the existence of sparing laws and provisions that stipulate the need for balanced industrial development." (Fenta, 2014, p. 330)

The Ethiopian government has become increasingly aware of inter-regional inequality in recent years (Anonymous 13, Anonymous 14). In order to address the uneven distribution of manufacturing industries and public enterprises more generally, the government has started to promote the development of industrial parks in all regional states. In late May 2016, the Ethiopian government has launched the construction of four new Industrial Parks as part of the Second Growth and Transformation Plan (GTP II). The IPDC has started to construct industrial parks in the southern capital of Adama, in the eastern town of Dire Dawa and in the northern towns of Kombolcha and Mekelle. The fact that industrial parks should no longer be centred around Addis Ababa is a strategic choice made by the government. The industrial parks "are spread out for political economy reasons" (Anonymous 13, 2016).

"We have to bring infrastructure, electricity, telecommunication, jobs and human development to each region in Ethiopia. All regions under the Ethiopian sky have to benefit from industrial parks." (Anonymous 14, 2016) 
The Ethiopian government and the IPDC view the industrial parks as new innovation for Ethiopia because these zones promote knowledge spillovers, facilitate infrastructural development thereby lowering water, gas and telecommunication costs for companies and promote a more effective and efficient utilization of resources (Anonymous 10, 2016; Anonymous 14, 2016). Table 6.15 provides an overview of all Ethiopian Industrial Parks operated or owned by the IPDC by September 2016 .

Mekelle, the regional capital of the Tigray region, is expected to become Ethiopia's "textile capital" (Anonymous 14, 2016). Many of the companies that have expressed their interests in being involved in the expansion plans are nonChinese, such as the Bangladeshi manufacturing conglomerate BDL Group, the Swedish state-owned investment fund Swedfund, the Italian garment maker Calzedonia, the Indian-based textile company Velocity Apparel Plc, PVH and H\&M, but also Ethiopia's Almeda Textile (Anonymous 5, 2016). Founded in 2000 in the Tigray region near Adwa, Almeda Textile has become one of the most vertically integrated textile companies not only in Ethiopia but also in East Africa that supplies, among others, apparel to H\&M.

The textile and garment sector is considered a strategic sector by the Ethiopian government. Once the government provides incentives for the private sector in a particular strategic industry, the private sector starts jumping into that sector. If the sector experiences excess capacity, the government will stop providing financial incentives (Anonymous 5, 2016). Ethiopia's private sector has become increasingly attractive for foreign investors over the last few years partly thanks to China's infrastructure investments. Beijing's investment in Ethiopia's infrastructure significantly contributed to a more favourable environment for attracting foreign investment (Anonymous 10, 2016; Anonymous 8, 2016). The African Growth and Opportunity Act launched by the Clinton administration in May 2000 gradually gave a strong impetus to Ethiopia's garment and textile industry as it allows the tariff and quota-free access for U.S. imports from specific eligible countries in Sub-Saharan Africa, including Ethiopia. 


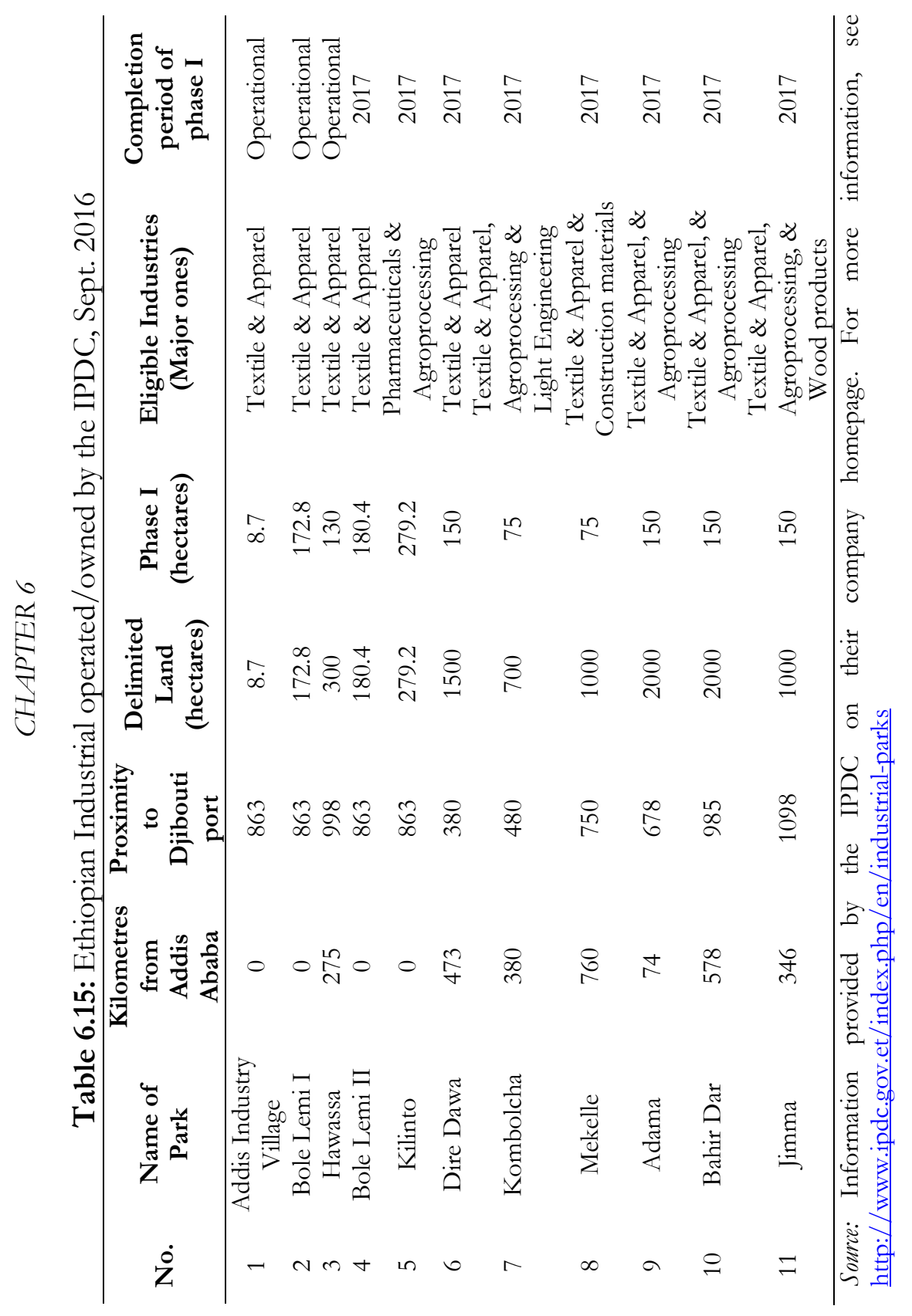

ลิ 


\section{CHAPTER 6}

Empirical evidence suggests that Ethiopia can exploit emerging opportunities in export-oriented manufacturing investment: "its inexpensive yet relatively skilled labour force, coupled with the government's proactive efforts to court Chinese investors, have enabled Ethiopia to attract substantial investments in labourintensive industries" (Pigato \& Tang, 2015, p. 4). Bräutigam (2009) is convinced that "the move by Chinese companies into production in Africa has the potential to catalyse a flying geese model in leather. If this happens, it is likely to happen first in Ethiopia” (p. 213). A study by Sonobe, Akoten and Otsuka (2009) suggests that "the development of the leather-shoe industry in Ethiopia bears similarities to the process of the cluster-based industrial development observed in East Asia” (p. 733).

The Ethiopian economy enjoys significant international comparative advantages in the footwear industry and in its leather sector in general due to its abundant raw materials and well-disciplined, cheap workforce. Nevertheless, despite increasing Chinese wages, Ethiopia's footwear sector faces increasing competition from cheap imports from Asia, particularly from China. Survey research suggests that a majority of local Ethiopian enterprises are severely affected by the influx of cheap imports (Gebre-Egziabher, 2007, 2009). GebreEgziabher $(2007,2009)$ surveyed Ethiopian micro firms and SMEs with regard to (i) the immediate impact of Chinese shoe imports and (ii) coping strategies to withstand Chinese competition in the shoe industry. Downsizing activities among local shoemaking firms was a major consequence of Chinese competition (Table 6.16).

Labour has been an extremely contentious issue in China's construction projects and manufacturing investment in Africa. There is a general perception that Chinese companies rarely form joint ventures with African firms, bring their own labour to Africa rather than hiring local workers and, if employed, the local workforce is drastically underpaid (Alden \& Davies, 2006). Such labour practices would prevent technological transfer, capability building, and prevent economic benefits of China's engagement from trickling down to the broader society and to local communities. Bräutigam and Tang (2011) argue that "inadequate local learning and local participation could affect the ability of the [special economic] zones to catalyse African industrialization” (p. 27). 
Table 6.16: Chinese Shoe Imports and the Ethiopian Shoe Industry

\begin{tabular}{|c|c|c|c|c|c|c|}
\hline & \multicolumn{2}{|c|}{$\begin{array}{c}\text { Micro } \\
\text { enterprises }\end{array}$} & \multicolumn{2}{|c|}{$\begin{array}{c}\text { Small \& medium } \\
\text { enterprises }\end{array}$} & \multicolumn{2}{|c|}{ Total } \\
\hline & Number & $\%$ & Number & $\%$ & Number & $\%$ \\
\hline \multicolumn{7}{|l|}{ Impact of Chinese shoe imports } \\
\hline Down size activity & 29 & 35.8 & 6 & 22.2 & 35 & 32.4 \\
\hline Bankrupt (lost money, assets etc.) & 19 & 23.4 & 11 & 40.7 & 30 & 27.8 \\
\hline $\begin{array}{l}\text { Closed down firm \& returned } \\
\text { license for a while }\end{array}$ & 9 & 11.1 & 3 & 11.1 & 12 & 11.1 \\
\hline $\begin{array}{l}\text { Resorted to shoe repair } \\
\text { \& work without license }\end{array}$ & 8 & 9.8 & 2 & 7.4 & 10 & 9.2 \\
\hline Brought market-related problems & 8 & 9.9 & 1 & 3.7 & 9 & 8.3 \\
\hline No impact & 8 & 9.9 & 4 & 14.8 & 12 & 11.1 \\
\hline Total & 81 & 100 & 27 & 100 & 108 & 100 \\
\hline \multicolumn{7}{|l|}{ Chosen Enterprise Strategy } \\
\hline Improved design & 55 & 58.5 & 29 & 63.0 & 84 & 60.0 \\
\hline Improved quality of products & 18 & 19.1 & 12 & 26.1 & 30 & 21.4 \\
\hline Lowered price and profit margin & 8 & 8.5 & 0 & 0 & 8 & 5.7 \\
\hline $\begin{array}{l}\text { Increased reliability in } \\
\text { delivery and supply }\end{array}$ & 1 & 1.1 & 4 & 8.6 & 5 & 3.6 \\
\hline $\begin{array}{l}\text { Increased average speed of } \\
\text { response time }\end{array}$ & 10 & 10.6 & 1 & 2.2 & 11 & 7.8 \\
\hline Introduced new shoes & 1 & 1.1 & 0 & 0 & 1 & 0.7 \\
\hline Shifted to lower products & 1 & 1.1 & 0 & 0 & 1 & 0.7 \\
\hline Total & 94 & 100 & 46 & 100 & 140 & 100 \\
\hline
\end{tabular}

Note: Multiple answers are possible.

Source: Gebre-Egziabher (2007) based on survey data.

According to Tang (2010), the "Chinese government has been consistently encouraging Chinese enterprises to hire local people and create a good social image. However, it is market competition and business needs that finally decide the behaviour patterns of enterprises" (p. 363). Compared to local workers, the rate of absenteeism of Chinese construction workers is practically zero. Chinese workers also tend to be highly organized and the entire personnel, live and work on the construction sites full time (Corkin et al., 2008). Empirical evidence suggests that the average level of education of Ethiopian workers hired by Chinese enterprises is significantly lower than that of their Chinese counterparts (Figure 6.10).

Inadequate education concomitant with lack of training among Ethiopian employees, particularly in the manufacturing and construction sectors, adversely affects labour productivity, management communication and skill transfer (World Bank, 2012). Figure 6.10 shows that Chinese enterprises usually hire lead 


\section{CHAPTER 6}

workers with 10-12 years of education from China. Those lead workers, in turn, provide on-site training for Ethiopian workers.

Figure 6.10: Average Education of Workers in Chinese Invested Enterprises in Ethiopia

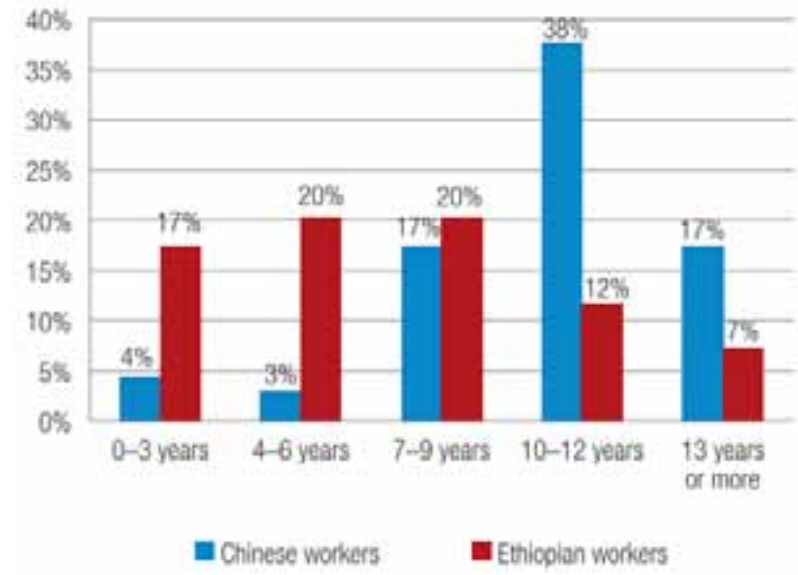

Source: World Bank Survey, Chinese FDI in Ethiopia (May 2012), World Bank (2012).

While there are several disadvantages of localized management structures in the eyes of Chinese enterprises, such as (i) the slow rhythm of local workers, (ii) difficulties in communicating with Chinese parent companies or (iii) difficulties of effectively managing Chinese employees, Chinese companies increasingly acknowledge the advantages of diverse and localized management in their African counterparts (Tang, 2010). Among others, local firms (i) have a better understanding of the local market, (ii) can handle local authorities and public relationships better and (iii) can better communicate with local employees.

By the end of 2011, almost 20,000 people from both China and Ethiopia were employed in Chinese enterprises operating in Ethiopia on a permanent basis (Table 6.17), even though it remains unclear how many of those permanent employees work in the manufacturing and construction sector, respectively. Between 2008 and 2011, employment increased by 19 percent. With 13,632 and 15,910 Ethiopian full-time workers for the two respective years, the share of Ethiopian workers employed by Chinese companies was equal to 88.3 percent in 2008 and 86.6 percent in 2011. Additionally, Chinese enterprises also hired 7,813 seasonal or temporary workers in 2011 . The quantitative and qualitative findings above suggest that the argument that Chinese companies mainly bring 
their own labour and create little employment opportunities for the local community does not hold in the Ethiopian context.

Table 6.17: Numbers of Ethiopian Employees in Chinese Invested Enterprises

\begin{tabular}{lcc}
\hline Employees & $\mathbf{2 0 0 8}$ & $\mathbf{2 0 1 1}$ \\
\hline Total Employees (Chinese and Ethiopian) & 15,435 & 18,368 \\
Ethiopian Employees & & \\
Total full-time and permanent & 13,632 & 15,910 \\
Average (by company) full-time and permanent & 368 & 257 \\
Total seasonal or temporary & $\mathrm{NA}$ & 7,813 \\
Number of firms reported & 37 & 61 \\
\hline Source: World Bank Survey, Chinese FDI in Ethiopia (May 2012), World Bank (2012).
\end{tabular}

\subsection{Theoretical Impact of China's Economic Embrace on Ethiopia}

A heated debate has emerged in academic literature as to whether China's entry into the development finance game can be viewed as a blessing or curse for recipient countries like Ethiopia and the African continent in general. The increased competition in the international donor community can certainly strengthen the bargaining power of African recipient governments. This is definitely true in the Ethiopian context. Even though the Ethiopian government already had strong confidence in its development agenda prior to China's entry into the foreign finance game - partly due to its long cultural history and its resistance to colonization -, the high bargaining power of the Ethiopian government has increased even further after strengthening Sino-Ethiopian ties. The Ethiopian government can play one donor off against the other (Anonymous 11, 2016; Anonymous 5, 2016; Anonymous 6, 2016; Anonymous $8,2016)$.

China's development assistance and investment in the Ethiopian economy can contribute positively to economic development, in the field of infrastructure development and the establishment of industrial economic zones. The theoretical and empirical literature highlights the positive economic consequences of road and railway investment in China and elsewhere, even though much of the past infrastructure investment in Africa has simply melted 


\section{CHAPTER 6}

away due to inadequate maintenance. ${ }^{150}$ Similarly, China's SEZs which acted as a centrepiece of China's industrial policy by combining liberalization and discriminatory policies have had a considerable positive impact on domestic economic growth and development (Aghion et al., 2015; Alder, Shao, \& Zilibotti, 2016). Holding all other factors constant, the introduction of a SEZ in a Chinese city led to a permanent increase in the city's GDP level of about 12 percent, and a permanent increase in the city's GDP per capita of about 9 percent. SEZs in China also contributed to physical capital accumulation, human capital investments and total factor productivity. Positive economic gains were not limited to the SEZ areas as neighbouring regions or cities witnessed significant, positive spillover effects of SEZs (Alder et al., 2016).

Perhaps not surprisingly, some of the respondents interviewed believe that Chinese FDI, rather than foreign aid, could therefore have the largest economic impact on the Ethiopian economy due to its long-term impact on the country (Anonymous 5, Anonymous 10, Anonymous 14), be it through market-based technology transfer within global value chains, knowledge spillover, integration into global production networks, employment creation and productivity gains (Geda \& Meskel, 2010). While the continent has once been marginalized from international trade and global capital flows, the injection of Chinese private capital, technology and entrepreneurial ideas can deepen trade and investment relationships between China and African countries and offer ample economic opportunities for countries like Ethiopia (Bräutigam \& Tang, 2014; Shen, 2013; World Bank, 2012; Zafar, 2007).

It is probably too early to predict whether China's business driven agricultural aid can contribute positively to rural development in Ethiopia. On the one hand, local food supply will most likely rise reducing the need for the Ethiopian government to use scarce foreign exchange to import grain, even though droughts are still prevalent in Ethiopia's highlands and lowlands, such as the 2015/2016 El Niño-induced drought. On the other hand, increased agribusiness could lead to a loss of access to land for families that crucially depend on it for

150 The positive economic effects are, among others, market access (Banerjee, Duflo, \& Qian, 2012; Baum-Snow, Brandt, Henderson, Turner, \& Zhang, 2017; Donaldson \& Hornbeck, 2016; Faber, 2014), agglomeration effects (Coughlin \& Segev, 2000), increased total factor productivity (Garcia-López, Holl, \& Viladecans-Marsal, 2015), increased exports (Yoshino, 2008) and inventory reduction (Han Li \& Li, 2013; Shirley \& Winston, 2004). 


\section{CHAPTER 6}

family food production. Potential health risks from agrochemicals and the loss of biodiversity are also potential negative consequences of increased agribusiness.

As mentioned above, some of the environmental, health and safety concerns with regard to Chinese aid, trade and investment projects in Ethiopia are well grounded. Several foreign companies and international financial institutions could not work together with Chinese companies due to their high social and environmental standards. As more and more international non-Chinese companies arrive in Ethiopia's manufacturing industries, however, little but gradual progress can be observed in terms of environmental, health and safety standards. On the demand-side, local workers push for better working conditions. At the time when Chinese companies almost exclusively operated in Ethiopia's industrial zones, Ethiopian workers accepted low social and environmental standards (Anonymous 10, 2016; Anonymous 5, 2016). Over the last few years, however, non-Chinese companies have also started to invest and operate in Ethiopia's SEZs. As a result, Ethiopian workers now have the option to work for other non-Chinese companies as well. In the meantime, the government has gradually implemented a stricter regulatory framework aimed at holding up higher social and environmental standards (Anonymous 14, 2016; Anonymous 5, 2016).

With the arrival of alternative sources of financing and policy models for recipient countries which do not attach political conditionality to the delivery of foreign aid, the argument that the international donor community should play an active role in the internal affairs and policies of their recipient countries has been increasingly challenged (Zimmermann \& Smith, 2011). There are fears that China's neglect of governance, democracy and human rights issues may be detrimental to the overall development efforts of recipient countries like Ethiopia, by delaying reforms that promote democratic accountability and transparency (Alden, 2005; Manning, 2006; Naim, 2007; Taylor, 2006, 2007a, 2013; Tull, 2006).

Thakur believes that due to China's policy of non-intervention in domestic political affairs 


\section{CHAPTER 6}

"there is a possibility that the incumbent regime in Ethiopia could use Chinese assistance to avoid changes in the direction of the rule of law, democratization, accountability and human rights. This has the potential of creating authoritarian stagnation, as opposed to authoritarian development." (Thakur, 2009, p. 18)

Some Western development organizations find it harder to push for good governance reforms due to China's increasing presence (Anonymous 13, 2016). Others, however, argue that China's impact on good governance reforms in Ethiopia is minimal and not a decisive factor since the Ethiopian government adopted the developmental state vision even before China's development finance rose substantially (Anonymous 11, 2016; Anonymous 12, 2016). When analysing Ethiopia's good governance trajectory, some scholars suggest that domestic policy reasons play a larger role than the increasing presence of China (see Hackenesch, 2015a, 2015b, among others).

\subsection{Ethiopia's Recent Economic and Political Development}

Using quantitative data mainly from the early 1990s until today, this section will critically discuss Ethiopia's current economic and political development. It will provide some tentative evidence as to whether China's increased involvement in Ethiopia can be regarded as a critical juncture with for Ethiopia's economic and political trajectory. It should be emphasized, however, that the analysis does not aim to establish a causal link between China's entry into the game of foreign finance and Ethiopia's recent economic and political developments. One can at best argue that there exists a correlation between the two. The analysis mainly covers the time period 1992-2012 and therefore coincides with the period when Meles Zenawi ruled Ethiopia as prime minister.

Contemporary Ethiopia is one of the fastest growing economies in the world (AfDB, 2013; Radelet, 2010). Over the last few years, Ethiopia recorded double digit GDP growth (Table 6.18). Between 2005 and 2012, the economy grew on average between 10.2 and 11.1 percent per year. GDP per capita grew on average by 7.1-8.6 percent each year during the same period. GDP growth was modest and GDP per capita growth was even negative during the transitional 
government period between 1991 and 1995. Both GDP and GDP per capita growth, however, increased significantly with Zenawi's tenure in power.

Table 6.18: Economic Growth Rates Under Three Regimes

\begin{tabular}{lcccc}
\hline & \multicolumn{2}{c}{$\begin{array}{c}\text { Average GDP } \\
\text { Growth Rate }\end{array}$} & \multicolumn{2}{c}{$\begin{array}{c}\text { Average GDP per } \\
\text { capita Growth Rate }\end{array}$} \\
\hline Pelassie regime (1950-1974) & 4.3 & 4.0 & 2.2 & 2.0 \\
Mengistu regime (1974-1991) & 1.2 & 0.9 & -1.4 & -0.7 \\
Zenawi regime (1991-2012) & 6.2 & 5.8 & 3.4 & 2.8 \\
Zenawi regime (1991-1995) & 1.4 & 1.7 & -1.9 & -1.3 \\
Zenawi regime (1995-2000) & 5.0 & 4.3 & 2.1 & 1.4 \\
Zenawi regime (2000-2005) & 6.5 & 5.6 & 3.9 & 2.6 \\
Zenawi regime (2005-2012) & 11.1 & 10.2 & 8.6 & 7.1 \\
Hailemariam regime (2012-2015) & 10.7 & 9.2 & 7.9 & 6.1 \\
\hline
\end{tabular}

t: Data was not available for the year 2015.

Source: Penn World Tables 8.1 (Feenstra et al., 2015), Maddison Historical Statistics from Groningen Growth and Development Centre (Bolt \& van Zanden, 2014).

When comparing the average economic growth rate between the three regimes, it is evident that the economic growth figures under the Zenawi regime outperform those under Selassie's and Mengistu's rule. The highly ambitious economic growth targets set in the GTP (11-15 percent) were not achieved by the Hailemarian regime, as average economic growth per year was 'only' 10.7 percent. This figure, however, still makes Ethiopia one of the fastest growing economies on the African continent. By virtue of its record of double digit GDP growth, Ethiopia has successfully joined the club of "emerging African countries" (Radelet, 2010).

In 2015, the Ethiopian government launched the Second Growth and Transformation Plan (GTP II) that runs until 2020. The positive achievements of the GTP I have provided the basis for the formulation of the GTP II. Two major pillars of the GTP II are the commercialization of agriculture, such as the establishment of industrial zones for aggro-processing industries, and enhancing the expansion and quality of infrastructure development, including power generation. At the same time, the government aims to build a globally competitive private sector even though certain sectors (like the banking sector) remain nationalized (Anonymous 10, 2016; Anonymous 5, 2016). The sustainable development goals (SDGs) are also contextualized in the GTP II 
"ensuring the sustainability of growth by fostering a stable macroeconomic framework and climate resilient green economy" (AfDB, 2016, p. iii). Similar to the GTP I, the DAG will also support the Ethiopian government with the implementation of the GTP II.

Figure 6.11: Evolution of Ethiopia's GDP per capita, 1950-2012

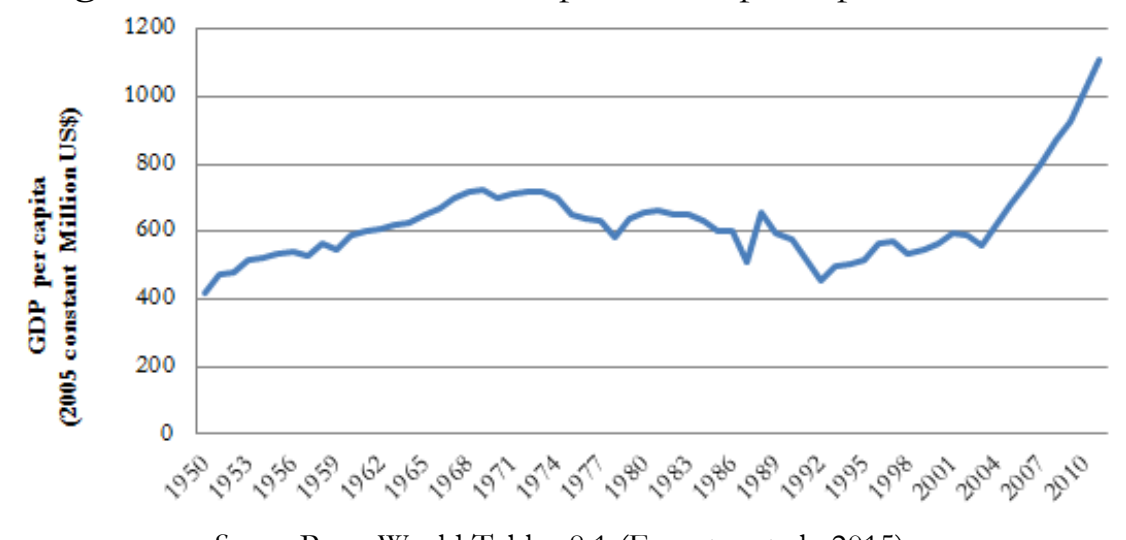

Source: Penn World Tables 8.1 (Feenstra et al., 2015).

Ethiopia's recent strong growth record contributed to a rise in real GDP per capita. In the early 1990s, Ethiopia's real GDP per capita stood at a level not much higher than in the mid-1950s. From the mid-2000s, however, real GDP per capita took off and almost doubled between 2005 and 2012 (Figure 6.11). Due to the use of outdated data and methods, measuring GDP for African countries often results in gross underestimates (Jerven, 2013a). Since "there is every reason to believe that the same is true for Ethiopia" (De Waal, 2013, p. 472), those figures must be interpreted as a lower benchmark estimate.

Table 6.19 shows the performance of Ethiopia's economic sector during the Zenawi era. By 2010, the agricultural sector value added still accounts for about 50 percent of Ethiopia's total GDP, while 75 percent of the Ethiopian population still worked in agriculture. In the same year, service value added stood at 41 percent and 16 percent of the population worked in the service sector. Compared to 1990, agriculture value added and employment in agriculture in relative terms fell considerably while the opposite is true for the service sector. The movement of workers out of agriculture started to accelerate and service activities expanded. In contrast to Sub-Saharan Africa as a whole, 
however, the Ethiopian economy is still largely agriculture based and less service based.

Table 6.19: Sectoral Data on Value Added and Employment in Ethiopia, 1990-2010

\begin{tabular}{|c|c|c|c|c|c|c|c|c|}
\hline \multirow{2}{*}{ ETHIOPIA } & \multicolumn{4}{|c|}{$\begin{array}{l}\text { Value added } \\
(\% \text { of GDP) }\end{array}$} & \multicolumn{4}{|c|}{$\begin{array}{c}\text { Employment } \\
\text { (\% of population) }\end{array}$} \\
\hline & 1990 & 2000 & 2005 & 2010 & 1990 & 2000 & 2005 & 2010 \\
\hline Agriculture & 64.1 & 49.7 & 47.4 & 48.0 & 89.4 & 84.9 & 83.3 & 75.1 \\
\hline Industry & 10.8 & 13.0 & 13.7 & 11.0 & 2.2 & 4.0 & 5.6 & 8.8 \\
\hline Manufacturing & 4.3 & 6.1 & 5.4 & 7.0 & 1.8 & 3.1 & 4.1 & 6.2 \\
\hline Services & 25.1 & 37.3 & 38.9 & 41.0 & 8.3 & 11.1 & 11.1 & 16.0 \\
\hline Total Economy & 100.0 & 100.0 & 100.0 & 100.0 & 100.0 & 100.0 & 100.0 & 100.0 \\
\hline \multicolumn{9}{|c|}{ SUB-SAHARAN AFRICA } \\
\hline & 1990 & 2000 & 2005 & 2010 & 1990 & 2000 & 2005 & 2010 \\
\hline Agriculture & 24.9 & 24.4 & 23.1 & 22.4 & 61.6 & 56.6 & 53.4 & 49.8 \\
\hline Industry & 32.6 & 28.8 & 28.0 & 27.8 & 14.3 & 13.0 & 13.0 & 13.4 \\
\hline Manufacturing & 14.0 & 11.9 & 11.1 & 10.1 & 8.9 & 8.3 & 8.1 & 8.3 \\
\hline Services & 42.6 & 46.8 & 48.9 & 49.8 & 24.1 & 30.5 & 33.6 & 36.9 \\
\hline Total Economy & 100.0 & 100.0 & 100.0 & 100.0 & 100.0 & 100.0 & 100.0 & 100.0 \\
\hline
\end{tabular}

Note: Figures are unweighted averages across 11 African countries. Numbers may not sum due to rounding. Relative productivity level is the ratio of the sector and total economy levels.

Source: Authors' own calculations using the Africa Sector Database (De Vries et al., 2015).

The data on the macroeconomics of Ethiopia's agriculture, however, hide the local political economy dynamics that presents a significant challenge to Ethiopia's long-run agricultural development. There is, for example, a large mismatch between the job description and professional qualifications of Ethiopian agriculture officials. An official who is running the agricultural department in a certain region is often not trained in the study of agriculture, but in the study of chemistry or sociology, for example. Those officials therefore have little expertise and are often not well respected by farmers (Anonymous 4, 2016). It is believed that officials often falsify reports by reporting fictitious numbers in order to get a promotion. The social well-being for a majority of farmers is adversely affected by mounting inflation. It is believed that the government's aim during the 1990s to significantly reduce Ethiopia's agricultural population from 85 percent has not succeeded as the agricultural population still hovers around 85 percent. While agricultural improvements are visible, they could be slightly exaggerated (Anonymous 4, 2016). 


\section{CHAPTER 6}

The data for manufacturing value added is particularly important as it is well established that industrialization has served as main engine of growth historically (Chenery \& Elkington, 1980; Fei \& Ranis, 1964; Kaldor, 1967; McMillan, Rodrik, \& Verduzco-Gallo, 2014; Syrquin, 1984; Szirmai, 2012a). While Sub-Saharan Africa witnessed a period of deindustrialization between 1990 and 2010 emphasized by the declining value added and employment shares in the industry sector (in particular manufacturing) - Ethiopia is one of the few African countries that succeeded in avoiding deindustrialization. While industry value added remained more or less constant between 1990 and 2010, manufacturing value added rose from 4.3 to 7.0 percent. Both industry and manufacturing employment shares also increased over the same time period.

In the same period employment rose more than threefold so labour productivity has been declining rapidly. With regard to Ethiopia, the data does not provide strong evidence for a development pattern reflecting the classic Lewis-type dual economy model with workers moving out of subsistence agriculture and being absorbed in modern manufacturing and services during the time period 19902010 (Lewis, 1954). The difficulty of using successful industrialization in catching-up is not limited to Ethiopia only, however, as manufacturing is generally becoming a more difficult route to growth than before 1990 for many developing countries (Szirmai \& Verspagen, 2015).

Manufacturing is still not a major source of employment in the Ethiopian economy. The increasing, albeit still weak, employment performance of Ethiopia's manufacturing sector can be attributed to simultaneous offsetting processes of job creation and job destruction (Shiferaw \& Bedi, 2013). Overall, however, Ethiopia is one of the few countries that had a significant acceleration of aggregate productivity growth after 2000, which is mainly accounted for by increasing productivity growth within sectors, but certainly not within the manufacturing sector (De Vries et al., 2015).

Ethiopia's recent economic growth and rising GDP per capita levels are not a direct indication of poverty reduction, Meles Zenawi's overarching goal during his tenure in office. While growth in per capita GDP can be a powerful force in reducing poverty it is far from certain whether growth has benefitted the poor. Growth in per capita GDP was only inclusive if, among others, poverty declined significantly during the same period. 


\section{CHAPTER 6}

The empirical evidence presented in this study suggests that the Ethiopian government made consistent progress with regard to monetary poverty reduction between 1992 and 2011. Since 1992, the poverty rate in Ethiopia has fallen gradually and substantially (Figure 6.12). At an aggregate level, poverty reduction in Ethiopia mainly took place from 2000 onwards. In the 1990s, Ethiopia's poverty rate was 10 to 30 percentage points higher than the overall poverty rate in Sub-Saharan Africa. By 2011, Ethiopia's poverty rate stood at 20 percent and lies below Sub-Saharan Africa's poverty rate.

Figure 6.12: Poverty Reduction in Ethiopia, 1990-2011

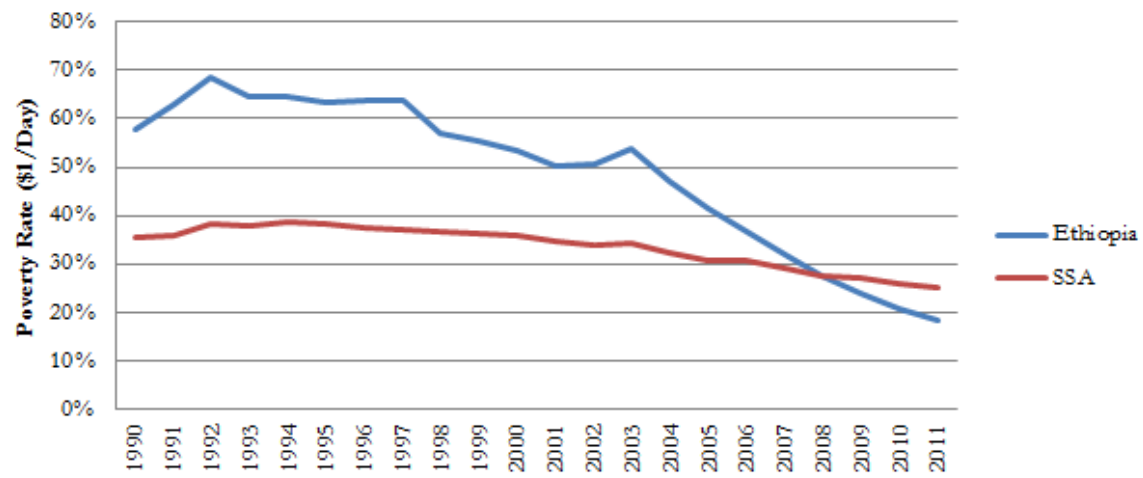

Source: Author's own calculations based on survey data from Pinkovskiy and Sala-i-Martin (2014).

Figure 6.13: Poverty Reduction and Economic Growth in Ethiopia,1990-2011

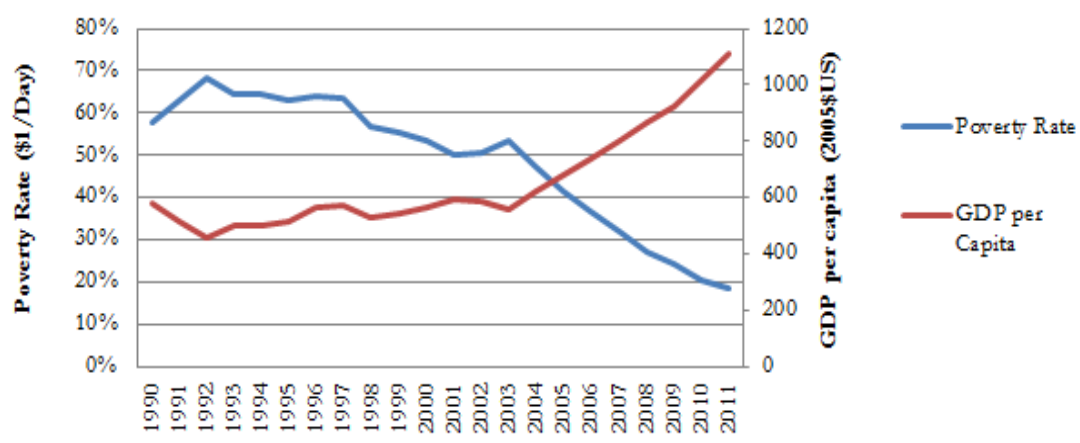

Source: Author's own calculations based on survey data from Pinkovskiy and Sala-i-Martin (2014) and GDP data from Penn World Tables 8.1 (Feenstra et al., 2015).

While African poverty has fallen significantly between 1990 and 2011, Ethiopian poverty fell much more rapidly. In the case of Ethiopia, the recent trend in poverty reduction is almost an exact mirror image of the evolution of GDP per capita (Figure 6.13). Those findings suggest that "the driving force that appears 
to explain the substantial reduction in poverty between 1992 and 2011 is economic growth" (Pinkovskiy \& Sala-i-Martin, 2014, p. 317).

The finding that Ethiopian poverty has fallen substantially does not apply exclusively to the standard $\$ 1$-a-day poverty measurement, but to a wide range of poverty lines. Table 6.20 shows the evolution of Ethiopia's poverty headcount ratio using the $\$ 1.25$ Purchasing Power Parity (PPP) poverty line and Ethiopia's national poverty line. When using the $\$ 1.25 \mathrm{PPP}$ poverty line as indicator, the proportion of Ethiopia's total population living in poverty was cut in half between 1996 and 2011. In a similar vein, the share of Ethiopians living below the national poverty line declined from 46 percent in 1996 to 30 percent in 2011. Poverty levels have fallen in both urban and rural areas, even though urban areas witnessed a stronger poverty reduction from the mid-2000s onwards.

There is evidence for a positive regional bias: Poverty levels differed remarkably across regions in 1996 with 54-56 percent of the population in Amhara, Tigray and the SNNP region living in poverty compared to 34.0 percent in Oromia or 30.3 percent in Addis Ababa. In 2011, poverty levels across those regions converged to a low poverty level of approximately 30 percent. With a generally lower poverty headcount ratio, the region of Harari is the prominent exception. The figures suggest that poverty reduction in Ethiopia was faster in those regions where poverty was substantially higher more than a decade ago (see also World Bank, 2015).151

Public investments in road quality and agricultural extension services brought significant welfare gains to rural communities in Ethiopia: "receiving at least one extension visit reduces headcount poverty by 9.8 percentage points and increases consumption growth by 7.1 percentage points. Access to all-weather roads reduces poverty by 6.9 percentage points and increases consumption growth by 16.3 percentage points" (Dercon, Gilligan, Hoddinott, \& Woldehanna, 2009, p. 1008). Despite the recent positive trends, a large number of the Ethiopian population remains persistently poor, particularly in rural areas. While the chronically poor tend to benefit from the same drivers of growth such as better road infrastructure or agricultural extension services, they face a considerable

\footnotetext{
151 Poverty convergence in Ethiopia contrasts with the lack of poverty convergence worldwide. At the global level, countries with higher initial poverty rates do not witness higher proportionate rates of poverty reduction (Ravallion, 2012).
} 


\section{CHAPTER 6}

growth handicap due to several time-invariant characteristics such as lack of physical assets, education and 'remoteness' based on the road distance to the nearest town (Dercon, Hoddinott, \& Woldehanna, 2012). Nevertheless, "out of a federal budget representing roughly a fifth of GDP, roughly two-thirds has been devoted to what the government calls 'poverty reduction programmes', which mainly target rural areas. (...) Few African governments, if any, have ever done so much for the peasantry" (Lefort, 2015, p. 367).

Table 6.20: Poverty Headcount Ratio in Ethiopia, 1996-2011

\begin{tabular}{|c|c|c|c|c|}
\hline & 1996 & 2000 & 2005 & 2011 \\
\hline $\begin{array}{l}\text { US\$ } 1.25 \text { PPP Poverty Line } \\
\text { (\% of total population) }\end{array}$ & 60.5 & 55.6 & 39.0 & 30.7 \\
\hline $\begin{array}{l}\text { National Poverty Line } \\
\text { (\% of adult population) }\end{array}$ & 45.5 & 44.2 & 38.7 & 29.6 \\
\hline \multicolumn{5}{|l|}{ By area } \\
\hline Urban & 33.2 & 36.9 & 35.1 & 25.7 \\
\hline Rural & 47.6 & 45.4 & 39.3 & 30.4 \\
\hline \multicolumn{5}{|l|}{$\underline{\text { By region }}$} \\
\hline Addis Ababa & 30.2 & 36.1 & 32.5 & 28.1 \\
\hline Afar & 33.1 & 56.0 & 36.6 & 36.1 \\
\hline Amhara & 54.3 & 41.8 & 40.1 & 30.5 \\
\hline Benishangul-Gumuz & 46.8 & 54.0 & 44.5 & 28.9 \\
\hline Dire Dawa & 29.4 & 33.1 & 35.1 & 28.3 \\
\hline Gambela & 34.2 & 50.5 & & 32.0 \\
\hline Harari & 22.5 & 25.8 & 27.0 & 11.1 \\
\hline Oromia & 34.0 & 39.9 & 37.0 & 28.7 \\
\hline SNNP & 55.9 & 50.9 & 38.2 & 29.6 \\
\hline Somali & 30.9 & 37.9 & 41.9 & 32.8 \\
\hline Tigray & 56.0 & 61.4 & 48.5 & 31.8 \\
\hline \multicolumn{5}{|c|}{$\begin{array}{l}\text { Note: The national absolute poverty line is set at } 3781 \text { Birr per adult equivalent } \\
\text { per year in } 2011 \text { prices. } 3781 \text { Birr in } 2011 \text { prices is equivalent to } 1.25 \text { USD PPP } \\
\text { using the } 2005 \text { International Comparison Project. } \\
\text { Source: World Bank (2015) using Household Income, Consumption and } \\
\text { Expenditure Survey for the years 1996, 2000, 2005, } 2011 \text { and Povcalnet (June } \\
\text { 2014). }\end{array}$} \\
\hline
\end{tabular}

Significant developments have also been made in the education and health sector (Table 6.21). There is one general pattern across all health indicators when comparing Ethiopia with Sub-Saharan Africa as a whole: the Ethiopian health performance indicators improved by a lot more if compared to the health performance indicators for Sub-Saharan Africa as a whole. In 1992, life 


\section{CHAPTER 6}

expectancy in Ethiopia was lower than in Sub-Saharan Africa; lifetime risk of maternal death and mortality rates in Ethiopia were considerably higher than in Sub-Saharan Africa. By 2012, Ethiopia's life expectancy was higher and both lifetime risk at maternal death and mortality rate were lower than the SubSaharan African average. It is only with regard to health expenditure where Ethiopia falls short of the Sub-Saharan African average. The health expenditure indicator must however be treated with caution as higher health expenditures do not necessarily lead to better health outcomes (Deaton, 2013).

Table 6.21: Education and Health Indicators in Ethiopia, 1992-2012

\begin{tabular}{|c|c|c|c|c|c|c|}
\hline \multirow[t]{2}{*}{ Health and Education Indicators } & \multicolumn{3}{|c|}{ Ethiopia } & \multicolumn{3}{|c|}{$\begin{array}{c}\text { Sub-Saharan } \\
\text { Africa }\end{array}$} \\
\hline & 1992 & & 2012 & 1992 & & 2012 \\
\hline \multicolumn{7}{|l|}{ Health } \\
\hline Life expectancy at birth, total (years) & 47.91 & & 62.79 & 49.91 & & 57.55 \\
\hline Lifetime risk of maternal death $(\%)$ & 8.06 & & 2.11 & 5.88 & & 3.06 \\
\hline Mortality rate, infant (per 1,000 live births) & 116.40 & & 46.20 & 106.89 & & 61.54 \\
\hline Mortality rate, under-5 (per 1,000) & 195.00 & & 67.70 & 177.95 & & 93.02 \\
\hline Health expenditure per capita (current US\$) & 4.03 & $\mathrm{a}$ & 22.26 & 38.09 & a & 96.40 \\
\hline Health expenditure per capita, PPP (2011 intern. \$) & 12.48 & a & 60.69 & 86.34 & a & 185.09 \\
\hline \multicolumn{7}{|l|}{ Education } \\
\hline Adjusted savings: education expenditure ( $\%$ of GNI) & 1.95 & & 2.90 & 4.68 & & 3.71 \\
\hline Gross enrolment ratio, primary, both sexes (\%) & 25.28 & & 94.78 & 73.43 & & 97.73 \\
\hline Net enrolment ratio, primary, both sexes (\%) & 19.15 & d & 78.92 & 54.11 & & 76.59 \\
\hline Gross enrolment ratio, secondary, both sexes (\%) & 12.16 & & 36.23 & 23.53 & & 41.79 \\
\hline Gross enrolment ratio, secondary, both sexes (\%) & 0.62 & d & 8.14 & 3.73 & & 8.31 \\
\hline $\begin{array}{l}\text { Pupil-teacher ratio in primary education } \\
\text { (headcount basis) }\end{array}$ & 30.17 & & 53.75 & 37.05 & & 42.60 \\
\hline $\begin{array}{l}\text { Pupil-teacher ratio in secondary education } \\
\text { (headcount basis) }\end{array}$ & 33.01 & & 38.78 & 24.40 & & 25.70 \\
\hline Primary to secondary general education transition rate & 81.98 & $\mathrm{~b}$ & 98.35 & 64.33 & & 78.56 \\
\hline Survival rate to Grade 5 of primary education & 24.66 & $\mathrm{~b}$ & 44.12 & c & & \\
\hline
\end{tabular}

a: refers to data from 1995. b: refers to data from 1994. c: refers to data from 2011; ${ }^{\text {d: }}$ refers to data from 1994.

Source: World Bank Development Indicators; Millennium Development Goals Indicators.

With regard to education we observe that the majority of Ethiopia's education performance indicators in the early 1990s were already close to or well above Sub-Saharan African average, with education expenditure as a percentage of gross national income (GNI) being an exception. But the potential shortcomings of this indicator are very similar to the aforementioned health expenditure indicator. Ethiopia's gross enrolment rates for primary, secondary and tertiary 


\section{CHAPTER 6}

education have risen over the last 20 years and converge to the Sub-Saharan African average. The net enrolment ratio data is only available for primary education but the data confirms the trend observed for gross enrolment rates. Ethiopia's pupil-teacher ratio in primary education in 1992 was lower than the Sub-Saharan African average but surpassed it over time. Ethiopia's pupil-teacher ratio in secondary education already outperformed the Sub-Saharan African average in 1992. Twenty years later, the gap has widened even further. The same is true for the transition rate between primary and secondary general education which measures the share of children enrolled in the first grade of primary school who eventually reach the fifth grade.

Compared to the health and education sector, Ethiopia's infrastructure still lags behind the Sub-Saharan African average in many sub-sectors even though considerable progress has been made (Table 6.22). The fact that access to electricity is higher among the urban than the rural population can be verified for both Ethiopia and Sub-Saharan Africa. The urban-rural gap in electricity access, however, is more pronounced for Ethiopia. The same is true for the percent of population with access to improved drinking water sources. ${ }^{152}$ In terms of air transport and communication infrastructure, such as telephone and mobile cellular subscriptions or internet usage, Ethiopia's economy witnessed gradual improvements between 1992 and 2012 but the same is true for SubSaharan Africa as a whole.

All in all, the African statistical tragedy notwithstanding (Devarajan, 2013; Jerven, 2013a, 2013b), these findings provide further evidence for a moderate but gradual socio-economic transformation in Ethiopia. The unprecedented level of economic expansion, however, went hand in hand with a new politics of authoritarianism as the next few paragraphs will show.

\footnotetext{
152 Improved drinking water sources include piped water on premises (piped household water connection located inside the user's dwelling, plot or yard), and other improved drinking water sources (public taps or standpipes, tube wells or boreholes, protected dug wells, protected springs, and rainwater collection).
} 
Table 6.22: Infrastructure Indicators in Ethiopia, 1992-2012

Infrastructure Indicators

\begin{tabular}{|c|c|c|c|c|}
\hline & 1992 & 2012 & 1992 & 2012 \\
\hline Access to electricity ( $\%$ of population) & 12.70 a & 26.56 & 26.06 a & 35.31 \\
\hline Access to electricity, urban ( $\%$ of urban population) & 83.85 a & 100.00 & 60.28 a & 71.61 \\
\hline Access to electricity, rural ( $\%$ of rural population) & 0.40 a & 7.55 & 9.73 a & 15.27 \\
\hline Electric power consumption (kWh per capita) & 21.65 & 57.43 & 504.42 & 511.87 \\
\hline Air transport, passengers carried (in millions) & 0.76 & 5.00 & 13.51 & 45.409 \\
\hline Air transport, freight (million ton-km) & 94.40 & 703.64 & 971.90 & 2559.17 \\
\hline Fixed telephone subscriptions (per 100 people) & 0.25 & 0.87 & 1.01 & 1.31 \\
\hline Mobile cellular subscriptions (per 100 people) & 0.00 & 22.37 & $<0.01$ & 59.72 \\
\hline Internet users (per 100 people) & $<0.01 \quad$ b & 1.48 & $0.07 \mathrm{~b}$ & 14.57 \\
\hline $\begin{array}{l}\text { Improved water source } \\
(\% \text { of population with access) }\end{array}$ & 13.60 & 51.60 & 48.15 & 64.96 \\
\hline $\begin{array}{l}\text { Improved water source, urban } \\
\text { ( } \% \text { of urban population with access) }\end{array}$ & 83.80 & 91.90 & 83.13 & 85.69 \\
\hline $\begin{array}{l}\text { Improved water source, rural } \\
\text { ( } \% \text { of rural population with access) }\end{array}$ & 3.00 & 42.70 & 34.89 & 53.20 \\
\hline
\end{tabular}

In the early 1990s, press freedom in Ethiopia was among the lowest in Africa and worldwide (Figure 6.14). Ethiopia's press freedom index was significantly lower than the African and sub-Saharan African average. In the early and mid1990s, the government allowed a more independent, diverse and critical media to develop. By that time,

Compared to the developed world, however, Ethiopia's level of press freedom was still significantly lower. Since the late 1990s, press freedom in Ethiopia gradually declined and fell below the (Sub-Saharan) African average. This pattern stands in stark contrast to the evolution of press freedom in Sub-Saharan Africa (and Africa as a whole) where the level of press freedom has been more or less 
at a constant - albeit very low - level throughout the entire period. According to Gagliardone (2014), the Ethiopian government has developed "one of the most restrictive systems for the regulation of new media in Africa” (p. 279). On the one hand, the government has increasingly tried to prevent opposition movements from using Internet and mobile phones to challenge the current regime. On the other hand, however, the strengthening Sino-African ties have played an important role in the government's strategy to use media channels and communication technologies for its state- and nation-building project (Gagliardone, 2014).

Figure 6.14: Press Freedom in Ethiopia, 1993-2013

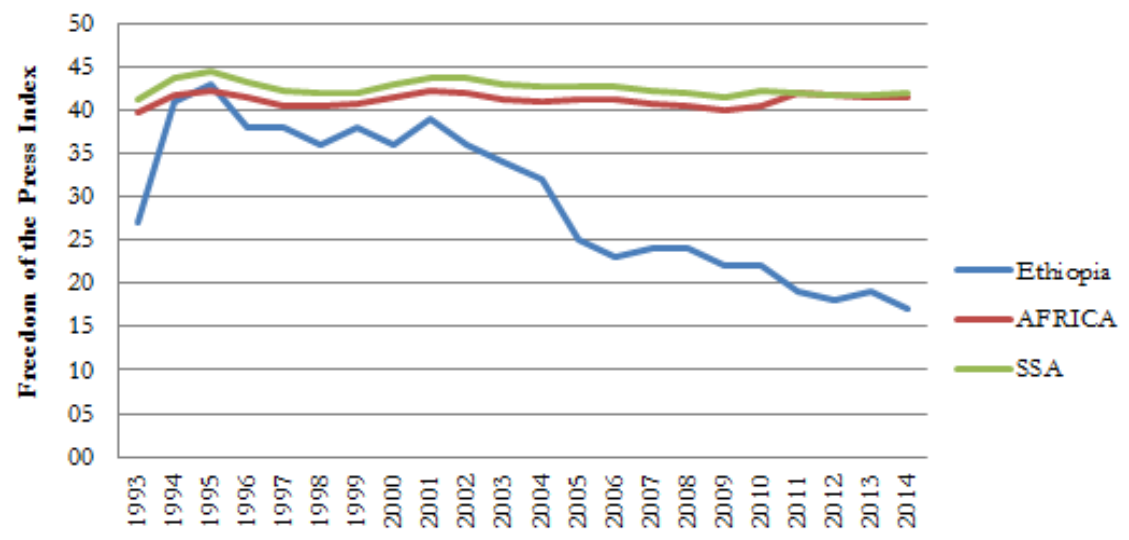

Note: The scale ranges from 0 (least free) to 100 (most free).

Source: Freedom House (2015).

Figure 6.15 shows the evolution of six key dimensions of good governance in Ethiopia. The six indicators measure three aspects of governance (Kaufmann, Kraay, \& Mastruzzi, 2010): (i) voice and accountability and political stability/absence of violence measure the process by which governments are selected, monitored and replaced; (ii) government effectiveness and regulatory quality measure the capacity of the government to formulate and implement sound policies in an effective way; (iii) rule of law and control of corruption measure the respect of citizens and the state for the institutions that govern economic and social interactions among them. Since the six good governance indicators are highly correlated with each other, we expect them to follow a similar trend. The empirical evidence with regard to Ethiopia, however, suggests something different. Deteriorations on certain good governance dimensions went hand in hand with significant improvements on other good governance dimensions. 
Over the entire period 1996-2012, voice and accountability as well as political stability/non-violence fell considerably. All the other four good governance indicators, however, remained either roughly the same or even went up. Rule of law and regulatory quality steadily improved, albeit by a small margin. Control of corruption improved if we use the year 1996 as benchmark. If we use the year 2000 as benchmark, however, corruption control remained constant. In comparison to the African average corruption control in Ethiopia was slightly better in 2012 while the opposite was true in 1996. The most remarkable gains, however, have been made in the sphere of government effectiveness. The quality of civil and public services and its independence from political pressure, as well as the quality of policy formulation and implementation, and the credibility of the government's commitment to such policies improved gradually.

Figure 6.15: World Governance ratings for Ethiopia, 1996-2012

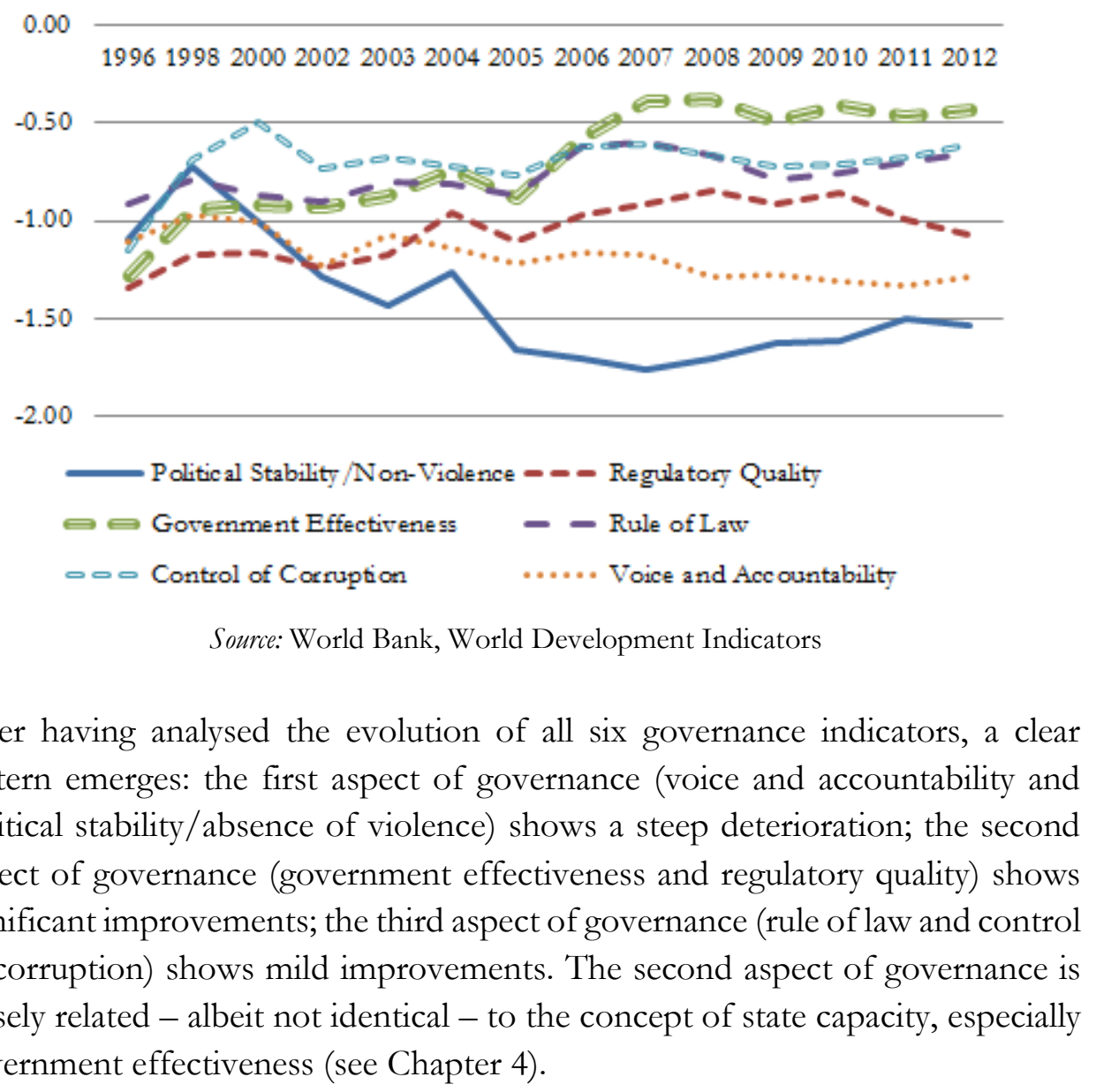


As already discussed in Chapter 4, one major proxy for state capacity is fiscal capacity. Since the early 1990s, Ethiopia's fiscal capacity became considerably stronger (Figure 6.16). While tax revenue as a percentage of GDP was below 6 percent in 1992, fiscal capacity increased by a factor of two over time. In 2013, tax revenue as a percentage of GDP amounted to more than 12 percent. Recent findings by Mascagni (2016b) suggest that there exists a strong positive relationship between aid and fiscal taxation in Ethiopia, largely due to both policy advice and technical assistance rather than conditionality.

Figure 6.16: Fiscal State Capacity in Ethiopia, 1990-2013

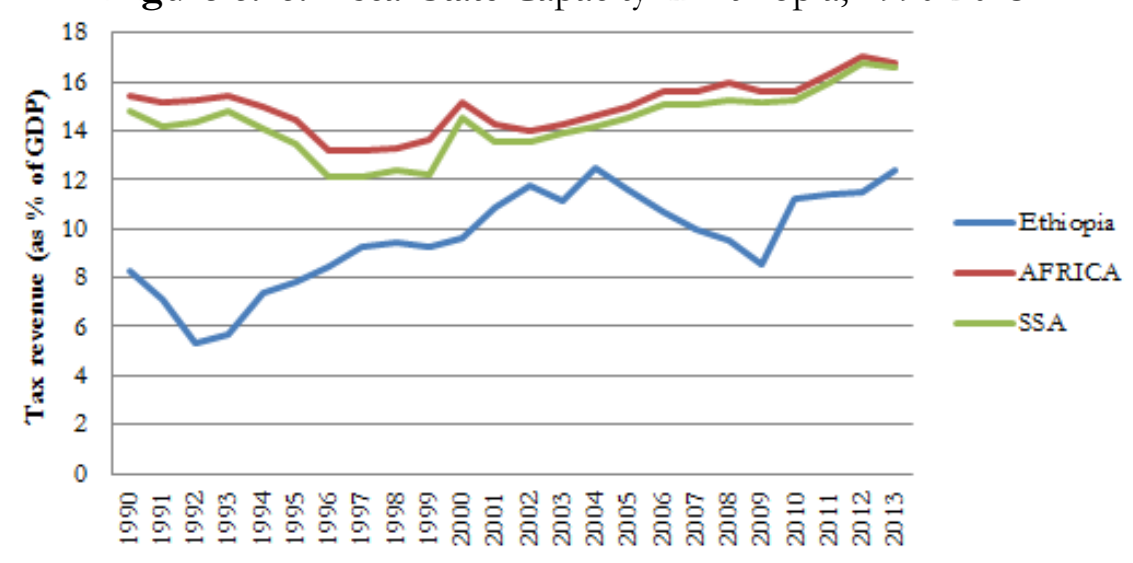

Source: IMF Database. World Revenue Longitudinal Data (2015).

Even though the level of Ethiopia's fiscal capacity is still significantly below the (Sub-Saharan) African average, the case at hand shows that

"under certain circumstances, including most notably a strong political
commitment and alignment of objectives, the establishment of
collaborative relations with development partners can be an important
catalyst for tax revenue mobilization." (Mascagni, 2016b, p. 12)

Ethiopia's bureaucratic quality significantly improved as well between 1990 and 2012 (Figure 6.17). In contrast to fiscal capacity, however, Ethiopia's bureaucratic quality has been slightly higher than the African average since the late 2000s. According to Fisher and Anderson (2015), the improvement of Ethiopia's bureaucratic and administrative state structures can partly be linked to foreign aid efforts. 


\section{CHAPTER 6}

“Overall, the increased focus on budget support in donors' relations with these regimes has greatly enhanced the ability of African governments to extend and reinforce state authority domestically. This has been realized directly in the augmenting of civilian security structures and bureaucracies." (Fisher \& Anderson, 2015, p. 130-140)

Figure 6.17: Bureaucratic State Capacity in Ethiopia, 1990-2012

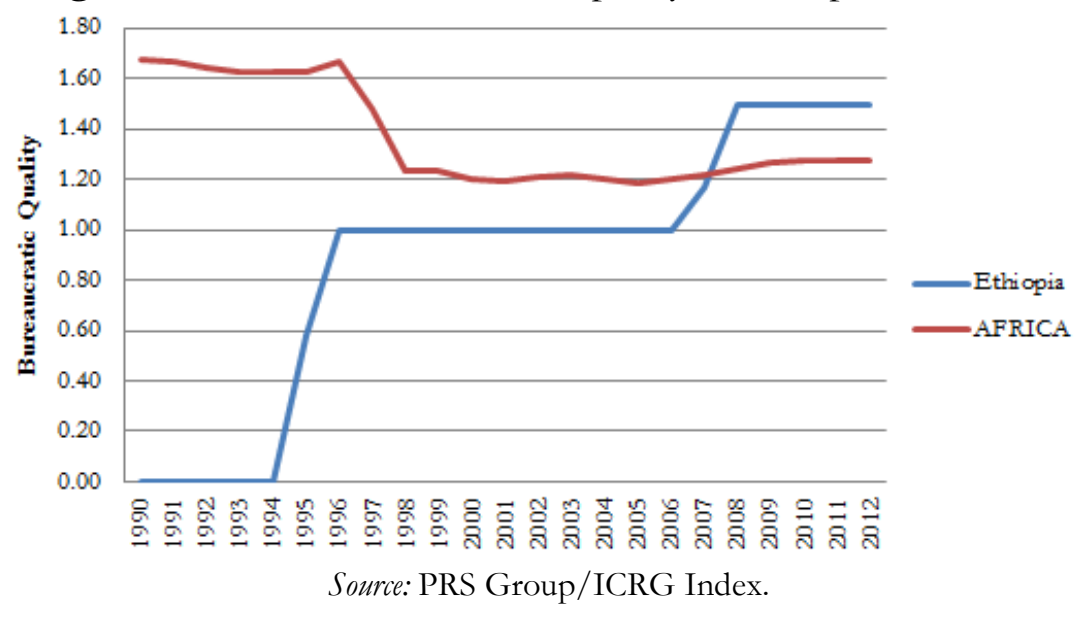

The empirical findings presented in Chapter 4 suggest that it is not foreign aid per se but rather Ethiopia's high bureaucratic tradition and high level of precolonial political centralisation that is primarily responsible for the recent improvements in bureaucratic state capacity (see Chapter 4). Merging the findings by Fisher and Anderson (2015) with those presented in Chapter 4, foreign aid has played a positive role in Ethiopia's improved bureaucratic and administrative state structures for two reasons: First, Ethiopia is a prime example of high precolonial centralisation with a long history of centralised rule. Second, the government emphasizes the coherence of development finance with its own policy framework.

Figure 6.18 shows the evolution of democracy in Ethiopia between 1990 and 2013. The figure shows four different democracy scores developed by the Varieties of Democracy Project (V-Dem): an index of (i) electoral democracy, 
(ii) liberal democracy, (iii) participatory democracy and (iv) egalitarian democracy. ${ }^{153}$ The four indices are strongly positively correlated with each other.

Figure 6.18: The Evolution of Democracy in Ethiopia, 1946-2013

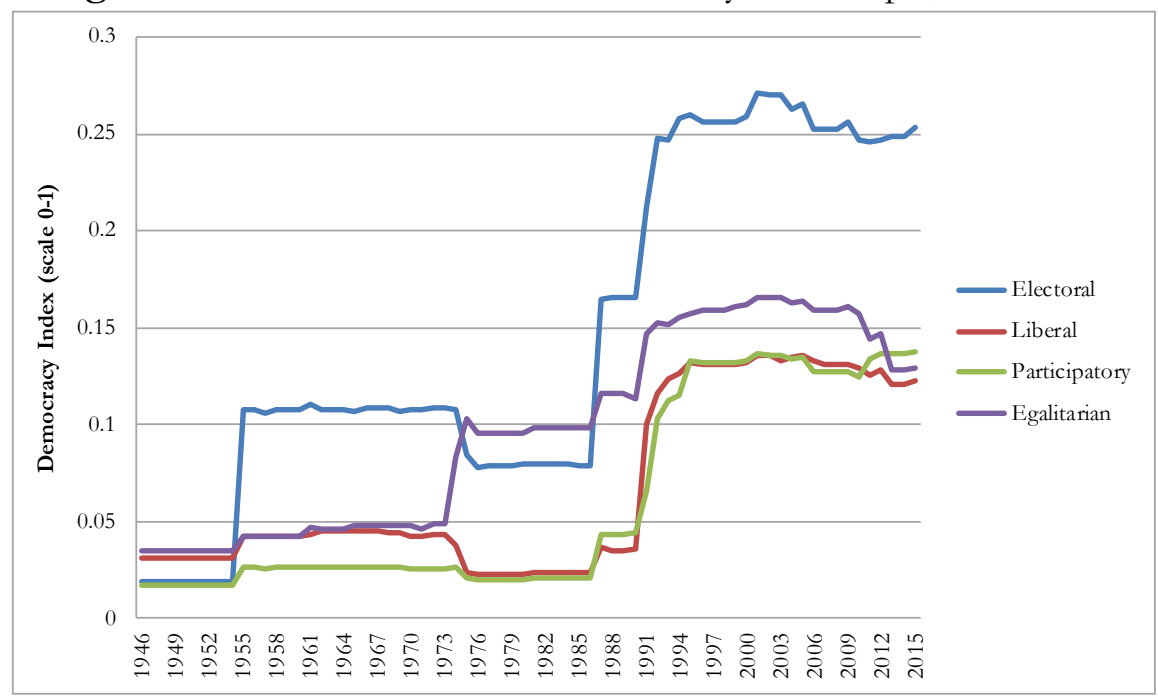

Note: The indices range from 0 (least democratic) to 1 (most democratic).

Source: Coppedge, Lindberg, Skaaning and Teorell (2016), Sigman and Lindberg (2015) and Teorell, Coppedge, Skaaning and Lindberg (2016).

Between 1990 and 2005, the Ethiopia government made a significant move towards democratization in all four dimensions displayed in the graph (electoral, liberal, participatory and egalitarian). The democratic transition, however, suffered a major setback in the mid-2000s. Following the 2005 national elections the country's democratization indices dropped and did not rebound significantly thereafter. The quantitative findings presented in Figure 6.18 therefore confirm the notion of a return of authoritarian politics discussed in the qualitative analysis above.

Figure 6.19 depicts the evolution of democracy in Africa. While the continent has made substantial gains with regard to democratic development since 1990, the significant advances in democratization have stagnated since the late 2000s. The data presented in Figure 6.20, however, clearly shows that the

\footnotetext{
${ }^{153}$ For more information on the electoral, liberal, participatory and egalitarian democracy index, see Coppedge, Lindberg, Skaaning and Teorell (2016), Sigman and Lindberg (2015) and Teorell, Coppedge, Skaaning and Lindberg (2016).
} 
(un)democratic developments in Ethiopia are not simply a reflection of a broader trend in Africa.

Figure 6.19: Africa Democracy Indices, 1900-2012

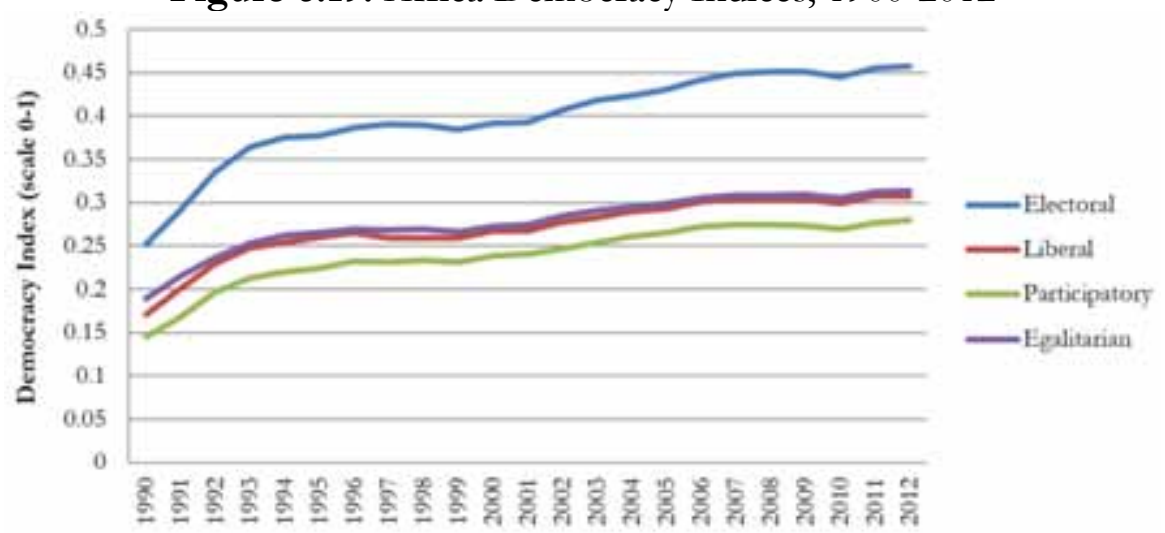

Sources: V-DEM: Coppedge, Lindberg, Skaaning and Teorell (2016); Sigman and Lindberg (2015); Teorell, Coppedge, Skaaning and Lindberg (2016)

Figure 6.20: Democratic Accountability in Ethiopia, 1990-2013

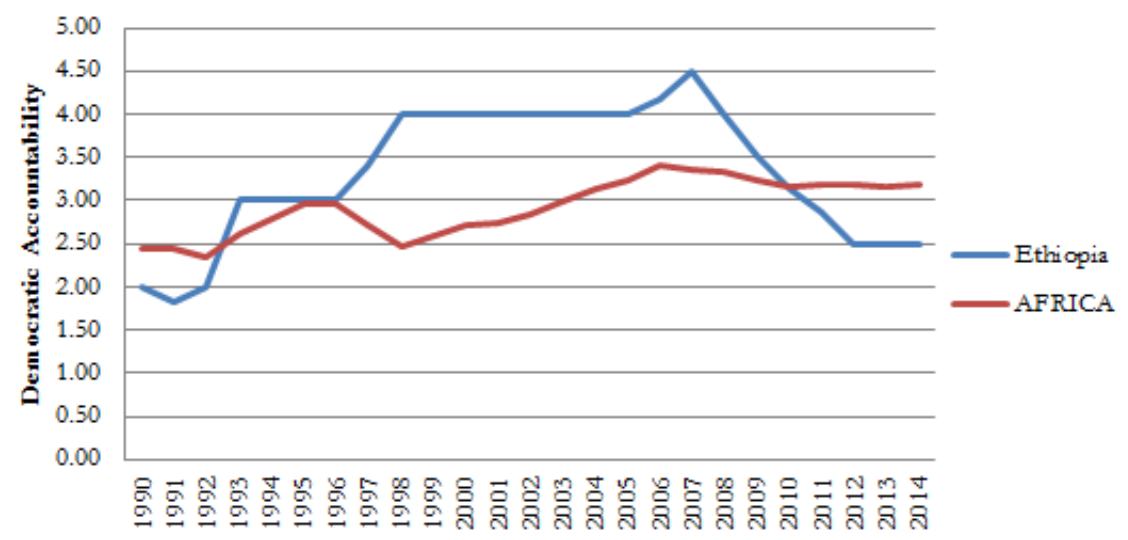

Source: PRS Group/ICRG Index.

The Ethiopian government found it increasingly difficult to reconcile democratic accountability with state survival. Data on democratic accountability comes from the PRS Group. The index measures "how responsive government is to its people, on the basis that the less responsive it is, the more likely it is that the government will fall, peacefully in a democratic society, but possibly violently in a non-democratic one." A higher score corresponds to a higher degree of responsiveness. Between 1990 and 2007, democratic accountability steadily improved and became significantly higher than the African average. From 2007, 


\section{CHAPTER 6}

onwards, and therefore shortly after the 2005 national elections results that politically challenged the regime survival, democratic accountability dropped significantly and fell below the African average.

Meles Zenawi's death in 2012 has left behind a power vacuum in Ethiopia leading to higher political instability and an increasing lack of political direction in the country (Anonymous 11, 2016). Under his rule, the EPRDF party was led by the EPRDF council and the Executive Committee. Zenawi who dominated the domestic policy arena was able to hold together the fractious ruling coalition. Until his death, he was in full control of the political system. After Hailemariam Desalegn assumed office, however, the de facto political power, has increasingly lain in the hands of the military with Prime Minister Hailemariam Desalegn being "dismissed by a range of officials as a 'regent" (Fisher \& Anderson, 2015, p. 138). Under Hailemariam Desalegn the Executive Committee is no longer united and the intra-party disputes are on the rise (Anonymous 11, 2016; Anonymous 12, 2016).

Lefort (2013) argues that the EPRDF regime was not successful in gaining true legitimacy among the Ethiopian population due to its strong ethnic bias. The return to authoritarian politics and the strong ethnic bias by the Tigrayan-led government has recently created political tensions and resentments:

"An outbreak of public protest unprecedented in its duration and spread since the ruling party took power in Ethiopia in 1991 is stirring a rare cocktail of discontent. (...) The protests have billowed into a much wider expression of outrage. People are complaining about land ownership, corruption, political repression and poverty." (The Economist, 2016)

The government's plan to expand the Ethiopian capital into Oromia in November 2015 has fuelled resentment among the Oromo people, the largest ethnic group in Ethiopia, fearing displacement. Additionally, both the Amhara and Oromo ethnic groups, 80 percent of Ethiopia's total population, accuse the government of ethnic discrimination and regional favouritism arguing that party loyalists, especially minority ethnic Tigrayans, occupy the key jobs in government and security forces and that public goods provision is substantially higher in Tigray if compared to the other regions in Ethiopia, including the Oromo and Amhara region (Anonymous 4, 2016; BBC, 2016; The Economist, 2016). In 


\section{CHAPTER 6}

addition, the most prestigious investment projects in Addis Ababa are run by the Tigrayan ruling class (Anonymous 11, 2016; Anonymous 9, 2016). A significant part of the Amhara and Oromo population therefore feel deprived as they perceive public goods provision (roads, electricity, education and health facilities) and economic progress more generally to be inferior compared to the Tigray region (Anonymous 4, 2016; Anonymous 9, 2016).

Between 6 and 8 August 2016, more than 300 people were killed in clashes between the Ethiopian police and anti-government protesters in the northwestern Ethiopian cities of Bahir Dar, Debre Tabor, Gayent and Gondar. Nationwide protests have started to spread to the capital Addis Ababa (BBC, 2016). The longstanding demands by the Oromo and the Amhara for greater equality and justice represent a challenge to Ethiopia's regional stability and political unity. The recent regime change (from Meles Zenawi to Hailemariam Desalegn) vividly shows that the weakness of an authoritarian regime becomes significantly stronger and an uprising of civil society concomitant with repression by the government becomes more prominent when a charismatic leader disappears.

Despite the return of authoritarian politics and increased ethnic (but also religious) tensions between the Oromo and Amhara population and the Tigrayan government, however, the EPRDF regime is not under immediate threat (Anonymous 7, 2016; Anonymous 11, 2016; Anonymous 12, 2016). The recent (i) policy successes in the fields of poverty reduction, social and economic development, and (ii) the EPRDF's much more pragmatic stance towards the international donor and investor community secures relentless, forthcoming economic assistance from both traditional donor countries like the United States and the United Kingdom as well as from emerging countries like China and India. Both factors have significantly contributed to the EPRDF's success in national democratic elections and in the international arena during the post-Cold War era. 


\subsection{Meles Zenawi's legacy - 'African Agency' in the Aid Game}

The legacy of Meles Zenawi is heavily debated. On the one hand, Lefort (2013) argues that Zenawi's totalitarian rule was primarily based on ethnic discrimination with favouritism towards his own Tigrayan ethnic group which significantly undermined ethnic-based federalism in Ethiopia. People from the Tigrayan minority ( 6 percent of the population) form the bedrock of the EPRDF:

"They therefore exert disproportionate influence over the executive and legislature. They also hold the key positions in the army, police, security services, public economic sector, and the para-public economic sector that is mostly in the hands of 'endowments' owned by the TPLF. Taken together, this suggests that Tigrayan leaders control around two-thirds of the country's economy, excluding traditional agriculture. This bias means that ethnic federalism has not translated into genuine power sharing between different communities" (Lefort, 2013, p. 463).

Prunier (2015b) believes that "lack of democracy, civil rights negligence, preference for numbers over quality in terms of training, a quantitative rather than qualitative approach to progress, civil service corruption, all these "Chinese" problems exist on a smaller, rougher scale in Ethiopia" (p. 432). Like many other African countries, some scholars suggest that Ethiopia remains a limited access society where the political system and the financial and economic resources fall in the hands of a narrow elite (Abbink, 2011; North et al., 2009). The EPRDF's general top-down approach is embedded in an authoritarian power structure limiting the space for alternative ideas and information to develop at the grassroot level. Ethiopia's developmental state model is regarded as part of the government's machinery to stay in power, maintain its hegemony and guarantee regime survival (Abbink, 2011; Lefort, 2013; Prunier, 2015):

"The leadership is increasingly cut off from the realities of the country. It is increasingly unable to take account of Ethiopia's extreme diversity, or to decentralize the process of adapting strategies to local conditions; it is thus unaware of the real impact of its policies" (Lefort, 2013, p. 465). 


\section{CHAPTER 6}

As shown above, several secondary sources and interviewees keep defaulting on an accusatory stance towards the government. However, it would be unwarranted to draw too strong conclusions based on the qualitative evidence from secondary sources and the opinions of informants mentioned above. The findings presented in this chapter were reliant on a small sample size of interviewees and a range of secondary sources while robust statistical evidence is lacking.

One the other hand, it is argued that the theory and practice under Meles Zenawi was deeply rooted in Ethiopian reality and its historical context. While Zenawi represented an authoritarian form of rule, he also represented the continuity of the Ethiopian state (Prunier, 2015). The EPRDF regime did "not measure their record or their policies against external standards; on the contrary, they evaluated outside perceptions against their own experience and logic" (De Waal, 2012, p. 150). Poverty alleviation was Zenawi's primary objective. Looking at Ethiopia's historical path dependence and modern day structural conditions, Zenawi found it increasingly difficult to reconcile economic development with democratization (Anonymous 11, 2016; De Waal, 2012, 2013). There was very little that prepared the country to undergo a successful democratic transition period.

"Democracy, in the Western sense of the word, was not a readily available option in Ethiopia in 1991 since none of its necessary underpinnings - a liberal bourgeoisie, a civil society, a semi-educated working class, an embryonic national political tradition - were even remotely operational. Obstacles were many and the tools to overcome them were all more or less authoritarian" (Prunier, 2015b, p. 423).

"Looking back over more than 2,000 years, whether the government was feudal, communist, or based on ethnic federalism, there has always been an effort to exercise strong control from the center, especially concerning security and political power (...) The vast majority of Ethiopians, 85 percent of whom are peasant farmers, seem to accept such a tradition. Hierarchy and obedience are important parts of Ethiopian culture" (Shinn, 2005, p. 106).

Zenawi's potential achievements and failures notwithstanding, this chapter argues that Ethiopia's strong resistance to accept input and policy recommendations from the international donor community (if those 


\section{CHAPTER 6}

recommendations went against the government's policy agenda) set the country apart from several other aid-dependent African recipient governments. This gives rise to crucial questions about African agency in managing the donorrecipient relationship. China's economic embrace of Ethiopia and Africa more generally is often presented as a relationship in which the Chinese government sets and dominates the agenda, with African governments and civil society portrayed as bystanders exercising little or no agency (Ramo, 2004). The same is true for the Western international donor community (Ayittey, 2005; Easterly, 2006). A growing literature, however, emphasises the importance of 'African agency'154 in the realm of international relations and the aid management process (Brown, 2012, 2013; Mohan \& Lampert, 2013).

This study has shown that Ethiopia's government under Meles Zenawi has exerted substantial agency in its international relations with the Western and emerging donor community (see also Gadzala, 2015). Ethiopia's strong state agency has enabled the government to negotiate successfully with powerful external actors, namely "maximizing resources to finance as much as possible, while giving up as little sovereignty in terms of control over the policy agenda as possible" (Furtado \& Smith, 2009, p. 144).

Ethiopia is being portrayed as a "unique case" in Africa by Western development organizations and international financial institutions (Anonymous 11, 2016; Anonymous 12, 2016; Anonymous 13, 2016; Anonymous 8, 2016). The Ethiopian government follows a clear development strategy and presents itself as a very determined and confident negotiating partner. Even though the negotiation process between the Ethiopian government and foreign investors is often tough, it can generally be described as very honest and respectful (Anonymous 5, 2016). ${ }^{155}$ The Ethiopian government is not resistant to foreign

154 Due to the large degree of heterogeneity on the continent, speaking of 'African agency' is
highly simplistic and can be hazardous. But as Brown (2012) argues, "there are at least three
senses in which speaking of 'Africa' as a whole might be justified in this context: as a collective
international actor; as a collection of states with (in the 'broadest of sweeps') a shared history;
and as a discursive presence, used by both Africans and outsiders, in international politics and
policy" (p. 1891).
155 Despite the often tedious negotiations with the Ethiopian government, both Western
development organizations and international financial institutions describe the negotiation
process with the Ethiopian government as very honest. Compared to negotiations with other
African nations, difficulties in cross-cultural negotiation encounters are less likely. It is very 


\section{CHAPTER 6}

influence but if international development assistance seems to threaten the government's ownership of its development agenda, the government will tend to resist the conditions attached to foreign aid (Anonymous 11, 2016; Anonymous 8, 2016). The government's bargaining strength derives from its own policy framework and not necessarily from China's increasing presence in Ethiopia. As one of the very few recipient countries in Africa, "the Ethiopian government brings development partners to its own playing field" (Anonymous 8, 2016).

In order to meet its 'developmental state' targets, the Ethiopian government successfully trades off several aid, investment and trade opportunities. It has adopted a two-way strategy: On the one hand, the government exploits international resources in projects where international governments, donors and investors are willing to provide foreign finance, such as the Addis Ababa Light Rail, the Addis Ababa Ring Road, or the numerous SEZs in the country. On the other hand, the government mobilizes domestic resources where there is no or little help from international sources of foreign finance, such as the Grand Renaissance Dam project (Anonymous 8, 2016). The example of Ethiopia shows that "African states do have opportunities to exert their agency, and guide negotiations in their favour, if they play their cards right" (Scoones, Cabral, \& Tugendhat, 2013, p. 13).

The Ethiopian government views Chinese development assistance and investment as highly compatible with its national development strategies. China's development assistance and investment has become increasingly attractive for the Ethiopian government mainly for two reasons. First, China's foreign aid does not come with political conditionality. As a result, China has become a preferred partner for many African autocratic leaders, including Meles Zenawi.

Taylor (2007) observes a "convergence between China's foreign policy and the continent's leaders” (p. 142). Following the East Asian developmental model, Ethiopia has adopted a system of developmental patrimonialism where an efficient system of governance with a strong formal rational-legal state apparatus

difficult to be misled by the Ethiopian government because "A 'yes' is 'yes'. A 'No' is a 'No"' (Anonymous 5, 2016). 


\section{CHAPTER 6}

coexists with an informal patrimonial system of close personal control by state and party elites (Kelsall, 2013). China's growing presence in Ethiopia enabled the Ethiopian government to harness neo-patromonialism for pro-poor economic growth and developmental ends.

Second, China's aid and investment addresses the large infrastructural and productivity gap which is largely in line with Zenawi's developmental state vision and the GTP issued in 2010. Large investments in infrastructure are critical and necessary (albeit not sufficient) for poverty reduction. With Beijing's upholding of the principle of non-intervention in domestic political affairs and Chinese development assistance actively supporting the developmental state model envisaged by the Ethiopian government, "many Ethiopians see China as a more appropriate development partner than Western countries because China is more responsive to the government's requests" (Shinn \& Eisenman, 2012, p. 275) despite potential adverse social and environmental effects of China's aid and investment activities at the national, regional and local level.

This case study also identifies four major reasons for Ethiopia's significant bargaining power in the international aid game and its consequent development success. First, with the Ethiopian government being fully aware of its particular position in regional geopolitics, the country has had a stronger bargaining power than any other African country in the aid negotiation processes.

The second reason is Meles Zenawi himself. Meles Zenawi was equally comfortable to promote South-South solidarity with party leaders from emerging economies such as China, as he was to work with Western governments as a special guest at G8 meetings, such as the Commission for Africa. Prunier (2015b) is convinced that Zenawi's "handling of global African issues put him in a kind of primus inter pares position vis-à-vis Africa and the rest of the world which was somehow reminiscent of Haile Selassie's" (p. 435). "The extraordinary openness, charm and intellectual brilliance" (Tadesse, 2015, p. 351) with which Zenawi was comfortable to approach both Western governments and party leaders from emerging donors secured him the goodwill of the international donor community.

Third, Ethiopia's strong ownership of its policy agenda and its, for African standards, relatively strong bureaucratic state capacity enabled the country to 


\section{CHAPTER 6}

play a proactive role in the aid negotiation process by channelling, coordinating and carefully controlling the aid policies of donors.

A fourth factor is the balancing act to cultivate good relationships with many partners and donor countries. The Ethiopian government takes a pragmatic stance in its aid relations. While the South-South cooperation plays an important role in Ethiopia's foreign policy, the government has tried to avoid any antagonism with the West since the Western donor community is still by far the largest provider of foreign aid to Ethiopia.

\subsection{Concluding Remarks}

Using Ethiopia as a case study, this chapter has examined the evolution of the international development finance game since the end of the Cold War accounting for the entry of China. The main lessons learnt are threefold.

First, this study has analysed how successive Ethiopian governments successfully pursued domestic policy strategies through the use of international development assistance. Ethiopia provides a good example for a recipient government with a large degree of control and ownership over its policy agenda. Ethiopia's strong resistance to accept input and policy recommendations - if they went against the government's policy agenda - from the international donor community sets the country apart from several other aid-dependent African recipient governments. Ethiopia has significantly diversified its international partners, including countries from the Global South such as China and India, thereby reducing its dependence on one major source of foreign finance. Ethiopia is no longer tied to the fortunes and goodwill of one particular donor or investor country.

Second, good governance as well as rule-of-law issues are no longer primary concerns for the Western donor community. The amount of DGA as a percentage of total aid allocated to Ethiopia by the DAC donors has been fairly low since the mid-2000s. A majority of Western donors, including the United States and the United Kingdom, decreased their DGA even further - in both absolute and relative terms - after the return of electoral authoritarianism in the late 2000s, with countries like Sweden being the prominent exception. 


\section{CHAPTER 6}

Third, China's entry into the development finance game and its policy of nonintervention in domestic political affairs has significantly increased the Ethiopian government's bargaining power in the aid negotiation process, even though the bargaining power of the Ethiopian government was already quite strong before China's increasing presence in the country. At the same time, Beijing's rising development assistance to and investment in Ethiopia partly fills the vacuum in the physical infrastructure and manufacturing sectors left by the Western donor community and private enterprises.

Based on the large theoretical literature about the potential impact of China's foreign aid and investment activities on African political and economic development, this chapter has evaluated recent economic developments in Ethiopia using descriptive statistics. While Ethiopia has made strong progress with regard to poverty reduction, education, health and economic development in general since the early 2000s, the decline in democratic accountability and the curtailing of press freedom provides evidence for a return to authoritarian politics

Some clear distinctions need to be made about good governance: while deteriorations are visible regarding voice and accountability and political stability since the mid-2000s, the government effectiveness and regulatory quality dimensions witnessed significant improvements since the mid-2000s. The good governance dimensions rule of law and control of corruption remained more or less unchanged. It remains, however, difficult to quantify the direct impact of both Chinese and Western development finance on recent political and economic developments in Ethiopia due to the lack of sophisticated econometric work on that subject matter and China's only very recent rising exposure to Ethiopia.

This chapter has argued that the Ethiopian government serves as a good example of how African recipient governments can exert substantial agency in their international relations with the Western and emerging donor community. In terms of development ideas, China's entry into the game of foreign finance has broken the Western donor cartel increasing the competition in the foreign finance market. Overall, the entry of China into the aid game represents vast opportunities, risks and challenges for Ethiopia. As time goes by, history will give its verdict. 


\section{CHAPTER 7}

\section{CHINA'S ENTRY INTO THE FOREIGN AID GAME AND ITS IMPLICATIONS FOR THE DONOR-RECIPIENT ELATIONSHIP - A GAME THEORETICAL APPROACH}

"Good governance can only come from inside. It cannot be imposed from outside. What the Chinese have done is explode that illusion. That doesn't in any way weaken the need for democracy and good governance in Africa. It does not in any way endanger the reforms of good governance and democracy in Africa. Because only those that were home grown ever had a chance of success." - Meles Zenawi, 2007

(1955-2012) $10^{\text {th }}$ Prime Minister of Ethiopia, 1995-2012

"Despite the extensive empirical and theoretical research into foreign aid, there remains little or no formal analysis of aid giving in a competitive donor environment." - Bruce Bueno De Mesquita, 2016 American Political scientist, Professor at New York University Senior Fellow at Stanford University's Hoover Institution 


\subsection{Introduction}

Until very recently, the majority of the non-DAC donors did not play a pivotal role in the international aid regime for two reasons: (i) most non-DAC donors mainly dealt with domestic political affairs rather than with international development cooperation and (ii) the strategic role of delivering development assistance considerably declined with the fall of the Iron Curtain (Kragelund, 2008). At the turn of the 21 st century, however, China, together with other countries from the Global South, significantly increased its aid and development projects in Africa to unprecedented levels.

The consequences of this transition are poorly understood. In particular, as noted by Bueno de Mesquita and Smith (2016) "despite the extensive empirical and theoretical research into foreign aid, there remains little or no formal analysis of aid giving in a competitive donor environment". In this chapter, I investigate the consequences of this shift to a more competitive donor environment, and find that it altered the balance of power between aid donors and recipients, with a decreasing emphasis on conditionality and good governance (reforms) as a consequence. I do this by developing an analytic narrative with the aim to explain the recent entry of China into the foreign aid game, with a simple game theory model complemented by a historical narrative for the country of Ethiopia. The game-theoretic model helps the author and reader to systematically think through the case of Ethiopia and the entry of China into the aid game, while the narrative part provides a detailed account of the context and the specific processes.

To be more specific about the framework developed in this chapter, the theoretical part models a recipient country's decision to accept aid from either just one, or two (competing), donors as a dynamic game of complete and perfect information. The traditional donor can offer foreign aid to the recipient government. The recipient government can either accept or reject the foreign offers made by the traditional donor. Foreign aid by the traditional donor is characterised by political conditionality in the form of good governance reforms.

The model predicts that, in the absence of a credible commitment to good governance reforms and conditional on countries accepting the initial proposal including good governance reforms, the donor has to offer more money in the 


\section{CHAPTER 7}

first stage to a recipient government that is more strongly affected (in terms of survival probability) by good governance reforms. However, if a strong credible commitment policy exists, the "outside option" for the recipient, i.e. the amount of aid and the utility it will receive if it rejects the aid offer from the donor, implies receiving no aid at all. The implication of the difference between the two scenarios, with and without donor commitment, is that commitment is a necessary condition for a complete withdrawal of the donor from a country.

The model is then extended in two ways. First, I will take into account that donors have different motivations for delivering aid money (Lancaster, 2007), and allow for the possibility that the traditional donor cares about gaining strategic influence in the recipient country. Consequently, aid allocations by the traditional strategic donor are at least partly driven by strategic motives. Second, I will account for the entry of a new (non-traditional) donor in order to model a competitive donor environment. In contrast to the traditional donor, the nontraditional donor does not attach any political conditionality to its aid.

This work can be placed in the context of Bates, Greif, Levi, Rosenthal and Weingast (1998, 2000), Rodrik (2015), Rubinstein (2012, 2017) and Shiller (2017) who emphasize the economic importance and relevance of powerful narratives. In a more narrow sense, the paper can be situated in the context of theory-based papers focusing on the impact of foreign aid. I review this literature in the section that follows, and then, in Section 7.3, provide a number of stylized facts that motivate the purpose and setup of theory development. The game-theoretical model is presented in Section 7.4, while Section 7.5 contains the narrative of Ethiopia. Section 7.6 concludes the chapter with a discussion of implications and a call for more research on related topics.

\subsection{Review of game theoretical literature}

During the Cold War, theoretical studies on donor-recipient relationships in foreign aid allocation included (i) recipient models that were based on the assumption that donors have purely humanitarian motives for providing aid and (ii) donor interest models that assumed that aid allocations are primarily driven by political, strategic and economic interests (Maizels \& Nissanke, 1984; McKinlay \& Little, 1977, 1978a, 1978b). With the end of the Cold War and the 


\section{CHAPTER 7}

demise of the Soviet Union as strategic competitor in the developing world (see Chapter 5), there has been a renewed interest in understanding and formalizing the motivations and effects of development assistance.

The seminal contribution by Boone (1996) triggered a wave of theoretical work into foreign aid. Most of the theoretical foreign aid literature models the donorrecipient relationship as a principal-agent relationship, whereby the principal the donor community - and the agent - the recipient government - have conflicting views about the volume, delivery mode and allocation of foreign aid (Azam \& Laffont, 2003; Killick, 1997; Svensson, 2000b, 2003). The donor country may be unfamiliar with the sociocultural context of the recipient government. Neither the principal nor the agent can fully observe the other player's strategy (Murshed \& Sen, 1995).

Some models attribute the ineffectiveness of foreign aid to incentive and knowledge problems of the recipient government (Azam \& Laffont, 2003; Bueno de Mesquita \& Smith, 2009; Murshed \& Sen, 1995). Recipient governments in developing countries often have an incentive to misappropriate foreign aid resources in a way that serves their own interests, such as maximizing their political survival (Ahmed, 2012; Bueno de Mesquita \& Smith, 2009, 2010). This commitment problem often goes hand in hand with a moral hazard problem surrounding foreign aid: To the extent that foreign aid allocation is based on poverty considerations, a recipient government may have little incentives to improve the welfare of the poor since it will result in more foreign aid granted by donors (Svensson, 2000b).

Several other studies have theoretically examined the effect of foreign aid on policy choice and private domestic investment (Adam \& O'Connell, 1999), rentseeking (Svensson, 2000a), corruption (Lahiri \& Raimondos-Møller, 2004), public goods provision (Bueno de Mesquita \& Smith, 2007), economic growth (Feeny \& McGillivray, 2009), democratization (Bermeo, 2016; Wright, 2009) and domestic fiscal capacity (Besley \& Persson, 2011).

Another strand of the political economy literature argues that the ineffectiveness of aid policies is deeply rooted in incentive and knowledge problems on the donor side (Cordella \& Dell'Ariccia, 2007; Lundborg, 1998; Svensson, 2000b, 2003; Torsvik, 2005; Villanger, 2006). In the 1990s, donor countries increasingly 
started to use political conditionalities to enhance the effectiveness of aid. The effectiveness of political conditionality, however, is severely weakened if geopolitical interests such as strengthening strategic alliances, economic interests such as promoting exports or budgetary motives such as maximizing aid budgets ${ }^{156}$ are primary motives for disbursing aid among bilateral and multilateral donor organizations (see Chapter 5). As a result, the donor country may lack a credible commitment to withholding foreign aid if the recipient government uses the aid money for non-developmental purposes (Azam \& Laffont, 2003). The aforementioned commitment problem by the donor country is one major explanation why the effectiveness of political conditionality is severely weakened (Killick, 1997; Svensson, 2000b).

Another reason why donor agencies find it difficult to enforce political conditionality is the budget-pressure problem. Donor agencies have a strong bias towards always allocating the aid funds regardless of the recipient government's political and economic performance as disbursing the committed aid money has become a key objective in itself (Svensson, 2003). The results by Svensson (2000b, 2003) suggest that the budget pressure budget can significantly be reduced if the donor country lets the recipient governments to compete for aid resources by linking aid disbursements to their relative political performance.

Villanger (2006) shows how private business interests can also diminish the strength of political conditionality. For instance, if foreign aid comes in the form of a construction project carried out by a company from the donor country, the company may lobby the donor agency for the implementation of the construction project. Withholding aid increases the risk of losing the new activity to a firm from another donor country. Finally, political conditionality is less effective when the number and heterogeneity of cooperating donors increases since the coordination and harmonization of aid efforts among the donor countries becomes more difficult (Bourguignon \& Platteau, 2015).

Most of these theoretical models, however, are not well equipped to explain the entry of an influential competing non-DAC donor into the international aid

\footnotetext{
156 According to public-choice theory, bureaucratic officials seek to lobby for maximizing the size of their budgets since their salary and prestige is positively correlated to higher budgets. For a general reference to the theory of bureaucratic interests, see Niskanen (1994). In the model, I do not necessarily assume this theory to hold but I allow for this possibility to be true.
} 


\section{CHAPTER 7}

arena. The theoretical literature that studies the aid negotiation process within a two donor-one recipient framework is surprisingly sparse (Bueno de Mesquita \& Smith, 2016; Bourguignon \& Platteau, 2015; Murshed \& Sen, 1995; Torsvik, 2005; Villanger, 2006). This chapter contributes to that sparse literature by developing a theoretical foreign aid model with rival aid donors, one traditional donor and one emerging (non-traditional) donor from the Global South.

\subsection{Stylized Facts}

This section presents a set of stylized empirical facts about development assistance and foreign finance to Africa more general and Ethiopia in particular. The reason why this chapter focuses on Africa is the following: the academic literature has predominantly focused on the domestic aspects of economic and political processes in the developing world (Bates, 2001; Remmer, 1995). However, in Sub-Saharan Africa the sheer magnitude of foreign aid flows makes the international aspects of political change important (Brown, 2005):

"[t]hough political change often has powerful domestic sources, the international component is particularly fundamental in Sub-Saharan Africa in large part due to the magnitude of foreign aid flows to African governments. Still, many authors minimise international influence and consider recent cases in Africa to be almost a purely endogenous affair. ${ }^{157}$ Nonetheless, when combined with domestic factors, the international dimension's explanatory strength is particularly pertinent to Africa." (Brown, 2005, p. 180)

Stylized fact 1: Foreign aid is given for starkly different purposes. However, poverty reduction and supporting democracy and governance are the two primary objectives for delivering foreign aid among Western donors.

The first stylized fact is linked to the changing nature of the international aid architecture at the end of the Cold War, as discussed in detail in Chapter 2. In the post-Cold War period, foreign aid policies became linked to political conditionality in the areas of democratic, judicial and human rights reform (Crawford, 1997; Riddell, 2007). The declining concern for fighting communism went hand in hand with a growing concern for promoting liberalism and

\footnotetext{
${ }^{157}$ See also, for example, Bates (2001), Remmer (1995), Widner (1994) and Young (1994).
} 


\section{CHAPTER 7}

democratization in both transition economies and developing countries (Boschini \& Olofsgård, 2007). ${ }^{158}$ The African continent was most severely affected by the change in the international aid architecture (Gibson, 2002; Olsen, 1998). Sub-Saharan African states were among the weakest in the world (Jackson \& Rosberg, 1982; Sandbrook, 1985). In 1996, the OECD-DAC developed a strategy aimed at reversing the trend of declining aid flows to the developing world by
"justifying the aid its members donated in terms of its impact on (an expanded notion of development, 'human development'. The DAC proposed recasting the aid relationship as a partnership between donors and recipient governments. Donors would provide more resources, improve the coordination of assistance in support of domestically owned development strategies, and achieve coherence between their aid policies and other policies which affect developing countries (trade, debt, arms sales, etc.). In return, recipient governments were expected to commit to poverty reduction objectives and accountable governance." (Fraser \& Whitfield, 2009, p. 77)

\section{Stylized fact 2: Western foreign aid is attached to political conditionality while Chinese foreign aid comes with no domestic policy conditions attached.}

Chinese aid funding is embedded into a wider foreign policy framework characterized by the non-interference in internal affairs and Beijing's upholding of political equality with recipient states (Huse \& Muyakwa, 2008; Wenping, 2007; Xue, 2014; Zhao, 2014). In contrast to the bulk of Western development assistance, Chinese aid is delivered with relatively little strings attached. In contrast to the political conditions imposed by the Western donor community, many non-DAC donors like China impose little or even no governance conditionality based on the principles of respect for national sovereignty and non-interference in domestic affairs. Much of Beijing's development assistance in Africa, however, is tied to (i) the purchase of Chinese goods and services or

\footnotetext{
158 Uvin (1993) provides two major reasons for the increasing popularity of political conditionality in the 1990s: first, the unpopularity of development assistance among the general public in high-income countries grew; second, the Western donor community felt increasingly tempted to dictate the ideological terms attached to foreign aid, as the competition for resources rose after former Eastern European countries became recipient countries of OECD development assistance as well.
} 
(ii) Chinese access to African natural and energy resources (see Chapters 2, 3 and 6).

Stylized fact 3: Most foreign aid to Africa (and the developing world in general) is provided by $D A C$ member countries. The absolute amount of Chinese foreign aid allocated to Africa is still smaller than the combined foreign aid provided by the major DAC donors (USA, United Kingdom, France, Germany), But Chinese foreign aid to Africa is rising rapidly.

Figure 7.1 shows that, after a period of donor fatigue in the 1990s, bilateral DAC-ODA disbursements to Africa rose significantly from the early 2000s onwards again. Non-DAC donors increased their development assistance to Africa since the early 2010s. While the absolute amount of their aid disbursements are still rather small if compared to those from the traditional DAC donors, they have risen almost exponentially over the last few years (see Chapter 2).

Figure 7.1: Bilateral ODA Disbursements to Africa, 1990-2014

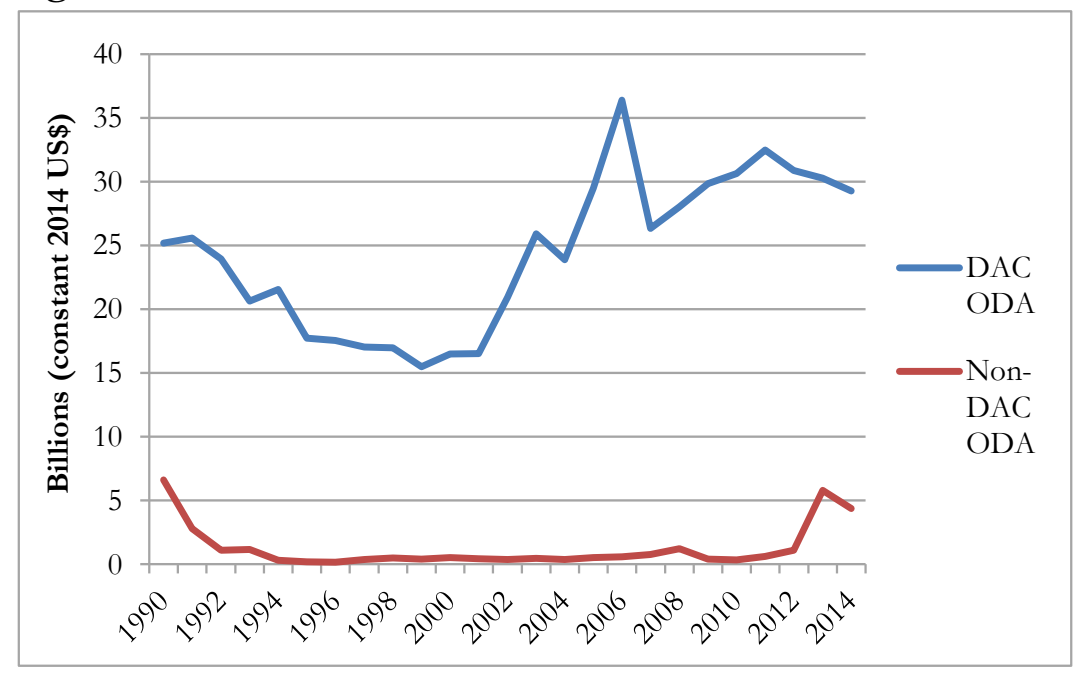

Source: OECD-DAC Database, http://stats.oecd.org

Table 7.1 portrays the long-run patterns and trends of both U.S. and Chinese foreign finance in Africa between 1990 and 2014. Comparing the volume of Chinese foreign aid that is comparable to official development assistance delivered by traditional DAC donors, we can draw two conclusions. First, China's foreign aid budget for Africa is still rather small when compared to the annual ODA disbursements by traditional DAC donors. Second, China's aid 
expenditures to Africa have increased rapidly and continuously since 1990 . China's foreign aid budget rose 23-fold between 1990 and 2012.

Table 7.1: U.S. and Chinese Foreign Finance to Africa, 1992 and 2012 (Current US\$ Billion)

\begin{tabular}{lccccc}
\hline Type of Foreign Finance & \multicolumn{2}{c}{1990} & & \multicolumn{2}{c}{2012} \\
\hline & USA & China & & USA & China \\
\cline { 2 - 3 } \cline { 5 - 6 } Foreign Aid (ODA-like) & 3.53 & 0.13 & & 9.67 & 2.99 \\
FDI & 3.65 & 0.05 & & 56.63 & 16.24 \\
Trade (two-way volume) & 21.01 & 1.70 & & 68.45 & 113.24 \\
\hline
\end{tabular}

Sources: OECC/DAC database, UNCTAD FDI/TNC Database; UN COMTRADE Database; MOFCOM (2009, 2011); Bräutigam (2009); Author's own calculations.

Stylized fact 4: Foreign aid makes up a larger part of Western foreign finance than it does for Chinese foreign finance. Chinese foreign aid acts as a signalling effect for African recipient countries. Beijing's foreign aid is coupled with investment and trade opportunities for both Chinese and African firms to participate in global markets.

Table 7.2 shows the evolution of Chinese official development finance to Africa between 2000 and 2013. The figures are based on Chinese AidData (Strange et al., 2013, 2017). The figures suggest that Chinese ODA only makes up a fraction of Chinese total development finance to Africa. Chinese total development finance rose significantly between 2000 and 2007. During the Great Financial Crisis, the budget was cut back significantly, but it has bounced back since 2010 .

As mentioned in Chapters 2 and 6, Beijing's foreign aid is coupled with investment and trade opportunities for both Chinese and African firms to participate in global markets. While Chinese FDI in Africa stood at US\$ 50 million in 1990, it rose to more than US\$ 16 billion in 2012, making it the biggest investor from the Global South in Africa. While China's FDI still falls short of U.S. investment on the continent, China has become Africa's largest trading partner. In 2012, China's two-way trade volume was almost twice as high as the US-Africa trade volume (see Table 7.1 again). 
Table 7.2: Chinese Official Development Finance to Africa, 2000-2013

\begin{tabular}{ccccc}
\hline & ODA-like & OOF-like & $\begin{array}{c}\text { Vague } \\
\text { Official } \\
\text { Finance }\end{array}$ & $\begin{array}{c}\text { TOTAL } \\
\text { Tillion 2011 } \\
\end{array}$ \\
\cline { 2 - 5 } & $\begin{array}{c}\text { (Billion 2011 } \\
\text { US\$) }\end{array}$ & $\begin{array}{c}\text { (Billion 2011 } \\
\text { (Billion 2011 }\end{array}$ & US\$) & US\$) \\
\cline { 2 - 5 } $\mathbf{2 0 0 1}$ & 2.44 & 0.06 & 0.37 & 2.87 \\
$\mathbf{2 0 0 2}$ & 1.60 & 0.10 & 0.66 & 2.36 \\
$\mathbf{2 0 0 3}$ & 0.44 & 1.11 & 0.72 & 2.26 \\
$\mathbf{2 0 0 4}$ & 1.15 & 0.64 & 1.57 & 3.36 \\
$\mathbf{2 0 0 5}$ & 1.68 & 1.46 & 0.37 & 3.51 \\
$\mathbf{2 0 0 6}$ & 1.04 & 3.91 & 1.13 & 6.08 \\
$\mathbf{2 0 0 7}$ & 4.37 & 2.92 & 2.82 & 10.11 \\
$\mathbf{2 0 0 8}$ & 2.33 & 15.78 & 3.19 & 21.30 \\
$\mathbf{2 0 0 9}$ & 1.09 & 0.91 & 2.31 & 4.32 \\
$\mathbf{2 0 1 0}$ & 1.69 & 1.26 & 7.66 & 10.61 \\
$\mathbf{2 0 1 1}$ & 2.94 & 3.82 & 2.87 & 9.63 \\
$\mathbf{2 0 1 2}$ & 3.58 & 8.03 & 2.61 & 14.22 \\
$\mathbf{2 0 1 3}$ & 7.77 & 2.77 & 4.30 & 14.84 \\
\hline
\end{tabular}

Source: Chinese AidData (2017). http://china.aiddata.org/downloads

\subsection{The Model}

\subsubsection{Model with single donor}

\subsubsection{Baseline Model without commitment strategy}

\section{Players and Preferences}

In this section I build a simple game-theoretical model of a recipient country's decision to accept aid from either just one, or two (competing), donors. The baseline version of the model consists of two players: a donor, $D$, and the recipient government, $R$. The donor can offer foreign aid, $A$, to the recipient government. The recipient government can either accept or reject the foreign aid offers made by the donor. Foreign aid offered by the donor is conditional on good governance reforms, $G$. The idea behind the inclusion of $G$ is that when accepting foreign aid from the donor, the recipient government might be forced 
to undergo political reforms that, all else equal, negatively affect the government's chances of remaining in power. The donor selects the degree of political conditionality attached to its foreign aid offer ex ante.

The recipient government's utility function depends on political survival, $P$, only. Political survival is a positive function of foreign aid. The idea here is that foreign aid can be used to satisfy demands from citizens - and hold down public discontent - by providing public goods or perhaps more direct benefits, alternatively it can be used to gain the upper hand in internal power struggles. ${ }^{159}$ For simplicity, I do not distinguish between different forms of aid (project aid versus budget support, for example), as foreign aid is highly fungible (Feyzioglu, Swaroop, \& Zhu, 1998; Pack \& Pack, 1990, 1993; Reinikka \& Svensson, 2004). ${ }^{160}$

While aid impacts political survival in a positive way, political survival is a negative function of governance reforms. Objectively, political reform tends to promote peaceful regime change in the long run, but it also guarantees that the losing party may return to power in later elections. In the short run, however, political reform reduces the chances of the incumbent government staying in power. The model is based on the perceptions of political leaders. Often, there is no straightforward alignment of interest between civil society and the political elite. In those cases, political leaders feel threatened by political reforms. I model $G$ as a binary variable that can take on the value 0 or $1: G \in\{0 ; 1\}$. The recipient country either implements political reform or it does not.

$$
\begin{gathered}
U_{R}=U(P(A, G)) \\
\frac{\mathrm{dU}}{\mathrm{dP}}>0, \frac{\partial \mathrm{P}}{\partial \mathrm{A}}>0, \frac{\partial \mathrm{P}}{\partial \mathrm{G}}<0
\end{gathered}
$$

\footnotetext{
${ }^{159}$ It has been shown that recipient governments can reallocate a significant part of aid money on, among others, non-developmental political purposes such as patronage and clientelism (Ahmed, 2012; Bueno de Mesquita, Smith, Siverson, \& Morrow, 2003; Bueno de Mesquita \& Smith, 2010; Morrison, 2007, 2009). Foreign aid can therefore help political leaders to hold onto power (Licht, 2010).

${ }^{160}$ Due to its fungibility, foreign aid can have large unintended effects in recipient countries even if foreign aid by donor countries is intended for developmental purposes such as poverty reduction, education, health, and physical infrastructure (Bader \& Faust, 2014; Kosack \& Tobin, 2006). Empirical evidence, however, suggests that the degree of fungibility is lower for foreign aid than for other rents such as oil (Van de Sijpe, 2013).
} 


\section{CHAPTER 7}

The donor derives positive utility from national development or economic welfare in the recipient country, $W$, and from the implementation of governance reforms, $G$. (Subscripts $\mathrm{R}$ and $\mathrm{D}$ refer to recipient and donor respectively.)

$$
\begin{gathered}
U_{D}=U(W(A), G) \\
\frac{\partial \mathrm{U}}{\partial \mathrm{W}}>0, \frac{\partial \mathrm{U}}{\partial \mathrm{G}}>0 ; \mathrm{W}^{\prime}(0)>0, \mathrm{~W}^{\prime \prime}(A)<0
\end{gathered}
$$

The donor's welfare function $W$ is a continuous function of aid resources, $A$. I assume that there is diminishing marginal utility of the donor's welfare over aid resources. The fact that $\frac{\partial \mathrm{U}}{\partial \mathrm{W}}>0$ takes into account that the donor cares about the well-being of the citizens in the recipient country, believing that the aid money allocated to the recipient government is spent for developmental purposes. I also allow for other, perhaps more cynical, interpretations, for instance that aid agencies prefer to spend money that is already allocated towards a specific purpose or country with limited consideration given to the actual (economic) impact.

The model assumes that, all else equal, the recipient government prefers (i) more aid to less aid and (ii) the status quo of the political system to political reforms. This does not mean, however, that the recipient government will never choose to launch political reforms. It depends on the "price" it will have to pay for agreeing to such reforms, in terms of the survival probability, and what the donor is willing to offer in return. In Section 7.4.2 I will extend the model by accounting for the entry of a second, non-traditional, competing donor.

\section{Extensive-form Game}

The interaction between the donor and the recipient government is modelled as a dynamic game of complete and perfect information where both players undertake actions in multiple periods. The sequential game consists of three stages:

i. The donor chooses between giving aid and not giving aid, and how much it will offer if it chooses to give. At this stage, the donor has the option to make the delivery of foreign aid conditional upon political reforms within the recipient 
country. Not giving aid ends the game with payoffs (utility value) $U_{D}(W(0), 0)$ and $U_{R}(P(0,0))$.

ii. The recipient government observes the donor's choice. If the donor offers aid, the recipient government can then either reject or accept the aid offer. If the recipient government accepts the aid offer, the recipient country is formally required to undergo political reforms. The game ends with payoffs (utility value) $U_{D}(W(A), G)$ and $U_{R}(P(A, G))$. If the recipient government rejects the offer, it does not receive aid but also does not have to implement the political reforms demanded by the donor.

iii. The donor observes the choice made by the recipient government. If the earlier choices were offer aid and reject aid offer, then the donor is faced with the decision to make another aid offer or to withhold foreign aid. At this stage, the donor no longer attaches political conditions to his offer of aid. The idea behind this modelling choice is the assumption that the donor cannot credibly commit to not giving out aid if the proposed political conditionality is rejected by the recipient. ${ }^{161}$ The donor will have a payoff equal to $U_{D}(W(A), 0)$ and the recipient government's payoff is equal to $U_{R}(P(A, 0))$.

In principle, there is a fourth stage, where the recipient government can either accept or reject the offer made in stage 3 . However, as offers given in stage 3 come with no conditionality attached, the recipient government will never reject in this fourth stage, and I do not model it explicitly. In the last stage, the donor will choose to offer the amount of foreign aid that maximizes his welfare function, knowing that any amount will be accepted:

$$
\max _{\{A\}} U_{D}(W(A), 0)
$$

I denote the level of foreign aid that maximizes this function $A^{*}$.

\footnotetext{
161 The term 'commitment capacity' or 'commitment capability' is used to highlight that the donor puts constraints on himself. Or put differently, the donor needs to have a credible way of tying his own hands and to signal to recipient countries his strong conviction of the necessity of good governance reforms. I therefore follow the approach taken by Svensson (2003) who argues that "while the country manager (and donor) has clear incentives ex ante to reward good polices and thereby induce reform, such an aid program requires a strong commitment ability. In its absence, aid will be disbursed irrespective of reform effort, since the opportunity cost of disbursing committed aid is zero" (p. 388).
} 


\section{CHAPTER 7}

At the second stage, the recipient government anticipates that if the game reaches the third stage then the traditional donor will deliver $A^{*}$, which would yield a payoff of $U_{R}\left(P\left(A^{*}, 0\right)\right)$ for the recipient government. The second-stage choice for the recipient government is therefore a payoff of $U_{R}\left(P\left(A^{*}, 0\right)\right)$ from rejecting the first aid offer or a payoff of $U_{R}\left(P\left(A^{1}, G\right)\right)$ from accepting an aid offer $A^{1}$ in the first stage. The optimal strategy chosen by the recipient government in the second stage is

$$
S_{R}= \begin{cases}\text { Accept, } & \text { if } A^{1} \geq \bar{A} \\ \text { Reject, } & \text { if } A^{1}<\bar{A},\end{cases}
$$

where $\bar{A}$ is the cut-off value of foreign aid. This is the amount of aid resources provided by the traditional donor that makes the recipient government indifferent between accepting and not accepting the foreign aid offer that comes with political strings attached: $U_{R}(P(\bar{A}, 1))=U_{R}\left(P\left(A^{*}, 0\right)\right)$.

If it wants to induce good governance reforms, the optimal approach for the donor is to offer the recipient $\bar{A}$ in the first stage. By providing, $\bar{A}$, the traditional donor delivers just enough amount of aid that makes the recipient government indifferent between accepting and rejecting the first aid offer. Put differently, the equilibrium offer by the traditional donor is to offer the optimal amount of foreign aid so that the donor adheres to political conditionality.

Now, we note that the amount of aid given by the donor in the third stage, $\mathrm{A}^{*}$, does not depend on the recipient governments level of (dis)like for conditionality and governance reforms. That is, any two governments (countries) with the same economic characteristics will receive the same amount of aid in the third stage. This means that, in the first stage, the donor has to offer more money to a government that is more strongly affected (in terms of survival probability) by good governance reforms, which directly leads to the following proposition:

Proposition 1. Conditional on aid money being spent, a recipient country that has a stronger dislike of good governance reforms will receive more money (or for some parameters the same) by the traditional donor in the first stage. 


\subsubsection{Baseline Model with commitment strategy}

In the previous subsection it was assumed that the donor is not able to commit to its first stage policy package: (some) aid money will eventually be provided even if the recipient rejects the first offer. If, instead, the donor can credibly commit to its policy reform package attached to foreign aid, it can offer the recipient country a take-it-or-leave-it offer, and the game ends after the second stage. In the second-stage, the recipient government then faces a choice between a payoff of $U_{R}\left(P\left(A^{1}, 1\right)\right)$ from accepting the first aid offer and a payoff of $U_{R}(P(0,0))$ from rejecting the aid offer. Its optimal strategy depends on the value of $A^{1}$. I denote the cut-off value of foreign aid resources $\overline{\bar{A}}$ in this scenario. $\overline{\bar{A}}$ is defined as follows:

$$
U_{R}(P(\overline{\bar{A}}, 1))=U_{R}(P(0,0))
$$

and the optimal strategy for the recipient government is:

$$
S_{R}= \begin{cases}\text { Accept, } & \text { if } A^{1} \geq \overline{\bar{A}} \\ \text { Reject, } & \text { if } A^{1}<\overline{\bar{A}}\end{cases}
$$

Now, the optimal strategy strategy chosen by the donor in stage 1 , if it wants to induce good governance reforms, is:

$$
S_{D 1}=(\overline{\bar{A}}, 1)
$$

Based on the same reasoning as in the previous subsection (leading up to Proposition 1), we again have the following result:

Proposition 2a. Conditional on aid money being provided in stage 1, a recipient country that has a stronger dislike of good governance reforms will receive more money from the traditional donor.

Now, note that in this case, with full commitment of the donor, the "outside option" for the recipient, i.e. the amount of aid and the utility it will receive if it rejects the offer from the donor, implies receiving no aid at all. In the case with no commitment to the reform package by the donor we saw that the donor offers a positive amount of aid in stage 3 , which will be accepted by the recipient. Hence, the effect of the commitment by the donor is that the outside option of 


\section{CHAPTER 7}

the recipient government worsens. This, in turn, implies that $\overline{\bar{A}}<\bar{A}$, i.e. the recipient government will be willing to accept an offer that comes with conditionality attached at a lower amount of aid than in the no-commitment case. This finding can be summarized in the following proposition:

Proposition 2b. A credible commitment to good governance reforms allows the donor to induce good governance reforms $(G=1)$ with less aid money.

A trivial, but perhaps still interesting, implication of the difference between the two scenarios, with and without donor commitment, is that commitment is a necessary condition for a complete withdrawal of the donor from a country:

Comment 1. (Only) with credible commitment can it be the case that no aid is provided by the donor.

To sum up, in this section I have shown that a recipient country that is more strongly affected (in terms of survival probability) by good governance reforms is more likely to receive a positive amount of foreign aid compared to the case where the donor could not credibly commit to good governance reforms (Section 7.4.1.1). I have also shown that there are differences between the setting with a credible commitment strategy and the setting without a credible commitment strategy: a recipient country will receive less aid money if the donor can credibly commit to good governance reforms.

\subsubsection{Introduction of strategic donor}

In the previous subsections I presented a model of the interaction between a recipient country and a donor with a straight-forward preference for recipient country development. I will now introduce a traditional donor with somewhat more complex, strategic interests. It is well known that donors often have different preferences and motivations for giving foreign aid (Lancaster, 2007). The model now takes into account that the traditional donor could also care about gaining strategic influence (for details, see Chapters 5 and 6). I denote the strategic interest by the traditional donor $I_{T}$ and model it as a binary variable that can take on a value of 0 or $1: I_{T} \in\{0 ; 1\}$. Let us call a donor with $I_{T}=1$ "strategic" and a donor with $I_{T}=0$ "non-strategic". The shape of $U_{D}$ depends 
on $I_{T}$. For the same $A$ and $G$, the utility function takes on a strictly higher value if $I_{T}$ is greater.

I return to the baseline assumption that the traditional donor does not credibly commit to the good governance reform package attached as a condition to the provision of foreign aid. The utility function of the donor changes to:

$$
U_{D}=U\left(W(A), G ; I_{T}\right) ; \frac{\partial \mathrm{U}}{\partial I_{T}}>0
$$

with the following assumption imposed.
Assumption
(AS1): If $\quad I_{T}>I_{T}{ }^{\prime} \quad$ then
$U\left(W\left(A ; I_{T}\right), G ; I_{T}\right)>$$$
U\left(W\left(A ; I_{T}\right), G ; I_{T}{ }^{\prime}\right) \text { and } W^{\prime}\left(A ; I_{T}\right)>W^{\prime}\left(A ; I_{T}{ }^{\prime}\right)
$$

Analyzing the game from the last stage, the assumptions above imply that the strategic donor will deliver more aid in the last stage. Hence, the outside option associated with rejecting the offer in the second stage becomes more attractive to the recipient. This, in turn, implies that the donor will have to "sweeten the deal", by offering more aid in the first stage, if it wants to see good governance reforms implemented. This can be summarized in the following proposition:

Proposition 3a. The amount of aid money a strategic donor has to offer in stage 1 to induce good governance reforms is higher than for the non-strategic donor.

In the introductory parts to this chapter, we saw that it might be particularly interesting to analyse what happens in a world where a non-strategic donor who put significant effort and resources into good governance reforms develops more strategic interests. The following theoretical result sheds light on this scenario:

Proposition 3b. Consider a scenario where a traditional non-strategic donor is willing to pay what is necessary to induce good governance reforms. Suppose that if this traditional nonstrategic donor becomes a strategic donor; there exist parameter values such that the strategic donor will no longer offer what is necessary to induce good governance reforms. 


\section{CHAPTER 7}

Proof. Consider a setting where the following things hold: (i) other things equal, introducing a strategic interest always increases the donor's utility; (ii) the donor is exactly willing to pay what is necessary to induce good governance reforms when it is non-strategic; (iii) at the amount $A^{*}$ that the donor, in equilibrium, was willing to pay to induce good governance reforms, the utility of the donor decreases with further increases in aid giving even when it is strategic. We know from the above assumptions that the strategic donor will contribute more in the last stage. But this also means that its utility increases if the game reaches this stage, as the strategic donor always has the option of contributing the same with its utility unaltered. Furthermore, we know that the donor's utility would decrease if it contributed more in the first stage, which we know from Proposition $3 \mathrm{a}$ that it would have to do to induce governance reforms when strategic. Together, this implies that the donor, when strategic, will not choose to contribute what is necessary to induce good governance reforms, which concludes the proof.

In this subsection, I have so far assumed that credible commitment is not possible. Let us now assume that the threat by the traditional strategic donor to withhold foreign aid disbursements if recipient countries do not engage in good governance reforms is fully credible. In this case, the aid value at which the recipient country rejects the offers made by the strategic and non-strategic donor is the same, namely $A=0$ (i.e. no aid funds are delivered). The equilibrium strategies by the strategic and non-strategic donor are the same. If the commitment to good governance reforms is credible, the strategic and nonstrategic traditional donor will provide the same amount of aid. Even though the strategic donor can theoretically provide more aid, he does not need to in order to enforce $G=1$ in the first stage. Assuming that the amount of aid necessary to induce good governance reform is greater than what the donor would simply prefer to give (call this assumption AS1), we have the implication that both types of donors will offer the same amount of aid in the first stage. If we combine this result with the fact that the strategic donor in the absence of commitment capacity has to offer more aid in order to induce governance reforms, we can make the following note: 
Comment 2. Under assumption AS1, it is more important for a traditional strategic donor (than for a traditional non-strategic donor) to develop a credible commitment to the good governance reform package.

\subsubsection{Model with multiple competing donors}

\subsubsection{Lack of credible commitment strategy}

The analysis will now be extended by accounting for the entry of a second competing donor. As a result, this section will model a competitive donor environment. In contrast to the traditional donor, $D_{T}$, the new (or nontraditional) donor, $D_{N}$, does not care about good governance reforms and has no interest in attaching political conditions to its aid. Similar to the traditional donor, national development in the recipient country enters positively into the utility function of the non-traditional donor. The utility function of the new donor has the following structure:

$$
\begin{gathered}
U_{D_{N}}=U\left(W\left(A_{N}\right)\right) \\
\frac{\partial U_{D_{N}}}{\partial W}>0, \frac{\partial W}{\partial A_{N}}>0
\end{gathered}
$$

For the moment, let us also assume again that the commitment to good governance reforms by the traditional donor is not credible. This assumption will be relaxed at a later stage. Let us also assume that the total volume of aid offered by the traditional donor is strictly larger than that offered by the new donor.

To keep the model simple, the game is modelled as a sequential move game, i.e. the non-traditional donor enters the game when the game between the traditional donor and the recipient government terminates. I believe that this is a reasonable representation of the real-world patterns, as the traditional donor has a well-established presence and therefore likely will be able to act as the "first-mover". More importantly, however, the fact that the game is sequential does not preclude that in earlier stages of the game, the traditional donor is aware of the actions of the new donor (and vice-versa). 


\section{CHAPTER 7}

Similar to the traditional donor and the recipient government, the nontraditional donor has full and complete information. I do not explicitly model the scenario in which a new donor offers aid while the traditional donors offers no aid at all for the following reason: the aim of the model is to understand how the entry of a new donor into the aid game affects the aid allocation decisions by the traditional donor. I therefore assume that the traditional donor is a permanent feature of the game. I now analyse the outcome under different assumptions imposed on the preferences of the new donor. Let us start by analysing the game under the following assumption:

Assumption (AS2): The new donor's preferences with regard to the amount of aid given are independent of the amount of aid given by the traditional donor.

This assumption implies that the new donor is willing to give the same amount of aid in the third stage regardless of the strategy chosen by the old donor in the previous stages. The following proposition can be derived:

Proposition 4a. Under Assumption (AS2), the additional amount of aid the traditional donor needs to offer in order to induce good governance reform is greater when the second (non-traditional) donor is present.

Proof. When $A_{N}>0$, this follows from the concavity of the recipient's utility function, and the fact that the "outside option" from rejecting is higher (for the recipient) when there is a second donor providing additional aid after the rejection.

From the recipient government's point of view, Proposition $4 \mathrm{a}$ can be interpreted as a wealth effect. The presence of a second donor that does not attach good governance reforms to the delivery of aid increases the aid resources available for the recipient government. The following, related result follows directly from Proposition 4a:

Comment 3: Under assumption (AS2), there are parameter values such that the traditional donor is willing to offer the amount of aid necessary to induce good governance reforms when this donor is interacting with the recipient alone, while it is not willing to do so when the second, non-traditional donor is present. 
$\underline{\text { Strategic motive by new donor }}$

I will now take into consideration that the new donor, similar to the traditional donor, also has a geostrategic motive for providing foreign aid. By receiving foreign aid from the non-traditional donor, the recipient government might, for instance, agree to diplomatically support the non-traditional donor in international security questions and in major international political organs like the United Nations General Assembly (UNGA) or the United Nations Security Council (UNSC) (see Chapter 3). ${ }^{162}$ Just like the traditional donor, the nontraditional donor cares about gaining strategic influence in the recipient country, but still does not pay any attention to good governance reforms.

As a result, the non-traditional donor's utility is also a positive function of geostrategic alignment, $I_{N}$. $I_{N}$ is a discrete variable that can take on a discrete value of 0 or $1, I_{N} \in\{0,1\}$. $I_{N}$ therefore enters into the new donor's utility function in the same way as does $I_{T}$ for the traditional donor. The implication of adding this geopolitical motive is that I have to relax assumption (AS2). I now assume that the non-traditional donor's preferences over aid giving are no longer independent of the giving behaviour of the traditional donor. Specifically, the model now has the feature that the ability of the new donor to achieve its geostrategic objectives in a recipient country $i$ is inversely related to the amount of aid money provided by the traditional donor in that specific country.

Assumption (AS3): The utility function of the new donor is directly affected by the strategy chosen by the old donor in the previous stage. Specifically, aid money spent by the new donor is more productive (in terms of buying influence) when there is less money spent by the old donor.

The utility function of the new donor can be rewritten as follows:

$$
U_{D_{N}}=U\left(W\left(A_{N}\right) ; I_{N}\left(A_{T}\right)\right)
$$

\footnotetext{
162 Empirical studies on the positive relationship between foreign aid and voting patterns in the UNGA or UNSC include, among others, Wittkopf (1973), Kuziemko and Werker (2006), Dreher, Nunnenkamp and Thiele (2008) and Dreher, Sturm and Vreeland (2009). However, the results presented in Chapter 3 do not find a strong link between Chinese development finance and voting patterns in the UNGA.
} 


$$
\begin{gathered}
\text { CHAPTER 7 } \\
\frac{\partial U_{D_{N}}}{\partial W}>0, \frac{\partial U_{D_{N}}}{\partial I_{N}}>0, \frac{\partial U_{I_{N}}}{\partial A_{T}}<0
\end{gathered}
$$

$A_{N}$ and $A_{T}$ denote the aid levels for the new and traditional donor, respectively. While the recipient country could suffer from reduced foreign policy space by always having to align with the non-traditional donor in international security issues, the recipient country also benefits from increased participation in global affairs. Since the utility function could be affected either way, I assume for simplicity that the utility function of the recipient government is unaltered by the introduction of a strategic interest for the non-traditional donor.

Proposition 4b. For some parameter values, the traditional donor is willing to contribute the amount of aid necessary to enforce good governance reforms under assumption (AS2) but not under assumption (AS3).

Proof. Consider parameter values such that the non-traditional donor delivers the same amount of aid in stage 4, after a rejection of the aid package with good governance conditionality, under assumption (AS3) as under assumption (AS2) for the amount of traditional donor aid that was optimal under assumption (AS2). This implies that the traditional donor will also offer the same amount of aid in stage 3 under both assumptions. In this case the new donor will be offering less aid under assumption (AS3) than under assumption (AS2) in the subgame that starts after an aid package with political conditionality has been accepted. Hence, the traditional donor will have to offer more aid in stage 1 in order for the recipient government to accept in stage 2. Hence, there exist parameter values such that the traditional donor will not be willing to offer what is necessary under assumption (AS3) to induce governance reforms even though it was willing to do so under assumption (AS2).

The interpretation of this result is that the traditional donor needs to offer more aid to induce $G=1$. That is, we observe a political effect at play when we account for geopolitical motives by the new donor. We have already shown that even without accounting for geopolitical motives on the new donor side, the wealth effect makes it less likely for the traditional donor to induce $G=1$. This holds true in the case of introducing geopolitical motives for the new donor, and the entry of a new donor with geopolitical motives further weakens good 


\section{CHAPTER 7}

governance reforms even if the traditional donor provides more aid compared to the previous case (where we only considered the wealth effect).

\subsubsection{Existence of credible commitment strategy}

In section 7.4.2.1, I assumed that the traditional donor cannot credibly commit to the good governance reforms attached to the aid delivery. In this section, I will briefly discuss how the interactions change under the assumption that the traditional donor is fully committed to his policy reform package.

I have shown that in the single donor game, commitment (capacity) to good governance reforms is always better than non-commitment for the traditional donor. The value of commitment, however, is reduced when a non-traditional donor enters into the aid game.

Proposition 5. When the traditional donor credibly commits to good governance reforms (i.e. it gives no aid after a rejection in stage 2), the new donor will give more aid compared to the scenario of no credible commitment by the traditional donor.

Proof. This follows from assumption (AS3). The highest amount of aid given by the new donor comes when no aid at all is given by the traditional donor, which by definition is the case after a rejection of good governance reforms in the case with commitment capacity.

The implication of this proposition is that the entrance of the non-traditional donor is particularly harmful for traditional donors that have been able to develop credible commitment strategies.

With regard to the commitment strategy of the old donor, it makes a big difference whether the non-traditional donor is in the game or not. The commitment strategy is not as valuable for the traditional donor when the nontraditional donor is in the game. The value of the commitment strategy is heavily undermined by the entry of the non-traditional donor. 


\subsection{The Aid Game applied to Ethiopia}

In this section, the testable implications derived from the theoretical framework will be applied to the country of Ethiopia. The analysis focuses on the time period 1990-2013. Figure 7.2 shows that Ethiopia must be considered one of the most aid dependent countries in Africa.

Figure 7.2: Ethiopia's Aid Dependence in Comparative Perspective, 1990-2013

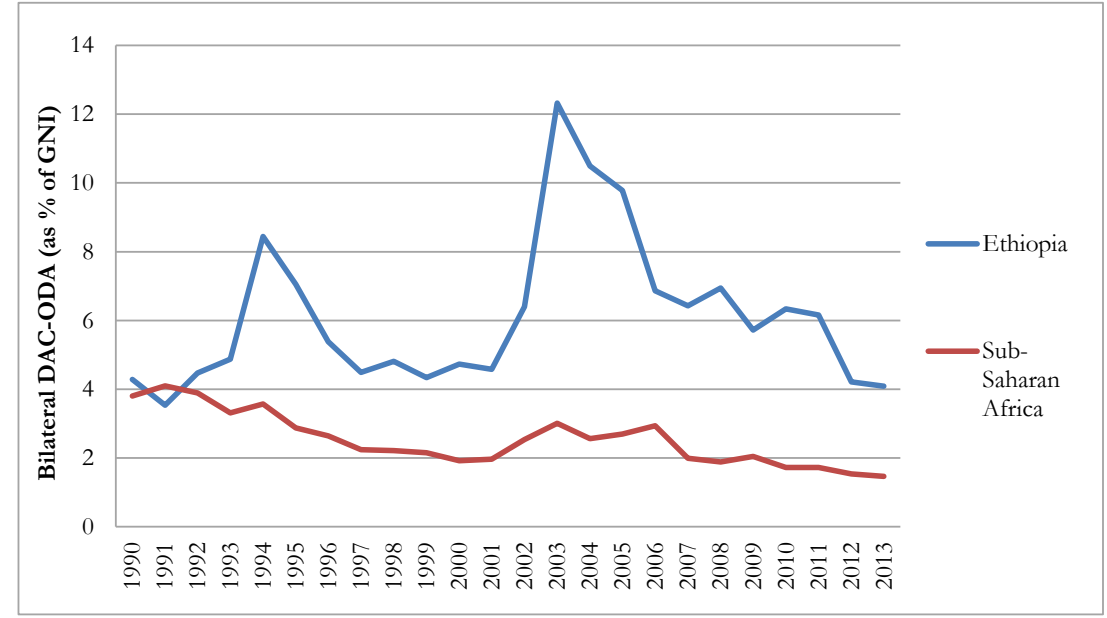

Source: OECD/DAC Database

The country's aid dependence rose significantly throughout the 1990s. In 2003, bilateral DAC ODA disbursements alone made up 12 percent of Ethiopia's GNI. Ethiopia's aid dependence in that year was 9 percentage points larger than the Sub-Saharan African average. Even though Ethiopia's aid dependence has been significantly been reduced since then, it still ranks significantly higher than the Sub-Saharan African average.

\subsubsection{Patterns of Western and Chinese Foreign Aid Allocation}

Figure 7.3 shows that the evolution of bilateral DAC-ODA disbursements to Ethiopia. Two major trends are evident. During the 1990s, DAC-ODA aid to Ethiopia declined significantly. Since 2001, however, DAC-ODA aid to Ethiopia 
rose steadily until the early 2010s. This section will explain these recent trends and patterns through the theory developed above.

As already discussed in Chapter 6, Meles Zenawi himself was perceived as belonging to a new breed of African leader among the Western donor community: "genuinely pro-poor and committed to modernizing and bringing development to his country" (Borchgrevink, 2008, p. 200). The transitional government, in turn, regarded the United States as the "ultimate guarantor of donor money" (Tadesse, 2015, p. 349).

Figure 7.3: Bilateral DAC-ODA to Ethiopia, 1990-2013 (absolute and per capita)

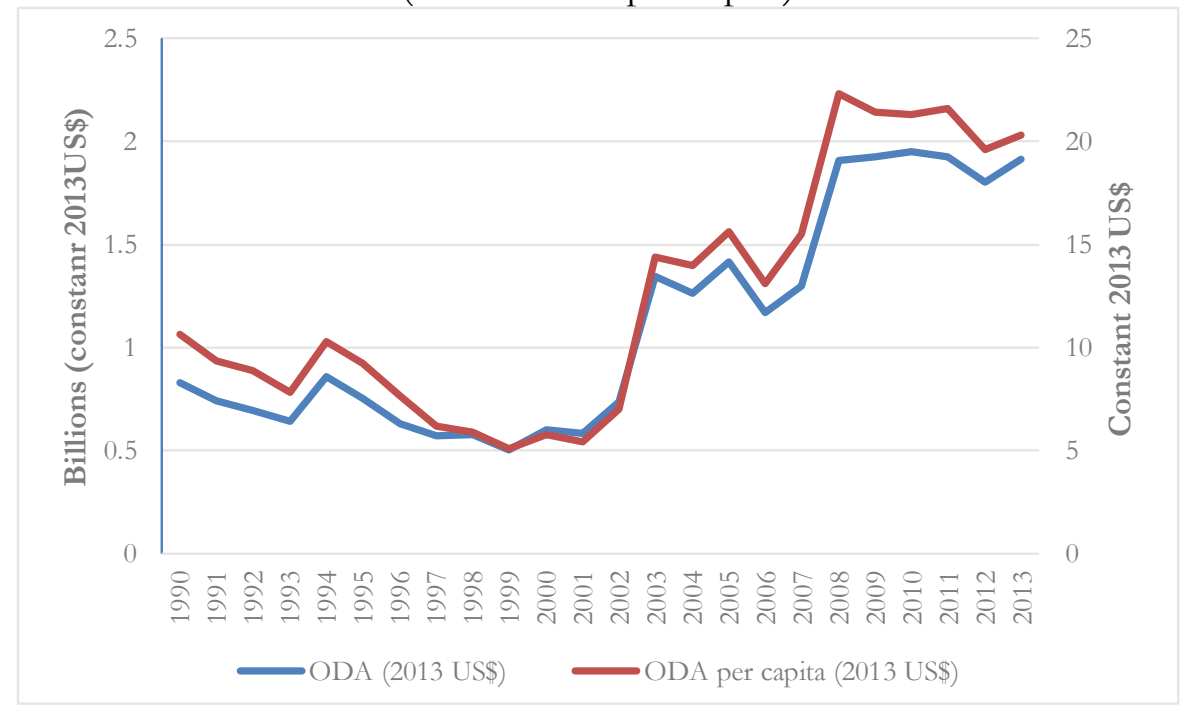

Source: OECD-DAC Database, http://stats.oecd.org

If we regard the DAC donor community as one single donor, the one donorone recipient model discussed above was the prevalent aid game in Ethiopia throughout the 1990s. During that time, Ethiopia's development strategy was therefore largely dictated by the Western donor community (Feyissa, 2011). The Ethiopian government therefore had to undergo some degree of political if it wanted to receive financial support from the West. Initially, Western donors showed a credible commitment to good governance reforms. The baseline model with a commitment strategy on the part of the traditional donor developed in Section 7.4.1.2 is highly applicable to the early and mid-1990s. Proposition 2b largely holds throughout the 1990s as Western donors could 
induce good governance reforms $(G=1)$ with less aid money if compared to today. In the early and mid-1990s, both internal and external actors posed no immediate threat to regime survival.

What was at stake during the early and mid-1990s was not primarily the political survival of the EPRDF regime, but rather gaining domestic legitimacy on developing strategies and programs for economic growth and poverty reduction. Zenawi feared that the reforms demanded by the international financial institutions would go against its own development agenda (see Chapter 6 again. The Ethiopian government under Zenawi increasingly resisted the conditions attached to foreign aid. IMF lending to Ethiopia, for example, came to a halt (see Chapter 6). The fact that no aid was provided to the Ethiopian government by the IMF underlines its credible commitment to political (and economic) reforms at that time as a strong commitment to good governance reforms is necessary for a complete withdrawal of the donor from a country (see Comment 1).

From the late 1990s onwards, Ethiopia's own national security and the political legitimacy of the EPRDF regime were increasingly challenged, primarily through the Ethio-Eritrean War (1998-2000) and the power struggle inside the ruling elite (Chapter 6). The applicability of the model is crucially dependent on the extent to which political reforms attached to foreign aid are perceived as a threat to regime survival in the short-run by the recipient government. This is one major reason why the Ethiopian government became increasingly hostile to the political conditions attached to the delivery of foreign aid, even though the government still undertook extensive good governance reforms prior to the general elections in 2005 .

The game presented above, however, can only partly explain the actions and choices made by the recipient government in the late 1990s and early 2000s. The model fails to capture how domestic policy factors can directly challenge the political survival of the incumbent government. Put differently, while the model captures the strategic game between the recipient government and the Western donor community, it fails to account for the strategic game played between the Ethiopian government and potential challengers (such as opposition groups, civil society, politicians of the ruling elite, etc.) inside the Ethiopian political and societal system. The Ethio-Eritrean War and the internal power struggle of the 


\section{CHAPTER 7}

EPRDF regime, two very important domestic policy factors, contributed to the changing perceptions of Zenawi's own political survival (Chapter 6). The internal power struggle is an example of how Zenawi's political survival was directly threatened by actors inside the ruling elite, a phenomenon which is not discussed in the game theoretical model above. Meles Zenawi emerged as undisputed leader from the internal power struggle and the Ethiopian military victory in the Ethio-Eritrean War further contributed to Zenawi's manifestation of power.

In the early 2000s, the commitment capacity by the Western donor community was no longer credible as the Western countries and international financial institutions had an ambivalent viewpoint towards the Ethiopian regime (Chapter 6). Despite doubts over Zenawi's sincerity in promoting democratic reform and private sector development, both bilateral and multilateral donors increased foreign aid substantially in the early 2000s.

This period is well summarized in Section 7.4.1.1, where the traditional donor cannot credibly commit to political conditionality. The Ethiopian government recognized that its resistance to good governance reforms would yield higher amounts of aid provided by the traditional Western donors (see Proposition 1a). The reason why the Western donor community kept providing foreign aid to Ethiopia can be attributed to the positive utility derived from promoting national development and increasing economic welfare in Ethiopia. The positive utility derived from the developmental motive of giving aid, however, was considerably higher than the positive utility derived from the political motive of giving aid, e.g. inducing good governance reforms.

\section{Entry of a new partner}

From the early 2000s onwards, the development aid landscape became increasingly characterized by the competing donor model described in Section 7.4.2. South-South cooperation in the areas of foreign aid, FDI and trade gained significant momentum in the early 2000s and has grown stronger ever since. As part of the revived South-South cooperation, Chinese-Ethiopian relationships strengthened significantly. Chinese-Ethiopian relationships were limited until the mid-1990s. Chinese aid (but also trade and investment flows) to Ethiopia were virtually absent in the early 1990s (Chapters 2 and 6). 


\section{CHAPTER 7}

From the recipient government's point of view, the entry of China acts as a wealth effect modelled in the first half of Section 7.4.2.1. For a given amount of Western foreign aid, China's foreign aid without political conditions became an increasingly popular alternative to the Zenawi regime as it increased the sources of foreign aid available to the government without challenging the political stability (and political survival) of the regime. The theory in the first half of Section 7.4.2.1 predicts that even without accounting for geostrategic motives on the part of the new donor it becomes increasingly difficult for the Western donor community to induce good governance reforms after the entry of China (see Proposition 4a), something that will be discussed further below.

The theory provided in Section 7.4.2., however, reflects a more accurate picture of the actual game as it is fair to assume that Beijing's geostrategic motives are particularly strong in Ethiopia, which is captured by the parameter $I_{N}$. While securing access to natural resources is one major motive for China's increasing economic presence in Africa (Chapters 2 and 4), the example of Ethiopia, a relatively resource-scarce country, highlights Beijing's much more complex and broader motives in its engagement with African recipient governments (see Chapter 6). In the case of China, it is evident that $I_{N}=1$. Consequently, the theory predicts that China's strong geostrategic interests in Ethiopia further weaken good governance reforms in the country (see Proposition 4b). The empirical evidence provided in the next few paragraphs largely supports this prediction.

The political development surrounding the 2005 Ethiopian national election and its aftermath led to a great disillusionment among the Western donor community (for more details, see Chapter 6 again). While there was no evidence that the regime had become less concerned with poverty alleviation, there were increasing concerns over Ethiopia's institutional development, human rights violations and the curtailing of press freedom. The Ethiopian government, in turn, did not show great willingness to compromise on the political issues that led to the crisis in the aftermath of the 2005 elections. Engaging with the Western international donor community on political reforms was perceived by 
the Ethiopian government as a direct threat to its political survival (Hackenesch, 2015a). ${ }^{163}$

The Western donor community partly gave in: the development funds were not withheld but reallocated to programmes characterized by stricter earmarking and monitoring procedures such as the joint donor-government Protection of Basic Services programme (Borchgrevink, 2008). This was once again an example of insufficient commitment on the part of the Western donor community at a time when emerging donors like China strengthened their ties with Ethiopia. This observation is consistent with the model presented in Section 7.4.2.1. As stated in Proposition 4b, with the presence of China in Ethiopia, the value of the Western commitment strategy to good governance reforms was heavily undermined.

The weakening of the Western commitment strategy to good governance reforms resulted in a return to "business as usual" with the Ethiopian government shortly after the 2005 elections (Table 7.3). The drop in bilateral ODA and ODF immediately after the 2005 election can be interpreted as a punishment by the Western donor community, as the Ethiopian government was accused of voting irregularities, election fraud and voter suppression. However, as the 2005 election is fading, aid figures have risen significantly again, while the Ethiopian government has continued and even extended its authoritarian mode of governance.

\footnotetext{
${ }^{163}$ It must be emphasized, however, that domestic policy factors - which are not captured in the model - such as the significant electoral gains for the opposition parties posed yet another survival threat to the recipient government (see Chapter 6). In this case, the political survival was directly threatened by actors outside the ruling elite. Once again, the game theoretical model fails to provide an explanation why and how domestic political factors during and after the 2005 national election affected the government's interest and ability to engage in political reforms demanded by the Western donor community.
} 


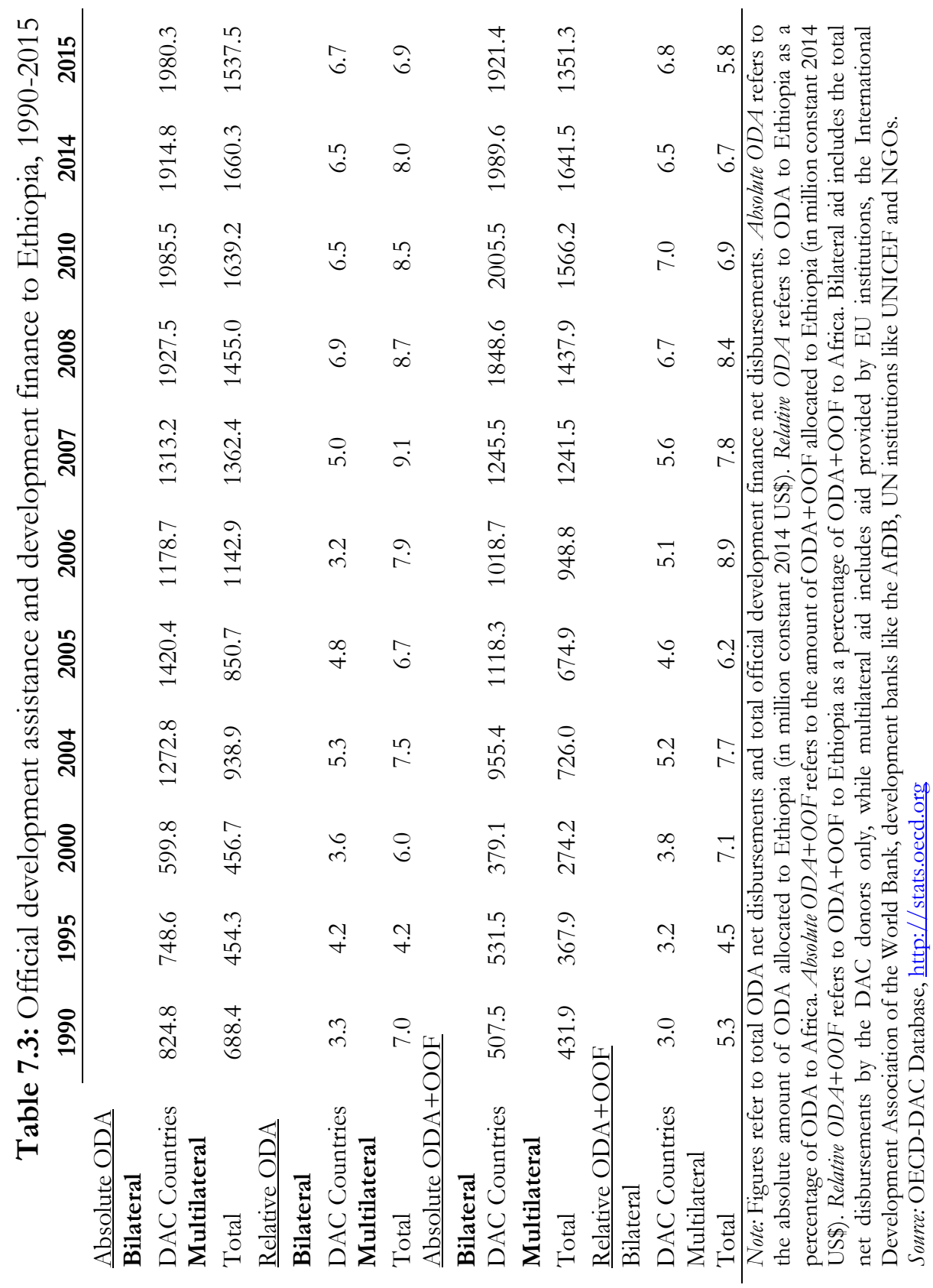

ㅎำ 
Declining democracy aid commitments on the part of the Western donor community cast additional doubt on the credible commitment strategy to good governance reforms by the West (Figure 7.4). Total democracy aid commitments have risen between 1995 and 2005, but declined gradually after the 2005 general elections. Overall, it is evident that the level of democracy aid commitments in 2015 is significantly lower than in the early and mid-2000s. Similarly, democracy aid commitments as a percentage of total aid dropped from 8 percent in 2007 to less than 1.5 percent in 2015 .

Figure 7.4: Democracy Aid Commitments to Ethiopia by DAC donors, 1995-2015

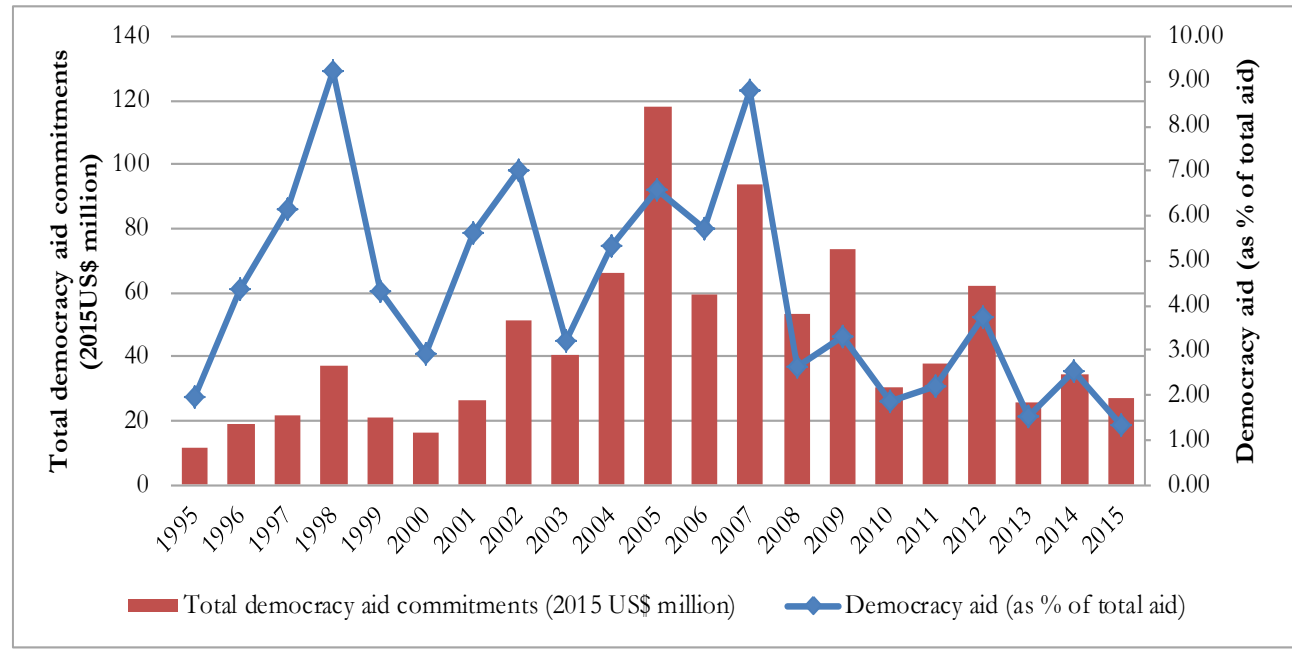

Note: Democracy aid commitments displayed in the graph only include bilateral flows. Data is retrieved from the OECD Development Assistance Committee Credit Reporting System. "Democracy aid" refers to data reported as "Government and Civil Society" which includes legal and judicial development, democratic participation and civil society, elections, legislature and political parties, media and free flow of information, human rights, women's equality organizations and institutions, public sector and administrative management, public finance management, decentralization and anti-corruption".

Source: Author's own calculations based on OECD-DAC Database, http://stats.oecd.org

These results stand in stark contrast to the narrative provided in Chapter 2 where I have shown that Western donor countries have significantly increased their democracy and governance aid at the global level, most notably in Africa, after the end of the Cold War. Figure 7.4 provides further evidence that the Ethiopian regime started a successful backlash against the Western good governance agenda since the mid-2000s, even though prior to 2005, the Ethiopian 
government was able to combine effective economic policies with a reasonable degree of democratic procedures (Hackenesch, 2015a, 2015b).

The data provided in this sub-section largely confirms the theoretical predictions made in Section 7.4.2: both the entry of China into the foreign aid game and an increasing resistance by the Ethiopian government to adhere to political conditionality was associated with (i) a rise in Western development assistance to Ethiopia from the mid-2000s onwards and (ii) a decreasing emphasis on good governance reforms.

\subsubsection{Varying Motivations for Giving Aid to Ethiopia}

Until now, I treated the DAC donors as a homogenous group assuming that the motivations for delivering foreign aid are largely similar among the Western donors. Qualitative and quantitative evidence, however, suggests that this is not the case as donors often have different motivations for providing foreign aid and often concentrate their resources in different sectors in the recipient country (Alesina \& Dollar, 2000; Alesina \& Weder, 2002; Bourguignon \& Platteau, 2015; Lancaster, 2007; Riddell, 2007). In this section, I show that, similar to China, the Western donor community also has strategic motives for providing foreign aid to Ethiopia, which implies that $I_{T}=0$ is no longer a valid assumption, at least for a large part of the Western donor community.

Table 7.4 displays the official development assistance to Ethiopia between 1990 and 2015 for a few selected bilateral DAC donors and multilateral donors: the United States, the United Kingdom, Sweden, the EU institutions and the International Development Association of the World Bank. Development assistance by all three bilateral donors rose in the pre-2005 election period. In the early 1990s, the United States, the United Kingdom and Sweden provided similar amounts of foreign aid to Ethiopia. The Ethiopian transitional government (1991-1995) adhered to political conditionality, partly because the commitment strategy by Western donor countries was credible initially. From the mid-1990s onwards, however, the Ethiopian government increasingly resisted good governance reforms. During that time, both bilateral and multilateral U.S. aid rose significantly while British aid stagnated and Swedish aid declined. 


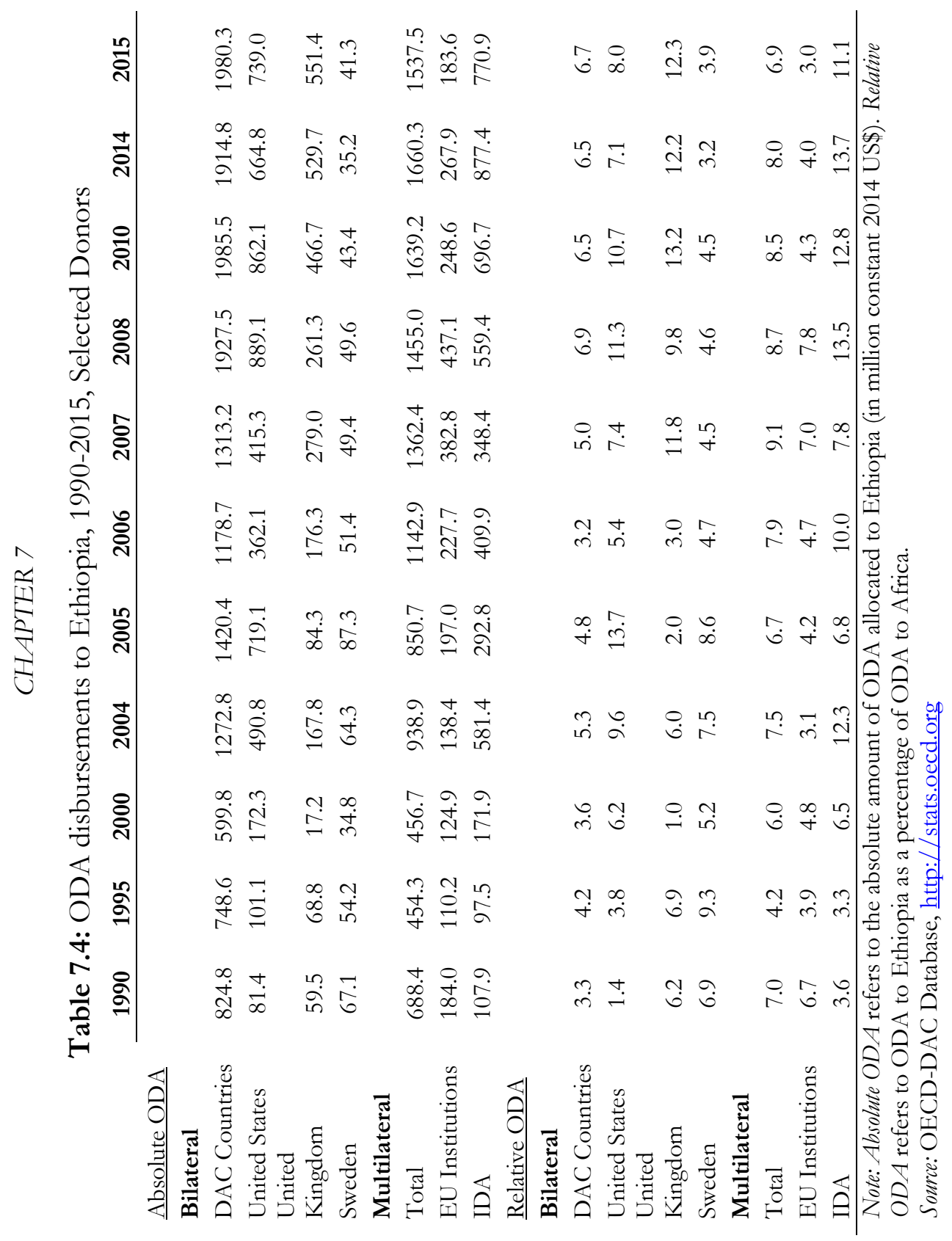


The increase in U.S. aid to Ethiopia can be interpreted as follows: the Ethiopian government was highly aware of the fact that the U.S.-Ethiopian relationships had strong historical roots (see Chapter 5). Based on Proposition 1, the Ethiopian government anticipated that if it showed more resistance to implement good governance reforms it would receive more money by the traditional donor with a relatively weak commitment strategy, such as the United States. Between the early 2000s and 2010s, British bilateral foreign aid to Ethiopia rose gradually, U.S. bilateral foreign aid fluctuated but remained more or less constant in the long-run, whereas Swedish bilateral foreign aid to Ethiopia has been significantly reduced since 2005 .

With the fading of the 2005 general elections, however, Ethiopia's relative importance as a recipient country on the African continent increased again from the U.S. and UK perspective. In contrast, Sweden has reduced its foreign aid disbursements to Ethiopia as a percentage of its total aid disbursements to Africa since the 2005 general election. The findings are very similar for official development finance rather than official development assistance (Table 7.5).

What can explain the different aid allocation patterns for these three countries in the context of Ethiopia? After the terrorist attacks on 11 September 2001, "the Bush administration - and its focus on the War on Terror - played a central role in reshaping aid policy" (Fleck \& Kilby, 2010, p. 185). As a result, foreign aid re-emerged as a crucial geopolitical tool in specific developing regions like the Horn of Africa as new security concerns have increasingly influenced foreign policy of several Western nations (Buzan, 2006; Woods, 2005). This recent phenomenon has often been described as "reversion to the Cold War pattern" (Buzan, 2006; Fleck \& Kilby, 2010). The presence of extremist Islamic groups such as Al-Shabaab in East Africa, Boko Haram in Nigeria and northern Cameroon or ISIS in Libya show that the African continent is not immune to the increasing influence of terrorist groups. 


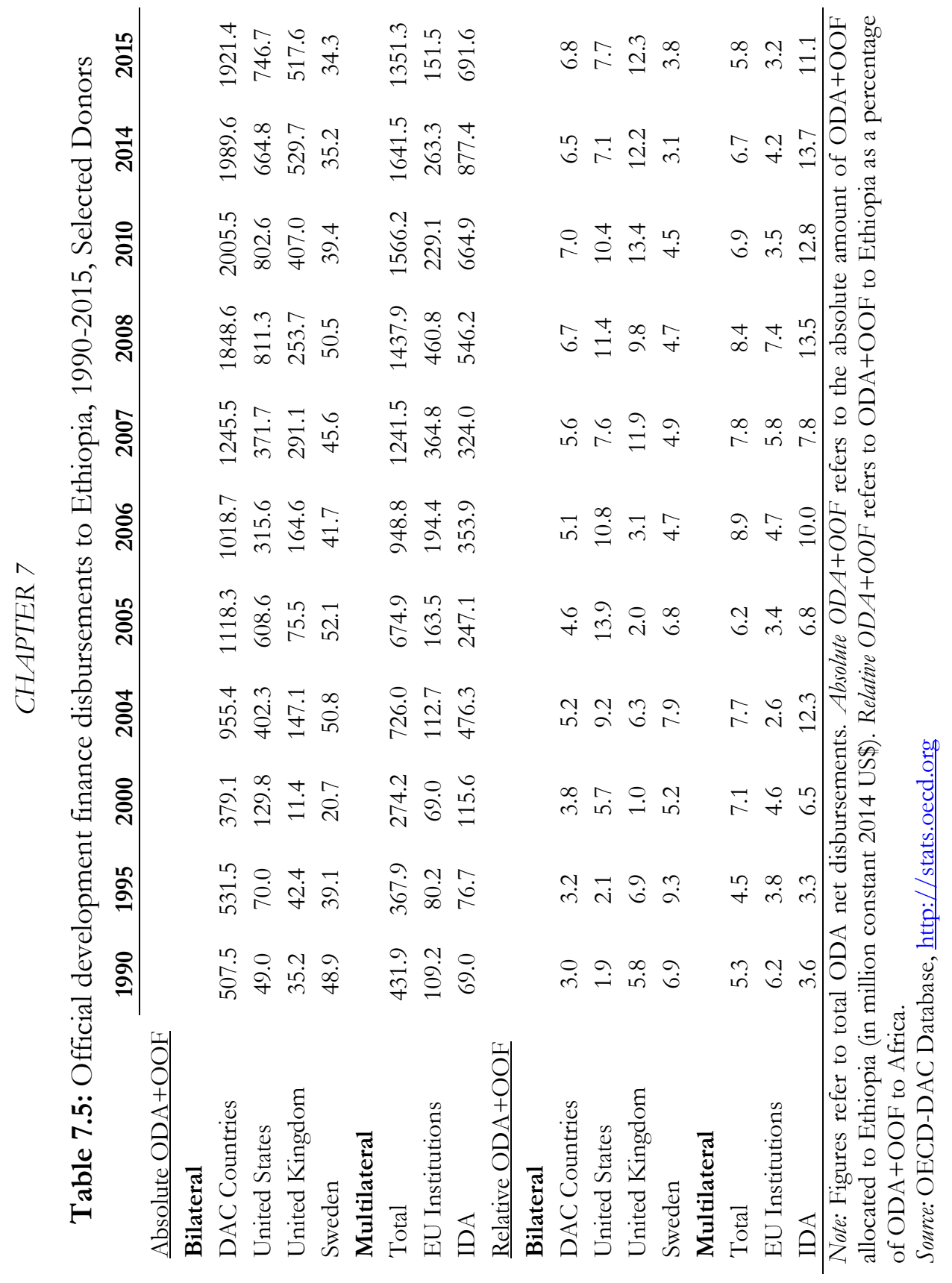

ণ্ণ 
Ethiopia's strong stance against Islamist militant groups has partly contributed to Ethiopia's donor darling status. Linking this "reversion to the Cold War pattern” (Buzan, 2006; Fleck \& Kilby, 2010) process back to the game-theoretic model, I argue that the immediate post-Cold War era in the early and mid-1990s can be seen as a period where the Western donor community was strongly committed to good governance reforms $(G=1)$ as the strategic interests were rather minimal $\left(I_{T}=0\right)$. The post $9 / 11$ era, however, can be interpreted as a scenario where strategic concerns increasingly shaped aid policies by Western donors (i.e. $I_{T}=1$ for a strategic Western donor but $I_{T}=0$ for a non-strategic Western donor). This trend and pattern is discussed in Section 7.4.1.3. As stated in Proposition 3a, the amount of aid money a strategic donor like the United States or the United Kingdom has to pay to induce good governance reforms is higher than for a non-strategic donor country like Sweden.

Figure 7.5 provides an overview of U.S., U.K. and Swedish total ODA net disbursements to countries located in the Horn of Africa between 1990 and 2014. Between the mid-1990s and early 2000s, Ethiopia became the most important recipient of U.S. foreign aid, together with Sudan. The U.S. government reduced foreign aid disbursements to Ethiopia immediately after Ethiopia's general election of 2005. One year later, foreign aid to Ethiopia rebound and rose significantly in the late 2000s until Ethiopia became the major recipient of U.S. foreign aid in the Horn of Africa region again in 2010. Overall, the United States are still the largest bilateral donor in Ethiopia and Ethiopia still ranks, together with South Sudan, as most important recipient country for the United States in the Horn of Africa.

The picture is very similar for the United Kingdom. Ethiopia was already a main recipient of U.K. development assistance in the mid-1990s. Since the early 2000s, U.K. bilateral foreign aid to Ethiopia rose gradually. While the British government reduced its foreign aid disbursements to Ethiopia in 2005, we see a strong rebound from 2006 onwards. Similar to U.S. bilateral aid, U.K. bilateral aid to Ethiopia dropped since 2011. Nevertheless, the United Kingdom still ranks as second largest bilateral donor in Ethiopia, behind the United States. 
Figure 7.5: Foreign Aid to the Horn of Africa, 1990-2014, Selected Donors

\section{United States of America}
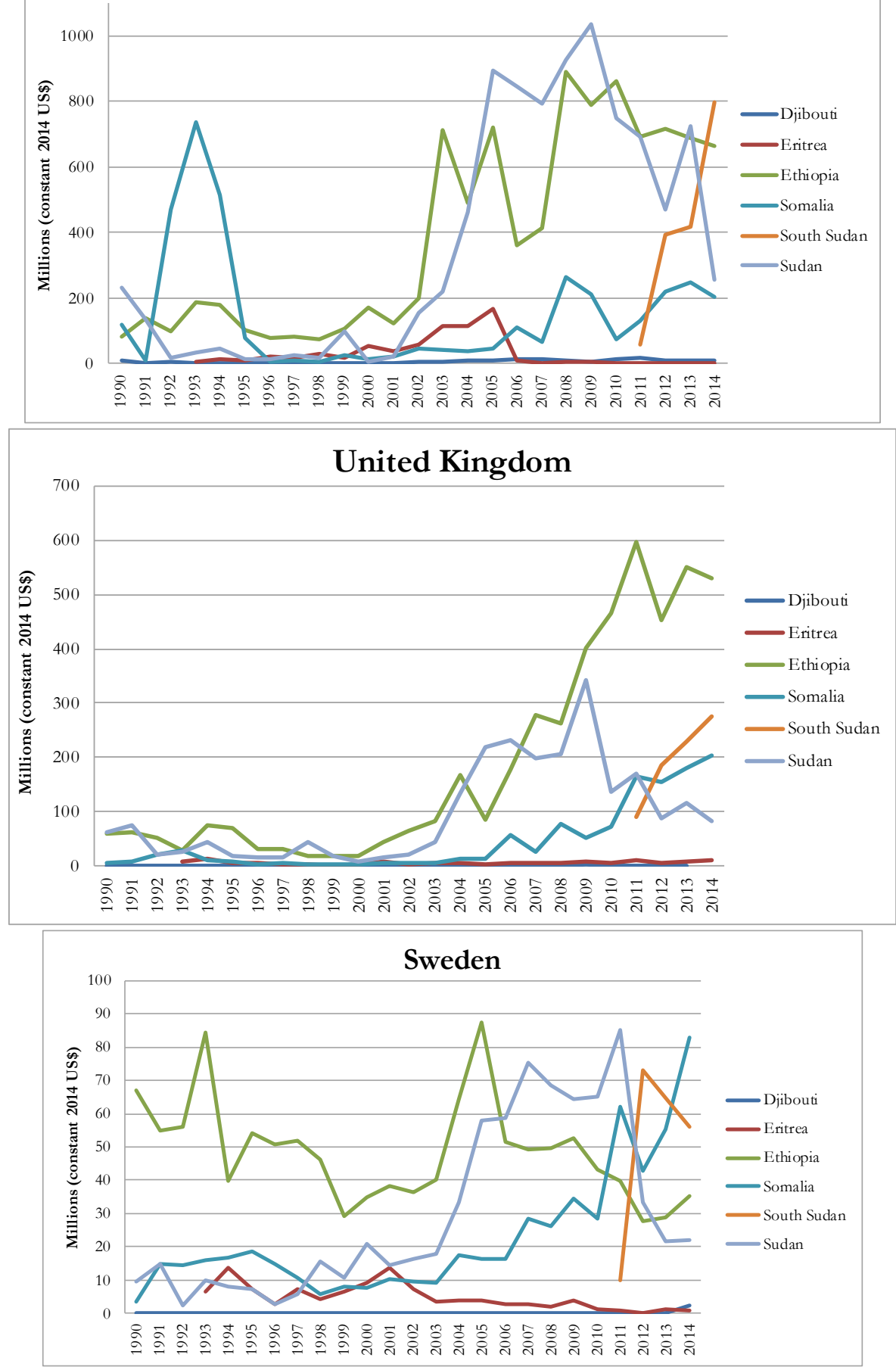

Source: Authors' own calculations based on OECD-DAC Database, http://stats.oecd.org 
Ethiopia, in turn, is not only the largest recipient of U.K. bilateral development assistance in the Horn of Africa, but the country has also been the largest recipient of British bilateral foreign aid in Africa since 2009.

Sweden is currently considered the largest DAC provider in terms of ODA as a percentage of GNI (1.4 percent in 2015), and the sixth largest by volume (OECD, 2016). Ethiopia was by far the largest recipient of Swedish bilateral foreign aid between 1990 and 2005. After the Ethiopian general election in 2005, however, Swedish bilateral development assistance dropped instantaneously by almost a half. As Ethiopia has increasingly adopted an authoritarian development model, Swedish foreign aid gradually declined. As of 2014, Ethiopia is no longer the main recipient of Swedish bilateral aid in the Horn of Africa region.

In line with Propositions 3a and 3b, non-strategic donor countries like Sweden are no longer primary donor countries in Ethiopia as their aid allocation is affected less by geostrategic concerns and more by domestic political factors, such as the return of authoritarian politics in Ethiopia. Strategic donor countries like the United States or the United Kingdom, in turn, did not reduce their development assistance to Ethiopia, both in absolute and relative terms, as they view Ethiopia as a strategic partner in the Horn of Africa region.

The re-emergence of the primacy of geostrategic considerations in the conduct of Western foreign policy is especially prominent in the Horn of Africa. With the emergence of the good governance agenda after the end of the Cold War, Western donor countries have significantly increased their democracy and governance aid (DGA) throughout the world, most notably in Africa - both in absolute terms and relative to other categories of aid (see Chapter 2). ${ }^{164}$ Between 1990 and the late 2000s, total DGA (both bilateral and multilateral) to Africa quadrupled (Dietrich \& Wright, 2013).

This general pattern, however, stands in stark contrast to the sectoral distribution of bilateral foreign aid to Ethiopia. Table 7.6 shows the yearly average amount

\footnotetext{
164 DGA programs include projects related to elections, human rights, civil society, woman's rights, political parties, rule of law, governmental reform, independent media and free flow of information (Carothers, 1999).
} 
of democracy and governance aid (DGA) allocated to Ethiopia by major DAC donors between 2002 and 2014. The amount of DGA as a percentage of total aid has been fairly low by the majority of DAC donors throughout the entire period.

Table 7.6: Yearly Average Foreign Aid and Democracy Assistance, 2002-2014, Selected Western Donors

\begin{tabular}{|c|c|c|c|c|c|}
\hline ETHIOPIA & $\begin{array}{l}\text { Total } \\
\text { aid } \\
(2014 \\
\text { million } \\
\text { US\$) }\end{array}$ & $\begin{array}{c}\text { Democracy } \\
\text { aid (2014 } \\
\text { million } \\
\text { US\$) }\end{array}$ & $\begin{array}{l}\text { Democracy } \\
\text { aid / total } \\
\text { aid }(\%)\end{array}$ & $\begin{array}{l}\text { Support for } \\
\text { democratic } \\
\text { government / } \\
\text { democracy aid } \\
(\%)\end{array}$ & $\begin{array}{l}\text { Support for } \\
\text { effective } \\
\text { government / } \\
\text { democracy aid } \\
(\%)\end{array}$ \\
\hline \multicolumn{6}{|l|}{$2002-2004$} \\
\hline DAC Donors & 1044.4 & 35.8 & 3.4 & 54.5 & 45.5 \\
\hline US & 488.4 & 3.3 & 0.7 & 70.1 & 29.9 \\
\hline EU & 480.8 & 26.3 & 5.5 & 50.3 & 49.7 \\
\hline United Kingdom & 91.2 & 2.9 & 3.2 & 66.3 & 33.7 \\
\hline Sweden & 42.5 & 1.5 & 3.6 & 12.4 & 87.6 \\
\hline \multicolumn{6}{|l|}{2005} \\
\hline DAC Donors & 1422.3 & 59.0 & 4.1 & 58.6 & 41.4 \\
\hline US & 802.5 & 9.6 & 1.2 & 60.6 & 39.4 \\
\hline $\mathrm{EU}$ & 532.0 & 43.4 & 8.2 & 57.3 & 42.7 \\
\hline United Kingdom & 84.0 & 15.4 & 18.3 & 89.9 & 10.1 \\
\hline Sweden & 63.3 & 5.6 & 8.9 & 4.2 & 95.8 \\
\hline \multicolumn{6}{|l|}{ 2006-2014 } \\
\hline DAC Donors & 1777.1 & 64.6 & 3.6 & 42.5 & 57.5 \\
\hline US & 676.5 & 4.5 & 0.7 & 52.1 & 47.9 \\
\hline $\mathrm{EU}$ & 896.7 & 51.8 & 5.8 & 38.1 & 61.9 \\
\hline United Kingdom & 407.0 & 14.5 & 3.6 & 61.8 & 38.2 \\
\hline Sweden & 41.9 & 8.2 & 19.7 & 1.8 & 98.2 \\
\hline
\end{tabular}

Note: Figures refer to total ODA gross disbursements. Data is retrieved from the OECD Development Assistance Committee Credit Reporting System. Total aid includes both bilateral and multilateral development assistance. "Democracy assistance" refers to data reported as "Government and Civil Society"; Support for "democratic government" refers to data reported as Legal and judicial development, democratic participation and civil society, elections, legislature and political parties, media and free flow of information, human rights, women's equality organizations and institutions; Support for "effective government" refers to data reported as public sector and administrative management, public finance management, decentralization and anti-corruption. DAC donors have only reported their aid to civil society since 2002 onwards.

Source: OECD-DAC Database, http://stats.oecd.org

In the early 2000s, DGA aid as a share of total aid varied between 0.7 percent for the United States and 5.5 percent for the European Union. In the run-up to 


\section{CHAPTER 7}

the general election year 2005, the DGA share rose for a majority of DAC donors. There are, however, huge variations. The United Kingdom, for example, allocated 18.3 percent of its total bilateral aid to democracy and governance projects in 2005. The U.S. contribution, in contrast, amounts to only a meagre 1.2 percent of its total bilateral aid budget in the same year.

During the return of electoral authoritarianism in the late 2000s, the DAC donor group as a whole increased its total aid to Ethiopia. Several bilateral donors like the United States and the United Kingdom, however, decreased their DGA in absolute terms and relative terms. The data presented above therefore highlight the return of strategic interests among the Western donor community, which implies that $I_{T}=1$. One prominent exception is Sweden. While Sweden reduced its yearly average absolute amount of total aid to Ethiopia after 2005, the amount of DGA rose both in absolute and relative terms.

Ethiopia has remained a donor darling for the United States and the United Kingdom, while Swedish foreign aid declined significantly after 2005. As Proposition $3 \mathrm{~b}$ makes clear, donor countries with strong strategic motivations increase their total foreign aid amount but decrease the share of democracy assistance in authoritarian recipient countries if strategic interests outweigh developmental concerns. In contrast, a non-strategic donor country like Sweden finds it easier to uphold its commitment capacity and can punish authoritarian recipient countries by decreasing its total foreign aid amount while raising the share of democracy assistance. While the Western donor community maintained a critical position towards Zenawi's increasingly authoritarian mode of governance, the strategic donor was still willing to provide aid in other specific sectors as the rise in total aid between 2005 and 2014 testifies. By "judging Ethiopia either as 'not mature enough' for parliamentary democracy, fair and free elections or the rule of law (even according to Ethiopia's constitution), or not realistically seeing themselves as having the leverage required to influence events" (Abbink, 2011, p. 234), several donors were able to extend their regional security agenda at the Horn of Africa.

Summarizing, while China's strengthening ties with the Ethiopian recipient government in the early 2000s can explain the move from the one donor-one recipient model to the two donor-one recipient model, the aftermath of 9/11 and the fight against terrorism explain the increasing prevalence of geostrategic 


\title{
CHAPTER 7
}

motives among the Western donor community. The competing donor model, described in Section 7.4.2.1, in which geostrategic motivations significantly affect the aid delivery of both the traditional and the new donor, has emerged in the mid-2000s and prevailed until the present day, whereby the existence of a non-strategic donor country like Sweden is the prominent exception to the rule.

\subsubsection{The Role of the Ethiopian Government}

Meles Zenawi's charismatic leadership and skilful rhetoric in positioning his country as the West's key ally on "the war on terror" contributed significantly to Ethiopia's status as donor darling among the Western donor community. Zenawi was

\begin{abstract}
"a master player of the diplomatic game and he managed both to charm the international community and to use it for Ethiopia's benefit. (...) He was useful to the Americans [and other Western nations] but he certainly got more from them in terms of economic aid and diplomatic support than he provided them with" (Prunier, 2015b, p. 435).
\end{abstract}

The Ethiopian government belonged to a small group of African regimes that sought "to persuade donors that threats to the African state's national security also represent threats to donors' security" (Fisher \& Anderson, 2015, p. 148). While the Horn of Africa is still haunted by the Somali civil war, disputes along the Eritrean border, migration and displacement flows as well as drought and famine, Ethiopia has positioned itself as the most stable and promising entity in the region. Meles Zenawi was very conscious of Ethiopia's geopolitical position: "Its position as a pillar of relative stability in an otherwise unstable part of the world, as well as its proximity to the Middle East, [made] it an important strategic ally for several Western capitals" (Furtado \& Smith, 2009, p. 153).

Zenawi realized that after $9 / 11$, Ethiopia was a too important partner for the Western donor community in its fight against terrorism. The EPRDF regime has deliberately used its important geopolitical position to attract larger amounts of development assistance - but less democracy assistance as part of total development assistance - through positioning itself as a bulwark against terrorism and as a government committed to poverty reduction. 
Furthermore, the Ethiopian government successfully strengthened its economic and political relationships with non-traditional donors such as China in order to diversify its foreign aid sources. Based on the Chinese diplomatic principle of non-intervention in domestic political affairs, Zenawi viewed China's development finance without any strings attached as a key instrument for promoting economic growth and retaining a firm grip on political power, especially when political reforms imposed by the Western donor community can threaten regime survival in the short run. Beijing's aid to Ethiopia has decreased the pressure for the Ethiopian government to undergo good governance reforms as the likelihood that the traditional donor will enforce good governance reforms $(G=1)$ has decreased after the entry of China.

By officially resisting democratization and good governance reforms more broadly from the early to mid-2000s onwards, the Ethiopian government knew that it could receive more money from the Western donor community, as the commitment capacity by the Western donor community was severely undermined by the entry of China into the foreign aid game, but also due to the re-emergence of geostrategic interests on the part of the DAC donors.

\subsection{Concluding Remarks}

This chapter provided a game theoretical approach to the recent entry of China into the foreign aid game, where the interaction between a traditional donor, a non-traditional donor and the recipient government is modelled as a dynamic game where all players take actions in multiple periods. The testable implications derived from the game theoretical model were then applied to the country of Ethiopia using both secondary data and qualitative evidence for the post-Cold War era. The validity of the theoretical predictions vary, and the propositions derived from the model work during different periods. In the Ethiopian context, the one donor-one recipient model is most appropriate as a way to analyse the situation during the 1990s, while the model of competing donors is more relevant from the 2000s onwards. During the early and mid-1990s, the Western donor community was characterized by a strong capacity to commit to good governance reforms as modelled in Section 7.4.1.2 and formulated in Proposition 2b. During the late 1990s and early 2000s, however, the first signs of a weakening commitment to good governance reforms became evident. As a 
result, the game started to be much more applicable to Proposition 1 and the surrounding theory discussed in Section 7.4.1.1.

It must be emphasized that the game becomes even more applicable in an environment where the recipient government deeply cares about regime survival and perceives political reforms demanded by the donors as a threat to the current political status quo. In the eyes of the Ethiopian government, what was at stake during the early and mid-1990s was not primarily political survival, but rather gaining domestic legitimacy on developing strategies and programs for economic growth and poverty reduction. However, from the early-2000s onwards, the recipient government became increasingly concerned about its political survival as the power struggle within the EPRDF in the early 2000s and the aftermath of the 2005 general elections can testify (see also Chapter 6 again).

In the early to mid-2000s, coinciding with China's entry into the foreign aid game, there were clear signs that the aid allocation by the traditional DAC donors was increasingly driven by geostrategic motives which further weakened the Western capacity to commit to good governance reforms (Proposition 3a and Proposition $3 \mathrm{~b}$ ). China's strengthening economic ties with Ethiopia during the early and mid-2000s increasingly challenged the hegemonic status of the Western donor community in Ethiopia. Around the same time, geostrategic motives increased significantly among the traditional DAC donor community. Thus, the competing donor model with a lack of a credible commitment strategy on the part of the traditional donor presented in Section 7.4.2.1 is the most applicable game in the Ethiopian context from the early and mid-2000s until now.

The main policy lessons learnt from this chapter are fourfold. First, if the policy threat by the traditional donor to withdraw foreign aid is not credible, the recipient government has even less incentives to implement political reforms that could threaten regime survival. Second, if strategic interests of the traditional donor become too important, the effectiveness of political conditionality is reduced even further. It is more important for a traditional strategic donor (than for a traditional non-strategic donor) to develop a credible commitment to the good governance reform package. Third, the traditional donor needs to offer more foreign aid to induce good governance reforms once a non-traditional donor enters into the foreign aid game. Fourth, the commitment strategy is not as valuable for the traditional donor when the non- 


\section{CHAPTER 7}

traditional donor is in the game. In fact, the entrance of a non-traditional donor is particularly harmful for a traditional donor that has been able to develop a credible commitment strategy.

The compromising on the good governance agenda by the Western donor community and the decreasing relative importance of democracy assistance in the case of Ethiopia highlights the re-emergence of the primacy of geopolitical considerations in the conduct of American and (to some extent European) foreign policy in the Horn of Africa. The entry of China into the foreign aid game strengthened the bargaining power of the Ethiopian government vis-à-vis the Western donor community even further. This, in turn, forced Western donors to raise the amount of development assistance in order to enforce compliance with political conditionality. Second, China's entry into the aid game led to an increasing resistance by the Ethiopian government to adhere to political conditionality, which has made it harder for Western donors to push for good governance reforms.

While the game theoretical model provides a theory of how the entrance of a new donor into the foreign aid game alters the aid negotiation strategies between a traditional donor and a recipient government, there is one important limitation: I do not formally analyse the relationship between regime survival and domestic policy factors. As the specific set-up of the theoretical model limits the analysis to the aid game between two competing donors and a recipient government, the model does not answer the question of how domestic policy factors, such as challenges to government survival from other key domestic players (e.g. individual members of the ruling party, opposition groups, mass movements, or civil society), influence the effectiveness of political conditionality by the Western donor community and the aid negotiation strategy by the recipient government. A theoretical analysis of how the strategic game between the recipient government and other key actors in the domestic policy process affects the choices and strategies in the two donor-one recipient model is therefore a promising avenue for further research 


\section{CHAPTER 8}

\section{CONCLUSION}

"The evil that is in the world always comes out of ignorance, and good intentions may do as much harm as malevolence, if they lack understanding." - Albert Camus, 1947

(1913-1960)

French philosopher, author, and journalist Nobel Prize in Literature, 1957 Citation is quoted from "The Plague"

"Give a man a fish and you feed him for a day. Teach a man to fish and you feed him for a lifetime" - Chinese proverb 
This dissertation has discussed the dynamics of traditional and non-traditional development finance on the African continent using an interdisciplinary approach fusing knowledge and insights from several social science disciplines (economics, political science, international relations, history, sociology and anthropology). The thesis sought to understand the consequences of strengthening Sino-African economic and political ties for the Western donor community and African recipient governments. The three major research questions that this dissertation addressed were:

- What is the role of both Western and Chinese foreign aid in explaining current economic, political and institutional developments in Africa?

- To what degree has China's economic embrace of Africa the potential to change the international development finance architecture?

- To what extent has the entry of China in the international development finance game increased the bargaining power of African recipient governments?

This dissertation has used both quantitative and qualitative research methods and provided both macro- and micro-level perspectives to address the aforementioned research questions. One major objective of this academic research was to provide novel theoretical and empirical results from which policy implications can be derived.

The final chapter of this dissertation is structured as follows. The next section will briefly summarize the main findings again. Based on the results presented in the previous chapters, a few policy implications will be outlined. Finally, the chapter will provide some concluding thoughts.

\subsection{Summary of Findings}

Part A of the dissertation was comprised of three chapters (Chapter 2, 3 and 4). Chapter 2 presented an analysis of long-run changes in the allocation of Western aid both globally and in Africa, along with estimates of the global sectoral allocation of Chinese aid. A similar analysis was also applied to China's FDI and international trade. While previous literature has predominantly attributed China's economic embrace of Africa to domestic factors, this chapter argued that the sectoral distribution of Beijing's foreign aid - and partly FDI - was also 


\section{CHAPTER 8}

affected by changes in the patterns of Western aid and investment flowing to the African continent. The chapter provided quantitative evidence for long-run trends, switches and breaks in Western development assistance. China's development finance typically flows into Africa's physical infrastructure and productive sectors of agriculture and manufacturing, filling the vacuum which emerged when Western financial flows shifted to other activities, most notably capacity building and good governance reforms.

Chapter 2 provided empirical support for scholars that attribute China's rising contemporary engagement with Africa to Beijing's need to access and secure natural resources (Alden, 2005; Moyo, 2012; Naidu \& Davies, 2006; Taylor, 2006a). According to the estimations presented in Chapter 2, more than half of China's FDI in Africa is concentrated in oil- or mineral-rich countries such as Nigeria, South Africa, Zambia, Angola, Sudan and more recently the Democratic Republic of Congo. Chapter 2 also showed that Chinese trade patterns in Africa are very similar to those of the Western World. Though trade between China and Africa is often labelled as South-South trade, its structure very much resembles North-South trade patterns. Africa's exports to their leading trading partners consist mainly of exports of natural resources. But this is only half the story. China's objectives in Africa are much broader as they go beyond the thirst for oil. Ethiopia, a resource-scarce country, is deliberately chosen as case study, to highlight how China's grand strategy in Africa is also increasingly driven by diplomatic, political and economic interests (see the findings in Chapter 5 and Chapter 6). China views Ethiopia as one of its most important strategic partners in Africa, even though the country is resource-scarce in relative terms.

Chapter 3 aimed to shed light on China's development finance activities in Africa using quantitative estimation techniques. More specifically, the chapter empirically investigated whether African authoritarian regimes receive more Chinese development assistance than democratic ones. In order to answer this question, four different measures of democracy/autocracy were used which allowed me to check the extent to which my results depended on the specific indicator chosen. The OLS results suggested that Chinese development finance does not systematically flow to more authoritarian countries, controlling for strategic, economic, political, institutional and geographic confounding factors. The results were not driven by the specific democracy indicator used in the analysis. The findings remained virtually unchanged when the sample was 


\section{CHAPTER 8}

reduced to Sub-Saharan Africa only. Furthermore, the results survived several robustness checks, including FE, RE and instrumental variable estimation.

Chapter 4 empirically examined the determinants of bureaucratic capacity in contemporary Africa connecting the aid-governance literature with historical and anthropological work on African state formation. The results showed a positive and statistically significant impact of precolonial centralisation on levels of bureaucratic quality in Africa, from the late-1990s onwards. Before the late1990s, however, there is no such relationship. The results suggested that negative effects of aid dependence on changes in bureaucratic capacity weaken or even disappear, once it is controlled for precolonial centralisation. As the colonial interlude is becoming more distant, the influence of precolonial political institutions on modern bureaucratic capacity is reasserting itself. The role of aid turns out to be less important than suggested by either its critics or its supporters. The empirical findings presented in Chapter 4 thus highlight the historical legacy of the precolonial bureaucratic state in Africa, and provide further evidence for the importance of precolonial centralisation in our understanding of present day economic and political developments on the continent.

Like Part A, Part B was comprised of three chapters (Chapter 5, 6 and 7) focusing on Ethiopia as a country case study. Chapter 5 provided a historical perspective of Ethiopia's position in the international aid game at the Horn of Africa during the Cold War era. It discussed the historical interrelationships between the international donor community and the two successive Ethiopian recipient governments, the imperial government under Haile Selassie (19411974) and the communist government under Mengistu Haile Mariam (19741991).

The main lessons of Chapter 5 were threefold: First, the countries of Ethiopia and Somalia became classic examples of pawns in Cold War politics. The two superpowers, the United States and the Soviet Union, switched sides to support countries which they had been furnishing assistance previously at the apex of the Cold War. Second, recipient governments can use international development assistance as a tool to implement as much of their policy agenda as possible. Both the imperial and communist governments of Ethiopia aimed at maximizing external financial resources while minimizing the amount of loss of sovereignty over the policy agenda. Third, the unprecedented 1984-86 famine in the Horn 


\section{CHAPTER 8}

of Africa region convincingly highlights the moral dilemma that the international donor community faced when assisting non-democratic recipient states. Furthemore, Ethiopia's history has provided two valuable lessons for the successive Ethiopian government during the post-Cold War era: first, lack of economic development and widespread death caused by famine and starvation eventually led to the demise of both Ethiopian governments during the Cold War era. Second, the large financial and military dependence of both the imperial government and the Marxist government on one major ally (United States and Soviet Union, respectively) during the Cold War contributed to the overthrow of both governments.

Chapter 6 examined the evolution of the international development finance game between Ethiopia and the donor community since the end of the Cold War accounting for the entry of China. The main lessons of this chapter were threefold: First, Ethiopia provides a good example for a recipient government with a large degree of control and ownership over its policy agenda. Second, the Western threat to reduce or withhold aid is not credible if the recipient country is economically and strategically valuable for the Western donor community. Third, China's entry into the development finance game has significantly increased the Ethiopian government's bargaining power in the aid negotiation process even though its bargaining power was already high before China's increasing influence in Africa. Using quantitative data, this chapter provided empirical evidence for Ethiopia's impressive economic growth rates and significant improvements in health and education. Chapter 6 also provides empirical evidence that the strong economic performance went hand in hand with a return of authoritarian politics as the decline in both democratic accountability and press freedom testifies. Evidence regarding Ethiopia's good governance suggests that both deteriorations and improvements can be observed depending on the good governance dimension chosen.

Chapter 7 used a game theoretical approach to explain the recent entry of China into the foreign aid game in Ethiopia by building a simple game theory model complemented by a historical narrative. More specifically, the game theoretical model discussed how the entry of an influential non-DAC donor affects the traditional donor-recipient relationship. The testable implications derived from the game theoretical model were then applied to the country of Ethiopia using both secondary data and qualitative evidence for the post-Cold War era. The key 


\section{CHAPTER 8}

lessons from Chapter 7 were fourfold: First, if the policy threat by the traditional Western donor to withdraw foreign aid is not credible, the recipient government has even less incentives to implement political reforms that could threaten regime survival. Second, if strategic interests of the traditional Western donor become too important, the effectiveness of political conditionality is reduced even further. It is more important for a traditional Western strategic donor (than for a traditional non-strategic donor) to develop a credible commitment to the good governance reform package. Third, traditional Western donor countries need to offer more foreign aid to induce good governance reforms once a nontraditional donor like China has entered into the foreign aid game. Fourth, the commitment strategy is not as valuable for the Western traditional donor when a non-traditional donor like China competes with the West. In fact, the entrance of China into the foreign aid game is particularly harmful for a traditional Western donor that has been able to develop a credible commitment strategy.

\subsection{Policy Implications}

\subsubsection{The Role of Foreign Aid in National Development}

From the onset of the post-Cold War era, the international development community viewed the promotion of political development (in the form of good governance, capacity building, human rights strengthening, etc.) and poverty reduction in the developing world as the two most fundamental challenges. After an initial phase of donor fatigue in the 1990s, the international development community viewed development assistance as a means to promote economic, political and social progress in the developing world.

Aid optimists have argued that, on average, foreign aid has had a positive impact on economic growth and development. The response by aid pessimists is that aid has had little or no effect and could actually undermine growth and development. While the positions brought forward by the two camps could not be more extreme, their views share one similarity: both aid optimists and aid pessimists give a large weight to foreign aid in the national development of recipient countries. The results presented in Chapter 4 suggest that the role of foreign aid turns out to be less important than suggested by either its critics or its supporters. Chapter 5 highlights the limited role of aid in preventing and 


\section{CHAPTER 8}

tackling several root causes of extreme poverty, when local conditions are hostile to development as in Ethiopia. Some of the results presented in this thesis echo the observation made by Nancy Birdsall, Dani Rodrik and Arvind Subramaniam in 2005:

"Development is (...) largely determined by poor countries themselves, and outsiders can play only a limited role. Developing countries themselves emphasize this point, but in the rich world it is often forgotten." (Birdsall, Rodrik, \& Subramanian, 2005, p. 136-137)

While it remains crucial to improve the effectiveness of foreign aid, there exists the danger that policymakers, government institutions and international aid agencies greatly overestimate the impact of foreign aid on poverty reduction, political and economic development. According to the author's knowledge, there does not exist any example where foreign aid can replace sound policy and good economic management within a recipient country for successful development. Foreign aid, however, can play a positive role in promoting conditions for self-reliant growth in a recipient country when it facilitates a coherent policy agenda chosen by the recipient government.

The ultimate aim of the international donor community should be a world in which developing countries will no longer need foreign aid and can be selfreliant. Self-reliance is essential to long run economic development. Making developing countries less dependent on aid, however, remains a significant challenge as donor countries face a trade-off:

"The more they channel their aid to where they believe it can make a more immediate, and often direct, impact on the lives of those in need, the less aid is available to be used to address many of the wider, less immediate and more systemic constraints which impede or hold back faster longterm development. This will mean prolonging the day when the recipient will no longer need aid; and it will probably result in donor having to provide more aid over time than if aid had been deployed differently. (...) $[F]$ ocusing aid on meeting immediate needs can even undermine the efforts of recipients to accelerate the process of wealth creation." (Riddell, 2007, p. 377-378) 


\subsubsection{The Hippocratic Oath of Development Finance: "Do no harm"}

While foreign finance can only be considered a secondary driver of national political and economic development, it can easily harm development of recipient countries in the short-run, medium-run and long-run if it does not abide by the Hippocratic Oath, a major guideline for development policy: "Seek to do good, but do no harm."

Chapter 2, 6 and 7 lend support to the claim that China's economic embrace of the African continent does not only provide opportunities for the African economies, governments, and civil society at large, but also involves significant risks and challenges. A significant part of China's development assistance in Africa is tied to the purchase of Chinese goods and services and to the requirement of using Chinese contractors for Chinese-funded infrastructure projects. Another form of tied aid is China's "Angola model" which involves financial assistance and the funding of construction projects in exchange for access to natural resources such as oil and gas.

The distribution of China's investment in Africa is highly skewed as the lion share of Chinese FDI targets the natural resource sector, even though Chinese investment also significantly extends to other sectors such as construction, manufacturing or financial services (Chapters 2, 4 and 6). The geographic destination of China's investment remains largely concentrated (South Africa, Nigeria, Zambia, Algeria, the Democratic Republic of Congo and Sudan). With a few exceptions, Chinese investment has mainly focused on extractive industries, a sector in which the prospects for local knowledge transfer and industrial development potential are low and in which investment can have a potential harmful impact on the natural environment

Chinese FDI, however, is believed to have its largest economic impact in the manufacturing sector as it could help to promote structural transformation and economic development through Africa's integration into global value chains, knowledge spillovers, employment creation and productivity gains. A majority of African countries, however, has failed to attract significant amounts of both Western and Chinese FDI, due to the existence of domestic bottlenecks in the local economies such as scarcity of capital, low infrastructure quality, lack of 


\section{CHAPTER 8}

regional integration, political uncertainty, corruption and the weak capacity of public institutions.

While strengthened trade relations with China and other emerging economies have enabled African countries to diversify their export destinations, natural resource-rich African exporting nations are exposed to a greater risk of commodity price fluctuations and may face lower incentives to diversify their economic and trade structure therefore inhibiting structural change.

Chapter 6 discusses to what extent the Ethiopian government has played or can play a (more) proactive role to guard the Ethiopian civil society and economy against the widely cited challenges of Chinese development cooperation, namely low quality infrastructure, lack of corporate social responsibility in business practices, poor labour conditions, relatively low social and environmental standards, little employment opportunities for the local workforce and intensified competition.

Both Chapter 3 and Chapter 4 dealt with very specific research questions to what extent Western and Chinese development assistance abide by the Hippocratic Oath. Chapter 3 analysed whether Chinese official foreign finance to Africa can be regarded as "rogue aid". I did not find a strongly negative and highly statistically significant relationship between the autocracy level of a recipient country and Chinese official finance. As a result, the claim that Chinese development assistance can be equated with "rogue aid" is ungrounded.

Chapter 4 looked at the relationship between Western aid dependence and bureaucratic state capacity of African recipient countries over the time period 1984-2014. The empirical results of this study suggest that the negative impact of Western foreign aid on bureaucratic quality has been greatly overstated, especially with regard to the post-Cold War era. These findings are very encouraging as they suggest that the detrimental consequences of foreign aid on bureaucratic state capacity have become less pronounced the further we move away from the Cold War period. The reason why a small but still partly significant negative impact of foreign aid exists during the Cold War era can be attributed to the importance of geostrategic objectives for delivering development assistance during the Cold War Era. While foreign aid certainly also served both developmental and humanitarian ends during that period (Lumsdaine, 1993; Noel \& Therien, 1995), most of Western foreign aid during 


\section{CHAPTER 8}

the Cold War era served as a tool to pursue national interests (Alesina \& Dollar, 2000; McKinlay \& Little, 1977, 1978a, 1978b; Morgenthau, 1962).

The Ethiopian case study that looks at the foreign aid game between the United States, the Soviet Union and the Ethiopian government during the Cold War in Chapter 5 is a testament to the potential damaging effects of foreign aid (i) if delivered purely for strategic reasons and (ii) if delivered unconditionally to authoritarian recipient governments. During the 1984-86 famine, the humanitarian response was slow as the Western world was initially hesitant to provide humanitarian assistance to a Marxist government. After the eventual delivery of humanitarian assistance, it often became, unintentionally, an instrument of conflict and for political survival of authoritarian elites as well. As Chapter 5 has shown, unconditional development finance flowing to the Ethiopian government contributed to prolonged military efforts through the purchase of weapons and to human rights abuses (in the resettlement programs, for example) and to the prolonged life of the Derg regime.

During the post-Cold War era, the international aid agenda underwent significant changes. On the one hand, foreign aid became "governancefocused", as Western aid agencies and international organizations increasingly shifted away from unconditional aid flows towards political conditionality-based foreign aid in the post-Cold War era. On the other hand, the foreign aid agenda became increasingly "poverty-focused", exemplified by the launching of the MDG agenda with its clear development objectives. The Ethiopian case study clearly shows that the international aid agenda is once again at crossroads and could undergo considerable changes in the future. While the Ethiopian government has made significant progress towards poverty reduction, the political system has become more authoritarian over the course of time.

The results presented in Chapter 6 cast significant doubt on the effectiveness of Western political conditionality in the delivery of foreign aid, if the recipient country is either economically or strategically valuable (or both) to the donor community. Both the quantitative and qualitative findings in Part B suggest that foreign aid has remained a crucial policy tool of donor countries until the present day which lends support to Morgenthau's (1962) view of foreign aid as crucial foreign policy tool. The Ethiopian case study in Chapter 6 and Chapter 7 also shows how strategic motivations still exist in the post-Cold War era thereby 


\section{CHAPTER 8}

supporting the empirical findings at the global level (Dreher, Nunnenkamp, \& Thiele, 2008; Faye \& Niehaus, 2012; Kilby, 2011; Kuziemko \& Werker, 2006; Nunn \& Qian, 2014).

Ethiopia remains a 'donor darling', even though the country has experienced a return to authoritarian politics. While Ethiopia's geo-strategic importance in the Horn of Africa is certainly one major reason for its donor darling status, one other major reason why development assistance and foreign finance is forthcoming is the Ethiopian government's strong development agenda, its commitment to poverty reduction and economic growth. Good governance, democracy and human rights can no longer be considered priority issues in the aid negotiation process between Western donor governments/agencies and strategically valuable African countries like Ethiopia.

The entry of China into the game could mark the beginning of a new era of the international aid agenda: supremacy of economics over politics, whereby influential players within the international donor community emphasize the priority of "poverty-focused" development assistance over "governancefocused" development assistance when preparing future aid budgets. Using formal theory, Chapter 7 highlights how authoritarian leaders and political elites more general can gain significant bargaining power, increase their political survival and hold a firmer grip on power through the non-credible commitment of "governance-focused" development assistance by the West, but also through the access of new sources of foreign finance, such as China. With political elites maintaining a strong grip on political power, the civil society space has been significantly curtailed, as the example of Ethiopia shows.

\subsubsection{The Changing Architecture of International Development Finance}

The international development finance architecture has been "shaken by the power shift occurring across the global economy" (Woods, 2008, p. 1205) and is currently undergoing a major transformation. The arrival of new donors (but also investors) from several emerging economies has not only brought new sources of foreign finance to the developing world, but has also broken the Western donor cartel and put an end to the monopoly of ideas in the world of development cooperation. This dissertation has mainly focused on China for 


\section{CHAPTER 8}

reasons already explained in the introduction and the following chapters. The fundamental differences between the Chinese system of development finance (and those of other emerging economies) and the development finance delivery approach by the traditional donors could have a strong impact on the future structure of the international development finance architecture.

Chinese aid funding is embedded into a wider foreign policy framework characterized by the non-interference in internal affairs and Beijing's upholding of political equality with recipient states. While most of the Western development aid in recent years is characterized by political conditionality and aid selectivity, the bulk of Southern development assistance comes with relatively 'few strings attached'. In contrast to most 'traditional' donors, Southern donors impose little or even no macroeconomic or governance conditionality based on the principles of respect for national sovereignty and non-interference in domestic affairs the eyes of African recipient governments, China's aid with almost no strings attached is viewed as welcome alternative.

Since the end of the Cold War, the international donor community has viewed accountable and transparent government, rule of law, freedom of the press and a vibrant civil society as necessary preconditions for successful poverty alleviation strategies (Burnside \& Dollar, 2000). Current Western development assistance primarily stresses the significance of the ultimate sources of growth, namely (political) intangibles offered by major West actors, for example capacity building, democratization, adherence to human rights principles and good governance. However, as Hyden (2007) reminds us:

"This effort to get not only prices but also politics right is ambitious and controversial but generally pursued in an astonishingly optimistic and assured fashion. This is particularly true in the African context, where socioeconomic conditions make both poverty reduction and improved governance especially difficult. (...) The international community has continued to rely more on business-as-usual than "thinking outside the box." Its efforts have continued to focus on transplanting institutional practices from the West with little attention to their fit in the African context and what timeline is suitable for such an approach. Building bureaucracies through public sector reform or democracy through the rule of law are processes that, in a historical perspective, have taken generations to complete.” (Hyden, 2007, p. 16751-16752) 
While China's development finance is not conditioned on political reforms in the recipient countries, its "no political conditionality" aid could increase the bargaining power for autocratic states and therefore undermine previous Western efforts in the area of capacity building, governance reforms and human rights protection. Chinese aid allocation is demand-driven, i.e., based on requests from recipient country governments. As Chapter 6 has shown, Beijing demands imposes few conditions in the aid and investment negotiation process. As some interview respodents during my fieldwork suggested, China's foreign finance is not primarily driven by development priorities but driven by demands from the recipient government. Moreover, China's approach to deliver foreign finance is often much closer aligned with the development vision and priorities of African leaders as China's negotiation process with recipient governments is often less donor-/investor-driven and more responsive to the demands of African governments, even though needs of Chinese manufacturing firms and SOEs do play an important role. Joaquim Chissano, former President of Mozambique, summarized the preceding and often recurring disagreements between the Western aid community and African recipient governments as follows:

"In most cases foreign aid to Africa did not start in a healthy atmosphere. (...) Therefore, even today many Africans see the relationship with donors as still influenced by the colonial past, where donors 'know' what, how much and when recipients need. Furthermore, the behavior of many donors may suggest the belief that because they provide resources, they have the right to dictate, in practice, the terms of use of that aid, which is done according to their own interests, irrespective of the views of the recipient. Thus, in some cases, the priorities of donors and recipients do not match: an example of this is the construction of infrastructure in Africa, viewed by Africans as a high priority for their sustainable development and systematically dismissed by donors" 165

There exists, however, one major downside of China's demand-driven aid and non-intervention in domestic politics affairs. Chinese unconditional demanddriven aid appears to be more generous in African political leaders' birth regions, which does not hold true for Western development assistance such as World

165 Joaquim Albert Chissano made that statement during the Conference 'New Directions in Development Assistance' at the University of Oxford, UK, on 10 June 2007. 


\section{CHAPTER 8}

Bank lending (Dreher et al., 2014). Demand-driven aid therefore bears the risk of allowing African political leaders to (mis)use Chinese aid and development finance more general for regional favouritism and patronage.

Chapter 1 has provided quantitative evidence for the declining share of Western development assistance in the field of physical infrastructure. Between the early 1960s and the mid-2000s, the share of bilateral and multilateral Western ODA flowing into physical infrastructure, but also productive sectors of recipient economies such as agriculture, manufacturing has steadily declined. The increasing emphasis of Western development assistance on the (political) intangibles of development, such as capacity building and governance, is in marked contrast to Beijing's emphasis on the (economic) tangibles of development such as productivity gains in agriculture, industrial processing, or the refurbishment of physical infrastructure. From the mid-2000s onwards, however, the share of Western development assistance flowing to both physical infrastructure and economic sectors is on the rise again.

Chapter 6 also documents how Western development organizations are slowly starting to rethink part of their own development agenda in Ethiopia and Africa more generally. Even though officials from Western development organizations strongly reject the notin of a causal relationship between China's large scale infrastructure investment in Africa and a Western re-focus on infrastructural development, the interviews conducted during my fieldwork and recent quantitative data on patterns and trends of Western development assistance suggest that both Western donor organizations and international financial institutions have acknowledged that infrastructure can indirectly help humanitarian ends and realize that infrastructure is an important factor for job creation, industrialization and economic development.

Chapter 7 shows that if the policy threat by the old donor to withdraw foreign aid is not credible, the recipient government has even less incentives to implement political reforms that could threaten regime survival. Second, if strategic interests by the old donor become too important, the effectiveness of political conditionality is reduced, even in the absence of China. Third, China's entry into the aid game led to an increasing resistance by the Ethiopian government to adhere to political conditionality which makes it harder for Western development organizations find it harder to push for good governance 


\section{CHAPTER 8}

reforms. The value of committing to good governance reforms by the Western donor community is being significantly reduced due to the entry of a nontraditional donor like China.

\subsubsection{Importance of African Agency in International Negotiations}

This dissertation also highlights the critical role of African agency in the international aid architecture (Chapter 5,6 and 7). How African recipient governments engage with both Western foreign finance providers and those from the Global South is ultimately responsibility of African governments. Similarly, to what extent foreign finance can serve developmental ends ultimately depends on the policy agenda chosen by African recipient governments. The high aid dependence of several African countries is usually associated with limited government agency in the development process

"as the realisation of national governments' policies hinge on external actors' funding priorities and will have to heed conditionality imposed by various financing agencies. Aid dependency, however, should not be understood as an absence of agency. Albeit limited in their financial range of manoeuvre, African states are no mere objects in international politics" (Grimm, 2014, p. 995)

The emerging multipolar world order, however, has opened up both political and economic space for African governments and African civil society (Dietz, Havnevik, Kaag, \& Oestigaard, 2011). The African continent needs to develop a structured and coherent framework at the national, regional and local levels for responding to multipolar globalization. It is often argued that both the West and emerging donors like China know what they want in Africa but Africa does not really know what it wants in this relationship, as the African continent is a fragmented house that "does not augur well for a common position or a united front when engaging with external powers such as China, the US, or the European Union" (Ong'ayo, 2011, p. 272). The fact that Africa remains the most fragmented continent in the world plays an important role in that relationship: A majority of African countries lack national unity and suffer from the legacy of socio-political divisions due to high ethnic fragmentation. Moreover, there exists very uneven and insufficient political and economic cooperation between 


\section{CHAPTER 8}

African states. African markets are fragmented and supply chain networks between neighbouring countries are often underdeveloped.

African engagement with the international community can take several forms. At the country level, African governments have to become proactive and develop their own negotiation strategies when engaging with both the Western and Chinese aid and investment community in order to reap the full benefits of development cooperation. In 2007, Rwandan President Paul Kagame illustrates the importance of African agency in the aid negotiation process:

"To realize our development vision, we in Africa must substitute external conditionality - that is, what the donors tell us to do - with internal policy clarity - that is, knowing ourselves what we need to do and articulating this clearly and consistently to our people and our development partners. ... To achieve these imperatives, we in Africa must adopt a 'development through growth' mindset, as opposed to a 'development through aid' one. This requires that, among other things, we need to learn to 'say no' to donors whenever the priorities do not align with domestic objectives and agenda"166

At the continent level, African countries need to develop a policy agenda that requires the creation of an 'African Consensus'. Identifying an appropriate 'African Consensus' can optimize the gains in aid, investment and trade negotiation deals with both traditional and non-traditional partners. Regionaland continental-level exchange programs like the African Union (AU), the Common Market for Eastern and Southern Africa (COMESA), the East African Community (EAC), the Economic Community of West African States (ECOWAS), or the Southern African Development Community (SADEC) could provide the foundation for a Pan-African dialogue about a coherent policy framework vis-à-vis the international donor community. Several of those bodies and platforms, however, have often been established for motives other than African unity towards external powers thereby inhibiting a paradigm shift towards an 'African consensus' on a development strategy vis-à-vis external stakeholders (Shivji, 2007).

\footnotetext{
166 Paul Kagame's statement can be found in the paper "Making aid work for Africa". Brenthurst Paper 7/2007. Johannesburg, South Africa: The Brenthurst Foundation.
} 


\section{CHAPTER 8}

It remains to be seen how and to what extent African values, interests and perspectives will be fully incorporated in the negotiation process with external powers. With the emergence of the new multipolar world, Africa's potential for global engagement, self-determination and economic development has never been greater. As the Ghanaian economist and author George Ayittey (1992) reminds us, "Africans will never demonstrate their intellectual capabilities if they must always rely on foreigners to do the thinking for them" (p. 208).

\subsection{Concluding Thoughts and Future Outlook}

At the Millennium Summit of the United Nations in New York in September 2000, world leaders adopted the United Nations Millennium Declaration. The United Nations Millennium Declaration, among others, was committed to form a new global partnership aimed at reducing extreme poverty with measurable targets and clear deadlines agreed by the international community. Those targets became known as the eight Millennium Development Goals (MDGs). The MDGs have been considered a milestone in global and national development efforts as it formed the blueprint for world development by 2015 .

At the Rio+20 Conference on Sustainable Development in Rio de Janeiro, Brazil, 20-22 June, 2012, world leaders discussed a post-2015 framework. One major outcome was the agreement by world leaders to establish an inclusive intergovernmental process for developing a set of Sustainable Development Goals (SDGs). Besides the traditional UN agencies, traditional Western donor agencies and international financial institutions, BRICS countries and other countries from the Global South have played an increasing role in shaping the post-2015 development agenda.

Development finance can make an important, albeit limited, contribution to the developmental progress in developing countries. But the exaggerated expectations that development finance acts as a fundamental tool to meet development targets such as the MDGs or SDGs only further undermines the effectiveness of development finance (Clemens, Kenny, \& Moss, 2007). Increased development cooperation in the realms of foreign aid, trade and investment is a necessary but not sufficient condition for progress on development indicators in the developing world, as domestic policy factors play the most 


\section{CHAPTER 8}

fundamental role in achieving developmental progress. The MDG agenda [as well as the post-2015 development agenda] have implied and will imply "fundamental transformations in society, which are invariably driven by domestic politics and local actors" (Vandemoortele, 2011, p. 1).

While the MDGs and the post 2015 development agenda with their global goals and quantifiable benchmarks have put pressure on governments and policymakers both in the developed and the developing world to meet concrete development objectives (Jolly, Emmerji, \& Weiss, 2005), one should be careful to regard the MDGs and post-2015 development agenda as a policy framework that can be applied to all developing nations. At the end of the day, the definition of a development strategy ultimately belongs to the realm of sovereign governments, policymakers and civil society at the country level (Vandemoortele, 2009).

The global development finance architecture has undergone major changes over the last two decades, partly due to the (re-)entry of major financial players from the Global South. With regard to the post-2015 UN Development Agenda, the most pressing question is not (i) whether both traditional donors and nontraditional donors will strengthen their cooperation in developing countries or (ii) whether Western and BRICS development finance will become increasingly competitive or complementary, but rather whether developing countries will be able to fully exploit the advantage of their new sources of funding, ideas and cooperation.

Africa's future must lie in the hands of African governments and civil society. Alluding to Birdsall and Fukuyama (2011), "development has never been something that the rich bestowed on the poor but rather something the poor achieved for themselves" (p. 53). If African developing countries start to fully exploit the advantage of the new sources of funding, ideas and cooperation for their own well-being, the veracity of Pliny the Elder's statement "that there is always something new out of Africa" can be confirmed once again. 


\section{REFERENCES}

Aalen, L., \& Tronvoll, K. (2008). The 2008 Ethiopian local elections: The return of electoral authoritarianism. African Affairs, 108(430), 111-120.

Aalen, L., \& Tronvoll, K. (2009). The End of Democracy? Curtailing Political and Civil Rights in Ethiopia. Review of African Political Economy, 36(120), 193-207.

Abbink, J. (2006). Discomfiture of democracy? The 2005 election crisis in Ethiopia and its aftermath. African Affairs, 105(419), 173-199.

Abbink, J. (2011). Democracy deferred: understanding elections and the role of donors in Ethiopia. In J. Abbink \& M. de Bruijn (Eds.), Land, law and politics in Africa: mediating conflict and reshaping the state (pp. 213-239). Leiden, The Netherlands: Brill Publishing.

Abbink, J. (2012). Ethnic-based federalism and ethnicity in Ethiopia: reassessing the experiment after 20 years. Journal of Eastern African Studies, 5(4), 596-618.

Abegaz, B. (2015). Aid, accountability and institution building in Ethiopia: the selflimiting nature of technocratic aid. Third World Quarterly, 36(7), 1382-1403.

Abir, M. (1980). Ethiopia and the Red Sea: The Rise and Decline of the Solomonic Dynasty and Muslim European Rivaly in the Region. London, UK: Frank Cass.

Acemoglu, D., Johnson, S., \& Robinson, J. A. (2001). The Colonial Origins of Comparative Development: An Empirical Investigation. American Economic Review, 91(5), 1369-1401.

Acemoglu, D., Johnson, S., \& Robinson, J. A. (2002). Reversal of Fortune: Geography and Institutions in the Making of the Modern World Income Distribution. Quarterly Journal of Economics, 117(4), 1231-1294.

Acemoglu, D., Johnson, S., \& Robinson, J. A. (2003). An African Success Story. Botswana. In D. Rodrik (Ed.), In Search of Prosperity: Analytic Narratives of Economic Growth (pp. 80-118). Princeton, NJ: Princeton University Press.

Acemoglu, D., Naidu, S., Restrepo, P., \& Robinson, J. A. (2015). Democracy, Redistribution, and Inequality. In A. B. Atkinson \& F. Bourguignon (Eds.), Handbook of Income Distribution (1st ed., Vol. 2, pp. 1885-1966). Amsterdam, The Netherlands: Elsevier B.V.

Acemoglu, D., \& Robinson, J. A. (2010). Why is Africa Poor? Economic History of Developing Regions, 25(1), 21-50.

Acemoglu, D., \& Robinson, J. A. (2012). Why Nations Fail: The Origins of Power, Prosperity, and Poverty. New York, NY: Crown Business.

Adam, C. S., \& O'Connell, S. A. (1999). Aid, Taxation and Development in Sub-Saharan Africa. Economics and Politics, 11(3), 225-253.

Adams, F. G., \& Shachmurove, Y. (2008). Modeling and Forecasting Energy Consumption in China: Implications for Chinese Energy Demand and Imports in 2020. Energy Economics, 30(3), 1263-1278.

Adem, S. (2012). China in Ethiopia: Diplomacy and Economics of Sino-optimism. African Studies Review, 55(1), 143-160.

Adem, S. (2013). The Lion of Judah and the Dragon. In A. A. Mazrui \& S. Adem (Eds.), Afrasia: A Tale of Two Continents (pp. 39-53). Lanham, MD: Rowman \& Littlefield. 
AfDB. (2013). AfDB and Ethiopia - Partnering for Inclusive Growth. Tunis, Tunisia: African Development Bank.

AfDB. (2016). Federal Democratic Republic of Ethiopia Country Strategy Paper 2016-2020. Tunis, Tunisia: African Development Bank.

AFRODAD. (2011). Mapping Chinese development assistance in Africa: an analysis of the experiences of Ethiopia. Harare, Zimbabwe: African Forum and Network on Debt and Development.

Aghion, P., Cai, J., Dewatripont, M., Du, L., Harrison, A., \& Legros, P. (2015). Industrial Policy and Competition. American Economic Journal: Macroeconomics, 7(4), 1-32.

Ahmed, F. Z. (2012). The Perils of Unearned Foreign Income: Aid, Remittances, and Government Survival. American Political Science Review, 106(1), 146-165.

AidData. (2016). China builds anti-malaria center in Ethiopia. Williamsburg, VA: AidData. Retrieved from http://china.aiddata.org/projects/34171?iframe $=y$

Aidt, T. S., \& Jensen, P. S. (2013). Democratization and the size of government: Evidence from the long 19th century. Public Choice, 157(3-4), 511-542.

Ajakaiye, O., \& Kaplinsky, R. (2009). China in Africa: A Relationship in Transition. European Journal of Development Research, 21(4), 479-484.

Akamatsu, K. (1962). A historical pattern of economic growth in developing countries. The Developing Economies, 1(1), 3-25.

Ake, C. (1996). Democracy and Development in Africa. Washington, D.C.: Brookings Institution.

Alden, C. (2005). China in Africa. Survival, 47(3), 147-164.

Alden, C. (2007). China in Africa: Partner, Competitor or Hegemon? London, UK: Zed Books Ltd.

Alden, C., \& Alves, C. (2008). History \& Identity in the Construction of China's Africa Policy. Review of African Political Economy, 35(115), 43-58.

Alden, C., \& Davies, M. (2006). A profile of the operations of Chinese multinationals in Africa. South African Journal of International Affairs, 13(1), 83-96.

Alder, S., Shao, L., \& Zilibotti, F. (2016). Economic reforms and industrial policy in a panel of Chinese cities. Journal of Economic Growth, 21(4), 305-349.

Alesina, A., Devleeschauwer, A., Easterly, W. R., \& Kurlat, S. (2003). Fractionalization. Journal of Economic Growth, 8(2), 155-194.

Alesina, A., \& Dollar, D. (2000). Who Gives Foreign Aid to Whom and Why? Journal of Economic Growth, 5(1), 33-63.

Alesina, A., Easterly, W. R., \& Matuszeski, J. (2011). Artificial States. Journal of the European Economic Association, 9(2), 246-277.

Alesina, A., \& Weder, B. (2002). Do Corrupt Governments Receive Less Foreign Aid? American Economic Review, 92(4), 1126-1137.

Alsan, M. (2015). The Effect of the Tse'Tse Fly on African Development. American Economic Review, 105(1), 382-410.

Altincekic, C., \& Bearce, D. H. (2014). Why there Should be No Political Foreign Aid Curse. World Development, 64, 18-32.

Ambrosio, T. (2009). Authoritarian Backlash: Russian Resistance to Democratization in the Former Soviet Union. Farnham, UK: Ashgate Publishing Ltd.

Ampiah, K. (2007). The Political and Moral Imperatives of the Bandung Conference of 1955: the 
Reactions of the US, UK and Japan. Folkestone, UK: Global Oriental.

Andersen, T. B., \& Dalgaard, C.-J. (2013). Power outages and economic growth in Africa. Energy Economics, 38, 19-23.

Andersen, T. B., Hansen, H., \& Markussen, T. (2006). US politics and World Bank IDAlending. Journal of Development Studies, 42(5), 772-794.

Andrew, C., \& Mitrokhin, V. (2005). The World Was Going Our Way: The KGB and the Battle for the Third World. New York, NY: Basic Books.

Angrist, J. D., Imbens, G. W., \& Rubin, D. B. (1996). Identification of Causal Effects Using Instrumental Variables. Journal of the American Statistical Association, 91(434), $444-455$.

Anonymous 1. (2016). Interview with a PhD student in Addis Ababa, Ethiopia, July.

Anonymous 2. (2016). Interview with an Ethiopian Researcher in Addis Ababa, Ethiopia, July.

Anonymous 3. (2016). Interview with an employee from an International Non-Profit Organization (NPO) in Addis Ababa, Ethiopia, July.

Anonymous 4. (2016). Interview with an Ethiopian researcher in Addis Ababa, Ethiopia, July.

Anonymous 5. (2016). Interview with an official from an International Financial Institution (IFI) in Addis Ababa, Ethiopia, July.

Anonymous 6. (2016). Interview with an employee from a Western Development Aid Agency in Addis Ababa, Ethiopia, July.

Anonymous 7. (2016). Interview with a professor from Addis Ababa University (AAU) in Addis Ababa, Ethiopia, July.

Anonymous 8. (2016). Interview with an Ethiopian researcher in Addis Ababa, Ethiopia, July.

Anonymous 9. (2016). Interview with an Ethiopian taxi driver in Addis Ababa, Ethiopia, August.

Anonymous 10. (2016). Interview with an official from an Ethiopian government organization in Addis Ababa, Ethiopia, August.

Anonymous 11. (2016). Interview with an employee from a Western Development Aid Agency in Addis Ababa, Ethiopia, August.

Anonymous 12. (2016). Interview with an employee from a Western Development Aid Agency in Addis Ababa, Ethiopia, August.

Anonymous 13. (2016). Interview with an employee from a Western Development Aid Agency in Addis Ababa, Ethiopia, August.

Anonymous 14. (2016). Interview with an official from an Ethiopian government organization in Addis Ababa, Ethiopia, August.

Ansell, B. (2010). From the Ballot to the Blackboard: The Redistributive Political Economy of Education. New York, NY: Cambridge University Press.

Aoki, M. (2007). Endogenizing Institutions and Institutional Changes. Journal of Institutional Economics, 3(1), 1-31.

Arellano, M., \& Bond, S. R. (1991). Some Tests of Specification for Panel Data: Monte Carlo Evidence and an Application to Employment Equations. Review of Economic Studies, 58, 277-297.

Arellano, M., \& Bover, O. (1995). Another look at the instrumental variable estimation 
of error-components models. Journal of Econometrics, 68(1), 29-51.

Arezki, R., Deininger, K., \& Selod, H. (2013). What Drives the Global "Land Rush"? The World Bank Economic Review, 29(2), 207-233.

Arndt, C., Jones, S., \& Tarp, F. (2010). Aid, Growth, and Development: Have We Come Full Circle? Journal of Globalization and Development, 1(2), 1-27.

Ashraf, Q., \& Galor, O. (2011). Dynamics and Stagnation in the Malthusian Epoch. American Economic Review, 101(5), 2003-2041.

Ashraf, Q., \& Galor, O. (2013). The "Out of Africa” Hypothesis, Human Genetic Diversity, and Comparative Economic Development. American Economic Review, $103(1), 1-46$.

Assefa, H., Bienen, D., \& Ciuriak, D. (2013). Ethiopia's Investment Prospects: A Sectoral Overview. African Review of Economics and Finance, 4(2), 203-246.

Asserate, A.-W. (2014). Der letəte Kaiser von Afrika - Triumph und Tragödie des Haile Selassie. Berlin, Germany: Propyläen Verlag.

Asserate, A.-W. (2015). King of Kings: The Triumph and Tragedy of Emperor Haile Selassie I of Ethiopia. London, UK: Haus Publishing.

Ayittey, G. B. N. (1992). Africa Betrayed. New York, NY: St Martin's Press.

Ayittey, G. B. N. (2005). Africa Unchained: The Blueprint for Africa's Future. New York, NY: Palgrave Macmillan.

Azam, J.-P., \& Laffont, J.-J. (2003). Contracting for aid. Journal of Development Economics, $70(1), 25-58$.

Bach, J.-N. (2011). Abyotawi democracy: neither revolutionary nor democratic, a critical review of EPRDF's conception of revolutionary democracy in post-1991 Ethiopia. Journal of Eastern African Studies, 5(4), 641-663.

Bader, J. (2015). China, Autocratic Patron? An Empirical Investigation of China as a Factor in Autocratic Survival. International Studies Quarterly, 59(1), 23-33.

Bader, J., \& Faust, J. (2014). Foreign Aid, Democratization, and Autocratic Survival. International Studies Review, 16(4), 575-595.

Bader, J., Grävingholt, J., \& Kästner, A. (2010). Would autocracies promote autocracy? A political economy perspective on regime-type export in regional neighbourhoods. Contemporary Politics, 16(1), 81-100.

Bailey, M. A., Strezhnev, A., \& Voeten, E. (2017). Estimating Dynamic State Preferences from United Nations Voting Data. Journal of Conflict Resolution, 61(2), 430-456.

Bairoch, P. (1988). Cities and Economic Development: From the Dawn of History to the Present. Chicago, IL: Chicago University Press.

Banerjee, A. V. (2007). Making Aid Work. Cambridge, MA: MIT Press.

Banerjee, A. V, \& Duflo, E. (2009). The Experimental Approach to Development Economics. Annual Review of Economics, 1(1), 151-178.

Banerjee, A. V, \& Duflo, E. (2011). Poor Economics: A Radical Rethinking of the Way to Fight Global Poverty. New York, NY: Public Affairs.

Banerjee, A. V, Duflo, E., \& Qian, N. (2012). On the Road: Access to Transportation Infrastructure and Economic Growth in China. NBER Working Paper 17897. National Bureau of Economic Research. Cambridge, MA.

Banerjee, A. V, \& Iyer, L. (2005). History, Institutions and Economic Performance: The 


\section{REFERENCES}

Legacy of Land Tenure Systems in India. American Economic Review, 95(4), 1190 1213.

Bates, R. H. (1981). Markets and States in Tropical Africa: The Political Basis of Agricultural Policies. Berkeley, CA: University of California Press.

Bates, R. H. (2001). Prosperity and Violence: The Political Economy of Development. New York, NY: W. W. Norton \& Company.

Bates, R. H. (2008). When Things Fell Apart: State Failure in Late-Century Africa. Cambridge, UK: Cambridge University Press.

Bates, R. H., Fayad, G., \& Hoeffler, A. (2012). The state of democracy in Sub-Saharan Africa. International Area Studies Review, 15(4), 323-338.

Bates, R. H., Greif, A., Levi, M., Rosenthal, J.-L., \& Weingast, B. R. (1998). Analytic Narratives. Princeton, NJ: Princeton University Press.

Bates, R. H., Greif, A., Levi, M., Rosenthal, J.-L., \& Weingast, B. R. (2000). The Analytical Narrative Project. American Political Science Review, 94(3), 696-702.

Bauer, P. T. (1972). Dissent on development: studies and debates in development economics. Cambridge, MA: Harvard University Press.

Bauer, P. T. (1975). N.H. Stern On Substance And Method In Development Economics. Journal of Development Economics, 2(4), 387-405.

Baum-Snow, N., Brandt, L., Henderson, J. V., Turner, M. A., \& Zhang, Q. (2017). Roads, Railroads and Decentralization of Chinese Cities. Review of Economics and Statistics, forthcoming. https://doi.org/10.1162/REST

Bayart, J.-F. (2000). Africa in the World: A History of Extraversion. African Affairs, 2(395), 217-267.

BBC. (2012). African Union opens Chinese-funded HQ in Ethiopia. Retrieved from http://www.bbc.com/news/world-africa-16770932

BBC. (2014). Country Rating Poll 2014 for BBC World Service. Retrieved from http://downloads.bbc.co.uk/mediacentre/country-rating-poll.pdf

BBC. (2016). What is behind Ethiopia's wave of protests? Retrieved from http://www.bbc.com/news/world-africa-36940906

BEA. (2015). GDP and the National Income and Product Account (NIPA) Historical Tables. Washington, D.C.: U.S. Department of Commerce. Bureau of Economic Analysis. Retrieved from http://www.bea.gov/national/

Behrman, G. (2007). The Most Noble Adventure: The Marshall Plan and the Time When America Helped Save Europe. New York, NY: Free Press.

Beim, D. (1964). The Communist Bloc and the Foreign aid Game. The Western Political Quarterly, 17(4), 784-799.

Berhe, A. (2003). Revisiting resistance in Italian-occupied Ethiopia: The Patriots' Movement (1936-1941) and the redefinition of post-war Ethiopia. In J. Abbink, M. De Bruijn, \& K. Van Walraven (Eds.), Rethinking Resistance: Revolt and Violence in African History (pp. 87-113). Leiden, The Netherlands: Brill Publishers.

Berman, J. (2013). Success in Africa: CEO Insights from a Continent on the Rise. Brookline, MA: Bibliomotion.

Bermeo, S. B. (2011). Foreign Aid and Regime Change: A Role for Donor Intent. World Development, 39(11), 2021-2031.

Bermeo, S. B. (2016). Aid Is Not Oil: Donor Utility, Heterogeneous Aid, and the Aid- 


\section{REFERENCES}

Democratization Relationship. International Organization, 70(1), 1-32.

Berthélemy, J. C. (2011). China's Engagement and Aid Effectiveness in Africa. AfDB Working Paper Series No. 129. African Development Bank Group. Tunis, Tunisia.

Bertocchi, G., \& Canova, F. (2002). Did colonization matter for growth? An empirical exploration into the historical causes of Africa's underdevelopment. European Economic Review, 46(10), 1851-1871.

Besley, T., \& Persson, T. (2008). Wars and State Capacity. Journal of the European Economic Association, 6(2-3), 522-530.

Besley, T., \& Persson, T. (2010). State Capacity, Conflict, and Development. Econometrica, 78(1), 1-34.

Besley, T., \& Persson, T. (2011). Pillars of Prosperity: The Political Economics of Development Clusters. Princeton, NJ: Princeton University Press.

Biggeri, M., \& Sanfilippo, M. (2009). Understanding China's move into Africa: an empirical analysis. Journal of Chinese Economic and Business Studies, 7(1), 31-54.

Birdsall, N., \& Fukuyama, F. (2011). The Post-Washington Consensus: Development after the Crisis. Foreign Affairs, 90(2), 45-53.

Birdsall, N., Rodrik, D., \& Subramanian, A. (2005). How to Help Poor Countries. Foreign Affairs, 84(4), 136-152.

Blundell, R., \& Bond, S. (1998). Initial conditions and moment restrictions in dynamic panel data models. Journal of Econometrics, 87(1), 115-143.

Bockstette, V., Chanda, A., \& Putterman, L. (2002). States and Markets: The Advantage of an Early Start. Journal of Economic Growth, 7(4), 347-369.

Bollen, K. A. (1979). Political Democracy and the Timing of Development. American Sociological Review, 44(4), 572-587.

Bollen, K. A. (1980). Issues in the Comparative Measurement of Political Democracy. American Sociological Review, 45(3), 370-390.

Bollen, K. A. (1993). Liberal Democracy: Validity and Method Factors in CrossNational Measures. American Journal of Political Science, 37(4), 1207-1230.

Bolt, J., \& van Zanden, J. L. (2014). The Maddison Project: Collaborative research on historical national accounts. Economic History Review, 67(3), 627-651.

Boone, C. (2003). Political Topographies of the African State: Territorial Authority and Institutional Choice. Cambridge, UK: Cambridge University Press.

Boone, P. (1996). Politics and the Effectiveness of Foreign Aid. European Economic Review, 40(2), 289-329.

Borchgrevink, A. (2008). Limits to Donor Influence: Ethiopia, Aid and Conditionality. Forum for Development Studies, 35(2), 195-220.

Boschini, A., \& Olofsgård, A. (2007). Foreign aid: An instrument for fighting communism? Journal of Development Studies, 43(4), 622-648.

Boserup, E. (1981). Population and Technological Change: A Study of Long-Term Trends. Chicago, IL: Chicago University Press.

Boserup, E. (1983). The Impact of Scarcity and Plenty on Development. Journal of Interdisciplinary History, 14(2), 383-407.

Bosworth, B. P., \& Collins, S. M. (2008). Accounting for Growth: Comparing China and India. Journal of Economic Perspectives, 22(1), 45-66.

Bourguignon, F., \& Platteau, J.-P. (2015). The Hard Challenge of Aid Coordination. 
World Development, 69, 86-97.

Bourguignon, F., \& Sundberg, M. (2007). Aid Effectiveness-Opening the Black Box. American Economic Review, 97(2), 316-321.

Bratton, M., \& van de Walle, N. (1997). Democratic Experiments in Africa: Regime Transitions in Comparative Perspective. Cambridge, UK: Cambridge University Press.

Braukämper, U. (2003). Islamic History and Culture in Southern Ethiopia: Collected Essays. Münster, Germany: LIT Verlag.

Bräutigam, D. A. (1998). Chinese Aid and African Development: Exporting Green Revolution. Basingstoke, UK: Palgrave MacMillan.

Bräutigam, D. A. (2003). Close Encounters: Chinese Business Networks as Industrial Catalysts in Sub-Saharan Africa. African Affairs, 102(408), 447-467.

Bräutigam, D. A. (2008). Introduction: taxation and state-building in developing countries. In D. A. Bräutigam, O.-H. Fjeldstad, \& M. Moore (Eds.), Taxation and State-Building in Developing Countries: Capacity and Consent (pp. 1-33). Cambridge, UK: Cambridge University Press.

Bräutigam, D. A. (2009). The Dragon's Gift: The Real Story of China in Africa: The Real Story of China in Africa. New York, NY: Oxford University Press.

Bräutigam, D. A. (2011a). Aid "With Chinese Characteristics": Chinese Foreign Aid and Development Finance Meet the OECD-DAC Aid Regime. Journal of International Development, 23(5), 752-764.

Bräutigam, D. A. (2011b). Chinese Development Aid in Africa - What, where, why, and how much? In J. Golley \& L. Song (Eds.), China Update 2011 (pp. 203-222). Canberra, Australia: Australia National University.

Bräutigam, D. A. (2013). Rubbery Numbers for Chinese Aid to Africa. Retrieved from http://www.chinaafricarealstory.com/2013/04/rubbery-numbers-on-chineseaid.html

Bräutigam, D. A. (2015a). Chinese Aid. Retrieved April 9, 2016, from http://www.chinaafricarealstory.com/p/chinese-aid.html

Bräutigam, D. A. (2015b). Will Africa Feed China? New York, NY: Oxford University Press.

Bräutigam, D. A., \& Knack, S. (2004). Foreign Aid, Institutions, and Governance in Sub-Saharan Africa. Economic Development and Cultural Change, 52(2), 255-285.

Bräutigam, D. A., \& Tang, X. (2009). China's Engagement in African Agriculture: "Down to the Countryside." China Quarterly, 199, 686-706.

Bräutigam, D. A., \& Tang, X. (2011). African Shenzhen: China's special economic zones in Africa. Journal of Modern African Studies, 49(1), 27-54.

Bräutigam, D. A., \& Tang, X. (2012). An Overview of Chinese Agricultural and Rural Engagement in Ethiopia. IFPRI Discussion paper 01185. Washington, D.C.

Bräutigam, D. A., \& Tang, X. (2014). "Going Global in Groups": Structural Transformation and China's Special Economic Zones Overseas. World Development, 63, 78-91.

Brietzke, P. M. (1976). Land reform in revolutionary Ethiopia. Journal of Modern African Studies, 14, 637-660.

Broadman, H. G. (2007). Africa's Silk Road: China's and India's New Economic Frontier. Washington, D.C.: World Bank Publications. 
Broich, T. (2017). Do authoritarian regimes receive more Chinese development finance than democratic ones? Empirical evidence for Africa, China Economic Review, 46, 180-207

Broich, T., \& Szirmai, A. (2014). China's Economic Embrace of Africa - An International Comparative Perspective. UNU-MERIT Working Paper Series No. 2014-049. Maastricht, The Netherlands: Maastricht Graduate School of Governance/UNUMERIT.

Brown, S. (2005). Foreign Aid and Democracy Promotion: Lessons from Africa. European Journal of Development Research, 17(2), 179-198.

Brown, W. (2012). A Question of Agency: Africa in international politics. Third World Quarterly, 33(10), 1889-1908.

Brown, W. (2013). Sovereignty matters: Africa, donors, and the aid relationship. African Affairs, 112(447), 262-282.

Bruk, S., \& Apenchenko, V. S. (Eds.). (1964). Atlas Narodov Mira. Glavnoe Upravlenie Geodezii i Kartografii, Moscow, Russia.

Buckley, P. J., Clegg, L. J., Cross, A. R., Liu, X., Voss, H., \& Zheng, P. (2007). The Determinants of Chinese Outward Foreign Direct Investment. Journal of International Business Studies, 38(4), 499-518.

Bueno de Mesquita, B., \& Smith, A. (2007). Foreign Aid and Policy Concessions. Journal of Conflict Resolution, 51(2), 251-284.

Bueno de Mesquita, B., \& Smith, A. (2009). A Political Economy of Aid. International Organization, 63(2), 309-340.

Bueno de Mesquita, B., \& Smith, A. (2010). Leader Survival, Revolutions, and the Nature of Government Finance. American Journal of Political Science, 54(4), 936-950.

Bueno de Mesquita, B., \& Smith, A. (2016). Competition and Collaboration in Aid-forPolicy Deals. International Studies Quarterly, 1-14.

Bueno de Mesquita, B., Smith, A., Siverson, R. M., \& Morrow, J. D. (2003). The Logic of Political Survival. Cambridge, MA: The MIT Press.

Burnside, C., \& Dollar, D. (1997). Aid Spurs Growth - in a Sound Policy Environment. Finance and Development, 34(4), 4-7.

Burnside, C., \& Dollar, D. (2000). Aid, Policies, and Growth. American Economic Review, 90(4), 847-868.

Buzan, B. (2006). Will the "global war on terrorism" be the new Cold War? International Affairs, 82(6), 1101-1118.

Cardenal, J. P., \& Araújo, H. (2013). China's Silent Army The Pioneers, Traders, Fixers and Workers Who are Remaking the World in Beijing's Image. London, UK: Penguin.

Carmody, P. R. (2011). The New Scramble for Africa. Cambridge, UK: Polity Press.

Carmody, P. R., \& Kragelund, P. (2016). Who is in Charge? State Power and Agency in Sino-African Relations. Cornell International Law Journal, 49, 1-24.

Carmody, P. R., \& Owusu, F. Y. (2007). Competing hegemons? Chinese versus American geo-economic strategies in Africa. Political Geography, 26(5), 504-524.

Carothers, T. (1999). Aiding Democracy Abroad: The Learning Curve. Washington, D.C.: Carnegie Endowment for International Peace.

Castells, M. (1996). The Rise of the Network Society. Malden, MA: Blackwell Publishers.

Ceglowski, J., \& Golub, S. S. (2011). Does China Still Have a Labor Cost Advantage? 
Global Economy Journal, 12(3), 1-28.

Chabal, P., \& Daloz, J.-P. (1999). Africa Works: Disorder as Political Instrument. Indianapolis, IN: Indiana University Press.

Chang, H.-J. (2010). Institutions and Economic Development: Theory, Policy and History. Journal of Institutional Economics, 7(4), 473-498.

Chaponnière, J.-R. (2009). Chinese aid to Africa, origins, forms and issues. In M. P. Van

Dijk (Ed.), The New Presence of China in Africa (pp. 55-82). Amsterdam, The Netherlands: Amsterdam University Press.

Chau, D. C. (2014). Exploiting Africa: The Influence of Maoist China in Algeria, Ghana, and Tanzania. Annapolis, MD: U.S. Naval Institute Press.

Chege, M. (1979). The revolution betrayed: Ethiopia 1974-77. Journal of Modern African Studies, 17, 359-380.

Cheibub, J. A., Gandhi, J., \& Vreeland, J. R. (2010). Democracy and dictatorship revisited. Public Choice, 143(1-2), 67-101.

Chen, S., \& Ravallion, M. (2010). The Developing World is Poorer than We Thought, But No Less Successful in the Fight Against Poverty. Quarterly Journal of Economics, 125(4), 1577-1626.

Chenery, H. B., Ahluwalia, M. S., Duloy, J. H., Bell, C. L. G., \& Jolly, R. (1974). Redistribution with Growth: Policies to Improve Income Distribution in Developing Countries in the Context of Economic Growth. Oxford, UK: Oxford University Press.

Chenery, H. B., \& Elkington, H. (1980). Structural Change and Development Policy. New York, NY: Oxford University Press.

Chenery, H. B., \& Strout, A. M. (1966). Foreign Assistance and Economic Development. American Economic Review, 56(4), 679-733.

China State Council. (2010). China-Africa Economic and Trade Cooperation. Beijing, People's Republic of China.

China State Council. (2011). China's Foreign Aid. Beijing, People's Republic of China.

China State Council. (2013). China-Africa Economic and Trade Cooperation. Beijing, People's Republic of China.

Chole, E. (2004). Underdevelopment in Ethiopia. Addis Ababa, Ethiopia: OSSREA.

Chowdhury, S. K. (2004). The effect of democracy and press freedom on corruption: an empirical test. Economics Letters, 85(1), 93-101.

Cingolani, L., Thomsson, K., \& De Crombrugghe, D. (2015). Minding Weber More Than Ever? The Impacts of State Capacity and Bureaucratic Autonomy on Development Goals. World Development, 72, 191-207.

Claessens, S., Cassimon, D., \& van Campenhout, B. (2009). Evidence on Changes in Aid Allocation Criteria. World Bank Economic Review, 23(2), 163-184.

Clapham, C. (1969). Imperial Leadership in Ethiopia. African Affairs, 68(271), 110-120. Clapham, C. (1988). Transformation and continuity in revolutionary Ethiopia. Cambridge, UK: Cambridge University Press.

Clapham, C. (1996). Africa and the International System: The Politics of State Survival. Cambridge, UK: Cambridge University Press.

Clapham, C. (2015). The Era of Haile Selassie. In G. Prunier \& É. Fiquet (Eds.), Understanding Contemporary Ethiopia. Monarchy, Revolution and the Legacy of Meles Zenawi (pp. 183-208). London, UK: Hurst \& Company. 
Clay, J. W., \& Holcomb, B. K. (1986). Politics and the Ethiopian Famine: 1984-1985. New Brunswick, NJ: Transaction Publishers.

Clemens, M. A., Kenny, C. J., \& Moss, T. J. (2007). The Trouble with the MDGs: Confronting Expectations of Aid and Development Success. World Development, 35(5), 735-751.

Clemens, M. A., Radelet, S., Bhavnani, R. R., \& Bazzi, S. (2011). Counting Chickens When They Hatch: Timing and the Effects of Aid on Growth. Economic Journal, 122(561), 590-617.

Collier, P. (1999). Aid "Dependency": a Critique. Journal of African Economies, 8(4), 528545.

Collier, P. (2007). The Bottom Billion: Why the Poorest Countries are Failing and What Can Be Done About It. Oxford, UK: Oxford University Press.

Collier, P., \& Dollar, D. (2002). Aid Allocation and Poverty Reduction. European Economic Review, 46(8), 1475-1500.

Connell, D. (2005). Eritrea: On a Slow Fuse. In R. I. Rotberg (Ed.), Battling Terrorism in the Horn of Africa, W ashington (pp. 64-92). Washington, D.C.: Brookings Institution Press.

Cooper, A. F. (2016). BRICS: A Very Short Introduction. Oxford, UK: Oxford University Press.

Coppedge, M., Alvarez, A., \& Maldonado, C. (2008). Two Persistent Dimensions of Democracy: Contestation and Inclusiveness. Journal of Politics, 70(3), 632-647.

Coppedge, M., Lindberg, S., Skaaning, S.-E., \& Teorell, J. (2016). Measuring High Level Democratic Principles using the V-Dem Data. International Political Science Review, 37(5), 580-593.

Cordella, T., \& Dell'Ariccia, G. (2007). Budget Support Versus Project Aid: A Theoretical Appraisal. Economic Journal, 117(523), 1260-1279.

Corkin, L. (2011). Redefining Foreign Policy Impulses Toward Africa: The Roles of the MFA, the MOFCOM and China Exim Bank. Journal of Current Chinese Affairs, 40(4), 61-90.

Corkin, L. (2013). Uncovering African Agency: Angola's Management of China's Credit Lines. Aldershot, UK: Ashgate Publishing Limited.

Corkin, L., Burke, C., \& Davies, M. (2008). China's Role in the Development of Africa's Infrastructure. Stellenbosch, South Africa: Centre for Chinese Studies.

Coughlin, C. C., \& Segev, E. (2000). Location Determinants of New Foreign-Owned Manufacturing Plants. Journal of Regional Science, 40(2), 323-351.

Crawford, G. (1997). Foreign aid and political conditionality: Issues of effectiveness and consistency. Democratization, 4(3), 69-108.

Creswell, J. W. (2013). Research Design: Qualitative, Quantitative, and Mixed Methods Approaches. Thousand Oakes, CA: SAGE Publications.

Curtin, P. D., Feierman, S., Thompson, L., \& Vansina, J. (1995). African History: From Earliest Times to Independence (2nd ed.). London, UK: Longman.

DAG. (2016). About DAG. Addis Ababa, Ethiopia: The Development Assistance Group. Retrieved from http://dagethiopia.org/new/about

Dahl, R. A. (1971). Polyarchy: Participation and Opposition. New Haven, CT: Yale University Press. 


\section{REFERENCES}

Dahl, R. A. (1988). On Democracy. New Haven, CT: Yale University Press.

Dahlberg, S., Holmberg, S., Rothstein, B., Khomenko, A., \& Svensson, R. (2016). The Quality of Government Basic Dataset. Gothenburg, Sweden: The Quality of Government Institute. Retrieved from http://www.qogdata.pol.gu.se/dataarchive/qog_bas_jan16.pdf

Davey, E. (2015). Idealism beyond Borders The French Revolutionary Left and the Rise of Humanitarianism, 1954-1988. Cambridge, UK: Cambridge University Press.

David, P. A. (1994). Why are institutions the "carriers of history"?: Path dependence and the evolution of conventions, organizations and institutions. Structural Change and Economic Dynamics, 5(2), 205-220.

Davies, M., Edinger, H., Tay, N., \& Naidu, S. (2008). How China Delivers Development Assistance to Africa. Stellenbosch, South Africa: Centre for Chinese Studies, University of Stellenbosch.

DCD-DAC. (2010). Boosting South-South Cooperation in the Context of Aid Effectiveness. Paris, France: OECD.

De Jager, N., \& Sebudubudu, D. (2017). Towards understanding Botswana and South Africa's ambivalence to liberal democracy. Journal of Contemporary African Studies, 35(1), 15-33.

Deaton, A. (2013). The Great Escape: Health, Wealth, and the Origins of Inequality. Princeton, NJ: Princeton University Press.

De Vries, G., Timmer, M. P., \& De Vries, K. (2015). Structural Transformation in Africa: Static Gains, Dynamic Losses. Journal of Development Studies, 51(6), 674-688.

De Waal, A. (1991). Evil days. 30 Years of War and Famine in Ethiopia. New York, NY: Human Rights Watch.

De Waal, A. (1997). Famine Crimes: Politics \& the Disaster Relief Industry in Africa. Indianapolis, IN: Indiana University Press.

De Waal, A. (2004). The Politics of Destabilisation in the Horn, 1989-2001. In A. De Waal (Ed.), Islamism and Its Enemies in the Horn of Africa (pp. 182-230). Indianapolis, IN: Indiana University Press.

De Waal, A. (2012). The theory and practice of Meles Zenawi. African Affairs, 112(446), $148-155$.

De Waal, A. (2013). The theory and practice of Meles Zenawi: A reply to to Rene Lefort. African Affairs, 112(448), 471-475.

De Waal, A., \& Abdel Salam, A. H. (2004). Africa, Islamism and America's "War on Terror." In A. De Waal (Ed.), Islamism and its Enemies in the Horn of Africa (pp. 231257). Bloomington, IN: Indiana University Press.

Deloitte. (2014). Ethiopia. A growth miracle. Johannesburg, South Africa.

Dercon, S., Gilligan, D. O., Hoddinott, J., \& Woldehanna, T. (2009). The Impact of Agricultural Extension and Roads on Poverty and Consumption Growth in Fifteen Ethiopian Villages. American Journal of Agricultural Economics, 91(4), 10071021.

Dercon, S., Hoddinott, J., \& Woldehanna, T. (2012). Growth and Chronic Poverty: Evidence from Rural Communities in Ethiopia. Journal of Development Studies, 48(2), 238-253.

Desmet, K., Ortuño-Ortín, I., \& Wacziarg, R. (2012). The political economy of linguistic 


\section{REFERENCES}

cleavages. Journal of Development Economics, 97(2), 322-338.

Devarajan, S. (2013). Africa's Statistical Tragedy. Review of Income and Wealth, 59(S1), 915.

Devereux, S., Teshome, A., \& Sabates-Wheeler, R. (2005). Too Much Inequality or Too Little? Inequality and Stagnation in Ethiopian Agriculture. IDS Bulletin, 36(2), 121126.

Dhar, A. (2011). India-Africa Partnership. In H. H. S. Viswanathan, A. Varma, \& D. Sharma (Eds.), ORF Seminar Series “India-Africa Partnership” (Vol. 1, pp. 1-52). New Delhi, India: Observer Research Foundation.

Diamond, J. (1997). Guns, Germs and Steel: The Fates of Human Societies. New York, NY: WW Norton \& Company.

Diamond, L. J. (2002). Thinking About Hybrid Regimes. Journal of Democracy, 13(2), 21 35.

Dietrich, S., \& Wright, J. (2013). Foreign Aid and Democratic Development in Africa. In D. Resnick \& N. van de Walle (Eds.), Democratic Trajectories in Africa: Unravelling the Impact of Foreign Aid (pp. 56-86). Oxford, UK: Oxford University Press.

Dietrich, S., \& Wright, J. (2015). Foreign Aid Allocation Tactics and Democratic Change in Africa. Journal of Politics, 77(1), 216-234.

Dietz, T., Havnevik, K., Kaag, M., \& Oestigaard, T. (2011). African engagements: On whose terms? Africa negotiating an emerging multipolar world. In T. Dietz, K. Havnevik, M. Kaag, \& T. Oestigaard (Eds.), African Engagements, Africa Negotiating an Emerging Multipolar World (pp. 1-32). Leiden, The Netherlands: Brill.

Dincecco, M., \& Prado, M. (2012). Warfare, fiscal capacity, and performance. Journal of Economic Growth, 17(3), 171-203.

Dippel, C. (2014). Forced Coexistence and Economic Development: Evidence From Native American Reservations. Econometrica, 82(6), 2131-2165.

Djankov, S., Montalvo, J. G., \& Reynal-Querol, M. (2008). The curse of aid. Journal of Economic Growth, 13(3), 169-194.

Dollar, D., \& Levin, V. (2006). The Increasing Selectivity of Foreign Aid, 1984-2003. World Development, 34(12), 2034-2046.

Donaldson, D., \& Hornbeck, R. (2016). Railroads and American Economic Growth: A "Market Access" Approach. Quarterly Journal of Economics, 131(2), 799-858.

Doucouliagos, H., \& Paldam, M. (2008). Aid effectiveness on growth: A meta study. European Journal of Political Economy, 24(1), 1-24.

Dreher, A. (2009). IMF conditionality: theory and evidence. Public Choice, 141(1-2), 233267.

Dreher, A., Eichenauer, V., \& Gehring, K. (2016). Geopolitics, Aid and Growth: The Impact of UN Security Council Membership on the Effectiveness of Aid. World Bank Economic Review, forthcoming.

Dreher, A., \& Fuchs, A. (2015). Rogue aid? An empirical analysis of China's aid allocation. Canadian Journal of Economics, 48(3), 988-1023.

Dreher, A., Fuchs, A., Hodler, R., Parks, B. C., Raschky, P. A., \& Tierney, M. J. (2014). Aid on Demand: African Leaders and the Geography of China's Foreign Assistance. Aid Data Working Paper No. 3. Williamsburg, VA: Aid Data.

Dreher, A., Fuchs, A., Parks, B., Strange, A. M., \& Tierney, M. J. (2017). Apples and 


\section{REFERENCES}

Dragon Fruits: The Determinants of Aid and Other Forms of State Financing from China to Africa. International Studies Quarterly, Forthcoming.

Dreher, A., Nunnenkamp, P., \& Thiele, R. (2008). Does US Aid Buy UN General Assembly Votes? A Disaggregated Analysis. Public Choice, 136(1/2), 139-164.

Dreher, A., Nunnenkamp, P., \& Thiele, R. (2011). Are "New”Donors Different? Comparing the Allocation of Bilateral Aid Between nonDAC and DAC Donor Countries. World Development, 39(11), 1950-1968.

Dreher, A., Sturm, J.-E., \& Vreeland, J. R. (2009). Global horse trading: IMF loans for votes in the United Nations Security Council. European Economic Review, 53(7), 742757.

Duflo, E., Glennerster, R., \& Kremer, M. (2007). Using Randomization in Development Economics Research: A Toolkit. In T. P. Schultz \& J. Strauss (Eds.), Handbook of Development Economics (Vol. 4, pp. 3895-3962). Amsterdam, The Netherlands: North Holland Elsevier Science Publishers B. V.

Dunning, T. (2004). Conditioning the Effects of Aid: Cold War Politics, Donor Credibility and Democracy in Africa. International Organization, 58(2), 409-423.

Easterly, W. R. (2006). The White Man's Burden: Why the West's Efforts to Aid the Rest Have Done So Much Ill and So Little Good. London, UK: Penguin Press.

Easterly, W. R. (2009). Can the West Save Africa? Journal of Economic Literature, 47(2), 373-447.

Easterly, W. R., \& Levine, R. (1997). Africa's Growth Tragedy: Policies and Ethnic Divisions. Quarterly Journal of Economics, 112(4), 1203-1250.

Easterly, W. R., Levine, R., \& Roodman, D. (2004). Aid, Policies, and Growth: Comment. American Economic Review, 94(3), 774-780.

Eckstein, H., \& Gurr, T. R. (1975). Patterns of Authority: A Structural Basis for Political Inquiry. New York, NY: Wiley-Interscience.

Eggen, Ø., \& Roland, K. (2013). Western Aid at a Crossroads: The End of Paternalism. Basingstoke, UK: Palgrave Macmillan.

Eichengreen, B. (2013). Number One Country, Number One Currency? The World Economy, 36(4), 363-374.

Elvin, M. (1973). The Pattern of the Chinese Past. Stanford, CA: Stanford University Press. Engerman, S. L., \& Sokoloff, K. L. (1997). Factor endowments, institutions, and differential paths of growth among new world economies: a view from economic historians of the United States. In S. Haber (Ed.), How Latin America Fell Behind. Essays on the Economic Histories of Brazil and Mexico, 1800-1914 (pp. 260-304). Stanford, CA: Stanford University Press.

Englebert, P. (2000). Pre-Colonial Institutions, Post-Colonial States, and Economic Development in Tropical Africa. Political Research Quarterly, 53(1), 7-36.

Ergas, Z. (1980). Why Did the Ujamaa Village Policy Fail? - Towards a Global Analysis. Journal of Modern African Studies, 18(3), 387-410.

Erlich, A., \& Sonne, C. R. (1963). The Soviet Union: Economic Activity. In Z. K. Brzezinski (Ed.), Africa and the Communist World (pp. 49-83). Stanford, CA: Stanford University Press.

Escribano, A., Gulasch, J. L., \& Pena, J. (2008). Impact of Infrastructure Constraints on Firm Productivity in Africa. AISD Working Paper 9. Washington, DC: The World Bank. 
EU-EOM. (2005). Preliminary Statement on the Election Appelas' Process, the Re-Run of Elections and the Somali Region Elections. Addis Ababa, Ethiopia.

EU-EOM. (2010). House of People's Representatives and State Council Elections May 2010. Ethiopia. Final Report. Addis Ababa, Ethiopia.

Evans, P. B. (1995). Embedded Autonomy: States and Industrial Transformation. New York, NY: Cambridge University Press.

Evans, P. B., \& Rauch, J. E. (1999). Bureaucracy and Growth: A Cross-National Analysis of the Effects of "Weberian" State Structures on Economic Growth. American Sociological Review, 64(5), 748-765.

Faber, B. (2014). Trade Integration, Market Size, and Industrialization: Evidence from China's National Trunk Highway System. The Review of Economic Studies, 81(3), 1046-1070.

Faye, M., \& Niehaus, P. (2012). Political Aid Cycles. American Economic Review, 102(7), 3516-3530.

Fearon, J. D., \& Laitin, D. D. (2003). Ethnicity, Insurgency, and Civil War. American Political Science Review, 97(1), 75-90.

Feenstra, R. C., Inklaar, R., \& Timmer, M. P. (2015). The Next Generation of the Penn World Table. American Economic Review, 105(10), 3150-3182.

Feeny, S., \& McGillivray, M. (2009). Aid allocation to fragile states: absorptive capacity constraints. Journal of International Development, 21(5), 618-632.

Fei, J. C. H., \& Ranis, G. (1964). Development of the Labour Surplus Economy. Theory and Policy. Homewood, IL: Irwin.

Fenske, J. (2014). Ecology, Trade, and States in Pre-Colonial Africa. Journal of the European Economic Association, 12(3), 612-640.

Fenta, K. (2014). Industry and Industrialization in Ethiopia: Policy Dynamics and Spatial Distributions. European Journal of Business and Management, 6(34), 326-345.

Feyissa, D. (2011). Aid negotiation: The uneasy "partnership" between EPRDF and the donors. Journal of Eastern African Studies, 5(4), 788-817.

Feyzioglu, T., Swaroop, V., \& Zhu, M. (1998). A Panel Data Analysis of the Fungibility of Foreign Aid. World Bank Economic Review, 12(1), 29-58.

Fisher, J., \& Anderson, D. M. (2015). Authoritarianism and the securitization of development in Africa. International Affairs, 91(1), 131-151.

Fleck, R. K., \& Kilby, C. (2006). How Do Political Changes Influence US Bilateral Aid Allocations? Evidence from Panel Data. Review of Development Economics, 10(2), 210-223.

Fleck, R. K., \& Kilby, C. (2010). Changing aid regimes? U.S. foreign aid from the Cold War to the War on Terror. Journal of Development Economics, 91(2), 185-197.

Fortes, M., \& Evans-Pritchard, E. E. (1940). African Political Systems. London, UK: Oxford University Press.

Foster, V., \& Briceño-Garmendia, C. (2010). Africa's Infrastructure - A Time for Transformation. Washington, D.C.: The World Bank.

Foster, V., Butterfield, W., Chen, C., \& Pushak, N. (2009). Building Bridges: China's Growing Role as Infrastructure Financier for Sub-Saharan Africa. Washington, D.C.: The World Bank.

Foster, V., \& Morella, E. (2010). Ethiopia's Infrastructure: A Continental Perspective. 
Washington, D.C.: The World Bank.

Frankema, E. (2011). Colonial taxation and government spending in British Africa, 1880-1940: Maximizing revenue or minimizing effort? Explorations in Economic History, 48(1), 136-149.

Frankema, E., \& van Waijenburg, M. (2014). Metropolitan Blueprints of Colonial Taxation? Lessons from Fiscal Capacity Building in British and French Africa, c. 1880-1940. Journal of African History, 55(3), 371-400.

Fraser, A., \& Whitfield, L. (2009). Understanding Contemporary Aid Relationships. In L. Whitfield (Ed.), The Politics of Aid. African Strategies for Dealing with Donors (pp. 74-107). Oxford, NY: Oxford University Press.

FreedomHouse. (2016). Methodology. Freedom in the World 2012. Retrieved from https:/ / freedomhouse.org/report/freedom-world-2012/methodology

French, H. D. (2014). China's Second Continent: How a Million Migrants are Building a New Empire in Africa. New York, NY: Knopf

Friedman, M. (1958). Foreign Economic Aid: Means and Objective. Yale Review, 47(4), $500-516$.

Fuchs, A., \& Vadlamannati, K. C. (2013). The Needy Donor: An Empirical Analysis of India's Aid Motives. World Development, 44, 110-128.

Furtado, X., \& Smith, W. J. (2009). Ethiopia: Retaining Sovereignty in Aid Relations. In L. Whitfield (Ed.), The Politics of Aid. African Strategies for Dealing with Donors. (pp. 131-155). Oxford, UK: Oxford University Press.

Gadzala, A. W. (2015). Ethiopia: Toward a Foreign-Funded "Revolutionary Democracy." In A. W. Gadzala (Ed.), Africa and China: How Africans and Their Governments are Shaping Relations with China (pp. 85-106). Lanham, MD: Rowman $\&$ Littlefield.

Gagliardone, I. (2014). New media and the developmental state in Ethiopia. African Affairs, 113(451), 279-299.

Galiani, S., Knack, S., Xu, L. C., \& Zou, B. (2017). The effect of aid on growth: evidence from a Quasi-experiment. Journal of Economic Growth, 22(1), 1-33.

Gallego, F. A. (2010). Historical Origins of Schooling: The Role of Democracy and Political Decentralization. Review of Economics and Statistics, 92(2), 228-243.

Gallup, J. L., Sachs, J. D., \& Mellinger, A. D. (1999). Geography and Economic Development. International Regional Science Review, 22(2), 179-232.

Gandhi, J., \& Przeworski, A. (2007). Authoritarian Institutions and the Survival of Autocrats. Comparative Political Studies, 40(11), 1279-1301.

Garcia-López, M.-Á., Holl, A., \& Viladecans-Marsal, E. (2015). Suburbanization and highways in Spain when the Romans and the Bourbons still shape its cities. Journal of Urban Economics, 85(1), 52-67.

Gebre-Egziabher, T. (2007). Impacts of Chinese imports and coping strategies of local producers: the case of small-scale footwear enterprises in Ethiopia. Journal of Modern African Studies, 45(4), 647-679.

Gebre-Egziabher, T. (2009). The Developmental Impact of Asian Drivers on Ethiopia with Emphasis on Small-scale Footwear Producers. World Economy, 32(11), 16131637.

Gebre-Medhin, M., \& Vahlquist, B. (1976). Famine in Ethiopia - a brief review. The 


\section{REFERENCES}

American Journal of Clinical Nutrition, 29, 1016-1020.

Gebreeyesus, M., \& Iizuka, M. (2012). Discovery of Flower Industry in Ethiopia: Experimentation and Coordination. Journal of Globalization and Development, 2(2), 1948-1837.

Geda, A., \& Meskel, A. G. (2010). Impact of China-Africa Investment Relations: Case Study of Ethiopia. Nairobi, Kenya: African Economic Research Consortium (AERC).

Geddes, B., \& Zaller, J. (1989). Sources of Popular Support for Authoritarian Regimes. American Journal of Political Science, 33(2), 319-347.

Gennaioli, N., \& Rainer, I. (2006). Precolonial Centralization and Institutional Quality in Africa. In M. Gradstein \& K. A. Konrad (Eds.), Institutions and Norms in Economic Development (pp. 21-46). Boston, MA: MIT Press.

Gennaioli, N., \& Rainer, I. (2007). The modern impact of precolonial centralization in Africa. Journal of Economic Growth, 12(3), 185-234.

Ghai, D. P., \& Lee, E. L. H. (1980). The basic needs approach to development: Some issues regarding concepts and methodology. Geneva, Switzerland: International Labour Office.

Gibson, C. C. (2002). Of Waves and Ripples: Democracy and Political Change in Africa in the 1990s. Annual Review of Political Science, 5(1), 201-221.

Gibson, C. C., Andersson, K., Ostrom, E., \& Shivakumar, S. (2005). The Samaritan's Dilemma: The Political Economy of Development Aid. New York, NY: Oxford University Press.

Gilkes, P. (1975). Ethiopia - A Real Revolution? The World Today, 31(1), 15-23.

Gilkes, P. (2015). Elections and Politics in Ethiopia, 2005-2010. In G. Prunier \& É. Fiquet (Eds.), Understanding Contemporary Ethiopia. Monarchy, Revolution and the Legacy of Meles Zenawi (pp. 313-332). London, UK: Hurst \& Company.

Gill, P. (1986). A Year in the Death of Africa: Politics, Bureaucracy and the Famine. Boulder, CO: Paladin Books.

Gill, P. (2010). Famine and Foreigners: Ethiopia Since Live Aid. New York, NY: Oxford University Press.

Giovannetti, G., \& Sanfilippo, M. (2009). Do Chinese Exports Crowd-out African Goods? An Econometric Analysis by Country and Sector. European Journal of Development Research, 21(4), 506-530.

Gleditsch, K. S., \& Ward, M. D. (1997). Double Take: A Reexamination of Democracy and Autocracy in Modern Polities. Journal of Conflict Resolution, 41(3), 361-383.

Goldsmith, A. A. (2001). Foreign Aid and Statehood in Africa. International Organization, 55(1), 123-148.

Good, K. (2008). Diamonds, Dispossession and Democracy in Botswana. Suffolk, UK: Boydell $\&$ Brewer.

Grant, K. (2005). A Civilised Savagery: Britain and the New Slaveries in Africa, 1884-1926. London, UK: Routledge.

Greif, A. (1994). Cultural Beliefs and the Organization of Society: A Historical and Theoretical Reflection on Collectivist and Individualist Societies. Journal of Political Economy, 102(5), 912-950.

Griffin, K. (1987). World Hunger and the World Economy. London, UK: Macmillan.

Grimm, S. (2014). China-Africa Cooperation: promises, practice and prospects. Journal of Contemporary China, 23(90), 993-1011. 
Grimm, S., Rank, R., McDonald, M., \& Schickerling, E. (2011a). Transparency of Chinese Aid: An analysis of the published information on Chinese external financial flows. Stellenbosch, South Africa.

Grimm, S., Rank, R., McDonald, M., \& Schickerling, E. (2011b). Transparency of Chinese Aid on Chinese external financial flows. Stellenbosch, South Africa: Centre for Chinese Studies at Stellenbosch University.

Gu, J. (2009). China's Private Enterprises in Africa and the Implications for African Development. European Journal of Development Research, 21(4), 570-587.

Hackenesch, C. (2013). Aid Donor Meets Strategic Partner? The European Union's and China's Relations with Ethiopia. Journal of Current Chinese Affairs, 42(1), 7-36.

Hackenesch, C. (2015a). It's Domestic Politics, Stupid! EU Democracy Promotion Strategies Meet African Dominant Party Regimes. World Development, 75, 85-96.

Hackenesch, C. (2015b). Not as bad as it seems: EU and US democracy promotion faces China in Africa. Democratization, 22(3), 419-437.

Hackley, R., \& van der Westhuizen, L. (2011). African Energy's New Friends in China. Bloomberg. Retrieved from http://www.bloomberg.com/bw/magazine/africanenergys-new-friends-in-china-09082011.html

Hadenius, A. (1992). Democracy and Development. Cambridge, UK: Cambridge University Press.

Hall, P. A., \& Taylor, R. C. R. (1996). Political Science and the Three New Institutionalisms. Political Studies, 44(5), 936-957.

Hanhimäki, J. M. (2012). The Rise and Fall of Détente: American Foreign Policy and the Transformation of the Cold War. Washington, D.C.: Potomac Books.

Hansen, H., \& Tarp, F. (2000). Aid Effectiveness Disputed. Journal of International Development, 12(3), 375-398.

Hariri, J. G. (2012). The Autocratic Legacy of Early Statehood. American Political Science Review, 106(3), 471-494.

Hassen, M. (1990). The Oromo of Ethiopia: A History, 1570-1860. Cambridge, UK: Cambridge University Press.

Haugen, H. Ø. (2011). Chinese Exports to Africa: Competition, Complementarity and Cooperation between Micro-Level Actors. Forum for Development Studies, 38(2), 157-176.

Hausman, J. A. (1978). Specification Tests in Econometrics. Econometrica, 46(6), 12511271.

He, Y. (2013). Does China's trade expansion help African development? - an empirical estimation. China Economic Review, 26, 28-38.

Hendrix, C. S. (2010). Measuring state capacity: Theoretical and empirical implications for the study of civil conflict. Journal of Peace Research, 47(3), 273-285.

Herbst, J. (1990). War and the State in Africa. International Security, 14(4), 117-139.

Herbst, J. (2000). States and Power in Africa. Princeton, NJ: Princeton University Press.

Hirono, M., \& Suzuki, S. (2014). Why Do We Need "Myth-Busting" in the Study of Sino-African Relations? Journal of Contemporary China, 23(87), 443-461.

Hirschman, A. O. (1958). The Strategy of Economic Development. New Haven, CT: Yale University Press.

Hjertholm, P., \& White, H. (2000). Foreign aid in historic perspective: background and 
trends. In F. Tarp (Ed.), Foreign Aid and Development: Lessons Learnt and Directions for the Future (pp. 80-102). London, UK: Routledge.

Hochschild, A. (1998). King Leopold's Ghost: A Story of Greed, Terror, and Heroism in Colonial Africa. Boston, MA: Houghton Mifflin.

Holt, J., \& Seaman, J. (1976). The Scope of the Drought. In A. M. Hussein (Ed.), Drought and Famine in Ethiopia. London, UK: International African Institute.

Holt, P. M., \& Daly, M. W. (2011). A History of the Sudan: From the Coming of Islam to the Present Day (6th ed.). New York, NY: Routledge.

Hopkins, R. F. (2000). Political economy of foreign aid. In F. Tarp (Ed.), Foreign Aid and Development: Lessons Learnt and Directions for the Future (pp. 329-348). London, UK: Routledge.

Huang, M. (2007). 中国的对外援助机制: 现状和趋势 [China's Foreign Aid Mechanism: Current State and Trends]. 国际经济合作 [International Economic Cooperation (IEC)], 6, 4-11.

Hubbard, P. (2007). Aiding Transparency: What We Can Learn About China ExIm Bank's Concessional Loans. CGD Working Paper No. 126. Washington, D.C.: Center for Global Development.

Huber, E., \& Stephens, J. D. (2001). Development and Crisis of the Welfare State: Parties and Policies in Global Markets. Chicago, IL: University of Chicago Press.

Hughes, T. (2005). Ghana: A donor success story. South African Journal of International Affairs, 12(2), 75-93.

Huillery, E. (2009). History Matters: The Long-Term Impact of Colonial Public Investments in French West Africa. American Economic Journal: Applied Economics, 1(2), 176-215.

Huillery, E. (2010). The Impact of European Settlement within French West Africa: Did Pre-colonial Prosperous Areas Fall Behind? Journal of African Economies, 20(2), 263-311.

Huntington, S. P. (1991). The Third Wave. Norman, OK: Oklahoma University Press.

Huse, M. D., \& Muyakwa, S. L. (2008). China in Africa: Lending, Policy Space and Governance. Oslo, Norway: Norwegian Council for Africa.

Hydén, G. (2007). Governance and poverty reduction in Africa. Proceedings of the National Academy of Sciences, 104(43), 16751-16756.

Jackson, R. H., \& Rosberg, C. G. (1982). Why Africa's Weak States Persist: The Empirical and Juridical in Statehood. World Politics, 35(1), 1-24.

Jacobs, B. (2011). A Dragon and a Dove? A Comparative Overview of Chinese and European Trade Relations with Sub-Saharan Africa. Journal of Current Chinese Affairs, 40(4), 17-60.

Jaggers, K., \& Gurr, T. R. (1995). Tracking Democracy's Third Wave with the Polity III Data. Journal of Peace Research, 32(4), 469-482.

Jalata, G. G. (2014). Development Assistance from the South: Comparative Analysis of Chinese and Indian to Ethiopia. Chinese Studies, 3(1), 24-39.

Jerven, M. (2013a). For richer, for poorer: GDP revisions and Africa's statistical tragedy. African Affairs, 112(446), 138-147.

Jerven, M. (2013b). Poor Numbers: How We Are Misled by African Development Statistics and What to Do About It. Ithaca, NY: Cornell University Press. 
Jolly, R., Emmerji, L., \& Weiss, T. G. (2005). The Power of UN Ideas: Lessons from the First 60 Years. The UN Intellectual History Project. New York, NY: United Nations.

Jonas, R. (2011). The Battle of Adwa: African Victory in the Age of Empire. Cambridge, MA: Belknap Press of Harvard University Press.

Jones, S., \& Tarp, F. (2016). Does foreign aid harm political institutions? Journal of Development Economics, 118(1), 266-281.

Kaberuka, D., Schwab, K., \& Zoellick, R. B. (2011). The Africa Competitiveness Report 2011. Geneva, Switzerland and New York, NY: World Economic Forum.

Kagan, R. (2008). The Return of History and the End of Dreams. New York, NY: Knopf.

Kahin, G. M. (1956). The Asian-African Conference: Bandung, Indonesia, April 1955. Ithaca, NY: Cornell University Press.

Kaldor, N. (1967). Strategic Factors in Economic Development. Ithaca, NY: Cornell University Press.

Kalyvitis, S., \& Vlachaki, I. (2012). When does more aid imply less democracy? An empirical examination. European Journal of Political Economy, 28(1), 132-146.

Kaplan, R. D. (2003). Surrender or Starve. Travels in Ethiopia, Sudan, Somalia, and Eritrea. New York, NY: Vintage Books.

Kaplinsky, R., \& Morris, M. (2009). Chinese FDI in Sub-Saharan Africa: Engaging with Large Dragons. European Journal of Development Research, 21(4), 551-569.

Kapuściński, R. (1978). The Emperor: Downfall of an Autocrat. New York, NY: Vintage Books.

Kaufmann, D., Kraay, A., \& Mastruzzi, M. (2010). The Worldwide Governance Indicators: Methodology and Analytical Issues. Policy Research Working Paper No. 5430. Washington, D.C.: The World Bank.

Kaufmann, D., Kraay, A., \& Zoido-Lobatón, P. (1999). Governance Matters. Policy Research Working Paper No. 2196. Washington, D.C.: The World Bank.

Kaufmann, D., Kraay, A., \& Zoido-Lobatón, P. (2000). Governance Matters: From Measurement to Action. Finance \& Development, 37(2), 10-13.

Keller, E. J. (1981). The revolutionary transformation of Ethiopia's twentieth century empire. Journal of Modern African Studies, 19(2), 307-335.

Keller, E. J. (1989). Revolutionary Ethiopia: From Empire to People's Republic. Bloomington, IN: Indiana University Press.

Keller, E. J. (1992). Drought, War, and the Politics of Famine in Ethiopia and Eritrea. Journal of Modern African Studies, 30(4), 609-624.

Keller, E. J. (1995). Remaking the Ethiopian State. In W. Zartman (Ed.), Collapsed States: The Disintegration and Restoration of Legitimate Authority (pp. 125-139). London, UK: Lynne Rienner Publishers.

Kelsall, T. (2013). Business, Politics and the State in Africa: Challenging the Orthodoxies on Growth and Transformation. London, UK: Zed Books Ltd.

Kersting, E. K., \& Kilby, C. (2016). With a little help from my friends: Global electioneering and World Bank lending. Journal of Development Economics, 121(C), 153-165.

Kilama, E. G. (2016). The influence of China and emerging donors aid allocation: A recipient perspective. China Economic Review, 38, 76-91.

Kilby, C. (2009). The political economy of conditionality: An empirical analysis of 
World Bank loan disbursements. Journal of Development Economics, 89(1), 51-61.

Kilby, C. (2011). Informal influence in the Asian Development Bank. Review of International Organizations, 6(3-4), 223-257.

Killick, T. (1997). Principals, Agents and the Failings of Conditionality. Journal of International Development, 9(4), 483-495.

King, K. (2013). China's Aid and Soft Power in Africa. Woodbridge, UK: Boydell Press.

Kissi, E. (2000). The Politics of Famine in U.S. Relations with Ethiopia, 1950-1970.

International Journal of African Historical Studies, 33(1), 113-131.

Kissi, E. (2005). Beneath International Famine Relief in Ethiopia: The United States, Ethiopia, and the Debate over Relief Aid, Development Assistance, and Human Rights. African Studies Review, 48(2), 111-132.

Kitano, N., \& Harada, Y. (2016). Estimating China's Foreign Aid 2001-2013. Journal of International Development, 28(7), 1050-1074.

Klare, M., \& Volman, D. (2006). America, China \& the Scramble for Africa's Oil. Review of African Political Economy, 33(108), 297-309.

Knack, S. (2001). Aid Dependence and the Quality of Governance: Cross-Country Empirical Tests. Southern Economic Journal, 68(2), 310-329.

Knack, S. (2004). Does Foreign Aid Promote Democracy? International Studies Quarterly, 48(1), 251-266.

Knack, S., \& Rahman, A. (2007). Donor fragmentation and bureaucratic quality in aid recipients. Journal of Development Economics, 83(1), 176-197.

Kobayashi, T. (2008). Evolution of China's Aid Policy. JBICI Working Paper No. 27. Tokyo, Japan: Japan Bank for International Cooperation Institute.

Koehn, P. (1979). Ethiopia: Famine, Food Production, and Changes in the Legal Order. African Studies Review, 22(1), 51-71.

Kosack, S., \& Tobin, J. (2006). Funding Self-Sustaining Development: The Role of Aid, FDI and Government in Economic Success. International Organization, 60(1), 205243.

Kragelund, P. (2008). The Return of Non-DAC Donors to Africa: New Prospects for African Development? Development Policy Review, 26(5), 555-584.

Krueger, A. O., Michalopoulos, C., \& Ruttan, V. W. (1989). Aid and Development. Baltimore, MD: Johns Hopkins University Press.

Kumar, G. (1990). Ethiopian Famines: 1973-1985. A Case Study. In J. Drèze \& A. Sen (Eds.), The Political Economy of Hunger. Oxford, UK: Clarendon Press.

Kurlantzick, J. (2006). Beijing's Safari: China’s Move into Africa and Its Implications for Aid, Development, and Governance. Policy Outlook, November), 1-7. Retrieved from http://carnegieendowment.org/files/kurlantzick_outlook_africa2.pdf

Kuziemko, I., \& Werker, E. (2006). How Much Is a Seat on the Security Council Worth? Foreign Aid and Bribery at the United Nations. Journal of Political Economy, 114(5), 905-930.

Kuznets, S. (1966). Modern Economic Growth. New Haven, CT: Yale University Press.

La Porta, R., Lopez-de-Silanes, F., Shleifer, A., \& Vishny, R. W. (1997). Legal Determinants of External Finance. Journal of Finance, 52(3), 1131-1150.

La Porta, R., Lopez-de-Silanes, F., Shleifer, A., \& Vishny, R. W. (1998). Law and 
Finance. Journal of Political Economy, 106(6), 1113-1155.

La Porta, R., Lopez-de-Silanes, F., Shleifer, A., \& Vishny, R. W. (1999). The Quality of

Government. Journal of Law, Economics, and Organization, 15(1), 222-279.

Lahiri, S., \& Raimondos-Møller, P. (2004). Donor Strategy under the Fungibility of Foreign Aid. Economics and Politics, 16(2), 213-231.

Laitin, D. D., \& Samatar, S. S. (1987). Somalia: Nation in Search of a State. Boulder, CO: Westview Press.

Lancaster, C. (2007a). Foreign Aid: Diplomacy, Development and Domestic Politics. Chicago, IL: Chicago University Press.

Lancaster, C. (2007b). The Chinese Aid System. Washington, D.C.: Center for Global Development.

Landes, D. S. (1998). The Wealth and Poverty of Nations: Why Some Are So Rich and Some So Poor. New York, NY: WW Norton \& Company.

Landes, D. S. (2006). Why Europe and the West? Why Not China? Journal of Economic Perspectives, 20(2), 3-22.

Lange, M. K. (2004). British Colonial Legacies and Political Development. World Development, 32(6), 905-922.

Lange, M. K. (2009). Lineages of Despotism and Development: British Colonialism and State Power. Chicago, IL: University of Chicago Press.

Larmer, B. (2017). Is China the World's New Colonial Power? The New York Times Magazine. Retrieved from https://www.nytimes.com/2017/05/02/magazine/ischina-the-worlds-new-colonial-power.html?_r=0

Lavers, T. (2012). "Land grab" as development strategy? The political economy of agricultural investment in Ethiopia. Journal of Peasant Studies, 39(1), 105-132.

Lawson, M. L. (2011). Foreign Aid: International Donor Coordination of Development Assistance. Journal of Current Issues in Globalization, 4(1), 77-99.

Lee, J. (2012). China's Geostrategic Search for Oil. The Washington Quarterly, 35(3), 7592.

Lefebvre, J. A. (1991). Arms for the Horn: U.S. Security Policy in Ethiopia and Somalia 19531991. Pittsburgh, PA: University of Pittsburgh Press.

Lefebvre, J. A. (1998). The United States, Ethiopia and the 1963 Somali - Soviet arms deal: containment and the balance of Africa. Journal of Modern African Studies, 36(4), 611-643.

Lefort, R. (2007). Powers - Mengist - and Peasants in Rural Ethiopia: The May 2005 Elections. Journal of Modern African Studies, 45(2), 253-273.

Lefort, R. (2013). The Theory and Practice of Meles Zenawi: A response to Alex de Waal. African Affairs, 112(448), 460-470.

Lefort, R. (2015). The Ethiopian Economy: The Developmental State vs. the Free Market. In G. Prunier \& É. Fiquet (Eds.), Understanding Contemporary Ethiopia. Monarchy, Revolution and the Legacy of Meles Zenawi (pp. 357-394). London, UK: Hurst \& Company.

Lekalake, R. (2016). Botswana's democratic consolidation What will it take? (No. Afrobarometer Policy Paper No. 30).

Lensink, R., \& White, H. (2001). Are There Negative Returns to Aid? Journal of Development Studies, 37(6), 42-65. 
Levi, M. (1988). Of Rule and Revenue. Berkeley, CA: University of California Press.

Levi, M. (2002). Modeling Complex Historical Processes with Analytic Narratives. In R. Mayntz (Ed.), Akteure - Mechanismen - Modelle: Zur Theoriefähigkeit makro-sozialer Analysen (pp. 108-127). Frankfurt/Main, Germany: Campus Verlag.

Levine, D. (1961). Haile Selassie's Ethiopia - Myth or Reality? Africa Today, 8(5), 11-14.

Lewis, W. A. (1954). Economic Development with Unlimited Supplies of Labour. Manchester School, 22, 139-191.

Li, A. (2011). Chinese Medical Cooperation In Africa. NAI Discussion Paper No. 52. Uppsala, Sweden.

Li, H., Li, L., Wu, B., \& Xiong, Y. (2012). The End of Cheap Chinese Labor. Journal of Economic Perspectives, 26(4), 57-74.

Li, H., \& Li, Z. (2013). Road investments and inventory reduction: Firm level evidence from China. Journal of Urban Economics, 76(1), 43-52.

Licht, A. A. (2010). Coming into Money: The Impact of Foreign Aid on Leader Survival. Journal of Conflict Resolution, 54(1), 58-87.

Lijphart, A. (2008). Thinking about Democracy: Power Sharing and Majority Rule in Theory and Practice. London, UK: Routledge.

Lin, J. Y. (2012). From Flying Geese to Leading Dragons: New Opportunities and Strategies for Structural Transformation in Developing Countries. Global Policy, 3(4), 397-409.

Lin, J. Y. (2015). China's Rise and Structural Transformation in Africa. Ideas and Opportunities. In C. Monga \& J. Y. Lin (Eds.), The Oxford Handbook of Africa and Economics: Volume 2: Policies and Practices (2nd ed., pp. 815-829). Oxford, UK: Oxford University Press.

Lin, J. Y., \& Pradhan, S. (2010). Forword. In D. Z. Zeng (Ed.), Building Engines for Growth and Competitiveness in China: Experience with Special Economic Zones and Industrial Clusters (pp. xiii-ix). Washington, D.C.: World Bank.

Lin, T. (1996). Beijing's Foreign Aid Policy in the 1990s: Continuity and Change. Issues \& Studies, 32(1), 32-56.

Liu, P., Guo, Y., Qian, X., Tang, S., Li, Z., \& Chen, L. (2014). China's distinctive engagement in global health. The Lancet, 384(9945), 793-804.

Lumsdaine, D. H. (1993). Moral Vision in International Politics: The Foreign Aid Regime, 19491989. Princeton, NJ: Princeton University Press.

Lundborg, P. (1998). Foreign Aid and International Support as Gift Exchange. Economics and Politics, 10(2), 127-142.

Lundström, K. J. (1976). North-Eastern Ethiopia: Society in Famine. A Study of Three Social Institutions in a Period of Severe Strain. Uppsala, Sweden: Scandinavian Institute of African Studies.

Mackie, J. (2005). Bandung 1955: Non-alignment and Afro-Asian Solidarity. Singapore: Editions Didier Millet.

Maddison, A. (1988). Ultimate and proximate growth causality: A critique of Mancur Olson on the rise and decline of nations. Scandinavian Economic History Review, 36(2), 25-29.

Maddison, A. (2010). Statistics on World Population, GDP and Per Capita GDP, 12008 AD. Groningen Growth and Development Center, University of 
Groningen, The Netherlands. Retrieved from http://www.ggdc.net/maddison/oriindex.htm

Madsen, J. B., Raschky, P. A., \& Skali, A. (2015). Does democracy drive income in the world, 1500-2000? European Economic Review, 78, 175-195.

Mahajan, V. (2008). Africa Rising: How 900 Million African Consumers Offer More Than You Think. Upper Saddle River, NJ: Pearson Prentice Hall.

Maizels, A., \& Nissanke, M. K. (1984). Motivations for Aid to Developing Countries. World Development, 12(9), 879-900.

Makinda, S. M. (1996). Democracy and Multi-Party Politics in Africa. Journal of Modern African Studies, 34(4), 555-573.

Mamdani, M. (1996). Citizen and Subject: Contemporary Africa and the Legacy of Late Colonialism. Princeton, NJ: Princeton University Press.

Manning, P. (1990). Slavery and African Life; Occidental, Oriental and African Slave Trades. Cambridge, UK: Cambridge University Press.

Manning, R. (2006). Will "Emerging Donors" Change the Face of International Cooperation? Development Policy Review, 24(4), 371-385.

Marcus, H. G. (1975). The Life and Times of Menelik II: Ethiopia 1844-1914. Oxford, UK: Clarendon Press.

Marcus, H. G. (2002). A History of Ethiopia. Berkeley, CA: University of California Press.

Maren, M. (1997). The Road to Hell: The Ravaging Effects of Foreign Aid and International Charity. New York, NY: Free Press.

Markakis, J. (2011). Ethiopia: the last two frontiers. Woodbridge, UK: James Curry.

Markakis, J., \& Ayele, N. (1977). Class and Revolution in Ethiopia. Review of African Political Economy, 4(8), 99-108.

Marshall, M. G. (2014). Major Episodes of Political Violence, 1946-2013. Center for Systemtic Peace, Vienna, VA.

Marshall, M. G., Jaggers, K., \& Gurr, T. R. (2014). Polity IV Project, Political Regime Characteristics and Transitions, 1800-2013. Center for Systemic Peace. Vienna, VA. Retrieved from http://www.systemicpeace.org/inscrdata.html

Mascagni, G. (2016a). A Fiscal History of Ethiopia: Taxation and Aid Dependence 1960-2010. ICTD Working Paper Series No. 49. International Centre for Tax and Development. Brighton, UK.

Mascagni, G. (2016b). Aid and Taxation in Ethiopia. Journal of Development Studies, 52(12), 1744-1758.

Matthews, N., Nicol, A., \& Seide, W. M. (2012). Constructing a new water future? An analysis of Ethiopia's current hydropower development. In J. A. Allan, M. Keulertz, S. Sojamo, \& J. Warner (Eds.), Handbook of Land and Water Grabs in Africa: Foreign Direct Investment and Food and Water Securi ty (pp. 311-323). Abingdonon-Thames, UK: Routledge.

Mayer, T., \& Zignago, S. (2011). Notes on CEPII's distances measures: The GeoDist database. CEPII Working Paper No. 2011-25. Paris, France: Centre d'Etudes Prospectives et d'Informations Internationales.

McEvedy, C., \& Jones, R. (1975). Atlas of World Population History. New York, NY: Facts on File.

McKinlay, R. D., \& Little, R. (1977). A Foreign Policy Model of U.S. Bilateral Aid 
Allocation Author. World Politics, 30(1), 58-86.

McKinlay, R. D., \& Little, R. (1978a). A Foreign-Policy Model of the Distribution of British Bilateral Aid, 1960-70. British Journal of Political Science, 8(3), 313-331.

McKinlay, R. D., \& Little, R. (1978b). The French aid relationship: a foreign policy model of the distribution of French bilateral aid, 1964-70. Development and Change, 9(3), 459-478.

McMillan, M. S., Rodrik, D., \& Verduzco-Gallo, Í. (2014). Globalization, Structural Change, and Productivity Growth, with an Update on Africa. World Development, $63,11-32$.

McVety, A. K. (2012). Enlightened Aid: U.S. Development as Foreign Policy in Ethiopia. New York, NY: Oxford University Press.

Médecins Sans Frontières. (1985). Mass Deportations in Ethiopia. Paris, France.

Meier, G. M. (1984). Emerging from Poverty: The Economics That Really Matters. New York, NY: Oxford University Press.

Mekasha, T. J., \& Tarp, F. (2013). Aid and Growth: What Meta-Analysis Reveals. Journal of Development Studies, 49(4), 564-583.

Melber, H. (2016). The Rise of Africa's Middle Class: Myths, Realities and Critical Engagements. London, UK: Zed Books.

Meltzer, A. H. (2000). Report of the International Financial Institutions Advisory Commission. Washington, D.C.: International Financial Institutions Advisory Committee.

Mengisteab, K. (1990). Ethiopia: Failure of land reform and agricultural crisis. New York, NY: Greenwood Press.

Meredith, M. (2005). The State of Africa: A History of the Continent Since Independence. London, UK: Simon \& Schuster Ltd.

Metaferia, G. (2009). Ethiopia and the United States: History, Diplomacy, and Analysis. New York, NY: Algora Publishing.

Michalopoulos, S., \& Papaioannou, E. (2013). Pre-Colonial Ethnic Institutions and Contemporary African Development. Econometrica, 81(1), 113-152.

Michalopoulos, S., \& Papaioannou, E. (2014). National Institutions and Subnational Development in Africa. Quarterly Journal of Economics, 129(1), 151-213.

Michalopoulos, S., \& Papaioannou, E. (2015). Further evidence on the link between pre-colonial political centralization and comparative economic development in Africa. Economics Letters, 126(1), 57-62.

Milkias, P. (2011). Ethiopia. Santa Barbara, CA: ABC-CLIO.

Miller, D. S., \& Holt, J. (1974). The Ethiopian famine. Proceedings of the Nutrition Society, 34(3), 167-172.

Mkandawire, T. (2001). Thinking about developmental states in Africa. Cambridge Journal of Economics, 25(3), 289-313.

Mockler, A. (2003). Haile Selassie's War. Oxford, UK: Signal Books.

MOFCOM. (2009). 2009 Statistical Bulletin of China's Outward Foreign Direct Investment. Beijing, People's Republic of China: Ministry of Commerce of the People's Republic of China.

MOFCOM. (2011). 2010 Statistical Bulletin of China's Outward Foreign Direct Investment. Beijing, People's Republic of China: Ministry of Commerce of the People's Republic of China. 
MOFCOM. (2014). 2013 Statistical Bulletin of China's Outward Foreign Direct Investment. Beijing, People's Republic of China.

Moghalu, K. C. (2014). Emerging Africa: How the Global Economy's "Last Frontier" Can Prosper and Matter. London, UK: Penguin.

Mohan, G., \& Lampert, B. (2013). Negotiating China: Reinserting African agency into China-Africa relations. African Affairs, 112(446), 92-110.

Mohan, G., \& Power, M. (2008). New African Choices? The Politics of Chinese Engagement. Review of African Political Economy, 35(115), 23-42.

MOI. (2014a). Envrionemntal and Social Management Framework for Bole Lemi II and Kilinto Industrial Zones. Addis Ababa, Ethiopia. Ethiopian Ministry of Industry.

MOI. (2014b). Envrionmental Social Impact Assessment Report for Bole Lemi II Industrial Zone. Addis Ababa, Ethiopia. Ethiopian Ministry of Industry.

Molenaers, N., Dellepiane, S., \& Faust, J. (2015). Political Conditionality and Foreign Aid. World Development, 75, 2-12.

Monga, C. (2011). Shifting Gears: Igniting Structural Transformation in Africa. Journal of African Economies, 21(Suppl 2), ii19-ii54.

Montalvo, J. G., \& Reynal-Querol, M. (2005). Ethnic Polarization, Potential Conflict, and Civil Wars. American Economic Review, 95(3), 796-816.

Morgenthau, H. (1962). A Political Theory of Foreign Aid. American Political Science Review, 56(2), 301-309.

Morrison, K. M. (2007). Natural resources, aid, and democratization: A best-case scenario. Public Choice, 131(3-4), 365-386.

Morrison, K. M. (2009). Oil, Nontax Revenue, and the Redistributional Foundations of Regime Stability. International Organization, 63(1), 107-138.

Moszynski, P. (2011). Ethiopia's controversial dam project. The Guardian. Retrieved from http://www.theguardian.com/global-development/povertymatters $/ 2011 / \mathrm{mar} / 07 /$ ethiopia-controversial-dam-criticism-communities

Moyo, D. (2009). Dead Aid: Why Aid Is Not Working and How There is a Better Way for Africa. New York, NY: Farrar, Straus and Giroux.

Moyo, D. (2012). Winner Take All: China's Race for Resources and What It Means for the World. New York, NY: Basic Books.

Munck, G. L., \& Verkuilen, J. (2002). Conceptualizing and Measuring Democracy. Evaluating Alternative Indices. Comparative Political Studies, 35(1), 5-34.

Munro-Hay, S. (1991). Aksum: An African Civilization of Late Antiquity. Edinburgh, UK: Edinburgh University Press.

Murdock, G. P. (1967). Ethnographic Atlas. Pittsburgh, PA: University of Pittsburgh Press.

Murrell, N. S., Spencer, W. D., \& McFarlane, A. A. (1998). Chanting Down Babylon: The Rastafari Reader. Philadelphia, PA: Temple University Press.

Murshed, S. M., \& Sen, S. (1995). Aid Conditionality and Military Expenditure Reduction in Developing Countries: Models of Asymmetric Information. Economic Journal, 105(429), 498-509.

Naidu, S., \& Davies, M. (2006). China Fuels Its Future with Africa's Riches. South African Journal of International Affairs, 13(2), 69-83.

Naím, M. (2007). Rogue Aid. Foreign Policy, 159, 95-96. 
Naudé, W. A., Szirmai, A., \& Haraguchi, N. (2015). Introduction and Overview. In W. A. Naudé, A. Szirmai, \& N. Haraguchi (Eds.), Structural Change and Industrial Development in the BRICS. Oxford, UK: Oxford University Press.

Ncube, M., \& Lufumpa, C. L. (2014). The Emerging Middle Class in Africa. Abingdon-onThames, UK: Routledge.

Neumayer, E. (2002). Do Democracies Exhibit Stronger International Environmental Commitment? A Cross-Country Analysis. Journal of Peace Research, 39(2), 139-164.

Neumayer, E. (2003a). Do Human Rights Matter in Bilateral Aid Allocation? A Quantitative Analysis of 21 Donor Countries. Social Science Quarterly, 84(3), 650666.

Neumayer, E. (2003b). What Factors Determine the Allocation of Aid by Arab Countries and Multilateral Agencies? Journal of Development Studies, 39(4), 134-147.

Neumayer, E. (2004). Arab-related Bilateral and Multilateral Sources of Development Finance: Issues, Trends, and the Way Forward. The World Economy, 27(2), 281300.

Neumayer, E. (2005). Is the Allocation of Food Aid Free from Donor Interest Bias? Journal of Development Studies, 41(3), 394-411.

Nielsen, R. A. (2013). Rewarding Human Rights? Selective Aid Sanctions against Repressive States. International Studies Quarterly, 57(4), 791-803.

Niskanen, W. A. (1994). Bureaucracy and Public Economics. Cheltenham, UK: Edward Elgar.

Noel, A., \& Therien, J. (1995). From Domestic to International Justice: The Welfare State and Foreign Aid. International Organization, 49(3), 523-553.

North, D. C. (1990). Institutions, Institutional Change and Economic Performance. New York, NY: Cambridge University Press.

North, D. C., Wallis, J. J., \& Weingast, B. R. (2009). Violence and Social Orders: A Conceptual Framework for Interpreting Recorded Human History. New York, NY: Cambridge University Press.

North, D. C., \& Weingast, B. R. (1989). Constitutions and Commitment: The Evolution of Institutional Governing Public Choice in Seventeenth-Century England. Journal of Economic History, 49(4), 803-832.

Ntsabane, T., \& Ntau, C. (2000). Youth and electoral participation in Botswana. Journal of African Studies, 4(1), 105-116.

Nunn, N. (2008). The Long-Term Effects of Africa's Slave Trades. Quarterly Journal of Economics, 123(1), 139-176.

Nunn, N., \& Qian, N. (2014). US Food Aid and Civil Conflict. American Economic Review, 104(6), 1630-1666.

Nunn, N., \& Wantchekon, L. (2011). The Slave Trade and the Origins of Mistrust in Africa. American Economic Review, 101(7), 3221-3252.

Nurkse, R. (1953). Problems of capital formation in underdeveloped countries. Oxford, UK: Basil Blackwell.

OECD. (2003). International Development Statistics CD Rom. Paris, France: Organisation for Economic Cooperation and Development.

OECD. (2016). DAC member profile: Sweden. Retrieved May 4, 2017, from http://www.oecd.org/dac/sweden.htm 
OECD. (2017). DAC members. Retrieved February 1, 2017, from http://www.oecd.org/dac/dacmembers.htm

Olsen, G. R. (1998). Europe and the Promotion of Democracy in Post Cold War Africa: How Serious Is Europe and for What Reason? African Affairs, 97(388), 343-367.

Ong'ayo, A. O. (2011). China-Africa Relations: The Relevance Of Strategic Engagement Of African Civil Society Organisations With China. In T. Dietz, K. Havnevik, M. Kaag, \& T. Oestigaard (Eds.), African Engagements, Africa Negotiating an Emerging Multipolar World (pp. 252-279). Leiden, The Netherlands: Brill.

Osafo-Kwaako, P., \& Robinson, J. A. (2013). Political centralization in pre-colonial Africa. Journal of Comparative Economics, 41(1), 6-21.

Ottaway, M. (1977). Land Reform in Ethiopia 1974-1977. African Studies Review, 20(3), 79-90.

Pack, H., \& Pack, J. R. (1990). Is Foreign Aid Fungible? The Case of Indonesia. Economic Journal, 100(399), 188-194.

Pack, H., \& Pack, J. R. (1993). Foreign Aid and the Question of Fungibility. Review of Economics and Statistics, 75(2), 258-265.

Pankhurst, A. (1992). Resettlement and Famine in Ethiopia: The Villagers' Experience. Manchester, UK: Manchester University Press.

Patey, L. A. (2014). The New Kings of Crude: China, India, and the Global Struggle for Oil in Sudan and South Sudan. London, UK: C Hurst \& Co Publishers Ltd.

Patman, R. G. (1990). The Soviet Union in the Horn of Africa: The Diplomacy of Intervention and Disengagement. New York, NY: Cambridge University Press.

Pausewang, S., \& Tronvoll, K. (2000). The Ethiopian 2000 Elections. Democracy Advanced Or Restricted? Oslo, Norway: Unipub Forlag/University of Oslo.

Pearce, J. (2014). Prevail: The Inspiring Story of Ethiopia's Victory over Mussolini's Invasion, 1935-1941. New York, NY: Skyhorse Publishing.

Perry, A. (2015). The Rift: A New Africa Breaks Free. New York, NY: Little, Brown and Company.

PewResearchCenter. (2013). Despite Challenges, Africans Are Optimistic about the Future.

Pierson, P., \& Skocpol, T. (2002). Historical Institutionalism in Contemporary Political Science. In I. Katznelson \& H. V. Milner (Eds.), Political Science: State of the Discipline (pp. 693-721). New York, NY: W.W. Norton \& Company.

Pigato, M., \& Tang, W. (2015). China and Africa: Expanding Economic Ties in an Evolving Global Context. Addis Ababa, Ethiopia: Investing in Africa Forum.

Pinkovskiy, M., \& Sala-i-Martin, X. (2014). Africa is on time. Journal of Economic Growth, 19(3), 311-338.

Plaut, M. (2010). Ethiopia famine aid "spent on weapons." Retrieved from http://news.bbc.co.uk/2/hi/8535189.stm

Plaut, M. (2013). How unstable is the Horn of Africa? Review of African Political Economy, 40(136), 321-330.

Plummer, J. (2012). Diagnosing Corruption in Ethiopia: Perceptions, Realities, and the Way Forward. Washington, D.C.: World Bank.

Plümper, T., \& Neumayer, E. (2010). The Level of Democracy during Interregnum Periods: Recoding the polity2 Score. Political Analysis, 18(2), 206-226.

Pomeranz, K. (2000). The Great Divergence: China, Europe, and the Making of the Modern 
World Economy. Princeton, NJ: Princeton University Press.

Power, M., Mohan, G., \& Tan-Mullins, M. (2012). China's Resource Diplomacy in Africa: Powering Development? London, UK: Palgrave MacMillan.

Prunier, G. (2015a). The Ethiopian Revolution and the Derg Regime. In G. Prunier \&

Ë. Fiquet (Eds.), Understanding Contemporary Ethiopia. Monarchy, Revolution and the Legacy of Meles Zenawi (pp. 209-232). London, UK: Hurst \& Company.

Prunier, G. (2015b). The Meles Zenawi Era: From revolutionary Marxism to State Developmentalism. In G. Prunier \& É. Fiquet (Eds.), Understanding Contemporary Ethiopia. Monarchy, Revolution and the Legacy of Meles Zenawi (pp. 415-437). London, UK: Hurst \& Company.

Przeworski, A., Alvarez, M. E., Cheibub, J. A., \& Limongi, F. (2000). Democracy and Development: Political Institutions and Well-Being in the World, 1950-1990. Cambridge, UK: Cambridge University Press.

Putnam, R. D. (1988). Diplomacy and Domestic Politics: The Logic of Two-Level Games. International Organization, 42(3), 427-460.

Putnam, R. D. (1993). Making Democracy Work: Civic Traditions in Modern Italy. Princeton, NJ: Princeton University Press.

Putterman, L. (2007). State Antiquity Index Dataset, Version 3. Providence, RI: Brown University.

Radelet, S. (2010). Emerging Africa: How 17 Countries Are Leading the Way. Washington, DC: Brookings Institution Press.

Rai, K. B. (1980). Foreign Aid and Voting in the UN General Assembly, 1967-1976. Journal of Peace Research, 17(3), 1967-1976.

Rajan, R. G., \& Subramanian, A. (2007). Does Aid Affect Governance? American Economic Review, 97(2), 322-327.

Rajan, R. G., \& Subramanian, A. (2008). Aid and Growth: What Does the CrossCountry Evidence Really Show? Review of Economics and Statistics, 90(4), 643-665.

Rakotoarisoa, M. A., Iafrate, M., \& Paschali, M. (2011). Why has Africa become a net food importer? Explaining Africa agricultural and food trade deficits. Rome, Italy: Food and Agriculture Organization of the United Nations.

Ramo, J. C. (2004). The Beijing Consensus. London, UK: Foreign Policy Centre.

Rauch, J. E., \& Evans, P. B. (2000). Bureaucratic structure and bureaucratic performance in less developed countries. Journal of Public Economics, 75(1), 49-71.

Ravallion, M. (2009). Are There Lessons for Africa from China's Success against Poverty? World Development, 37(2), 303-313.

Ravallion, M. (2012). Why Don't We See Poverty Convergence? American Economic Review, 102(1), 504-523.

Ravallion, M., \& Chen, S. (2007). China's (Uneven) Progress Against Poverty. Journal of Development Economics, 82(1), 1-42.

Reinikka, R., \& Svensson, J. (2004). Local Capture. Evidence from a Central Government Transfer Program in Uganda. Quarterly Journal of Economics, 119(2), 679-705.

Remmer, K. L. (1995). New Theoretical Perspectives on Democratization. Comparative Politics, 28(1), 103-122.

Reynaud, J., \& Vauday, J. (2009). Geopolitics and international organizations: An 


\section{REFERENCES}

empirical study on IMF facilities. Journal of Development Economics, 89(1), 139-162.

Reynolds, L. G. (1986). Economic Growth in the Third World. New Haven, CT: Yale University Press.

Ricardo, D. (1817). The Principles of Political Economy and Taxation. London, UK: John Murray.

Rich, T. S. (2009). Status for Sale: Taiwan and the Competition for Diplomatic Recognition. Issues \& Studies, 45(4), 159-188.

Riddell, R. C. (2007). Does Foreign Aid Really Work? Oxford, UK: Oxford University Press.

Rodrik, D. (1996). Understanding Economic Policy Reform. Journal of Economic Literature, 34(1), 9-41.

Rodrik, D. (2006). Goodbye Washington Consensus, Hello Washington Confusion? A Review of the World Bank's Economic Growth in the 1990s: Learning from a Decade of Reform. Journal of Economic Literature, 44(4), 973-987.

Rodrik, D. (2015). Economics Rules: The Rights and Wrongs of the Dismal Science. New York, NY: W.W. Norton \& Company.

Rodrik, D., Subramanian, A., \& Trebbi, F. (2004). Institutions Rule: The Primacy of Institutions over Geography and Integration in Economic Development. Journal of Economic Growth, 9(2), 131-165.

Rosenstein-Rodan, P. N. (1943). Problems of Industrialisation of Eastern and SouthEastern Europe. Economic Journal, 53(210), 202-211.

Rosenstein-Rodan, P. N. (1961). International Aid for Underdeveloped Countries. Review of Economics and Statistics, 43(2), 107-138.

Ross, M. L. (2013). Oil and Gas Data, 1932-2011. Harvard Dataverse Network. Retrieved from http://hdl.handle.net/1902.1/20369

Rostow, W. W. (1959). The Stages of Economic Growth. Economic History Review, 12(1), $1-16$.

Rotberg, R. I. (2013). Africa Emerges: Consummate Challenges, Abundant Opportunities. Cambridge, UK: Polity Press.

Rubinstein, A. (2012). Economic Fables. Cambridge, UK: Open Book Publishers.

Rubinstein, A. (2017). Comments on Economic Models, Economics, and Economists: Remarks on Economics Rules by Dani Rodrik. Journal of Economic Literature, 55(1), 162-172.

Rueschemeyer, D., \& Stephens, J. D. (1997). Comparing Historical Sequences: A Powerful Tool for Causal Analysis. Comparative Social Research, 17, 55-72.

Sachs, J. D. (2005). The End of Poverty: Economic Possibilities for Our Time. New York, NY: Penguin Press.

Salini Impreglio. (2016). Grand Ethiopian Rennaissance Project in Ethiopia. Retrieved from http://www.salini-impregilo.com/en/projects/in-progress/damshydroelectric-plants-hydraulic-works/grand-ethiopian-renaissance-damproject.html\#

Sandbrook, R. (1985). The Politics of Africa's Economic Stagnation. New York, NY: Cambridge University Press.

Sandbrook, R. (1990). Taming the African Leviathan. World Policy Journal, 7(4), 673-701. Sanfilippo, M. (2010). Chinese FDI to Africa: What Is the Nexus with Foreign 


\section{REFERENCES}

Economic Cooperation? African Development Review, 22(S1), 599-614.

Sautman, B., \& Hairong, Y. (2007). Friends and Interests: China's Distinctive Links with Africa. African Studies Review, 50(3), 75-114.

Schmidt, E. (2013). Foreign Intervention in Africa: From the Cold $W$ ar to the $W$ ar on Terror. New York, NY: Cambridge University Press.

Schultz, T. W. (1956). Reflections on Agricultural Production, Output and Supply. Journal of Farm Economics, 38(3), 748-762.

Schultz, T. W. (1964). Transforming Traditional Agriculture. New Haven, CT: Yale University Press.

Schwab, K., \& Sala-i-Martin, X. (2011). The Global Competitiveness Report 2011-2012. Geneva, Switzerland: World Economic Forum.

Scoones, I., Cabral, L., \& Tugendhat, H. (2013). New Development Encounters : China and Brazil in African Agriculture. IDS Bulletin, 44(4), 1-19.

Seaman, J., \& Holt, J. (1975). The Ethiopian Famine of 1973-4: I. Wollo Province. Proceedings of the Nutrition Society, 34, 114A.

Selaya, P., \& Thiele, R. (2012). The Impact of Aid on Bureaucratic Quality. Does the Mode of Delivery Matter? Journal of International Development, 24(3), 379-386.

Sen, A. (1981). Poverty and Famines: An Essay on Entitlement and Deprivation. Oxford, UK: Oxford University Press.

Sen, A. (1999). Development as Freedom. Oxford, UK: Oxford University Press.

Severino, J.-M. (2011). Africa's Moment. Cambridge, UK: Polity Press.

Shen, X. (2013). Private Chinese Investment in Africa Myths and Realities. Policy Research Working Paper No. 6311. Washington, D.C.: World Bank.

Shepherd, J. (1975). The Politics of Starvation. New York, NY: Carnegie Endowment for International Peace.

Shepherd, J. (1985). Ethiopia: The Use of Food as an Instrument of U.S. Foreign Policy. Issue: A Journal of Opinion, 14, 4-9.

Shiferaw, A., \& Bedi, A. S. (2013). The Dynamics of Job Creation and Job Destruction in an African Economy: Evidence from Ethiopia. Journal of African Economies, 22(5), 651-692.

Shiller, R. J. (2017). Narrative Economics. American Economic Review, 107(4), 967-1004.

Shinn, D. H. (2005). Ethiopia: Governance and Terrorism. In R. I. Rotberg (Ed.), Battling Terrorism in the Horn of Africa (pp. 93-118). Washington, D.C.: Brookings Institution Press.

Shinn, D. H. (2006). Africa, China and Health Care. Inside AISA, 3 and 4(October/December), 14-16.

Shinn, D. H. (2013). Foreign Direct Investment in Africa. Retrieved from http://davidshinn.blogspot.nl/2013/03/foreign-direct-investment-in-africa.html

Shinn, D. H. (2014). Ethiopia and China: Two Former Empires Connect in the 20th Century. Paper presented at the 13th International Conference of Africanists. Russian Academy of Sciences. Moscow, Russia: Institute for African Studies.

Shinn, D. H., \& Eisenman, J. (2012). China and Africa: A Century of Engagement. Philadelphia, PA: University of Pennsylvania Press.

Shinn, D. H., \& Ofcansky, T. P. (2013). Historical Dictionary of Ethiopia (2nd ed.). Lanham, MD: Rowman \& Littlefield Publishing Group. 
Shirley, C., \& Winston, C. (2004). Firm inventory behavior and the returns from highway infrastructure investments. Journal of Urban Economics, 55(2), 398-415.

Shivji, I. G. (2007). Silences in NGO Discourse: The role and future of NGOs in Africa. Nairobi, Kenya: Fahamu Books, Pambazuka Press.

Sigman, R., \& Lindberg, S. I. (2015). The Index of Egalitarian Democracy and its Components: $V$-Dem's Conceptualization and Measurement. V-DEM Working Paper Series 2015:22. The Varieties of Democracy Institute: Gothenburg, Sweden.

Snow, P. (1988). The Star Raft: China's Encounter With Africa. New York, NY: Grove Press.

Sokoloff, K. L., \& Engerman, S. L. (2000). History Lessons: Institutions, Factor Endowments, and Paths of Development in the New World. Journal of Economic Perspectives, 14(3), 217-232.

Sonobe, T., Akoten, J. E., \& Otsuka, K. (2009). An Exploration into the Successful Development of the Leather-Shoe Industry in Ethiopia. Review of Development Economics, 13(4), 719-736.

Staiger, D., \& Stock, J. H. (1997). Instrumental Variables Regression with Weak Instruments. Econometrica, 65(3), 557-586.

Stiglitz, J. E. (2002). Globalization and Its Discontents. New York, NY: W.W. Norton \& Company.

Stock, J. H., \& Watson, M. W. (2012). Introduction to Econometrics (3rd ed.). Boston, MA: Pearson Addison-Wesley.

Stock, J. H., Wright, J. H., \& Yogo, M. (2002). A Survey of Weak Instruments and Weak Identification in Generalized Method of Moments. Journal of Business \& Economic Statistics, 20(4), 518-529.

Stokke, O. (2009). The UN and Development: From Aid to Cooperation. Bloomington, IN: Indiana University Press.

Strange, A. M., Dreher, A., Fuchs, A., Parks, B., \& Tierney, M. J. (2017). Tracking Underreported Financial Flows: China's Development Finance and the AidConflict Nexus Revisited. Journal of Conflict Resolution, 61(5), 935-963.

Strange, A. M., Parks, B., Perla, C., \& Desai, H. (2015). AidData's Methodology for Tracking Underreported Financial Flows. Williamsburg, VA: AidData.

Strange, A. M., Parks, B., Tierney, M. J., Fuchs, A., \& Dreher, A. (2013). China's Development Finance to Africa: A Media-Based Approach to Data Collection. CGD Working Paper No. 323. Washington, D.C.: Center for Global Development.

Strüver, G. (2016). What Friends are Made of: Bilateral Linkages and Domestic Drivers of Foreign Policy Alignment with China. Foreign Policy Analysis, 12, 170-191.

Svensson, J. (2000a). Foreign Aid and Rent-Seeking. Journal of International Economics, $51(2), 437-461$.

Svensson, J. (2000b). When is foreign aid policy credible? Aid dependence and conditionality. Journal of Development Economics, 61(1), 61-84.

Svensson, J. (2003). Why Conditional Aid Does Not Work and What Can Be Done About It? Journal of Development Economics, 70(2), 381-402.

Svolik, M. W. (2012). The Politics of Authoritarian Rule. Cambridge, MA: Cambridge University Press. 
Swain, A. (2011). Challenges for water sharing in the Nile basin: changing geo-politics and changing climate. Hydrological Sciences Journal, 56(4), 687-702.

Syrquin, M. (1984). Resource allocation and productivity growth. In M. Syrquin, L. Taylor, \& L. E. Westphal (Eds.), Economic Structure and Performance-Essays in Honor of Hollis B. Chenery (pp. 75-101). Orlando, FL: Academic Press Inc.

Szirmai, A. (2012a). Industrialisation as an engine of growth in developing countries, 1950-2005. Structural Change and Economic Dynamics, 23(4), 406-420.

Szirmai, A. (2012b). Proximate, intermediate and ultimate causality: Theories and experiences of growth and development. UNU-MERIT Working Paper No. 2012-032. Maastricht, Netherlands: UNU-MERIT.

Szirmai, A. (2015). Socio-Economic Development (2nd ed.). Cambridge, UK: Cambridge University Press.

Szirmai, A., \& Ren, R. (2000). Comparative performance in Chinese manufacturing, 1980-1992. China Economic Review, 11(1), 16-53.

Szirmai, A., \& Verspagen, B. (2015). Manufacturing and economic growth in developing countries, 1950-2005. Structural Change and Economic Dynamics, 34, 46-59.

Taddesse, T. (1972). Church and State in Ethiopia (1270-1527). Oxford, UK: Clarendon Press.

Tadesse, F. (2014). Ethiopia: Nation's Most Expensive Dam Undertaken By SinoEthiopia JV. Retrieved from http://allafrica.com/stories/201409160441.html

Tadesse, M. (2015a). Making Sense of Ethiopia's Regional Influence. In G. Prunier \& É. Fiquet (Eds.), Understanding Contemporary Ethiopia. Monarchy, Revolution and the Legacy of Meles Zenawi (pp. 333-356). London, UK: Hurst \& Company.

Tadesse, M. (2015b). The Tigray People's Liberation Front (TPLF). In G. Prunier \& É. Fiquet (Eds.), Understanding Contemporary Ethiopia. Monarchy, Revolution and the Legacy of Meles Zenawi (pp. 257-282). London, UK: Hurst \& Company.

Tadesse, M., \& Young, J. (2003). TPLF: reform or decline? Review of African Political Economy, 30(97), 389-403.

Tammen, R., \& Kugler, J. (2012). The Performance of Nations. Lanham, MD: Rowman and Littlefield.

Tan-Mullins, M., Mohan, G., \& Power, M. (2010). Redefining “Aid” in the China Africa Context. Development and Change, 41 (5), 857-881.

Tang, X. (2010). Bulldozer or Locomotive? The Impact of Chinese Enterprises on the Local Employment in Angola and the DRC. Journal of Asian and African Studies, 45(3), 350-368.

Tareke, G. (2009). The Ethiopian Revolution: War in the Horn of Africa. New Haven, CT: Yale University Press.

Taylor, I. (1998). China's foreign policy towards Africa in the 1990s. Journal of Modern African Studies, 36(3), 443-460.

Taylor, I. (2006a). China's Oil Diplomacy in Africa. International Affairs, 82(5), 937-959.

Taylor, I. (2006b). China and Africa: Engagement and Compromise. Abingdon-on-Thames, UK: Routledge Contemporary China.

Taylor, I. (2007a). Governance in Africa and Sino-African Relations: Contradictions or Confluence? Politics, 27(3), 139-146.

Taylor, I. (2007b). Sino-African Relations and the Problem of Human Rights. African 
Affairs, 107(426), 63-87.

Taylor, I. (2011). The Forum on China-Africa Cooperation (FOCAC). Oxford, UK: Routledge.

Teorell, J., Coppedge, M., Skaaning, S.-E., \& Lindberg, S. I. (2016). Measuring Electoral Democracy with V-Dem Data: Introducing a New Polyarchy Index. V-DEM Working Paper Series 2016:25. The Varieties of Democracy Institute: Gothenburg, Sweden. Thakur, M. (2009). Building on Progress? Chinese Engagement in Ethiopia (SAIIA Occasional Paper No. 38). SAIIA Occasional Paper No. 38. Johannesburg, South Africa: South African Institute of International Affairs.

The British Ministry of Overseas Development. (1976). Changing Emphasis in British Aid Policies: Help for the Poorest. Population and Development Review, 2(1), 157-160. The Economist. (2016). Unrest in Ethiopia. Grumbling and rumbling. Retrieved from http://www.economist.com/news/middle-east-and-africa/21695402-monthsprotests-are-rattling-fragile-federation-grumbling-and-rumbling

The Ethiopian Ministry of Agriculture. (1973). Final Report of Crop Condition Survey for the 1972-3 Harvest. Addis Ababa, Ethiopia.

Thies, C. G. (2009). National Design and State Building in Sub-Saharan Africa. World Politics, 61(4), 623-669.

Tierney, M. J., Nielson, D. L., Hawkins, D. G., Roberts, J. T., Findley, M. G., Powers, R. M., ... Hicks, R. L. (2011). More Dollars than Sense: Refining Our Knowledge of Development Finance Using AidData. World Development, 39(11), 1891-1906.

Tilly, C. (1975). Reflections on the History of State Making. In C. Tilly (Ed.), The Formation of National States in Western Europe (pp. 3-83). Princeton, NJ: Princeton University Press.

Tilly, C. (1990). Coercion, Capital and European States, AD 990-1990. Cambridge, MA: Basil Blackwell.

Torsvik, G. (2005). Foreign Economic Aid: Should Donors Cooperate? Journal of Development Economics, 77(2), 503-515.

Tronvoll, K. (2010). The Ethiopian 2010 federal and regional elections: Re-establishing the one-party state. African Affairs, 110(438), 121-136.

Tull, D. M. (2006). China's engagement in Africa: scope, significance and consequences. Journal of Modern African Studies, 44(3), 459-479.

Tullock, G. (1987). Autocracy. Boston, MA: Kluwer Academic Publishers.

UNCTAD. (2000). World Investment Report 2000. Geneva, Switzerland: United Nations Conference on Trade and Development.

UNCTAD. (2006). World Investment Report 2006. Geneva, Switzerland: United Nations Conference on Trade and Development.

UNCTAD. (2007). Asian Foreign Direct Investment in Africa: Towards a New Era of Cooperation among Developing Countries. Geneva, Switzerland and New York, NY: United Nations Conference on Trade and Development.

UNCTAD. (2008). Investment Directory. Volume X Africa. Geneva, Switzerland: United Nations Conference on Trade and Development: United Nations Conference on Trade and Development.

UNCTAD. (2010). South-South Cooperation: Africa and the New Forms of Development Partnership. Geneva, Switzerland: United Nations Conference on Trade and 
Development.

UNCTAD. (2012). Economic Development in Africa Report 2012. Geneva, Switzerland: United Nations Conference on Trade and Development.

UNCTAD. (2013a). The Rise of BRICS FDI and Africa. Geneva, Switzerland and New York, NY.

UNCTAD. (2013b). World Investment Report 2013 - Global Value Chains: Investment and Trade for Development. Geneva, Switzerland: United Nations Conference on Trade and Development.

UNCTAD. (2014). Bilateral FDI Statistics 2014. Geneva, Switzerland.

UNDP. (2015). Comparative Study on Special Economic Zones in Africa and China. UNDP Working Paper Series No. 06. New York, NY: United Nations Development Programme.

UNDP-EUE. (1995). Monthly Situation Report for Ethiopia: May 1995. Addis Ababa, Ethiopia. Retrieved from http://www.africa.upenn.edu/eue_web/strp0595.htm

US-DOS. (2009). International Religious Freedom Report. Retrieved December 19, 2016, from http://www.state.gov/j/drl/rls/irf/2007/90097.htm

USAID. (2016). Power Africa - The Roadmap. Washington, D.C.: U.S. Agency for International Development.

Uvin, P. (1985). Regime, Surplus, and Self-Interest: The International Politics of Food Aid. International Studies Quarterly, 36(3), 293-312.

Uvin, P. (1993). "Do as I Say, Not as I Do": The Limits of Political Conditionality. European Journal of Development Research, 5(1), 63-84.

van de Sijpe, N. (2013). Is Foreign Aid Fungible? Evidence from the Education and Health Sectors. The World Bank Economic Review, 27(2), 320-356.

van de Walle, N. (1999). Aid's Crisis of Legitimacy: Current Proposals and Future Prospects. African Affairs, 98(392), 337-352.

van de Walle, N. (2001). African Economies and the Politics of Permanent Crisis, 1979-1999. New York, NY: Cambridge University Press.

van Dijk, M.P. (2009). Introduction: objectives and instruments for China's new presence in Africa. In M. P. Van Dijk (Ed.), The New Presence of China in Africa (pp. 9-30). Amsterdam, The Netherlands: Amsterdam University Press.

van Reybrouck, D. (2010). Congo. Een geschiedenis. Amsterdam, The Netherlands: De Bezige Bij.

Vandemoortele, J. (2009). The MDG Conundrum: Meeting the Targets Without Missing the Point. Development Policy Review, 27(4), 355-371.

Vandemoortele, J. (2011). The MDG Story: Intention Denied. Development and Change, 42(1), 1-21.

Vanderhill, R. (2012). Promoting Authoritarianism Abroad. Boulder, CO: Lynne Rienner Publishers.

Vanhanen, T. (2000). A New Dataset for Measuring Democracy, 1810-1998. Journal of Peace Research, 37(2), 251-265.

Vanhanen, T. (2016). The polyarchy dataset: Vanhanen's index of democracy. Retrieved from https://www.prio.org/Data/Governance/Vanhanens-index-ofdemocracy/Polyarchy-Dataset-Downloads /

Varnis, S. L. (1990). Reluctant Aid or Aiding the Reluctant?: U.S. Food Aid Policy and Ethiopian 


\section{REFERENCES}

Famine Relief. Piscataway, NJ: Transaction Publishers.

Vaughan, S. (2015). Federalism, Revolutionary Democracy and the Developmental State, 1991-2012. In É. Fiquet \& G. Prunier (Eds.), Understanding Contemporary Ethiopia. Monarchy, Revolution and the Legacy of Meles Zenawi (pp. 283-312). London, UK: Hurst \& Company.

Verhoeven, H. (2013). China shifts power balance in the Nile river basin. Retrieved from https://www.chinadialogue.net/article/show/single/en/6178-Chinashifts-power-balance-in-the-Nile-river-basin

Vestal, T. (2011). The Lion of Judah in the New World: Emperor Haile Selassie of Ethiopia and the Shaping of Americans' Attitudes toward Africa. Santa Barbara, CA: Praeger.

Villanger, E. (2006). Company interests and foreign aid policy: Playing donors off against one another. European Economic Review, 50(3), 533-545.

Wagaw, T. G. (1993). For Our Soul: Ethiopian Jews in Israel. Detroit, MI: Wayne State University Press.

Wang, J.-Y. (2007). What Drives China's Growing Role in Africa? IMF Working Paper Series WP/07/211. Washington DC: International Monetary Fund.

Way, L. A. (2015). The limits of autocracy promotion: The case of Russia in the "near abroad." European Journal of Political Research, 54(4), 691-706.

Webb, P., \& Von Braun, J. (1994). Famine and Food Security in Ethiopia: Lessons for Africa. Chichester, UK: John Wiley and Sons.

Weber, M. (1922). Wirtschaft und Gesellschaft. Tübingen, Germany: Mohr Verlag.

Weingast, B. R. (1995). The Economic Role of Political Institutions: The MarketPreserving Federalism and Economic Development. Journal of Law, Economics, and Organization, 11(1), 1-31.

Welde Giorgis, A. (2014). Eritrea at a Crossroads: A Narrative of Triumph, Betrayal and Hope. Houston, TX: Strategic Book Publishing \& Rights Agency.

Wenping, H. (2007). The Balancing Act of China's Africa Policy. China Security, 3(3), 23-40.

Westad, O. A. (2005). The Global Cold War: Third World Interventions and the Making of Our Times. New York, NY: Cambridge University Press.

Whitfield, L., \& Fraser, A. (2009). Negotiating Aid. In L. Whitfield (Ed.), The Politics of Aid. African Strategies for Dealing with Donors (pp. 27-44). Oxford, NY: Oxford University Press.

Widner, J. A. (1994). Economic Change and Political Liberalization in Sub-Saharan Africa. Baltimore, MD: Johns Hopkins University Press.

Williamson, J. (1990). Latin American Adjustment: How Much Has It Happened? Washington, D.C.: Institute for International Economics.

Wintrobe, R. (1990). The Tinpot and the Totalitarian: An Economic Theory of Dictatorship. American Political Science Review, 84(3), 849-872.

Wittkopf, E. R. (1973). Foreign Aid and United Nations Votes: A Comparative Study. American Political Science Review, 67(3), 868-888.

Wodajo, T., \& Senbet, D. (2013). Distributions Of Public And Private Manufacturing Firms And Determinants Of Productivity In Ethiopia. Regional and Sectoral Economic Studies, 13(1), 157-179.

Wolde Giorgis, D. (1989). Red Tears: War, Famine, and Revolution in Ethiopia. Trenton, NJ: 
Red Sea Press.

Woldemeskel, G. (1989). The Consequences of Resettlement in Ethiopia. African Affairs, 88(352), 359-374.

Woods, N. (2005). The shifting politics of foreign aid. International Affairs, 81(2), 393409.

Woods, N. (2008). Whose aid? Whose influence? China, emerging donors and the silent revolution in development assistance. International Affairs, 84(6), 1205-1221.

Wooldridge, J. M. (1995). Score diagnostics for linear models estimated by two stage least squares. In G. S. Maddala, T. N. Srinivasan, \& P. C. B. Phillips (Eds.), Advances in Econometrics and Quantitative Economics: Essays in Honor of Professor C.R. Rao (pp. 66-87). Oxford, UK: Wiley-Blackwell.

Wooldridge, J. M. (2002). Econometric Analysis of Cross Section and Panel Data. Cambridge, MA: MIT Press.

World Bank. (1997). World Development Report 1997. The State in a Changing World. Washington, D.C.: The World Bank.

World Bank. (1998). Assessing Aid. What works, what doesn't, and why. New York, NY: Oxford University Press.

World Bank. (2000). Ethiopia: Country Assistance Evaluation. Washington, D.C.: The World Bank.

World Bank. (2006). Interim Country Assistance Strategy for The Federal Democratic Republic of Ethiopia. Washington, D.C.: The World Bank.

World Bank. (2007). Agriculture for Development. Washington, D.C.: The World Bank.

World Bank. (2012). Chinese FDI in Ethiopia. A World Bank Survey. Washington, D.C.: The World Bank.

World Bank. (2015). Ethiopia Poverty Assessment 2014. Washington, D.C.: The World Bank.

Wright, J. (2009). How Foreign Aid Can Foster Democratization in Authoritarian Regimes. American Journal of Political Science, 53(3), 552-571.

Wrong, M. (2005). I Didn't Do It for You: How the World Betrayed a Small African Nation. London, UK: Harper Perennial.

Wu, X., \& Perloff, J. M. (2004). China's Income Distribution over Time: Reasons for Rising Inequality. Paper presented at the American Agricultural Economics Association Annual Meeting, Denver Colorado, July 1-4, 2004.

Xu, X., Li, X., Qi, G., Tang, L., \& Mukwereza, L. (2016). Science, Technology, and the Politics of Knowledge: The Case of China's Agricultural Technology Demonstration Centers in Africa. World Development, forthcoming.

Xue, L. (2014). China's Foreign Aid Policy and Architecture. IDS Buleltin, 45(4), 36-45. Yang, J., Zhang, W., \& Tokgoz, S. (2013). Macroeconomic impacts of Chinese currency appreciation on China and the Rest of World: A global CGE analysis. Journal of Policy Modeling, 35(6), 1029-1042.

Yepes, T., Pierce, J., \& Foster, V. (2009). Making Sense of Africa's Infrastructure Endowment: A Benchmarking Approach. Policy Research Working Paper No. 4912. Washington, D.C.: The World Bank.

Yordanov, R. A. (2016). The Soviet Union and the Horn of Africa during the Cold War: Between Ideology and Pragmatism. Lanham, MD: Lexington Books. 
Yoshino, Y. (2008). Domestic Constraints, Firm Characteristics, and Geographical Diversification of Firm-Level Manufacturing Exports in Africa. Policy Research Working Paper 4575. Washington, DC: World Bank.

Young, C. (1994). The African Colonial State in Comparative Perspective. New Haven, CT: Yale University Press.

Yuan, C., Liu, S., Fang, Z., \& Xie, N. (2010). The Relation between Chinese Economic Development and Energy Consumption in the Different Periods. Energy Policy, 38(9), 5189-5198.

Zafar, A. (2007). The Growing Relationship Between China and Sub-Saharan Africa: Macroeconomic, Trade, Investment, and Aid Links. World Bank Research Observer, 22(1), 103-130.

Zewde, B. (1991). A History of Modern Ethiopia 1855-1974. Addis Ababa, Ethiopia: Addis Ababa University Press.

Zewde, B. (1994). Hayla Sellassie: From Progressive to Reactionary. In A. Zegeye \& S. Pausewang (Eds.), Ethiopia in Change: Peasantry, Nationalism and Democracy (pp. 3045). London, UK: British Academic Press.

Zhang, X. (2011). China's Aid to Africa: A Challenge to the EU? In J. Men \& B. Barton (Eds.), China and the European Union in Africa. Partners or Competitors. (pp. 209-224). Farnham, UK: Ashgate Publishing Ltd.

Zhao, S. (2014). A Neo-Colonialist Predator or Development Partner? China's engagement and rebalance in Africa. Journal of Contemporary China, 23(90), 1033 1052.

Zimmermann, F., \& Smith, K. (2011). More actors, more money, more ideas for international development cooperation. Journal of International Development, 738(5), 722-738.

Zwartjes, O. (2011). Portuguese Missionary Grammars in Asia, Africa and Brazil, 1550-1800. Amsterdam, The Netherlands: John Benjamins Publishing Company.

Zweig, D., \& Jianhai, B. (2005). China's Global Hunt for Energy. Foreign Affairs, 84(5), 25-38. 


\section{VALORIZATION}

In accordance to Article 23 of the Regulation governing the attainment for doctoral degree in the Maastricht University, the following section discusses the valorisation opportunities offered by this $\mathrm{PhD}$ thesis. Following the corresponding guidelines, these opportunities are analysed in terms of the social and economic relevance of the thesis, the potential target groups to whom the results can be interesting and the degree of innovativeness of the research methods used.

The project originated as an attempt to understand, both theoretically and empirically, how the entry of players from the Global South like China into the foreign aid game affects the current framework of international development cooperation between the traditional Western donors and investors on the one hand and African recipient countries on the other hand.

Regarding the innovativeness of the research methods proposed, the thesis offers an interdisciplinary approach using both quantitative and qualitative research methods due to their complementarity. More specifically, I have created a large comprehensive dataset on both Western and Chinese foreign aid, foreign direct investment and international trade covering more than 50 years (Chapter 2). This database allowed me to systematically compare the magnitude, the geographic destination and the sectoral distribution of Chinese and Western foreign aid, investment and trade in Africa over time.

The study presented in Chapter 3 is among the first to utilize the new and comprehensive V-DEM dataset in the analysis of political systems in Africa. The systematic, historical and disaggregated approach by V-Dem addresses several deficiencies and drawbacks in existing measures of electoral democracy. V-DEM is a new approach to conceptualizing and measuring democracy, as it provides a multidimensional and disaggregated dataset that reflects the complexity of the concept of democracy as a system of rules that goes beyond the simple presence of elections.

In Chapter 4, I use econometric regression techniques to revisit the aid debate between aid optimists and aid pessimists. My findings suggest that the previous 


\section{VALORIZATION}

empirical literature on the aid-governance link failed to account for more ultimate causes of bureaucratic development. Foreign aid simply appears less important than deeper historical experiences in explaining the recent evolution of bureaucratic quality in Africa.

Furthermore, the qualitative interview data obtained from personal fieldwork in Ethiopia, presented in Chapter 6, helps the author and the reader to better understand to what extent China's entry into the aid game and its policy of nonintervention in domestic political affairs has significantly increased the Ethiopian government's bargaining power in the aid negotiation process vis-à-vis the international donor community.

Last but not least, the thesis also provides an interesting contribution to the theoretical models that are used to study the dynamics of foreign aid (Chapter 7). There remains little or no formal analysis of aid giving in a competitive donor environment. The game theoretic model, in turn, can be a powerful tool to forecast the outcomes of different aid policies. The theory is complemented by a historical narrative for the country of Ethiopia. While the model helps the author and reader to systematically think through the case of Ethiopia and the entry of China into the aid game, the narrative part provides a detailed account of the context and the specific processes.

Overall, the six studies presented in this doctoral dissertation contribute to advance our understanding of the subject matter as they provide interesting insights to national and international policy makers focusing on foreign aid, development cooperation and development policy. The main results, practical findings, and policy recommendations of this dissertation can be relevant for a wide target audience. As the next few paragraphs will show the thesis has social and economic relevance that goes beyond the pure scientific relevance.

The first target audience is the wider academic community as well as the readership of journals and blogs (such as the UNU-MERIT blog). The research conducted in this dissertation has been widely disseminated, in working papers, conferences, seminars, and public events. This has constituted an opportunity not only to disseminate the results of this research, but also to receive important comments and suggestions on how to further improve the research. 


\section{VALORIZATION}

In particular, the main results of Chapter 2 have been presented at the International UNU-MERIT Conference "Future perspectives on innovation and governance in development", held in Maastricht on 26-28 November 2014, at the CSAE Conference "Economic Development in Africa", held in Oxford, United Kingdom, on 22-24 March 2015, the Annual Conference of the Chinese Economic Association (CEA) "China's New Way of Integration with the World: The New Silk Road and the Opportunities for the World Economy", held at the Institute of East Asian Studies at University Duisburg-Essen, Germany, on 1-3 September 2016. A preliminary version of Chapter 3 was presented at the European Centre for Development Policy Management (ECDPM) in Maastricht during a lunch seminar on 19 April 2016.

The main results of Chapter 4 were presented at the $13^{\text {th }}$ GLOBELICS International Conference "Innovation to reduce poverty and inequalities for inclusive and sustainable development", held in Havana, Cuba, on 23-25 September 2015, at the UNU-MERIT/CRES 2nd International Conference on Sustainable Development in Africa, held in Dakar, Senegal, on 26-27 November 2015, at the 6th Euro-African Conference in Finance and Economics, held in Marseille, France, on 31 March-1 April 2016, at the Worldwide Universities Network (WUN) Annual General Meeting, held in Maastricht on 2-7 April 2016, at the Annual International Conference of the German Economic Association "Development Economics and Policy", held in Heidelberg, Germany, on 3-4 June 2016, the 4th African Studies Conference "African Globalities - Global Africans", held in Pécs, Hungary, on 9-10 June 2016, at the Annual Conference of the Society for Institutional and Organizational Economics (SIOE), held in Paris, France, on 15-17 June 2016, at the Dutch Economist Day, held at the Dutch Central Bank in Amsterdam on Friday 4 November 2016, and at the WINIR Symposium "Interdisciplinary perspectives on institutions, agency and uncertainty", held in Johannesburg, South Africa, on 11-13 April 2017.

The main outcomes of the thesis have already been published in several working papers from UNU-MERIT/MGSoG. The output of Chapter 2 was discussed in a short interview, available on the UNU-MERIT/Graduate School of Governance YouTube channel, as part of the dissemination efforts. All research in this dissertation is to be published in peer-reviewed and internationally acclaimed journals or books. As a first step in this direction, a reduced version of Chapter 2 is currently included in a book proposal called Africa and the 


\section{$V A L O R I Z A T I O N$}

Sustainable Development Goals to Springer's Sustainable Development Goals series. Chapter 3 has recently been published in the China Economic Review (see Broich, 2017), Chapter 4 is currently under review at a journal. The findings in Chapter 6 and Chapter 7 are currently being reshaped in order to be submitted to journals in the field of foreign aid, development economics and political economy.

The second target audience is the research community of development economists who work on emerging and developing countries, and who are interested in how the entry of emerging donors and investors from the "Global South" affect the international aid architecture. At the continent level, my doctoral dissertation has shown that the role of foreign aid in determining current day institutional development is less important than suggested by either aid optimists or aid pessimists. This dissertation highlighted the limited role of aid in preventing and tackling several root causes of extreme poverty if the political and institutional environment within a recipient country is weak and hostile.

The empirical results presented in this dissertation also have implications for Western government officials that are involved in formulating, designing and implementing new aid policies that have an effect on both the economic and social sectors in the economy. Part of China's successful rise in Africa can be attributed partly to its emphasis on win-win situations for all on an equal and reciprocal basis as well as fruitful engagements in mutual consultation with mutual understanding vis-à-vis African recipient governments. Chinese and African government officials frequently point out that dialogue and mutual understanding between recipient countries and donor organizations is necessary for effective and efficient development cooperation.

Several African governments identify the infrastructural deficit as a major obstacle to economic development on the continent. Since the early 1960s however, Western bilateral donors increasingly turned away from building roads, bridges, irrigation, power and the like in both Ethiopia and Africa as a whole. Emerging donors and investors, most notably China have started to address the infrastructure deficit thereby filling the vacuum left by the Western donor community. Western governments, for example, now start to recognize the importance of physical infrastructure for development (again) as they become increasingly responsive to demands from African recipient governments. 


\section{VALORIZATION}

African recipient governments often regard practices of Western aid workers as imperialistic and describe the Western conditionalities (such as democratic reforms) as paternalistic. Irrespective of whether this claim is well grounded or not, the results presented in this dissertation do not suggest that the Western commitment to political conditionality should be softened as foreign aid would be more effective if it were more systematically conditioned on good policy.

African policymakers, in turn, can also learn valuable policy lessons from this doctoral dissertation as it highlights the critical role of African agency in the international aid architecture (Chapter 5,6 and 7). How African recipient governments engage with both Western foreign finance providers and those from the Global South is ultimately responsibility of African governments. Consequently, it is crucial for African countries to develop a policy agenda that requires the creation of an 'African Consensus'. Identifying an appropriate 'African Consensus' can optimize the gains in aid, investment and trade negotiation deals with both traditional and non-traditional partners.

The fourth target audience is anyone involved in the analysis, evaluation and implementation of policies, who is not necessarily part of the research community nor the government, for example aid workers, or more broadly the development community. There exists the danger that international aid agencies greatly overestimate the impact of foreign aid on poverty reduction, political and economic development. In this doctoral dissertation, I have argued that development finance can only be considered a secondary driver of national political and economic development. In fact, foreign aid can easily harm development of recipient countries in the long run if it does not abide by the Hippocratic Oath, a major guideline for development policy: "Seek to do good, but do no harm."

The last but not least target audience is the media and the general public. Despite the rising literature on Sino-African relations, several accusations, prejudices and stereotypes about China's increasing presence in Africa have been remarkably durable. The great anxiety about China's rising activities in Africa is often based on prejudice, inaccurate reporting, lack of information and misinterpreting data, primarily - but not always - driven by Eurocentric sentiments. One major objective of this doctoral dissertation was to contribute to the literature aimed at separating myths from facts on the subject matter. Accordingly, this text and 


\section{VALORIZATION}

its individual chapters aim for a humble goal: to gauge a better understanding of the causes and characteristics of strengthening Sino-African ties and its consequences for the Western donor community, Western governments, African recipient governments and African civil society at large. 



\section{SHORT BIOGRAPHY}

Tobias holds a Bachelor and Master Degree in Economics from the School of Business and Economics (SBE), Maastricht University. During his studies, Tobias spent half a year abroad at Simon Fraser University (SFU) in Vancouver, Canada. Tobias completed a development internship at AIESEC Yaoundé, Cameroon, an international non-governmental not-for-profit organization. Tobias also interned for the Hans-Böckler-Foundation in Düsseldorf, Germany. Tobias joined the PhD program at UNU-MERIT/Maastricht Graduate School of Governance in 2012. His research fields are development economics, political economy, institutional economics, African history and applied econometrics. During his PhD, Tobias conducted fieldwork in Ethiopia where he interviewed Ethiopian government officials, staff from international aid agencies, and NGOs on the role of development finance and international cooperation on poverty reduction. At the graduate school, Tobias taught several courses in statistics and econometrics. Tobias is a member of the Society of Institutional and Organizational Economics (SIOE), the World Interdisciplinary Network for Institutional Research (WINIR), the Chinese Economic Association (CEA) and the Royal Dutch Association for Economists (KVS). He is a referee for the Journal of African Development and the Social Science Quarterly. Between October 2016 and July 2017, he was a Lecturer at the School of Business and Economics (SBE) at Maastricht University where he taught Development Economics, Doing Business in Emerging Markets, Country Risk Analysis, International Macroeconomics, Innovation in Business and Economic Growth and Understanding Society. Since July 2017, Tobias works in the International Development Unit of the economic research and consulting company ECORYS in Rotterdam, Netherlands, as a consultant in the area Public Finance Management. In his free time, Tobias enjoys travelling, playing and watching football, swimming, reading and photography. 


\section{UNU-MERIT/MGSoG Dissertation Series}

2017

Bernard Nikaj

From No-government to E-government

UNU-MERIT/MGSoG Dissertation

Series № 193

Ali Safarnejad

Prioritizing the HIV Response

UNU-MERIT/MGSoG Dissertation

Series № 192

Clovis Freire

Diversification and Structural

Economic Dynamics

UNU-MERIT/MGSoG Dissertation

Series № 191

Michael Verba

Innovation and Knowledge Dynamics:

Essays on the Knowledge Economy

UNU-MERIT/MGSoG Dissertation

Series № 190

Pui Hang Wong

The Hearts and Minds in Conflict and

Peace:The Economics of

Counterinsurgency and the Psychology

of Reconstruction

UNU-MERIT/MGSoG Dissertation

Series № 189

Brenda Yamba

Schooling Despite All Odds: Evidence from Lesotho on Female Child Carers

who Stayed in School

UNU-MERIT/MGSoG Dissertation

Series № 188

Sheng Zhong

Moving towards An Energy Efficient

Future; Essays on Energy Efficiency,

Technology and Development

UNU-MERIT/MGSoG Dissertation

Series № 187

Julieta Marotta

Access to Justice and Legal

Empowerment of Victims of Domestic

Violence through Legal Organizations

in the City of Buenos Aires; A

Qualitative Empirical Legal Study

UNU-MERIT/MGSoG Dissertation

Series, № 186

Andrea Franco-Correa

On the Measurement of

Multidimensional Poverty as a Policy

Tool; Empirical Applications to Chile,

Colombia, Ecuador and Peru

UNU-MERIT/MGSoG Dissertation

Series, № 185 
Yesuf Awel

Insurance for Growth; Empirical

Essays on Insurance Demand and

Impacts in Africa

UNU-MERIT Dissertation Series,

№ 108

Tigist Mekonnen Melesse

Grow More Food using Fewer

Resources;

Agricultural Technology Adoption and Innovation Practices for Inclusive and Sustainable Development

UNU-MERIT Dissertation Series, № 107

Eleni Yitbarek

Getting Ahead or left Behind?; Essays on Poverty Dynamics and Social

Mobility in Africa

UNU-MERIT Dissertation Series,

№ 106

Thuy Dieu Nguyen

Firm-Level Theory and Evidence of

Corruption

UNU-MERIT Dissertation Series, № 105

Raquel Tsukada Lehman

Essays on Household Production with

Labor-Saving Technology

UNU-MERIT Dissertation Series, № 104
Eva Barteková

Multi-Problem Challenges for a

Renewable Future; Empirical Studies

on Competitive Disadvantages from

Electricity Price Differentials and

Mineral Supply Risk in an Open

Economy

UNU-MERIT Dissertation Series,

№ 103

Jocelyn Olivari

Entrepreneurial Traits and Innovation;

Evidence from Chile

UNU-MERIT Dissertation Series,

№ 102

Muhammad Shafique

Essays on the role of knowledge, RED, and Technology-based Firms in the

Evolution of Socio-techno-economic

System

UNU-MERIT Dissertation Series,

№ 101

Serdar Türkeli

Governance of Innovation Policy;

Empirical Studies on Applied Political

Economy by Multi-Methods Analysis

UNU-MERIT Dissertation Series,

№ 100

Ayokunu Adedokun

Pathways to Sustainable Peacebuilding in Divided Societies; Lessons and Experiences from Mozambique

MGSoG Dissertation Series, № 75 
Luiz Rothier Bautzer

Organizing Concurrent Engineering

through ICT Platforms

Blueprinting Product Lifecycle

Management Platforms across

Disciplinary Agencies

MGSoG Dissertation Series, № 74

Natalia Popova

Migration in the Periphery of the

European Union;

Determinants of Successful and

Sustainable Labour Market Integration of Return Migrants in Albania, Egypt, Moldova and Tunisia

MGSoG Dissertations Series, № 73

Richard A. Martina

Uncertainty and Resource Constraint in the Small Island Developing States;

Essays in Entrepreneurial Cognition

MGSoG Dissertations Series, № 72

Cécile Cherrier

The Expansion of Basic Social

Protection in Low-income Countries;

An Analysis of Foreign Aid Actors'

Role in the Emergence of Social

Transfers in Sub-Saharan Africa

MGSoG Dissertations series, № 71
Paul Caldron

The Tacit Bargain in Short-Term

Medical Missions; Why U.S.

physicians go and what it costs

MGSoG Dissertation Series, № 70

\section{Mahmut Kobal}

Customs \& Excellence: A Comparative Approach on Administrative and Regulatory Compliance Perspectives of the EU-Turkey Customs Union

MGSoG Dissertation Series, № 69

Craig Loschmann

Essays on Conflict-related Migration

and Development in the Case of

Afghanistan

MGSoG Dissertations Series, № 68

Andrea Milan

Rural Livelihoods, Location and

Vulnerable Environments; Approaches

to Migration in Mountain areas of

Latin America

MGSoG Dissertation Series, № 67

Farida Lada

On Guarding the Welfare of Clinical

Trial Subjects While Promoting Novel

Drug Innovation

A Game Theoretical Approach

MGSoG Dissertation Series, № 66

\section{5}

Hibret Belete Maemir

Dissecting Aggregate Productivity;

International Integration and Growth

with Heterogeneous Firms

UNU-MERIT Dissertation Series, № 96 
Giorgio Triulzi

Looking for the Right Path; Technology

Dynamics, Inventive Strategies and

Catching-up in the Semiconductor

Industry

UNU-MERIT Dissertation Series, № 95

Abdul Baseer Qazi

Knowledge flows and networks in the

ICT sector; The case of Pakistan

UNU-MERIT Dissertation Series,

№ 94

Ajay Thutupalli

Technology Paradigm Shifts in

Agriculture; Drivers of Sustainability

and Catch up

UNU-MERIT Dissertation Series,

№ 93

Eduardo Urias

Improving access to HIVIAIDS

treatment in Brazil; When are

Compulsory Licenses effective in Price

Negotiations?

UNU-MERIT Dissertation Series, № 92

Francesca Guadagno

Why have so few Countries

Industrialised?

UNU-MERIT Dissertation Series, № 91

Daniel Opolot

The Evolution of Beliefs and Strategic

Behaviour

UNU-MERIT Dissertation Series, № 90
Alejandro Lavopa

Structural Transformation and

Economic Development; Can

Development Traps be Avoided

UNU-MERIT Dissertation Series, № 89

Jinjin Zhao

Urban water management reform; The

Case of China

UNU-MERIT Dissertation Series,

№ 88

Simona Vezzoli

Borders, Independence and Post-

colonial Ties; the Role of the State in

Caribbean Migration

MGSoG Dissertation Series, № 65

Silvia Consuelo Gómez Soler

Civil Conflict and Education; How

Does Exposure to Civil Conflict Affect

Human Capital Accumulation?

Evidence from Standardized Exit

Exams in Colombia

MGSoG Dissertation Series, № 64

Paula Nagler

Occupational Choice in the Developing

World

MGSoG Dissertation Series, № 63

Jasmin Kientzel

Determinants of Professional

Commitment to Environmental

Sustainability

MGSoG Dissertation Series, № 62 
Mehmet Güney Celbiş

Regional Policies; Convergence, Trade, and the Allocation of Public Capital

MGSoG Dissertation Series, № 61

Florian Henning

Living Up to Standard;

Interoperability Governance and

Standards Adoption in Government

Information Networks

MGSoG Dissertation Series, № 60

Niels P. Groen

The Never-Ending Project

Understanding E-Government Project

Escalation

MGSoG Dissertation Series, № 59

\section{Derek Copp}

Teacher-Based Reactivity to Provincial

Large-scale Assessment in Canada

MGSoG Dissertation Series, № 58

Michaella Vanore

Family-Member Migration and the

Psychosocial Health Outcomes of

Children in Moldova and Georgia

MGSoG Dissertation Series, № 57

\section{4}

\section{Dirk Crass}

The Impact of Brands on Innovation and Firm Performance; Empirical

Evidence from Germany

UNU-MERIT Dissertation Series, № 87

\section{Sonja Fransen}

The Economic and Social Effects of Remittances and Return Migration in Conflict-Affected Areas; The Case of Burundi

MGSoG Dissertation Series, № 56

Ibrahim Khalil Conteh

The Impact of Floods on Primary

School Education in Zambia

MGSoG Dissertation Series, № 55

Richard Bluhm

Growth Dynamics and Development

Essays in Applied Econometrics and

Political Economy

MGSoG Dissertation Series, № 54

Nevena P. Zhelyazkova

Work-Family Reconciliation and Use of

Parental Leave in Luxembourg;

Empirical Analysis of Administrative

Records

MGSoG Dissertation Series, № 53
Samyukta Bhupatiraju

The Geographic Dimensions of Growth and Development

UNU-MERIT Dissertation Series, № 86

François Lafond

The Evolution of Knowledge Systems

UNU-MERIT Dissertation Series, № 85 
Annalisa Primi

Promoting Innovation in Latin

America; What Countries Have

Learned (and What They Have Not) in

Designing and Implementing

Innovation and Intellectual Property

Policies

UNU-MERIT Dissertation Series, № 84

Fatoumata Lamarana Diallo

Evaluation of Meal and Deworming

Programs for Primary Schools in Rural

Senegal

UNU-MERIT Dissertation Series, № 83

Sachin Kumar Badkas

Metachoice and Metadata; Innovating with Environmental Policy Analysis in Europe

MGSoG Dissertation Series, № 52

Irina S. Burlacu

An Evaluation of Tax-Benefit Systems Impact on the Welfare of Frontier

Worker;

The Case of Luxembourg and Belgium MGSoG Dissertation Series, № 51

Özge Bilgili

Simultaneity in Transnational

Migration Research; Links Between

Migrants' Host and Home Country

Orientation

MGSoG Dissertation Series, № 50
Yulia Privalova Krieger

Reshaping the Big Agenda;

Transnational Politics and Domestic

Resistance Financial crisis and social

protection reform in Bosnia and

Herzegovina

MGSoG Dissertation Series, № 49

Marieke van Houte

Moving Back or Moving Forward?

Return migration after Conflict

MGSoG Dissertation Series, № 48

Oxana Slobozhan

Global Governance in the Management of Natural Resources; The Case of the Extractive Industries Transparency Initiative (EITI)

MGSoG Dissertation Series, № 47

Luis Bernardo Mejia Guinand

The Changing Role of the Central

Planning Offices in Latin America; A

Comparative Historical Analysis

Perspective (1950-2013)

MGSoG Dissertation Series, № 46

Cheng Boon Ong

Ethnic Segregation in Housing,

Schools and Neighbourhoods in the

Netherlands

MGSoG Dissertation Series, № 45

Luciana V. Cingolani

Bureaucracies for Development;

Oxymoron or Reality? Studies on State

Capacity in Challenging Governance

Contexts

MGSoG Dissertation Series, № 44 
Carlos Cadena Gaitán

Green Politics in Latin American

Cities - Sustainable Transport Agendas

MGSoG Dissertation Series, № 43

Katie Kuschminder

Female Return Migration and

Reintegration Strategies in Ethiopia

MGSoG Dissertation Series, № 42

Metka Hercog

Highly-Skilled Migration and New

Destination Countries

MGSoG Dissertation Series, № 41

\section{3}

Anant Kamath

Information Sharing through Informal

Interaction in Low-Tech Clusters

UNU-MERIT Dissertation Series, № 82

Flavia Pereira de Carvalho

What we talk about when we talk about

Brazilian Multinationals; An

Investigation on Brazilian FDI,

Economic Structure, Innovation and

the Relationship between them

UNU-MERIT Dissertation Series,

№ 81

Jun Hou

Complementarity in Innovation and

Development; A Cross-country

Comparison

UNU-MERIT Dissertation Series, № 80
Margaret Agaba Rugadya

Can Remittances Influence the Tenure

and Quality of Housing in Uganda?

MGSoG Dissertation Series, № 40

Ilire Agimi

New Governance Under Limited

Statehood; The Case of Local

Government Reform in Kosovo

MGSoG Dissertation Series, № 39
Rufin Baghana

Impacts of Government Incentives to $R \mathcal{E} D$, Innovation and Productivity; A Micro econometric Analysis of the Québec Case

UNU-MERIT Dissertation Series, № 79

Lilia I. Stubrin

High-Tech Activities in Emerging Countries; A Network perspective on the Argentinean Biotech Activity UNU-MERIT/MGSoG Dissertation Series, № 78

Kristine Farla

Empirical Studies on Institutions, Policies and Economic Development MGSoG Dissertation Series, № 38 
Marina Petrovic

Social Assistance and Activation in the

Pursuit of Happiness; Shedding New

Light on Old Policy Solutions to Social Exclusion

MGSoG Dissertation Series, № 37

Laura Torvinen

Assessing Governance Assessments;

The Case of Mozambique; Governance

Assessments in the Context of Aid

Effectiveness Discourse

MGSoG Dissertation Series, № 36

Biniam Egu Bedasso

Institutional Change in the Long

Shadow of Elite; Essays on

Institutions, Human Capital and

Ethnicity in Developing Countries

MGSoG Dissertation Series, № 35

\section{2}

Abdul Waheed

Innovation Determinants and

Innovation as a Determinant; Evidence

from Developing Countries

UNU-MERIT Dissertation Series, № 77

Bilal Mirza

Energy Poverty and Rural Energy

Markets in Pakistan

UNU-MERIT Dissertation Series, № 76

Benjamin Engelstätter

Enterprise Software and Video Games;

An Empirical Analysis

UNU-MERIT Dissertation Series,

№ 75
Sepideh Yousefzadeh Faal Deghati Childhoods Embargoed; Constructing and Reconstructing Multidimensional Child Poverty in Iran 1984-2009

MGSoG Dissertation Series, № 34

Robert Bauchmüller

Investing in Early Childhood Care and

Education; The Impact of Quality on

Inequality

MGSoG Dissertation Series, № 33

Martin Rehm

Unified Yet Separated; Empirical

Study on the Impact of Hierarchical

Positions within Communities of

Learning

MGSoG Dissertation Series, № 32
Fulvia Farinelli

Natural Resources, Innovation and

Export Growth; The Wine Industry in

Chili and Argentina

UNU-MERIT Dissertation Series

Rodolfo Lauterbach

Innovation in Manufacturing; From

Product Variety and Labor

Productivity Growth to Economic

Development in Chile

UNU-MERIT Dissertation Series 
Kirsten Wiebe

Quantitative Assessment of

Sustainable Development and Growth

in Sub-Saharan Africa

UNU-MERIT/MGSoG Dissertation

Series, № 74

Julio Miguel Rosa

Organizational Strategies, Firms'

Performance and Spatial Spillovers;

The Canadian Case in Research and

Development.

UNU-MERIT Dissertation Series, № 73

Johannes Wilhelmus Marie Boels Joseph Schumpeter, Honderd Jaar Economische Ontwikkeling; Een Historisch-theoretische Beschouwing. UNU-MERIT Dissertation Series

Dorcas Mbuvi

Utility Reforms and Performance of the Urban Water Sector in Africa MGSoG Dissertation Series, № 31

\section{1}

Daniel Vertesy

Interrupted Innovation; Emerging

Economies in the Structure of the

Global Aerospace Industry

UNU-MERIT Dissertation Series,

№ 72

Tina Saebi

Successfully Managing Alliance

Portfolios; An Alliance Capability

View

UNU-MERIT Dissertation Series, № 71
Lina Salanauskaite

Distributional Impacts of Public

Policies; Essays in Ex-Ante and Ex-

Post Evaluation

MGSoG Dissertation Series, № 30

Esther Schüring

To Condition or not - is that the

Question?

An Analysis of the Effectiveness of ExAnte and Ex-Post Conditionality in Social Cash Transfer Programs

MGSoG Dissertation Series, № 29

Joe Abah

Strong Organisations in Weak States;

Atypical Public Sector Performance in

Dysfunctional Environments

MGSoG Dissertation Series, № 28

Zina Samih Nimeh

Social Citizenship Rights; Inequality and Exclusion

MGSoG Dissertation Series, № 27

Nora Engel

Tuberculosis in India; A Case of

Innovation and Control

UNU-MERIT/MGSoG Dissertation

Series, № 70

Evans Mupela

Connectivity and growth in Sub-

Saharan Africa; The Role of

Communication Satellites

UNU-MERIT Dissertation Series, № 69 
Nantawan Kwanjai

Cross Cultural Intelligence amid

Intricate Cultural Webs; A Tale of the

UnDutchables in the Land of 1002

Smiles

UNU-MERIT Dissertation Series, № 68

Lina Sonne

Innovation in Finance to Finance

Innovation; Supporting Pro-poor

Entrepreneur-based Innovation

UNU-MERIT Dissertation Series,

№ 67

Lenka Eisenhamerová

Legitimacy of 'Humanitarian Military

Intervention'

MGSoG Dissertation Series, № 26

Sonila Tomini

Informal Payments for Health Care

Services in Albania

MGSoG Dissertation Series, № 25

Jinjing Li

Dynamic Microsimulation in Public

Policy Evaluation

MGSoG Dissertation Series, № 24

Aziz Atamanov

Rural Nonfarm Employment and

International Migration as

Alternatives to Agricultural

Employment; The Case of Kyrgyzstan

MGSoG Dissertation Series, № 23

Frieda Vandeninden

Poverty Alleviation; Aid and Social

Pensions

MGSoG Dissertation Series, № 22
Juliana Nyasha Tirivayi

The Welfare Effects of Integrating

AIDS Treatment with Food Transfers;

Evidence from Zambia

MGSoG Dissertation Series, № 21

Agnieska Ewa Sowa

Who's Left Behind? Social Dimensions

of Health Transition and Utilization of

Medical Care in Poland

MGSoG Dissertation Series, № 20

Emmanaouil Sfakianakis

The Role of Private Actors in the

Provision of Public Goods with

Applications to Infrastructure and

Financial Stability

MGSoG Dissertation Series, № 19

Siu Hing Lo

White Collars Green Sleeves; An Inter-

organizational Comparison of

Determinants of Energy-Related

Behaviors among Office Workers

MGSoG Dissertation Series, № 18

Treena $\mathrm{Wu}$

Constraints to Human Capital

Investment in Developing Countries;

Using the Asian Financial Crisis in

Indonesia as a Natural Experiment

MGSoG Dissertation Series, № 17

Henry Espinoza Peña

Impact Evaluation of a Job-Training

Programme for Disadvantaged Youths;

The Case of Projoven

MGSoG Dissertation Series, № 16 
Fernando Santiago

Human Resources Management

Practices and Learning for Innovation

in Developing Countries;

Pharmaceutical Firms in Mexico

UNU-MERIT Dissertation Series,

№ 66

Zakaria Babutsidze

Essays on Economies with

Heterogeneous Interacting Consumers

UNU-MERIT Dissertation Series,

№ 65

Bertha Vallejo

Learning and Innovation Under

Changing Market Conditions; The

Auto Parts Industry in Mexico

UNU-MERIT Dissertation Series,

№ 64

Donatus Ayitey

Technical Change, Competitiveness

and Poverty Reduction; A Study of the

Ghanaian Apparel Industry

UNU-MERIT Dissertation Series,

№ 63

Sergey Filippov

Multinational Subsidiary Evolution;

Corporate Change in New EU Member

States

UNU-MERIT Dissertation Series, № 62
Asel Doranova

Technology Transfer and Learning

under the Kyoto Regime; Exploring the

Technological Impact of CDM Projects

in Developing Countries

UNU-MERIT Dissertation Series, № 61

Florian Tomini

Between Family and Friend;

Understanding the Interdependency of

Private Transfers

MGSoG Dissertation Series, № 15

Michał Polalowski

The Institutional Transformation of

Social Policy in East Central Europe;

Poland and Hungary in Comparative

and Historical Perspective

MGSoG Dissertation Series, № 14

Maha Ahmed

Defining, Measuring and Addressing

Vulnerability; The Case of Post

Conflict Environments

MGSoG Dissertation Series, № 13

Pascal Beckers

Local Space and Economic Success; The

Role of Spatial Segregation of Migrants in the Netherlands

MGSoG Dissertation Series, № 12 
Victor Cebotari

Conflicting Demands in Ethnically

Diverse Societies; Ethno political

Contention and Identity Values in

Europe

MGSoG Dissertation Series, № 11

Dennis Gyllensporre

Competing and Complementary

Perspectives on the EU as a Crisis

Management Actor;

An Examination of the Common

Security and Defence Policy through

the Lenses of Idealism and Realism

MGSoG Dissertation Series, № 10

Judit Vall Castello

Business Cycle and Policy Effects on

Labour Market Transitions of Older

and Disabled Workers in Spain

MGSoG Dissertation Series, № 9

\section{9}

Alexis Habiyaremye

From Primary Commodity Dependence to Diversification and Growth;

Absorptive Capacity and Technological

Catch Up in Botswana and Mauritius.

UNU-MERIT Dissertation Series,

№ 60

Yoseph Getachew

The Role of Public Capital in Economic

Development

UNU-MERIT Dissertation Series,

№ 59
Keetie Roelen

False Positives or Hidden Dimensions;

The Definition and Measurement of

Child Poverty

MGSoG Dissertation Series, № 8

Denisa Maria Sologon

Earning Dynamics in Europe

MGSoG Dissertation Series, № 7

Melissa Siegel

Money and Mobility; Migration and

Remittances

MGSoG Dissertation Series, № 6

Jessica S. Hagen-Zanker

Modest Expectations; Causes and

Effects of Migration on Migrant

Households in Source Countries

MGSoG Dissertation Series, № 5

Sandra Leitner

Embodied Technological Change and

Patterns of Investment in Austrian

Manufacturing

UNU-MERIT Dissertation Series, № 58

Semih Akçomak

The Impact of Social Capital on

Economic and Social Outcomes

UNU-MERIT Dissertation Series, № 57 
Abraham Garcia

The Role of Demand in Technical

Change

UNU-MERIT Dissertation Series, № 56

Saurabh Arora

Coherence in Socio-technical Systems;

A Network Perspective on the

Innovation Process

UNU-MERIT Dissertation Series, № 55
Mirtha R. Muniz Castillo

Human Development and Autonomy in Project Aid; Experiences from four bilateral projects in Nicaragua and $\mathrm{El}$ Salvador

MGSoG Dissertation Series, № 4

Christiane Arndt

Governance Indicators

MGSoG Dissertation Series, № 3

Britta Augsburg

Microfinance; Greater Good or Lesser Evil?

MGSoG Dissertation Series, № 2

2008

Rutger Daems

Medicines for the Developing World UNU-MERIT Dissertation Series, № 54

Johannes Hanel Assessing Induced Technology; Sombart's Understanding of Technical Change in the History of Economics UNU-MERIT Dissertation Series, № 53

Rifka Weehuizen

Mental Capital; the Economic Significance of Mental Health UNU-MERIT Dissertation Series, № 52
Danielle Cloodt

The Relationship between RED

Partnership Formation, Social

Embeddedness and Innovative

Performance

UNU-MERIT Dissertation Series, № 51

Sabine Fuss

Sustainable Energy Development

under Uncertainty

UNU-MERIT Dissertation Series, № 50

Geranda Notten

Measuring and Managing Poverty

Risks

MGSoG Dissertation Series, № 1 
Tobias Kronenberg

Reconciling Environmental

Conservation with Economic

Prosperity; The Feasibility of Double

Dividends in the Short and Long Run

UNU-MERIT Dissertation Series,

№ 49

Viktoria Kravtsova

Assessing the Impact of Foreign Direct

Investment in Transition Economies

UNU-MERIT Dissertation Series,

№ 48

2006

Bulat Sanditov

Essays on Social Learning and

Imitation

UNU-MERIT Dissertation Series, № 46

Mamata Parhi

Dynamics of New Technology

Diffusion; A Study of the Indian

Automotive Industry

UNU-MERIT Dissertation Series, № 45

Andreas Reinstaller

Social Structures and the Innovation

Process; Their Role in the Demand of

Firms and Consumers

UNU-MERIT Dissertation Series, № 44
Suhail Sultan

The Competitive Advantage of Small and Medium Sized Enterprises; The

Case of Jordan's Natural Stone

Industry

UNU-MERIT Dissertation Series, № 47

Rose Kiggundu

Innovation systems and Development;

The Journey of a Beleaguered Nile

Perch Fishery in Uganda

UNU-MERIT Dissertation Series, № 43

Thomas Pogue

The Evolution of Research

Collaboration in South African Gold

Mining; 1886-1933

UNU-MERIT Dissertation Series, № 42

Geoffrey Gachino

Foreign Direct Investment, Spillovers

and Innovation; The Case of Kenyan

Manufacturing Industry

UNU-MERIT Dissertation Series, № 41 
Önder Nomaler

Technological Change, International

Trade and Growth; An Evolutionary,

Multi-Agents-Based Modeling

Approach

UNU-MERIT Dissertation Series,

№ 40

2005

Samia Satti Osman Mohamed-Nour

Change and Skill Development in the Arab Gulf Countries

UNU-MERIT Dissertation Series, № 39

Elad Harison

Intellectual Property Rights;

Economics and Policy Analysis

UNU-MERIT Dissertation Series, № 38

Daniel Dalohoun

The Relationship between RED

Partnership Formation, Social

Embeddedness and Innovative

Performance; a Multi-level Approach of Social Embeddedness

UNU-MERIT Dissertation Series, № 37

Müge Ozman

Networks, Organizations and

Knowledge

UNU-MERIT Dissertation Series, № 36
Bas Straathof

Product Variety and Economic

Growth; The Counteracting Effects of

Scale and Idiosyncrasy

UNU-MERIT Dissertation Series, № 35

Wilfred Schoenmakers

Knowledge Flows between

Multinational Companies; A Patent

Data Analysis

UNU-MERIT Dissertation Series,

№ 34

Myriam Cloodt

Mergers and Acquisitions ( $M$ and As)

in High-Tech Industries; Measuring

the Post-M and A Innovative

Performance of Companies

UNU-MERIT Dissertation Series, № 33 
Paola Criscuolo

$R \mathcal{E D}$ Internationalisation and

Knowledge Transfer; Impact on MNEs and their Home Countries

UNU-MERIT Dissertation Series, № 32

Maarten Verkerk

Trust and Power on the Shop Floor UNU-MERIT Dissertation Series, № 31

Nadine Roijakkers

Inter-firm Cooperation in High-tech Industries; a Study of RED

Partnerships in Pharmaceutical

Biotechnology

UNU-MERIT Dissertation Series, № 28

Viki Sonntag

Speed, Scale and Sustainability

UNU-MERIT Dissertation Series, № 27

2002

Annelies Hogenbirk

Determinants of Inward Foreign

Direct Investment; the Case of the

Netherlands

UNU-MERIT Dissertation Series, № 24
Gottfried Leibbrandt

Adoption, Harmonization and

Succession of Network Technologies

across Countries

UNU-MERIT Dissertation Series, № 30

Mark Sanders

Skill Biased Technical change; Its

Origins, the Interaction with the

Labour Market and Policy Implications

UNU-MERIT Dissertation Series,

№ 29

Masaru Yarime

From End-of-Pipe Technology to Clean

Technology

UNU-MERIT Dissertation Series,

№ 26

Stéphane Malo

The Combinatorial Chemistry

Revolution; Sustaining a Superior

Performance Position through

Technological Learning

UNU-MERIT Dissertation Series,

№ 25

Bastiaan Johan ter Weel

The Computerization of the Labour

Market

UNU-MERIT Dissertation Series 
John Adeoti

Technology Investment in Pollution

Control in Sub-Saharan Africa; The

Case of the Nigerian Manufacturing Industry

UNU-MERIT Dissertation Series, № 23
Edward Huizenga

Innovation Management; How

Frontrunners Stay Ahead; An

Empirical Study on Key Success

Factors in the ICT sector

UNU-MERIT Dissertation Series, № 22

2000

Machiel van Dijk

Technological Change and the Dynamics of Industries; Theoretical Issues and Empirical evidence from Dutch Manufacturing

UNU-MERIT Dissertation Series, № 21

1999

Jan Cobbenhagen

Managing Innovation at the Company

Level; A Study on Non-Sector-Specific

Success Factors

UNU-MERIT Dissertation Series, № 20
Marjolein Caniëls

Regional Growth Differentials; The

Impact of Locally Bounded Knowledge

Spillovers

UNU-MERIT Dissertation Series, № 19

1998

\section{Aldo Geuna}

Resource Allocation and Knowledge production; Studies in the Economics of University Research

UNU-MERIT Dissertation Series, № 18

1996

Reinoud Joosten

Dynamics, Equilibria, and Values

UNU-MERIT Dissertation Series, № 17
Hugo Kruiniger

Investment, RED, and the Financing

Decisions of the Firm

UNU-MERIT Dissertation Series, № 16 
Hans van Meijl

Endogenous Technological Change;

The Case of Information Technology,

Theoretical Considerations and

Empirical Results

UNU-MERIT Dissertation Series, № 15

René Kemp

Environmental Policy and Technical

Change; A Comparison of the

Technological Impact of Policy

Instruments

UNU-MERIT Dissertation Series, № 14
Rohini Acharya

The Impact of New Technologies on

Economic Growth and Trade; A Case

Study of Biotechnology

UNU-MERIT Dissertation Series, № 13

Geert Duysters

The Evolution of Complex

Industrial Systems; The Dynamics of Major IT Sectors

UNU-MERIT Dissertation Series, № 12

Marjan Groen

Technology, Work and Organisation;

A Study of the Nursing Process in

Intensive Care Units

UNU-MERIT Dissertation Series,

№ 11

Hans Voordijk

Naar Integrale Logistiek in

Bedrijfsketens; Ontwikkelingen in de Bouw

UNU-MERIT Dissertation Series, № 8

Theon van Dijk

The Limits of Patent Protection; Essays

on the Economics of Intellectual

Property Rights

UNU-MERIT Dissertation Series,

№ 9 
Paul Diederen

Technological Progress in Enterprises and Diffusion of Innovation;.

Theoretical Reflections and Empirical Evidence

UNU-MERIT Dissertation Series,

№ 7

1992

Bart Verspagen

Uneven Growth Between

Interdependent Economies; An

Evolutionary View on Technology

Gaps, Trade and Growth

UNU-MERIT Dissertation Series,

№ 4

1989

John Spangenberg

Economies of Scale, and Atmosphere in Research Organisations

UNU-MERIT Dissertation Series, № 2

\section{8}

John Hagedoorn

Evolutionary and Heterodox Innovation Analysis; A Study of Industrial and

Technological Development in Process Control and Information Technology

UNU-MERIT Dissertation Series, № 1
Ben Dankbaar

Economic Crisis and Institutional

Change; The Crisis of Fordism from the

Perspective of the Automobile Industry

UNU-MERIT Dissertation Series,

№ 6

Hanno Roberts

Accountability and Responsibility; The

Influence of Organisation Design on

Management Accounting

UNU-MERIT Dissertation Series,

№ 5

Sjoerd Romme

A Self-organization Perspective on

Strategy Formation

UNU-MERIT Dissertation Series,

№ 3 